\title{
Contribuições ao estudo da influência de propriedades de agregados no comportamento de misturas asfálticas densas
}

Tese apresentada ao Departamento de Transportes da Escola de Engenharia de São Carlos - Universidade de São Paulo, como parte dos requisitos para obtenção do título de Doutor em Engenharia Civil - Área de Transportes

Orientador: Prof. Dr. José Leomar Fernandes Júnior 

A Antônio Joaquim de Gouveia 



\section{Agradecimentos}

Sinto-me muito feliz em escrever estes agradecimentos àqueles que de alguma forma ajudaram a tornar possível a realização deste trabalho.

Agradeço ao professor José Leomar Fernandes Júnior pela orientação e liberdade para o desenvolvimento da pesquisa. Agradeço por sua bondade e por ter sido tão tranqüila e agradável nossa convivência por tantos anos.

Agradeço aos bons companheiros de trabalho Alessandro Ito, Marcos Bottene Cunha, Elisa Picchi, Vivian Silveira dos Santos Bardini, Patrícia Teodorovski Garbin e Ana Paula Furlan pela disposição e dedicação.

Agradeço ao professor Glauco Tulio Pessa Fabbri pelas sugestões valiosas dadas no transcorrer da pesquisa.

Agradeço aos técnicos do laboratório de estradas, do Departamento de Transportes da EESC, João Domingos Filho, Paulo Toyama e Antônio Carlos Gigante pela colaboração direta ou indireta na realização de alguns ensaios.

Agradeço aos técnicos do laboratório de química e de mecânica dos solos, do Departamento de Geotecnia da EESC, Antônio Garcia e Décio Aparecido Lourenço pelo auxílio na realização de alguns ensaios.

Agradeço ao professor José Eduardo Rodrigues por tão prontamente viabilizar a análise petrográfica do agregado de gabro e por gentilmente disponibilizar a utilização dos laboratórios do Departamento de Geotecnia da EESC, confiando-me as chaves do Departamento.

Agradeço à Pedreira Santa Isabel e ao engenheiro Odair pela disposição e interesse em fornecer as amostras do agregado de basalto.

Agradeço à Pedreira São Roque e a seu proprietário Sr. Abel, pela presteza em dispor das amostras do agregado de gabro.

Agradeço à Mineradora Jundu e ao engenheiro Pedro pela simpatia e empenho no fornecimento das amostras de areia natural e também pelo interesse demonstrado pela pesquisa. 
Agradeço à Mineradora Areia Munhoz e ao Sr. Neto Munhoz pela notável satisfação em disponibilizar as amostras de areia natural.

Agradeço à Fapesp pelo financiamento desta pesquisa, na forma de bolsa de doutorado.

Agradeço aos amigos, Douglas Xavier Teodoro de Oliveira, Márcio Augusto de Souza, Nadja Cristina Pena, Nazira Harb, Renato Porfírio Ishii, Caio Peres Sabo, Omar Andres Carmona Cortes, Elaine Carmona, Mário Meireles Teixeira, Rodrigo Fernandes de Mello e Cláudia Mello, pela amizade verdadeira.

Agradeço à minha mãe, Selma Alves de Gouveia, pelo carinho e dedicação de uma vida inteira. Agradeço ao meu pai, Antônio Joaquim de Gouveia, meu amigo, por tudo e por tanto, que, com sua companhia agradável, seu senso de humor refinado, sua sabedoria e inteligência, impregnou nossas almas. Agradeço-o também imensamente por ter-me ensinado o prazer da leitura.

Agradeço ao Luciano José Senger por seu amor e amizade, por ser sempre tão companheiro e leal e, que, mais uma vez, teve o carinho e a paciência de ler e revisar esta dissertação. Agradeço-o também por encaminhar-me ao mundo do software livre. 
Quanto maior for o número de olhares, de olhares distintos que saibamos empregar para ver uma mesma coisa, tanto mais completo será nosso conceito sobre ela, tanto mais completa será nossa objetividade...

Friedrich Wilhelm Nietzsche 



\section{Resumo}

O objetivo principal desta pesquisa é avaliar a influência que as propriedades estudadas dos agregados exercem sobre propriedades volumétricas e mecânicas de misturas asfálticas densas. Para tanto, foram avaliadas as propriedades de consenso e de origem, especificadas pelo Superpave, de um conjunto de agregados, além de suas densidades, porosidade, absorção e adesividade. Foram estudados agregados de gabro, basalto e areia natural e três tipos de granulometrias, uma denominada AZR, passando acima da zona de restrição da especificação Superpave, e outras duas, obtidas através do sistema de seleção granulométrica Bailey. Também três níveis de energia de compactação foram aplicados às misturas, 75, 110 e 155 golpes por face do corpo-de-prova Marshall. Avaliou-se o comportamento mecânico das misturas através dos ensaios de estabilidade e fluência Marshall, fluência por compressão uniaxial uniforme, fluência por compressão uniaxial dinâmica, resistência à tração, módulo de resiliência e fadiga. Os resultados mostraram que, de uma maneira geral, o agregado de gabro apresentou superioridade em relação ao agregado de basalto e de areia natural, tanto quando analisado isoladamente como quando analisado nas misturas asfálticas. Suas características de forma, angularidade e textura superficial permitiram arranjos entre partículas adequados, formando esqueletos estruturais resistentes à deformação permanente e também à fadiga. As análises das misturas à luz da granulometria mostram que, de uma maneira geral, a granulometria AZR produziu misturas mais estáveis, mais resistentes à deformação permanente e à fadiga. Pôde-se constatar, também, que as propriedades volumétricas são sensíveis às densidades dos agregados e à taxa de absorção destes, além de serem influenciadas diretamente pelas características de superfície dos agregados e pela energia de compactação. Com o aumento da energia de compactação aplicada, as partículas angulosas e rugosas dos agregados de gabro e de basalto arranjaram-se de maneira mais próxima e, por conseqüência, houve a diminuição dos vazios do agregado mineral e elevação da estabilidade e rigidez das misturas, sem, contudo, causar prejuízos à vida de fadiga. Os estudos sobre a absorção de asfalto pelos agregados revelaram que os agregados absorvem mais asfalto quanto mais fina a espessura da película de asfalto que os envolve e, também, que misturas com um mesmo teor de asfalto absorvem quantidades semelhantes de asfalto, sendo o tempo necessário para que a absorção se complete diretamente proporcional à viscosidade (temperatura) do asfalto.

Palavras-chave: propriedades dos agregados; granulometria; energia de compactação; misturas asfálticas; propriedades volumétricas, propriedades mecânicas. 



\section{Abstract}

The main objective of this research is to evaluate the influence that the studied properties of aggregates have on volumetric and mechanical characteristics of dense asphalt mixtures. It was evaluated origin and consensus properties, specified by the Superpave, for a set of aggregates, besides their densities, porosity, absorption and adhesiveness. Aggregates of gabbro, basalt and natural sand were studied and three types of aggregate gradations, one called AZR, passing above the zone of restriction of the Superpave specification, and two others, obtained through the Bailey method. Three levels of compaction energy were applied, corresponding respectively to 75, 110 and 155 blows of the Marshall hammer per face of the specimen. The mechanical behavior of the hot mix asphalt (HMA) was evaluated through the Marshall stability and flow, static and dynamic creep, indirect tensile strength, resilient modulus and fatigue tests. The results showed that, in general terms, the gabbro aggregate presented a superior behavior compared to the natural sand aggregate and the basalt aggregate, based on both aggregate and asphalt mixture evaluation tests. Its characteristics of form, angularity and surface texture resulted in an adequate arrangement between particles, building a resistant structural skeleton to both permanent deformation and fatigue cracking. Analyses of the HMA mixtures as a function of gradation showed that, in general terms, AZR mixtures were more stable, more resistant to permanent deformation and to fatigue cracking than Bailey mixtures. It could be evidenced that the volumetric properties depends on the specific gravity and the absorption rate of the aggregates, being also directly influenced by aggregate surface characteristics and compaction energy. Increasing the energy applied for specimen compaction resulted, for the angular and rough particles of gabbro and basalt aggregates, in a closer arrangement, with reduction of the voids in mineral aggregate and increase of the stability and stiffness of the mixtures, without, however, causing damages that could conduct to a shorter fatigue life. The studies about absorption of asphalt by aggregates showed that the smaller the asphalt film thickness the greater the asphalt absorption. The results also showed that HMA with the same asphalt content absorb similar amounts of asphalt, although the necessary time to complete the absorption is directly proportional to the asphalt viscosity (temperature).

Keywords: properties of aggregates; aggregate gradation; level of compaction energy; hot mix asphalt (HMA); volumetric properties; mechanical properties. 

1 Introdução 1

2 Propriedades dos Agregados Especificadas pelo Superpave 11

2.1 Considerações Iniciais . . . . . . . . . . . . . . . . . . . . 11

2.2 Propriedades de Consenso . . . . . . . . . . . . . . . . . . . 14

2.2.1 Angularidade do Agregado Grosso . . . . . . . . . . . . . . . . . . . . . . . . . . . . . . . 14

2.2.2 Angularidade do Agregado Fino . . . . . . . . . . . . . . . . . . . . . . 15

2.2.3 Partículas Planas e Alongadas . . . . . . . . . . . . . . . . 18

2.2 .4 Finos Plásticos . . . . . . . . . . . . . . . . . . . . . . . . . . . . . . . . . . . . . . . . .

2.3 Propriedades de Origem . . . . . . . . . . . . . . . . . 22

2.3.1 Resistência à Abrasão . . . . . . . . . . . . . . . . . . . . . . . . . . . . . 22

2.3 .2 Sanidade . . . . . . . . . . . . . . . . 23

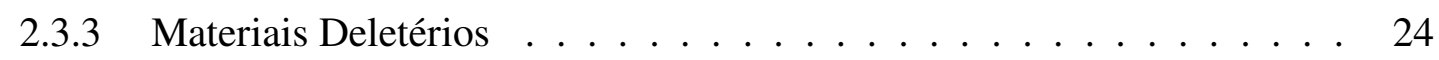

2.4 Experimentos Laboratoriais . . . . . . . . . . . . . . . . . . . . . . . . . . . . . . . . . . . . . .

2.4.1 Agregados Estudados . . . . . . . . . . . . . . . . 25

2.4.2 Ensaio de Partículas Fraturadas . . . . . . . . . . . . . . . . . 26

2.4.3 Ensaio de Angularidade do Agregado Fino . . . . . . . . . . . . . . . . . . 27

2.4.4 Ensaio de Partículas Planas e Alongadas . . . . . . . . . . . . . . . . . . . . . . 28

2.4.5 Ensaio do Equivalente de Areia . . . . . . . . . . . . . . . . 31

2.4 .6 Abrasão Los Angeles . . . . . . . . . . . . . . . . . . . . . . . . . . . . . . . 35

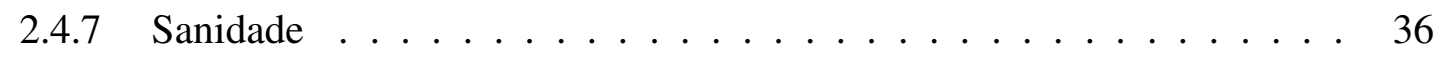

2.4.8 Torrões de Argila e Partículas Friáveis . . . . . . . . . . . . . . . . . . . . . 40

2.5 Resultados da Caracterização Superpave dos Agregados . . . . . . . . . . . . . . . . . 41

2.5.1 Angularidade do Agregado Grosso . . . . . . . . . . . . . . . . . . . . . . . . . 41

2.5.2 Angularidade do Agregado Fino . . . . . . . . . . . . . . . . . . . . . . . 44

2.5.3 Forma do Agregado Grosso . . . . . . . . . . . . . . . . . . . . . . . . . . . . . . 48

2.5 .4 Equivalente de Areia . . . . . . . . . . . . . . . . . . . . . 50

2.5 .5 Abrasão Los Angeles . . . . . . . . . . . . . . . . . . . . . . . . . . . . . 51

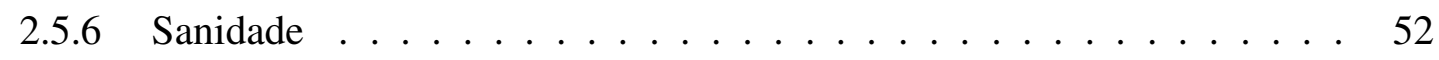

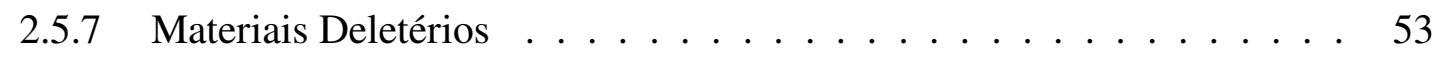

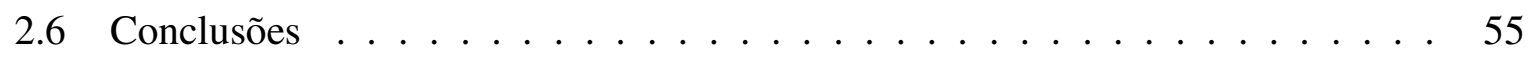

2.7 Considerações Finais . . . . . . . . . . . . . . . . . . 57 
3 Absorção de Asfalto $\quad 61$

3.1 Considerações Iniciais . . . . . . . . . . . . . . . . . . . . . . . . . . 61

3.2 Características da Absorção . . . . . . . . . . . . . . . . . . . . . 62

3.3 Efeito das Propriedades do Agregado na Absorção . . . . . . . . . . . . 63

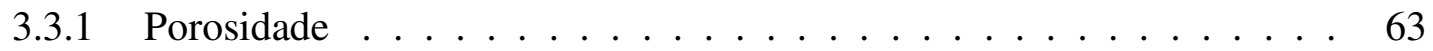

3.3.2 Distribuição e Tamanhos dos Poros . . . . . . . . . . . . . . . . 64

3.3.3 Composição Química e Mineralógica do Agregado . . . . . . . . . . . 64

3.4 Efeito das Propriedades do Asfalto na Absorção . . . . . . . . . . . . . . 65

3.5 Absorção Seletiva . . . . . . . . . . . . . . . . . . . . . 67

3.6 Métodos de Determinação da Absorção . . . . . . . . . . . . . . . . . . 68

3.7 Experimentos Laboratoriais . . . . . . . . . . . . . . . . . . . . . . 70

3.7 .1 Asfalto Utilizado . . . . . . . . . . . . . . . . . . . . 70

3.7.2 Método Rice de Determinação da Densidade Máxima Medida . . . . . 70

3.7.3 Densidade aparente do Agregado Grosso . . . . . . . . . . . . 75

3.7.4 Densidade aparente do Agregado Fino . . . . . . . . . . . . . . . . 78

3.8 Resultados da Absorção de Asfalto . . . . . . . . . . . . . . . . . . . . 83

3.8.1 Comportamento da Absorção de Asfalto pelo Agregado de Gabro em Relação ao Tempo e ao Teor de Asfalto . . . . . . . . . . . . . . . . . 84

3.8.2 Comportamento da Absorção de Longo Prazo após 2 Horas de Cura . . 89

3.9 Conclusões . . . . . . . . . . . . . . . . . . . . . . . . . . . . . . . . . . 91

3.10 Considerações Finais $\ldots \ldots \ldots \ldots$. . . . . . . . . . 92

4 Relações entre Propriedades Volumétricas, Densidades e Absorção de Asfalto 95

4.1 Considerações Iniciais . . . . . . . . . . . . . . . . . . . . . . 95

4.2 Parâmetros Volumétricos Primários . . . . . . . . . . . . . . . . . . . 96

4.3 Parâmetros Volumétricos Secundários . . . . . . . . . . . . . . . . . . 97

4.4 Relações entre Propriedades Volumétricas, Densidades e Absorção de Asfalto . 97

4.4.1 Entendimento Conceitual das Densidades dos Agregados . . . . . . . 98

4.4 .2 Exemplo Prático . . . . . . . . . . . . . . . . . . . . . . . . . . 99

4.5 Método Seguro . . . . . . . . . . . . . . . . . . . . . . . . . . 104

4.5.1 Vazios do Agregado Mineral . . . . . . . . . . . . . . . 105

4.5.2 Volume de Vazios . . . . . . . . . . . . . . . . . . . . . . . . 105

4.5.3 Relação Betume-Vazios . . . . . . . . . . . . . . . . . . . 106

4.5.4 Densidade Efetiva do Agregado . . . . . . . . . . . . . . . 106

4.5.5 DMM para Diferentes Teores de Asfalto . . . . . . . . . . . . . 107

4.5.6 Absorção de Asfalto . . . . . . . . . . . . . . . . . . . . . . 108

4.5.7 Exemplo de Utilização do Método Seguro . . . . . . . . . . . . . . 109

4.6 Diagrama de Componentes . . . . . . . . . . . . . . . . . . . . . . . . 111

4.6.1 Dados de Entrada . . . . . . . . . . . . . . . . . . . . . 112

4.6.2 Composição do Diagrama de Componentes . . . . . . . . . . . 112

4.7 Considerações Finais . . . . . . . . . . . . . . . . . . . . . . . . . . . 119

5 Propriedades Volumétricas e Seleções Granulométricas 121

5.1 Considerações Iniciais . . . . . . . . . . . . . . . . . . . . . . . . . . 121

5.2 Granulometria . . . . . . . . . . . . . . . . . . . . . . 124

$5.2 .1 \quad$ Linha de Densidade Máxima . . . . . . . . . . . . . . . . . 126

5.2 .2 Método Bailey . . . . . . . . . . . . . . . . . . . . 131

5.2 .3 Método Superpave . . . . . . . . . . . . . . . . . . . . . . . 141

5.3 Experimentos Laboratoriais . . . . . . . . . . . . . . . . . . . . . . 147

5.3.1 Seleções Granulométricas . . . . . . . . . . . . . . . . . 147 
5.3.2 Massas Específicas dos Agregados . . . . . . . . . . . . . . 151

5.3.3 Execução dos Corpos-de-Prova Marshall . . . . . . . . . . . . . . . . 152

5.4 Resultados e Análises dos Resultados . . . . . . . . . . . . . . . . . . 155

5.4.1 Dosagens das Misturas Asfálticas AZR . . . . . . . . . . . . . . . . 155

5.4.2 Dosagens das Misturas Asfálticas Bailey . . . . . . . . . . . . . . . 162

5.4.3 Comparando Misturas AZR e Bailey . . . . . . . . . . . . . . . . 167

5.5 Conclusões . . . . . . . . . . . . . . . . . . . 171

5.6 Considerações Finais . . . . . . . . . . . . . . . . . . . . 173

6 Vazios do Agregado Mineral e Energia de Compactação 177

6.1 Considerações Iniciais ． . . . . . . . . . . . . . . . . 177

6.2 Vazios do Agregado Mineral . . . . . . . . . . . . . . . . . . . . . 179

6.3 Vazios do Agregado Mineral e Energia de Compactação . . . . . . . . . . . . . 180

6.4 Experimentos Laboratoriais . . . . . . . . . . . . . . . . . . . . . . . 181

6.5 Resultados e Análises dos Resultados . . . . . . . . . . . . . . . . . . 184

6.5.1 Análise de Quebra de Partículas . . . . . . . . . . . . . . . . . . . 184

6.5.2 Propriedades Volumétricas das Misturas AZR versus Energia de Compactação . . . . . . . . . . . . . . . . . . 185

6.5.3 Asfalto Efetivo e Espessura do Filme de Asfalto versus Energia de Compactação . . . . . . . . . . . . . . . . . . . 187

6.5 .4 RBV sob Nova Óptica . . . . . . . . . . . . . . . . . . . . . . . . . . . . . . . . . . 188

6.6 Conclusones . . . . . . . . . . . . . . . . . . . . . . . 190

6.7 Considerações Finais . . . . . . . . . . . . . . . . . . . . . 191

7 Propriedades Mecânicas e de Adesividade das Misturas Asfálticas 195

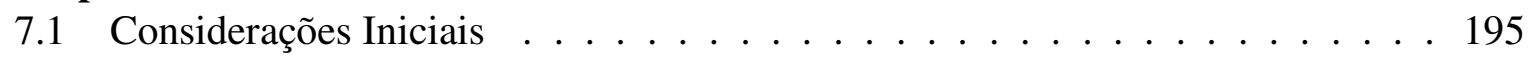

7.2 Deformação Permanente . . . . . . . . . . . . . . . . . . 196

7.3 Trincas por Fadiga . . . . . . . . . . . . . . . . . . . . . . 199

7.4 Desgaste . . . . . . . . . . . . . . . . . . . 201

7.5 Experimentos Laboratoriais . . . . . . . . . . . . . . . . 203

7.5.1 Estabilidade e Fluência Marshall . . . . . . . . . . . . . . . . . . 203

7.5.2 Ensaio de Fluência por Compressão Uniaxial Estática . . . . . . . . . . . 204

7.5.3 Ensaio de Fluência por Compressão Uniaxial Dinâmica . . . . . . . . . . 206

7.5.4 Ensaios de Compressão Diametral . . . . . . . . . . . . . . . . . . . 208

7.5.5 Adesividade entre o Asfalto e o Agregado . . . . . . . . . . . . . . . . 219

7.6 Resultados das Propriedades Mecânicas das Misturas . . . . . . . . . . . . 223

7.6.1 Estabilidade e Fluência Marshall . . . . . . . . . . . . . . . . . . . 223

7.6.2 Fluência por Compressão Uniaxial Estática . . . . . . . . . . . . . . . 225

7.6.3 Fluência por Compressão Uniaxial Dinâmica . . . . . . . . . . . . . . 232

7.6.4 Ensaios de Resistência à Tração e de Módulo de Resiliência . . . . . . 241

7.6.5 Estimativa da Vida de Fadiga . . . . . . . . . . . . . . . . . . . . 249

7.7 Resultados de Adesividade das Misturas . . . . . . . . . . . . . . . . . . . 264

7.7.1 Adesividade entre o Asfalto e o Agregado - Análise Visual . . . . . . . 264

7.7.2 Sensibilidade à Umidade das Misturas Asfálticas . . . . . . . . . . . . . . 266

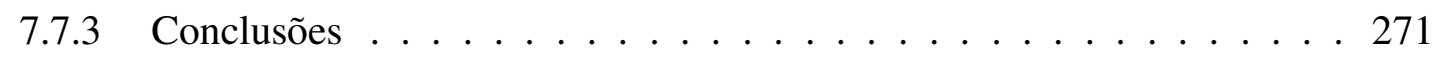

8 Conclusões e Sugestões para Estudos Futuros 273

$\begin{array}{ll}\text { Referências Bibliográficas } & 281\end{array}$

$\begin{array}{ll}\text { Apêndices } & 281\end{array}$ 
$\begin{array}{llr}\text { A Análise Petrográfica } & 291\end{array}$

B Análises Estatísticas $\quad 297$

B.1 Ensaios de Estabilidade e Fluência Marshall . . . . . . . . . . . . . . . . . . 297

B.2 Ensaios de Fluência por Compressão Uniaxial Uniforme . . . . . . . . . . . 301

B.3 Ensaios de Fluência por Compressão Uniaxial Dinâmica . . . . . . . . . . . . 304

B.4 Ensaios de Resistência à Tração e de Módulo de Resiliência . . . . . . . . . . 307 
2.1 Ensaio de determinação de partículas fraturadas . . . . . . . . . . . . . 15

2.2 Ensaio de angularidade do agregado fino . . . . . . . . . . . . . . 16

2.3 Paquímetro dimensional usado nesta pesquisa . . . . . . . . . . . . . . . 19

2.4 Ensaio do equivalente de areia . . . . . . . . . . . . . . . 21

2.5 Máquina Los Angeles usada nesta pesquisa . . . . . . . . . . . . . . 23

2.6 Aparência do agregado antes e depois de submetido a ciclos de sanidade . . . . 25

2.7 Ensaio de porcentagem de faces fraturadas do agregado grosso - exemplo de avaliação do agregado de areia natural estudado nesta pesquisa . . . . . . . . . 27

2.8 Ensaio de avaliação da forma da partícula - exemplo de avaliação do agregado de basalto estudado nesta pesquisa . . . . . . . . . . . . . . . . . . 29

2.9 Dimensões da partícula do agregado (ASTM D 4791) . . . . . . . . . . . . . 30

2.10 Amostra utilizada no ensaio do equivalente de areia . . . . . . . . . . . . . . . . 32

2.11 Agitação da proveta . . . . . . . . . . . . . . . . . . 32

2.12 Leitura do nível superior da areia - exemplo de leitura realizada numa amostra de agregado de gabro estudado nesta pesquisa . . . . . . . . . . . . . 33

2.13 Equipamento necessário para a realização do ensaio do equivalente de areia . . 34

2.14 Preparo da solução de sulfato de sódio . . . . . . . . . . . . . . . . . . . 36

2.15 Determinação da densidade da solução . . . . . . . . . . . . . . . . . . . 37

2.16 Cristais retirados da solução de sulfato de sódio durante um ensaio de sanidade desta pesquisa . . . . . . . . . . . . . . . . 37

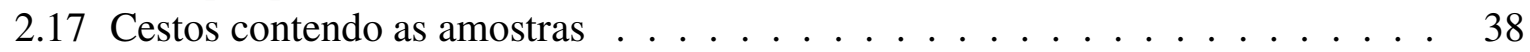

2.18 Imersão das amostras . . . . . . . . . . . . . . . . . . . . . 38

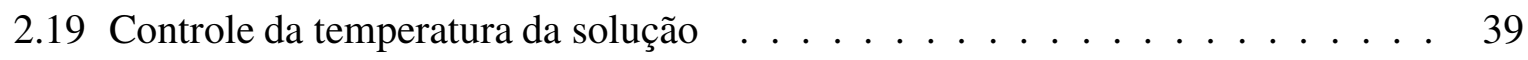

2.20 Ensaio de detecção de torrões de argila e partículas friáveis . . . . . . . . . . . 40

2.21 Graus de arredondamento. Do topo para a base: angular, subangular, subarredondado, arredondado, altamente arredondado (Russel \& Taylor (1937) apud Suguio (1973)) . . . . . . . . . . . . . . . . . . . 43

2.22 Escala de comparação visual para graus de esfericidade bidimensional (Rittenhouse (1943) apud Suguio (1973)) . . . . . . . . . . . . . . . . . . 45

2.23 Definições de forma, angularidade e textura superficial das partículas (Barrett (1980) apud Bowman et al. (2000)) . . . . . . . . . . . . . . . . . . . . . 46

3.1 Procedimento de resfriamento da amostra . . . . . . . . . . . . . 71

3.2 Determinação da massa seca da amostra . . . . . . . . . . . . . . . 71

3.3 Dispositivo de nivelamento . . . . . . . . . . . . . . . . . 72

3.4 Kitassato modificado . . . . . . . . . . . . . . . . . . . . . . . . . . . . .

3.5 Extração de ar da amostra . . . . . . . . . . . . . . . . . . . . 73 
3.6 Determinação da massa do conjunto . . . . . . . . . . . . . . . . . . . 73

3.7 Determinação da temperatura da água . . . . . . . . . . . . . . . . . 74

3.8 Amostra úmida . . . . . . . . . . . . . . . . . . . . . 76

3.9 Procedimento para atingir a condição de secura superficial da amostra . . . . . 76

3.10 Determinação da massa da amostra ao ar . . . . . . . . . . . . . . . . . . 77

3.11 Determinação da massa da amostra submersa na água . . . . . . . . . . . . 78

3.12 Amostra úmida . . . . . . . . . . . . . . . . . . . . . . 79

3.13 Procedimento para atingir a condição de secura superficial da amostra . . . . . 79

3.14 Colocação da amostra no cone . . . . . . . . . . . . . . . . . 80

3.15 Procedimento para verificar a condição de secura superficial da amostra . . . . 80

3.16 Verificação da condição de secura superficial da amostra . . . . . . . . . . . . 81

3.17 Ponto de secura superficial da amostra . . . . . . . . . . . . . . . . 81

3.18 Determinação da massa com superfície seca da amostra . . . . . . . . . . . . . . . . 82

3.19 Extração de bolhas de ar da amostra . . . . . . . . . . . . . . . . 83

3.20 Variação da absorção de curto prazo para os diferentes teores de asfalto . . . . 85

3.21 Variação da absorção de longo prazo para os diferentes teores de asfalto . . . . 86

3.22 Absorção de curto prazo versus tempo e modelo hiperbólico . . . . . . . . . . 87

3.23 Absorção de longo prazo versus tempo e modelo hiperbólico . . . . . . . . . . 88

3.24 Absorção versus DMM para a mistura produzida com agregado de gabro . . . . 88

3.25 Absorção versus tempo . . . . . . . . . . . . . . . . . . . . . 89

3.26 Comparação entre a absorção de longo prazo e a absorção de longo prazo após 2 horas de cura . . . . . . . . . . . . . . . . . . 90 90

4.1 Volumes do agregado . . . . . . . . . . . . . . . . . . . . 96

4.2 Vazios do agregado mineral, considerando-se a densidade aparente do agregado 101

4.3 Vazios do agregado mineral, considerando-se a densidade efetiva do agregado . 101

4.4 Vazios do agregado mineral, considerando-se a densidade real do agregado . . 102

4.5 Volume de vazios, considerando-se a densidade efetiva do agregado . . . . . . 102

4.6 Volume de vazios, considerando-se a densidade aparente do agregado . . . . . 103

4.7 Volume de vazios, considerando a densidade real do agregado . . . . . . . . . 103

4.8 Diagrama de componentes da mistura asfáltica compactada (Motta et al., 1994) 111

4.9 Composição do diagrama de componentes - 1 . . . . . . . . . . . . . . 113

4.10 Composição do diagrama de componentes $-2 \ldots \ldots$. . . . . . . . . . 113

4.11 Composição do diagrama de componentes $-3 \ldots \ldots$. . . . . . . . . . . . 114

4.12 Composição do diagrama de componentes $-4 \ldots \ldots$. . . . . . . . . . . . . . . . . 115

4.13 Composição do diagrama de componentes $-5 \ldots \ldots$. . . . . . . . . . 115

4.14 Composição do diagrama de componentes $-6 \ldots \ldots$. . . . . . . . . 116

4.15 Diagrama de componentes . . . . . . . . . . . . . . . . 118

5.1 Granulometrias utilizadas para avaliar o arranjo entre as partículas de agregados (Nijboer (1948) apud Huber \& Shuler (1992)) . . . . . . . . . . . . . . . . 126

5.2 VAM da mistura versus inclinação das curvas granulométricas (Nijboer (1948) apud Huber \& Shuler (1992)) . . . . . . . . . . . . . . . . . . . . . . . . 127

5.3 Granulometrias estudadas por Goode \& Lufsey (1962) . . . . . . . . . . . . 128

5.4 Granulometrias do tipo "S" estudadas por Goode \& Lufsey (1962) . . . . . . . 129

5.5 Peneiras de controle - Primeira Peneira de Controle (PPC) . . . . . . . . . . . 134

5.6 Combinação entre formas de partículas e vazios resultantes (Vavrik et al., 2001) 134

5.7 Peneiras de controle - Peneira Média $(\mathrm{PM}) \ldots \ldots$. . . . . . . . . . . 135

5.8 Peneiras de controle - Segunda Peneira de Controle (SPC) . . . . . . . . . . . 137

5.9 Peneiras de controle - Terceira Peneira de Controle (TPC) . . . . . . . . . . . 138 
5.10 Seleção da massa específica solta dos agregados grossos para misturas densas (adaptada de Vavrik et al. (2002)) . . . . . . . . . . . . . . . . . . . . 140

5.11 Representação gráfica da especificação granulométrica Superpave, para o diâmetro máximo nominal de $12,5 \mathrm{~mm}$

5.12 Curva granulométrica AZR utilizada na composição de misturas asfálticas com agregados de gabro (AZRg), basalto (AZRb) e areia natural (AZRa) . . . . . 149

5.13 Curva granulométrica Bailey para agregado de basalto $(\mathrm{Bb})$. . . . . . . . . . . 149

5.14 Curva granulométrica Bailey para agregado de gabro $(\mathrm{Bg}) \ldots \ldots \ldots$

5.15 Curvas granulométricas utilizadas nesta pesquisa . . . . . . . . . . . . 150

5.16 Curva de viscosidade Saybolt-Furol versus temperatura do asfalto . . . . . . . 153

5.17 Termômetros usados, nesta pesquisa, para controle da temperatura . . . . . . . 154

5.18 Compactador Marshall usado nesta pesquisa . . . . . . . . . . . . . . . . 154

5.19 Propriedades volumétricas obtidas na dosagem das misturas AZRg, AZRb e AZRa compactadas com 75 golpes por face . . . . . . . . . . . . . . 157

5.20 Espessura do filme de asfalto obtidas na dosagem das misturas AZRg, AZRb e AZRa . . . . . . . . . . . . . . . . . . . 160

5.21 Estabilidade e Fluência Marshall obtidas na dosagem das misturas AZRg, AZRb

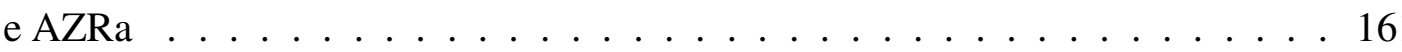

5.22 Propriedades volumétricas obtidas nas dosagens das misturas Bg e Bb, compactadas com 75 golpes por face . . . . . . . . . . . . . . . . . . . . . . 164

5.23 Estabilidade e Fluência Marshall obtidas na dosagem das misturas Bg e Bb, compactadas com 75 golpes por face . . . . . . . . . . . . . . 166

5.24 VAM das misturas AZRg, AZRb, AZRa, Bg e Bb . . . . . . . . . . . . . . 167

5.25 Comparação entre a estabilidade e fluência Marshall das misturas AZR e Bailey 168

5.26 Comparação entre o asfalto efetivo, espessura do filme de asfalto e relação betume-vazios das misturas AZR e Bailey . . . . . . . . . . . . . . . . . . . . 169

6.1 Procedimento para escolha das energias de compactação correspondentes a 110 e 155 golpes por face do corpo-de-prova Marshall . . . . . . . . . . . . . . 181

6.2 Equipamento utilizado para extração de asfalto . . . . . . . . . . . . . . . 182

6.3 Processo de extração de asfalto . . . . . . . . . . . . . . . . . . . . 183

6.4 Curvas granulométricas AZRg e AZRb obtidas após compactação e curva granulométrica AZR de projeto . . . . . . . . . . . . . . . . . . 185

6.5 Variação dos vazios do agregado mineral das misturas AZRg e AZRb, conforme a energia de compactação aplicada . . . . . . . . . . . . . . . . . . 186

6.6 Variação da relação betume-vazios das misturas AZRg e AZRb conforme a energia de compactação aplicada . . . . . . . . . . . . . . . . . . . . 187

6.7 Variação do asfalto efetivo e espessura do filme de asfalto das misturas AZRg e AZRb, conforme a energia de compactação aplicada . . . . . . . . . . . . . . 189

7.1 Exemplo de deformação permanente associada a problemas na mistura asfáltica 196

7.2 Exemplo de trincas por fadiga . . . . . . . . . . . . . . . 199

7.3 Exemplo de perda de adesividade entre o asfalto e o agregado na presença de água202

7.4 Prensa empregada na realização dos ensaios Marshall . . . . . . . . . . . . . 203

7.5 Equipamento usado nos ensaios de fluência por compressão uniaxial estática . . 204

7.6 Exemplo da tela de registro do ensaio de fluência por compressão uniaxial estática206

7.7 Exemplo da tela de cálculo do ensaio de fluência por compressão uniaxial estática207

7.8 Exemplos das telas de um ensaio de fluência por compressão uniaxial dinâmica 207

7.9 Ensaio de resistência à tração por compressão diametral estática . . . . . . . . 209

7.10 Exemplos de ruptura do corpo-de-prova por compressão diametral estática . . . 210

7.11 Equipamento do ensaio de compressão diametral . . . . . . . . . . . . . . . 212 
7.12 Frisos e suporte do LVDT . . . . . . . . . . . . . . . . . . . . 213

7.13 Vistas do equipamento de ensaio de módulo de resiliência . . . . . . . . . . . 213

7.14 Telas obtidas após um ensaio de módulo de resiliência . . . . . . . . . . . . 214

7.15 Curva de deformação versus tempo, para um ciclo de carregamento . . . . . . . 215

7.16 Ensaio realizado para a estimativa da vida de fadiga das misturas . . . . . . . 218

7.17 Exemplo de descolamento da película de asfalto, observado nesta pesquisa . . . 220

7.18 Exemplo de descolamento da película de asfalto do agregado fino, observado nesta pesquisa . . . . . . . . . . . . . . . . . 221

7.19 Variação da estabilidade em função da energia de compactação aplicada . . . . 224

7.20 Variação da estabilidade Marshall em função do VAM das misturas . . . . . . . 225

7.21 Variações das deformações total, elástica e plástica das misturas AZRb e Bb, compactadas com 75 golpes por face . . . . . . . . . . . . . . . . . 227

7.22 Variações da recuperação elástica, módulo de fluência e inclinação, obtidas através do ensaio de fluência uniaxial estática, das misturas AZRg, Bg, AZRb e $\mathrm{Bb}$, compactadas com 75 golpes por face . . . . . . . . . . . .

7.23 Variação das deformações das misturas produzidas com gabro, obtidas através do ensaio de fluência uniaxial estática, conforme o aumento da energia de compactação

7.24 Variações da recuperação e do módulo de fluência, obtidos através do ensaio de fluência uniaxial estática, das misturas produzidas com agregado de gabro e de basalto, em função da energia de compactação aplicada

7.25 Variação das deformações das misturas produzidas com basalto, obtidas através do ensaio de fluência uniaxial estática, conforme o aumento da energia de compactação

7.26 Parâmetros do ensaio de fluência uniaxial dinâmica para misturas com granulometrias AZR e Bailey, produzidas com agregados de gabro e de basalto, compactadas com 75 golpes por face . . . . . . . . . . . . . .

7.27 Parâmetros do ensaio de fluência uniaxial dinâmica das misturas produzidas com agregados de gabro e de basalto com energias de compactação de 75, 110 e 155 golpes . . . . . . . . . . . . . . . . . . . . . 236

7.28 Parâmetros do ensaio de fluência uniaxial dinâmica das misturas AZRg e AZRb ao variar a energia de compactação aplicada . . . . . . . . . . . . . . . . 238

7.29 Resistência à tração, módulos de resiliência e módulos de resiliência instantâneo das misturas produzidas com agregados de gabro e de basalto compactadas com 75 golpes por face . . . . . . . . . . . . . . . . . . 243

7.30 Relação $M R / R T$ das misturas AZRg, AZRb, Bg e Bb . . . . . . . . . . . . . 244

7.31 Relação $M R / R T$ das misturas AZR produzidas com agregados de gabro (AZRg) e com agregado de basalto (AZRb), compactadas com 110 e 155 golpes por face 245

7.32 Resistência à tração, módulos de resiliência e módulos de resiliência instantâneo das misturas AZR produzidas com gabro e com basalto, compactadas com 110 e 155 golpes por face . . . . . . . . . . . . . . . . . 246

7.33 Variação de resistência à tração das misturas AZR, produzidas com agregados de gabro e de basalto, com a elevação da energia de compactação aplicada . . . 247

7.34 Variação do módulo de resiliência das misturas AZR, produzidas com agregados de gabro e de basalto, com a elevação da energia de compactação aplicada . 248

7.35 Variação da relação $M R / R T$ das misturas AZR, produzidas com agregados de gabro e de basalto, com a elevação da energia de compactação aplicada . . . . 249

7.36 Curvas de fadiga das misturas AZR e Bailey produzidas com agregado de gabro e energia de compactação de 75 golpes por face . . . . . . . . . . . . . . 253 
7.37 Curvas de fadiga das misturas AZR e Bailey produzidas com agregado de basalto e energia de compactação de 75 golpes por face . . . . . . . . . . . 253

7.38 Curvas de fadiga das misturas AZR produzidas com agregados de gabro e de basalto com energia de compactação de 75 golpes por face . . . . . . . . . . . 254

7.39 Curvas de fadiga das misturas AZR produzidas com agregados de gabro e de basalto com energia de compactação de 110 golpes por face . . . . . . . . . . 255

7.40 Curvas de fadiga das misturas AZR produzidas com agregados de gabro e de basalto com energia de compactação de 155 golpes por face . . . . . . . . . . . 255

7.41 Curvas de fadiga das misturas AZR produzidas com agregados de gabro com energias de compactação de 75,110 e 155 golpes por face . . . . . . . . . . 256

7.42 Curvas de fadiga das misturas AZR produzidas com agregados de basalto com energias de compactação de 75,110 e 155 golpes por face . . . . . . . . . . . 256

7.43 Perfis utilizados, características e localização do carregamento e pontos de aferição das tensões . . . . . . . . . . . . . . . . . . . . . . . . 259

7.44 Variação da vida de fadiga das misturas AZR produzidas com agregado de gabro, em função da energia de compactação aplicada . . . . . . . . . . . . . . . 261

7.45 Variação da vida de fadiga das misturas AZR produzidas com agregado de basalto, em função da energia de compactação aplicada . . . . . . . . . . . . . . 261

7.46 Comparação entre as vidas de fadiga das misturas produzidas com agregado de gabro e agregado de basalto, em função da energia de compactação aplicada . 262

7.47 Modo de análise visual da adesividade entre o asfalto e o agregado grosso . . . 264

7.48 Detalhamento da análise visual da adesividade entre o asfalto e o agregado grosso264

7.49 Análise visual da adesividade entre o asfalto e os agregados finos . . . . . . . 265

7.50 Misturas avaliadas pelo método da ASTM D 4867 . . . . . . . . . . . . . 269

7.51 Misturas avaliadas pelo método da AASHTO T $283 \ldots \ldots$. . . . . . . . 270 

2.1 Especificação Superpave para valores mínimos de partículas fraturadas . . . . . 15

2.2 Frações granulométricas usadas nos métodos A e B . . . . . . . . . . . . . 17

2.3 Especificação Superpave para valores mínimos da AAF (método A) . . . . . . 18

2.4 Especificação Superpave para partículas planas/alongadas . . . . . . . . . . . . 19

2.5 Especificação do California Division of Highways para equivalente de areia . . 21

2.6 Especificação Superpave para o equivalente de areia . . . . . . . . . . . . . . 22

2.7 Peneiras de controle usadas no ensio de sanidade . . . . . . . . . . . . . . . . . 39

2.8 Composição das amostras usadas no ensaio de partículas friáveis . . . . . . . . 40

2.9 Peneiras de controle usadas no ensaio de partículas friáveis . . . . . . . . . . . 41

2.10 Resultados do ensaio de porcentagem de partículas fraturadas . . . . . . . . . . 41

2.11 Resultados da análise visual comparativa da angularidade e da textura superficial 43

2.12 Resultados do ensaio de angularidade do agregado fino . . . . . . . . . . . . 44

2.13 Resultados da análise visual comparativa quanto à angularidade, à forma e à textura superficial . . . . . . . . . . . . . . . . . . 47

2.14 Porcentagem de partículas planas, alongadas e lamelares $-5: 1 \ldots \ldots$. . . 48

2.15 Porcentagem de partículas planas, alongadas e lamelares $-3: 1 \ldots$. . . . . 48

2.16 Resultados do ensaio do equivalente de areia . . . . . . . . . . . . . . . . 50

2.17 Relação entre valores de azul de metileno e previsão de desempenho de pavimentos . . . . . . . . . . . . . . . . . . 51

2.18 Resultados do ensaio de abrasão Los Angeles . . . . . . . . . . . . . . . . . 52

2.19 Resultados do ensaio de sanidade . . . . . . . . . . . . . . . . . . 53

2.20 Resultados do ensaio de partículas friáveis . . . . . . . . . . . . . . . . . . . 54

2.21 Resultados do ensaio de partículas friáveis modificado . . . . . . . . . . 54

3.1 Características físicas do CAP 20 utilizado . . . . . . . . . . . . . . . 70

3.2 Absorção de curto prazo para teores de asfalto de $5,7 \%, 6,2 \%$ e $6,7 \%$. . . 84

3.3 Absorção de longo prazo para teores de asfalto de $5,7 \%, 6,2 \%$ e $6,7 \%$. . . 85

3.4 Propriedades dos agregados relacionadas à absorção . . . . . . . . . . . . . . 93

4.1 Exemplo 1 - Dados dos materiais constituintes da mistura AZRg . . . . . . . 100

4.2 Propriedades volumétricas da mistura AZRg . . . . . . . . . . . . . . . 100

4.3 Dados de entrada da mistura AZRg - método seguro . . . . . . . . . . . . . . 109

4.4 Dados de entrada da mistura AZRg - diagrama de componentes . . . . . . . . . 112

4.5 Resumo da composição do diagrama de componentes . . . . . . . . . . . . . . 118

4.6 Comparação entre métodos de determinação das propriedades volumétricas da mistura asfáltica AZRg . . . . . . . . . . . . . . . . . . . . . . . . 119 
5.1 Especificação Marshall para Vv e RBV . . . . . . . . . . . . . . . . . . . . 122

5.2 Especificação Marshall para VAM . . . . . . . . . . . . . . . . 123

5.3 Especificação Superpave para VAM . . . . . . . . . . . . . . . . . 123

5.4 Especificação Superpave para RBV . . . . . . . . . . . . . . . . . . . 123

5.5 Valores recomendados para as proporções de AG, GAF e FAF em misturas densas 139

5.6 Resumo classificatório das notas dadas pelos especialistas do SHRP para os métodos de controle da granulometria . . . . . . . . . . . . . . . . 142

5.7 Especificação granulométrica para o diâmetro máximo nominal de 37,5 mm . . 143

5.8 Especificação granulométrica para o diâmetro máximo nominal de $25 \mathrm{~mm}$. . . 144

5.9 Especificação granulométrica para o diâmetro máximo nominal de $19 \mathrm{~mm}$. . . 144

5.10 Especificação granulométrica para o diâmetro máximo nominal de 12,5 mm . . 145

5.11 Especificação granulométrica para o diâmetro máximo nominal de $9,5 \mathrm{~mm}$. . 145

5.12 Curva granulométrica AZR . . . . . . . . . . . . . . . . . . . . . 148

5.13 Curvas granulométricas Bailey . . . . . . . . . . . . . . 151

5.14 Dosagem Marshall - mistura AZR - gabro . . . . . . . . . . . . . . 155

5.15 Dosagem Marshall - mistura AZR - basalto . . . . . . . . . . . . . 155

5.16 Dosagem Marshall - mistura AZR - areia natural . . . . . . . . . . . . 156

5.17 Propriedades das misturas AZR . . . . . . . . . . . . . . . . 156

5.18 Dosagem Marshall - mistura Bailey - gabro . . . . . . . . . . . . . . . . 162

5.19 Dosagem Marshall - mistura Bailey - basalto . . . . . . . . . . . . . . . . . 162

5.20 Propriedades das misturas Bailey . . . . . . . . . . . . . . . . . 163

5.21 Comparação entre as distâncias da linha de densidade máxima e VAM . . . . . 170

6.1 Resultados, em porcentagem, referentes à quebra de partículas . . . . . . . . . 184

6.2 Resultados das propriedades volumétricas das misturas AZR para energias de compactação de 75,110 e 155 golpes . . . . . . . . . . . . . . . . . 186

6.3 Resultados do asfalto efetivo e da espessura do filme de asfalto, para energias de compactação de 75,110 e 155 golpes por face . . . . . . . . . . . . 188

6.4 Resumo classificatório das notas dadas pelos especialistas do SHRP para as características das misturas asfálticas . . . . . . . . . . . . . . . .

7.1 Resumo dos procedimentos de ensaio da ASTM D 4867 e da AASHTO T 283 . 223

7.2 Resultados da estabilidade (E) e fluência (F) Marshall das misturas AZR compactadas com energias de 75,110 e 155 golpes por face . . . . . . . . . . 223

7.3 Resultados do VAM e do asfalto efetivo, para energias de compactação de 75 , 110 e 155 golpes . . . . . . . . . . . . . . . . . . . . . 224

7.4 Valores médios do ensaio de fluência por compressão uniaxial estática para misturas produzidas com 75 golpes por face . . . . . . . . . . . 226

7.5 Valores médios do ensaio de fluência por compressão uniaxial estática para misturas produzidas com 110 e 155 golpes por face . . . . . . . . . . . . . 229

7.6 Valores médios do ensaio de fluência por compressão uniaxial dinâmica para misturas produzidas com 75 golpes por face . . . . . . . . . . . . . . 232

7.7 Valores médios do ensaio de fluência por compressão uniaxial dinâmica para misturas produzidas com 110 e 155 golpes por face

7.8 Valores médios de resistência à tração, módulo de resiliência, módulo de resiliência instantâneo e da relação $M R / R T$, para misturas compactadas com 75 golpes por face . . . . . . . . . . . . . . . . . . . . 241

7.9 Valores médios de resistência à tração, módulo de resiliência, módulo de resiliência instantâneo e da relação $M R / R T$, para misturas compactadas com 110 e 155 golpes por face . . . . . . . . . . . . . . . . . . 241

7.10 Relações $M R / R T$ encontradas em estudos realizados a $25^{\circ} C \ldots \ldots$ 
7.11 Resultados do ensaio de fadiga das misturas produzidas com granulometria AZR utilizando agregado de gabro e energia de compactação de 75 golpes por face

7.12 Resultados do ensaio de fadiga das misturas produzidas com granulometria Bailey gabro utilizando agregado de gabro e energia de compactação de 75 golpes por face

7.13 Resultados do ensaio fadiga das misturas produzidas com granulometria AZR utilizando agregado de basalto e energia de compactação de 75 golpes por face

7.14 Resultados do ensaio de fadiga das misturas produzidas com granulometria Bailey basalto utilizando agregado de basalto e energia de compactação de 75 golpes por face . . . . . . . . . . . . . . . .

7.15 Resultados do ensaio de fadiga das misturas produzidas com granulometria AZR utilizando agregado de gabro e energia de compactação de 110 golpes por face . . . . . . . . . . . . . . . . . . .

7.16 Resultados do ensaio de fadiga das misturas produzidas com granulometria AZR utilizando agregado de basalto e energia de compactação de 110 golpes por face

7.17 Resultados do ensaio de fadiga das misturas produzidas com granulometria AZR utilizando agregado de gabro e energia de compactação de 155 golpes por face . . . . . . . . . . . . . . . . . . .

7.18 Resultados do ensaio de fadiga das misturas produzidas com granulometria AZR utilizando agregado de basalto e energia de compactação de 155 golpes por face . . . . . . . . . . . . . . . . . . . 252

7.19 Características mecânicas e de fadiga das misturas - Análise 1 - Perfil 1 . . . . 258

7.20 Características mecânicas e de fadiga das misturas - Análise 2 - Perfil 2 . . . 258

7.21 Variação da absorção de asfalto . . . . . . . . . . . . . . . . . 266

7.22 Resultados de suscetibilidade aos danos por umidade ao avaliar a propriedade de resistência à tração .

7.23 Resultados de suscetibilidade aos danos por umidade ao avaliar a propriedade módulo de resiliência

B.1 Análise estatística dos resultados de Estabilidade e Fluência Marshall das misturas AZRg e Bg

B.2 Análise estatística dos resultados de Estabilidade e Fluência Marshall das misturas $\mathrm{AZRb}$ e $\mathrm{Bb}$

B.3 Análise estatística dos resultados de Estabilidade e Fluência Marshall das misturas AZRg e AZRb . . . . . . . . . . . . . . . . .

B.4 Análise estatística dos resultados de Estabilidade e Fluência Marshall das misturas 110AZRg e 110AZRb .

B.5 Análise estatística dos resultados de Estabilidade e Fluência Marshall das misturas 155AZRg e 155AZRb .

B.6 Análise estatística dos resultados de Estabilidade e Fluência Marshall das misturas AZRg e 110AZRg .

B.7 Análise estatística dos resultados de Estabilidade e Fluência Marshall das misturas AZRg e 155AZRg . . . . . . . . . . . . . . .

B.8 Análise estatística dos resultados de Estabilidade e Fluência Marshall das misturas 110AZRg e 155AZRg . . . . . . . . . . . . . . .

B.9 Análise estatística dos resultados de Estabilidade e Fluência Marshall das misturas AZRb e 110AZRb . 
B.10 Análise estatística dos resultados de Estabilidade e Fluência Marshall das misturas AZRb e 155AZRb . . . . . . . . . . . . . . . . .

B.11 Análise estatística dos resultados de Estabilidade e Fluência Marshall das misturas $110 \mathrm{AZRb}$ e $155 \mathrm{AZRb}$.

B.12 Análise estatística dos resultados de fluência por compressão uniaxial estática

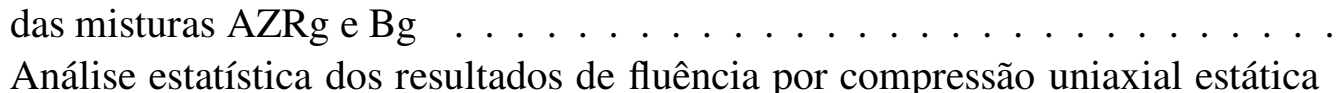

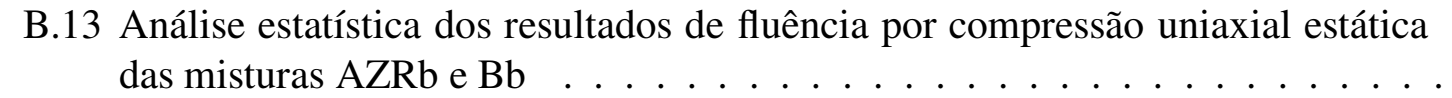

B.14 Análise estatística dos resultados de fluência por compressão uniaxial estática das misturas AZRg e AZRb . . . . . . . . . . . . . . . . . . 301

B.15 Análise estatística dos resultados de fluência por compressão uniaxial estática das misturas 110AZRg e 110AZRb . . . . . . . . . . . . . . . . . . . . 302

B.16 Análise estatística dos resultados de fluência por compressão uniaxial estática das misturas 155AZRg e 155AZRb . . . . . . . . . . . . . .

B.17 Análise estatística dos resultados de fluência por compressão uniaxial estática das misturas AZRg e 110AZRg . . . . . . . . . . . . . . . . . . . 302

B.18 Análise estatística dos resultados de fluência por compressão uniaxial estática das misturas AZRg e 155AZRg .

B.19 Análise estatística dos resultados de fluência por compressão uniaxial estática das misturas 110AZRg e 155AZRg . . . . . . . . . . . . . . 303

B.20 Análise estatística dos resultados de fluência por compressão uniaxial estática das misturas AZRb e 110AZRb .

B.21 Análise estatística dos resultados de fluência por compressão uniaxial estática das misturas AZRb e 155AZRb . . . . . . . . . . . . . . . . . . . 303

B.22 Análise estatística dos resultados de fluência por compressão uniaxial estática das misturas 110AZRb e 155AZRb . . . . . . . . . . . . . . . . .

B.23 Análise estatística dos resultados de fluência por compressão uniaxial dinâmica das misturas AZRg e Bg

B.24 Análise estatística dos resultados de fluência por compressão uniaxial dinâmica

B.25 Análise estatística dos resultados de fluência por compressão uniaxial dinâmica das misturas AZRg e AZRb . . . . . . . . . . . . . . . .

B.26 Análise estatística dos resultados de fluência por compressão uniaxial dinâmica das misturas 110AZRg e 110AZRb . . . . . . . . . . . . . . . . 305

B.27 Análise estatística dos resultados de fluência por compressão uniaxial dinâmica das misturas 155AZRg e 155AZRb . . . . . . . . . . . . .

B.28 Análise estatística dos resultados de fluência por compressão uniaxial dinâmica das misturas AZRg e 110AZRg . . . . . . . . . . . . . . . . . . 305

B.29 Análise estatística dos resultados de fluência por compressão uniaxial dinâmica das misturas AZRg e 155AZRg . . . . . . . . . . . . . . . . 305

B.30 Análise estatística dos resultados de fluência por compressão uniaxial dinâmica das misturas 110AZRg e 155AZRg . . . . . . . . . . . . . . 306

B.31 Análise estatística dos resultados de fluência por compressão uniaxial dinâmica das misturas AZRb e 110AZRb . . . . . . . . . . . . . . . 306

B.32 Análise estatística dos resultados de fluência por compressão uniaxial dinâmica das misturas AZRg e 155AZRg . . . . . . . . . . . . . . . 306

B.33 Análise estatística dos resultados de fluência por compressão uniaxial dinâmica das misturas 110AZRb e 155AZRb . . . . . . . . . . . . . . . . 306

B.34 Análise estatística dos resultados de resistência à tração e de módulo de resili-

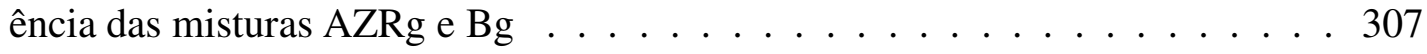


B.35 Análise estatística dos resultados de resistência à tração e de módulo de resiliência das misturas AZRb e Bg . . . . . . . . . . . . . . . . 307

B.36 Análise estatística dos resultados de resistência à tração e de módulo de resiliência das misturas AZRg e AZRb . . . . . . . . . . . . . . . . . 307

B.37 Análise estatística dos resultados de resistência à tração e de módulo de resiliência das misturas 110AZRg e 110AZRb . . . . . . . . . . . . . . . . 308

B.38 Análise estatística dos resultados de resistência à tração e de módulo de resiliência das misturas 155AZRg e 155AZRb . . . . . . . . . . . . . . 308

B.39 Análise estatística dos resultados de resistência à tração e de módulo de resiliência das misturas AZRg e 110AZRg . . . . . . . . . . . . . . . . 308

B.40 Análise estatística dos resultados de resistência à tração e de módulo de resiliência das misturas AZRg e 155AZRg . . . . . . . . . . . . . . . . . 308

B.41 Análise estatística dos resultados de resistência à tração e de módulo de resiliência das misturas 110AZRg e 155AZRg . . . . . . . . . . . . . . . . . 309

B.42 Análise estatística dos resultados de resistência à tração e de módulo de resiliência das misturas AZRb e 110AZRb . . . . . . . . . . . . . . . . . . 309

B.43 Análise estatística dos resultados de resistência à tração e de módulo de resiliência das misturas AZRb e 155AZRb . . . . . . . . . . . . . . . . . . 309

B.44 Análise estatística dos resultados de resistência à tração e de módulo de resiliência das misturas 110AZRb e 155AZRb . . . . . . . . . . . . . . . . . . 309 



\section{Lista de Abreviaturas e Siglas}

$\% A b_{a g}$ Porcentagem de água absorvida

$\rho_{b} \quad$ Densidade do asfalto

$\rho_{r} \quad$ Densidade real do agregado

$\rho_{a p} \quad$ Densidade aparente do agregado

$\rho_{e f} \quad$ Densidade efetiva do agregado

$A_{a b s}$ Porcentagem de asfalto absorvido, por massa de agregado

$A b s L p_{2 c}$ Absorção de Longo prazo após 2 horas de cura

d Densidade aparente da mistura compactada

$E f_{b} \quad$ Espessura do filme de asfalto

Ma Massa do agregado

Mb Massa total do asfalto na mistura

$M b_{a b s}$ Massa do asfalto absorvido

Mt Massa total da mistura compactada

$\mathrm{Pb} \quad$ Porcentagem de asfalto na mistura

$\mathrm{Pb}_{\text {ef }} \quad$ Porcentagem de asfalto efetivo

$V_{a p} \quad$ Volume aparente do agregado

$V_{a r} \quad$ Volume de ar na mistura

$V_{e f} \quad$ Volume efetivo do agregado

$V_{T M} \quad$ Volume total da mistura asfáltica solta (sem vazios)

$\mathrm{Vb} \quad$ Volume do asfalto na mistura

$V b_{a b s}$ Volume do asfalto absorvido

$V b_{e f} \quad$ Volume do asfalto efetivo na mistura 
Vt Volume total da mistura compactada

Vv Volume de vazios na mistura compactada

AASHTO American Association of State Highway and Transportation Officials

AbsCp Absorção de Curto prazo

AbsLp Absorção de Longo prazo

ASTM American Society for Testing and Materials

AZRa Mistura AZR produzida com agregado de areia natural

AZRb Mistura AZR produzida com agregado de basalto

AZRg Mistura AZR produzida com agregado de gabro

AZR Curva granulométrica que passa Acima da Zona de Restrição

Bb Mistura Bailey - basalto

Bg Mistura Bailey - gabro

CP Corpo-de-Prova

DER-PR Departamento de Estradas de Rodagens do Paraná

DMM Densidade Máxima Medida

DMN Diâmetro máximo nominal

DMT Densidade Máxima Teórica

DM Diâmetro máximo

DNER Departamento Nacional de Estradas de Rodagens

E Estabilidade Marshall

F Fluência Marshall

HRB Highway Research Board

LVDT Linear Variable Differential Transducers

PT Porosidade total

RBV Relação betume-vazios

SHRP Strategic Highway Research Program

Superpave Superior Performing Asphalt Pavements

VAM Vazios do agregado mineral 


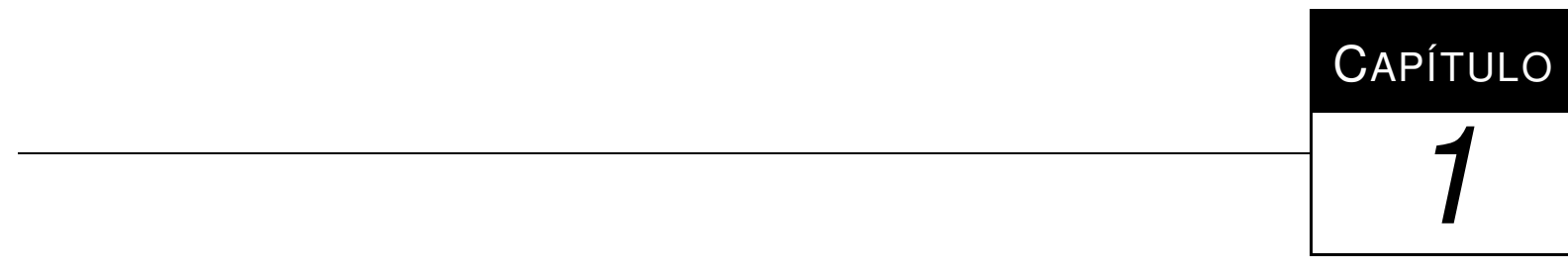

\section{Introdução}

Desde muito tempo a humanidade procura aprimorar suas técnicas de construção de estradas buscando mais conforto e segurança, considerando que a superfície terrestre em seu estado natural raramente proporciona condições adequadas de tráfego.

A primeira estrada que se tem notícia fora construída no Antigo Egito, há aproximadamente 4.500 anos, destinada a facilitar o transporte de blocos rochosos utilizados na construção da pirâmide do faraó Keops, uma das 7 maravilhas do mundo antigo que ainda permanece em pé. Há relatos de que essa estrada fora pavimentada com grandes fragmentos de rochas alinhados lado a lado, cujas faces superiores, caprichosamente lapidadas, facilitavam o transporte de blocos gigantescos de rochas (Costa \& Figueiredo, 2001).

Pesquisas arqueológicas revelaram a existência de outras estradas primitivas, construídas a partir de trilhas usadas por povos pré-históricos, localizadas no sudoeste da Ásia, numa ampla área delimitada pelos mares Negro, Cáspio, Mediterrâneo e pelo golfo Pérsico. Provavelmente, o início das construções de estradas coincidiu com o surgimento dos primeiros veículos com rodas. Arqueólogos encontraram na Anatólia (parte asiática da Turquia) restos de veículos de duas rodas que datam de 3000 a.C., feitos pelos sumérios com madeira das florestas do Cáucaso. A carroça ou carruagem suméria, à qual atavam onagros (burros selvagens), era constituída por cestas entretecidas apoiadas a um sólido sistema composto por quatro-rodas (CEPA, 2006).

Após longo período sem relatos históricos sobre construções de estradas, há registros da utilização de quatro grandes estradas, que partiam da Babilônia e ligavam pontos distantes do Império, trafegadas por veículos com rodas tracionados por animais. 
Com a queda da Babilônia, as civilizações hegemônicas que lhe sucederam, a persa e a grega, tiveram um desempenho modesto quanto à evolução dos transportes terrestres. Uma das mais expressivas contribuições foi a construção da Estrada Real Persa, construída pelo rei Dario I no século V a.C.. Essa estrada proporcionava comunicação rápida dentro do grande Império Persa, permitindo que seus mensageiros percorressem $2.699 \mathrm{~km}$ em apenas sete dias. O historiador grego Heródoto escreveu: "Não há nada no mundo que viaje mais rápido que esses mensageiros persas". E ainda: "Nem a neve, nem a chuva, nem o calor e nem a escuridão da noite impedem que realizem a tarefa proposta a eles com a máxima velocidade"(Herodoto, 424a).

Com o surgimento do Império Romano, em 27 a.C., a engenharia rodoviária atingiu seu ponto máximo de eficiência e aprimoramento tecnológico da antiguidade. Os romanos, como bons estrategistas, sabiam da importância das estradas para governar e manter a unidade de tão vasto Império. As estradas tinham a função dupla de conquistar territórios e preservá-los. $\mathrm{O}$ sistema de transporte criado permitia deslocamento rápido para qualquer ponto onde a presença das Legiões Romanas fosse necessária. Irradiavam de Roma 29 grandes estradas militares, das quais a mais conhecida é a via Ápia, que se estendia por 660 km entre Roma e o sul da Itália (em dias atuais) (CEPA, 2006). A construção da via Ápia iniciou-se em 312 a.C., durante o período republicano, e fora assim chamada em homenagem a Appius Claudius Caecus, conselheiro romano e principal responsável por sua construção (Kaszynski, 2000).

A largura de uma estrada romana variava entre 2,5 e $4 \mathrm{~m}$, no entanto, a via Ápia chegava a ter, em certos trechos, $10 \mathrm{~m}$ de largura. Geralmente a espessura do revestimento variava em torno de 1 a 1,5 m, com agregados (fragmentos de rochas) dispostos em camadas, onde a camada imediatamente superior era composta de agregados de menor diâmetro que a inferior, conferindo intertravamento adequado entre as partículas, através do preenchimento de vazios (CEPA, 2006). Pedras largas e chatas eram empregadas na camada inferior do revestimento e outras cada vez menores eram usadas nas camadas subsequientes. A camada final apresentava superfície regular e lisa, proporcionando tráfego seguro e confortável das carruagens e carretas.

As estradas romanas caracterizavam-se pela solidez de sua construção e pelo traçado reto, independentemente do obstáculo que tivessem que superar, sendo construídas sobre pântanos, lagos, vales e montanhas e, para tanto, engenhavam pontes e túneis magníficos. Por sua concepção audaciosa, ainda hoje as técnicas de engenharia empregadas na época despertam a admiração dos engenheiros. 
Com o declínio do Império Romano, a partir do século IV da era cristã, as estradas tornaram-se caminhos de invasão, e passaram a sofrer um processo de decadência. O período de decadência do sistema rodoviário das antigas civilizações mediterrâneas coincidiu com o surgimento e o auge, em outro continente, de outro império de notáveis construtores de estradas: o Império Inca. Muito antes da chegada do europeu ao continente americano, os incas já haviam construído um extraordinário sistema de estradas que ligava Quito, no Equador, a diversos pontos ao sul de Cuzco, no Peru. Esse sistema de estradas era composto por duas estradas paralelas, uma ao longo do litoral, com aproximadamente $3.600 \mathrm{~km}$ de extensão e outra que acompanhava os Andes por cerca de $2.640 \mathrm{~km}$, cada uma delas com diversos cruzamentos e conexões. No começo do século XVI, período coincidente com a chegada dos espanhóis na América do Sul, o sistema rodoviário atendia a uma área de quase dois milhões de quilômetros quadrados, onde viviam perto de dez milhões de pessoas. Parte do sistema original inca é usada até hoje (CEPA, 2006).

A rota dos Andes tinha características notáveis. Estradas com larguras de 7,5 m, que cruzavam os mais altos pontos com cortes e rampas suaves, continham galerias cortadas na rocha compacta e muros de contenção de dezenas de metros. Com superfície de pedra em sua maior parte, essas estradas contavam com trechos em que materiais asfálticos foram usados com abundância. Trafegadas apenas por animais de carga (lhamas) ou por pessoas a pé, essas estradas venciam as subidas mais íngremes através de escadas esculpidas na rocha. Acredita-se que os incas não tinham conhecimento sobre o uso da roda.

Os incas eram mestres em cortar e unir grandes blocos de pedra; a cidade-fortaleza de Machu Picchu é o exemplo mais espetacular dessa arte. Entre suas realizações está a arquitetura, a construção de estradas, pontes, engenhosos sistemas de irrigação e um importante sistema agrícola. A chave do sucesso da agricultura inca era a existência de estradas e trilhas que possibilitavam uma boa distribuição de suas colheitas numa vasta região, desde a Colômbia até o Chile. Além disso, os incas tinham um exército muito bem treinado e sabiam da importância das estradas para manter e expandir seu Império. Todo o Império era unido por excelentes estradas e pontes, que possibilitava o intercâmbio rápido de informações através de mensageiros, chamados de chasquis. Com construções sólidas em pedra, as estradas transpunham abismos e desfiladeiros e atravessavam os mais largos rios entre montanhas, através de pontes pênseis feitas com cabos de madeira ou fibra (Kaszynski, 2000).

Também é importante citar a existência do sistema rodoviário da China imperial, contemporâneo ao da Estrada Real da Pérsia, que se destacava pela importância comercial e extensão de suas estradas. Esse sistema rodoviário representou para o sudeste da Ásia papel semelhante 
ao que tiveram as estradas romanas na Europa e na Anatólia (Ásia Menor). A estrada comercial entre China, Anatólia e Índia era conhecida como a Rota da Seda. Interligada ao sistema rodoviário romano, a Rota da Seda se estendia por $12.800 \mathrm{~km}$, ligando Xangai, na China, a Cádiz, na Espanha, espalhando-se por toda a Europa (CEPA, 2006). Muitas estradas chinesas eram largas, bem construídas e pavimentadas com pedras. Rios eram atravessados por pontes ou barcas e os trechos mais íngremes das montanhas eram alcançados através de degraus largos. O declínio dessas estradas ocorreu com a queda do Império Romano e os constantes ataques de mongóis e outros povos nômades, fazendo com que seu uso se tornasse muito perigoso.

Após a queda do Império Romano do Ocidente, em 476, teve início a Idade Média, milênio no qual o ocidente se dividiu em pequenas comunidades denominadas feudos. Nesse período da história, caracterizado pela economia ruralizada, enfraquecimento comercial, supremacia da Igreja Católica, sistema de produção feudal e sociedade hierarquizada, poucas pessoas se arriscavam a viajar, pois haviam muitos assaltantes de estradas. Nesse fase, as estradas que durante toda a história desempenharam papel tão importante, entraram no período das trevas.

Com a busca européia pela conquista de territórios no Oriente, por meio das Cruzadas, suas antigas cidades começam a renascer e a desenvolver novamente o comércio. No século XIV, a vida das populações européias sofreu modificações que alteraram o equilíbrio do sistema feudal vigente na maior parte da Europa, fazendo surgir uma uma nova classe social, a burguesia, que com o auxílio da monarquia, ajudou a destruir a base do sistema feudal. Como consequiência, novos reinados e reinantes se estabeleceram, passando mais uma vez a preocupar-se com a unidade de seus domínios e, portanto, com os meios de transporte. As estradas saíram da obscuridade e voltaram a reinar soberanas.

Na França, durante o reinado de Luiz XIV - o Rei Sol, houve grande desenvolvimento econômico e militar, com atenções especiais à construção e manutenção de estradas. Em 1716, com o início do reinado de Luiz XV, foi criado em Paris o Corpo de Engenheiros de Ponts et Chaussées. Na Inglaterra, os engenheiros de origem escocesa, Thomas Telford e John Loudon MacAdam, criam processos de pavimentação de rodovias ainda hoje utilizados, como a base de Telford e os diversos tipos de macadame. Contudo, apesar de seu desenvolvimento, as estradas continuavam a ser transitadas exclusivamente por veículos de tração animal, embora já bastante aperfeiçoados.

Então, no final do século XIX, surgiram novos veículos, as bicicletas. As primeiras bicicletas produzidas em série percorriam silenciosamente as ruas de Paris, com seus pneus de borracha em vez das barulhentas rodas de madeira. A bicicleta possibilitou uma maior liberdade 
de movimento e contribuiu para uma revolução sexual, quando as mulheres, desejando a mesma liberdade de movimento dos homens, insistiram em ter suas próprias bicicletas e, para andar nelas, usaram calças (culotes) pela primeira vez (Hoffman, 2004).

Os primeiros carros a motor surgiram logo em seguida, no mesmo século, com velocidades inferiores a $16 \mathrm{~km} / \mathrm{h}$. O aperfeiçoamento do automóvel foi, a princípio, lento. Apenas no início do século XX, é que o automóvel passou a ser usado em escala comercial, devido ao barateamento dos custos de produção através das linhas de montagem idealizadas por Henry Ford.

No Brasil, durante o período da colonização e grande parte do Império, os transportes de mercadorias eram feitos por burros de carga e por carros de boi. Os passageiros viajavam a cavalo e, muito raramente, em carruagem de tração animal, pois havia um número muito reduzido de estradas apropriadas a esses veículos. A maioria das estradas existentes era caminhos de tropas, trafegadas também por carros de boi, por serem veículos rústicos e adaptáveis a condições adversas.

Nos primórdios do período colonial, o governo português estabelecera, nos contratos de doação de sesmarias, uma cláusula que tornava obrigatória para os sesmeiros a construção de estradas dentro dos limites de suas propriedades. Nos séculos seguintes, Portugal fizera constantes apelos às autoridades coloniais no Brasil para a construção de uma estrada que interligasse o Sul ao Norte do país, como estratégia alternativa de comunicação entre as várias províncias brasileiras, em caso de bloqueio marítimo por alguma potência estrangeira (Galvão, 2006).

Algumas estradas foram construídas no período imperial, entre as quais destacam-se a Via Anchieta, ligando São Paulo a Santos; a União Indústria, de Petrópolis a Juiz de Fora; a Estrela, de Magé a Petrópolis e a Graciosa, de Paranaguá a Curitiba. Porém, o desenvolvimento rodoviário no Brasil foi estimulado, a partir da década de 40 do século XX, com o Decreto-Lei 8.463 de 27 de dezembro de 1945, conhecido como Lei Joppert, que criou o Fundo Rodoviário Nacional, reorganizou o Departamento Nacional de Estradas de Rodagens e possibilitou a criação dos Departamentos de Estradas de Rodagens estaduais (Costa \& Figueiredo, 2001). Nesse período, houve um crescimento extraordinário da malha rodoviária. Porém, durante o Regime Militar, implantado no Brasil a partir de 1964, o Fundo Rodoviário foi sendo pulverizado para atender finalidades distintas daquelas para o qual foi criado, de tal forma que tornou-se insuficiente até mesmo para a conservação da rede existente. 
A história da utilização do asfalto também é muito antiga. Segundo a Bíblia, Noé calafetou sua barcaça com asfalto, material usado na Antiguidade para essa e outras finalidades em várias regiões do Oriente. No Egito, o asfalto era usado para embalsamar os mortos e calafetar pirâmides (Keller, 2002).

Mais recentemente, no século XIX, o asfalto obtido de forma natural, que ocorre ainda hoje em "lagos" na Ásia e também na Venezuela, fora inicialmente usado como medicamento nos EUA. Mas o advogado e empreendedor George Bissel, suspeitando das potencialidades do material, financiou pesquisas para a análise do petróleo, donde obteve-se, através da destilação, querosene e graxa. O próximo passo foi contratar um furador de poços artesianos para perfurar uma área em Titusville, onde o solo exsudava petróleo. Em agosto de 1859, ao perfurar apenas 20 metros, o ouro negro jorrou, dando início a uma nova etapa da história (Scientific American, 2004).

No Brasil, a história do asfalto começou em 1858, quando D. Pedro II assinou duas concessões de lavra, autorizando a exploração do carvão, turfa e betume. O belga Auguste Colon, pioneiro das pesquisas no Brasil, indicou Bofete, no estado de São Paulo, como uma região promissora para a exploração do petróleo. No entanto, em 1892, um cafeicultor furou um poço de 488 metros de profundidade em sua propriedade, mas só dois barris foram extraídos. Petróleo em quantidade só foi obtido a partir de 1939, num poço do campo de Lobato, no Recôncavo Baiano (Scientific American, 2004). Atualmente, o Brasil encontra-se auto-suficiente na produção do petróleo e a Petrobrás destaca-se como referência mundial em exploração de petróleo em altas profundidades marítimas.

O petróleo pode ser encontrado na natureza sob forma gasosa (gás natural), sólida (asfalto) e líquida (óleo crú). Esse material, produto de milhões e milhões de anos de decomposição de sedimentos orgânicos armazenados no subsolo terrestre, possui em sua complexa estrutura química uma enorme flexibilidade. Em estado bruto, todo petróleo é uma mistura complexa de hidrocarbonetos, ou seja, as mais variadas moléculas formadas basicamente por átomos de hidrogênio e carbono. Devido às suas propriedades químicas fundamentais, o carbono propicia várias possibilidades de combinações com outros elementos químicos, dando origem a substâncias de grande variedade estrutural (Scientific American, 2004).

Antes da introdução do asfalto como material de pavimentação, as estradas eram construídas basicamente com partículas rochosas de vários diâmetros, que proporcionavam travamento à estrutura. No entanto, a idéia primeira de usar o asfalto como material de pavimentação tem causado controvérsias históricas. Alguns historiadores afirmam que o asfalto fora usado pela 
primeira vez como material de pavimentação durante a construção da avenida Champs-Élysées, 1824, quando blocos de rochas asfálticas serviram de revestimento. Outros contestam, afirmando que a primeira mistura asfáltica a quente fora desenvolvida alguns anos antes, em 1820, na Inglaterra, produzida com um tipo de alcatrão para dar coesão entre as partículas dos agregados (Bellis, 2004b). Também muito se fala que a primeira mistura asfáltica idealizada foi a usada no projeto de pavimentação da Pennsylvania Avenue, em Washington, em 1876. Avenida essa, também chamada de Avenida dos Presidentes, cujo revestimento fora produzido com asfalto natural e agregado mineral, permanecendo em excelentes condições por 11 anos, apesar do tráfego intenso para a Casa Branca (Bellis, 2004a). Apesar dessas controvérsias históricas, uma das mais antigas citações sobre o uso do asfalto em pavimentação data de 700 a.C., indicando que habitantes da região da Mesopotâmia pavimentavam suas estradas, que ligavam templos e palácios das antigas cidades de Assur e Babilônia, com pedras e ladrilhos unidos com argamassa betuminosa (CEPA, 2006).

Acompanhando o crescimento da indústria de veículos automotores e da necessidade de pavimentação das vias de tráfego, aperfeiçoaram-se os meios e os recursos de exploração e processamento do petróleo. A sofisticação progressiva do processo de refino é uma conseqüência do desenvolvimento industrial e também uma resposta da indústria petroquímica às necessidades geradas pelas duas guerras mundiais do século XX. Na Primeira Guerra (1914 18), as grandes potências investiram em pesquisas de substitutos da borracha natural, produzida a partir do látex. A borracha sintética desenvolvida foi usada inicialmente na fabricação de pneus, isolantes e condutores elétricos. Na Segunda Guerra (1939 - 45), desenvolveu-se nova série de substitutos sintéticos, devido à carência de matérias primas tradicionais, a exemplo o asfalto (Scientific American, 2004).

Durante a Segunda Guerra, o comando militar estadunidense teve necessidade de produzir asfalto em grande escala, para a construção de pistas de pouso para aviões de grande porte. Para que o asfalto tivesse as características necessárias para a construção das pistas, os militares padronizaram uma receita de sua composição, equilibrando componentes mais leves (maltenos) e mais duros (asfaltenos), para que o produto final tivesse consistência, resistência e durabilidade necessárias. Esse padrão, definido em meados do século XX, mantém-se até hoje como referência industrial no mundo todo (Scientific American, 2004).

A história mostra que desde a antiguidade são estratégias de governo construir e manter seu sistema viário para garantir a soberania nacional e estimular o comércio e o desenvolvimento da nação. Conseqüentemente, também deve ser de interesse nacional o desenvolvimento de pesquisas que fomentem técnicas de construção de estradas, de maneira a avançar tecnicamente 
e otimizar a utilização dos materiais usados na pavimentação. Muitos são os exemplos de trabalhos desenvolvidos para promover avanços nesse sentido, dentre eles, as recentes pesquisas desenvolvidas pelo SHRP (Strategic Highway Research Program), com o objetivo de melhorar o desempenho, durabilidade e segurança das rodovias estadunidenses.

As tentativas incessantes de produzir pavimentos de qualidade superior e duráveis deparam-se com a falta de conhecimento profundo sobre os materiais usados na pavimentação, principalmente quando se trata de agregados. A importância dos agregados para a pavimentação tem sido demonstrada através de fatos, como a Via Ápia, construída há mais de 2.000 anos, e de vários trabalhos de pesquisa, nos quais muitos pesquisadores relatam a influência predominante dos agregados para a produção de misturas mais rígidas e resistentes ao cisalhamento, além de ser também aos agregados atribuída a responsabilidade principal de fornecer ligações adesivas eficientes com o asfalto. Até mesmo no estudo da resistência à fadiga das misturas, onde o asfalto merece destaque, o agregado exerce parcela de influência considerável.

Com vistas na importância indiscutível do agregado para a produção de misturas asfálticas de qualidade, neste trabalho, agregados minerais foram pesquisados e avaliados em seus aspectos qualitativos e quantitativos quanto à sua influência sobre o produto final, a mistura asfáltica. Definiu-se como etapa inicial de desenvolvimento a identificação dos parâmetros de desempenho das misturas que podem ser afetados pelas propriedades dos agregados e, posteriormente, a identificação das propriedades dos agregados que influenciam esses parâmetros de desempenho. Absorvidas essas informações, deu-se início às etapas laboratoriais do trabalho.

O objetivo maior deste trabalho é avaliar a influência das propriedades dos agregados estudados sobre as propriedades volumétricas e mecânicas das misturas asfálticas densas. Com base nisso, as pesquisas desenvolvidas envolveram:

- Análise das propriedades dos agregados:

- propriedades de consenso e de origem;

- densidade;

- porosidade;

- absorção;

- adesividade.

- Análise do comportamento da absorção de asfalto pelo agregado em função:

- do tempo; 
- do teor de asfalto;

- da porosidade do agregado.

- Análise das relações entre as propriedades volumétricas das misturas, as densidades dos agregados e a absorção de asfalto pelo agregado;

- Análise das propriedades volumétricas e granulométricas das misturas asfálticas;

- Análise do comportamento das propriedades volumétricas e mecânicas das misturas em função:

- da granulometria;

- do agregado;

- da energia de compactação aplicada.

Esta pesquisa está apresentada em 8 capítulos. Cada capítulo foi estruturado com considerações iniciais, desenvolvimento do assunto abordado, experimentos laboratoriais pertinentes ao assunto que versa cada capítulo, resultados, conclusões parciais e considerações finais.

O Capítulo 2 trata da caracterização dos agregados através das propriedades de consenso e de origem especificadas pelo Superpave, objetivando, além da obtenção de resultados experimentais, uma análise crítica sobre os critérios estabelecidos pelo SHRP para selecionar, avaliar e estabelecer limites para essas propriedades.

O Capítulo 3 apresenta uma discussão sobre o fenômeno da absorção de asfalto pelos agregados com base em seus princípios fundamentais, assim como, apresenta uma investigação laboratorial sobre a absorção em função do tempo e do teor de asfalto presente na mistura, com o objetivo de prever seu comportamento durante os processos de mistura e ao longo da vida em serviço do pavimento.

O Capítulo 4 traz uma visão global das relações entre densidades dos agregados, absorção e propriedades volumétricas das misturas. São apresentados métodos adequados de determinação das propriedades volumétricas, além de exemplos reais da dimensão dos erros cometidos no cálculo dos parâmetros volumétricos ao se negligenciar a absorção de asfalto.

O Capítulo 5 trata das relações granulométricas e de superfície dos agregados com as propriedades volumétricas das misturas, bem como esclarece a evolução, ao longo dos anos, dos métodos de projeto e de determinações granulométricas estabelecidos com base em critérios volumétricos. Além de uma conceituação histórica sobre a evolução dos métodos de 
determinação da granulometria, esse capítulo traz uma discussão sobre os métodos Bailey e Superpave de especificação e controle granulométrico. Os resultados laboratoriais apresentados são referentes à dosagens de misturas produzidas ora com um mesmo tipo de agregado, porém com granulometrias diferentes, ora com uma mesma granulometria, porém com tipos de agregados diferentes, com o objetivo de avaliar a influência desses fatores na variação das propriedades volumétricas.

No Capítulo 6 é apresentada a pesquisa desenvolvida sobre os vazios do agregado mineral (VAM) em função da energia de compactação aplicada e sua implicação nas propriedades volumétricas das misturas. Já o Capítulo 7 trata das alterações mecânicas sofridas pelas misturas em função da energia de compactação aplicada, assim como traz as avaliações quanto às propriedades adesivas das misturas.

No Capítulo 8 apresentam-se as conclusões finais do trabalho, com especial atenção às propostas de desenvolvimento de estudos futuros. Nos apêndices A e B encontram-se, respectivamente, a análise petrográfica do agregado de gabro estudado e as tabelas referentes às análises estatísticas efetuadas.

Algumas observações antecipadas, ao início da leitura desta tese, são agora citadas, com o objetivo de elucidar possíveis equívocos. Dentre elas, a que nesta pesquisa o termo agregado é utilizado referindo-se a materiais não coesivos de fragmentos de rochas. O termo areia natural empregado nesta tese não se refere à fração granulométrica, mas ao tipo de agregado utilizado. O termo agregado fino refere-se às partículas de agregados passantes na peneira de abertura de $2,36 \mathrm{~mm}$ e retidas na peneira de $0,075 \mathrm{~mm}$, enquanto o termo agregado grosso diz respeito às frações do agregado retidas na peneira de $2,36 \mathrm{~mm}$ e fíler mineral refere-se às partículas passantes na peneira de $0,075 \mathrm{~mm}$.

Vale mencionar, também, que a redação desta tese foi desenvolvida utilizando o sistema de tipografia e compilação eletrônica de textos $\mathrm{LT}_{\mathrm{E}} \mathrm{X}$, juntamente com a ferramenta de gerenciamento de referências $\mathrm{BIBT}_{\mathrm{E}} \mathrm{X}$, de maneira a facilitar o tratamento das referências, imagens e tabelas e pela qualidade de impressão observada na versão final deste documento. Além desse sistema de tipografia, optou-se pela utilização do sistema operacional GNU/Linux ${ }^{1}$, através da distribuição Slackware ${ }^{2}$, por ser um sistema altamente estável e produtivo, quando comparado ao demais sistemas operacionais disponíveis atualmente. Em resumo, optou-se pela utilização de software livre em todas as etapas da editoração eletrônica desta tese.

\footnotetext{
${ }^{1}$ http://www.linux.org

${ }^{2} \mathrm{http}: / / w w w . s l a c k w a r e . o r g$
} 


\section{CAPÍTULO}

\section{Propriedades dos Agregados Especificadas pelo Superpave}

\subsection{Considerações Iniciais}

Os estudos do SHRP (Strategic Highway Research Program), agrupados e patenteados sob a denominação Superpave (Superior Performing Asphalt Pavements), desenvolveram métodos de análise de ligantes asfálticos e de misturas asfálticas com base em propriedades fundamentais, diretamente destinados à redução e ao controle da deformação permanente, das trincas por fadiga e das trincas devido a temperaturas baixas. Muito do SHRP focou o desenvolvimento de ensaios e especificações para os ligantes asfálticos, assim como ensaios e especificações para as misturas asfálticas, não havendo, de início, esforços de pesquisa específicos para os agregados.

Devido à importância fundamental dos agregados para o estudo das misturas asfálticas, os pesquisadores do SHRP perceberam que teria de ser tomada alguma providência. Para conseguir informações relevantes, em um curto espaço de tempo e com um mínimo de pesquisa bibliográfica e experimental, decidiram por realizar uma abordagem consensual entre um grupo de 14 especialistas, mediante utilização do método de Delfos modificado. 
O método de Delfos, desenvolvido na década de 50 e 60 por Brown ${ }^{1}$; Dalkey ${ }^{2}$; Dalkey \& Helmer ${ }^{3}$ apud Cominsky et al. (1994), tem como principal aspecto o anonimato dos participantes, para evitar o efeito negativo que pode resultar de um grupo dinâmico, em tomadas de decisões conjuntas.

O método de Delfos é geralmente aplicado através do uso de questionários, os quais são administrados por um coordenador. Os especialistas interagem somente com o coordenador e não com os outros membros do grupo. O processo é evolutivo, ocorrendo através de uma série de etapas (tipicamente de quatro a seis), as quais começam com um assunto geral e convergem para um assunto específico. Ao final de cada etapa, o coordenador coleta os questionários e, através de análises estatísticas, faz um resumo classificatório das respostas, que é disponibilizado aos participantes junto com o questionário seguinte. Após, os participantes são questionados quanto à possibilidade de reconsiderar suas respostas prévias em vista das respostas dos outros membros e, só então, passam para o próximo questionário. Esse processo tende a estreitar as divergências entre as respostas, contudo não garante um consenso (Cominsky et al., 1994).

O SHRP utilizou um método de Delfos modificado, que permite o encontro face-a-face entre os membros do grupo durante todo o processo. Essa modificação foi implantada na tentativa de obtenção de um maior número de informações possíveis, em um menor espaço de tempo, para o estabelecimento das especificações dos agregados (Smith, 1992). O procedimento de Delfos modificado foi aplicado em cinco etapas, onde a primeira, a quarta e a quinta etapas foram conduzidas via correio. A segunda e a terceira etapas foram conduzidas em Washington, durante um encontro de todos os especialistas.

Com base nos resultados obtidos através do método de Delfos modificado, as propriedades dos agregados que devem ser controladas para a obtenção de materiais adequados ao propósito da pavimentação são:

- Controle da granulometria, definida por pontos de controle e uma zona de restrição;

- Angularidade do agregado grosso, definida como a porcentagem em massa das partículas dos agregados maiores que $4,75 \mathrm{~mm}$ com uma ou mais faces fraturadas;

\footnotetext{
${ }^{1}$ Brown, B. B. (1968). Delphi Process: A methodology used for the elicitation of opinions of experts. Relatório Técnico P-3925, RAND Corporation, Washington.

${ }^{2}$ Dalkey N. C. (1967). Delphi. Relatório Técnico P-3704, RAND Corporation, Washington.

${ }^{3}$ Dalkey N. C.; Helmer, O. (1951). The use of experts for the estimation of bombing requirements - A project Delphi experiment. Relatório Técnico RM-727, RAND Corporation, Washington.
} 
- Angularidade do agregado fino, definida como a porcentagem de vazios de uma amostra de agregados não compactados, como determinada no National Aggregates Association Test Method A;

- Resistência à abrasão, definida como a porcentagem de perda de material quando a amostra de agregados é submetida ao ensaio de abrasão Los Angeles;

- Sanidade, definida como a porcentagem de degradação da amostra, ao ser submetida ao ensaio de sanidade do agregado com uso de sulfato de sódio ou sulfato de magnésio;

- Materiais deletérios, definida como uma porcentagem em massa de contaminantes indesejáveis;

- Finos Plásticos, definida como a proporção relativa de finos plásticos contidos nos agregados, quando submetidos ao ensaio do equivalente de areia;

- Partículas planas e alongadas ou lamelaridade das partículas, definida como a porcentagem, em massa, das partículas do agregado grosso que têm razão, entre a máxima dimensão (comprimento) e a mínima dimensão (espessura), maior que 5.

Os resultados também demonstram que, na opinião dos especialistas, as propriedades das misturas asfálticas que devem ser controladas são:

- Volume de vazios, definido pelo volume dos vazios de ar contidos entre as partículas do agregado cobertas pelo filme de asfalto, em uma mistura asfáltica compactada;

- Vazios do agregado mineral, definidos como a soma do volume de vazios e o volume de asfalto efetivo, expresso como uma porcentagem do volume total da mistura compactada;

- Vazios preenchidos por asfalto ou relação betume-vazios, definidos como a porcentagem dos vazios do agregado mineral que são preenchidos por asfalto;

- Teor de fíler (dust to asphalt ratio), definido como a razão entre a porcentagem, em massa, do material passante na peneira de abertura de 0,075 $\mathrm{mm}$ (\# $n$. 200) pelo teor efetivo de asfalto, expresso como porcentagem da massa total da mistura.

Detalhes sobre as propriedades das misturas asfálticas, selecionadas pelos especialistas do SHRP e incorporadas pelo Superpave, são apresentados no Capítulo 5.

As propriedades dos agregados, consideradas pelo Superpave como de fundamental importância para a seleção de agregados adequados à pavimentação, foram classificadas dentro de duas categorias: propriedades de consenso e propriedades de origem, a seguir apresentadas. 


\subsection{Propriedades de Consenso}

O consenso do grupo de especialistas é que as propriedades de angularidade do agregado grosso, angularidade do agregado fino, partículas planas e alongadas e finos plásticos são críticas e devem ser avaliadas em todos os casos, a fim de demonstrar a adequabilidade ou não dos agregados para gerar misturas com desempenho satisfatório.

\subsubsection{Angularidade do Agregado Grosso}

Há muitos anos tem-se notado que a angularidade das partículas dos agregados influenciam diretamente a estabilidade e a trabalhabilidade das misturas asfálticas. A angularidade ou arredondamento são características atribuídas segundo o grau de amaciamento dos cantos ou arestas das partículas. Agregados angulares, ou seja, com cantos agudos, proporcionam maior intertravamento e atrito interno entre suas partículas, formando uma estrutura granular mais rígida e proporcionando maior estabilidade às misturas. Já as partículas dos agregados com cantos arredondados, ao invés de intertravarem-se, tendem a deslizar umas sobre as outras, resultando em uma estrutura granular mais fraca e, portanto, em misturas menos estáveis.

Por outro lado, as misturas que contêm partículas com cantos arredondados, como os seixos, possuem melhor trabalhabilidade e requerem menor esforço de compactação para se atingir a densidade necessária. Porém, essa facilidade de compactação não é necessariamente uma vantagem, pois quando a mistura possui fácil compactação durante a construção pode continuar a se densificar sob a ação do tráfego, causando deformação permanente.

O Superpave especifica o ensaio de Porcentagem de Partículas Fraturadas para Agregados Grossos (ASTM D 5821) para a avaliação da angularidade do agregado grosso. Esse ensaio consiste na avaliação visual de partículas de agregados grossos (maiores que 4,75 $\mathrm{mm}$ ou \# n. 4) selecionando as partículas que apresentem ou não faces fraturadas (Figura 2.1).

O Superpave especifica valores mínimos maiores de porcentagens de partículas fraturadas com o aumento do tráfego ou com a proximidade da camada em relação à superfície do pavimento, como se pode verificar na Tabela 2.1. 


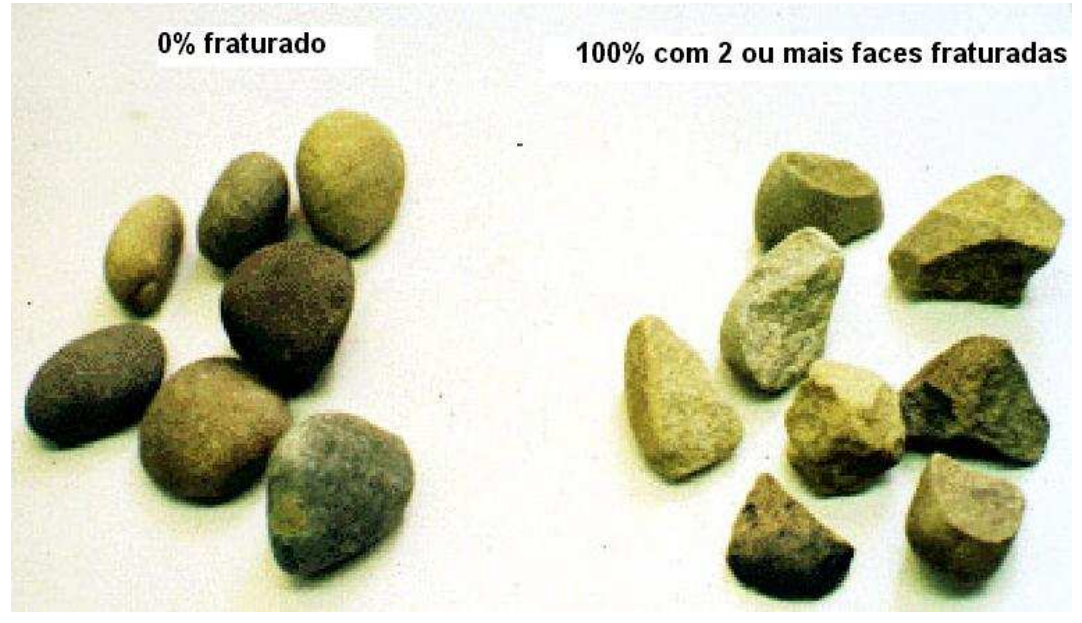

Figura 2.1: Ensaio de determinação de partículas fraturadas

Tabela 2.1: Especificação Superpave para valores mínimos de partículas fraturadas

\begin{tabular}{ccc}
\hline $\begin{array}{c}\text { Tráfego } \\
\mathbf{N}=\mathbf{1 0}^{\mathbf{6}}\end{array}$ & \multicolumn{2}{c}{$\begin{array}{c}\text { Profundidade da camada em relação } \\
\text { à superfície do pavimento }\end{array}$} \\
\hline & $<\mathbf{1 0 0} \mathbf{~ m m}$ & $>\mathbf{1 0 0} \mathbf{~ m m}$ \\
\hline$<0,3$ & $55 /-$ & $-/-$ \\
$<1$ & $65 /-$ & $-/-$ \\
$<3$ & $75 /-$ & $50 /-$ \\
$<10$ & $85 / 80$ & $60 /-$ \\
$<30$ & $95 / 90$ & $80 / 75$ \\
$<100$ & $100 / 100$ & $95 / 90$ \\
$\geq 100$ & $100 / 100$ & $100 / 100$ \\
\hline
\end{tabular}

Obs.: "85/80" significa que $85 \%$ do agregado grosso têm pelo menos uma face fraturada e $80 \%$ têm pelo menos duas faces fraturadas (Cominsky et al., 1994).

\subsubsection{Angularidade do Agregado Fino}

Devido à dificuldade de avaliação visual das partículas de agregados finos e ao grande tempo consumido nesses processos de avaliação, o Superpave adota o ensaio do National Aggregates Association Test Method A para a determinação indireta da forma, da angularidade e da textura superficial das partículas. Esse ensaio é comumente encontrado na literatura inglesa sob a denominação FAA (Fine Aggregate Angularity), em português AAF (angularidade do agregado fino). Através do ensaio AAF, normalizado pela ASTM C 1252, pode-se determinar a porcentagem dos vazios não compactados contidos entre as partículas de agregados, quando estas são vertidas de uma altura de queda estabelecida, dentro de um cilindro de volume conhecido $\left(100 \mathrm{~cm}^{3}\right)$, conforme ilustra a Figura 2.2. 


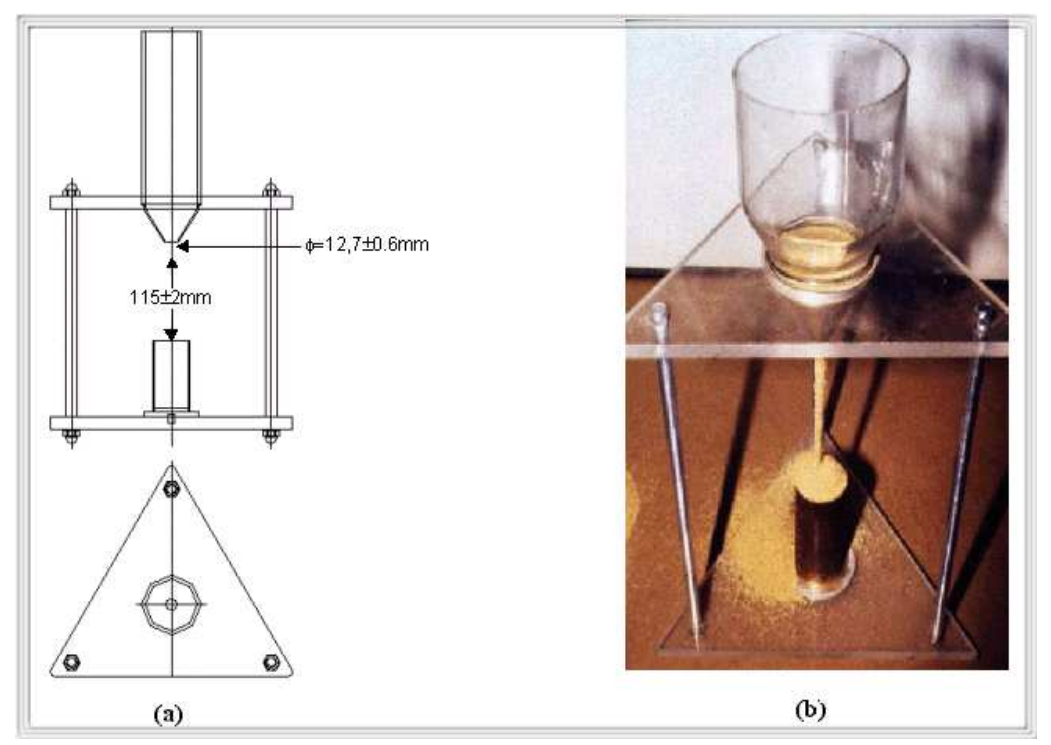

Figura 2.2: Ensaio de angularidade do agregado fino

Valores mais elevados de AAF serão encontrados quanto maior a angularidade e rugosidade das partículas, pois quando estas caem livremente umas sobre as outras, sem sofrer acomodação por compactação, suas arestas e cantos agudos fazem com que fiquem mais distantes umas das outras, aumentando o volume de vazios entre partículas. Já as partículas menos angulares (com cantos arredondados) e com textura superficial lisa, ao caírem livremente umas sobre as outras, acomodam-se com mais facilidade, diminuindo assim o volume de vazios existentes entre partículas, proporcionando valores de AAF menores.

Estudos de avaliação do ensaio de angularidade do agregado fino, desenvolvidos por Gouveia (2002), indicam que esse ensaio não é sensível aos efeitos da forma da partícula. Partículas cúbicas, que são mais desejáveis para o propósito da pavimentação, com angularidade e textura superficial adequadas, podem apresentar valores menores de AAF que partículas com formas planas.

\section{Métodos do Ensaio AAF}

O ensaio AAF pode ser realizado de acordo com três métodos distintos (A, B ou C). No método A, a granulometria da amostra é controlada através das frações utilizadas e das porcentagens retidas de material em cada fração, como apresentado na Tabela 2.2. No Método B, a granulometria da amostra também é controlada, sendo usada, para cada fração, uma quantidade de $190 \mathrm{~g}$ de material (Tabela 2.2). Porém, nesse método, o ensaio é realizado para cada fração do agregado separadamente, onde o valor de AAF corresponderá à média das três determinações feitas para cada fração. Já no Método C, não há controle da granulometria. A 
amostra ensaiada será composta por $190 \mathrm{~g}$ de agregado fino passante na peneira de 4,75 $\mathrm{mm}$ (\# n.4).

Tabela 2.2: Frações granulométricas usadas nos métodos A e B

\begin{tabular}{ccc}
\hline $\begin{array}{c}\text { Peneiras } \\
(\mathbf{m m})\end{array}$ & $\begin{array}{c}\text { Método A } \\
\text { massa }(\mathbf{g})\end{array}$ & $\begin{array}{c}\text { Método B } \\
\text { massa }(\mathbf{g})\end{array}$ \\
\hline $2,36-1,18$ & 44 & 190 \\
$1,18-0,60$ & 57 & 190 \\
$0,60-0,30$ & 72 & 190 \\
$0,30-0,15$ & 17 & - \\
Total & 190 & - \\
\hline
\end{tabular}

(ASTM C 1252)

Os estudos realizados por Fernandes et al. (2000) demonstram que a granulometria utilizada em cada método do ensaio afeta o volume de vazios não compactados entre as partículas (AAF). Os resultados apresentados pelos pesquisadores mostram que agregados melhor graduados, como ocorre no método A, apresentam menor volume de vazios não compactados do que agregados contendo partículas mais uniformemente graduadas, como no método B. No entanto, apesar dos métodos apresentarem valores de AAF de magnitudes diferentes, os métodos A e $\mathrm{B}$ resultam em uma mesma hierarquização, indicando que ambos os métodos são sensíveis às mesmas características dos agregados e que, para o propósito de classificação, são equivalentes.

\section{Limites de AAF Especificados pelo Superpave}

O Superpave especifica valores mínimos crescentes de AAF com o aumento do nível de tráfego ou com a proximidade da camada em relação à superfície do pavimento, como se pode verificar na Tabela 2.3. Os especialistas do SHRP acreditavam que quanto maior o nível de solicitação do pavimento, mais resistentes ao cisalhamento deveriam ser as misturas e, portanto, partículas mais angulares e rugosas deveriam ser usadas. A especificação Superpave estabelece o valor de AAF igual a $45 \%$ como o mínimo admissível para rodovias com volume de tráfego alto. Para volume de tráfego médio, especifica valores entre $40 \%$ e $45 \%$ e, para volume de tráfego baixo, não atribui valor para AAF, pois as areias naturais com AAF menores que $40 \%$ são consideradas aceitáveis. 
Tabela 2.3: Especificação Superpave para valores mínimos da AAF (método A)

\begin{tabular}{|c|c|c|}
\hline \multirow[t]{2}{*}{$\begin{array}{c}\text { Tráfego } \\
\mathrm{N}=10^{6}\end{array}$} & \multicolumn{2}{|c|}{$\begin{array}{c}\text { Profundidade da camada em relação } \\
\text { à superfície do pavimento }\end{array}$} \\
\hline & $<100 \mathrm{~mm}$ & $>100 \mathrm{~mm}$ \\
\hline$<0,3$ & - & - \\
\hline$<1$ & 40 & - \\
\hline$<3$ & 40 & 40 \\
\hline$<30$ & 45 & 40 \\
\hline$<100$ & 45 & 45 \\
\hline$\geq 100$ & 45 & 45 \\
\hline
\end{tabular}

(Cominsky et al., 1994)

\subsubsection{Partículas Planas e Alongadas}

A forma ideal dos agregados, para uso em misturas asfálticas, é a arredondada, porém, ao considerar que a partícula deve ser também angulosa, pode-se entender como forma ideal a cúbica. As características de forma e de angularidade das partículas não devem ser confundidas, pois, independentemente de sua forma, as partículas podem possuir angularidades distintas, ou seja, ter seus cantos e arestas agudos ou desgastados.

A utilização de partículas com formas planas e/ou alongadas em misturas asfálticas pode causar vários problemas, dentre eles, a quebra de partículas durante a compactação e a diminuição da trabalhabilidade da mistura. Quebras, além de alterar a granulometria da mistura, fazem com que o filme de asfalto que cobre o agregado se rompa, facilitando a entrada de umidade dentro do agregado e podendo ocasionar problemas de adesividade entre o asfalto e o agregado. Além disso, o uso de quantidades excessivas de partículas planas e/ou alongadas diminui a trabalhabilidade da mistura, dificultando a compactação e promovendo um consumo maior de asfalto, pois, partículas planas e/ou alongadas possuem superfície específica maior que partículas de forma cúbica. Assim, na tentativa de minimizar os problemas causados pelo uso de quantidades excessivas dessas partículas, o ensaio de Partículas Planas e Alongadas em Agregados Grossos (ASTM D 4791), adaptado do ensaio U.S. Army Corps of Engineers Method CRD-C 119, foi adotado pelo Superpave.

Esse ensaio consiste na utilização de um paquímetro para medir a razão dimensional das partículas dos agregados grossos, possibilitando a determinação das porcentagens de partículas planas, alongadas e planas/alongadas (lamelares) contidas na amostra. O paquímetro dimensional possibilita a avaliação de razões de $2: 1,3: 1$ e $5: 1$ (Figura 2.3). 


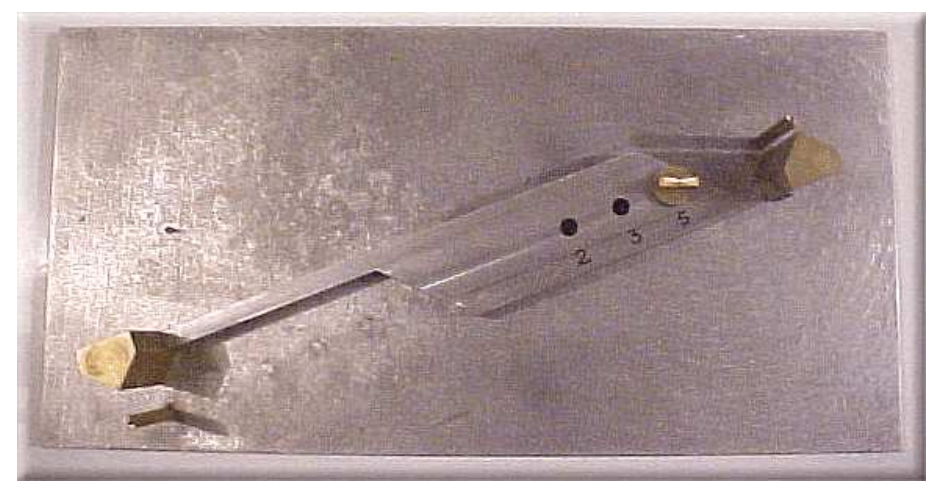

Figura 2.3: Paquímetro dimensional usado nesta pesquisa

A determinação Superpave é para que se use no máximo 10\% de partículas planas/alongadas (lamelares) na produção de misturas asfálticas utilizadas em pavimentos com volume de tráfego médio a alto (Tabela 2.4).

Tabela 2.4: Especificação Superpave para partículas planas/alongadas

\begin{tabular}{cc}
\hline $\begin{array}{c}\text { Tráfego } \\
\mathbf{N}=\mathbf{1 0}^{\mathbf{6}}\end{array}$ & $\begin{array}{r}\text { Porcentagem máxima de partículas com razão dimensional } \\
\text { comprimento/espessura maiores que } 5: 1\end{array}$ \\
$<0,3$ & - \\
$<1$ & - \\
$<3$ & 10 \\
$<10$ & 10 \\
$<30$ & 10 \\
$<100$ & 10 \\
$\geq 100$ & 10 \\
\hline
\end{tabular}

(Cominsky et al., 1994)

\subsubsection{Finos Plásticos}

Como última propriedade, dentre as classificadas no grupo de propriedades de consenso, tem-se a dos finos plásticos contidos nos agregados. Considera-se como finos plásticos os argilominerais ou partículas muito finas (frações argilosas) que possam, mesmo em pequenas quantidades, ser prejudiciais ao desempenho das misturas asfálticas, especialmente quando se encontrem como uma camada de pó sobre a superfície da partícula. Nesse caso, o asfalto pode aderir na camada argilosa (pó) fixada sobre a partícula ao invés de aderir na superfície do agregado, ocasionando vários tipos de problemas, dentre eles, a desagregação do agregado da mistura em decorrência do descolamento da película de asfalto.

A quantificação dos finos plásticos ou da fração argilosa contidos no agregado pode ser feita através do ensaio do equivalente de areia, desenvolvido na Divisão de Estradas da Califórnia 
(California Division of Highways), sob a orientação de Francis N. Hveem. A transcrição, na íntegra, do resumo do trabalho Sand Equivalent Test for Control of Materials During Construction de autoria de Hveem e publicado em 1953 nos anais do Highway Research Board (HRB), vol. 32, está a seguir apresentado, para que se possa encontrar as origens do ensaio e o seu significado.

"O ensaio do equivalente de areia para o controle da qualidade de agregados de misturas betuminosas e de bases não tratadas está sendo proposto para ser incluído nas Standard Specifications of the California Division of Highways e apresenta-se correntemente em cláusulas especiais de muitos contratos.

A rapidez das construções tem aumentado incessantemente há vários anos. As dimensões das empreiteiras e a quantidade de equipamentos de transporte utilizados nas obras demonstram que os materiais para bases, sub-bases e revestimentos betuminosos estão sendo produzidos e transportados em enormes proporções comparativamente ao que se via anos atrás. Muitas cascalheiras ou pedreiras apresentam quantidades variáveis de materiais finos, os quais podem também variar desde areia fina a argila e, freqüentemente, essas frações não são distribuídas uniformemente. O excesso de argila é, em geral, prejudicial ao desempenho de qualquer agregado, quer nas bases de cascalho, nas misturas betuminosas ou no concreto de cimento portland. É importante que o engenheiro de campo possa verificar com rapidez a presença de quantidades nocivas de materiais argilosos.

O termo "equivalente de areia" expressa a idéia de que a maioria dos solos, bases de cascalhos etc. são misturas de partículas graúdas, areia e, geralmente, indesejáveis partículas finas ou argila. O ensaio do equivalente de areia constitui um meio rápido para separar as partículas mais finas, como as argilas, dos grãos mais graúdos ou das areias, sendo as proporções relativas comparadas em uma base arbitrária de volumes por um processo simples, que tende a realçar ou expandir o volume de argila proporcionalmente aos efeitos prejudiciais ou indesejáveis dessa fração. O ensaio é aplicado em uma fração de material granular passante na peneira n. 4, requer aparelhagem relativamente simples e pode ser realizado em cerca de 40 minutos. Maior atenção deve ser direcionada para o significado fundamental das relações volumétricas em contraposição às porcentagens em massa comumente adotadas para descrever a composição dos solos e agregados."

O ensaio do equivalente de areia, como idealizado por Hveem, consiste em agitar energicamente a amostra de agregados finos numa proveta graduada contendo solução floculante, de 
modo a soltar as partículas de argilominerais ou da fração argilosa do próprio agregado, aderidas na superfície do agregado. A solução floculante força o material argiloso ou a fração argilosa a formar uma suspensão sobre o material granular, para, após um período curto de sedimentação, ser medida a altura da argila suspensa e da areia parcialmente sedimentada, determinando-se, assim, a relação entre volumes de areia e de argila (Figura 2.4). O valor do equivalente de areia é calculado como uma relação entre a leitura da altura da areia pela leitura da altura da argila, expresso em termos percentuais.

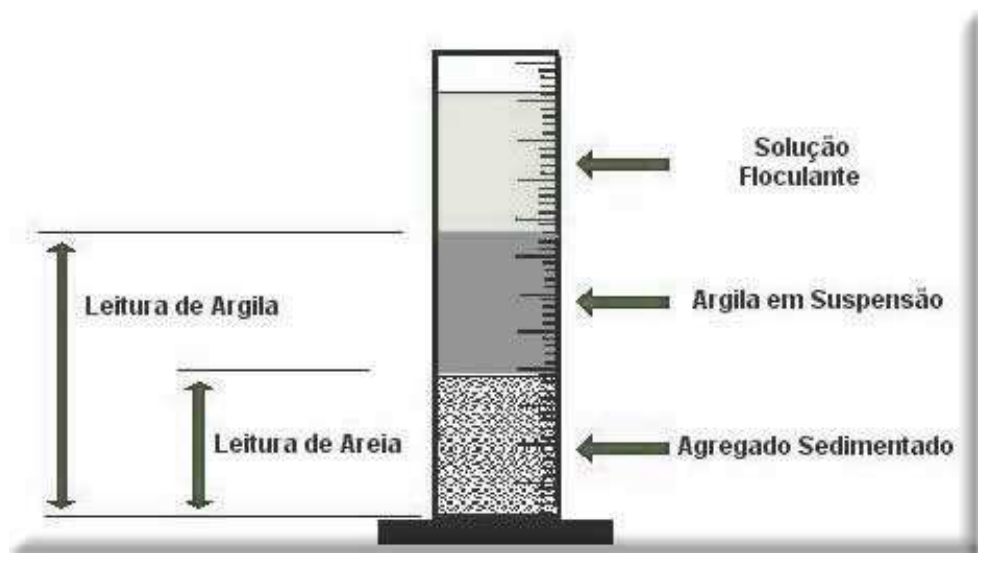

Figura 2.4: Ensaio do equivalente de areia

Na década de 1950, os valores mínimos do EA, especificados pelo California Division of Highways, variavam em relação ao tipo de camada na qual o agregado era utilizado, como mostra a Tabela 2.5 .

Tabela 2.5: Especificação do California Division of Highways para equivalente de areia

\begin{tabular}{lc}
\hline Tipo de camada & Equivalente de areia mínimo (\%) \\
\hline Base de agregado mineral britado ou natural & 30 \\
Tratamentos betuminosos & 35 \\
Concreto asfáltico & 55 \\
Misturas de areia e asfalto & 80 \\
\hline
\end{tabular}

(Hveem, 1953)

Atualmente, o método Superpave estabelece alguns valores mínimos do EA conforme o aumento do volume de tráfego, sendo indiferente quanto à camada do pavimento na qual o agregado será utilizado. Como pode ser visto na Tabela 2.6, um valor do EA igual a $50 \%$ é especificado como o mínimo admissível para rodovias com volume de tráfego alto. Já para as rodovias com volumes de tráfego médio e baixo são especificados valores mínimos do EA igual a $45 \%$ e $40 \%$, respectivamente. No Brasil, o valor mínimo do EA é de $55 \%$ para qualquer volume de tráfego (Motta et al., 1994). 
Tabela 2.6: Especificação Superpave para o equivalente de areia

\begin{tabular}{cc}
\hline Tráfego & Equivalente de areia mínimo \\
$\mathbf{N}=\mathbf{1 0}^{\mathbf{6}}$ & $\boldsymbol{\%}$ \\
\hline$<0,3$ & 40 \\
$<30$ & 45 \\
$\geq 30$ & 50 \\
\hline
\end{tabular}

(Cominsky et al., 1998)

\subsection{Propriedades de Origem}

O grupo de especialistas, selecionados pelo SHRP, também concordou que outras propriedades dos agregados eram críticas para o propósito da pavimentação. Entretanto, não houve consenso para os valores limites que deveriam ser estabelecidos para essas propriedades por serem muito dependentes da origem dos materiais. Assim, foi proposto que as propriedades de resistência à abrasão, sanidade e materiais deletérios, classificadas como de origem, tivessem seus valores limites estabelecidos pelos departamentos rodoviários de cada estado, por estes estarem familiarizados com os materiais próprios da região.

\subsubsection{Resistência à Abrasão}

Os agregados utilizados com o propósito de pavimentação são submetidos a vários processos de manipulação rigorosos, dentre eles a britagem, o armazenamento, a manipulação abrasiva durante a produção da mistura, o lançamento e espalhamento, seguido da compactação e, após o pavimento ser aberto ao tráfego, passam a resistir e a transmitir as cargas do tráfego às camadas subjacentes do pavimento. Para tanto, esses agregados devem ser resistentes o suficiente para que possam passar por esses processos sem sofrerem degradação ou polimento, que podem gerar graves problemas durante a construção e ao longo da vida em serviço do pavimento.

Existem alguns ensaios que procuram estabelecer a qualidade dos agregados em função de sua utilização. Dentre os mais conhecidos destaca-se o ensaio de abrasão Los Angeles, que, segundo Wu et al. (1998), é o ensaio utilizado por cerca de $94 \%$ das agências rodoviárias dos Estados Unidos. Esse ensaio foi desenvolvido mais ou menos na metade da década de 1920 pelo Municipal Testing Laboratory da cidade de Los Angeles, Califórnia (Kandhal \& Parker Jr., 1998), para a avaliação da resistência à degradação ou ao desgaste por abrasão e impacto, através da máquina Los Angeles. 
O ensaio consiste na colocação da amostra de agregado graúdo e esferas de ferro fundido no tambor da máquina Los Angeles, submetendo-as a movimentos rotatórios do tambor. $\mathrm{O}$ equipamento utilizado para a realização do ensaio pode ser visto na Figura 2.5. As rotações do tambor reproduzem o impacto sofrido pelo agregado durante a usinagem da mistura, através da queda das esferas de ferro fundido sobre os agregados e da queda dos próprios agregados, uns sobre os outros, e simula o desgaste por meio do atrito dos agregados entre si e com as paredes do tambor.

Terminado o período de rotações, o material é retirado do tambor, peneirado e determinada a massa remanescente do material. O resultado do ensaio é a porcentagem de perda do material em decorrência da degradação mecânica sofrida, ou seja, a porcentagem de massa do material grosso perdido durante as rotações do tambor. Os valores máximos aceitáveis, por exemplo, pelo DNER são de 50\% de perda e pelo DER-PR de 45\% (Motta et al., 1994).

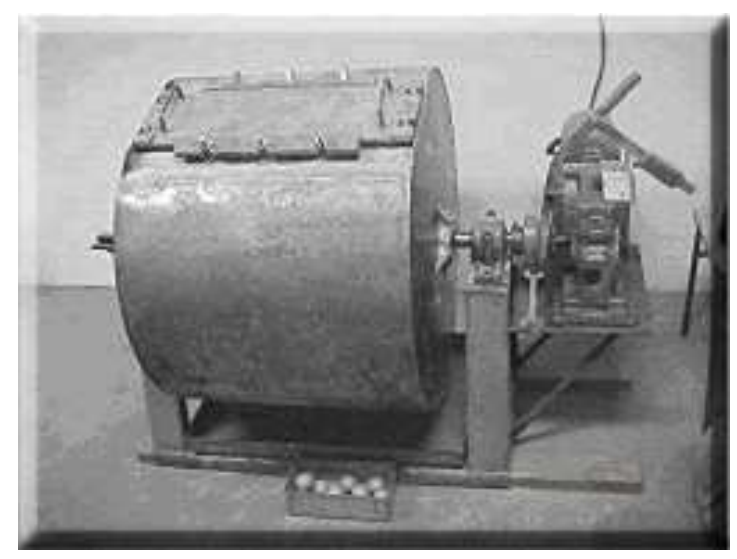

Figura 2.5: Máquina Los Angeles usada nesta pesquisa

\subsubsection{Sanidade}

Adicionalmente à resistência à degradação por abrasão e impacto, o agregado deve ter resistência à ação das intempéries, referentes a ciclos de molhagem e secagem e, no caso de regiões com invernos rigorosos, a ciclos de congelamento e descongelamento, sem sofrer quebras ou deterioração.

Pesquisadores como Wu et al. (1998) e Roberts et al. (1991) acreditam que os ciclos de molhagem e secagem, congelamento e descongelamento, não têm grande efeito nas misturas asfálticas se, durante a usinagem da mistura, for promovida a secagem total do agregado antes de ser envolvido pelo asfalto. Portanto, se o filme de asfalto que envolve a partícula do agregado permanecer intacto, impedindo assim que o agregado absorva quantidades significativas de umidade, os ciclos de molhagem e secagem e de congelamento e descongelamento não devem 
ocasionar problemas. Entretanto, se ocorrerem problemas de quebra de partículas (planas e alongadas) durante a construção ou causados pelo tráfego, ou ainda, problemas de perda de adesividade entre o asfalto e o agregado, a água pode penetrar nas partículas e, nesse caso, os ciclos de molhagem e secagem podem comprometer a integridade do pavimento, caso o agregado utilizado não apresente sanidade adequada.

Dentre os ensaios mais utilizados para avaliar a sanidade dos agregados destacam-se o ensaio de sanidade com uso de soluções de sulfato de sódio, empregado por $53 \%$ das agências rodoviárias dos Estados Unidos, e o ensaio de sanidade com uso de sulfato de magnésio, empregado por $19 \%$ das agências. As outras agências rodoviárias usam métodos de avaliação de perdas através de ciclos de congelamento e descongelamento e $16 \%$ não empregam nenhum método de determinação de sanidade (Wu et al., 1998).

Desenvolvido para detectar a presença de argilominerais contidos nas partículas de agregados de natureza basáltica que, quando expostos à ação das intempéries, prejudicam a durabilidade do agregado (Kandhal \& Parker Jr., 1998), o ensaio de sanidade é hoje utilizado para fornecer uma indicação da durabilidade, diante da ação do tempo, de agregados de diversas composições mineralógicas, tal qual um índice da qualidade geral.

O ensaio de sanidade consiste em submeter as amostras de agregados a ciclos de imersão em solução de sulfato de sódio ou sulfato de magnésio e, em seguida, promover a secagem do material em estufa. Uma imersão/secagem é chamada de ciclo de sanidade. Essa forma cíclica de desenvolvimento do ensaio se faz necessária para que, na etapa de imersão do primeiro ciclo, a solução salina penetre nos interstícios das partículas e, na etapa de secagem do primeiro ciclo, os sais da solução se cristalizem no interior das partículas. Quando iniciado o segundo ciclo, na etapa de imersão, os cristais de sal se hidratam e crescem nos interstícios das partículas, exercendo forças de expansão interna que causam a degradação das partículas não sãs.

O resultado do ensaio fornece a porcentagem de perda de material, devido à degradação, para um dado número de ciclos de sanidade. As Figuras 2.6(a) e 2.6(b) são ilustrativas da aparência do agregado antes e após serem submetidos aos ciclos de sanidade. Os valores máximos de perda admitidos, por exemplo, pelo DER-PR é de $12 \%$ para 5 ciclos de sanidade.

\subsubsection{Materiais Deletérios}

Geralmente são chamados de materiais deletérios partículas individuais constituídas de materiais fracos, reativos ou deteriorados, que inibam a cobertura dos agregados pelo asfalto, 


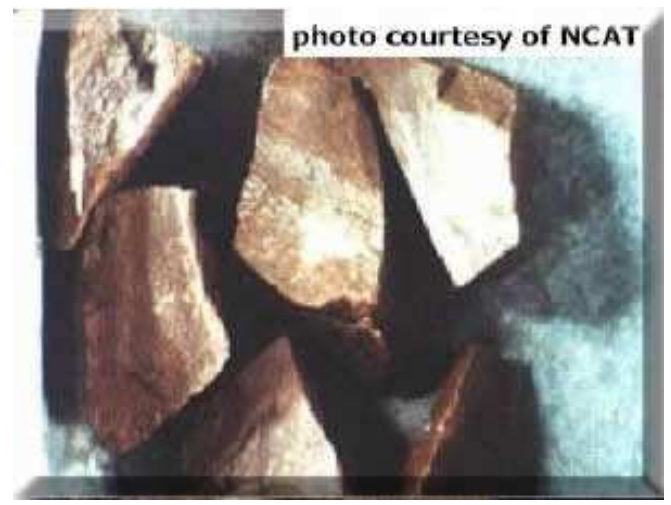

(a) Antes

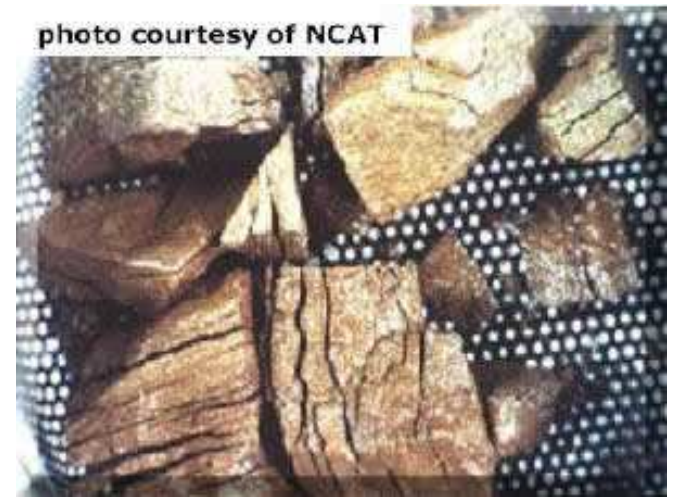

(b) Depois

Figura 2.6: Aparência do agregado antes e depois de submetido a ciclos de sanidade

que reajam com o meio ambiente ou que não sejam constituídas de material rochoso. Alguns exemplos de materiais considerados deletérios são: torrões de argila, xisto, carvão, partículas vítreas, mica livre e vegetação.

O ensaio de Torrões de Argila e Partículas Friáveis (ASTM C 142), adotado pelo Superpave para avaliar a presença de materiais deletérios tanto nas frações grossas como nas frações finas dos agregados, consiste no espalhamento de uma fina camada de partículas no fundo de um recipiente, cobrindo-as com água destilada e deixando-as submersas por um período de 24 horas. Após esse período, cada partícula é rolada e apertada entre os dedos polegar e indicador na tentativa de quebrá-la em partes menores. Qualquer partícula que se quebre é classificada como uma partícula friável. A quantidade máxima aceitável de materiais deletérios na amostra é bastante ampla, variando de $0,2 \%$ até $10 \%$, dependendo da composição dos contaminantes (Motta et al., 1994).

\subsection{Experimentos Laboratoriais}

\subsubsection{Agregados Estudados}

Três tipos de agregados minerais utilizados em obras de pavimentação asfáltica, foram selecionados: agregados de basalto, de gabro e de areia natural.

O agregado de basalto é proveniente da Pedreira Santa Isabel, localizada na cidade de Ribeirão Preto - SP. Para o agregado de areia natural foram selecionados dois materiais, devido à impossibilidade de usar apenas um tipo de areia natural que contivesse frações grossa e fina adequadas ao estudo. A areia natural do Rio Moji-Guaçú (Rincão - SP) foi escolhida para a 
composição da fração grossa da mistura e, para a composição da fração fina, foi selecionada a areia natural de cava, proveniente da Mineradora Jundu, localizada em Analândia - SP.

O agregado de gabro selecionado, procedente da Pedreira São Roque localizada em Limeira - SP, foi inicialmente denominado granito, com base nas informações dos especialistas da pedreira. Dúvidas quanto à origem e classificação do material foram levantadas, surgindo a necessidade de uma análise petrográfica da rocha. O material foi então analisado e classificado, no Departamento de Petrologia e Metalogenia, do Instituto de Geociências e Ciências Exatas, da Universidade Estadual Paulista em Rio Claro, como Leucodiabásio ou Leucogabro. O relatório completo da análise do material encontra-se no Apêndice A.

\subsubsection{Ensaio de Partículas Fraturadas}

O ensaio de determinação da porcentagem de partículas fraturadas contidas na amostra (ASTM D 5821) utilizado para a determinação da angularidade do agregado grosso, consiste em espalhar as partículas de agregados em uma superfície plana, limpa e grande o suficiente para proporcionar um exame visual cuidadoso de cada partícula. Cada partícula é classificada de acordo com o seu número de faces fraturadas, por exemplo, uma face fraturada (Figura 2.7(a)), duas ou mais faces fraturadas (Figura 2.7(b)), ou ainda, sem faces fraturadas (Figura 2.7(c)).

Considera-se como face fraturada do agregado a face que contém forma e bordas bem definidas e que expõem o interior da partícula através de uma área não inferior a $1 / 4$ da área máxima da partícula. A face fraturada apresenta-se como uma parte quebrada, rugosa e/ou angular, criada através de processos de britagem ou pela da ação da natureza.

A determinação da porcentagem de partículas fraturadas é realizada através da contagem ou pesagem das partículas, com um determinado número de faces fraturadas, em relação ao número total de partículas ou da massa total da amostra, como mostra a Equação 2.1.

$$
P F_{x}=\frac{F+\frac{Q}{2}}{F+Q+N} \times 100
$$

onde:

$P F_{x}=$ porcentagem de partículas com o número especificado de faces fraturadas;

$F=$ massa ou número de partículas com pelo menos o número especificado de faces fraturadas;

$Q=$ massa ou número de partículas que se encontram na categoria de fronteira;

$N=$ massa ou número de partículas que não possuem faces fraturadas. 


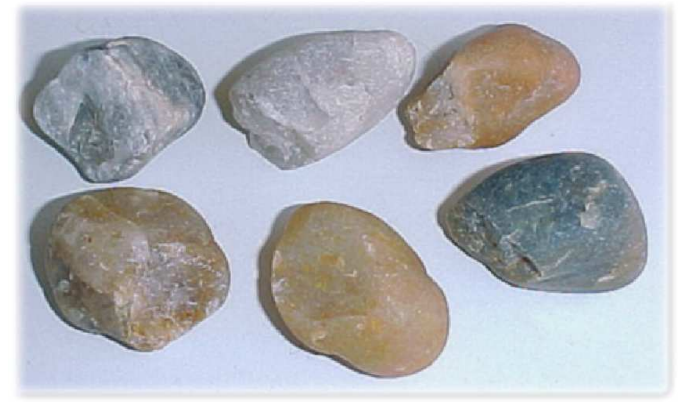

(a) Uma face fraturada

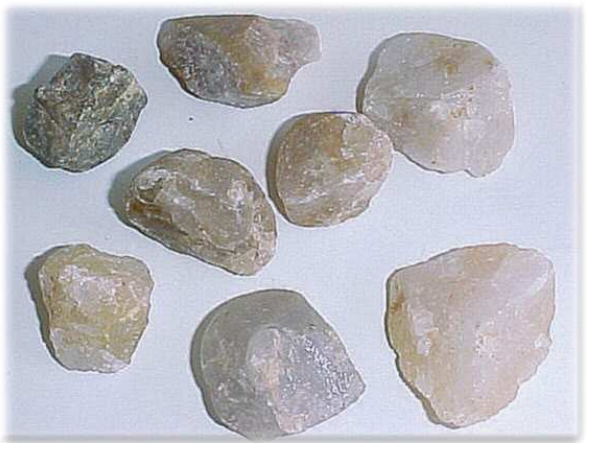

(b) Duas ou mais faces fraturadas

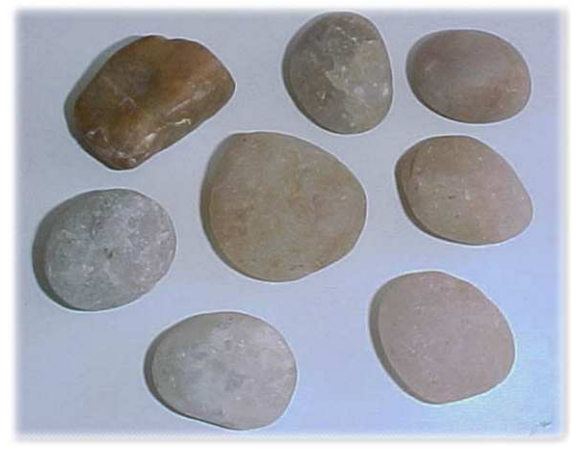

(c) Nenhuma face fraturada

Figura 2.7: Ensaio de porcentagem de faces fraturadas do agregado grosso - exemplo de avaliação do agregado de areia natural estudado nesta pesquisa

A classificação visual das partículas quanto ao número de faces fraturadas é passível de variações quando diferentes examinadores avaliam uma mesma amostra. Mas, embora as avaliações visuais para partículas individuais possam variar de modo significativo, estudos feitos por Rosenfeld e Griffiths ${ }^{4}$ apud Suguio (1973) demonstram que valores médios baseados em cinqüenta ou mais partículas tendem a ser representativos, pois os erros são compensados. Nesta pesquisa, o número total de partículas ensaiadas para cada amostra variou entre 175 a 220 partículas.

\subsubsection{Ensaio de Angularidade do Agregado Fino}

A angularidade do agregado fino é avaliada indiretamente através da determinação dos vazios formados entre as partículas do agregado, na condição não compactada, ou seja, quando a amostra é vertida de uma altura de queda de aproximadamente $115 \mathrm{~mm}$, dentro de um cilindro de volume de $100 \mathrm{~cm}^{3}$, como estabelece a norma da ASTM C 1252. O ensaio consiste em deixar a amostra cair livremente no interior do cilindro, retirar o excesso de material que se acumula sobre o topo do cilindro com o auxílio de uma espátula, tomando cuidado para não causar

\footnotetext{
${ }^{4}$ Rodenfeld, M. A.; Griffiths, J. C. (1953). An experimental test of visual technique in estimating two dimensional sphericity of quartz grains. Amer. Journal of Sci., n. 251, p. 553-585.
} 
nenhum tipo de vibração no cilindro, para que não ocorra acomodações entre as partículas. Após esse processo, faz-se a determinação da massa do agregado contida dentro do cilindro e, sendo conhecida a densidade aparente do agregado fino (ASTM C 128), pode-se calcular a porcentagem de vazios não compactados através da diferença entre o volume do cilindro e o volume de agregado contido no cilindro, como mostra a Equação 2.2.

$$
A A F=\frac{V-\frac{m_{a}}{\rho_{a p}}}{V} \times 100
$$

onde:

$A A F=$ vazios não compactados $(\%)$

$m_{a}=$ massa do agregado contida no cilindro $(g)$;

$\rho_{a p}=$ densidade aparente do agregado fino;

$V=$ volume do cilindro $\left(\mathrm{cm}^{3}\right)$.

Nesta pesquisa, o ensaio de AAF foi realizado utilizando-se o método A, que tem como característica o controle da granulometria da amostra (Tabela 2.2). O equipamento usado para a realização do ensaio teve seu projeto adaptado da norma ASTM C 1252 no setor de projetos do Departamento de Transportes, sendo posteriormente construído na oficina mecânica da Escola de Engenharia de São Carlos da Universidade de São Paulo.

\subsubsection{Ensaio de Partículas Planas e Alongadas}

O ensaio de análise de determinação das porcentagens de partículas planas, alongadas e planas/alongadas contidas nos agregados grossos, normalizado pela ASTM D 4791, consiste na utilização de um paquímetro dimensional (Figura 2.3) para medir a razão dimensional entre largura e espessura (planificação), largura e comprimento (alongamento) e entre o comprimento e a espessura (lamelaridade) de uma amostra representativa dos agregados grossos.

O paquímetro dimensional usado para a realização do ensaio teve seu projeto adaptado da norma ASTM D 4791 no setor de projetos do Departamento de Transportes, sendo posteriormente construído na oficina mecânica da Escola de Engenharia de São Carlos da Universidade de São Paulo.

Ao analisar as partículas utilizando o paquímetro dimensional, estas podem ser classificadas como: 
- partículas planas, se tiverem razão dimensional entre largura e espessura maior que proporções específicas, que no caso desta pesquisa são de $3: 1$ e $5: 1$;

- partículas alongadas, se tiverem razão dimensional entre comprimento e largura maior que $3: 1$ e $5: 1$;

- partículas planas/alongadas (lamelares), se tiverem razão dimensional entre comprimento e espessura maior que $3: 1$ e $5: 1$.

Um exemplo do procedimento básico de análise das partículas consiste em posicionar a abertura maior do paquímetro igual ao comprimento da partícula (Figura 2.8(a)) e tentar passar a espessura da partícula pela abertura menor do paquímetro (Figura 2.8(b)). Se a partícula passar pela abertura, ela é classificada como plana/alongada (lamelar), para a razão dimensional de $3: 1$.

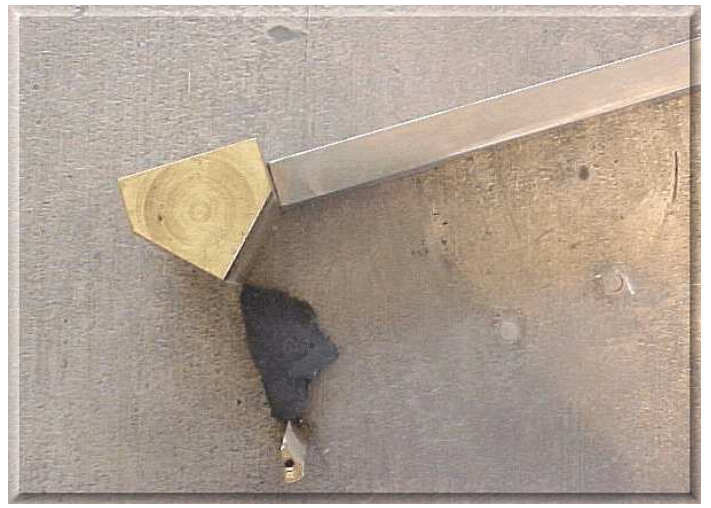

(a) Comprimento da partícula

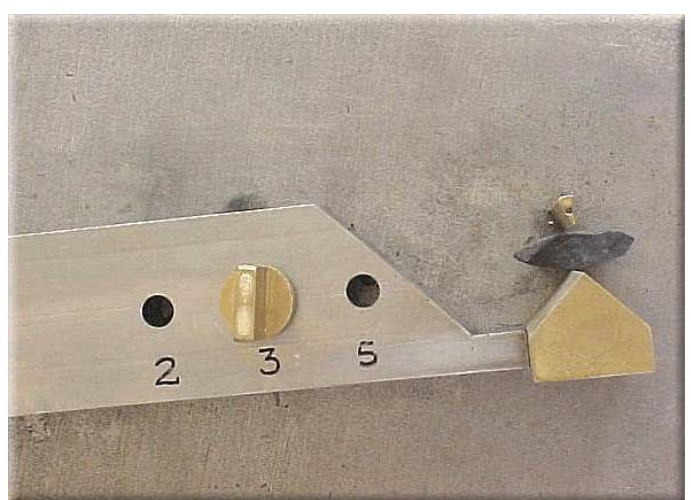

(b) Espessura da partícula

Figura 2.8: Ensaio de avaliação da forma da partícula - exemplo de avaliação do agregado de basalto estudado nesta pesquisa

Neste estudo, é considerado como comprimento a maior dimensão da partícula, como largura a maior dimensão da partícula em um plano perpendicular ao comprimento e como espessura a maior dimensão da partícula em um plano perpendicular ao comprimento e à largura (Figura 2.9).

É especificado pelo Superpave a avaliação da forma da partícula somente quanto à sua lamelaridade, com razão dimensional de $5: 1$, estabelecendo um limite máximo de 10\%. Porém, uma avaliação mais rigorosa da lamelaridade utilizando a proporção de $3: 1$ foi sugerida em 1998 pela Federal Highway Administration (FHWA), com base numa revisão feita pelo seu grupo de pesquisa (Cominsky et al., 1998). Atualmente, vários grupos de pesquisa estadunidenses como The Stone Matrix Asphalt Technical Working Group utilizam um limite mais rigoroso do que o especificado pelo Superpave, limite máximo de $5 \%$ para razão dimensional de $5: 1$ e também 


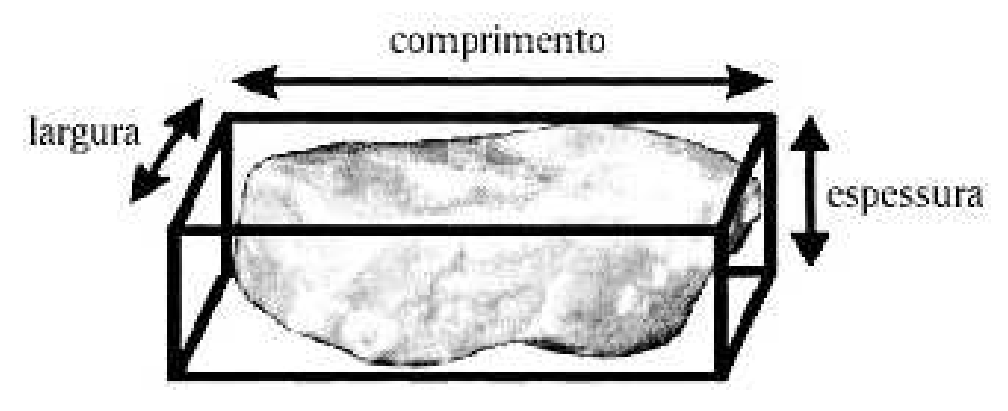

Figura 2.9: Dimensões da partícula do agregado (ASTM D 4791)

estabelecem análises para razão dimensional de $3: 1$ limitando a lamelaridade em 20\% (Prowell et al., 2005).

Independentemente da razão dimensional da partícula, uma discussão pode ser levantada quanto a análise de suas formas, ou seja, planicidade, alongamento e lamelaridade. O Superpave estabelece que seja feito um levantamento apenas da porcentagem de partículas lamelares do agregado estudado, ou seja, a porcentagem de partículas que têm o comprimento cinco vezes maior que sua espessura. No entanto, ao se tomar conhecimento da porcentagem de partículas lamelares, por exemplo de $30 \%$, o que isso significa? Significa que se tem $30 \%$ de partículas alongadas, que podem quebrar durante a compactação, ou então que se tem $30 \%$ de partículas planas, que causam vários problemas, dentre eles, a diminuição da durabilidade das misturas, em função da diminuição dos vazios do agregado mineral? A determinação da lamelaridade da partícula é questionável, pois não representa o quanto as partículas são planas nem o quanto são alongadas.

Em vista disso, nesta pesquisa, as partículas foram analisadas não somente quanto à sua lamelaridade (comprimento/espessura), mas também quanto à sua planicidade (largura/espessura) e quanto ao seu alongamento (comprimento/largura), utilizando razões dimensionais de $5: 1$ e também de $3: 1$, impondo, dessa forma, uma avaliação mais rigorosa. Nesta pesquisa, o número mínimo de partículas ensaiadas para cada amostra foi de 100 .

A porcentagem de partículas, de determinada classificação, pode ser calculada da seguinte maneira:

$$
\% P_{x}=\frac{C}{N} \times 100
$$

onde:

$\% P_{x}=$ porcentagem de partículas de determinada classificação (plana, alongada ou lamelar); $C=$ massa ou número de partículas de determinada classificação; 
$N=$ massa ou número total de partículas da amostra.

\subsubsection{Ensaio do Equivalente de Areia}

O equivalente de areia é uma relação volumétrica que corresponde à razão entre a altura do nível superior da areia e a altura do nível superior da suspensão argilosa de uma determinada quantidade de solo ou agregado fino, numa proveta, em condições estabelecidas no método. $\mathrm{O}$ método consiste em agitar energicamente a amostra de agregados finos, composta do material passante na peneira de abertura 4,75 $\mathrm{mm}$ (\# $n$. 4), numa proveta graduada contendo solução floculante, de modo a soltar as partículas de argilominerais ou da fração argilosa, aderidas ao agregado. Esse método, aqui apresentado, está baseado nas normas DNER ME 054 e ASTM D 2419.

\section{Procedimento para a obtenção da solução floculante}

O primeiro passo é obter a solução concentrada, composta por:

- $557 \mathrm{~g}$ de cloreto de cálcio anidro técnico;

- $2510 \mathrm{~g}$ ou $2010 \mathrm{ml}$ de glicerina U.S.P.;

- $57,5 \mathrm{~g}$ de solução de formaldeído a $40 \%$ em volume.

O procedimento de preparo consiste em dissolver o cloreto de cálcio em 2 litros de água destilada, agitando-se energicamente a solução. A solução de cloreto de cálcio funciona como agente floculante, acelerando a velocidade de sedimentação dos argilominerais ou da fração argilosa da amostra. Hveem (1953) justifica a escolha desse agente floculante por ser de relativamente baixo custo, estável e inofensivo à saúde.

Após a obtenção da solução, esta é filtrada utilizando um papel de filtro apropriado e, em seguida, a glicerina, a solução de formaldeído e os 5 litros de água destilada são adicionados à solução filtrada. A intenção de Hveem, ao adicionar uma quantidade de glicerina à solução, foi produzir um efeito estabilizador aumentando assim a reprodutibilidade do ensaio. Hveem (1953) também relata que o formaldeído só foi adicionado à solução para servir de agente destruidor dos fungos que tendem a formar-se na solução, de modo a torná-la estéril. A solução 
floculante ou solução de trabalho é então obtida após diluir $125 \mathrm{ml}$ da solução concentrada em água destilada, até completar 5 litros, misturando-as cuidadosamente.

\section{Descrição do ensaio}

A solução de trabalho é transferida para uma proveta, até atingir o traço de referência a $10 \mathrm{~cm}$ da base. A seguir, o conteúdo do recipiente de medida, preenchido com a amostra preparada (Figura 2.10), é transferido para a proveta com o auxílio de um funil.

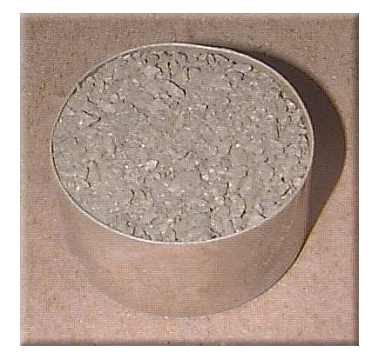

Figura 2.10: Amostra utilizada no ensaio do equivalente de areia

Em seguida, bate-se várias vezes com a mão no fundo da proveta, para deslocar as bolhas de ar e ajudar a molhar a amostra. Então, a proveta é deixada em repouso durante 10 minutos. Passados os 10 minutos, a proveta é tapada com uma rolha de borracha e agitada horizontalmente (90 vezes em 30 segundos) num movimento alternado, como ilustra a Figura 2.11. Essa agitação pode ser realizada manualmente ou através de equipamentos.

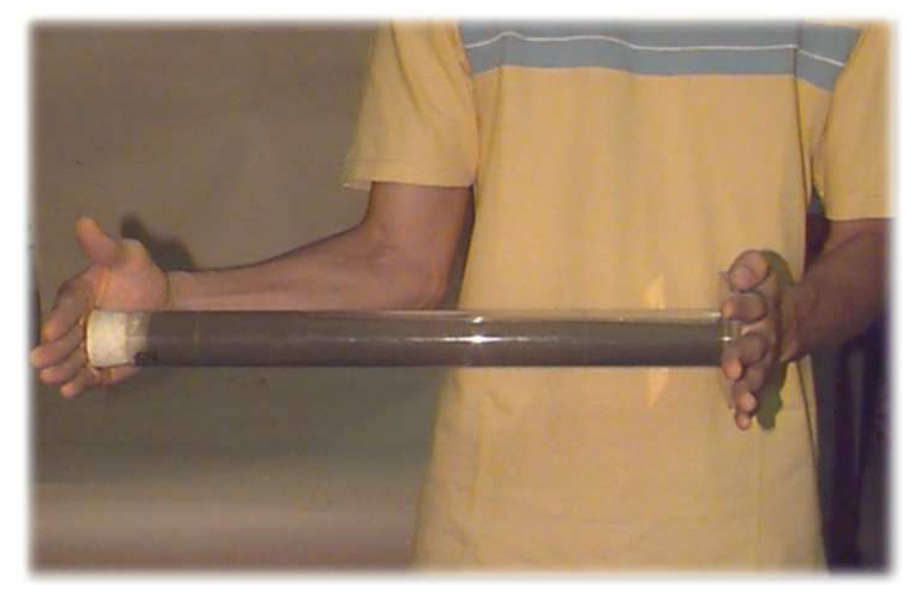

Figura 2.11: Agitação da proveta

Após a retirada da rolha, as paredes da proveta são lavadas, com o auxílio do tubo lavador, para desprender as partículas de agregados aderidas. Então, o tubo lavador é posicionado no fundo da proveta, permitindo que a solução floculante flua para o interior da proveta, até 
atingir o traço de referência superior, suspendendo-se o tubo lavador lentamente sem parar o escoamento, de tal modo que aquele nível se mantenha constante. Então, a proveta é deixada em repouso, sem perturbação, durante 20 minutos. Qualquer vibração ou movimento da proveta durante esse período poderá interferir na velocidade normal de sedimentação da argila em suspensão, alterando os resultados.

Após o período de 20 minutos, é feita a leitura da altura do nível superior da argila em suspensão, para em seguida, ser introduzido o pistão na proveta, até assentá-lo sobre a amostra, promovendo um pequeno giro em sua haste, até que um de seus parafusos de ajustagem, torne-se visível. O nível do centro do parafuso de ajustagem é adotado como leitura correspondente ao nível superior da amostra (Figura 2.12). O equipamento completo necessário para a realização do ensaio pode ser visto na Figura 2.13.

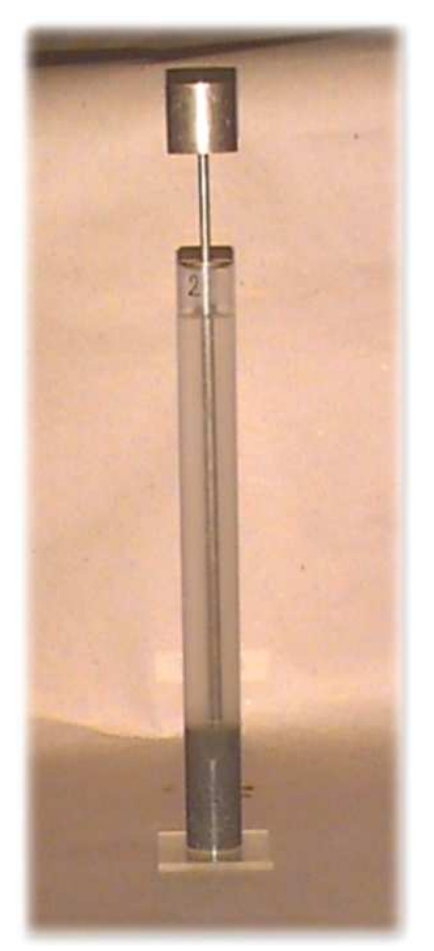

Figura 2.12: Leitura do nível superior da areia - exemplo de leitura realizada numa amostra de agregado de gabro estudado nesta pesquisa

O equivalente de areia pode ser então calculado através da razão entre a leitura no topo da areia (amostra) e a leitura no topo da argila, através da Equação 2.4:

$$
E A=\frac{L_{\text {areia }}}{L_{\text {argila }}} \times 100
$$

onde:

$L_{\text {areia }}=$ leitura no topo da areia, em mm;

$L_{\text {argila }}=$ leitura no topo da argila, em mm. 


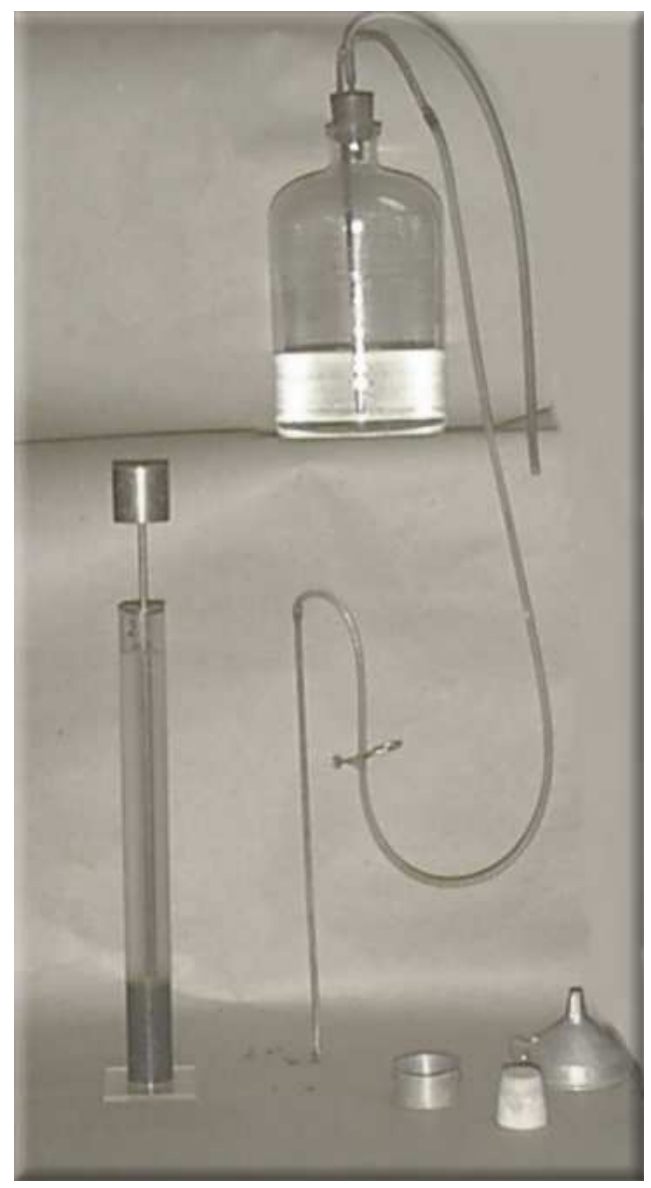

Figura 2.13: Equipamento necessário para a realização do ensaio do equivalente de areia

Durante a realização do ensaio, é usual anotar, além da leitura da altura da areia com o pistão, a leitura correspondente à altura da areia visível, com o intuito de colher dados para uma melhor interpretação do ensaio. As proporções relativas às frações granulométricas de agregados passantes na peneira de abertura $4,75 \mathrm{~mm}$ podem variar muito, dependendo do agregado. Amostras mais grossas ou mais finas, com quantidades apreciáveis de partículas angulares, tendem a apresentar leituras muito próximas de altura da areia visível e de altura da areia realizada com o pistão. Porém, se a amostra for muito fina, no momento em que o pistão de $1 \mathrm{~kg}$ assenta sobre seu topo, este pode afundar consideravelmente. Esse fato indica que uma amostra contendo partículas muito finas, pode ter, ainda que desprovida de argilominerais, um valor do equivalente de areia bastante inferior a 100, desde que o pistão nela afunde. Nesse caso, o equivalente de areia não está relacionado com a plasticidade do material, mas com a finura do material. A escolha de Hveem por um pistão de peso relativamente elevado pode ter sido proposital, para tentar limitar o emprego de agregados com quantidades grandes de finos e com partículas arredondadas, em obras de pavimentação (Medina, 1962). 


\subsubsection{Abrasão Los Angeles}

O ensaio consiste em colocar a amostra do agregado e as esferas metálicas, com massa de aproximadamente $440 \mathrm{~g}$ cada, dentro do tambor da máquina Los Angeles que passa a girar à velocidade de 30 a $33 \mathrm{rpm}$ até que sejam completadas 500 rotações. A rotação do tambor permite que as abas internas deste apanhem as partículas do agregado e as esferas metálicas, girando-as até serem tombadas para o lado oposto do tambor e, através da queda das esferas sobre os agregados e da queda dos próprios agregados, uns sobre os outros, é criada a condição de britagem da amostra por impacto. As partículas do agregado e as esferas, ao rolarem dentro do tambor, atritam-se entre si e com as paredes do tambor, promovendo abrasão entre as partes.

O número de esferas metálicas colocadas dentro do tambor está condicionado à faixa granulométrica da amostra. A escolha da granulometria da amostra é uma etapa importante do ensaio. As normas DNER ME 035 e ASTM C 131 determinam várias faixas granulométricas possíveis, devendo ser escolhida a granulometria mais próxima da que será utilizada na mistura estudada ou na obra. Nesta pesquisa, foi utilizada a granulometria $\mathrm{C}$, cujas frações controladas encontram-se entre as peneiras de abertura de $9,5 \mathrm{~mm}$ e $6,3 \mathrm{~mm}$ e entre $6,3 \mathrm{~mm}$ e $4,8 \mathrm{~mm}$.

Terminadas as rotações, o conteúdo do tambor é removido e o material granular é peneirado, lavado na peneira de abertura de 1,7 mm e, então, seco em estufa. Após, é determinada a porcentagem perdida ou degradada mecanicamente, através da diferença entre a massa inicial e a massa final da amostra, como mostra a Equação 2.5:

$$
A_{L A}=\frac{m_{i}-m_{f}}{m_{i}} \times 100
$$

onde:

$A_{L A}=$ abrasão Los Angeles;

$m_{i}=$ massa inicial da amostra colocada na máquina;

$m_{f}=$ massa final da amostra lavada e seca, após o ensaio.

Esse ensaio avalia a degradação do agregado mineral, resultante das ações combinadas do atrito e do impacto, devendo ser utilizado como indicador da qualidade relativa ou competência de agregados com composição mineral similar. Como alertado na norma ASTM C 131, os resultados desse ensaio não permitem que comparações automáticas sejam feitas entre agregados de diferentes origens, estruturas e composições mineralógicas. 


\subsubsection{Sanidade}

Esse ensaio avalia a sanidade ou a resistência à desintegração dos agregados sujeitos à ação do tempo. Para tanto, o agregado é submetido a ciclos de imersão em solução de sulfato de sódio ou sulfato de magnésio e, em seguida, levado para secagem em estufa. O objetivo desses ciclos de imersão é exercer, através da hidratação dos cristais contidos nas microfissuras do agregado, forças de expansão interna que causem a degradação das partículas não sãs.

\section{Preparação da solução de sulfato de sódio}

O procedimento de preparo da solução consiste em dissolver, aos poucos, aproximadamente $350 \mathrm{~g}$ de sulfato de sódio anidro $\left(\mathrm{Na}_{2} \mathrm{SO}_{4}\right)$ em 1 litro de água destilada, agitando-se energicamente a solução, como ilustra a Figura 2.14. A temperatura da água deve estar próxima aos $30^{\circ} \mathrm{C}$ para facilitar a dissolução do sal na água e diminuir a cristalização.

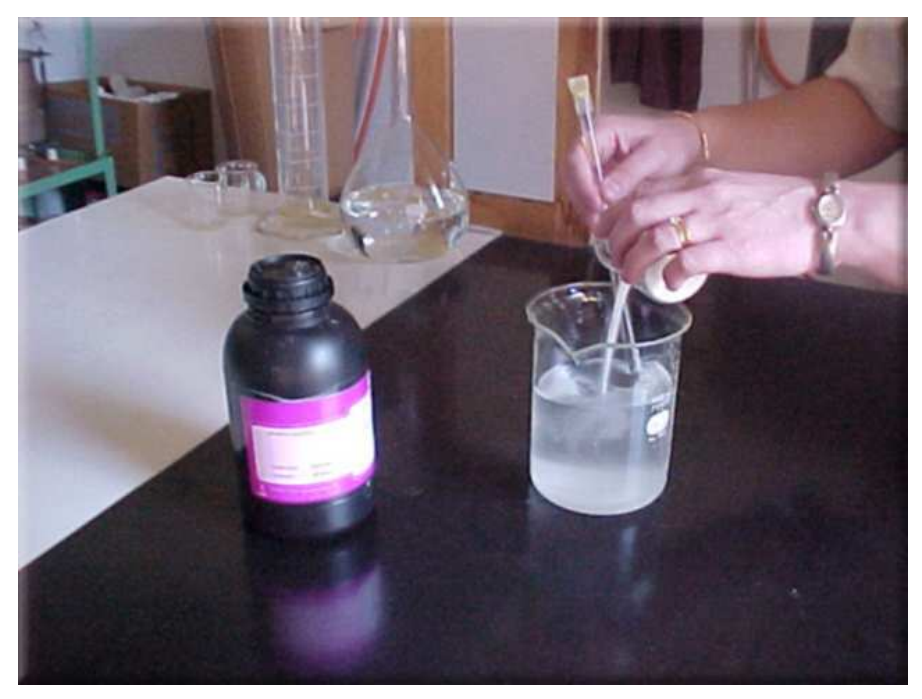

Figura 2.14: Preparo da solução de sulfato de sódio

Após a dissolução completa do sal na água, deve-se continuar a agitar a solução até resfriá-la, para que não se inicie a formação de cristais. Em seguida, a solução é levada à incubadora, que mantém a temperatura da solução em $21^{\circ} \mathrm{C}$ por um período mínimo de 48 horas, antes da realização do ensaio. No momento da utilização, a solução deve ser novamente agitada e determinada a sua densidade, que deve estar entre 1, 151 e 1, 174 (Figura 2.15).

Ao longo do ensaio pode ocorrer a formação de cristais na solução, que devem ser retirados. A Figura 2.16 ilustra alguns cristais retirados da solução durante um ensaio realizado nesta pesquisa. A cada novo ciclo, antes da imersão das amostras na solução, a densidade da solução 


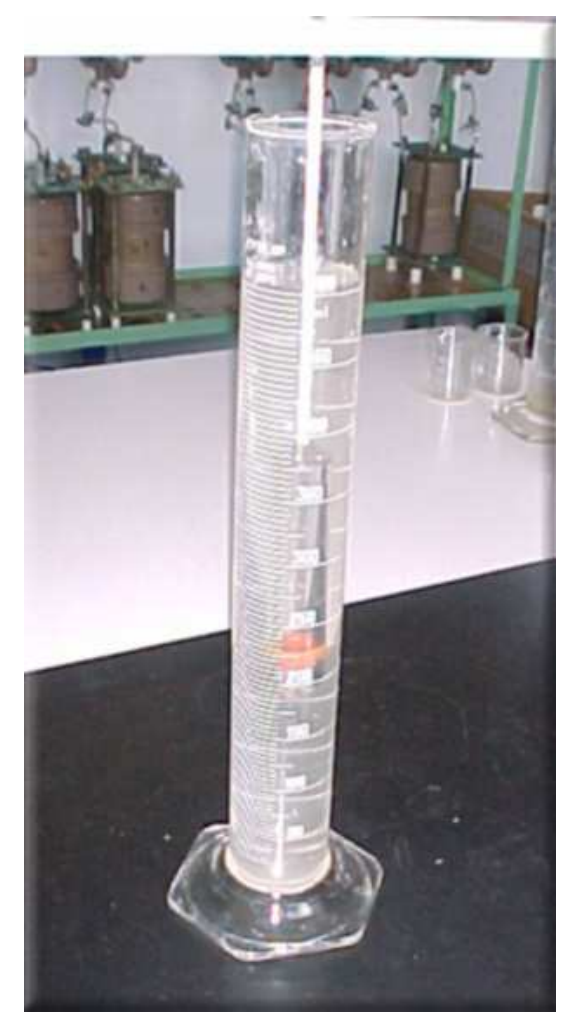

Figura 2.15: Determinação da densidade da solução

deve ser novamente avaliada, cuidando-se para que permaneça dentro do limite de 1,151 a 1, 174, especificado pelas normas DNER ME 089 e ASTM C 88 .

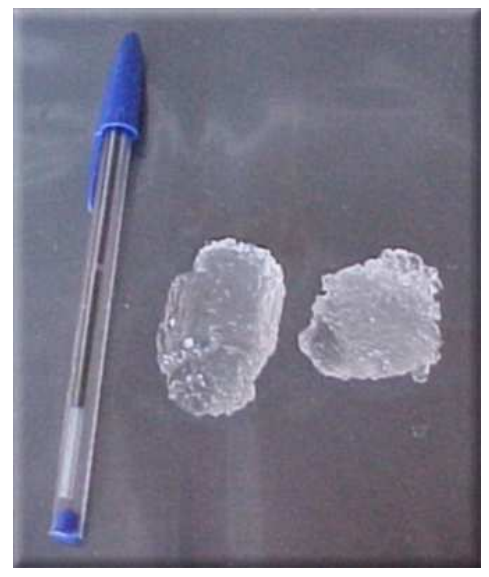

Figura 2.16: Cristais retirados da solução de sulfato de sódio durante um ensaio de sanidade desta pesquisa

\section{Descrição do ensaio}

As amostras, após serem lavadas e secas em estufa, são separadas por peneiramento em frações entre as peneiras de abertura $19,0 \mathrm{~mm}$ a $12,5 \mathrm{~mm}$, com aproximadamente $670 \mathrm{~g}$ de material, $12,5 \mathrm{~mm}$ a $9,5 \mathrm{~mm}$, com aproximadamente $330 \mathrm{~g}$ e $9,5 \mathrm{~mm}$ a 4,75 $\mathrm{mm}$, com cerca 
de 300 g de material. Após determinada a massa exata de cada uma das frações que compõem a amostra, elas são remisturadas e colocadas dentro de cestos (Figura 2.17).

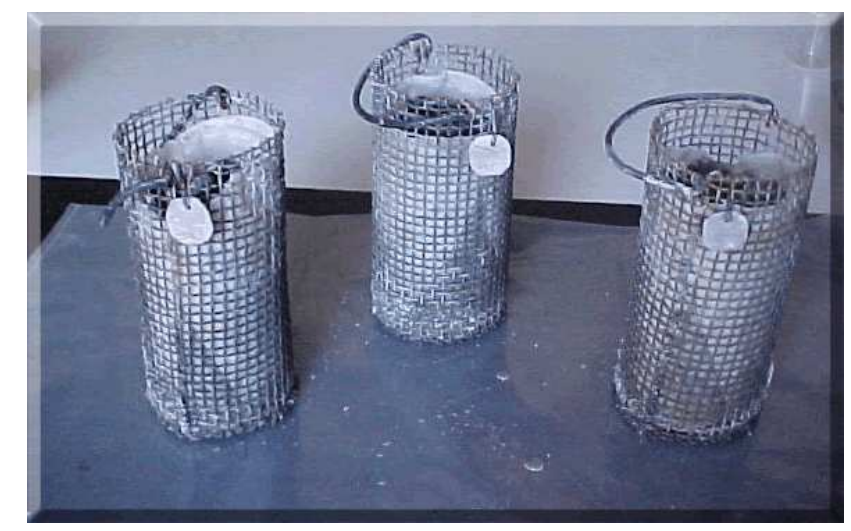

Figura 2.17: Cestos contendo as amostras

Cada cesto, revestido internamente com papel de filtro para impedir a perda de partículas finas, deve ser identificado, para, em seguida, ser submerso em solução de sulfato de sódio, por um período de 16 a 18 horas (Figura 2.18). O nível da solução deve permanecer com $1 \mathrm{~cm}$ acima do topo da amostra durante todos os cinco ciclos de imersão/secagem.

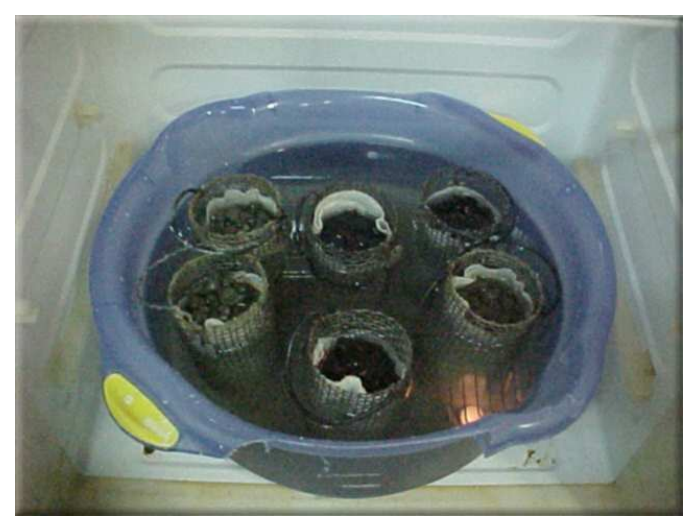

Figura 2.18: Imersão das amostras

No período de imersão, o recipiente contendo as amostras submersas em solução de sulfato de sódio é colocado dentro de uma incubadora, para que a temperatura da solução seja mantida em $21^{0} C$ (Figuras 2.19(a) e 2.19(b)).

Após o período de imersão, as amostras são retiradas da solução e drenadas por 15 minutos, sendo então colocadas na estufa para secar. Após a secagem, as amostras são resfriadas até que atinjam a temperatura ambiente. O final dessa etapa corresponde ao término de um ciclo de imersão/secagem. 


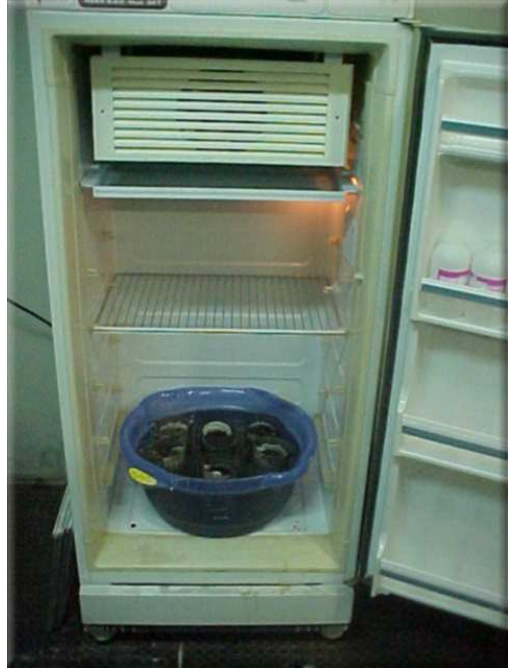

(a) Amostras dentro da incubadora

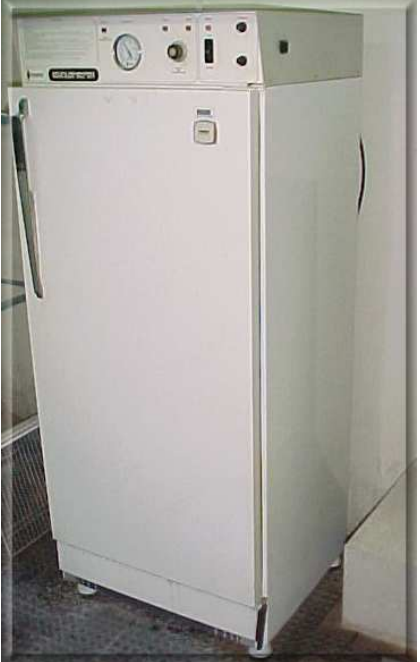

(b) Incubadora

Figura 2.19: Controle da temperatura da solução

Terminado o quinto ciclo de imersão/secagem, as amostras são lavadas com solução de cloreto de bário a $10 \%$ e, em seguida, com água corrente para retirar o excesso de sulfato de sódio contido nas partículas. Na sequiência, as amostras são levadas à estufa para secagem completa, com posterior determinação de suas massas.

Para determinação da porcentagem de perda de material durante o ensaio, as amostras são peneiradas na mesma série de peneiras anteriormente controladas e adicionalmente nas peneiras de $8 \mathrm{~mm}$ e $4 \mathrm{~mm}$, conforme mostra a Tabela 2.7 .

Tabela 2.7: Peneiras de controle usadas no ensio de sanidade

\begin{tabular}{cc}
\hline $\begin{array}{c}\text { Fração da amostra } \\
(\mathbf{m m})\end{array}$ & $\begin{array}{c}\text { Peneira de controle } \\
(\mathbf{m m})\end{array}$ \\
\hline 19,0 a 9,5 & 8,0 \\
9,5 a 4,75 & 4,0 \\
\hline
\end{tabular}

O resultado é expresso como uma porcentagem de perda de material, cujo valor representa a média ponderada calculada em função da porcentagem de perda de cada fração e com base na granulometria da mistura. Além da determinação da porcentagem de perda de material, deve-se analisar cada partícula visualmente, observando se houve fendilhamento excessivo, ou ainda, outra forma de deterioração como desintegração, esmagamento, quebra ou laminagem. 


\subsubsection{Torrões de Argila e Partículas Friáveis}

Pode-se entender como torrões uma porção de terra endurecida e como partículas friáveis aquelas que se partem ou se esboroam com facilidade (Ferreira, 1999). O ensaio de torrões de argila e partículas friáveis, normalizado pela ASTM C 142, é adotado pelo Superpave para a avaliação da porcentagem de materiais deletérios presentes na amostra de agregados. O procedimento de ensaio consiste, inicialmente, em separar o agregado por peneiramento nas seguintes frações:

Tabela 2.8: Composição das amostras usadas no ensaio de partículas friáveis

\begin{tabular}{cc}
\hline $\begin{array}{c}\text { Fração da amostra } \\
(\mathbf{m m})\end{array}$ & $\begin{array}{c}\text { Massa mínima } \\
(\mathbf{g})\end{array}$ \\
\hline 19,0 a 9,5 & 2.000 \\
9,5 a 4,75 & 1.000 \\
4,75 a 1,18 & 25 \\
\hline
\end{tabular}

Em seguida, é realizado o espalhamento da amostra no fundo de uma bandeja, para que forme uma fina camada. Após, a amostra é coberta com água destilada, permanecendo submersa por 24 horas (Figura 2.20(a)).

O próximo passo é drenar a água da amostra e em seguida analisar cada partícula rolando-a e apertando-a entre os dedos polegar e indicador, tentando quebrá-la em partículas menores (Figura 2.20(b)). Ao rolar a partícula entre os dedos deve-se tomar o cuidado para não quebrá-las com a unha, nem esfregá-las entre si.

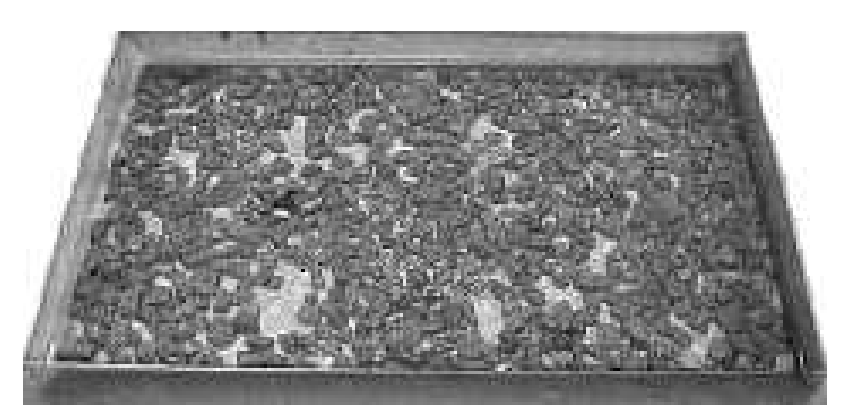

(a) Amostra submersa

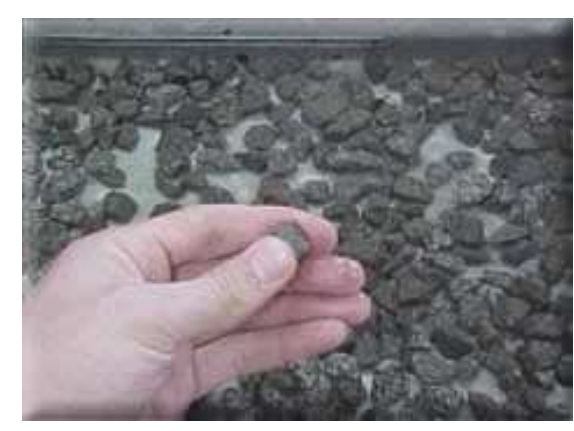

(b) Análise da partícula

Figura 2.20: Ensaio de detecção de torrões de argila e partículas friáveis

Qualquer partícula que se quebre é classificada como torrão de argila ou partícula friável, dependendo de sua composição. Após proceder a análise de quebra em todas as partículas, as frações da amostra são lavadas nas peneiras de controle apresentadas na Tabela 2.9. 
Tabela 2.9: Peneiras de controle usadas no ensaio de partículas friáveis

\begin{tabular}{cc}
\hline $\begin{array}{c}\text { Fração da amostra } \\
(\mathbf{m m})\end{array}$ & $\begin{array}{c}\text { Peneira de controle } \\
(\mathbf{m m})\end{array}$ \\
\hline 19,0 a 9,5 & 4,75 \\
9,5 a 4,75 & 2,36 \\
4,75 a 1,18 & 0,85 \\
\hline
\end{tabular}

Em seguida, a amostra é colocada na estufa para a secagem até atingir constância de massa. A determinação da porcentagem de torrões de argila ou partículas friáveis na amostra pode ser calculada através da Equação 2.6.

$$
P F=\frac{W-R}{W} \times 100
$$

onde:

$P F=$ porcentagem de materiais deletérios ou partículas friáveis presentes na amostra;

$W=$ massa da amostra;

$R=$ massa das partículas retidas na peneira de controle (Tabela 2.9).

O resultado é expresso como uma porcentagem de perda de material, cujo valor representa a média ponderada calculada em função da porcentagem de perda de cada fração e com base na granulometria da mistura.

\subsection{Resultados da Caracterização Superpave dos Agregados}

\subsubsection{Angularidade do Agregado Grosso}

Na Tabela 2.10, encontram-se as porcentagens de faces fraturadas das partículas dos agregados grossos de gabro, de basalto e de areia natural estudados.

Tabela 2.10: Resultados do ensaio de porcentagem de partículas fraturadas

\begin{tabular}{lc}
\hline Tipo de Agregado & Faces Fraturadas \\
\hline Gabro & $100 / 100$ \\
Basalto & $100 / 100$ \\
Areia Natural & $50 / 35$ \\
\hline
\end{tabular}

O agregado de gabro e o agregado de basalto possuem todas as suas partículas com duas ou mais faces fraturadas. O número de partículas fraturadas apresentadas por ambos os agre- 
gados são adequadas, considerando a Tabela 2.1 da especificação Superpave. Portanto, tanto o agregado de gabro como o agregado de basalto poderiam ser utilizados em todas as camadas do pavimento, inclusive na capa asfáltica de rodovias com volume de tráfego alto.

Já o agregado de areia natural possui $50 \%$ de suas partículas com uma face fraturada e apenas $35 \%$ de suas partículas com duas ou mais faces fraturadas. Essas porcentagens de faces fraturadas não são suficientes, segundo a Tabela 2.1 da especificação Superpave, para garantir que as partículas apresentem intertravamento e atrito interno adequados. Portanto, o agregado de areia natural não deve ser utilizado como parte integrante de misturas asfálticas, mesmo em rodovias com volume de tráfego baixo.

A realização desse ensaio, conforme estabelece a norma ASTM D 5821, não permite a avaliação real da angularidade dos agregados grossos, mas apenas do número de faces fraturadas desses agregados, que são dados insuficientes para ter-se conhecimento do grau de angularidade (agudeza) dos cantos e arestas das fraturas. Sendo assim, pode-se assumir que o ensaio de avaliação da porcentagem de faces fraturadas da partícula, adotado pelo Superpave, não atende ao propósito de avaliação da angularidade do agregado grosso.

Há modos mais eficientes de avaliação da angularidade do agregado grosso, um deles é a análise visual comparativa das partículas. Nesta pesquisa, utilizou-se para a avaliação visual a tabela de comparação de angularidade de agregados finos, desenvolvida por Russel \& Taylor ${ }^{5}$ apud Suguio (1973), que permite classificar as partículas com cinco diferentes graus de angularidade: angular, subangular, subarredondado, arredondado e altamente arredondado. Maiores detalhes quanto à utilização dessa tabela, assim como a forma de avaliação visual comparativa dos agregados, podem ser vistos em Gouveia (2002).

A avaliação visual da angularidade do agregado grosso (agudeza de seus cantos) foi realizada concomitantemente à avaliação da porcentagem de faces fraturadas do agregado grosso. Poder-se-ia incorrer como ponto negativo da avaliação visual da angularidade o longo tempo consumido, no entanto, normalmente para a realização do ensaio de determinação do número de faces fraturadas, as partículas já são avaliadas uma a uma, portanto, não foi despendido muito mais do que já é necessário para a realização do ensaio adotado pelo Superpave.

Outra característica bastante importante dos agregados não avaliada pelo ensaio especificado pelo Superpave é a rugosidade ou textura superficial. Essa característica também poderia ser facilmente determinada durante o processo de avaliação do número de faces fraturadas,

\footnotetext{
${ }^{5}$ Russel, R. D; Taylor, R. E. (1937). Roundness and shape of Mississipi River sands. Journal of Geology, n. 45, p. 225-267.
} 
pois, rapidamente, poder-se-ia constatar aspereza superficial ou não das partículas através da visualização e do toque.

Então, nesta pesquisa, durante a análise do número de faces fraturadas das partículas, como estabelece o Superpave, procedeu-se, também, as análises de angularidade dos agregados (agudeza dos cantos das partículas), utilizando a tabela de Russel \& Taylor (Figura 2.21), assim como da textura superficial das partículas, cujos resultados estão apresentados na Tabela 2.11. A textura superficial foi classificada como lisa ou rugosa, em função da presença de sulcos, estrias, microcrateras, projeções e desigualdades observadas na superfície das partículas.

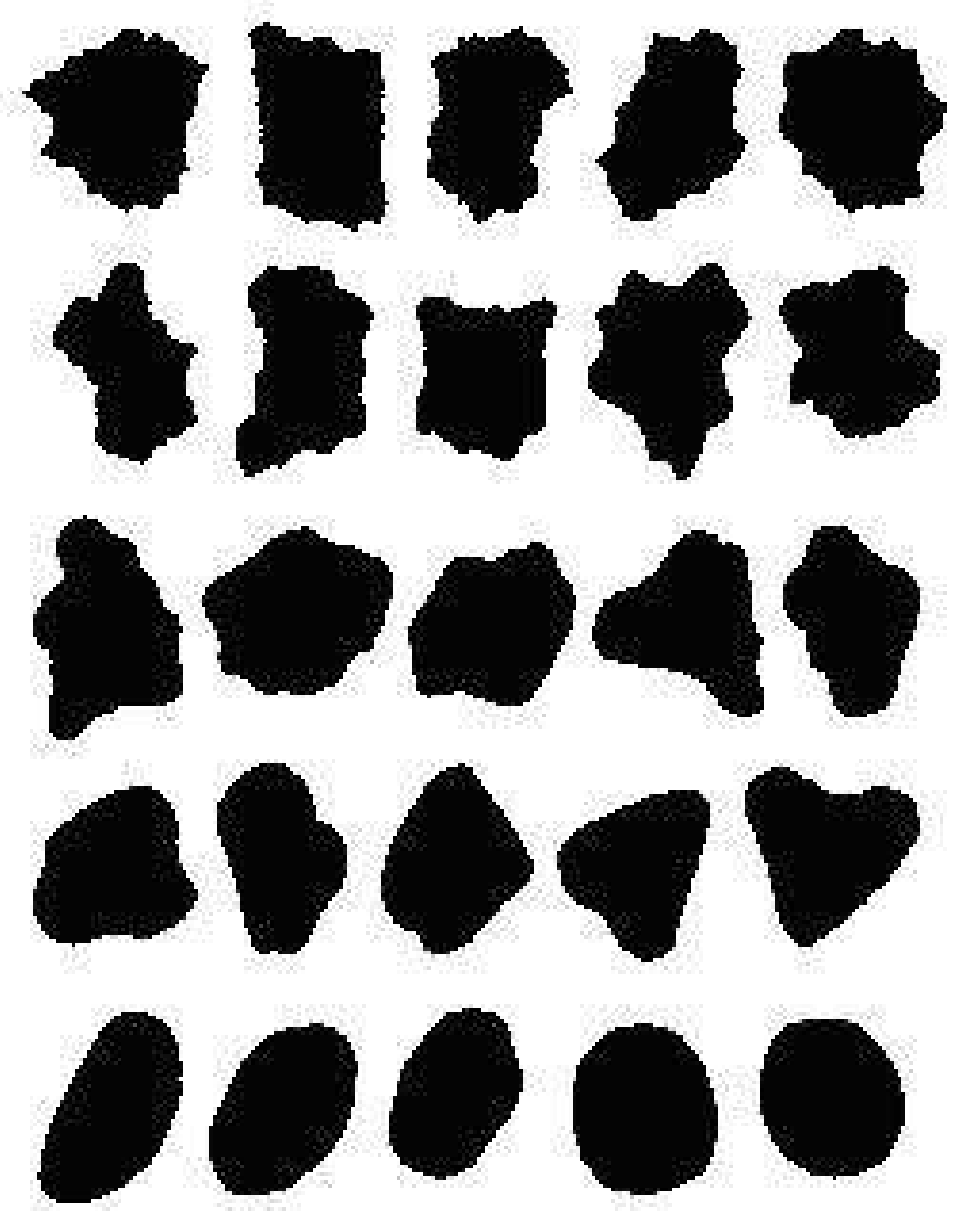

Figura 2.21: Graus de arredondamento. Do topo para a base: angular, subangular, subarredondado, arredondado, altamente arredondado (Russel \& Taylor (1937) apud Suguio (1973))

Tabela 2.11: Resultados da análise visual comparativa da angularidade e da textura superficial

\begin{tabular}{lcc}
\hline Tipo de Agregado & $\begin{array}{c}\text { Grau de Arredondamento } \\
\text { Angularidade }\end{array}$ & Textura superficial \\
\hline Gabro & subangular & rugosa \\
Basalto & angular & rugosa \\
Areia Natural & altamente arredondada & lisa \\
\hline
\end{tabular}


Após essas análises visuais, têm-se dados mais esclarecedores quanto à angularidade dos agregados grossos e sua textura superficial. Agora, pode-se dizer que o agregado de gabro possui todas as suas partículas com duas ou mais faces fraturadas (Tabela 2.10), com cantos e arestas apresentando desgaste incipiente (partículas subangulares) e textura superficial rugosa (Tabela 2.11). O agregado de basalto possui todas as suas partículas com duas ou mais faces fraturadas (Tabela 2.10), porém, com cantos e arestas agudos e não apresentando sinais de desgaste (partículas angulares) e textura superficial rugosa (Tabela 2.11). Vale notar que esse processo de avaliação mais completo permite que se faça distinção entre a angularidade das partículas do agregado de gabro e basalto, o que não é possível somente informando o número de faces fraturadas desses agregados.

Também, com vistas nesse processo de análise da angularidade do agregado grosso, pode-se dizer que o agregado de areia natural possui $50 \%$ de suas partículas com uma face fraturada e $35 \%$ com duas ou mais faces fraturadas (Tabela 2.10), com cantos e arestas bem desgastados e textura superficial lisa (Tabela 2.11).

Através desse processo de avaliação proposto é possível obter dados sobre a angularidade e textura superficial das partículas. Esse conhecimento se faz necessário devido à importância dessas características no comportamento mecânico das misturas, que afetam diretamente o grau de intertravamento e atrito interno entre as partículas, influenciando o desempenho quanto à deformação permanente e à fadiga.

\subsubsection{Angularidade do Agregado Fino}

Na Tabela 2.12, estão apresentados os valores médios dos resultados de angularidade do agregado fino (AAF) realizados utilizando o método A. Todos os resultados obtidos de AAF correspondem a média aritmética entre três determinações feitas com diferentes amostras de um mesmo agregado. A diferença entre dois resultados do ensaio, executado por um mesmo operador em amostras similares, não diferiu mais que $0,37 \%$, como estabelecido na norma ASTM C 1252.

Tabela 2.12: Resultados do ensaio de angularidade do agregado fino

\begin{tabular}{lcc}
\hline Tipo de Agregado & $\rho_{a p}$ & AAF (\%) \\
\hline Gabro & 2,830 & 48,3 \\
Basalto & 2,742 & 51,1 \\
Areia Natural & 2,591 & 40,7 \\
\hline
\end{tabular}


Análises visuais comparativas da forma, angularidade e textura superficial das partículas foram realizadas nesta pesquisa com o objetivo de estabelecer comparações com o ensaio AAF. A angularidade foi determinada com base na tabela de comparação de graus de arredondamento de Russel \& Taylor, como angulares, subangulares, subarredondadas, arredondadas e altamente arredondadas, como descrito no item 2.5.1. Para a determinação da forma da partícula utilizou-se a tabela de comparação de graus de esfericidade de Rittenhouse ${ }^{6}$ apud Suguio (1973) (Figura 2.22). A textura superficial das partículas foi classificada como lisa ou rugosa. Maiores detalhes quanto à utilização da tabela de Rittenhouse, assim como, do modo de avaliação visual dos agregados pesquisados, podem ser vistos em Gouveia (2002).

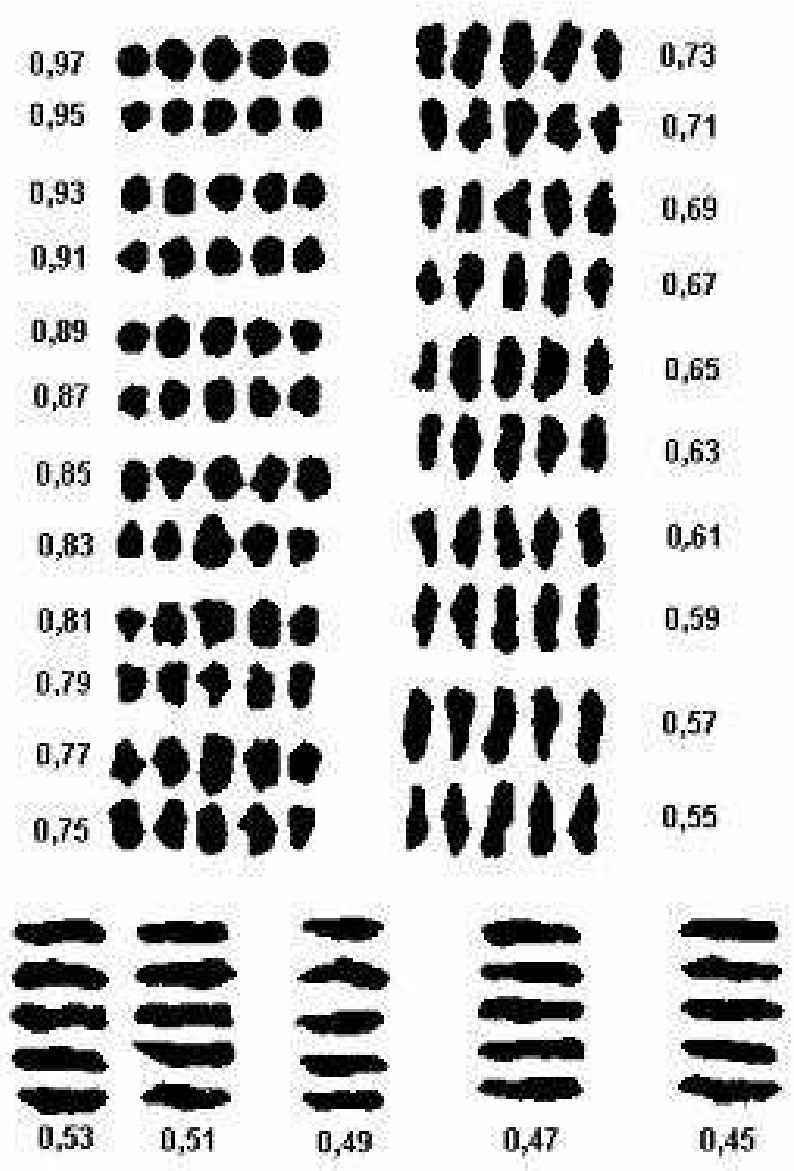

Figura 2.22: Escala de comparação visual para graus de esfericidade bidimensional (Rittenhouse (1943) apud Suguio (1973))

Esfericidade e arredondamento são medidas de duas propriedades muito diferentes de superfície das partículas. A esfericidade está relacionada com a forma da partícula e o arredondamento com a angularidade e textura superficial. Segundo Suguio (1973), a esfericidade é uma grandeza que tenta expressar numericamente o grau de aproximação da forma de uma partícula qualquer com a de uma esfera perfeita. A tabela de Rittenhouse classifica graus de esfericidade

\footnotetext{
${ }^{6}$ Rittenhouse, G. (1943). A visual method of estimating two dimensional sphericity. Journal of Sedimentary Petrology, n. 13, p. 79-81.
} 
numericamente de 0,45 até 0,97 , quanto mais próximo de 1 mais próxima de uma esfera será a forma da partícula. A esfericidade é essencialmente mais sensível ao alongamento da partícula e o arredondamento está mais relacionado à agudeza das saliências da partícula.

Pode-se fazer uma distinção clara entre forma, angularidade e textura superficial das partículas através das definições assumidas por Barrett ${ }^{7}$ apud Bowman et al. (2000), que podem ser elucidadas por intermédio da Figura 2.23.

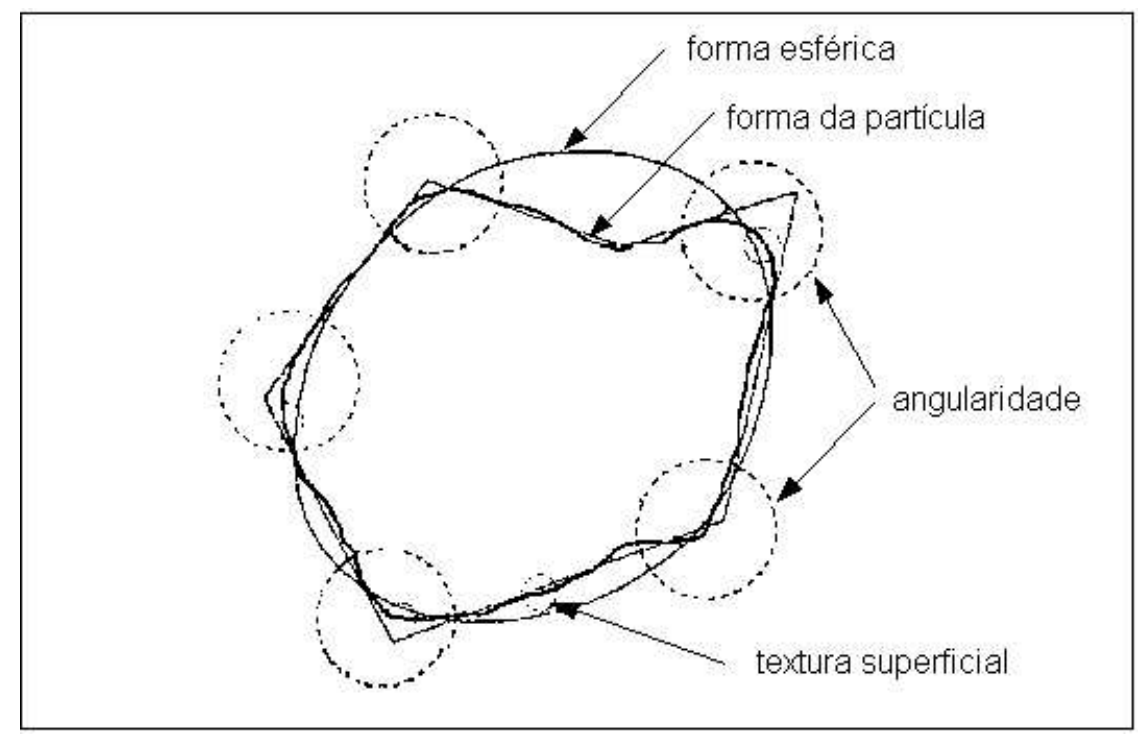

Figura 2.23: Definições de forma, angularidade e textura superficial das partículas (Barrett (1980) apud Bowman et al. (2000))

A Tabela 2.13 traz os resultados das análises visuais comparativas quanto à forma, à angularidade e à textura superficial realizadas para os agregados estudados. O agregado de gabro apresentou subangularidade em suas partículas, sinalizada por seus cantos e arestas suavemente desgastados. O valor da esfericidade do agregado de gabro foi de 0,84 , indicando forma arredondada, e sua textura superficial foi classificada como rugosa. Já as partículas de basalto apresentaram-se angulares (cantos e arestas agudos), com valor de esfericidade de 0,65, indicando forma alongada, e textura superficial rugosa. As partículas do agregado de areia natural apresentaram angularidade baixa (cantos e arestas bem desgastados), com valor de esfericidade igual à do agregado de gabro $(0,84)$, indicando forma arredondada, e sua textura superficial foi classificada como lisa.

Se a angularidade fosse considerada como um fator isolado, poder-se-ia dizer que houve correlação entre os resultados de AAF e os resultados das análises comparativas visuais, indicando sensibilidade do ensaio AAF quanto às variações de angularidade das partículas. O agregado de basalto que apresentou valor maior de $\operatorname{AAF}(51,1)$, também apresentou agudeza maior de

\footnotetext{
${ }^{7}$ Barrett, P. J. (1980). The shape of rock particles, a critical review Sedimentology, n. 27, p. 291-303.
} 
Tabela 2.13: Resultados da análise visual comparativa quanto à angularidade, à forma e à textura superficial

\begin{tabular}{lccc}
\hline Tipo de Agregado & $\begin{array}{c}\text { Grau de Arredondamento } \\
\text { Angularidade }\end{array}$ & $\begin{array}{c}\text { Grau de Esfericidade } \\
\text { Forma }\end{array}$ & Textura superficial \\
\hline Gabro & subangular & 0,84 & rugosa \\
Basalto & angular & 0,65 & rugosa \\
Areia Natural & arredondada & 0,84 & lisa \\
\hline
\end{tabular}

(Gouveia, 2002)

seus cantos e arestas. O agregado de gabro, que apresentou valor de AAF intermediário $(48,3)$, mostrou subangularidade de suas partículas, verificada através do desgaste suave de seus cantos e arestas. O agregado de areia natural, com seus cantos e arestas bastante desgastados, apresentou o valor mais baixo AAF (40,7\%). Porém, vale lembrar que os resultados obtidos através do ensaio AAF correspondem a uma mistura das características de superfície do agregado fino (forma, angularidade e textura superficial).

O ensaio AAF não foi capaz de detectar variações da forma dos agregados. Como pode ser visto na Tabela 2.13, o agregado de basalto que possui partículas alongadas apresentou AAF mais elevado que o agregado de gabro, que possui partículas com forma mais arredondada. Esse fato pode levar à escolha de agregados com formas desfavoráveis à pavimentação (partículas planas e/ou alongadas) por possuírem valores de AAF mais altos.

O ensaio AAF indica a quantidade de vazios não compactados entre as partículas, que é uma forma de determinar indiretamente a forma, angularidade e textura superficial dos agregados. Porém, esta pesquisa mostra que partículas alongadas, mas com angularidade alta e textura superficial rugosa, podem causar um afastamento maior entre partículas, portanto, uma quantidade maior de vazios não compactados (AAF mais alto). E, contrariando a hipótese Superpave, esse valor de AAF mais alto pode não corresponder a um agregado que promoverá um melhor arranjo estrutural entre partículas e, portanto, misturas mais resistentes à deformação permanente, antecipando o que será apresentado no Capítulo 7. Os resultados desta pesquisa, assim como outros trabalhos desenvolvidos sobre o assunto, mostram que não se pode afirmar que quanto mais elevado for o valor do AAF, melhor será o arranjo estrutural entre as partículas, promovendo misturas mais estáveis. Em outras palavras, não se pode afirmar que agregados com valores de AAF de $51 \%$ produzirão misturas mais estáveis que agregados com AAF de $45 \%$. Por outro lado, tanto nesta pesquisa como em outros trabalhos, fica claro que misturas produzidas com agregados com valores de AAF baixos, por exemplo 40\%, apresentam problemas quanto à estabilidade. Portanto, o AAF deve ser visto como um divisor de águas entre classes de agregados com características de superfície (forma, angularidade e textura) 
satisfatórias ou não, o que já é de grande importância para a realização de projetos adequados de misturas asfálticas.

\subsubsection{Forma do Agregado Grosso}

As partículas de agregados foram avaliadas quanto à forma considerando a sugestão de classificação da norma ASTM D 4791 como planas, alongadas e nem planas nem alongadas e, considerando a especificação Superpave, como planas/alongadas (lamelares) e não planas/alongadas (não lamelares). Também foram consideradas duas proporções dimensionais de classificação, como especificada pelo Superpave, $5: 1$ e a proporção $3: 1$. Nas Tabelas 2.14 e 2.15 encontram-se as porcentagens de partículas planas, alongadas e planas/alongadas (lamelares) obtidas para as proporções de $5: 1$ e $3: 1$, respectivamente.

Tabela 2.14: Porcentagem de partículas planas, alongadas e lamelares - $5: 1$

\begin{tabular}{l|ccc|cc}
\hline Tipos de Agregados & \multicolumn{3}{|c|}{ ASTM D 4791 } & \multicolumn{2}{c}{ Superpave } \\
& planas & alongadas & não planas ou along & lamelares & não lamelares \\
\hline Gabro & 0,1 & 0,0 & 99,9 & 0,5 & 99,5 \\
Basalto & 0,2 & 0,0 & 99,8 & 2,5 & 97,5 \\
Areia Natural & 0,1 & 0,0 & 99,9 & 0,1 & 99,9 \\
\hline
\end{tabular}

Tabela 2.15: Porcentagem de partículas planas, alongadas e lamelares - $3: 1$

\begin{tabular}{l|ccc|cc}
\hline Tipo de Agregado & \multicolumn{3}{|c|}{ ASTM D 4791 } & \multicolumn{2}{c}{ Superpave } \\
& planas & alongadas & não planas ou along & lamelares & não lamelares \\
\hline Gabro & 0,8 & 0,1 & 99,1 & 5,6 & 94,4 \\
Basalto & 5,2 & 0,0 & 94,8 & 18,3 & 81,7 \\
Areia Natural & 0,2 & 0,0 & 99,8 & 3,9 & 96,1 \\
\hline
\end{tabular}

Ao fazer a análise de forma utilizando-se a proporção de $5: 1$ pode-se verificar que os agregados estudados encontram-se abaixo do limite máximo de 10\%. Considerando a classificação ASTM D 4791, aproximadamente 100\% das partículas dos agregados de gabro, basalto e areia natural não são planas nem alongadas. Já a classificação Superpave indica que 2,5\% das partículas do agregado de basalto, 0,5\% das partículas do agregado de gabro e $0,1 \%$ das partículas do agregado de areia natural são planas/alongadas.

No entanto, a avaliação mais rigorosa das partículas através da razão dimensional de $3: 1$ permite que se faça distinção entre as características de forma dos agregados. Considerando a classificação Superpave, pode-se verificar que o agregado de basalto apresenta aproximadamente $18 \%$ de suas partículas planas/alongadas, valor bastante superior aos aproximados $6 \%$ e $4 \%$ encontrados para o agregado de gabro e areia natural, respectivamente. Porém, a 
avaliação da forma da partícula como plana/alongada não permite dizer se as partículas são todas planas ou são todas alongadas ou ainda se esse agregado é composto tanto de partículas planas como de partículas alongadas. Ao classificar as partículas considerando formas definidas como planas e alongadas, essas dúvidas foram esclarecidas, mostrando que aproximadamente $5 \%$ das partículas do agregado de basalto são planas, não havendo partículas alongadas. Já o agregado de gabro é composto por $0,8 \%$ de partículas planas e $0,1 \%$ de partículas alongadas e o agregado de areia natural possui quase que $100 \%$ de suas partículas não planas nem alongadas. Portanto, através dos dados apresentados, pode-se concluir que ao utilizar a razão dimensional de $5: 1$ fica difícil perceber que se trata de agregados com características bem distintas de forma, ao passo que a razão dimensional de $3: 1$ identifica essas diferenças. Esses resultados corroboram os resultados descritos por Prowell et al. (2005), que mostram a insensibilidade do ensaio, com razão dimensional de $5: 1$, para indicar mudanças de forma do agregado. Também pode-se concluir que ao classificar as partículas por formas definidas, planas e alongadas, é possível uma compreensão melhor de suas características de forma, importante para prognósticos de quebras de partículas no momento da compactação da mistura ou durante a vida em serviço do pavimento.

É interessante notar que, se fosse considerado o limite máximo de $10 \%$ e razão dimensional de $3: 1$, o agregado de basalto não poderia ser utilizado em rodovias com volume de tráfego de médio a alto, se suas partículas fossem classificadas como sugere o Superpave, pois teria $18 \%$ de partículas planas/alongadas. Ao fazer a diferenciação entre formas, as mesmas partículas do agregado de basalto seriam consideradas adequadas para utilização em rodovias de tráfego alto, pois apresentam apenas $5 \%$ de partículas planas. A razão disso é que a avaliação Superpave, por analisar a razão dimensional entre o comprimento e espessura da partícula (dimensão máxima e mínima), acaba por penalizar agregados que possuem formas ligeiramente alongadas, com espessura fina, ao passo que a avaliação separada da planicidade da partícula (largura/espessura) e alongamento (comprimento/largura) permite o discernimento entre as formas do agregado, o que propicia um julgamento mais justo quanto a possíveis quebras. Essa afirmação fica reforçada ao atentar para o fato de que o agregado de basalto, supostamente impróprio para ser utilizado em pavimentação de rodovias com volume de tráfego alto (razão $3: 1$, da classificação Superpave), foi utilizado nesta pesquisa para produção de misturas asfálticas compactadas com energias de compactação ainda mais elevadas que os tradicionais 75 golpes por face (110 e 155 golpes), apresentando porcentagens de quebra muito pequenas e bastante semelhantes às porcentagens obtidas com o agregado de gabro, como pode ser visto no Capítulo 6, item 6.5.1.

Ainda não existem pesquisas conclusivas quanto ao limite máximo de partículas planas, alongadas ou planas/alongadas, avaliadas com a proporção de $3: 1$, que podem ser utilizadas 
no pavimento sem prejudicar o seu desempenho. Mas, certamente, o monitoramento de formas definidas das partículas na proporção $3: 1$ deve trazer mais informações sobre a forma dos agregados que as encontradas com a proporção $5: 1$ e, portanto, poderá ser melhor vislumbrada a influência da forma das partículas sobre as propriedades volumétricas das misturas. Alguns estados estadunidenses limitam a utilização de partículas planas/alongadas (3: 1) em $20 \%$ enquanto outros estabelecem um limite máximo de 10\% (Prowell et al., 2005). De qualquer maneira, mais pesquisas devem ser realizadas para inferir um limite máximo realístico e indicativo das características de forma dos agregados brasileiros.

\subsubsection{Equivalente de Areia}

Os resultados do ensaio do equivalente de areia estão apresentados na Tabela 2.16. Esses resultados correspondem à média aritmética entre três determinações feitas com diferentes amostras de um mesmo agregado, arredondada para o número inteiro superior. A diferença entre dois resultados do ensaio, executado por um mesmo operador em amostras similares, não diferiu mais que $4,2 \%$ para valores maiores que $80 \%$ e $8,2 \%$ para valores menores que $80 \%$, como estabelece a norma ASTM C 1252.

Tabela 2.16: Resultados do ensaio do equivalente de areia

\begin{tabular}{lc}
\hline Tipo de Agregado & Equivalente de Areia (\%) \\
\hline Gabro & 75 \\
Basalto & 100 \\
Areia Natural & 100 \\
\hline
\end{tabular}

O agregado de gabro aparentou valor do equivalente de areia de $75 \%$ e os agregados de basalto e areia natural de $100 \%$. Esse valor de $75 \%$, apesar de estar acima do valor mínimo de $50 \%$ estabelecido pelo Superpave, portanto, ser um agregado que pode ser utilizado em pavimentos com volume de tráfego alto, indica a presença de argilominerais, ou então, de frações argilosas no agregado.

Pode-se indicar pelo menos duas possíveis causas para esse valor de $75 \%$ do equivalente de areia do agregado de gabro, a primeira é a presença de pó sobre a superfície da partícula e a segunda é a presença de quantidades elevadas de material fino geradas na britagem do agregado. Foi observada a presença de uma camada fina de pó sobre cada partícula do agregado de gabro, fornecendo à partícula uma certa opacidade comparada à sua aparência após lavada e seca. A presença de quantidades elevadas de material fino, passantes nas peneiras 0,60; 0,30; 0,15 e $0,075 \mathrm{~mm}$, também foi constatada durante o peneiramento do agregado. Chamou a 
atenção durante o peneiramento a facilidade de obtenção das frações mais finas se comparada à dificuldade de aquisição dessas mesmas frações para o agregado de basalto e de areia natural. A característica de gerar poucos finos tanto do agregado de basalto como do agregado de areia natural podem explicar a não incorrência de frações argilosas em excesso nesses materiais, apontada pelos valores dos equivalentes de areia de $100 \%$ encontrados.

O agregado de gabro, ainda que possivelmente desprovido de argilominerais, pode ter apresentado valor de EA mais baixo devido à camada de pó presente sobre suas partículas e à presença excessiva de frações muito finas do próprio agregado, também indesejáveis à pavimentação. Porém, o ensaio do equivalente de areia permite a determinação da quantidade de frações argilosas, no entanto, não permite a determinação da composição dessa fração argilosa, levando a dúvidas quanto à presença ou não de argilominerais no agregado.

Tanto a presença de frações argilosas como a de argilominerais podem influenciar negativamente o potencial a danos por umidade de misturas asfálticas. Essa dúvida poderia ser esclarecida, por exemplo, através do ensaio de Azul de Metileno. Esse ensaio francês é recomendado pelo International Slurry Seal Association (ISSA) para quantificar argilominerais como a montmorilonita, materiais orgânicos e hidróxidos de ferro, presentes no agregado fino (Kandhal \& Parker Jr., 1998). O princípio do ensaio é adicionar quantidades da solução de azul de metileno na amostra até que a adsorção termine. Como resultado, tem-se a quantidade, em miligramas, de azul de metileno por grama de uma fração específica do agregado utilizado. O consumo maior de azul de metileno é proporcional ao argilominaral existente em função de sua superfície específica. Aschenbrener ${ }^{8}$ apud Kandhal \& Parker Jr. (1998) relacionou valores de azul de metileno e o desempenho dos pavimentos, como mostra a Tabela 2.17.

Tabela 2.17: Relação entre valores de azul de metileno e previsão de desempenho de pavimentos

\begin{tabular}{cc}
\hline Azul de Metileno $(\mathbf{m g} / \mathbf{g})$ & Desempenho Esperado \\
\hline $5-6$ & excelente \\
$10-12$ & aceitável \\
$16-18$ & possíveis problemas \\
$20+$ & não aceitável \\
\hline
\end{tabular}

\subsubsection{Abrasão Los Angeles}

As propriedades de origem dos agregados especificadas pelo Superpave estão destinadas a avaliar duas propriedades dos agregados: durabilidade e presença de materiais deletérios. A

\footnotetext{
${ }^{8}$ Aschenbrener, T. (1992) Comparisons of Colorado Component Hot Mix Asphalt Materials with Some European Specifications. Colorado Department of transportation, Report n. CDO-DTD-R-92-14.
} 
durabilidade abrange geralmente duas categorias de ensaios, aqueles que avaliam a resistência à abrasão e quebras do agregado durante o sua manipulação, mistura, espalhamento, compactação e tráfego, e aqueles que avaliam a sanidade do material em função de sua durabilidade quando exposto a ciclos de molhagem e secagem. Esses ensaios devem ser utilizados conjuntamente para verificar se os agregados destinados à pavimentação serão resistentes e duráveis.

Os resultados obtidos através do ensaio de abrasão Los Angeles, relacionados com a expectativa de quebra das partículas, estão apresentados na Tabela 2.18. Esses resultados correspondem à média aritmética entre três determinações feitas com diferentes amostras de um mesmo agregado, arredondada para um número inteiro superior. A diferença entre dois resultados do ensaio, executado por um mesmo operador em amostras similares de um mesmo agregado, não diferiu mais que 5,7\% de sua média, como estabelece a norma ASTM C 131.

Tabela 2.18: Resultados do ensaio de abrasão Los Angeles

\begin{tabular}{lc}
\hline Tipo de Agregado & Abrasão Los Angeles (\%) \\
\hline Gabro & 18 \\
Basalto & 16 \\
Areia Natural & 36 \\
\hline
\end{tabular}

Os resultados de abrasão Los Angeles obtidos para o agregado de gabro e de basalto indicam que são materiais resistentes, pois apresentaram perdas por abrasão em torno de $18 \%$ e $16 \%$, respectivamente. Já o agregado de areia natural apresentou perdas em torno de $36 \%$.

Muito comenta-se sobre adequabilidade ou não desse ensaio como indicativo do desempenho satisfatório do agregado no campo. Estudos recentes têm indicado pouca correlação dos resultados desse ensaio com o desempenho do agregado no campo, embora, estudos mais antigos indicassem correlações melhores (Prowell et al., 2005). Atualmente, entre os pesquisadores estadunidenses, há uma tendência em indicar o ensaio Micro-Deval como uma alternativa ao ensaio de abrasão Los Angeles, embora os dois ensaios avaliem diferentes formas de deterioração do agregado.

\subsubsection{Sanidade}

A sanidade dos agregados em função de sua durabilidade quando exposto a ciclos de molhagem e secagem foi avaliada através do ensaio de sulfato de sódio. Os resultados apresentados na Tabela 2.19 correspondem à média aritmética entre três determinações feitas com diferentes amostras de um mesmo tipo de agregado (gabro, basalto e areia natural). A diferença entre dois 
resultados do ensaio, executado por um mesmo operador em amostras similares, não diferiu mais que $68 \%$ de sua média, como estabelecido na norma ASTM C 88.

Tabela 2.19: Resultados do ensaio de sanidade

\begin{tabular}{lc}
\hline Tipo de Agregado & Porcentagem de Perda \\
\hline Gabro & 3,3 \\
Basalto & 5,7 \\
Areia Natural & 11,6 \\
\hline
\end{tabular}

Tanto o agregado de gabro como o agregado de basalto apresentaram valores de sanidade bem abaixo do limite máximo de $12 \%$ especificado pelo DER-PR. Já o agregado de areia natural apresentou valor de sanidade bem próximo a esse limite. Uma análise conjunta dos resultados de sanidade com os resultados de abrasão Los Angeles permite concluir que o agregado de gabro, por apresentar valores de sanidade de aproximadamente $3 \%$ e de abrasão Los Angeles de $18 \%$, pode ser considerado resistente e durável, portanto adequado aos serviços de pavimentação. O mesmo pode-se concluir para o agregado de basalto, que apresentou valor de sanidade de aproximadamente $6 \%$ e de abrasão Los Angeles de 16\%. Já o agregado de areia natural apresentou valor de sanidade no limite máximo de $12 \%$ e, embora tenha apresentado perdas por abrasão abaixo do limite máximo de $50 \%, 36 \%$ representa um valor considerável de perdas, portanto, esse agregado pode vir a apresentar problemas de resistência e durabilidade quando em serviço.

\subsubsection{Materiais Deletérios}

Kandhal \& Parker Jr. (1998), que realizaram um extenso estudo sobre agregados e ensaios de caracterização que estariam melhor relacionados com o desempenho esperado desses agregados, não citam e nem consideram o ensaio de Torrões de Argila e Partículas Friáveis (ASTM C 142), adotado pelo Superpave. Também o trabalho de Prowell et al. (2005), compreendido como um relatório final que traz uma revisão da literatura, desde a conclusão do SHRP em 1993, sobre as propriedades dos agregados especificadas pelo Superpave, não menciona nenhuma pesquisa utilizando esse ensaio nem tampouco faz menção a ele. No entanto, esse ensaio foi publicado como sendo o especificado pelo Superpave para avaliação de materiais deletérios no relatório do SHRP-A-408, de autoria de Cominsky et al. (1994). Devido a isso, o ensaio de determinação de torrões de argila e partículas friáveis foi realizado nesta pesquisa e os resultados obtidos encontram-se na Tabela 2.20. Esses resultados correspondem à média aritmética entre três determinações feitas com diferentes amostras de um mesmo agregado. 
Tabela 2.20: Resultados do ensaio de partículas friáveis

\begin{tabular}{lc}
\hline Tipo de Agregado & Partículas Friáveis (\%) \\
\hline Gabro & 0,20 \\
Basalto & 0,64 \\
Areia Natural & 0,14 \\
\hline
\end{tabular}

O ensaio foi realizado exatamente como especifica a norma ASTM C 142, que estabelece que cada partícula deva ser rolada e pressionada entre os dedos polegar e indicador, tentando quebrá-la. As partículas que puderem ser quebradas apenas com a pressão dos dedos serão consideradas como friáveis. Como mostram os resultados da Tabela 2.20, os agregados de gabro, de basalto e de areia natural apresentaram porcentagens pequenas de partículas friáveis, pois, dentre os materiais deletérios presentes nas amostras, apenas os torrões de argila foram detectados pelo ensaio, por serem os únicos a serem quebrados com os dedos. Partículas deletérias como gravetos e conchas, encontradas principalmente nas amostras do agregado de areia natural, não puderam ser computadas como partículas friáveis. Outro problema desse ensaio é a subjetividade da pressão dos dedos destinada à quebra das partículas deletérias. Pessoas com mais força nos dedos poderão quebrar mais partículas que aquelas menos fortes, prejudicando a reprodutibilidade do ensaio.

Portanto, com o objetivo de melhorar a sensibilidade desse ensaio, tomou-se a liberdade de incluir uma etapa de análise visual e de classificação de partículas deletérias presentes na amostra. Então, o procedimento adotado nesta pesquisa, além de rolar as partículas entre os dedos tentando quebrá-las, permite análises visuais de cada partícula, de forma a selecionar aquelas que não sejam constituídas por materiais rochosos. Assim, foram encontrados os resultados contidos na Tabela 2.21 .

Tabela 2.21: Resultados do ensaio de partículas friáveis modificado

\begin{tabular}{lcc}
\hline Tipo de Agregado & Porcentagem & Partículas Friáveis \\
& 0,20 & Tipo \\
\hline Gabro & 0,72 & torrões de terra \\
Basalto & 2,52 & torrões de terra \\
Areia Natural & torrões, gravetos, conchas e palha \\
\hline
\end{tabular}

Os resultados indicaram que $0,20 \%$ e $0,72 \%$ de torrões de argila compõem as amostras dos agregados de gabro e de basalto, respectivamente. Já a areia natural possui uma variedade maior de partículas friáveis como torrões de argila, gravetos, conchas e palha.

Os resultados obtidos através desse procedimento dão uma idéia melhor do material deletério que se encontra na amostra, porém, não é o ideal, pois os resultados apresentados como 
porcentagem de massa podem ser enganosos. Partículas que ocorram em quantidades elevadas, porém, que sejam bastante leves, por exemplo gravetos, palhas e conchas, poderão ter sua quantidade presente na amostra substimada, devido à massa dessas partículas serem bastante inferiores à massa de uma partícula rochosa.

O ideal seria que fossem determinadas as porcentagens volumétricas dos materiais deletérios e que essas porcentagens, acima de um valor limite, fossem analisadas e classificadas quanto à sua inércia química, pois assim, poder-se-ia ter uma idéia mais realística dos materiais deletérios presentes entre as partículas dos agregados e quais prejuízos poderiam trazer se fossem incorporados às misturas asfálticas.

\subsection{Conclusões}

- Os valores obtidos através do ensaio de determinação do número de faces fraturadas dos agregados grossos (ASTM D 5821) permitem concluir que os agregados de gabro e de basalto possuem todas as suas partículas com duas ou mais faces fraturadas, portanto, de acordo com as especificações Superpave, são adequados ao propósito da pavimentação. O agregado de areia natural, por possuir $50 \%$ de suas partículas com uma face fraturada e apenas $35 \%$ de suas partículas com duas ou mais faces fraturadas, foi considerado, segundo as especificações Superpave, como de qualidade insuficiente para ser utilizado como material de revestimento de rodovias;

- O ensaio de determinação de porcentagens de faces fraturadas não permite a avaliação da angularidade dos agregados grossos, apenas avalia o número de faces fraturadas das partículas, não fazendo menção ao grau de angularidade (agudeza) dos cantos dessas fraturas, assim como, também não avalia a textura superficial das partículas;

- O ensaio de determinação de porcentagens de faces fraturadas, sugerido pelo Superpave, é ineficaz para desempenhar o papel ao qual foi idealizado: informar as características de forma, angularidade e textura superficial dos agregados grossos;

- Através de um processo de análise visual das partículas é possível obter informações sobre a forma, angularidade e textura superficial do agregado grosso, informações estas valiosas para a previsão de desempenho das misturas no campo;

- Os valores de angularidade do agregado fino (AAF) encontrados para os agregados de gabro, de basalto e de areia natural foram de $51,1 \%$; $48,3 \%$ e $40,7 \%$, respectivamente; 
- O ensaio de angularidade do agregado fino não foi capaz de detectar variações quanto à forma dos agregados, fato que pode levar à escolha de agregados com formas desfavoráveis à pavimentação por possuírem valores de AAF mais elevados;

- Partículas alongadas, mas com angularidade alta e textura superficial rugosa, podem causar um afastamento maior entre partículas, e portanto, valores de AAF mais elevados;

- Não se pode afirmar que agregados com valores de AAF de $51 \%$ produzirão misturas mais estáveis que agregados com AAF de 45\%, portanto, é falsa a afirmação de que quanto mais elevado for o valor o AAF, melhor será o arranjo estrutural entre as partículas e, portanto, maior a estabilidade da mistura. Por outro lado, misturas produzidas com agregados com valores de AAF muito baixos, por exemplo 40\%, apresentam problemas quanto à estabilidade, e, nesse caso, a afirmação é verdadeira. Isso mostra que o AAF deve ser visto como um divisor de águas entre classes de agregados com características de superfície (forma, angularidade e textura) satisfatórias ou não, o que já é de grande importância para a realização de projetos adequados de misturas asfálticas;

- A avaliação das partículas grossas do agregado através de formas definidas (planicidade e alongamento) permite um julgamento mais realístico quanto à possíveis prejuízos ao pavimento causados por quebras de partículas;

- Avaliar as formas das partículas utilizando a razão dimensional de $3: 1$ traz mais informações sobre a forma dos agregados comparada às informações de forma obtidas com razão dimensional de $5: 1$;

- O agregado de gabro apresentou valor do equivalente de areia de $75 \%$ e os agregados de basalto e areia natural valores de $100 \%$;

- Não é possível saber com certeza se os resultados do ensaio do equivalente de areia indicam a presença de argilominerais, ou então, apenas de frações argilosas presentes no agregado;

- O agregado de gabro, ainda que possivelmente desprovido de finos plásticos, apresentou equivalente de areia de $75 \%$, provavelmente, esse valor esteja associado à finura do material;

- O ensaio do equivalente de areia não permite que se faça distinção entre finos plásticos e frações argilosas do agregado;

- Os resultados de abrasão Los Angeles obtidos para o agregado de gabro e basalto indicam que são materiais resistentes, pois apresentaram perdas por abrasão em torno de $18 \%$ e $16 \%$, respectivamente. O agregado de areia natural apresentou perdas de $36 \%$; 
- Tanto o agregado de gabro como o agregado de basalto apresentaram valores de sanidade bem abaixo do limite máximo de $12 \%$, especificado pelo DER-PR, $3 \%$ e $6 \%$ respectivamente. Já o agregado de areia natural apresentou valor de sanidade no limite máximo de $12 \%$;

- A análise conjunta dos resultados de sanidade com os resultados de abrasão Los Angeles permite concluir que o agregado de gabro e o agregado de basalto podem ser considerados resistentes e duráveis. Já o agregado de areia natural apresentou valor de sanidade no limite máximo e perdas por abrasão relativamente altas, portanto, pode vir a apresentar problemas de resistência e durabilidade quando em serviço;

- O procedimento de análise de materiais deletérios especificado pelo Superpave (ASTM C 142) possibilita a detecção apenas de partículas deletérias que possam ser quebradas com a pressão dos dedos. Partículas mais duras e/ou resistentes não identificadas como fragmentos rochosos não são computadas como partículas deletérias;

- Nesta pesquisa, adotou-se um procedimento diferenciado para detecção de materiais deletérios, ou seja, além de rolar as partículas entre os dedos tentando quebrá-las, estas foram analisadas visualmente, partícula a partícula, selecionando aquelas que não eram constituídas por material rochoso e indicando sua possível origem. Esse procedimento torna possível que outros materiais deletérios, além daqueles que possam ser quebrados com a pressão dos dedos, sejam computados e, também, dá uma idéia melhor do material deletério que encontra-se na amostra;

- Alguns problemas quanto ao procedimento especificado pelo Superpave para a análise de materiais deletérios (ASTM C 142) puderam ser detectados. Dentre eles, constatou-se que nem todo material com constituição diferente do material rochoso é computado como material deletério e também que os resultados obtidos como porcentagens de massa podem ser enganosos, além de que a subjetividade da pressão aplicada com os dedos, destinada à quebra das partículas deletérias, pode prejudicar os resultados.

\subsection{Considerações Finais}

Em pavimentos rodoviários e também em pavimentos urbanos é utilizada uma grande variedade de tipos de agregados. Esses agregados podem variar muito em relação às suas propriedades e essas propriedades podem determinar a conveniência do agregado para o uso ou não em misturas asfálticas. Portanto, é muito importante o conhecimento dessas propriedades essenciais dos agregados para a seleção de materiais adequados para a pavimentação. 
Através do método de Delfos modificado, os especialistas do SHRP identificaram duas categorias de propriedades, denominadas de propriedades consenso e propriedades de origem. Contudo, propriedades também muito importantes dos agregados para o bom desempenho dos pavimentos, tais como, forma e textura superficial do agregado grosso, densidades, porosidade e absorção não foram consideradas pelos especialistas.

Pode-se observar também, com base na literatura consultada, que o critério de escolha dos ensaios para análise das propriedades de consenso e de origem dos agregados parece basear-se nos ensaios mais comumente utilizados pelas agências rodoviárias dos Estados Unidos. Esse critério de escolha desconsidera ensaios utilizados em outros países, já consagrados por produzirem bons resultados, que poderiam ser utilizados para a análise das mesmas propriedades de maneira mais eficaz.

Os ensaios de Flakiness Index e Elongation Index, padronizados pelo British Standard 812 e muito usados na Europa e na Austrália na determinação da forma do agregado grosso, são exemplos de ensaios que poderiam ter sido adotados. Basicamente, o ensaio de Flakiness Index consiste em passar a amostra de agregado grosso por peneiras cujas aberturas possuem largura de 0,6 em relação à dimensão média da partícula. A dimensão média da partícula é definida no intervalo de abertura de duas peneiras entre as quais as partículas são retidas por peneiramento. Já o ensaio de Elongation Index consiste em passar a amostra de agregado grosso por aberturas apropriadas para determinar se o comprimento da partícula é 1, 8 vezes maior que a dimensão média da partícula. Para a determinação do Flakiness Index e do Elongation Index, determina-se a massa total das partículas do agregado que passam pela abertura das peneiras, expressas em porcentagem da massa total da amostra. Os ensaios de Flakiness Index e de Elongation Index não são subjetivos, possuem boa reprodutibilidade, praticidade e relativamente baixo custo (Kandhal \& Parker Jr., 1998).

Outro exemplo é o ensaio que avalia a quantidade de vazios não compactados do agregado grosso, similar ao ensaio de avaliação dos vazios não compactados do agregado fino (AAF). O ensaio dos vazios não compactados do agregado grosso consiste, basicamente, em verter uma amostra de uma altura de queda estabelecida, dentro de um cilindro de volume conhecido, cuja porcentagem de vazios não compactados é determinada em função do volume total da amostra. Detalhes sobre o ensaio podem ser encontrados no apêndice D do periódico National Cooperative Highway Research Program, report 405. O ensaio dos vazios não compactados do agregado grosso não é subjetivo, portanto, não depende do julgamento da pessoa que realiza o ensaio, como ocorre no ensaio de porcentagem de partículas fraturadas, adotado pelo Superpave. No entanto, essa maneira de avaliação indireta das propriedades de forma, angularidade 
e textura superficial do agregado grosso provavelmente apresentaria os mesmos problemas já discutidos quanto ao ensaio de AAF.

A determinação da forma, da angularidade e da textura superficial das partículas finas do agregado com o uso de ensaio AAF ou através de análises visuais também pode não trazer informações realísticas. Com base na experiência adquirida nesta pesquisa, pode-se constatar como um diferencial positivo do ensaio AAF em relação à análise visual das partículas sua facilidade e rapidez de execução, em comparação ao processo longo e cansativo de analisar visualmente, com o auxílio de lupas, partículas de agregados finos. No entanto, o ensaio AAF pode trazer informações enganosas quando utilizado para estabelecer comparações quanto a maior ou menor adequabilidade de agregados para uso em misturas asfálticas. Mas, a análise visual comparativa também pode trazer resultados deficitários por determinar a forma das partículas apenas em duas direções (2D), prejudicando a obtenção de informações quanto à planicidade.

Portanto, para análises de forma, angularidade e textura superficial tanto dos agregados finos quanto dos agregados grossos, seria necessário que se utilizasse formas de análises mais rápidas e precisas. Atualmente, técnicas de processamento de imagens digitais já são realidade na indústria da pavimentação. Esses métodos de imagens não são subjetivos, como o utilizado para determinação das faces fraturadas do agregado grosso e nem indiretos, como o utilizado para a determinação da AAF, adotados pelo Superpave, além de serem rápidos e permitirem a obtenção de resultados com maior precisão e mais reprodutíveis.

Várias propriedades importantes dos agregados, dentre as selecionadas pelo Superpave, não foram adequadamente avaliadas devido às deficiências dos métodos de análise especificados. Além disso, propriedades também muito importantes, como a absorção de asfalto pelos agregados, não foram consideradas. No entanto, a absorção é uma propriedade fundamental e, portanto, será abordada nesta pesquisa. No próximo capítulo, será apresentada uma discussão sobre o fenômeno da absorção de asfalto, de maneira a facilitar e elucidar a compreensão de seus princípios fundamentais e alertar sobre os riscos que se corre ao desconsiderar esse fenômeno. 



\section{CAPÍTULO}

\section{Absorção de Asfalto}

\subsection{Considerações Iniciais}

Absorção pode ser definida como a fixação de uma substância, líquida ou gasosa, no interior da massa de outra substância, geralmente sólida, e resultante de um conjunto complexo de fenômenos de capilaridade, atrações eletrostáticas, reações químicas etc. (Ferreira, 1999). A absorção de asfalto pelo agregado é um fenômeno de alta complexidade, influenciado por características do agregado e do asfalto, assim como por fatores externos.

Basicamente, a consequiência direta do fenômeno da absorção nas misturas asfálticas é a diminuição do filme de asfalto que envolve as partículas do agregado, ou seja, a diminuição da quantidade de asfalto efetivo na mistura. Essa diminuição torna a mistura mais suscetível às tensões causadas pelo tráfego e às intempéries, influenciando também o endurecimento e o envelhecimento do asfalto prematuramente e, conseqüentemente, passa a ser uma causa importante para o surgimento de vários problemas no pavimento.

A absorção não é um fenômeno que ocorre eventualmente, pelo contrário, a maioria dos agregados apresenta algum grau de absorção. Em vista disso, se no projeto de misturas a absorção não for considerada, certamente serão produzidas misturas com teores de asfalto efetivos inferiores àqueles projetados, pois parte do asfalto adicionado durante a produção dessas misturas será absorvido, portanto, não estará mais disponível para agir como ligante. 
Essa diferença entre o teor de asfalto projetado e o teor de asfalto efetivo implica também em diferenças entre as propriedades volumétricas projetadas e as propriedades volumétricas reais da mistura após a compactação. Em outras palavras, ao se negligenciar a absorção de asfalto se está considerando erroneamente que todo o asfalto adicionado à mistura está envolvendo as partículas do agregado e, nesse caso, as propriedades volumétricas de projeto (volume de vazios, vazios do agregado mineral e vazios preenchidos por asfalto) serão diferentes daquelas encontradas após a compactação da mistura, pois a quantidade de asfalto absorvido altera a proporção de vazios. Como essas propriedades volumétricas são utilizadas como critérios de projeto, desconsiderar a capacidade de absorção dos agregados é o mesmo que desacreditar a importância dessas propriedades volumétricas para o desenvolvimento de projetos adequados de misturas asfálticas. Detalhes sobre a influência exercida pela absorção nos parâmetros volumétricos das misturas serão discutidos no Capítulo 4.

\subsection{Características da Absorção}

Uma característica importante da absorção, que pode se tornar um complicador para o cálculo dos parâmetros volumétricos das misturas, é sua dependência em relação ao tempo (tempo-dependência). Os agregados podem absorver o asfalto rapidamente no momento da produção das misturas ou mais lentamente, ao longo dos meses, após a mistura ter sido compactada no pavimento (Kandhal \& Khatri, 1991; Lee, 1969) . Para se contornar o problema da absorção, poder-se-ia pensar em aumentar a quantidade de asfalto na mistura. Essa seria uma saída eficiente se a absorção de asfalto pelo agregado fosse rápida o suficiente para ser completada durante o processo de mistura. No entanto, se a absorção ocorresse lentamente, nos meses seguintes da construção do pavimento, a necessidade de uma maior quantidade de asfalto na mistura poderia não ser detectada, o que resultaria, a médio e longo prazos, em uma mistura com pouco asfalto e, conseqüentemente, com problemas de durabilidade. Adicionalmente, se uma quantidade extra de asfalto fosse adicionada à mistura produzida com agregados de absorção lenta, esta teria excesso de asfalto quando compactada, ocasionando estabilidade inicial baixa e problemas de exsudação de asfalto (Lee et al., 1990; Lettier et al., 1949).

Outra característica da absorção é sua seletividade. Na absorção seletiva os agregados podem absorver preferencialmente certas frações do asfalto, alterando as propriedades do asfalto efetivo (asfalto não absorvido) em relação ao asfalto original. A ocorrência da absorção seletiva é função de características tanto do agregado como do asfalto, como será visto neste capítulo. 
Resumidamente, a não observância da absorção de asfalto pelos agregados pode ocasionar os seguintes problemas:

- Cálculo incorreto das propriedades volumétricas das misturas: volume de vazios (Vv), vazios do agregado mineral (VAM) e vazios preenchidos por asfalto (relação betume-vazios, RBV);

- Falta de asfalto efetivo na mistura, resultando em desgaste, perda de adesividade entre o asfalto e o agregado na presença de água (stripping) ou em trincas;

- Película de asfalto mais suscetível às tensões e às intempéries;

- Prematuro endurecimento e envelhecimento do asfalto em decorrência da absorção seletiva.

\subsection{Efeito das Propriedades do Agregado na Absorção}

As propriedades mais importantes dos agregados diretamente relacionadas com a absorção são: porosidade, tamanho e distribuição dos poros e composição química e mineral do agregado.

\subsubsection{Porosidade}

Pode-se entender porosidade como uma relação entre o volume de vazios e o volume total de um material. Lettier et al. (1949) relacionaram porosidade e absorção através da densidade aparente do agregado, verificando que, quanto menor a densidade aparente entre agregados de mesma origem, maior a absorção de água, em uma escala linear. Isso indica que a capacidade de absorção do agregado, como função da densidade, está diretamente relacionada com a porcentagem de interstícios (poros) na massa cristalina das partículas. Os poros podem ser descritos como cavidades formadas irregularmente, conectadas ou não por capilares, com forma e diâmetro variados (Kandhal \& Lee, 1972).

A porosidade pode ser determinada direta ou indiretamente, através de vários métodos. Um método comum de determinação direta é através da avaliação visual, onde uma seção do agregado é analisada microscopicamente ou por métodos de fotomicrografia para a determinação da área de vazios presente na partícula (espaço do poro) (Lee et al., 1990). Um método bastante usado de determinação indireta da porosidade é através da razão entre a densidade aparente e 
a densidade real do agregado, como mostra a Equação 3.1. A porosidade obtida dessa forma é denominada de porosidade total, pois funciona como um indicador da capacidade de absorção máxima do agregado, que na prática, pode nunca vir a ocorrer.

$$
P T=100-\frac{\rho_{a p}}{\rho_{r}} \times 100
$$

onde:

$P T=$ porosidade total, $\%$;

$\rho_{r}=$ densidade real do agregado;

$\rho_{a p}=$ densidade aparente do agregado.

As densidades aparente e real são geralmente determinadas através de métodos de flutuabilidade, conforme os procedimentos padronizados pela ASTM C 127 e ASTM C 128, descritos nos itens 3.7.3 e 3.7.4.

\subsubsection{Distribuição e Tamanhos dos Poros}

Tanto a capacidade de absorção dos agregados quanto a natureza da absorção são influenciadas diretamente pelo tamanho dos poros presentes nas partículas (macro ou micro poros) e pela freqüência que cada faixa de tamanho ocorre nas partículas.

Tipos diferentes de agregados possuem tamanhos de poros diferentes e suas frequiências variam de maneira desigual (Lee, 1969). Geralmente tamanhos de poros maiores que 0,5 micron, chamados de macroporos, possuem capacidade de absorver asfalto. Já poros menores que 0,1 micron (microporos) não conseguem absorver asfalto.

\subsubsection{Composição Química e Mineralógica do Agregado}

A composição química dos agregados também pode influenciar indiretamente a absorção, quando proporciona porosidade à partícula. Foi o que constatou Lee (1969) ao executar ensaios de absorção de asfalto por imersão, percebendo uma grande variação na taxa de absorção dos agregados de rochas calcárias estudados. Após análises químicas e de distribuição de tamanhos dos poros em agregados de alta, média e baixa absorção de asfalto, Lee (1969) verificou que quanto maior a quantidade de $\mathrm{MgCO}_{3}$ presente no agregado, mais porosa era a partícula e, portanto, com maior capacidade de absorver asfalto. 
Lettier et al. (1949) estudaram a estrutura cristalina de agregados com mesma classificação mineral, mas com características de absorção distintas, verificando que os agregados com absorção baixa de asfalto possuem estruturas cristalinas compactas, densas e de granulação fina e que agregados absorvedores são caracterizados por numerosos interstícios entre seus cristais e/ou são compostos de cristais com granulação grossa. Os pesquisadores observaram também que os mecanismos físicos da absorção se processam através da passagem do asfalto pelos canais existentes entre os cristais que compõem as partículas, verificando que não há penetração de asfalto dentro dos cristais.

Ambos os estudos de Lee (1969) e Lettier et al. (1949) mostram que a capacidade de absorção dos agregados está diretamente relacionada com a porosidade da partícula e não diretamente com a composição química dos agregados, pois existem agregados com mesma composição química que absorvem e que não absorvem asfalto.

Resumidamente, seguem algumas considerações sobre a absorção de asfalto em relação às propriedades dos agregados.

- A absorção de asfalto pode afetar misturas adequadamente projetadas, devido à sua característica de tempo-dependência;

- A absorção de asfalto está diretamente relacionada com a porosidade do agregado;

- A porosidade total é um indicador da capacidade de absorção máxima do agregado;

- Tanto a porosidade da partícula como o tamanho de seus poros e a frequiência de ocorrência desses tamanhos de poros influenciam a taxa de absorção de asfalto bem como a natureza da absorção;

- A absorção está diretamente relacionada com as densidades do agregado, indicativas da porosidade da partícula;

- Os mecanismos físicos da absorção se processam através da passagem do líquido por canais intercristalinos, que constituem vazios com formas e tamanhos variados (poros).

\subsection{Efeito das Propriedades do Asfalto na Absorção}

A quantidade de asfalto absorvido pelo agregado é função de algumas propriedades do asfalto, tais como: viscosidade, composição, distribuição do tamanho molecular e propriedades 
de molhamento (ângulo de contato e tensão superficial). No entanto, essas propriedades se interrelacionam e dependem de outras variáveis, como a temperatura e o tempo.

Wingrave et al. ${ }^{1}$ e Wade ${ }^{2}$ apud Lee et al. (1990), que estudaram a absorção de vários hidrocarbonetos e da água, mostram que a taxa de absorção, em um dado volume, é dada por:

$$
-\frac{1}{3} \times A-\frac{1}{2} \times\left[(1-A)^{\frac{2}{3}}-1\right]=t_{r}
$$

onde:

$A=$ fração preenchida do volume do poro $(0 \leq A \leq 1)$;

$t_{r}=$ tempo reduzido, dado por:

$$
t_{r}=\frac{K p t}{R^{2} \mu}
$$

onde:

$K$ = coeficiente de permeabilidade de Darcy;

$p=$ pressão de capilaridade;

$t=$ tempo de absorção;

$R=$ raio da partícula;

$\mu=$ viscosidade do fluido.

Para um poro circular de raio $r$ :

$$
\begin{gathered}
p=\frac{2 \sigma \cos \theta}{r} \\
K=\frac{r^{2}}{8}
\end{gathered}
$$

As Equações 3.2, 3.3, 3.4 e 3.5 mostram que o processo de absorção é regido pela tensão superficial $(\sigma)$, ângulo de contato $(\theta)$ e viscosidade $(\mu)$ do asfalto, assim como pelo raio ou tamanho do poro $(r)$, raio ou tamanho da partícula $(R)$ e pela permeabilidade (porosidade) da partícula $(K)$.

Analisando as Equações 3.2, 3.3, 3.4 e 3.5 pode-se depreender que a taxa de absorção de hidrocarbonetos e da água aumentam em função do tempo e em função da diminuição da viscosidade do fluido, o que vem corroborar qualitativamente com os resultados dos estudos desenvolvidos por pesquisadores como Kandhal \& Khatri (1991), Kandhal \& Lee (1972) e Lee (1969), que mostram um aumento da taxa de absorção de asfalto pelos agregados ao longo do tempo e com a diminuição da viscosidade do asfalto.

\footnotetext{
${ }^{1}$ Wingrave J. A.; Wade W. H.; Schechter R. S. (1978). Liquid Imbibition into Evacuated Mesoporous Media. Padday, J. F., editor, Wetting, Spreading and Adhesion, capítulo 12, p. 261-288. Academic Press, New York.

${ }^{2}$ Wade, W. H. (1974). Spontaneous Imbition of Fluids into Porous Vycor. Soc. of Petrol. Eng. J., p. 139-144
} 
Seguem, resumidamente, algumas considerações sobre a absorção e as propriedades do asfalto:

- A quantidade de asfalto absorvido é diretamente proporcional à pressão de capilaridade $\mathrm{e}$ ao tempo e inversamente proporcional à viscosidade do asfalto;

- A quantidade de asfalto absorvido diminui com o aumento de sua viscosidade, fazendo da temperatura uma variável crítica.

\subsection{Absorção Seletiva}

No momento em que o asfalto é absorvido pelo agregado, pode ocorrer absorção preferencial de alguns constituintes do asfalto. Essa absorção preferencial é denominada de absorção seletiva. A absorção seletiva gera alterações na composição do asfalto absorvido dentro do poro em relação ao não absorvido, ou asfalto efetivo, que age como filme de asfalto.

Vários fatores podem desencadear a absorção seletiva, dentre eles a utilização de agregados altamente porosos. Agregados altamente porosos possuem uma parcela grande de sua área superficial pertencente ao espaço do poro, o que vem facilitar a remoção preferencial de partes do asfalto efetivo (filme de asfalto) mais absorvíveis (Kandhal \& Lee, 1972). Dependendo do tamanho dos poros do agregado, essa difusão seletiva e os efeitos de particionamento levam à segregação e a diferenças composicionais entre o asfalto absorvido e o não absorvido. Por exemplo, moléculas de tamanho menores, como as dos maltenos, podem ser preferencialmente absorvidas dentro do volume do poro, enquanto moléculas grandes, como as dos asfaltenos, permanecem no filme de asfalto efetivo (Kandhal \& Khatri, 1992; Lettier et al., 1949). Portanto, pode-se entender como efeito direto da absorção seletiva, modificações composicionais entre o asfalto absorvido e o não absorvido, como também, entre ambos e o asfalto original. Em outras palavras, significa dizer que o filme de asfalto que cobre o agregado terá propriedades reológicas, físicas, químicas e de envelhecimento diferentes das do asfalto original, adicionado à mistura durante sua preparação.

Uma forma prática de detecção da absorção seletiva é observar se as propriedades mecânicas das misturas, por exemplo a estabilidade Marshall, mostram-se muito maiores do que as geralmente encontradas. Caso isso ocorra, uma maneira de corrigir o problema é através da utilização de asfaltos menos viscosos. No entanto, os efeitos de absorção seletiva só poderiam ser percebidos se ela ocorresse no momento da mistura, pois, se ocorresse com o passar dos 
dias ou dos meses, não seria possível sua detecção para que possíveis ajustes fossem efetuados e, provavelmente, o pavimento viria a desenvolver defeitos prematuros (Lee et al., 1990).

\subsection{Métodos de Determinação da Absorção}

Muitos pesquisadores vêm tentando avaliar a absorção de asfalto pelos agregados através de correlações com a absorção de outros líquidos, dos quais a água e o querosene têm sido os mais comumente usados.

Em 1936, Reagel ${ }^{3}$ apud Kandhal \& Khatri (1991) propôs um procedimento para a determinação da absorção de água e de líquidos betuminosos, pela fração grossa dos agregados, usando um método de deslocamento de água. Nesse método, a amostra de agregado é colocada submersa em água por 24 horas, sendo então determinada a sua massa imersa. Após, a amostra é seca em estufa e determinada a sua massa seca. Então, uma quantidade de asfalto igual a $8 \%$, em relação à massa da amostra, é misturada ao agregado. A mistura permanece aquecida a $60{ }^{\circ} \mathrm{C}$ $\left(140{ }^{0} \mathrm{~F}\right.$ ) por 20 dias. Passados os 20 dias, o excesso de asfalto é removido de cada partícula do agregado por esfregamento. Então, é feita a determinação da massa da amostra ao ar e submersa e a quantidade de material betuminoso absorvido é calculada através da manipulação dessas quatro massas.

Em 1942, Goshorn e Williams ${ }^{4}$ apud Kandhal \& Khatri (1991) desenvolveram um método de imersão para a determinação da capacidade de absorção máxima do agregado. O procedimento estabelece o aquecimento de uma amostra de agregado a cerca de $148,9{ }^{0} \mathrm{C}\left(300{ }^{0} \mathrm{~F}\right) \mathrm{e}$ a suspensão dessa amostra, por meio de um cesto, em asfalto com penetração entre 85 a 100, a uma temperatura de $135{ }^{\circ} \mathrm{C}\left(275{ }^{0} \mathrm{~F}\right)$, por 2 horas. Em seguida, a amostra, ainda imersa, é resfriada até que atinja temperatura ambiente e, então, reaquecida e mantida a uma temperatura de $135{ }^{\circ} C$, por mais 1 hora. Após essa etapa, o cesto contendo a amostra é retirado da imersão e suspenso em uma corrente de ar a $135{ }^{\circ} \mathrm{C}$, até que todo o excesso de asfalto seja drenado. A amostra é removida do cesto e resfriada até atingir temperatura ambiente, sendo então, medidas suas massas ao ar e imersa em água, para determinação da absorção.

Hveem (1942) ao desenvolver o centrifuge kerosene equivalent test (CKE), que mede a quantidade de querosene absorvido por $100 \mathrm{~g}$ de agregado, sob condições especificadas de

\footnotetext{
${ }^{3}$ Reagel, F. V. (1937). Absorption of Liquid Bituminous Material by Coarse Aggregate. Highway Research Abstracts, n. 40.

${ }^{4}$ Goshorn, J. H.\& Williams, F. M. (1942). Absorption of Bituminous Materials by Aggregates. Association of Asphalt Paving Technologists, v. 13.
} 
submersão e centrifugação, demonstrou que a quantidade de querosene retida pelo agregado é função da sua capacidade superficial. Segundo esse autor, a capacidade superficial do agregado é composta de três fatores: área superficial, textura superficial (rugosidade) e porosidade efetiva. Hveem justificou a utilização do querosene por acreditar que fosse um representante melhor, como agente de absorção, do que a água, por ter propriedades de molhamento similares às do asfalto. No entanto, métodos que utilizem outros líquidos em vez de asfalto devem ser utilizados apenas como estimativas da absorção de asfalto, devido às diferenças entre as propriedades de molhamento e viscosidade desses líquidos em relação ao asfalto.

Rice (1953) propôs um método de determinação indireta da absorção de asfalto através da densidade máxima medida (DMM) das misturas. Esse método será descrito detalhadamente no item 3.7.2 deste capítulo. Uma limitação desse método é a necessidade de cobertura total das partículas do agregado pela película de asfalto, pois, no momento da saturação por vácuo parcial, se as partículas não estiverem completamente envolvidas pelo asfalto, estas passam a absorver água, comprometendo os resultados do ensaio. Entretanto, Rice (1953) propôs também um procedimento suplementar para correção desse problema, caso venha a acorrer, descrito na norma ASTM D 2041.

Mais recentemente, Castro Neto (1996) desenvolveu outro método de determinação indireta da absorção de asfalto, também através da densidade máxima medida, no entanto, empregando querosene, ao invés do vácuo parcial proposto por Rice, para expulsar os vazios de ar das misturas. Esse método é particularmente atraente para utilização em campo por ser rápido, com vantagens sobre o método Rice, que necessita da aplicação de vácuo para a retirada de vazios de ar da mistura, o que torna a sua prática em obras muito delicada, principalmente tendo em vista a precisão necessária. Segundo Vasconcelos et al. (2003), os resultados obtidos tanto através do método Rice como através do método do Querosene produzem praticamente os mesmos valores de DMM, porém, apesar do método do Querosene parecer bastante promissor, necessita ser melhor investigado, pois o querosene é um solvente natural do asfalto.

Atualmente, o Superpave estabelece o uso do Método Rice para a determinação da DMM das misturas, por ser um ensaio de execução relativamente rápida, realístico e apropriado também para a determinação da absorção de asfalto. 


\subsection{Experimentos Laboratoriais}

\subsubsection{Asfalto Utilizado}

Para o desenvolvimento desta pesquisa utilizou-se um CAP 20, com suas propriedades satisfazendo às exigências contidas no Regulamento Técnico do Departamento Nacional de Combustíveis DNC n. ${ }^{\circ}$ 01/92, como mostra a Tabela 3.1.

Tabela 3.1: Características físicas do CAP 20 utilizado

\begin{tabular}{lcc}
\hline Ensaios & Resultados & Exigência DNC 01/92 \\
\hline Viscosidade absoluta a $60^{\circ} C$ (poise) & 3200 & 2000 a 3500 \\
Viscosidade Saybolt Furol a $135^{\circ} C(\mathrm{~s})$ & 165 & 120 mín. \\
Viscosidade Saybolt Furol a $177^{\circ} C(\mathrm{~s})$ & 35 & 30 a 150 \\
Índice de suscetibilidade térmica & $-0,45$ & $-1,5$ a 1,0 \\
Penetração, $25^{\circ} C, 100 \mathrm{~g}, 5 \mathrm{~s}(0,1 \mathrm{~mm})$ & 55 & 50 mín. \\
Ponto de fulgor $\left({ }^{\circ} \mathrm{C}\right)$ & 264 & 235 mín. \\
Densidade real & $1,02^{*}$ & - \\
\hline
\end{tabular}

* Resultado de ensaio fornecido pela Petrobrás Petróleo Brasileiro S.A.

\subsubsection{Método Rice de Determinação da Densidade Máxima Medida}

Nesta pesquisa, o procedimento utilizado para a determinação da DMM está baseado na norma ASTM D 2041, cujos detalhes de execução serão apresentados a seguir.

\footnotetext{
Amostra

O processo de preparo da amostra para a determinação da DMM é o mesmo utilizado na composição dos corpos-de-prova Marshall, excluindo a etapa de compactação. Esse procedimento consiste em peneirar o material granular nas frações necessárias e, então, compor a mistura de agregados de acordo com a curva granulométrica utilizada. A mistura deve ser produzida com o teor de asfalto de projeto ou então num teor muito próximo dele, caso este ainda não seja conhecido. Após a produção da mistura asfáltica, esta deve permanecer durante 2 horas na temperatura de compactação, como sugere a AASHTO PP2, para que o processo de absorção de asfalto pelo agregado possa ocorrer.
} 
Após ser retirada da estufa, a mistura passa a ser resfriada manualmente, com o auxílio de uma espátula, para evitar a formação de grumos, como ilustra a Figura 3.1.

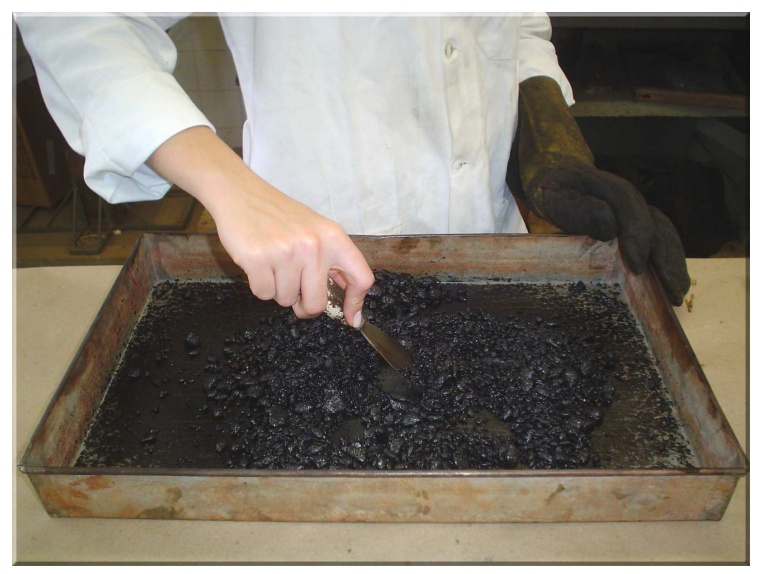

Figura 3.1: Procedimento de resfriamento da amostra

\section{Determinação da massa seca}

Em seguida, a mistura é colocada dentro de um kitassato modificado para que a massa seca da amostra possa ser determinada (Figura 3.2).

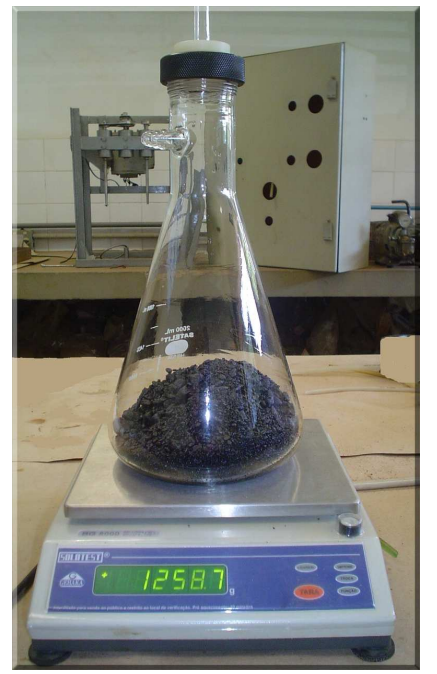

Figura 3.2: Determinação da massa seca da amostra

\section{Kitassato Modificado}

Um kitassato comum foi modificado, nesta pesquisa, para atender às necessidades do ensaio, com a finalidade de obter um dispositivo de nivelamento que proporcionasse maior precisão. O dispositivo desenvolvido, que pode ser visualizado na Figura 3.3(a), é composto por três 


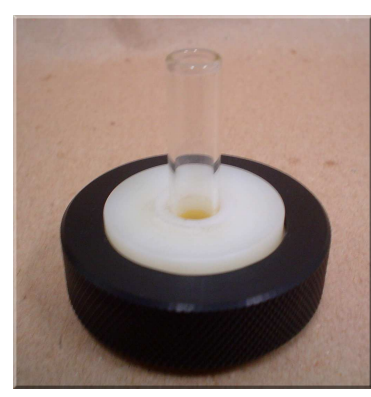

(a) Dispositivo montado

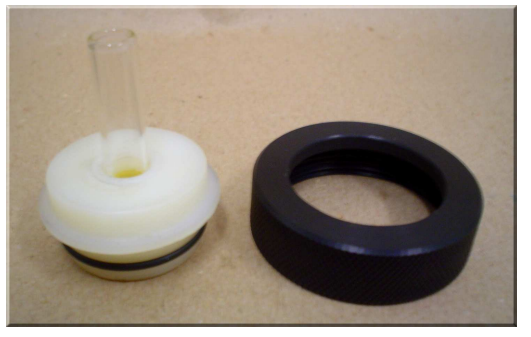

(b) Detalhe 1

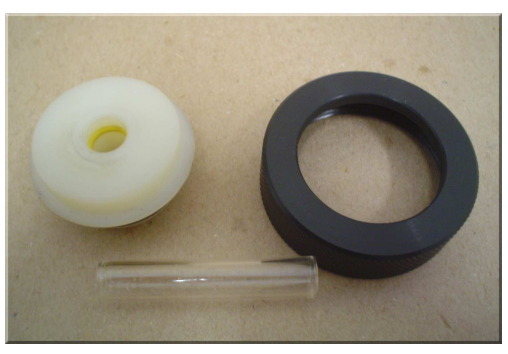

(c) Detalhe 2

Figura 3.3: Dispositivo de nivelamento

partes, uma mais externa rosqueável (na cor preta), utilizada para fixar o dispositivo na boca do kitassato, outra interna (na cor branca), utilizada para fixar o conjunto ( parte branca e cilindro de vidro) na boca do kitassato, e um cilindro de vidro de diâmetro pequeno. A parte interna (branca) também é composta por dois anéis de borracha, um situado em sua parte externa, que evita o vazamento de água da parte rosqueável à boca do kitassato, e outro anel fixado em sua parte interna, que evita o vazamento de água ao redor das paredes do cilindro de vidro. Esses detalhes podem ser melhor esclarecidos com o auxílio das Figuras 3.3(b) e 3.3(c), que apresentam as partes destacadas do dispositivo. Na Figura 3.4, podem ser vistas as modificações sofridas pelo kitassato original, tais como a feitura de rosca em sua boca e o fechamento de seu dispositivo original de nivelamento, situado lateralmente.

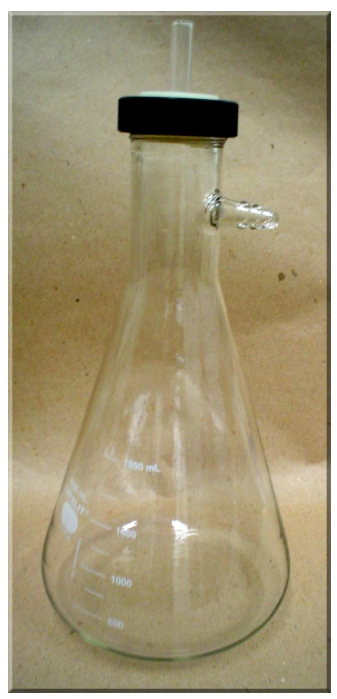

Figura 3.4: Kitassato modificado

\section{Determinação da massa do conjunto (kitassato, amostra e água)}

Após a determinação da massa seca da amostra, adiciona-se água fervida ao kitassato modificado, em quantidade suficiente para que o nível de água permaneça $2 \mathrm{~cm}$ acima da amostra. Toda água utilizada nesse ensaio foi fervida durante aproximadamente 1 hora. Embora esta 


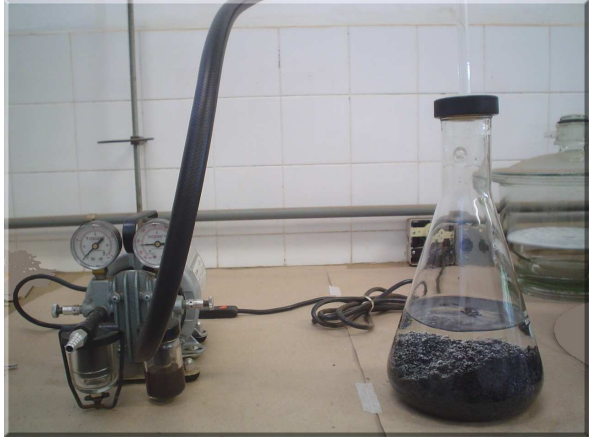

(a) Bomba de vácuo parcial

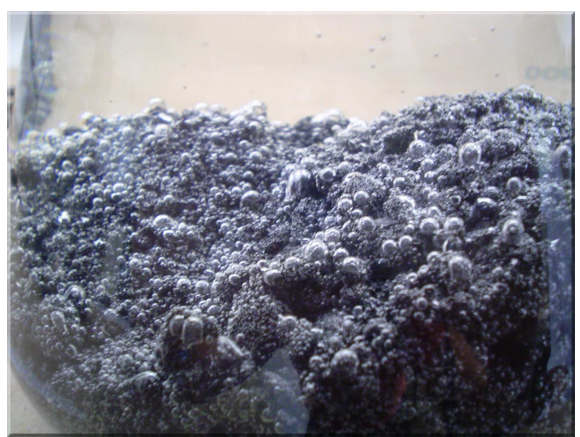

(b) Bolhas de ar sendo extraídas

Figura 3.5: Extração de ar da amostra

não seja uma etapa sugerida por norma, tomou-se esse cuidado para diminuir a oxigenação da água e melhorar a precisão do ensaio. Em seguida, conecta-se o conjunto (kitassato, amostra e água) à bomba de vácuo parcial (30 mmHg, correspondente à diferença entre 760 e $730 \mathrm{mmHg}$ ) para a extração de bolhas de ar da amostra, por aproximadamente 15 minutos, como ilustram as Figuras 3.5(a) e 3.5(b).

Terminada a extração de ar, adiciona-se água fervida, com muito cuidado para não haver incorporação de ar ou formação de bolhas, até o limite superior do kitassato modificado, para em seguida, rosquear o dispositivo de nivelamento. Com o auxílio de uma toalha felpuda, enxuga-se a água que extravasa e escorre pelas paredes do kitassato modificado no momento do nivelamento da água, para então determinar a massa do conjunto (Figura 3.6).

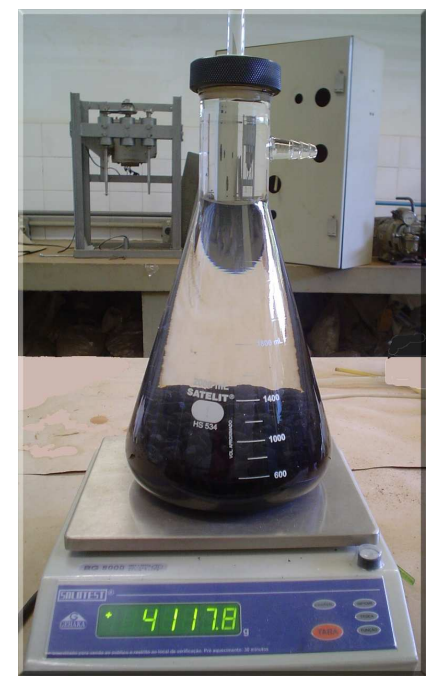

Figura 3.6: Determinação da massa do conjunto 


\section{Determinação da Temperatura}

O próximo passo é fazer a leitura da temperatura do conjunto, como ilustra a Figura 3.7. Deve-se atentar para a colocação do termômetro sempre em uma mesma posição no interior do kitassato, na sucessão de ensaios, pois a temperatura da água pode variar dependendo do local em que o termômetro é colocado.

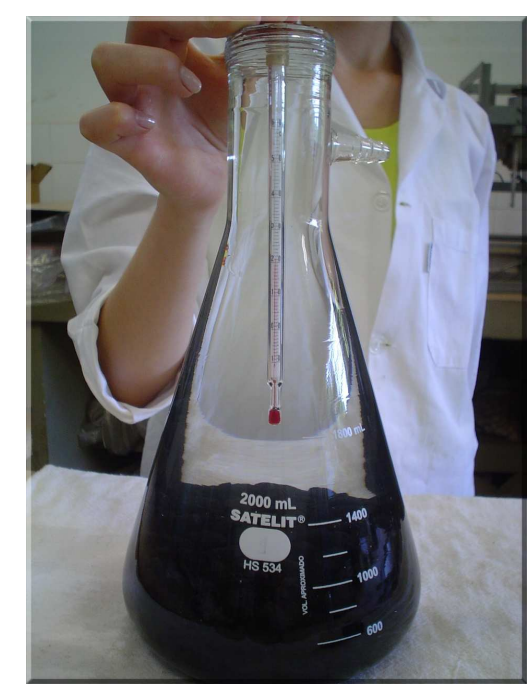

Figura 3.7: Determinação da temperatura da água

\section{Determinação da Taxa de Absorção de Asfalto}

Sendo conhecidas as massas da amostra seca e do conjunto, determinadas durante o ensaio, e tendo sido definida a curva de calibração do kitassato modificado, ou seja, a massa do kitassato preenchido com água fervida em função da variação da temperatura, pode-se calcular a DMM da mistura asfáltica, como mostra a Equação 3.6.

$$
D M M=\frac{A}{A+D-E}
$$

onde:

$A=$ massa da amostra seca;

$D=$ massa do kitassato modificado preenchido com água em função da temperatura (curva de calibração);

$E=$ massa do conjunto (kitassato, amostra e água). 
Conhecida a DMM da mistura, pode-se calcular a densidade efetiva do agregado através da Equação 3.7.

$$
\rho_{e f}=\frac{1-P b}{\frac{1}{D M M}-\frac{P b}{\rho_{b}}}
$$

onde:

$\rho_{e f}=$ densidade efetiva do agregado;

$\mathrm{Pb}=$ porcentagem de asfalto na mistura;

$\rho_{b}=$ densidade do asfalto.

E, sendo conhecidas as densidades efetiva e aparente do agregado e a densidade do asfalto, pode-se calcular a taxa de absorção através da Equação 3.8.

$$
A_{a b s}=100 \times \frac{\rho_{e f}-\rho_{a p}}{\rho_{e f} \times \rho_{a p}} \times \rho_{b}
$$

onde:

$A_{a b s}=$ porcentagem de asfalto absorvido por massa de agregado;

$\rho_{e f}=$ densidade efetiva do agregado;

$\rho_{a p}=$ densidade aparente do agregado;

$\rho_{b}=$ densidade do asfalto.

\subsubsection{Densidade aparente do Agregado Grosso}

A ASTM C 127 padroniza o método de determinação da densidade aparente do agregado grosso, assim como, da porcentagem de água absorvida pelo agregado.

\section{Amostra}

O material que compõe a amostra de agregado grosso é aquele retido na peneira de abertura de 4,75 mm, lavado para a remoção de pó ou outros contaminantes da superfície da partícula e, seco em estufa. A quantidade de material da amostra é função do diâmetro máximo nominal do agregado. Nesta pesquisa, como o diâmetro máximo nominal dos agregados é de $12,5 \mathrm{~mm}$, usou-se no mínimo $2 \mathrm{~kg}$ de material para a composição de cada amostra. 


\section{Procedimento de Secagem Superficial}

Inicialmente, deve-se submergir a amostra em água destilada por um período de aproximadamente 24 horas. Após esse período, retira-se a amostra da água colocando-a sobre uma toalha absorvente, para dar início ao procedimento de secagem superficial da amostra (Figura 3.8).

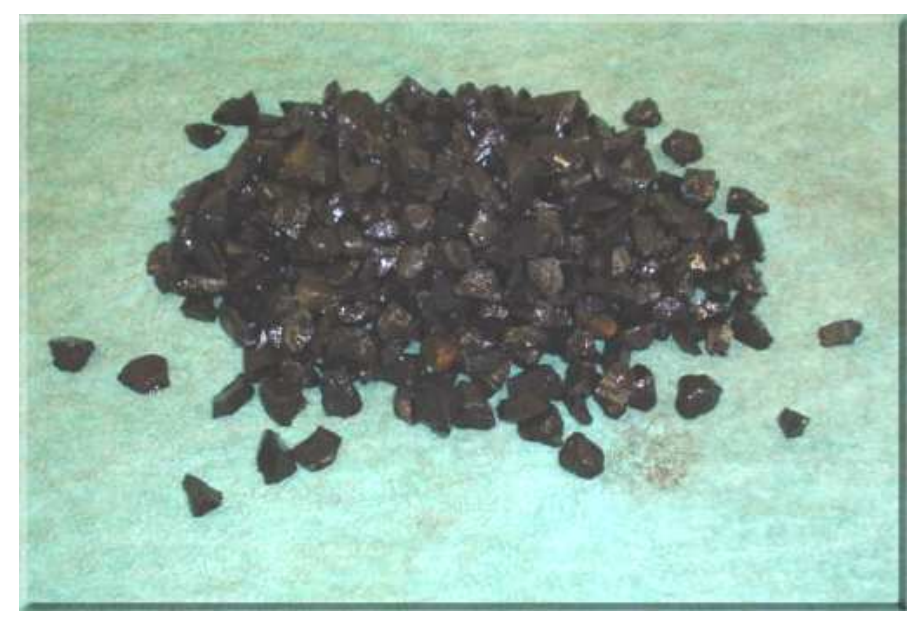

Figura 3.8: Amostra úmida

O procedimento de secagem superficial consiste em espalhar as partículas sobre a toalha absorvente (Figura 3.9(a)) e, em seguida, promover a rolagem destas, fazendo com que suas faces toquem na toalha, até que o filme fino de água que envolve cada partícula não seja mais visível, atingindo-se, nesse momento, a condição de secura superficial (Figura 3.9(b)). Pode-se julgar que a condição de secura superficial foi atingida quando a partícula tornar-se fosca, sem o brilho da luz que é refletido pela água, ou ainda, se forem observadas alterações de cor da partícula.

Ao secar a amostra, deve-se tomar cuidado para não retirar a água contida nos poros do agregado. Manter a toalha úmida durante o desenvolvimento do ensaio favorece a secagem

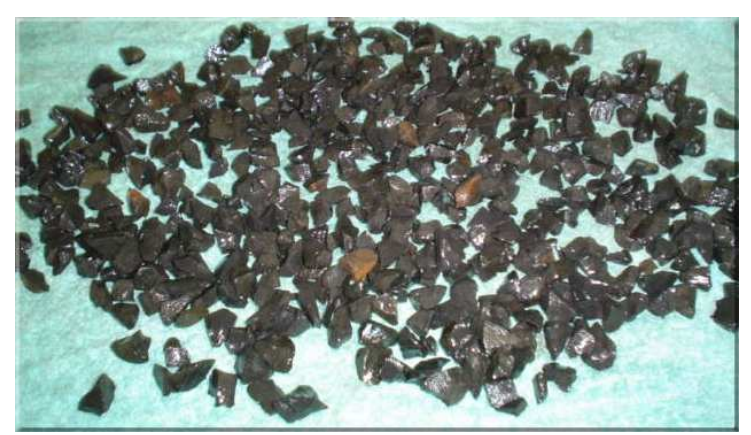

(a) Espalhamento da amostra

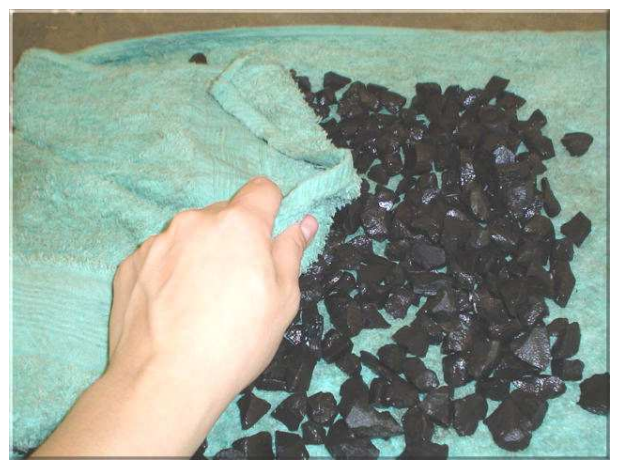

(b) Secagem superficial da amostra

Figura 3.9: Procedimento para atingir a condição de secura superficial da amostra 
da partícula apenas superficialmente, sem que haja a retirada de água do interior dos poros da partícula. Se a toalha estiver totalmente seca, o risco de absorver água além daquela superficial é bem maior. Outro cuidado importante, que se deve tomar para obter resultados bons nesse ensaio, é determinar a massa da amostra em sua condição de secura superficial imediatamente após o procedimento de secagem estar concluído, evitando-se assim a evaporação da água contida nos poros das partículas (Figura 3.10). A não observância desses cuidados pode ser a causa de erros no resultado final.

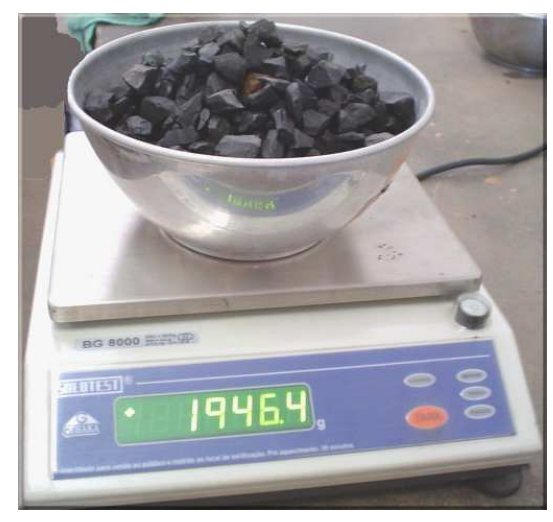

Figura 3.10: Determinação da massa da amostra ao ar

\section{Determinação das massas submersa e seca}

Em seguida, submerge-se a amostra em água, para a determinação de sua massa submersa (Figura 3.11), cuidando para que todo o ar contido entre as partículas seja expulso. Uma maneira de expulsar bolhas de ar que possam estar entre as partículas é promover algumas sacudidelas no recipiente que contém a amostra, após submergi-lo. Depois de determinada a massa da amostra submersa em água, drena-se o excesso de água do recipiente que contém a amostra, colocando-o na estufa para secar. Com a amostra seca e resfriada à temperatura ambiente, determina-se então a sua massa seca.

\section{Determinação da Densidade Aparente}

A densidade aparente do agregado pode então ser calculada através da Equação 3.9.

$$
\rho_{a p}=\frac{A}{B-C}
$$

onde:

$A=$ massa da amostra seca em estufa, determinada ao ar;

$B=$ massa da amostra seca superficialmente, determinada ao ar; 


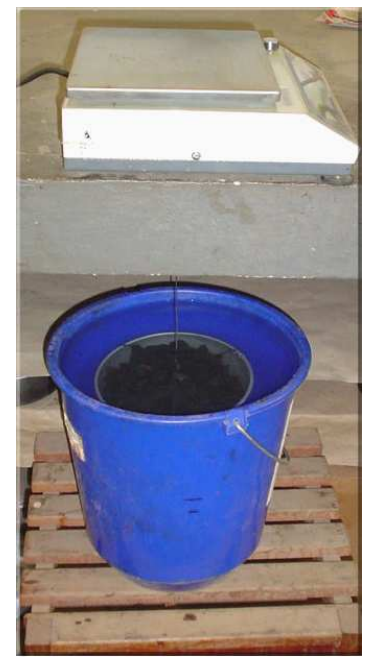

Figura 3.11: Determinação da massa da amostra submersa na água

$C=$ massa da amostra seca superficialmente, determinada quando submersa na água.

De posse das massas obtidas no decorrer do ensaio, pode-se determinar também, se houver necessidade, a porcentagem de água absorvida pelo agregado após 24 horas de imersão, através da Equação 3.10 e, também, a densidade real do agregado, através da Equação 3.11.

$$
\begin{gathered}
\% A b_{a g}=\frac{B-A}{A} \times 100 \\
\rho_{r}=\frac{A}{A-C}
\end{gathered}
$$

\subsubsection{Densidade aparente do Agregado Fino}

A ASTM C 128 padroniza o método de determinação da densidade aparente do agregado fino e também permite calcular a porcentagem de água absorvida pelo agregado.

\section{Amostra}

O procedimento de ensaio é iniciado com a preparação da amostra de agregado fino, composta por cerca de $1 \mathrm{~kg}$ de material passante na peneira de abertura de 2,36 mm e retido na peneira de $0,075 \mathrm{~mm}$, com posterior lavagem nesta última peneira, para a remoção de pó ou outros contaminantes da superfície da partícula. Após a lavagem, a amostra permanece submersa em água destilada por um período de aproximadamente 24 horas, sendo em seguida drenada e 
espalhada, como uma camada fina e de espessura uniforme, em uma bandeja (Figura 3.12), para então dar início ao procedimento de secagem.

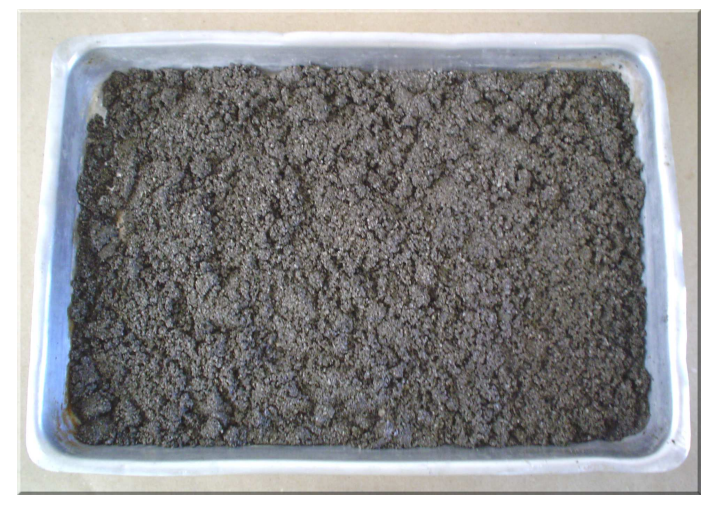

Figura 3.12: Amostra úmida

\section{Procedimento de Secagem Superficial}

Inicia-se o processo de secagem através da passagem de uma corrente de ar quente e suave sobre a bandeja, revolvendo-se a amostra para que ocorra uma secagem uniforme, como ilustram as Figuras 3.13(a) e 3.13(b).

Quando ocorrer mudança de cor do agregado e/ou as partículas começarem a desgrudar umas das outras é o momento de cessar a corrente de ar e avaliar a secura superficial da amostra, utilizando o molde cônico e o soquete, que podem ser visualizados na Figura 3.15. Utilizando-se o molde cônico, sobre uma superfície plana e horizontal não absorvente, a amostra é colocada rapidamente em seu interior (Figura 3.14), distribuindo-a uniformemente. Em seguida, são aplicados 25 golpes do soquete, distribuídos sobre a superfície livre do agregado, aplicados de uma altura de $5 \mathrm{~mm}$ acima do topo da amostra, como mostram as Figuras 3.15(a) e 3.15(b).

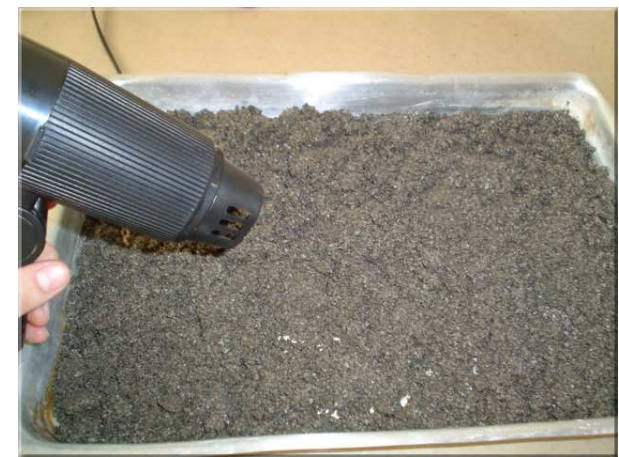

(a) Fluxo de ar

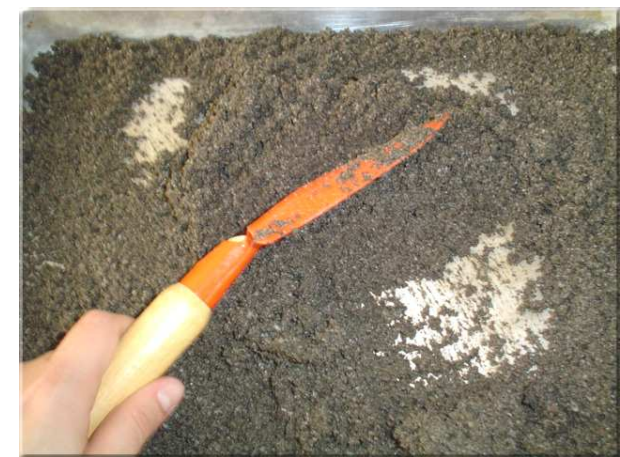

(b) Secagem da amostra

Figura 3.13: Procedimento para atingir a condição de secura superficial da amostra 


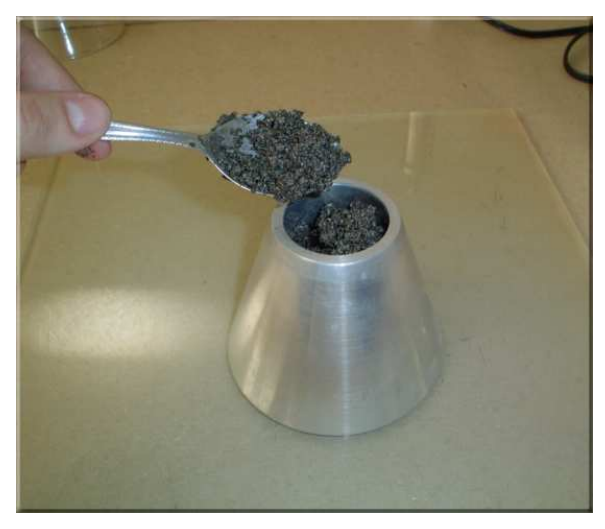

Figura 3.14: Colocação da amostra no cone

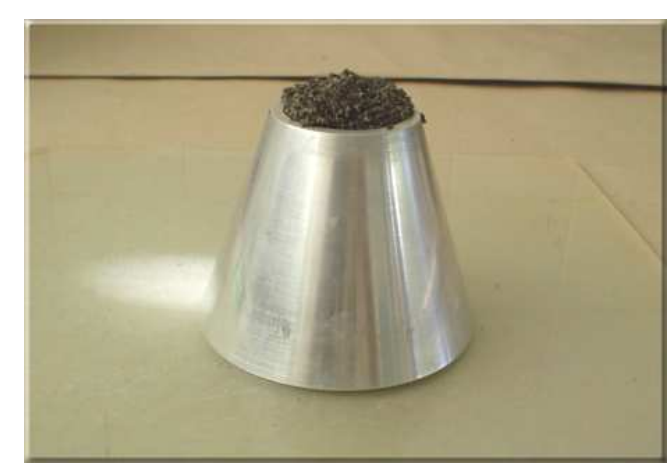

(a) Cone com a amostra antes da compactação

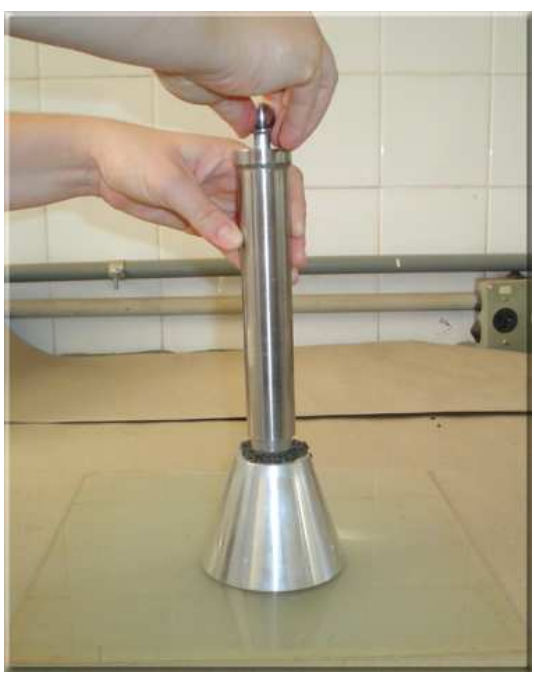

(b) Processo de compactação

Figura 3.15: Procedimento para verificar a condição de secura superficial da amostra

Em seguida, retira-se verticalmente o molde, tomando-se cuidado para não esbarrar no cone formado pela amostra (Figura 3.16). Se o cone de agregado não desmoronar parcial ou totalmente no momento da retirada do molde, significa que ainda existe umidade na superfície das partículas, ou seja, ainda não foi atingido o ponto de secura superficial, e portanto, a amostra deve voltar para a bandeja para ser reiniciado o processo de secagem.

A amostra deve ser testada repetidamente utilizando-se o molde cônico e o soquete, até que o cone formado pela amostra desmorone parcial ou totalmente ao ser retirado do molde, pois, nesse momento, entende-se que a condição de secura superficial da amostra foi alcançada, como ilustram as Figuras 3.17(a) e 3.17(b).

Ao atingir a condição de secura superficial, cerca de $500 \mathrm{~g}$ de material deve ser transferido para um picnômetro para a determinação da massa da amostra (Figuras 3.18(a) e 3.18(b)). 


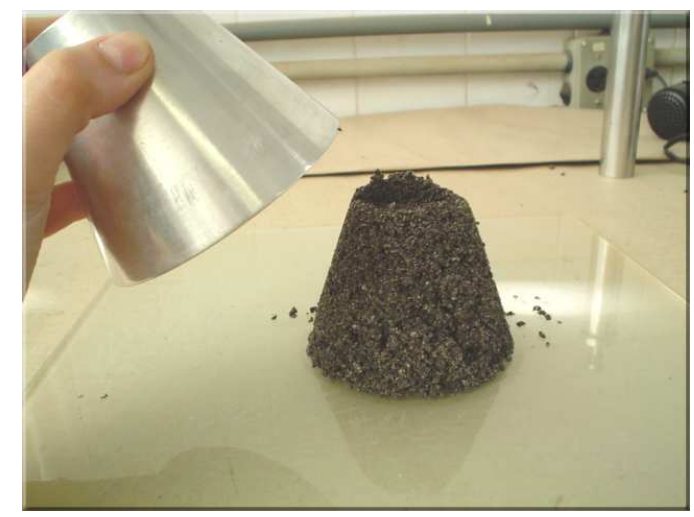

Figura 3.16: Verificação da condição de secura superficial da amostra

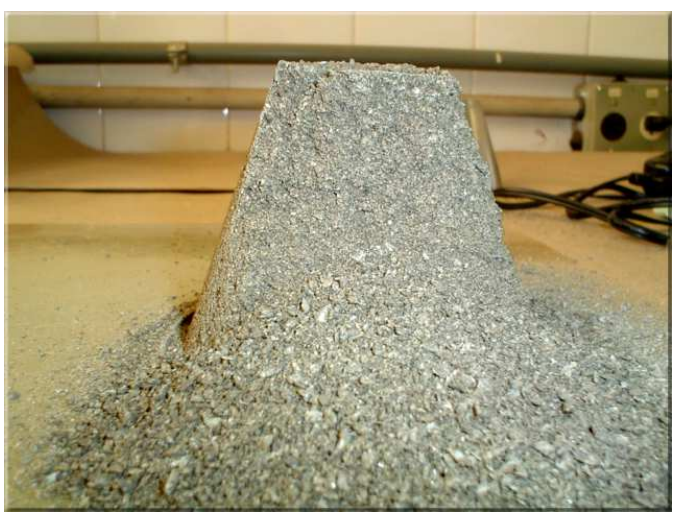

(a) Desmoronamento parcial do cone

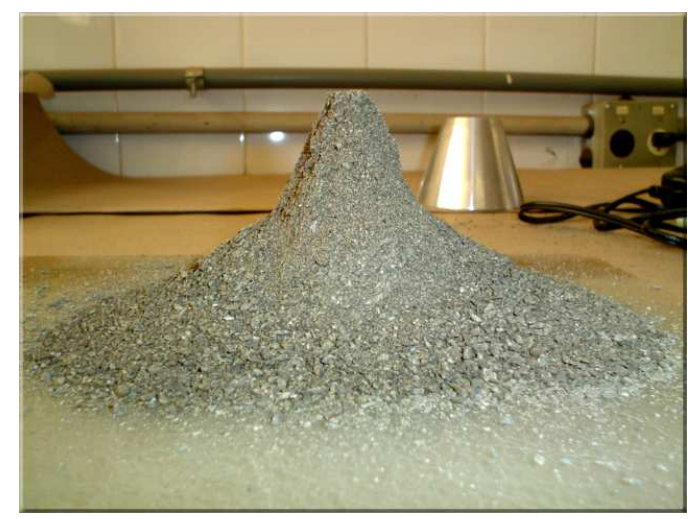

(b) Desmoronamento total do cone

Figura 3.17: Ponto de secura superficial da amostra

\section{Determinação das massas}

Após, água destilada é adicionada ao picnômetro até cobertura total da amostra e, mediante agitação do picnômetro, faz-se com que todas as partículas sejam molhadas pela água. $\mathrm{O}$ próximo passo é acoplar o picnômetro à bomba de vácuo parcial, submetendo a amostra à extração das bolhas de ar de seu interior, por cerca de 15 minutos (Figura 3.19).

Posteriormente, o picnômetro contendo a amostra e a água é deixado em repouso durante 1 hora, num banho mantido à temperatura de aproximadamente $25^{0} \mathrm{C}$, para a estabilização da temperatura. Com a temperatura estabilizada, é adicionada a quantidade de água destilada necessária para o preenchimento do picnômetro até que o menisco tangencie seu traço de referência, para em seguida, proceder a determinação da massa do conjunto (picnômetro, amostra e água) e da temperatura.

Logo depois, a amostra é removida do interior do picnômetro, tomando-se cuidado para não perder material, e levada à estufa para a secagem total. Retirada a amostra da estufa, esta é resfriada à temperatura ambiente e, então, determinada sua massa seca. 


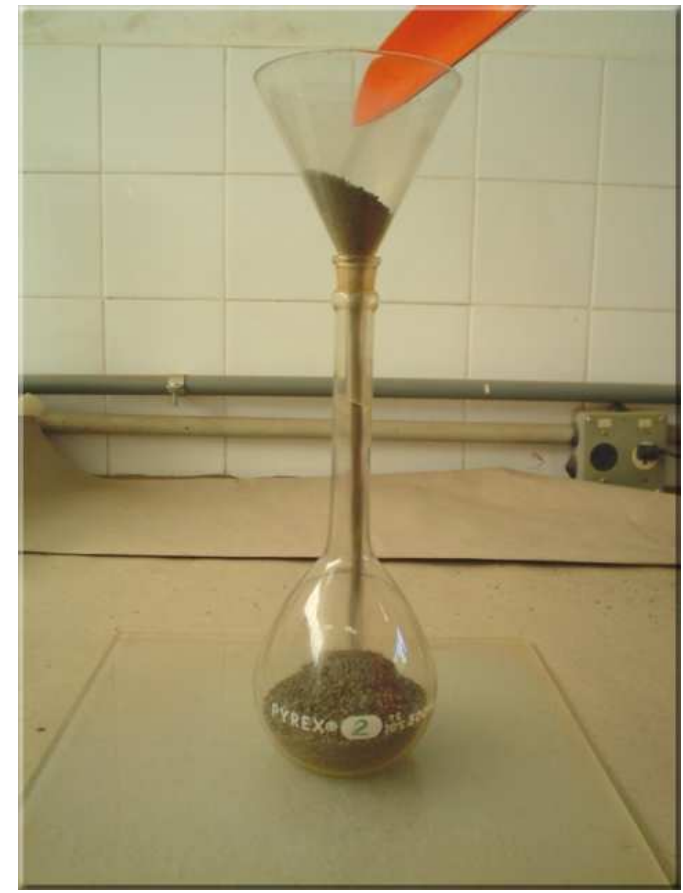

(a) Amostra no picnômetro

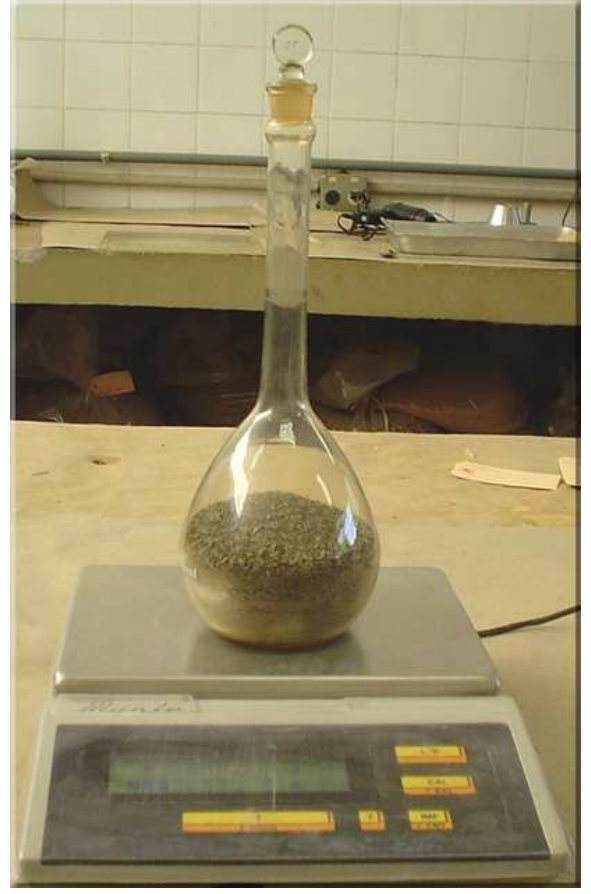

(b) Massa ao ar

Figura 3.18: Determinação da massa com superfície seca da amostra

\section{Determinação da Densidade Aparente}

A densidade aparente do agregado fino pode então ser calculada através da Equação 3.12.

$$
\rho_{a p}=\frac{A}{B+S-C}
$$

onde:

$A=$ Massa da amostra seca em estufa;

$B=$ Massa do picnômetro preenchido com água em função da temperatura (curva de calibração);

$S$ = Massa da amostra seca superficialmente;

$C=$ Massa do conjunto (picnômetro, amostra e água).

De posse das massas obtidas no decorrer do ensaio, pode-se determinar, se forem necessárias, a porcentagem de água absorvida pelo agregado após 24 horas de imersão, através da Equação 3.13, e também a densidade real do agregado, através da Equação 3.14.

$$
\begin{gathered}
\% A b_{a g}=\frac{S-A}{A} \times 100 \\
\rho_{r}=\frac{A}{B+A-C}
\end{gathered}
$$




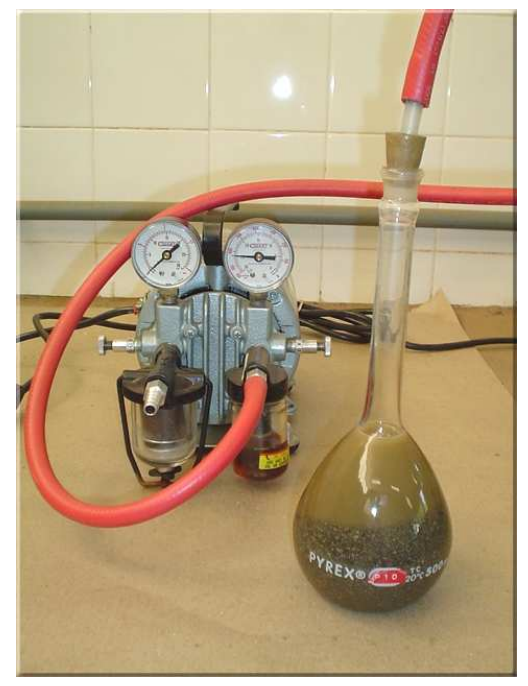

Figura 3.19: Extração de bolhas de ar da amostra

O molde cônico e o soquete utilizados para a realização do ensaio tiveram seus projetos adaptados da norma ASTM C 128 no setor de projetos do Departamento de Transportes e foram posteriormente construídos na oficina mecânica da Escola de Engenharia de São Carlos da Universidade de São Paulo.

\subsection{Resultados da Absorção de Asfalto}

Um dos objetivos desta pesquisa é avaliar o comportamento da absorção de asfalto pelos agregados durante os processos de mistura e ao longo da vida em serviço do pavimento. Inicialmente, a absorção de asfalto não era um dos assuntos a ser abordado nesta pesquisa, mas, devido à verificação da absorção alta de asfalto pelo agregado de gabro e sabendo-se da sua influência direta no cálculo dos parâmetros usados como critério de projeto da mistura (volume de vazios, vazios do agregado mineral e relação betume-vazios), tomou-se a decisão de investigar mais detalhadamente o assunto.

A investigação foi direcionada para a avaliação das características da absorção do agregado de gabro em função de alguns fatores importantes, tais como tempo e teor de asfalto. Como função do tempo observou-se a absorção que ocorre rapidamente durante a produção das misturas asfálticas, aqui denominada como absorção de curto prazo (AbsCp) e também a absorção que ocorre mais lentamente, com o passar dos meses, denominada de absorção de longo prazo (AbsLp). Quanto ao teor de asfalto foram produzidas misturas com o teor de asfalto de projeto e misturas com $\pm 0,5 \%$ de asfalto em relação ao teor de projeto. 
Para a avaliação da absorção de curto prazo foram produzidas misturas asfálticas com o teor de projeto $(6,2 \%)$, correspondente a um volume de vazios de $4 \%$ quando compactadas com 75 golpes por face, e misturas com teores de asfalto de $5,7 \%$ e 6,7\%. Logo após a produção das mistura, foram realizadas as primeiras determinações da Densidade Máxima Medida, denominadas de DMM de tempo zero. Em seguida, as misturas foram colocadas na estufa, onde permaneceram durante 2 horas em temperatura de compactação $\left(146^{\circ} C\right)$. Passadas as 2 horas e, após resfriadas, as misturas foram novamente submetidas à avaliação da DMM, correspondentes às DMM de 2 horas e, assim, sucessivamente, para as 8 horas previstas.

Para a avaliação da absorção de longo prazo também foram produzidas misturas asfálticas com $5,7 \%, 6,2 \%$ (teor de projeto) e $6,7 \%$ de asfalto, sendo as misturas logo após produzidas, resfriadas em temperatura ambiente e, então, realizadas as primeiras determinações da DMM, correspondentes às DMM de mês zero. Após essas primeiras determinações, as misturas permaneceram ao abrigo da luz por 1 mês. Passado esse período, novas determinações da DMM foram realizadas, correspondentes à DMM de mês 1 , e, em seguida, as misturas foram novamente acondicionadas permanecendo ao abrigo da luz por mais um mês, sendo realizadas novas determinações da DMM e, assim, sucessivamente, por um período de 6 meses.

\subsubsection{Comportamento da Absorção de Asfalto pelo Agregado de Gabro em Relação ao Tempo e ao Teor de Asfalto}

Nas Tabelas 3.2 e 3.3 estão exibidos os valores da densidade máxima medida $(D M M)$, da densidade efetiva do agregado $\left(\rho_{e f}\right)$ e da absorção de asfalto de curto prazo $(A b s C p)$ e de longo prazo $(A b s L p)$, correspondentes à média aritmética entre duas determinações, feitas com diferentes amostras de um mesmo agregado. Os respectivos gráficos contendo a variação da absorção de asfalto de curto e longo prazos estão ilustrados nas Figuras 3.20 e 3.21.

Tabela 3.2: Absorção de curto prazo para teores de asfalto de 5,7\%, 6, 2\% e 6, $7 \%$

\begin{tabular}{|c|c|c|c|c|c|c|c|c|c|}
\hline & \multicolumn{3}{|c|}{ teor de asfalto de $5,7 \%$} & \multicolumn{3}{|c|}{ teor de asfalto de $6,2 \%$} & \multicolumn{3}{|c|}{ teor de asfalto de $6,7 \%$} \\
\hline $\begin{array}{c}\text { Tempo } \\
\text { (hora) }\end{array}$ & $\overline{D M M}$ & $\overline{\rho_{e f}}$ & $\begin{array}{c}A b s \\
(\%)\end{array}$ & $D M M$ & $\overline{\rho_{e f}}$ & $\begin{array}{l}A b s \\
(\%)\end{array}$ & $\overline{D M M}$ & $\overline{\rho_{e f}}$ & $\begin{array}{c}\boldsymbol{A b s} \\
(\%)\end{array}$ \\
\hline 0 & 2,515 & 2,811 & 0,92 & 2,505 & 2,797 & 0,73 & 2,494 & 2,783 & 0,54 \\
\hline 2 & 2,528 & 2,828 & 1,13 & 2,524 & 2,823 & 1,06 & 2,503 & 2,795 & 0,71 \\
\hline 4 & 2,534 & 2,836 & 1,23 & 2,527 & 2,828 & 1,12 & 2,511 & 2,806 & 0,84 \\
\hline 6 & 2,538 & 2,841 & 1,30 & 2,527 & 2,827 & 1,12 & 2,511 & 2,806 & 0,84 \\
\hline 8 & 2,539 & 2,843 & 1,33 & 2,533 & 2,834 & 1,21 & 2,513 & 2,809 & 0,88 \\
\hline
\end{tabular}


Ao analisar a Figura 3.20, correspondente aos resultados apresentados na Tabela 3.2 para a absorção de curto prazo, pode-se verificar que a absorção aumenta ao longo das horas de exposição das misturas à temperatura de compactação, de maneira mais acentuada nas primeiras horas, em seguida tendendo à estabilização. Pode-se perceber, também, que as misturas com teores de asfalto mais elevados absorvem menos asfalto quando comparadas às misturas com teores mais baixos de asfalto, mostrando que quanto menor o teor de asfalto maior é a absorção.

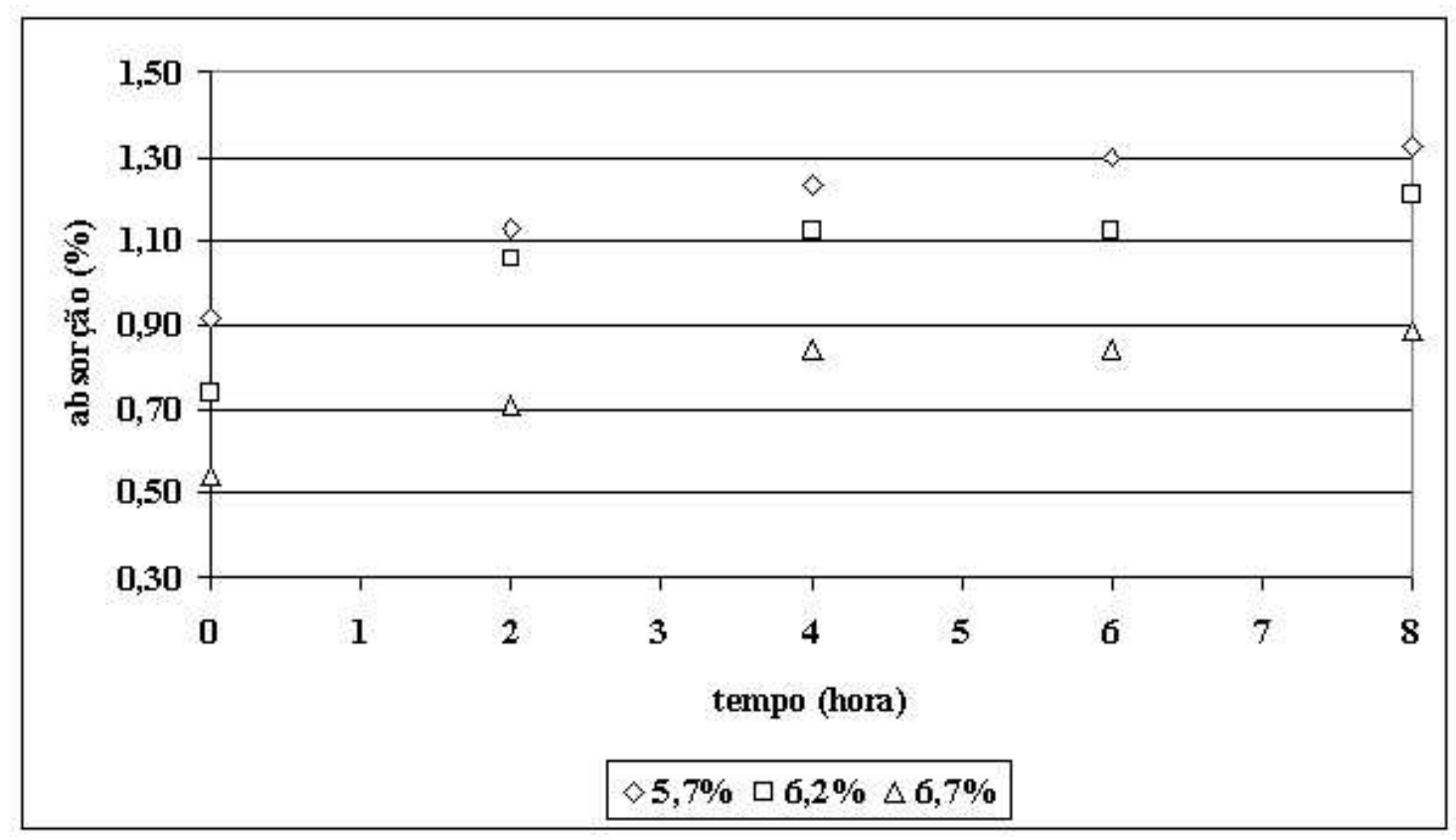

Figura 3.20: Variação da absorção de curto prazo para os diferentes teores de asfalto

Tabela 3.3: Absorção de longo prazo para teores de asfalto de 5,7\%, 6, 2\% e 6,7\%

\begin{tabular}{c|ccc|ccc|ccc}
\hline & \multicolumn{2}{|c|}{ teor de asfalto de $5,7 \%$} & \multicolumn{2}{|c|}{ teor de asfalto de $6,2 \%$} & \multicolumn{3}{|c}{ teor de asfalto de $6,7 \%$} \\
\hline $\begin{array}{c}\text { Tempo } \\
(\mathrm{mês})\end{array}$ & $\boldsymbol{D} \boldsymbol{M} \boldsymbol{M}$ & $\boldsymbol{\rho}_{\boldsymbol{e f}}$ & $\begin{array}{c}\boldsymbol{A b s} \\
(\%)\end{array}$ & $\boldsymbol{D} \boldsymbol{M} \boldsymbol{M}$ & $\boldsymbol{\rho}_{\boldsymbol{e f}}$ & $\begin{array}{c}\boldsymbol{A b s} \\
(\%)\end{array}$ & $\boldsymbol{D M} \boldsymbol{M}$ & $\boldsymbol{\rho}_{\boldsymbol{e f}}$ & $\begin{array}{c}\boldsymbol{A b s} \\
(\%)\end{array}$ \\
\hline 0 & 2,514 & 2,810 & 0,90 & 2,496 & 2,785 & 0,57 & 2,496 & 2,785 & 0,57 \\
\hline 1 & 2,528 & 2,829 & 1,14 & 2,506 & 2,799 & 0,75 & 2,501 & 2,792 & 0,66 \\
\hline 2 & 2,537 & 2,840 & 1,28 & 2,512 & 2,807 & 0,86 & 2,503 & 2,795 & 0,70 \\
\hline 3 & 2,540 & 2,845 & 1,34 & 2,517 & 2,814 & 0,95 & 2,506 & 2,799 & 0,76 \\
\hline 4 & 2,541 & 2,846 & 1,35 & 2,521 & 2,818 & 1,01 & 2,507 & 2,801 & 0,78 \\
\hline 5 & 2,542 & 2,847 & 1,37 & 2,521 & 2,818 & 1,01 & 2,510 & 2,804 & 0,82 \\
\hline 6 & 2,542 & 2,847 & 1,37 & 2,521 & 2,818 & 1,01 & 2,509 & 2,803 & 0,82 \\
\hline
\end{tabular}

Analisando-se a Figura 3.21, correspondente aos resultados apresentados na Tabela 3.3 para a absorção de longo prazo, pode-se verificar a mesma tendência de absorção já observada no curto prazo, ou seja, misturas com maiores teores de asfalto absorvem menos asfalto. Isso mostra uma tendência dos agregados de absorver mais asfalto quanto menor a espessura da película que os envolve. Uma possível explicação para esse fato é que, quando o teor de asfalto 
na mistura é menor, também é menor a espessura da película de asfalto que envolve a partícula do agregado, permitindo que o asfalto migre com mais facilidade ao interior dos poros devido à diminuição de sua tensão superficial.

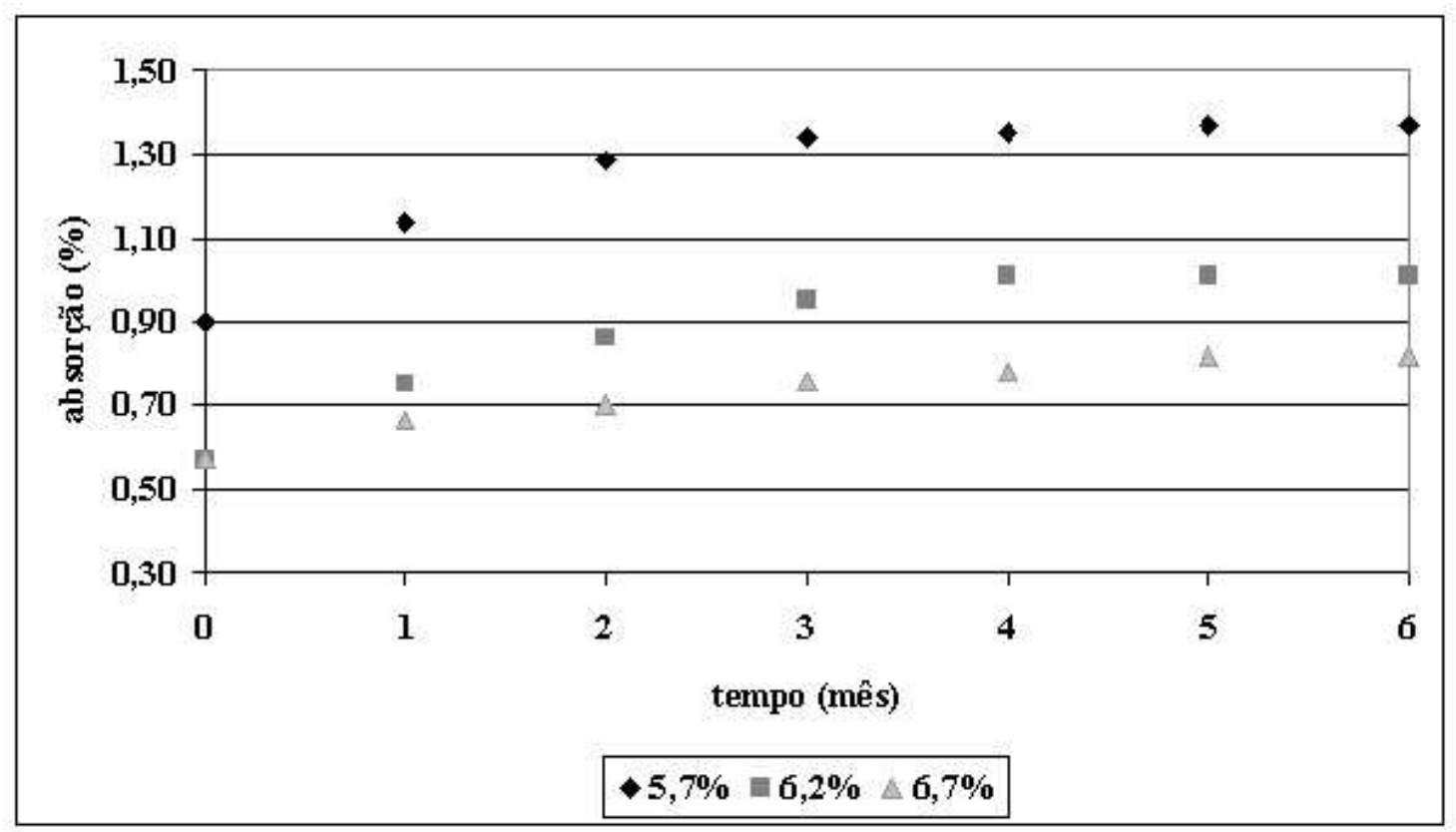

Figura 3.21: Variação da absorção de longo prazo para os diferentes teores de asfalto

\section{Ajuste Hiperbólico das Curvas de Absorção}

Os valores da absorção de asfalto versus tempo podem ser ajustados a uma curva hiperbólica. Essa constatação também fora verificada por Kandhal \& Khatri (1991), que apresentaram equações de cálculo da absorção estimada de asfalto para qualquer tempo de absorção, sendo conhecidas as absorções para o tempo zero e para mais dois pontos de tempo. As equações estão apresentadas a seguir.

$$
\begin{gathered}
A=A_{0}+\frac{t}{a+b t} \\
a=\frac{t_{1} t_{2}}{t_{2}-t_{1}}\left(\frac{1}{\Delta A_{1}}-\frac{1}{\Delta A_{2}}\right) \\
b=\frac{1}{t_{2}-t_{1}}\left(\frac{t_{2}}{\Delta A_{2}}-\frac{t_{1}}{\Delta A_{1}}\right) \\
A_{L}=A_{0}+\frac{1}{b}
\end{gathered}
$$


onde:

$A=$ absorção de asfalto para qualquer tempo t;

$A_{0}=$ absorção de asfalto para o tempo zero;

$\Delta A_{1}=A_{1}-A_{0}$;

$\Delta A_{2}=A_{2}-A_{0}$

$A_{1}$ e $A_{2}=$ taxas de absorção para os tempos $t_{1}$ e $t_{2}$;

$A_{L}=$ absorção limite ou absorção última, para o tempo tendendo ao infinito.

Os gráficos de absorção versus tempo, ilustrados nas Figuras 3.22 e 3.23, apresentam as curvas hiperbólicas calculadas e as curvas de absorção obtidas para curto prazo e para longo prazo, respectivamente. Os coeficientes de correlação entre as curvas de absorção e as curvas hiperbólicas, para um mesmo teor de asfalto, são de aproximadamente 0,98 , indicando uma forte relação entre a absorção estimada, obtida através das Equações 3.15, 3.16 e 3.17, e a absorção determinada.

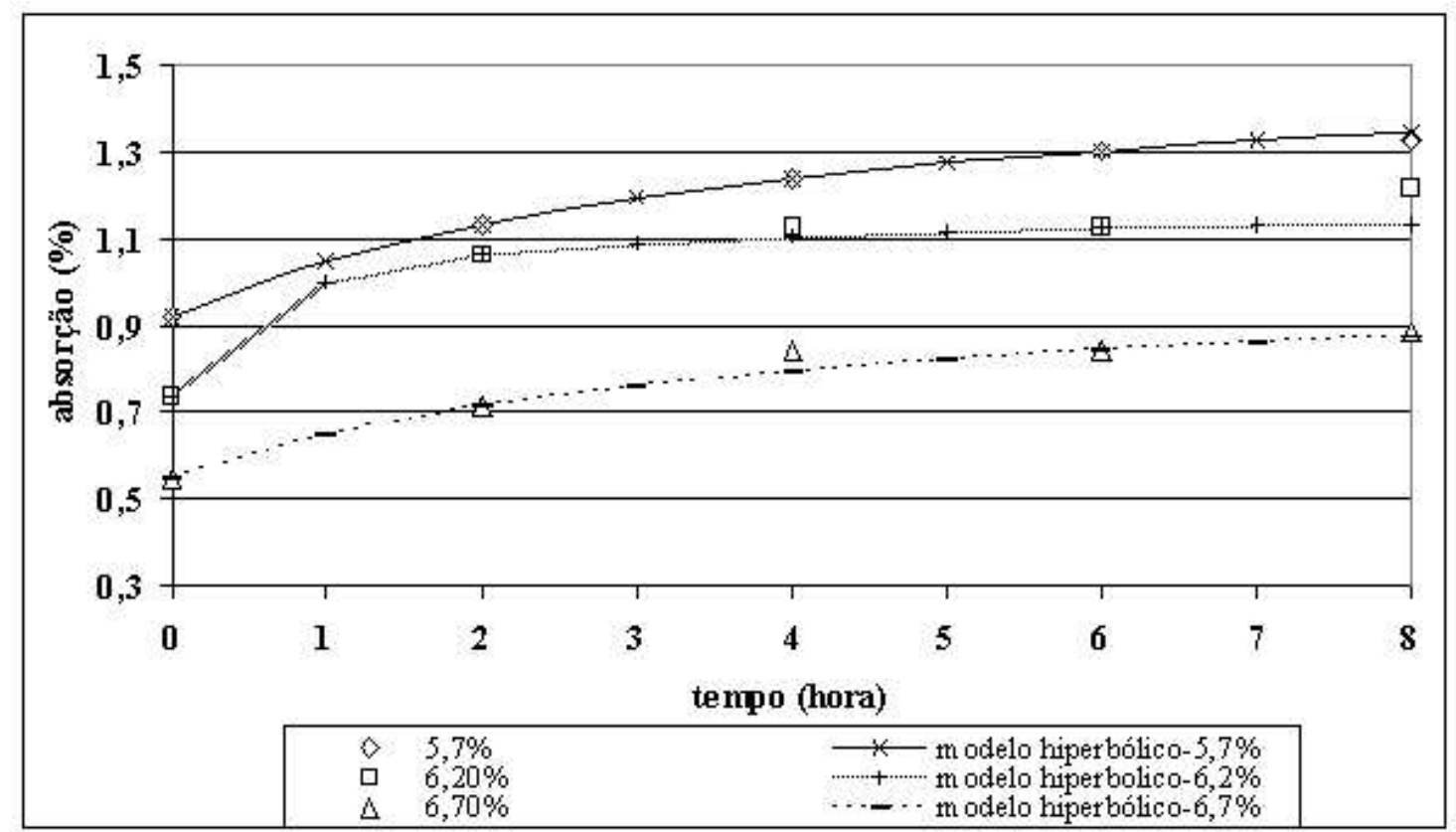

Figura 3.22: Absorção de curto prazo versus tempo e modelo hiperbólico

\section{Previsão da DMM em função do tempo de Absorção}

Uma vantagem de se conhecer a absorção num determinado tempo é poder predizer a DMM da mistura com base na absorção. Ao plotar o gráfico de absorção em função da DMM, com valores estimados de absorção, ou então, com valores calculados, como é o caso do gráfico apresentado na Figura 3.24, pode-se traçar a reta DMM versus absorção para o agregado de 


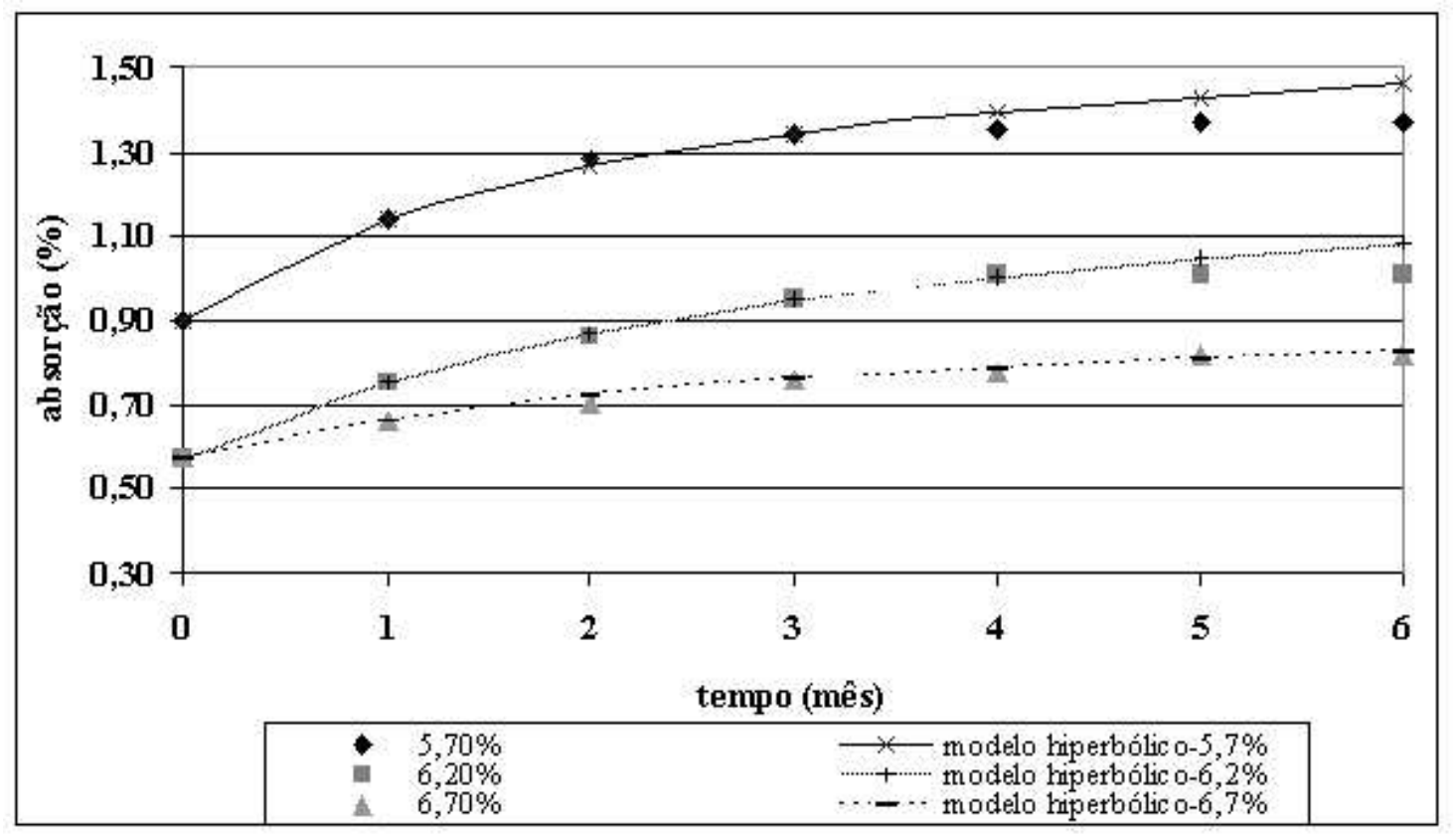

Figura 3.23: Absorção de longo prazo versus tempo e modelo hiperbólico

gabro com teor de asfalto inicial de $5,7 \%$, por exemplo. Através dessa reta pode-se estimar qual seria o Vv da mistura, após a compactação, se transcorrido um tempo conhecido de armazenamento e transporte da mistura. Ou ainda, se estimado o tempo gasto para o transporte da mistura até o local da obra, poder-se-ia prever a taxa de absorção nesse intervalo de tempo, para correção do teor de asfalto da mistura.

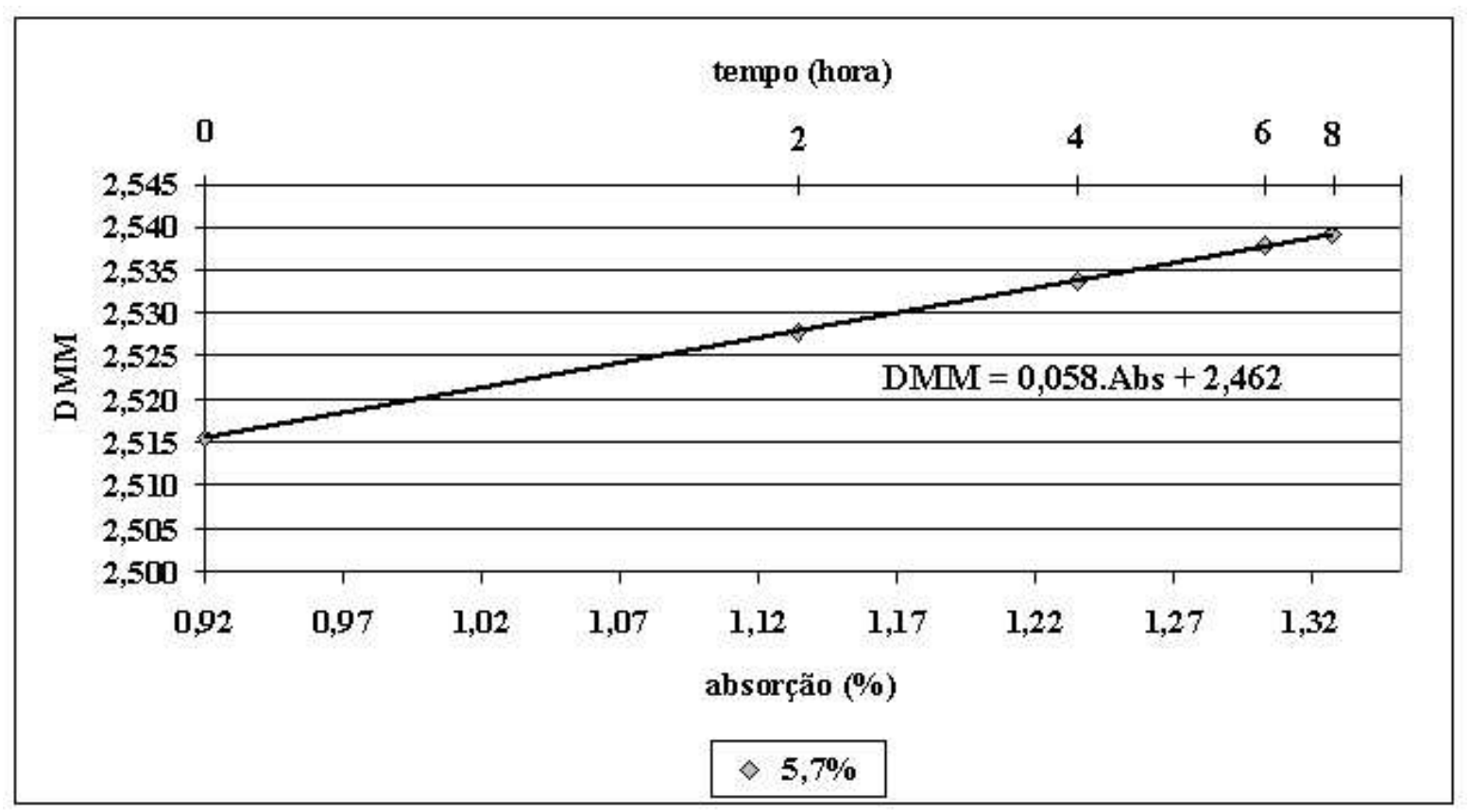

Figura 3.24: Absorção versus DMM para a mistura produzida com agregado de gabro 


\section{Comportamento da Absorção}

No gráfico apresentado na Figura 3.25 estão plotados os valores obtidos para absorção de curto e longo prazos em função do tempo, para os teores de asfalto de $5,7 \%, 6,2 \%$ e $6,7 \%$. Pode-se observar uma proximidade dos valores de absorção que ocorrem a curto e longo prazos, indicando que, mesmo estando em temperaturas diferentes, ou seja, em situação diferente de viscosidade do asfalto, as misturas com um mesmo teor de asfalto parecem absorver quantidades parecidas de asfalto, ainda que transcorridos períodos de tempo diferentes. Parece indicar, também, que o agregado absorve uma certa quantidade de asfalto, independentemente de quanto tempo leve para isso, ou seja, os interstícios ou poros das partículas dos agregados absorvem asfalto até alcançar sua possível saturação, podendo essa saturação ser alcançada mais facilmente, num menor tempo, quando a temperatura do asfalto está mais elevada (viscosidade mais baixa), ou em um período mais prolongado, com o passar dos meses, quando o asfalto está na temperatura ambiente, numa viscosidade mais elevada.

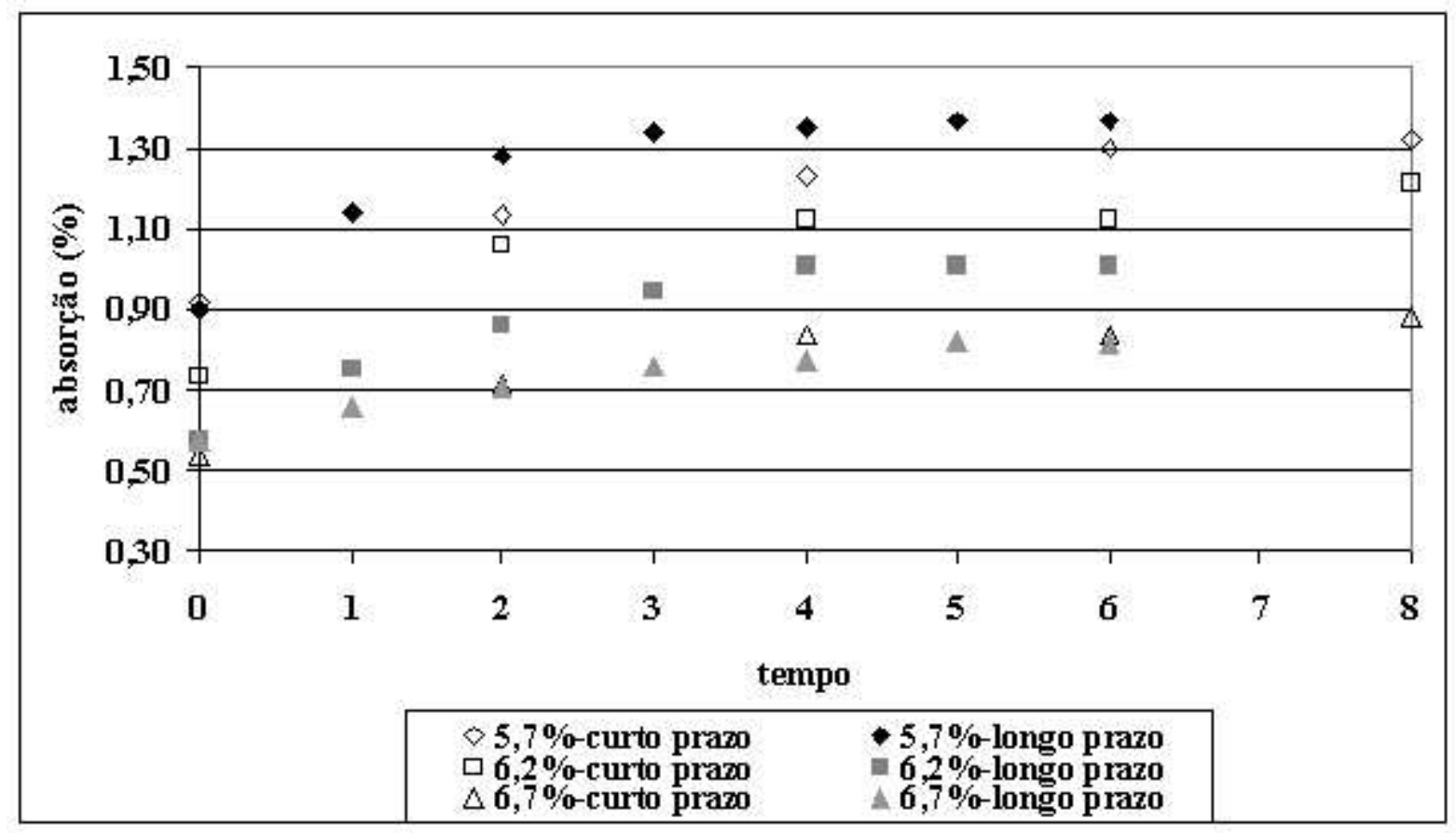

Figura 3.25: Absorção versus tempo

\subsubsection{Comportamento da Absorção de Longo Prazo após 2 Horas de Cura}

Ao observar o comportamento da absorção tanto de curto como de longo prazos já apresentados, imaginou-se como seria o comportamento da absorção de longo prazo se a mistura permanecesse durante 2 horas na temperatura de compactação (cura), com avaliações posterio- 
res mensais, durante 6 meses, da taxa de absorção de asfalto. Os resultados encontrados estão apresentados na Figura 3.26. Essas 2 horas de cura simulam o tempo médio que a mistura permanece na temperatura de compactação, desde sua usinagem até o espalhamento no campo. No item 5.6 do Capítulo 5, encontra-se uma discução sobre o estabelecimento do tempo de cura das misturas asfálticas.

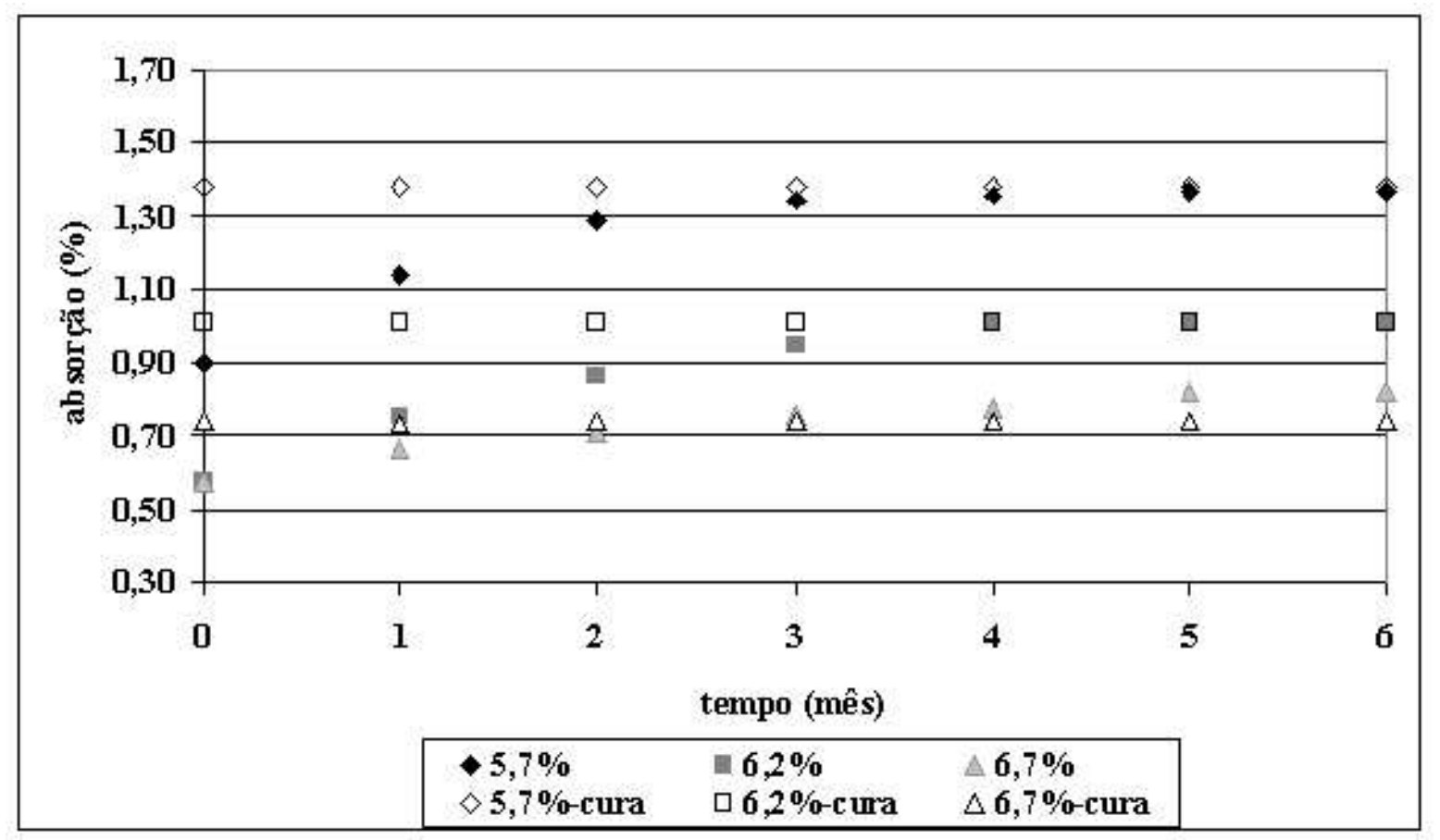

Figura 3.26: Comparação entre a absorção de longo prazo e a absorção de longo prazo após 2 horas de cura

Os resultados da absorção de longo prazo após 2 horas de cura $\left(A b s L p_{2 c}\right)$ mostram que o agregado absorveu asfalto apenas durante as duas horas de permanência da mistura na temperatura de compactação, não alterando sua taxa de absorção ao longo dos seis meses. A mistura com $5,7 \%$ de asfalto apresentou taxa de absorção de aproximadamente 1,13\% no período de cura e, as avaliações mensais feitas durante os seis meses seguintes, não indicaram alterações relevantes da taxa de absorção. O mesmo ocorreu com as misturas com $6,2 \%$ de asfalto, com taxa de absorção de 1,06\% no período de cura e com as misturas com $6,7 \%$ de asfalto, que absorveram aproximados $0,71 \%$. É interessante notar que também para a $A b s L p_{2 c}$ verificou-se o mesmo comportamento da absorção em função do teor de asfalto, como já observado tanto na $A b s C p$ como na $A b s L p$, ou seja, a mesma tendência de absorções maiores quanto menor a espessura do filme de asfalto.

Uma análise comparativa entre a $A b s L p$ e a $A b s L p_{2 c}$ indicam valores muito próximos das absorções ao final dos seis meses, ou melhor, a taxa da absorção de AbsLp aumenta de maneira mais acentuada nos primeiros três meses tendendo à estabilização nos três meses últimos, 
chegando a valores finais bastante próximos aos encontrados para a $A b s L p_{2 c}$. Esses resultados vêm corroborar com as duas hipóteses já levantadas durante a observação do comportamento da absorção de curto e de longo prazos, que são:

- Misturas com um mesmo tipo de agregado e com um mesmo teor de asfalto, mesmo em temperaturas diferentes (viscosidade diferente do asfalto), podem apresentar taxas de absorção de asfalto semelhantes;

- Os agregados absorvem asfalto até alcançarem a saturação de seus poros.

Uma outra hipótese que pode ser levantada é:

- Misturas submetidas a períodos de cura de 2 horas não apresentam absorções de longo prazo.

Isso indicaria que 2 horas de cura seria um tempo adequado para promover a saturação dos poros dos agregados.

O comportamento da absorção, verificado através desta pesquisa, tanto em função do tempo como do teor de asfalto são reveladores. Porém, deve-se realizar os mesmos experimentos com uma amostragem maior de agregados para validação dessas hipóteses de comportamento.

\subsection{Conclusões}

Com base nos experimentos laboratoriais apresentados, pode-se concluir que:

- a absorção aumenta ao longo do tempo, mas tende à estabilização;

- na absorção de curto prazo, de longo prazo e também na de longo prazo com 2 horas de cura, o agregado tende a absorver mais asfalto quanto menor a espessura da película de asfalto que o envolve, provavelmente em razão da diminuição da tensão superficial, que permite que o asfalto migre com mais facilidade para o interior dos poros;

- a DMM e, conseqüentemente, a absorção, variam com o teor de asfalto adicionado à mistura;

- quanto menor a temperatura do asfalto (maior viscosidade) maior o tempo necessário para a estabilização da absorção ou saturação dos poros do agregado; 
- os valores de absorção de curto prazo não diferem significativamente dos de longo prazo, indicando que o agregado absorve a quantidade de asfalto necessária para atingir a saturação de seus poros, independentemente de quanto tempo leve para isso;

- os valores da absorção de asfalto em função do tempo podem ser ajustados através de uma curva hiperbólica, apresentando elevado coeficiente de correlação entre a absorção ensaiada e a absorção estimada;

- é possível predizer a variação da DMM de uma mistura asfáltica com base na absorção, em função do tempo;

- A taxa de absorção de asfalto pelo agregado é dependente do tempo, da temperatura (viscosidade do asfalto) e do teor de asfalto da mistura, assim como das características dependentes do agregado;

- Mesmo estando em situações de diferentes temperaturas (viscosidade do asfalto), as misturas com um mesmo tipo de agregado e mesmo teor de asfalto tendem a absorver quantidades semelhantes de asfalto, ainda que transcorridos períodos de tempo diferentes;

- Os poros das partículas dos agregados absorvem asfalto até alcançarem sua saturação. A saturação pode ser alcançada mais facilmente, num menor tempo, quando a temperatura do asfalto está mais alta (viscosidade mais baixa), ou em um período mais prolongado, com o passar dos meses, quando o asfalto está na temperatura ambiente, numa viscosidade mais elevada;

- Ao submeter as misturas a períodos de cura de 2 horas pode-se evitar que absorções de longo prazo venham a ocorrer.

\subsection{Considerações Finais}

Além da verificação do comportamento da absorção em função do tempo e do teor de asfalto, optou-se por também analisá-la comparativamente em função das propriedades dos agregados de gabro e de basalto, ou seja, considerando o comportamento da absorção em tipos diferentes de agregados de mesma origem. Para tanto, foram analisadas as densidades aparente $\left(\rho_{a p}\right)$ e real $\left(\rho_{r}\right)$ dos agregados de gabro e de basalto, suas porosidades totais $(P T)$ e também suas taxas de absorção de água $\left(A b_{a g}\right)$ e de asfalto $\left(A_{a b s}\right)$, cujos resultados estão apresentados na Tabela 3.4. A taxa de absorção de água obtida corresponde à absorção após 24 horas de imersão. Já a taxa de absorção de asfalto de ambos os agregados corresponde à absorção média após 2 horas de cura. 
Tabela 3.4: Propriedades dos agregados relacionadas à absorção

\begin{tabular}{lccccc}
\hline Tipo de Agregado & $\boldsymbol{\rho}_{\boldsymbol{a} \boldsymbol{p}}$ & $\boldsymbol{\rho}_{\boldsymbol{r}}$ & $\boldsymbol{P} \boldsymbol{T}$ & $\boldsymbol{A b}_{\boldsymbol{a g}}(\%)$ & $\boldsymbol{A}_{\boldsymbol{a b s} \boldsymbol{s}}(\%)$ \\
\hline gabro & 2,742 & 2,875 & 4,63 & 1,67 & 1,0 \\
basalto & 2,863 & 2,929 & 2,27 & 1,14 & 0,2 \\
\hline
\end{tabular}

Os resultados mostram que quanto menor a densidade aparente entre agregados de mesma origem, maior é a absorção de água e também de asfalto, devido à maior a porosidade total do agregado. Pode-se depreender, através dos resultados, que a absorção, como função da densidade, está diretamente relacionada com a porcentagem de interstícios (poros) da massa cristalina das partículas. Em outras palavras, apesar dos agregados possuírem a mesma composição química, verifica-se que o basalto apresenta granulação fina e maior densidade aparente que o gabro, que possui granulação grossa. Agregados de granulação grossa apresentam mais interstícios entre seus cristais, facilitando assim a penetração de asfalto no interior de suas partículas.

Apesar de não terem sido feitos ensaios para a determinação da distribuição do tamanho dos poros, pode-se notar através dos resultados que a absorção de água do agregado de basalto é aproximadamente cinco vezes maior que sua absorção de asfalto, enquanto que a absorção de água do gabro é próxima de sua absorção de asfalto. Essa diferença entre as absorções de água e de asfalto pelo agregado de basalto evidenciam a existência de poros pequenos nesse agregado que podem ser penetrados pela água mas não pelo asfalto, em função da viscosidade do asfalto ser bem mais elevada que a viscosidade da água.

Como visto neste capítulo, a absorção é um fenômeno complexo, que envolve vários fatores e influencia as propriedades volumétricas das misturas e pode ser a responsável pelo aparecimento de vários defeitos no pavimento, caso seja negligenciada.

A absorção não é um fenômeno que ocorre eventualmente, pelo contrário, a maioria dos agregados possui algum grau de absorção. Portanto, durante o desenvolvimento de projetos de misturas asfálticas, deve-se, sempre, considerar a possibilidade de absorção de asfalto pelos agregados, para que não ocorram erros de cálculo de parâmetros volumétricos, utilizados como critério de projeto.

Ao utilizar agregados que não absorvem asfalto ou que possuem absorções muito baixas, pode-se calcular as propriedades volumétricas das misturas sem se preocupar com a escolha da densidade do agregado mais adequada aos cálculos, pois, agregados não absorsores apresentam valores de densidade (densidade aparente, efetiva e real) teoricamente iguais. Entretanto, quando os agregados são moderadamente ou altamente absorsores, o cálculo correto das pro- 
priedades volumétricas depende da escolha correta das densidades dos agregados e também da quantidade de asfalto absorvido pelo agregado.

O próximo capítulo traz uma visão global entre relações de densidades e de propriedades volumétricas, demonstrando o real significado de se utilizar uma ou outra densidade do agregado na mistura, bem como será demonstrado, com detalhes, a dimensão dos erros cometidos ao se negligenciar a absorção de asfalto no cálculo dos parâmetros volumétricos. 
CAPítulo

\section{Relações entre Densidades, Absorção e Propriedades Volumétricas da Mistura}

\subsection{Considerações Iniciais}

Há muito tempo, as propriedades volumétricas das misturas asfálticas vêm sendo sugeridas como requisitos necessários para assegurar um desempenho adequado dos pavimentos. Em 1905, Richardson ${ }^{1}$ apud Coree (1999) constatou a importância das proporções volumétricas dos componentes das misturas asfálticas em relação ao desempenho dos pavimentos. Na década de 1940, Marshall propôs a incorporação conceitual de volume de vazios e de grau de saturação dos vazios da mistura por asfalto (relação betume-vazios) para o desenvolvimento de misturas asfálticas. Na década de 1950, McLeod $(1956,1957)$ difundiu o conceito de vazios do agregado mineral, destacando a necessidade de sua utilização para assegurar a durabilidade do pavimento. Atualmente, as propriedades volumétricas das misturas asfálticas foram subdivididas e passaram a ser classificadas como parâmetros volumétricos primários e secundários (Coree, 1999), como será visto a seguir, onde a nomenclatura utilizada está baseada naquela empregada pelo Asphalt Institute e adotada pelo Superpave.

\footnotetext{
${ }^{1}$ Richardson, C. (1905). The Modern Asphalt Pavement. John Wiley \& Sons, 1 edição
} 


\subsection{Parâmetros Volumétricos Primários}

Os parâmetros volumétricos primários estão relacionados diretamente com os volumes relativos dos componentes individuais das misturas:

- Volume de ar, $V_{a r}$;

- Volume de agregados, $V_{a g}$;

- Volume de asfalto, $V_{b}$.

Devido à absorção de asfalto pelo agregado, as cavidades porosas do agregado (espaço poroso) e a porção de asfalto absorvido passam a compartilhar um mesmo espaço, ou seja, a soma dos volumes $\left(V_{b}+V_{a g}\right)$ são maiores que os seus volumes combinados $\left(V_{b+a g}\right)$. Isso leva a uma subdivisão dos parâmetros volumétricos primários em:

- Volume de asfalto efetivo, $V_{b e f}$, volume de asfalto não absorvido pelo agregado;

- Volume de asfalto absorvido, $V_{b a}$, volume de asfalto absorvido dentro dos poros do agregado;

- Volume aparente do agregado, $V_{a p}$, volume do agregado que inclui o volume dos poros permeáveis à agua e o volume dos poros permeáveis ao asfalto (Figura 4.1(a));

- Volume efetivo do agregado, $V_{e f}$, volume do agregado que inclui o volume dos poros permeáveis à água mas não ao asfalto (Figura 4.1(b));

- Volume real do agregado, $V_{r}$, somente o volume sólido do agregado, não incluindo o volume dos poros permeáveis à água ou ao asfalto (Figura 4.1(c)).

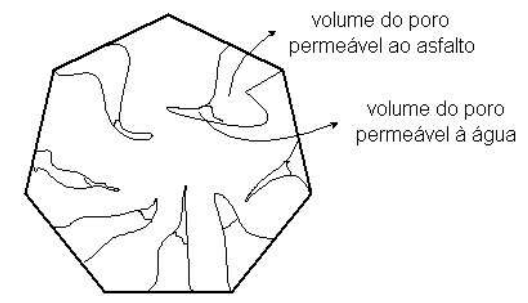

(a) Volume aparente

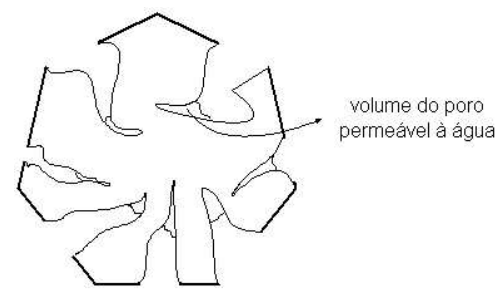

(b) Volume efetivo

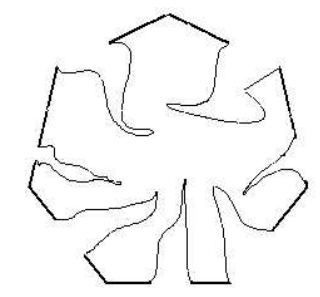

(c) Volume real

Figura 4.1: Volumes do agregado 


\subsection{Parâmetros Volumétricos Secundários}

São chamados de parâmetros volumétricos secundários (ou propriedades volumétricas das misturas) o $V_{v}, V A M$ e $R B V$, por serem calculados com base nos parâmetros volumétricos primários. Conceitualmente, esses parâmetros podem ser definidos como:

- Volume de vazios, $V v$, é o volume de ar $\left(V_{a r}\right)$ existente entre as partículas do agregado envoltas pelo filme de asfalto, expresso como uma porcentagem do volume total da mistura compactada;

- Vazios do agregado mineral, $V A M$, é a soma do volume de vazios $(V v)$ e do volume de asfalto efetivo $\left(V_{b e}\right)$, expresso como uma porcentagem do volume total da mistura compactada;

- Relação betume-vazios, $R B V$, é o grau de preenchimento do $V A M$ por asfalto, expresso em porcentagem.

\subsection{Relações entre Propriedades Volumétricas e Densidades do Agregado em Função da Absorção de Asfalto}

O ponto principal das relações entre as propriedades volumétricas das misturas e as densidades do agregado é a existência ou não de absorção pelos agregados. Se o agregado não tiver nenhum grau de absorção, então, não importa qual valor de densidade do agregado (aparente, efetiva ou real) será utilizada no cálculo das propriedades volumétricas das misturas, porque, nesse caso, o valor das densidades do agregado são teoricamente iguais. Entretanto, quando os agregados possuem algum grau de absorção, os valores obtidos para cada um dos parâmetros (Vv, VAM e RBV) dependem da densidade do agregado selecionada e da taxa de absorção de asfalto.

Ao fazer uso das densidades incorretamente, muitas vezes, pode-se assumir que uma porção ou toda a porosidade do agregado faz parte do Vv da mistura, caso em que se utiliza a densidade real do agregado para o cálculo do Vv; ou que o asfalto absorvido está preenchendo os vazios entre os agregados na mistura, caso que se utiliza a densidade aparente do agregado para o cálculo do Vv.

Portanto, já que os valores obtidos para o Vv, VAM e RBV dependem do valor da densidade do agregado e da existência ou não de asfalto absorvido pelos agregados, é imperativo que se 
saiba o significado real de utilizar uma ou outra densidade do agregado e entender o efeito que essa escolha terá nos resultados das propriedades volumétricas das misturas.

\subsubsection{Entendimento Conceitual das Densidades dos Agregados}

Para um melhor entendimento conceitual das densidades do agregado, pode-se fazer um paralelo com as densidades da mistura asfáltica.

Uma partícula de agregado possui vazios superficiais e vazios internos, assim como as misturas asfálticas. A densidade aparente do agregado, $\rho_{a p}$, é a razão entre a massa seca do agregado, $M a$, pelo seu volume aparente, multiplicado pela massa específica da água, como mostra a Equação 4.1. O volume aparente da partícula de agregado, $V_{a p}$, inclui o volume dos vazios superficiais permeáveis à água e ao asfalto, assim como os vazios internos (vazios impermeáveis).

$$
\rho_{a p}=\frac{M a}{V_{a p} \times \rho_{a g u a}}=\frac{M a}{V_{a p} \times 1,000}=\frac{M a}{V_{a p}}
$$

A mesma discussão pode ser aplicada para a mistura asfáltica, onde a densidade aparente da mistura, $d$, é a massa da mistura, $M t$, dividida por seu volume aparente, multiplicado pela massa específica da água, como apresentado na Equação 4.2.

$$
d=\frac{M t}{V_{a p} \times \rho_{\text {agua }}}=\frac{M t}{V_{a p} \times 1,000}=\frac{M t}{V_{a p}}
$$

A densidade real do agregado, $\rho_{r}$, corresponde à razão entre a massa seca da partícula, $M a$, pelo seu volume real (Equação 4.3). O volume real, $V_{r}$, inclui os vazios impermeáveis somente, ou seja, não inclui o volume de qualquer poro ou capilar que se encontre preenchido com água após 24 horas de imersão (vazios permeáveis), por definição.

$$
\rho_{r}=\frac{M a}{V_{r} \times \rho_{\text {agua }}}=\frac{M a}{V_{r} \times 1,000}=\frac{M a}{V_{r}}
$$

Paralelamente, a densidade máxima teórica da mistura, DMT, é a razão entre a massa total da mistura, $M t$, que compreende a soma das massas do asfalto e do agregado utilizadas na mistura pelo volume dos sólidos, $V_{s}$, que corresponde ao volume do agregado mais o volume do asfalto na mistura. O volume dos sólidos é geralmente calculado utilizando as densidades dos constituintes da mistura.

$$
D M T=\frac{M t}{V_{s} \times \rho_{\text {agua }}}=\frac{M t}{V_{s} \times 1,000}=\frac{M t}{V_{s}}
$$


A densidade efetiva do agregado, $\rho_{e f}$, é a razão entre a massa seca do agregado, $M a$, pelo seu volume efetivo, multiplicado pela densidade da água, como mostra a Equação 4.5. O volume efetivo da partícula do agregado, $V_{e f}$, inclui o volume dos vazios superficiais permeáveis à água mas não ao asfalto, assim como os vazios internos (vazios impermeáveis).

$$
\rho_{e f}=\frac{M a}{V_{e f} \times \rho_{\text {agua }}}=\frac{M a}{V_{e f} \times 1,000}=\frac{M a}{V_{e f}}
$$

Analogamente à $\rho_{e f}$, tem-se a densidade máxima medida da mistura, DMM, que é a razão entre a massa total da mistura, $M t$, que compreende a soma das massas do asfalto e do agregado utilizadas na mistura, pelo volume dos sólidos efetivo, $V_{s_{e f}}$, que corresponde ao volume efetivo do agregado mais o volume do asfalto na mistura.

$$
D M M=\frac{M t}{V_{s_{e f}} \times \rho_{\text {agua }}}=\frac{M t}{V_{s_{e f}} \times 1,000}=\frac{M t}{V_{s_{e f}}}
$$

Após o entendimento conceitual das densidades do agregado, permanecem, no entanto, dúvidas quanto à seleção dos valores das densidades que devem ser empregados no cálculo das propriedades volumétricas das misturas, para que resultados realísticos sejam encontrados. Ao analisar a explanação conceitual realizada sobre o volume do agregado, pode-se perceber que utilizar uma única densidade do agregado nos cálculos das propriedades volumétricas não é suficiente, pois, duas das três propriedades volumétricas (Vv, VAM e RBV) seriam calculadas incorretamente. Essa afirmação pode ser melhor explicada através de um exemplo prático, utilizando uma das misturas asfálticas projetadas neste trabalho de pesquisa, denominada AZRg.

\subsubsection{Exemplo Prático}

A mistura AZRg, cuja granulometria pode ser encontrada na Tabela 5.12, foi produzida com o agregado de gabro estudado e CAP 20, empregando-se energia de compactação de 75 golpes por face do corpo-de-prova Marshall. Na Tabela 4.1, estão apresentados os dados relevantes do agregado de gabro, do asfalto CAP 20 e da mistura asfáltica produzida, para a análise comparativa das propriedades volumétricas obtidas ao se utilizar cada uma das densidades do agregado. Na Tabela 4.2, encontram-se as propriedades volumétricas da mistura AZRg calculadas da maneira mais comumente vista em misturas projetadas no Brasil, ou seja, utilizando-se apenas uma das densidades do agregado (ou aparente, ou efetiva, ou real) e empregando-se a Densidade Máxima Teórica (DMT) da mistura.

Pode-se afirmar, fundamentando-se nos conceitos básicos de densidade do agregado, que dos nove valores listados na Tabela 4.2, os únicos calculados corretamente são o VAM obtido 
Tabela 4.1: Exemplo 1 - Dados dos materiais constituintes da mistura AZRg

\begin{tabular}{lc}
\hline Agregado de gabro & \\
\hline Densidade aparente, $\left(\rho_{a p}\right)$ & 2,742 \\
Densidade efetiva, $\left(\rho_{e f}\right)$ & 2,808 \\
Densidade real, $\left(\rho_{r}\right)$ & 2,875 \\
Porcentagem de asfalto absorvido, $\left(A_{a b s}\right)$ & 0,9 \\
\hline Asfalto - CAP-20 & 1,02 \\
\hline Densidade, $\left(\rho_{b}\right)$ & \\
\hline Misturas asfáltica compactada - AZRg & 6,2 \\
\hline Teor de asfalto, $(P b)$ & 2,423 \\
\hline Densidade aparente, $(d)$ &
\end{tabular}

Tabela 4.2: Propriedades volumétricas da mistura AZRg

\begin{tabular}{ll|cccc}
\hline \multicolumn{2}{l|}{ Densidades do Agregado } & DMT & $\begin{array}{c}\text { VAM } \\
\text { (\%) }\end{array}$ & $\begin{array}{c}\text { Vv } \\
(\mathbf{\%})\end{array}$ & $\begin{array}{c}\text { RBV } \\
(\mathbf{\%})\end{array}$ \\
\hline Densidade Aparente & 2,742 & 2,482 & $\mathbf{1 7 , 1}$ & 2,4 & 86,1 \\
Densidade Efetiva & 2,808 & 2,533 & 19,1 & $\mathbf{4 , 3}$ & 77,2 \\
Densidade Real & 2,875 & 2,583 & 20,9 & 6,2 & 70,3 \\
\hline
\end{tabular}

com base na densidade aparente do agregado $(17,1 \%)$ e o Vv determinado com base na densidade efetiva do agregado $(4,3 \%)$. Essa afirmação será justificada a seguir.

\section{Influência das Densidades do Agregado no Cálculo do VAM}

Como por definição o VAM constitui os espaços vazios entre as partículas dos agregados, pode-se justificar que apenas empregando a densidade aparente do agregado, que considera o volume do agregado como a soma dos volumes dos poros permeáveis à água e ao asfalto, o VAM poderia ser calculado corretamente, pois, desse modo, nenhuma porosidade da partícula estaria inclusa como parte do volume de vazios entre partículas, como mostra a Figura 4.2.

Se em vez de utilizar a densidade aparente no cálculo do VAM fosse empregada a densidade efetiva, seria o mesmo que considerar que o volume de vazios entre os agregados (VAM) fosse a soma dos vazios entre as partículas do agregado mais o volume dos poros do agregado permeáveis ao asfalto, como ilustra a Figura 4.3. A inclusão dos espaços porosos do agregado permeáveis ao asfalto como parte do VAM justifica o valor mais elevado (19,1\%), em comparação com o VAM de 17,1\% corretamente calculado. Portanto, um erro conceitual quanto à escolha da densidade do agregado mais adequada ao propósito de cálculo do VAM implicaria num erro de aproximadamente $2 \%$ no valor do VAM. 


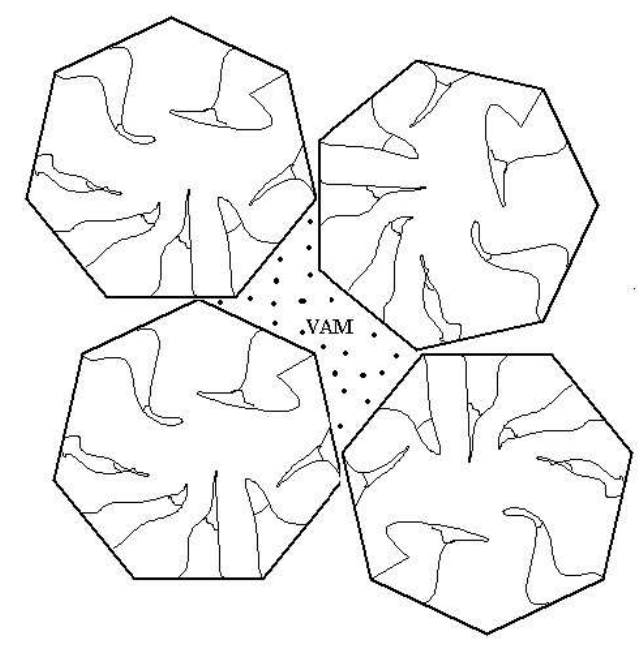

Figura 4.2: Vazios do agregado mineral, considerando-se a densidade aparente do agregado

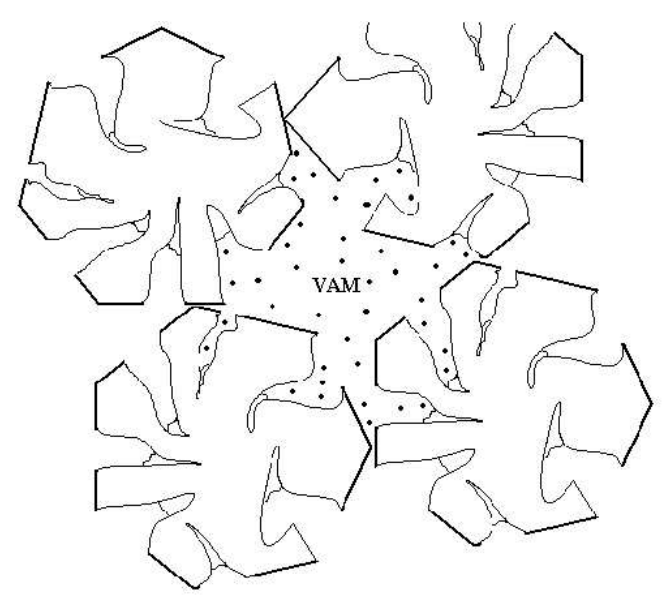

Figura 4.3: Vazios do agregado mineral, considerando-se a densidade efetiva do agregado

Já se fosse utilizada a densidade real do agregado no cálculo do VAM, o VAM seria considerado como a soma dos vazios entre as partículas de agregados mais o volume dos poros da partícula permeáveis à água e ao asfalto, como ilustra a Figura 4.4. Essa inclusão dos vazios do agregado permeáveis à água e ao asfalto como parte integrante dos vazios entre partículas implicaria numa elevação do valor do VAM da ordem de $3,8 \%$.

\section{Influência das Densidades do Agregado no Cálculo do Vv}

Por definição, o Vv compreende os espaços vazios entre as partículas dos agregados já envoltas pela película de asfalto. Portanto, a utilização da densidade efetiva do agregado é necessária para que seja considerada que parte da quantidade de asfalto foi absorvida e não faz mais parte da mistura. Isso significa dizer que somente o asfalto não absorvido (efetivo) pode ser o responsável pelo preenchimento dos vazios entre as partículas dos agregados (Figura 4.5). 


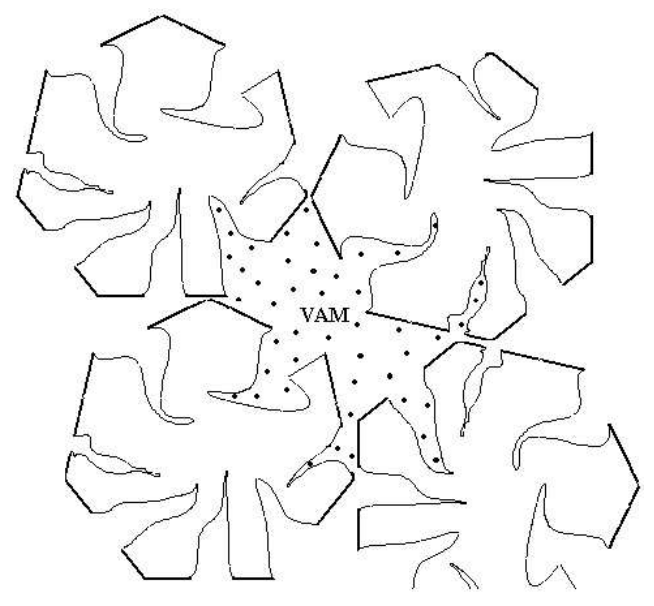

Figura 4.4: Vazios do agregado mineral, considerando-se a densidade real do agregado

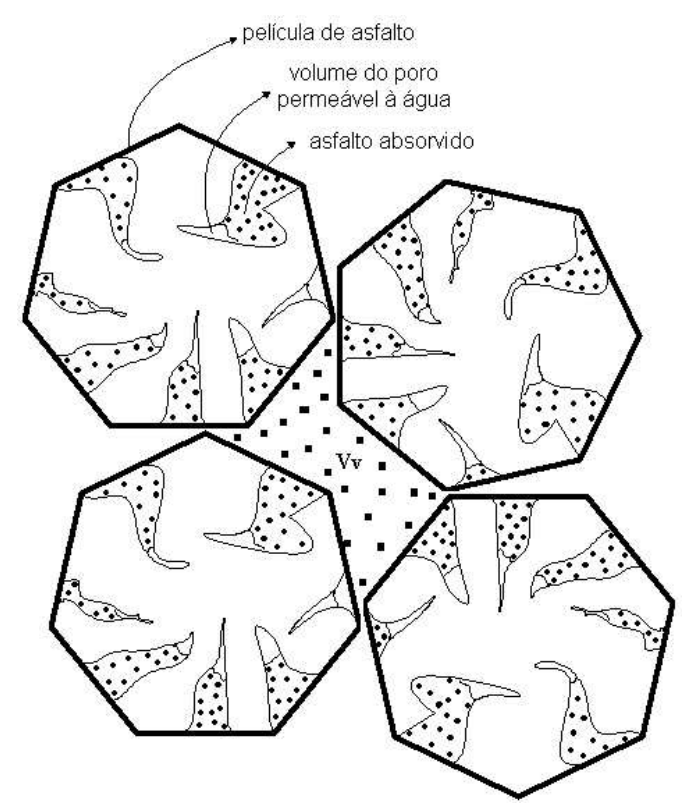

Figura 4.5: Volume de vazios, considerando-se a densidade efetiva do agregado

No entanto, empregar a densidade aparente no cálculo do Vv seria o mesmo que considerar que toda a quantidade de asfalto adicionada à mistura estaria preenchendo os vazios entre as partículas, ou seja, que nenhuma quantidade de asfalto fora absorvida (Figura 4.6). Então, ao se empregar a densidade aparente do agregado no cálculo do $\mathrm{Vv}$, ignora-se a capacidade de absorção de asfalto pelo agregado, fato que explica o valor bem mais baixo de Vv $(2,4 \%)$ encontrado em relação ao corretamente calculado com a densidade efetiva (4, 3\%).

Da mesma forma, se utilizada a densidade real no cálculo do $\mathrm{Vv}$, seria o mesmo que considerar que toda a porosidade do agregado, ou seja, seus poros permeáveis à água e também ao asfalto fariam parte do $\mathrm{Vv}$ das misturas, ao passo que somente os vazios entre as partículas dos agregados já envoltas pela película de asfalto poderiam ser computados (Figura 4.7). Nesse exemplo, a utilização inadequada da densidade real do agregado no cálculo do $\mathrm{Vv}$ das misturas 


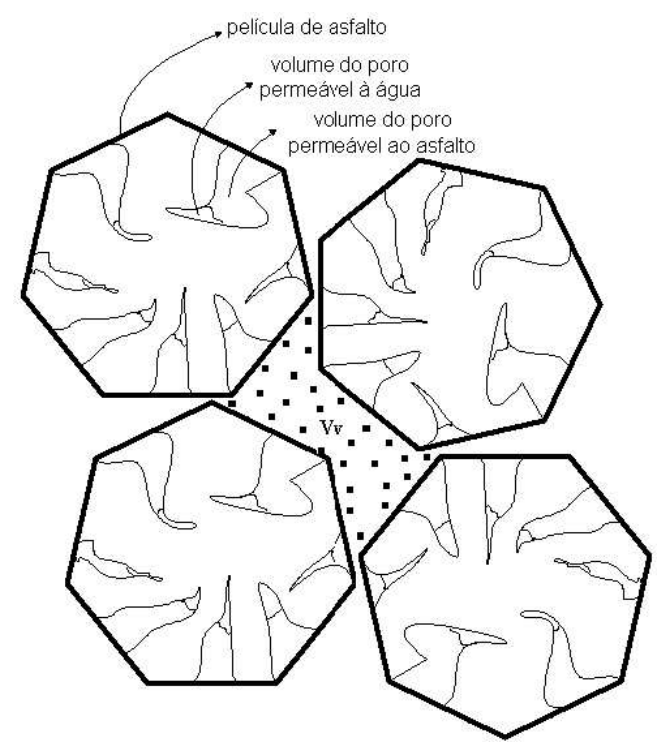

Figura 4.6: Volume de vazios, considerando-se a densidade aparente do agregado

implicou numa elevação do valor do $\mathrm{Vv}$ da ordem de $1,9 \%$ ( $\mathrm{Vv}$ de $6,2 \%$ ) em relação ao valor corretamente calculado $(4,3 \%)$.

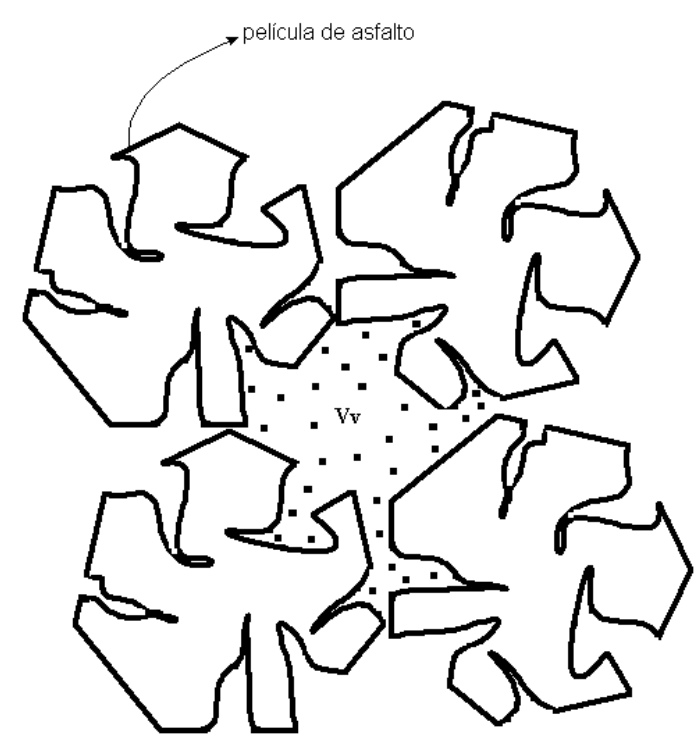

Figura 4.7: Volume de vazios, considerando a densidade real do agregado

\section{Influência das Densidades do Agregado no Cálculo do RBV}

Ao analisar os dados apresentados na Tabela 4.2, pode-se perceber que nenhum dos três valores encontrados para a relação betume-vazios foi corretamente calculado, pois, o RBV é função do VAM e do teor de asfalto efetivo na mistura e não há como obter valores reais do VAM e do Vv calculando-os com base numa mesma densidade. O valor da relação betume-vazios corretamente calculado é de $74,9 \%$, cálculo este que pode ser encontrado no item 4.5 .7 deste 
capítulo. Deve-se notar que, ao utilizar particularmente a densidade real dos agregados, nenhum dos valores encontrados para VAM, Vv e RBV foram corretamente calculados.

\section{Conclusões Parciais}

O exemplo prático apresentado procura mostrar que, para a obtenção de valores adequadamente calculados das propriedades volumétricas das misturas, deve-se ter sempre em mente alguns conceitos básicos:

- Somente os espaços entre as partículas de agregados, já envoltas pela película de asfalto em uma mistura compactada, podem ser considerados como volume de vazios;

- A porosidade da partícula do agregado (vazios permeáveis à água ou ao asfalto) não deve ser incluída como parte dos vazios das misturas;

- Deve-se sempre considerar que o asfalto absorvido pelo agregado já não faz mais parte da mistura e, portanto, não está disponível para preenchimento dos vazios do agregado mineral.

Com base no que foi apresentado, pode-se concluir que a maneira adequada de calcular os parâmetros volumétricos de misturas compostas por agregados que absorvem asfalto é empregar sempre a densidade aparente do agregado para o cálculo do VAM e a densidade efetiva do agregado para o cálculo do Vv das misturas. A seguir será apresentado, passo a passo, um método seguro de cálculo das propriedades volumétricas das misturas que utiliza a densidade aparente e a densidade efetiva do agregado.

\subsection{Método Seguro}

A apresentação do Método Seguro, como forma adequada de calcular as propriedades volumétricas das misturas, parte da definição conceitual do parâmetro em questão, seguido por sua dedução, até atingir a equação simplificada utilizada para o cálculo. As deduções das equações têm como base as deduções apresentadas por Roberts et al. (1991). 


\subsubsection{Vazios do Agregado Mineral}

Por definição,

$$
V A M=\frac{V t-V_{a p}}{V t} \times 100
$$

simplificando,

$$
V A M=100-\frac{V_{a p}}{V t} \times 100
$$

substituindo o volume pela massa dividida pela densidade, tem-se:

$$
V A M=100-\frac{\frac{M a}{\rho_{a p}}}{\frac{M t}{d}} \times 100
$$

substituindo,

$$
M a=M t-M t \times P b
$$

e simplificando,

$$
V A M=100-\left(1-\frac{d(1-P b)}{\rho_{a p}}\right) \times 100
$$

onde:

$V_{a p}=$ volume aparente do agregado;

$V t=$ volume total da mistura compactada;

$M a=$ massa do agregado;

$M t=$ massa total da mistura compactada;

$\rho_{a p}=$ densidade aparente do agregado;

$d=$ densidade aparente da mistura compactada;

$\mathrm{Pb}=$ porcentagem de asfalto.

\subsubsection{Volume de Vazios}

Por definição,

$$
V v=\frac{V_{a r}}{V t} \times 100
$$

substituindo,

$$
V_{a r}=V t-V b_{e f}-V_{a p}
$$




$$
\begin{aligned}
& V v=\frac{V t-V b_{e f}-V_{a p}}{V t} \times 100 \\
& V v=\left(1-\frac{V b_{e f}+V_{a p}}{V t}\right) \times 100
\end{aligned}
$$

multiplicando o numerador e o denominador por Mt e simplificando,

$$
V v=\left(1-\frac{M t / V t}{M t /\left(V b_{e f}+V_{a p}\right)}\right) \times 100
$$

substituindo,

$$
V v=\left(1-\frac{d}{D M M}\right) \times 100
$$

onde:

$V v=$ volume de vazios na mistura compactada;

$V_{a r}=$ volume de ar na mistura;

$V t=$ volume total da mistura compactada;

$V b_{e f}=$ volume do asfalto efetivo na mistura;

$V_{a p}=$ volume aparente do agregado;

$M t=$ massa total da mistura compactada;

$d=$ densidade aparente da mistura compactada;

$D M M=$ densidade máxima medida.

\subsubsection{Relação Betume-Vazios}

Por definição, a relação betume-vazios é a porcentagem dos vazios do agregado preenchida por asfalto.

$$
R B V=\frac{V A M-V v}{V A M} \times 100
$$

\subsubsection{Densidade Efetiva do Agregado}

A densidade efetiva do agregado, $\rho_{e f}$, por definição, é igual à massa do agregado dividida pelo volume efetivo do agregado, $V_{e f}$.

$$
\rho_{e f}=\frac{M a}{V_{e f}}
$$


Como o volume efetivo do agregado, por definição, é o volume do agregado incluindo seus poros externos permeáveis à água mas não permeáveis ao asfalto, pode-se determinar o $V_{e f}$ através da subtração do volume total da mistura asfáltica solta (sem vazios), $V_{T M}$, do volume do asfalto na mistura, $V b$.

$$
\rho_{e f}=\frac{M t-(P b \times M t)}{V_{T M}-V b}
$$

$\mathrm{O} V_{T M}$ é obtido através da razão entre a massa da mistura e sua densidade máxima medida e o volume do asfalto na mistura $(V b)$ é determinado da massa e da densidade do asfalto.

Então, substituindo,

$$
\rho_{e f}=\frac{M t-(P b \times M t)}{\frac{M t}{D M M}-\frac{M b}{\rho_{b}}}
$$

e simplificando, tem-se:

$$
\rho_{e f}=\frac{1-P b}{\frac{1}{D M M}-\frac{P b}{\rho_{b}}}
$$

onde:

$M a=$ massa do agregado;

$V_{e f}=$ volume efetivo do agregado;

$V b=$ volume do asfalto na mistura;

$M t=$ massa total da mistura;

$V_{T M}=$ volume total da mistura asfáltica solta (sem vazios);

$\mathrm{Pb}=$ porcentagem de asfalto na mistura;

$M b=$ massa total do asfalto na mistura;

$\rho_{b}=$ densidade do asfalto;

$D M M=$ densidade máxima medida da mistura.

\subsubsection{DMM para Diferentes Teores de Asfalto}

Normalmente, a densidade máxima medida da mistura asfáltica é obtida para um teor de asfalto (preferencialmente próximo ao teor de projeto) e, então, é calculada a densidade efetiva do agregado através da Equação 4.22. Mas é necessário que se conheça a DMM da mistura para outros teores de asfalto, para que seja possível o cálculo do Vv em cada teor. Então, sendo conhecidos a densidade efetiva do agregado, a densidade do asfalto e o teor de asfalto desejado, pode-se determinar a DMM em função do teor de asfalto desejado, como demonstrado a seguir:

$$
D M M=\frac{M a+M b}{V_{e f}+V b}
$$


substituindo,

$$
\begin{gathered}
D M M=\frac{M t}{\frac{M a}{\rho_{e f}}+\frac{M b}{\rho_{b}}} \\
D M M=\frac{M t}{\frac{M t(1-P b)}{\rho_{e f}}+\frac{M t \times P b}{\rho_{b}}}
\end{gathered}
$$

simplificando,

$$
D M M=\frac{1}{\frac{1-P b}{\rho_{e f}}+\frac{P b}{\rho_{b}}}
$$

onde,

$M a=$ massa do agregado;

$M b=$ massa total do asfalto na mistura;

$V_{e f}=$ volume efetivo do agregado;

$V b=$ volume do asfalto na mistura;

$M t=$ massa total da mistura;

$\rho_{e f}=$ densidade efetiva do agregado;

$\rho_{b}=$ densidade do asfalto;

$\mathrm{Pb}=$ porcentagem de asfalto na mistura.

\subsubsection{Absorção de Asfalto}

A taxa de absorção de asfalto pelo agregado é calculada através das densidades efetiva e aparente do agregado, assim como da densidade do asfalto. Conceitualmente, a taxa de absorção de asfalto pelo agregado é uma relação entre a massa do asfalto absorvido pela massa do agregado na mistura, como ilustra a Equação 4.27.

$$
A_{a b s}=\frac{M b_{a b s}}{M a} \times 100
$$

substituindo, massa $=$ volume $\mathrm{x}$ densidade

$$
A_{a b s}=\frac{V b_{a b s} \times \rho_{b}}{M a} \times 100
$$

Como o volume de asfalto absorvido é a diferença entre o volume aparente do agregado e o volume efetivo do agregado, tem-se:

$$
A_{a b s}=100 \times \frac{\left(V_{a p}-V_{e f}\right) \times \rho_{b}}{M a}
$$


substituindo, volume $=$ massa $/$ densidade

$$
A_{a b s}=100 \times \frac{\left(\frac{M a}{\rho_{a p}}-\frac{M a}{\rho_{e f}}\right) \times \rho_{b}}{M a}
$$

simplificando,

$$
A_{a b s}=100 \times \frac{\rho_{e f}-\rho_{a p}}{\rho_{e f} \times \rho_{a p}} \times \rho_{b}
$$

onde:

$A_{a b s}=$ porcentagem de asfalto absorvido por massa de agregado;

$M b_{a b s}=$ massa do asfalto absorvido;

$M a=$ massa do agregado;

$V b_{a b s}=$ volume do asfalto absorvido;

$V_{a p}=$ volume aparente do agregado;

$V_{e f}=$ volume efetivo do agregado;

$\rho_{b}=$ densidade do asfalto;

$\rho_{e f}=$ densidade efetiva do agregado;

$\rho_{a p}=$ densidade aparente do agregado.

\subsubsection{Exemplo de Utilização do Método Seguro}

De forma a facilitar o entendimento do Método Seguro, será apresentado um exemplo de sua utilização. Os dados de entrada necessários estão apresentados na Tabela 4.3.

Tabela 4.3: Dados de entrada da mistura AZRg - método seguro

\begin{tabular}{lc}
\hline Propriedades & Mistura AZRg \\
\hline Teor de asfalto, $(P b)$ & 6,2 \\
Densidade do asfalto, $\left(\rho_{b}\right)$ & 1,02 \\
Densidade aparente dos agregados, $\left(\rho_{a p}\right)$ & 2,742 \\
Densidade aparente da mistura compactada, $(d)$ & 2,423 \\
\hline
\end{tabular}

- Primeiro Passo - Cálculo da DMM da mistura asfáltica para um teor qualquer de asfalto. A DMM calculada para um teor de asfalto de $5,2 \%$, através do método Rice, é de 2,573 .

- Segundo Passo - Cálculo da densidade efetiva do agregado. 


$$
\begin{gathered}
\rho_{e f}=\frac{1-P b}{\frac{1}{D M M}-\frac{P b}{\rho_{b}}} \\
\rho_{e f}=\frac{1-0,052}{\frac{1}{2,573}-\frac{0,052}{1,02}}=2,808
\end{gathered}
$$

- Terceiro Passo - Cálculo da DMM para o teor de 6, 2\% de asfalto, usado na dosagem da mistura.

$$
\begin{gathered}
D M M=\frac{1}{\frac{1-P b}{\rho_{e f}}+\frac{P b}{\rho_{b}}} \\
D M M=\frac{1}{\frac{1-0,062}{2,808}+\frac{0,062}{1,02}}=2,533
\end{gathered}
$$

- Quarto Passo - Cálculo dos vazios do agregado mineral da mistura asfáltica compactada.

$$
\begin{gathered}
V A M=\left(1-\frac{d(1-P b)}{\rho_{a p}}\right) \times 100 \\
V A M=\left(1-\frac{2,423(1-0,062)}{2,742}\right) \times 100=17,1 \%
\end{gathered}
$$

- Quinto Passo - Cálculo do volume de vazios da mistura asfáltica compactada.

$$
\begin{gathered}
V v=\left(1-\frac{d}{D M M}\right) \times 100 \\
V v=\left(1-\frac{2,423}{2,533}\right) \times 100=4,3 \%
\end{gathered}
$$

- Sexto Passo - Cálculo da relação betume-vazios da mistura asfáltica compactada.

$$
\begin{gathered}
R B V=\frac{V A M-V v}{V A M} \times 100 \\
R B V=\frac{17,1-4,3}{17,1} \times 100=74,9 \%
\end{gathered}
$$

Sendo conhecidas as densidades aparente e efetiva do agregado e a densidade do asfalto, pode-se calcular a taxa de absorção de asfalto pelos agregados, assim como o teor de asfalto efetivo na mistura.

- Cálculo da absorção de asfalto pelos agregados. 


$$
\begin{gathered}
A_{a b s}=100 \times \frac{\rho_{e f}-\rho_{a p}}{\rho_{e f} \times \rho_{a p}} \times \rho_{b} \\
A_{a b s}=100 \times \frac{2,808-2,742}{2,808 \times 2,742} \times 1,02=0,9 \%
\end{gathered}
$$

- Porcentagem de asfalto efetivo na mistura asfáltica compactada.

$$
A_{e f}=P b-A_{a b s}=6,2-0,9=5,3 \%
$$

\subsection{Diagrama de Componentes}

Outro modo de calcular corretamente os parâmetros volumétricos das misturas é através do diagrama de componentes, utilizado pelos pesquisadores do Superpave (Motta et al., 1994), que representa uma mistura asfáltica compactada, com seus vazios, asfalto e agregado (Figura 4.8), representando um volume unitário (por exemplo, $1 \mathrm{~cm}^{3}$ ou $1 \mathrm{~m}^{3}$ ) e uma massa conhecida (por exemplo, em g ou kg).

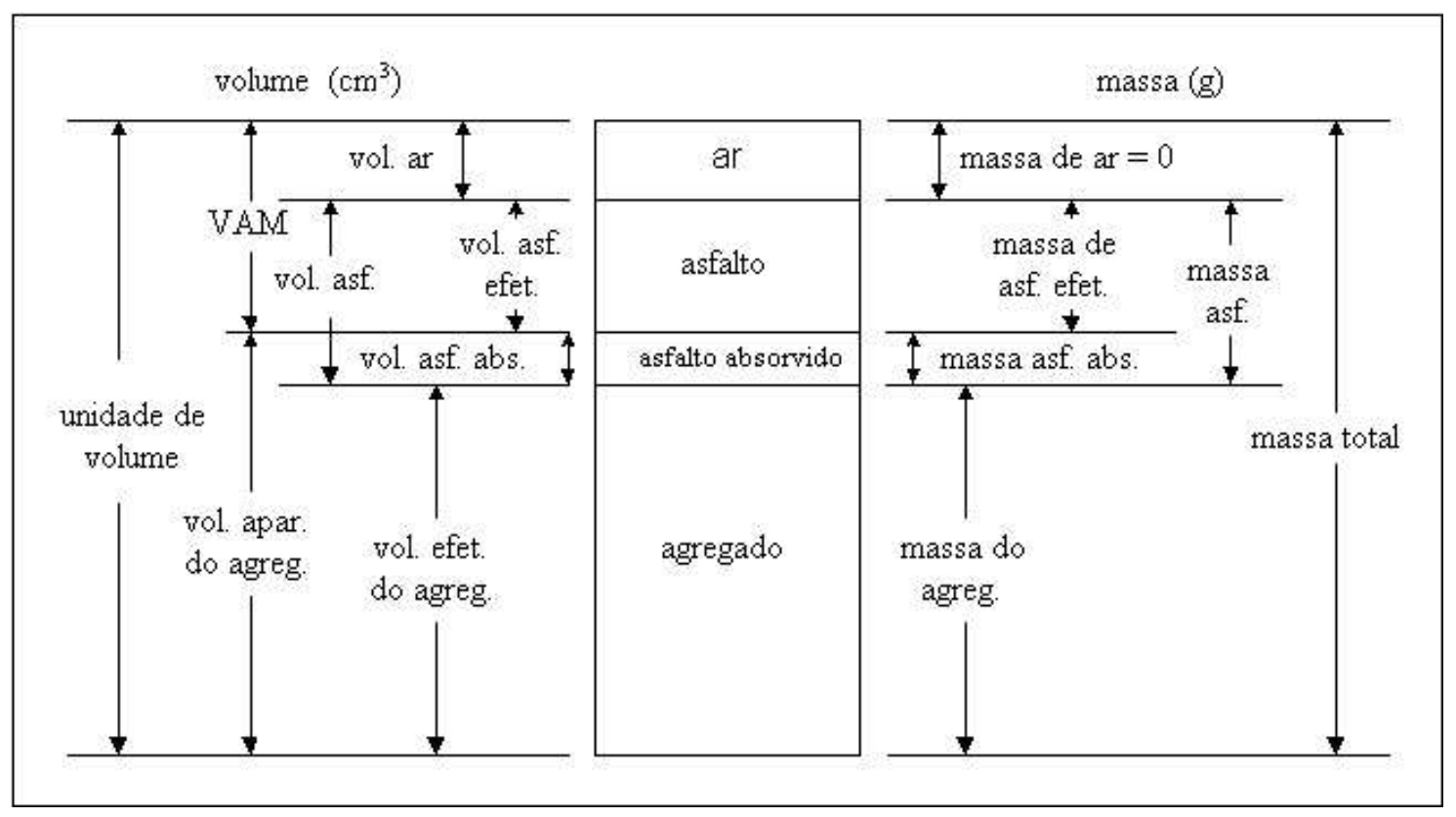

Figura 4.8: Diagrama de componentes da mistura asfáltica compactada (Motta et al., 1994)

O diagrama de componentes é um método interessante de cálculo dos parâmetros volumétricos, pois fornece uma visão clara das proporções volumétricas dos componentes da mistura, de modo a facilitar o seu entendimento. No entanto, uma desvantagem do modelo é representar, no mesmo diagrama de componentes, tanto as propriedades de massa como as propriedades de volume em uma mesma escala, contrariando as leis da física. Mas essa incoerência pode 
ser justificada por permitir a observação das proporções de massa e de volume da mistura de maneira fácil e clara.

\subsubsection{Dados de Entrada}

Estão apresentados na Tabela 4.4 os dados de entrada necessários para o desenvolvimento do diagrama de componentes, cuja demonstração de sua composição será vista, passo a passo, a seguir.

Tabela 4.4: Dados de entrada da mistura AZRg - diagrama de componentes

\begin{tabular}{lc}
\hline Propriedades & Mistura AZRg \\
\hline Teor de asfalto, $(P b)$ & 6,2 \\
Densidade do asfalto, $\left(\rho_{b}\right)$ & 1,02 \\
Densidade aparente dos agregados, $\left(\rho_{a p}\right)$ & 2,742 \\
Densidade efetiva dos agregados, $\left(\rho_{e f}\right)$ & 2,808 \\
Densidade aparente da mistura compactada, $(d)$ & 2,423 \\
\hline
\end{tabular}

\subsubsection{Composição do Diagrama de Componentes}

O diagrama de componentes fornece uma definição clara de densidade, que é a massa por unidade de volume do material compactado. Como o modelo consiste de vários materiais distintos, a densidade do material como um todo é denominada como densidade aparente da mistura $(d)$. Através da densidade aparente da mistura pode-se determinar a massa total $(M t)$ da mistura, como mostra a Equação 4.45 e ilustra a Figura 4.9. O diagrama de componentes é geralmente desenvolvido em unidades métricas, pois, nesse caso, a massa específica da água e sua densidade são numericamente iguais.

$$
M t=V \times d \times 1,000=1,0 \times 2,423 \times 1,0=2,423 g
$$

Sendo conhecida a massa total da mistura, $M t$, pode-se calcular a massa do asfalto contida na mistura, $M b$, (Equação 4.46), assim como a massa do agregado na mistura, $M a$, (Equação 4.47), representadas no diagrama 2 (Figura 4.10).

$$
\begin{aligned}
& M b=P b \times M t=0,062 \times 2,423=0,150 \mathrm{~g} \\
& M a=M t-M b=2,423-0,150=2,273 \mathrm{~g}
\end{aligned}
$$




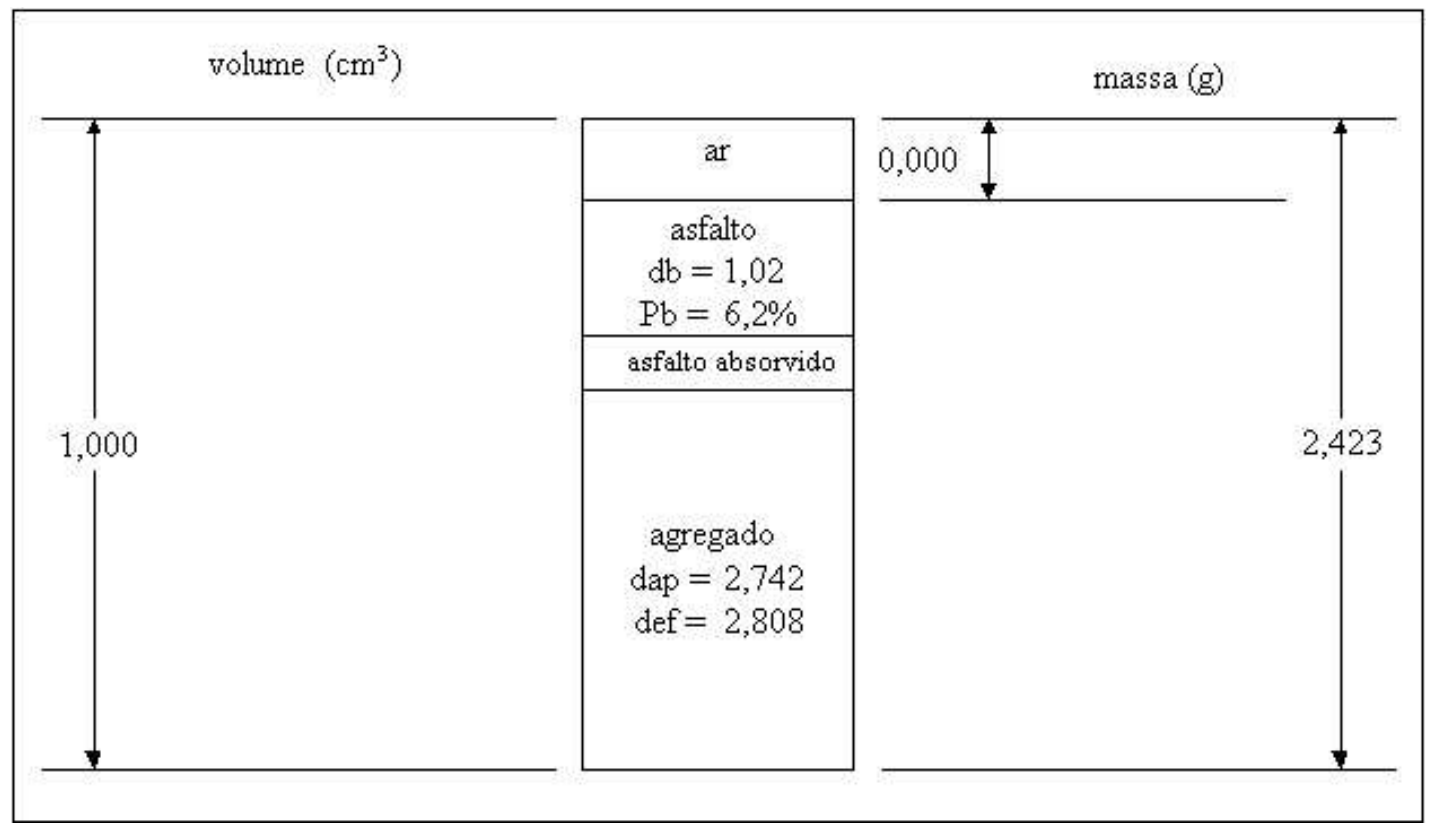

Figura 4.9: Composição do diagrama de componentes - 1

Obs.: Nas Figuras 4.9, 4.10, 4.11, 4.12, 4.13 e 4.14, onde se lê "db", entender $\rho_{b}$; "dap", entender $\rho_{a p}$; e "def", entender $\rho_{e f}$.

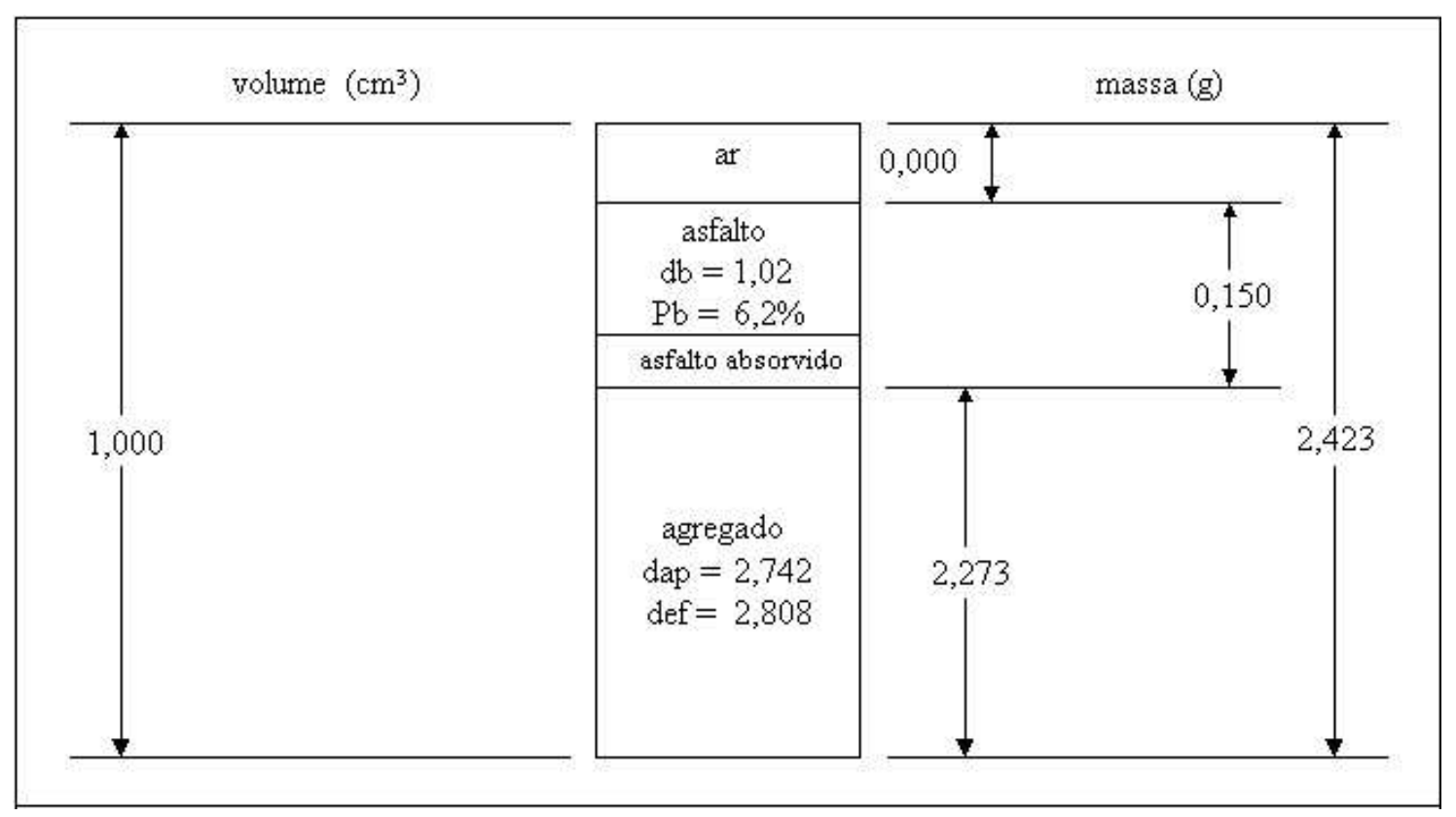

Figura 4.10: Composição do diagrama de componentes - 2 
Dando continuidade ao desenvolvimento do diagrama de componentes, após calcular a massa do agregado, $M a$, e as densidades efetiva, $\rho_{e f}$, e aparente do agregado, $\rho_{a p}$, pode-se calcular o volume efetivo, $V_{e f}$ (Equação 4.48), e o volume aparente, $V_{a p}$ (Equação 4.49), do agregado na mistura, como mostra o diagrama 3 (Figura 4.11).

$$
\begin{aligned}
& V_{e f}=\frac{M a}{\rho_{e f} \times 1,0}=\frac{2,273}{2,808 \times 1,0}=0,809 \mathrm{~cm}^{3} \\
& V_{a p}=\frac{M a}{\rho_{a p} \times 1,0}=\frac{2,273}{2,742 \times 1,0}=0,830 \mathrm{~cm}^{3}
\end{aligned}
$$

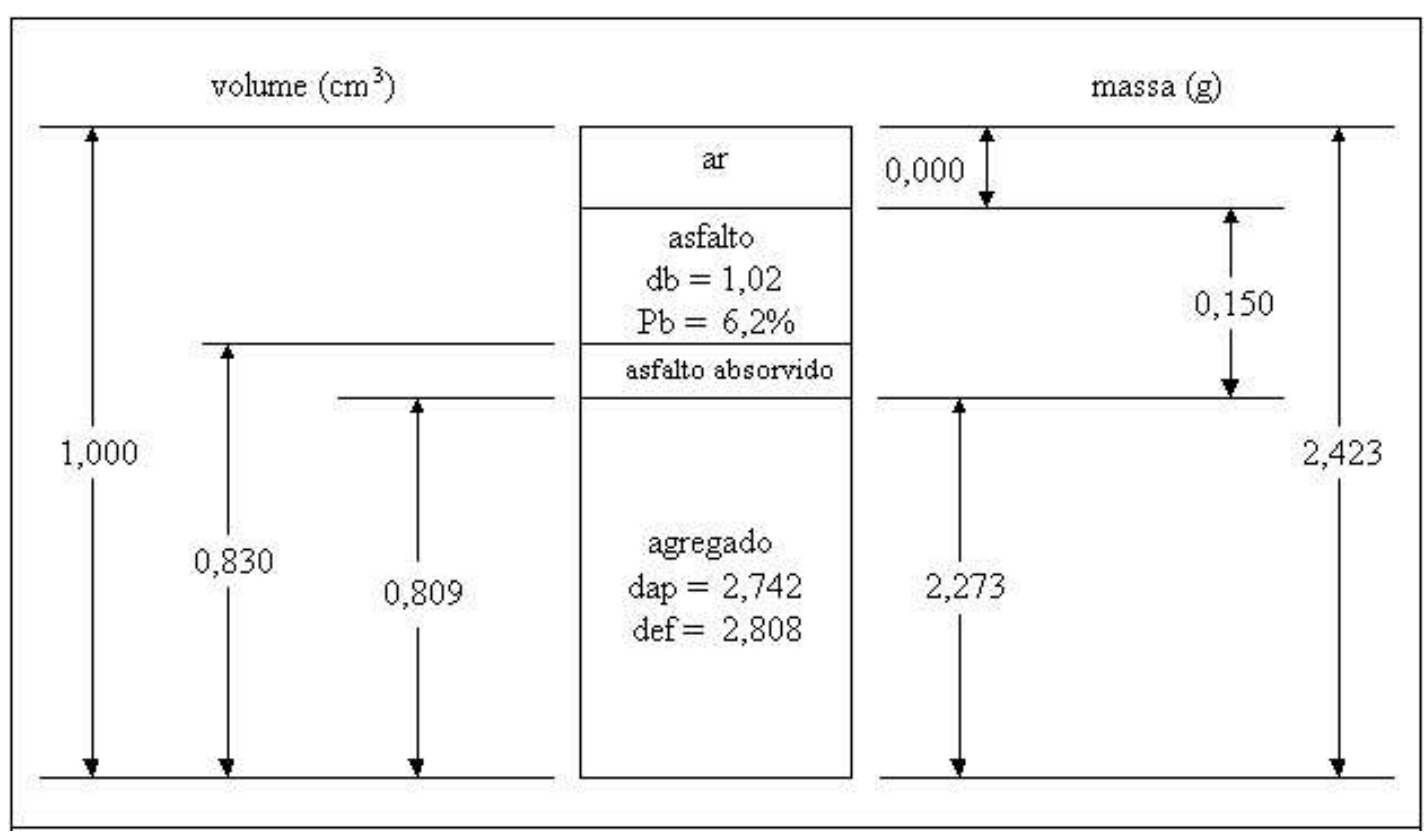

Figura 4.11: Composição do diagrama de componentes - 3

Após, tendo calculado os volumes efetivo, $V_{e f}$, e aparente do agregado, $V_{a p}$, é possível calcular o volume absorvido de asfalto, $V b_{a b s}$, como mostra a Equação 4.50. O volume total de asfalto na mistura, $V b$, pode ser calculado através da massa do asfalto, $M b$, dividida por sua densidade, como mostra a Equação 4.51. O volume de asfalto absorvido pelos agregados e o volume de asfalto na mistura estão representados no diagrama 4 (Figura 4.12).

$$
\begin{gathered}
V b_{a b s}=V_{a p}-V_{e f}=0,830-0,809=0,021 \mathrm{~cm}^{3} \\
V_{b}=\frac{M b}{\rho_{b} \times 1,0}=\frac{0,150}{1,02 \times 1,0}=0,147 \mathrm{~cm}^{3}
\end{gathered}
$$

A diferença entre o volume de asfalto na mistura, $V b$, e o volume de asfalto absorvido pelo agregado, $V b_{a b s}$, fornece o volume efetivo de asfalto na mistura, $V b_{e f}$, (Equação 4.52). $\mathrm{O}$ volume de ar contido na mistura compactada, $V_{a r}$, pode então ser calculado, subtraindo-se o volume de asfalto e o volume efetivo de agregado na mistura do volume total da mistura, $V t$, 
como mostra a Equação 4.53. O volume de asfalto efetivo e o volume de ar contidos na mistura estão representados no diagrama 5 (Figura 4.13).

$$
\begin{gathered}
V b_{e f}=V_{b}-V b_{a b s}=0,147-0,021=0,127 \mathrm{~cm}^{3} \\
V_{a r}=V t-V_{b}-V_{e f}=1,000-0,147-0,809=0,043 \mathrm{~cm}^{3}
\end{gathered}
$$

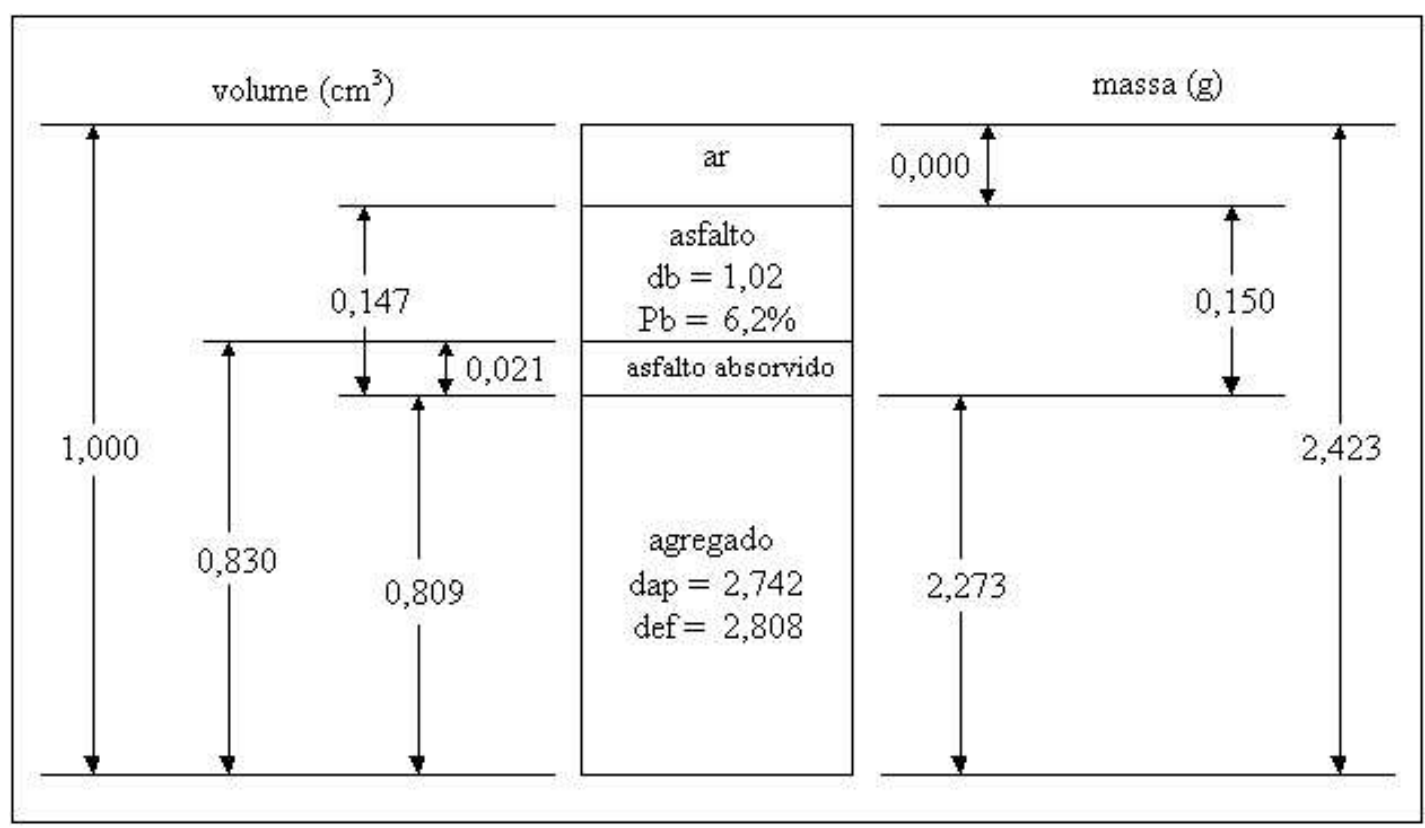

Figura 4.12: Composição do diagrama de componentes - 4

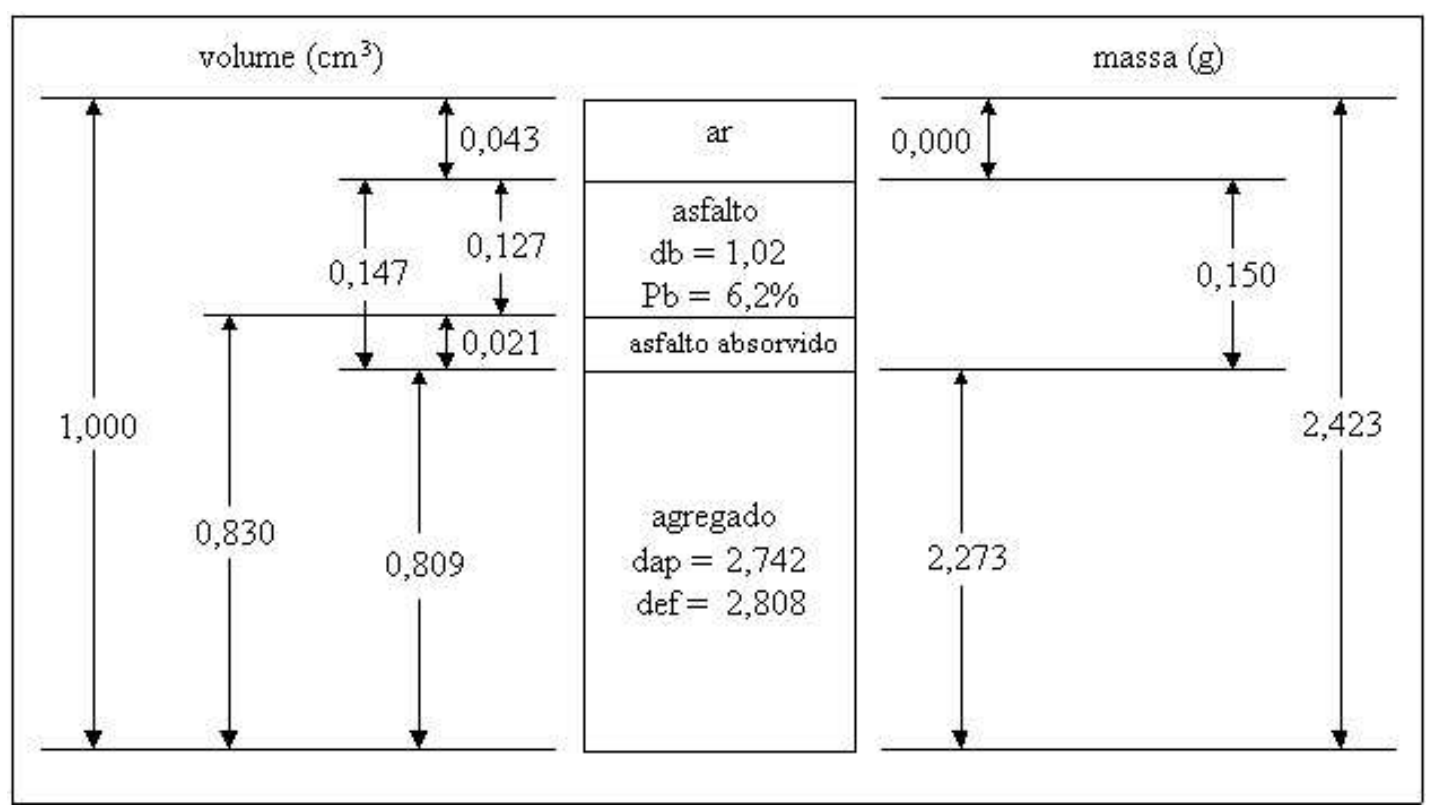

Figura 4.13: Composição do diagrama de componentes - 5 
Calcula-se então a massa do asfalto efetivo na mistura, $M b_{e f}$, através do volume efetivo de asfalto, $V b_{e f}$, e da densidade do asfalto, $\rho_{b}$, como mostra a Equação 4.54. Já a massa do asfalto absorvido pelos agregados, $M b_{a b s}$, pode ser obtida da diferença entre a massa do asfalto, $M b$, e a massa do asfalto efetivo, $M b_{e f}$, (Equação 4.55). As massas do asfalto efetivo e do asfalto absorvido contidos na mistura asfáltica compactada estão representadas no diagrama 6 (Figura 4.14).

$$
\begin{gathered}
M b_{e f}=V b_{e f} \times \rho_{b} \times 1,000=0,127 \times 1,02 \times 1,000=0,129 \mathrm{~g} \\
M b_{a b s}=M b-M b_{e f}=0,150-0,129=0,021 \mathrm{~g}
\end{gathered}
$$

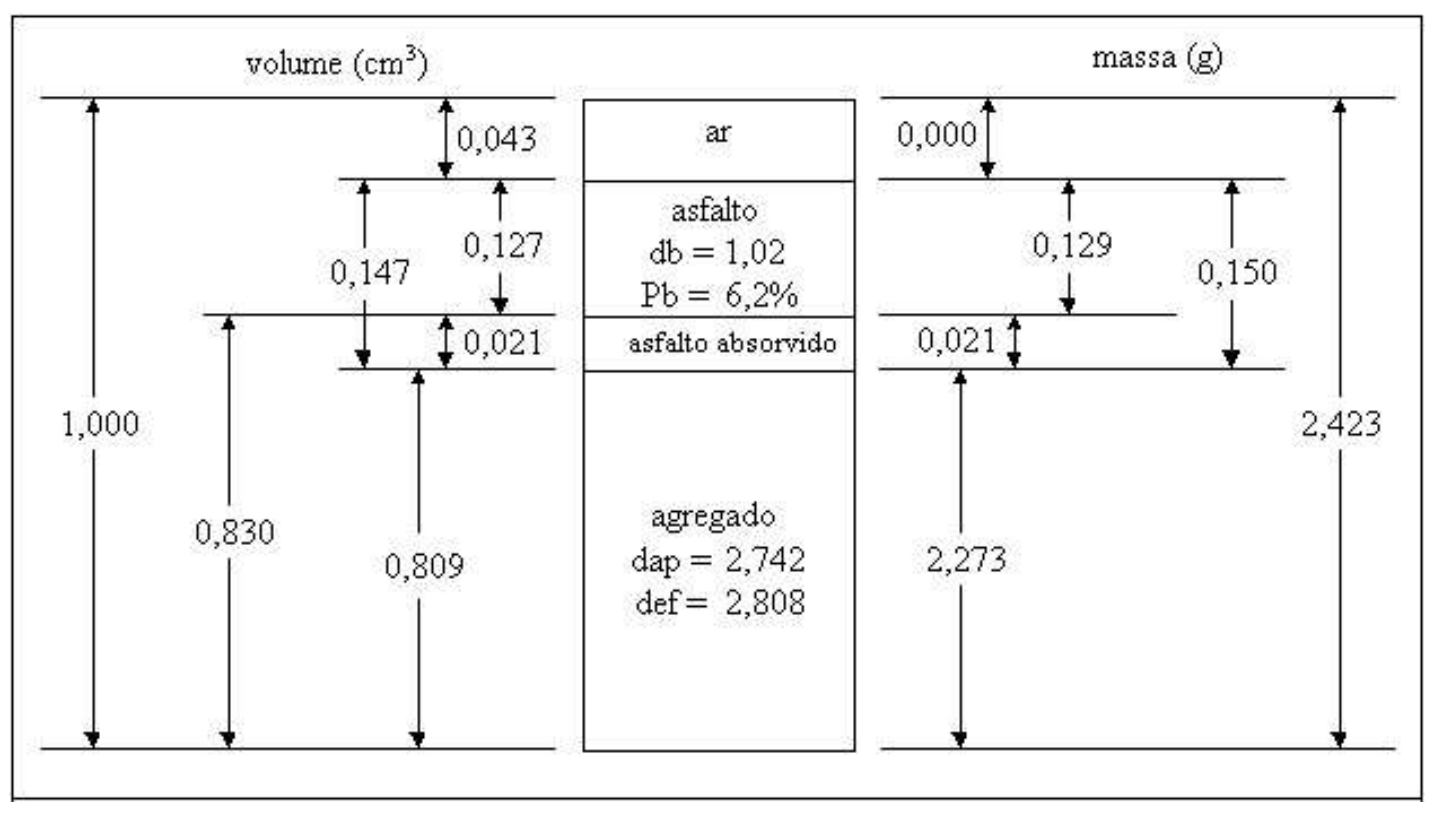

Figura 4.14: Composição do diagrama de componentes - 6

Tendo as massas e os volumes dos componentes da mistura compactada, pode-se calcular as propriedades volumétricas $(V A M, V v, R B V)$, assim como o teor de asfalto efetivo $\left(A_{e f}\right)$, a taxa de absorção de asfalto pelo agregado $\left(A_{a b s}\right)$ e a densidade máxima medida da mistura $D M M$.

O VAM da mistura compactada pode ser determinado através da soma do volume de ar e do volume de asfalto efetivo contidos na mistura, expressos como uma porcentagem do volume total da mistura compactada, como mostra a Equação 4.56.

$$
V A M=\left(V_{a r}+V b_{e f}\right) \times 100=(0,043+0,127) \times 100=17,1 \%
$$


O volume de vazios é igual ao volume de ar, expresso como uma porcentagem do volume total da mistura compactada (Equação 4.57).

$$
V v=V_{a r} \times 100=0,043 \times 100=4,3 \%
$$

A relação betume-vazios correspondente ao grau em que os vazios do agregado mineral são preenchidos pelo asfalto, expresso em porcentagem (Equação 4.58).

$$
R B V=\frac{V b_{e f}}{V A M} \times 100=\frac{0,127}{0,17} \times 100=74,5 \%
$$

Além das propriedades volumétricas, pode-se determinar também o teor de asfalto efetivo contido mistura, através da massa do asfalto efetivo pela massa total da mistura compactada, expresso em porcentagem, como mostra a Equação 4.59:

$$
A_{e f}=\frac{M b_{e f}}{M t} \times 100=\frac{0,129}{2,423} \times 100=5,3 \%
$$

A absorção de asfalto pelo agregado pode ser determinada da massa de asfalto absorvido dividida pela massa do agregado na mistura, expresso em porcentagem, como mostra a Equação 4.60:

$$
A_{a b s}=\frac{M b_{a b s}}{M a} \times 100=\frac{0,021}{2,273} \times 100=0,92 \%
$$

A densidade máxima medida também pode ser determinada dividindo-se a massa total da mistura pelo seu volume total, diminuído do volume de ar contido na mistura, como mostra a Equação 4.61:

$$
D M M=\frac{M t}{\frac{V t-V_{a x}}{\rho_{\text {agua }}}}=\frac{2,423}{\frac{1,000-0,043}{1,000}}=2,533
$$

$\mathrm{Na}$ Tabela 4.5, encontra-se um resumo dos cálculos necessários para a composição do diagrama de componentes, passo a passo, assim como o produto desses cálculos, que estão detalhadamente representados no diagrama de componentes ilustrado pela Figura 4.15. 
Tabela 4.5: Resumo da composição do diagrama de componentes

\begin{tabular}{lccc}
\hline Propriedades & \multicolumn{3}{c}{ Gabro } \\
\hline Volume Total & $(V t)$ & 1 & $\mathrm{~cm}^{3}$ \\
Densidade Aparente da Mistura & $(d)$ & 2,423 & $\mathrm{~g} / \mathrm{cm}^{3}$ \\
Densidade do Asfalto & $\left(\rho_{b}\right)$ & 1,02 & $\mathrm{~g} / \mathrm{cm}^{3}$ \\
Porcentagem de Asfalto & $(P b)$ & 6,2 & $\%$ \\
Densidade Aparente do Agregado & $\left(\rho_{a p}\right)$ & 2,742 & $\mathrm{~g} / \mathrm{cm}^{3}$ \\
Densidade Efetiva do Agregado & $\left(\rho_{e f a}\right)$ & 2,808 & $\mathrm{~g} / \mathrm{cm}^{3}$ \\
\hline Massa Total da Mistura & $(M t)$ & 2,423 & $\mathrm{~g}$ \\
Massa do Asfalto & $(M b)$ & 0,150 & $\mathrm{~g}$ \\
Massa do Agregado & $(M a)$ & 2,273 & $\mathrm{~g}$ \\
\hline Volume Efetivo do Agregado & $\left(V_{e f a}\right)$ & 0,809 & $\mathrm{~cm}^{3}$ \\
Volume Aparente do Agregado & $\left(V_{a p a}\right)$ & 0,830 & $\mathrm{~cm}^{3}$ \\
Volume do Asfalto & $(V b)$ & 0,147 & $\mathrm{~cm}^{3}$ \\
Volume do Asfalto Absorvido & $\left(V b_{a b s}\right)$ & 0,021 & $\mathrm{~cm}^{3}$ \\
Volume Asfalto Efetivo & $\left(V b_{e f}\right)$ & 0,127 & $\mathrm{~cm}^{3}$ \\
Volume de Ar & $\left(V_{a r}\right)$ & 0,043 & $\mathrm{~cm}^{3}$ \\
\hline Massa do Asfalto Efetivo & $\left(M b_{e f}\right)$ & 0,129 & $\mathrm{~g}$ \\
Massa do Asfalto Absorvido & $\left(M b_{a b s}\right)$ & 0,021 & $\mathrm{~g}$ \\
\hline Porcentagem de Volume de Vazios & $(V v)$ & 4,3 & $\%$ \\
Vazios do Agregado Mineral & $(V A M)$ & 17,0 & $\%$ \\
Relação Betume Vazios & $(R B V)$ & 74,5 & $\%$ \\
Asfalto Efetivo & $\left(A_{e f}\right)$ & 5,3 & $\%$ \\
Asfalto Absorvido & $\left(A_{a b s}\right)$ & 0,9 & $\%$ \\
Densidade Máxima Medida & $(D M M)$ & 2,533 & \\
\hline
\end{tabular}

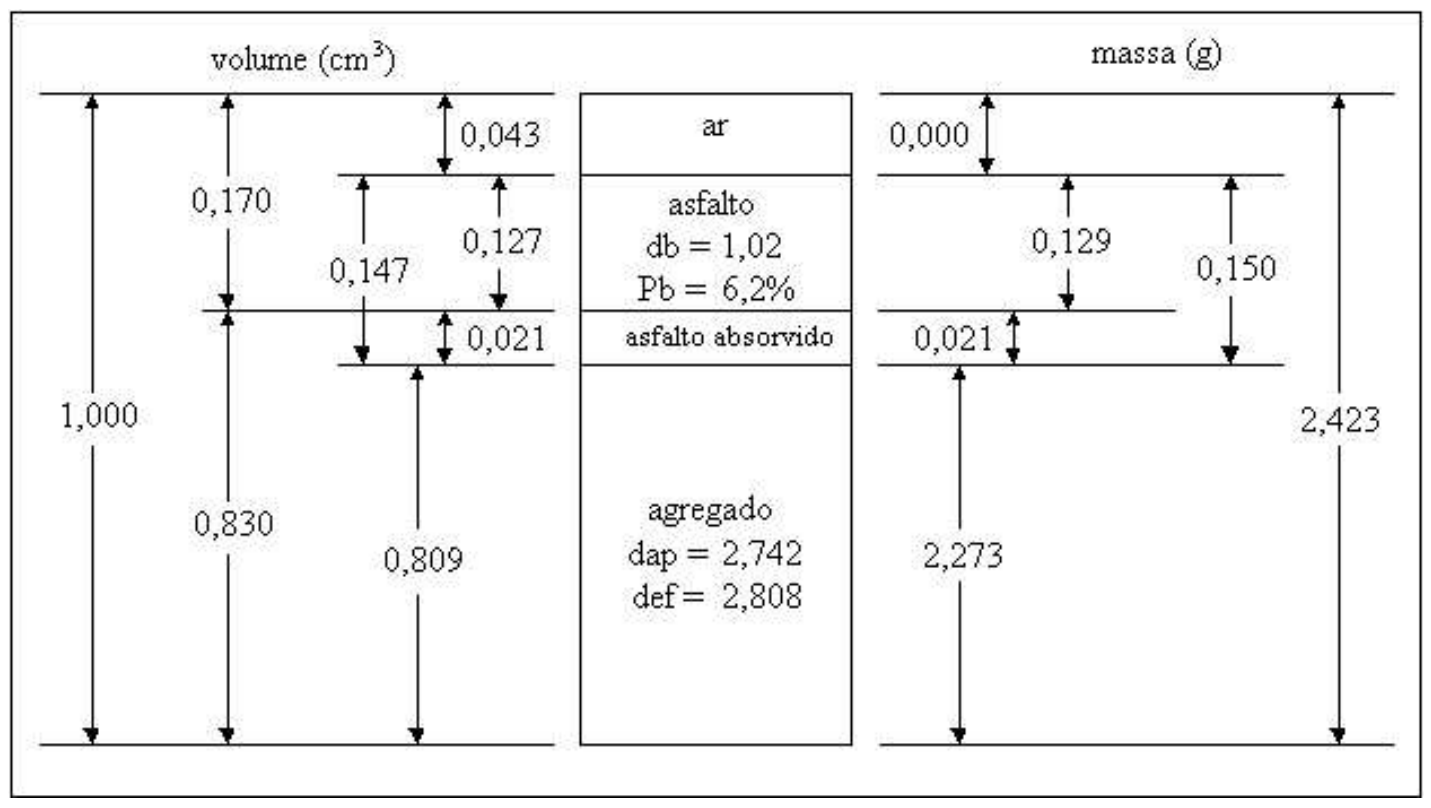

Figura 4.15: Diagrama de componentes 


\subsection{Considerações Finais}

Neste Capítulo, foram apresentados métodos de determinação das propriedades volumétricas das misturas que consideram e que não consideram a absorção de asfalto pelos agregados. Como visto, as formas de determinação mais apropriadas das propriedades volumétricas são através do Método Seguro apresentado ou do Diagrama de Componentes.

O Método Seguro permite a determinação correta das propriedades volumétricas, da taxa de absorção de asfalto pelo agregado e do teor de asfalto efetivo na mistura. O método tradicionalmente usado no Brasil para cálculo das propriedades volumétricas, que leva em consideração a DMT da mistura e apenas uma das densidades do agregado, que na maioria das vezes é a densidade real, impossibilita que resultados confiáveis quanto ao Vv, VAM e RBV sejam obtidos para misturas compostas por agregados que absorvem asfalto.

Com o intuito de ilustrar a dimensão dos erros cometidos ao se negligenciar a absorção de asfalto, foram comparados os valores das propriedades volumétricas adequadamente calculadas através do Método Seguro com os valores das propriedades volumétricas obtidos da maneira tradicional brasileira, cujos resultados estão apresentados na Tabela 4.6. É importante lembrar que o agregado de gabro é considerado pelos padrões internacionais como um material de absorção baixa, por apresentar absorção de asfalto média abaixo de 1, 5\%.

Tabela 4.6: Comparação entre métodos de determinação das propriedades volumétricas da mistura asfáltica AZRg

\begin{tabular}{|c|c|c|c|}
\hline \multicolumn{4}{|c|}{ Método Prático: densidade aparente e efetiva do agregado e DMM da mistura } \\
\hline & \multicolumn{3}{|c|}{ VAM (\%) Vv (\%) RBV (\%) } \\
\hline Densidade aparente $(2,742)$ & 17,0 & 4,3 & 74,5 \\
\hline \multicolumn{4}{|l|}{ Densidade efetiva $(2,808)$} \\
\hline \multicolumn{4}{|c|}{ Método Tradicional: uma densidade do agregado e DMT da mistura } \\
\hline & VAM $(\%$ & $\mathbf{V v}(\%)$ & RBV (\%) \\
\hline Densidade aparente $(2,742)$ & 17,0 & 2,4 & 86,1 \\
\hline Densidade efetiva $(2,808)$ & 19,1 & 4,3 & 77,2 \\
\hline Densidade real $(2,875)$ & 20,9 & 6,2 & 70,3 \\
\hline
\end{tabular}

Pode-se verificar que o Vv calculado utilizando o método tradicional e a densidade aparente do agregado é aproximadamente 1,9\% mais baixo que seu valor adequadamente calculado $(4,3 \%)$ e o RBV é cerca de $12 \%$ mais elevado comparado ao seu valor de $74,5 \%$ corretamente calculado. Ainda utilizando o mesmo método tradicional e a densidade real do agregado, pode-se perceber que a magnitude dos erros continua expressiva, pois o Vv apresenta-se com 
cerca de 1,9\% a mais de vazios, assim como o VAM com aproximadamente $3,8 \%$ de vazios em excesso e, conseqüentemente, o RBV mostra-se $4,2 \%$ mais baixo, ambos comparados a seus valores de referência corretamente calculados. Já ao se utilizar a densidade efetiva no método tradicional de cálculo das propriedades volumétricas, percebe-se que se erra no valor do VAM, elevando-o em $2 \%$, e no valor do RBV em $2,7 \%$. Isso permite concluir que, independentemente do valor da densidade usada para calcular as propriedades volumétricas das misturas através do método tradicional, os valores das propriedades são expressivamente diferentes dos valores obtidos através do Método Seguro, que considera a absorção de asfalto.

Os dados apresentados na Tabela 4.6 são ilustrativos da magnitude dos erros cometidos no cálculo das propriedades volumétricas quando utilizados métodos que consideram e que não consideram a absorção de asfalto pelos agregados. Como a maioria dos agregados usados na pavimentação absorve asfalto em maior ou menor grau, deixa-se aqui um alerta quanto à necessidade de uma revisão do método tradicionalmente usado no Brasil na determinação das propriedades volumétricas, pois são cometidos erros apreciáveis mesmo quando o agregado usado não apresenta absorção alta, indicando que esses erros podem ser ainda maiores se usados agregados com taxa de absorção mais elevada.

É importante comentar que o uso de uma determinada densidade do agregado pode estabelecer a adequação ou não da mistura projetada às especificações requeridas em um método de dosagem. Por exemplo, se a mistura estudada fosse projetada com base na densidade real do agregado, poderia ser considerada inadequada para o propósito da pavimentação por, aparentemente, apresentar déficit de asfalto, pois o Vv está acima de $6 \%$ e o RBV abaixo do valor especificado por norma. Porém, ao se calcular as propriedades volumétricas das misturas de maneira correta, ou seja, usando a densidade aparente e efetiva do agregado, verifica-se que a mistura está adequadamente projetada. Portanto, fica bastante claro que uma mistura pode ser aceita ou não dependendo da densidade do agregado empregada e da existência ou não de asfalto absorvido pelos agregados.

As propriedades volumétricas das misturas, além de serem sensíveis às densidades dos agregados e à taxa de absorção destes, é influenciada diretamente pela granulometria das misturas, assim como pelas características de superfície dos agregados e energia de compactação aplicada. O próximo capítulo trata das relações granulométricas e de superfície dos agregados com as propriedades volumétricas das misturas, bem como esclarece a evolução dos métodos de projeto e de determinações granulométricas estabelecidos com base nesses critérios volumétricos, no decorrer dos anos. 


\section{Propriedades Volumétricas e Seleções Granulométricas}

\subsection{Considerações Iniciais}

Métodos comumente usados para projetar misturas asfálticas incorporam critérios volumétricos, os quais são calculados a partir das proporções volumétricas dos materiais constituintes das misturas, como visto no capítulo anterior. No tradicional método Marshall, o teor de asfalto de projeto é determinado em função das propriedades volumétricas (Vv, VAM e RBV) e mecânicas das misturas. No método Superpave, a seleção do teor de asfalto de projeto também se baseia nas propriedades volumétricas das misturas, assim como nas porcentagens de compactação inicial (\%Gmmi) e máxima (\%Gmm), função do número de giros do compactador giratório e no teor de fíler (dust proportion).

Tanto no método Marshall quanto no método Superpave as propriedades volumétricas estão em posição de destaque, pois influenciam diretamente o desempenho das misturas. O desafio no entanto está em estabelecer um equilíbrio ideal das propriedades volumétricas focando as propriedades mecânicas das misturas e suas características de desempenho. Espera-se que as misturas asfálticas sejam estáveis o suficiente para evitar a ocorrência de deformações permanentes, flexíveis o suficiente para que não ocorram trincas devido à fadiga e que sejam duráveis, para resistir às ações do tráfego, das intempéries e do tempo. Para que essas propriedades de desempenho almejadas sejam alcançadas, há que se estabelecer um equilíbrio perfeito entre o esqueleto estrutural formado pelos agregados e o teor de asfalto adicionado à mistura. Essa 
mistura formada deve possuir agregados com tamanhos, formas, angularidades e texturas superficiais que permitam, além da formação de espaços suficientes para a adição da quantidade de asfalto necessária à durabilidade e à flexibilidade das misturas, a formação de um esqueleto estrutural resistente para garantir estabilidade e também flexibilidade à mistura.

Esse balanceamento ideal de proporções dos agregados e de asfalto nas misturas é sempre o objetivo principal da maioria das pesquisas desenvolvidas no estudo de misturas asfálticas. Alguns pesquisadores, através de verificações empíricas do comportamento das misturas frente às variações dos tipos e das proporções do agregado e do asfalto, propuseram métodos indicando quais seriam as proporções adequadas desses materiais conforme as características de desempenho dos pavimentos necessárias para a época. O método Marshall, desenvolvido por Bruce Marshall do Mississippi Highway Department por volta de 1939 e atualmente ainda o mais utilizado em território nacional, estabelece que o Vv das misturas deve permanecer entre 3 e $5 \%$. Já o método Superpave, que vem sendo utilizado e também bastante pesquisado principalmente nos Estados Unidos, estabelece Vv de exatamente $4 \%$.

Além do Vv, tanto o método Marshall como também o método Superpave, estabelecem valores para VAM e RBV. O método Marshall especifica valores de Vv e de RBV em função do volume de tráfego, como apresentado na Tabela 5.1. Os valores do VAM são especificados em função do diâmetro máximo nominal do agregado e do Vv de projeto, como mostra a Tabela 5.2.

Tabela 5.1: Especificação Marshall para Vv e RBV

\begin{tabular}{ccccccc}
\hline Propriedade & \multicolumn{4}{c}{ Tráfego e Critério } & \multicolumn{2}{c}{ tráfego alto } \\
& tráfego baixo & \multicolumn{2}{c}{ tráfego médio } & mín. & máx. \\
& mín. & máx. & mín. & máx. & mín. & máx. \\
\hline $\mathrm{VV}(\%)$ & 3 & 5 & 3 & 5 & 3 & 5 \\
$\mathrm{RBV}(\%)$ & 70 & 80 & 65 & 78 & 65 & 75 \\
\hline
\end{tabular}

Hand \& Epps (2000)

Já o método Superpave especifica valores mínimos do VAM em função do diâmetro máximo nominal do agregado (Tabela 5.3) e especifica valores mínimos e máximos do RBV, em função do volume de tráfego (Tabela 5.4).

Pode-se perceber, ao analisar as Tabelas 5.2 e 5.3, que os valores mínimos do VAM especificados pelo Superpave são iguais aos especificados para as misturas densas pelo método Marshall. Ao revisar a literatura, percebe-se que a verdadeira razão de se especificar um VAM mínimo é para incorporar uma quantidade mínima necessária de asfalto dentro da mistura, na tentativa de assegurar a sua durabilidade. No entanto, alguns estudos, como o de Kandhal 
Tabela 5.2: Especificação Marshall para VAM

\begin{tabular}{cccc}
\hline DMN & \multicolumn{3}{c}{ VAM Mínimo (\%) } \\
Vv de Projeto (\%) \\
& 3 & 4 & 5 \\
\hline 1,18 & 21,5 & 22,5 & 23,5 \\
2,36 & 19,0 & 20,0 & 21,0 \\
4,75 & 16,0 & 17,0 & 18,0 \\
9,5 & 14,0 & 15,0 & 16,0 \\
12,5 & 13,0 & 14,0 & 15,0 \\
19,0 & 12,0 & 13,0 & 14,0 \\
25,0 & 11,0 & 12,0 & 13,0 \\
37,5 & 10,0 & 11,0 & 12,0 \\
50,0 & 9,5 & 10,5 & 11,5 \\
63,0 & 9,0 & 10,0 & 11,0 \\
\hline
\end{tabular}

Hand \& Epps (2000)

Tabela 5.3: Especificação Superpave para VAM

\begin{tabular}{cc}
\hline DMN & VAM mínimo \\
$(\mathrm{mm})$ & $(\%)$ \\
\hline 9,5 & 15 \\
12,5 & 14 \\
19,0 & 13 \\
25,0 & 12 \\
37,5 & 11 \\
\hline
\end{tabular}

Cominsky et al. (1994)

et al. (1998), mostram que misturas asfálticas duráveis estão diretamente relacionadas com a espessura da película de asfalto que envolve o agregado. Segundo Kandhal et al. (1998), o VAM mínimo deve se basear na espessura mínima da película de asfalto ao invés de em uma quantidade mínima necessária de asfalto dentro da mistura, pois a quantidade mínima de asfalto que deve ser incorporada à mistura para proporcionar-lhe durabilidade, varia conforme a granulometria. Esse assunto será tratado, em detalhes, no Capítulo 6.

O valor do RBV especificado pelos métodos Marshall e Superpave têm gerado divergências na comunidade científica. Pesquisadores como Cominsky et al. (1998) apresentam como valor de referência $75 \%$ e comentam que se utilizados valores de RBV menores que $65 \%$ em mis-

Tabela 5.4: Especificação Superpave para RBV

\begin{tabular}{cc}
\hline Tráfego & $\begin{array}{c}\text { RBV } \\
(\%)\end{array}$ \\
\hline$<3 \times 10^{5}$ & $70-80$ \\
$<30 \times 10^{6}$ & $65-78$ \\
$<1 \times 10^{8}$ & $65-75$ \\
$\geq 1 \times 10^{8}$ & $65-75$ \\
\hline
\end{tabular}

Cominsky et al. (1994) 
turas projetadas para rodovias com volume de tráfego médio a alto, podem ocorrer problemas de endurecimento prematuro ou excessivo do asfalto, ocasionando trincas e desagregação do pavimento, enquanto valores maiores que $85 \%$ podem levar à exsudação de asfalto, ou ainda, à corrugação e à deformação permanente da mistura. Já Hand \& Epps (2000) acham redundante especificar valores mínimos e máximos de RBV se os limites estabelecidos para o Vv e VAM forem respeitados. Chama à atenção também que no Brasil especifica-se valores de RBV entre 75 e $82 \%$ para revestimentos asfálticos (NBR 12891), limites estes bastante superiores aos admitidos tanto pelo Superpave quanto pelo método Marshall em normas estadunidenses.

Como visto, as propriedades volumétricas das misturas são a base para o desenvolvimento de projetos e influenciam diretamente o desempenho das misturas. Os fatores principais que controlam e alteram essas propriedades volumétricas são: a granulometria, assunto que será abordado neste Capítulo, o volume de agregados na mistura, discutido no Capítulo 4, o grau de compactação, que será tratado no Capítulo 6, e o teor de asfalto, discutido ao longo de todo o trabalho.

\subsection{Granulometria}

A importância da graduação dos agregados foi reconhecida como essencial para o desenvolvimento adequado de projetos de misturas asfálticas muito antes do estabelecimento dos métodos formais de projeto de misturas (Huber \& Shuler, 1992). Ao longo dos anos, vários métodos de análise de graduações dos agregados foram pesquisados na tentativa de se obter uma "lei", a qual pudesse ser usada na seleção da granulometria "ideal" da mistura. Uma das mais conhecidas é a da curva de Fuller, proposta por Fuller \& Thompson em $1907{ }^{1}$ apud Roberts et al. (1991), que propõe a obtenção da curva de densidade máxima da mistura através da utilização da Equação 5.1. Os estudos realizados por Fuller \& Thompson demonstraram que a densidade máxima pode ser obtida quando $n=0,5$.

$$
P=100 \times\left(\frac{d}{D}\right)^{n}
$$

onde:

$P=$ porcentagem passante total;

$d=$ diâmetro da peneira em questão;

$D=$ diâmetro máximo do agregado.

\footnotetext{
${ }^{1}$ Fuller, W. B. e Thompson S. E. (1907) The laws of proportioning concrete. Journal of Transportation Division, American Society of Civil Engineers, vol. 59.
} 
Por volta de 1920, durante o desenvolvimento do método Hubbard Field de projeto de misturas, a importância do volume de vazios foi reconhecida como um parâmetro chave para o controle do desempenho das misturas no campo (Hubbard \& Field, 1932). O projeto de misturas Hubbard Field tem como princípio estabelecer o volume de vazios necessários para garantir uma quantidade mínima de asfalto na mistura, onde tanto o Vv como o VAM são especificados.

Além desses dois métodos citados, muitos outros foram elaborados, mas todos baseados na certeza da existência dessa "lei de graduação", a qual controlaria o conjunto de características das partículas dos agregados, responsáveis pela formação do esqueleto estrutural da mistura. Associada à lei de graduação, estava a idéia da existência de uma granulometria "ideal" que proporcionasse espaço suficiente para que a mistura tivesse uma quantidade mínima de asfalto e de volume de vazios e, ao mesmo tempo, proporcionasse estabilidade adequada à mistura sob a ação do tráfego.

Entre 1940 e 1960, vários pesquisadores propuseram curvas granulométricas que acreditavam representar a graduação "ideal" para proporcionar o melhor arranjo estrutural entre as partículas de agregados. Uma das publicações mais importantes foi a de Nijboer em $1948^{2}$ apud Huber \& Shuler (1992), quando demonstra experimentalmente que o arranjo mais denso das partículas de agregados são obtidos da granulometria plotada em um gráfico log-log de porcentagem passante versus abertura da peneira, tendo inclinação de 0,45. Com base nesse conhecimento, Goode \& Lufsey (1962) desenvolveram o gráfico de potência 0, 45 para avaliar as graduações dos agregados, sendo no eixo vertical a porcentagem passante do agregado, em escala aritmética, e no eixo horizontal a abertura das peneiras elevadas à potência de 0,45 . Esse gráfico, além de ser utilizado para avaliar as graduações dos agregados, destinava-se a estimar os vazios do agregado mineral da mistura compactada.

Porém, na publicação original, Goode \& Lufsey omitiram o método de determinação da linha de densidade máxima. Em resposta à curiosidade da comunidade científica, eles recomendaram um método de seleção do diâmetro máximo dependendo da forma da curva granulométrica. Esse método não foi muito aceito. Então, foram propostos vários outros métodos de determinação da linha de densidade máxima. No entanto, existem diferenças significativas entre esses métodos, sendo que nenhum deles mostra-se superior aos outros (Huber \& Shuler, 1992).

Uma grande vantagem da utilização da linha de densidade máxima é poder aumentar ou diminuir o VAM ao afastar ou aproximar a curva granulométrica dessa linha. Mas, devido aos

\footnotetext{
${ }^{2}$ Nijboer, L. W. (1948) Plasticity as a factor in the design of dense bituminous road carpets, Elsevier.
} 
vários métodos de determinação da linha de densidade máxima, há dúvidas quanto à execução correta de seu traçado.

\subsubsection{Linha de Densidade Máxima}

A história da linha de densidade máxima como usada na indústria do asfalto é baseada nos trabalhos de Campen (1940), Nijboer (1948) e Goode \& Lufsey (1962). Campen (1940) demonstrou como obter a mais densa graduação, ou seja, a linha de densidade máxima para os agregados por ele estudados. Nijboer ao avaliar várias granulometrias, com um mesmo diâmetro máximo, plotadas como retas em um gráfico log-log de porcentagem passante e abertura da peneira em mícrons, pôde determinar, além do VAM das misturas, as suas diferentes inclinações (n), como mostra a Figura 5.1. Ao plotar o VAM de cada mistura compactada contra a sua inclinação (n), verificou que os vazios do agregado mineral mínimo ocorriam quando a inclinação da granulometria, no gráfico $\log$-log, era de 0,45, como mostra a Figura 5.2. Nijboer, ao repetir seus experimentos com misturas de agregados britados (angulares) e naturais (arredondados), obteve os mesmos resultados.

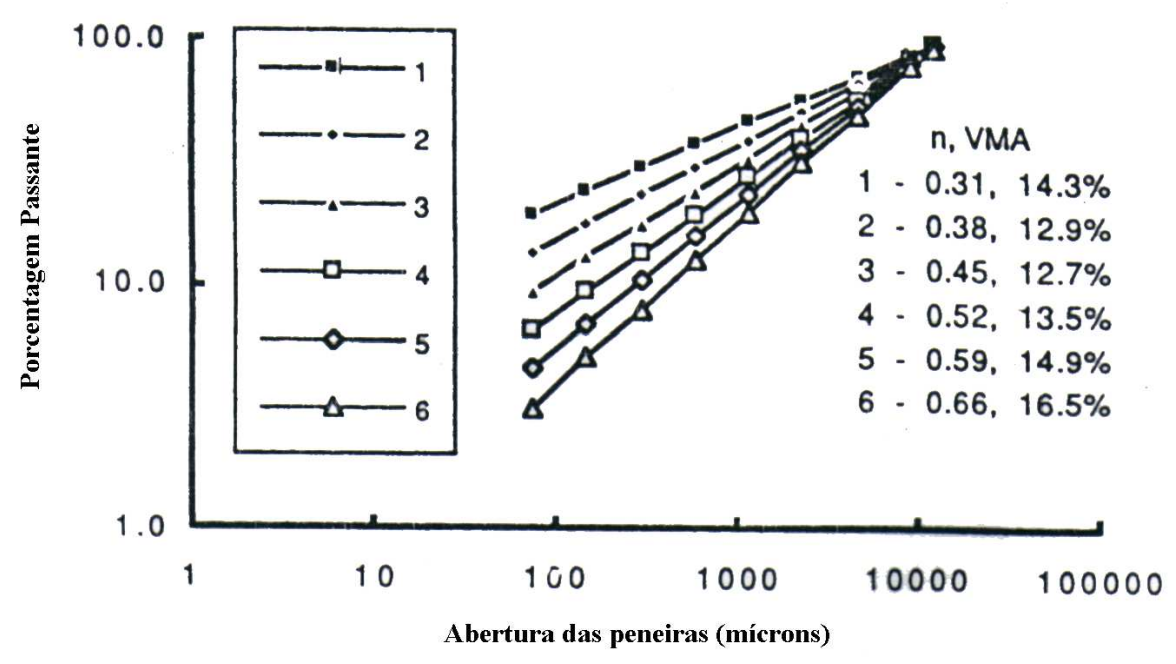

Figura 5.1: Granulometrias utilizadas para avaliar o arranjo entre as partículas de agregados (Nijboer (1948) apud Huber \& Shuler (1992))

Em sua publicação de 1962, Goode \& Lufsey reproduziram os experimentos de Nijboer com misturas de agregados naturais (arredondados), confirmando que a reta da granulometria obtida no gráfico log-log, com inclinação de 0,45 , proporcionava o menor VAM. Esse artigo traz a descrição do desenvolvimento matemático do gráfico de potência 0,45 , tendo no eixo vertical 


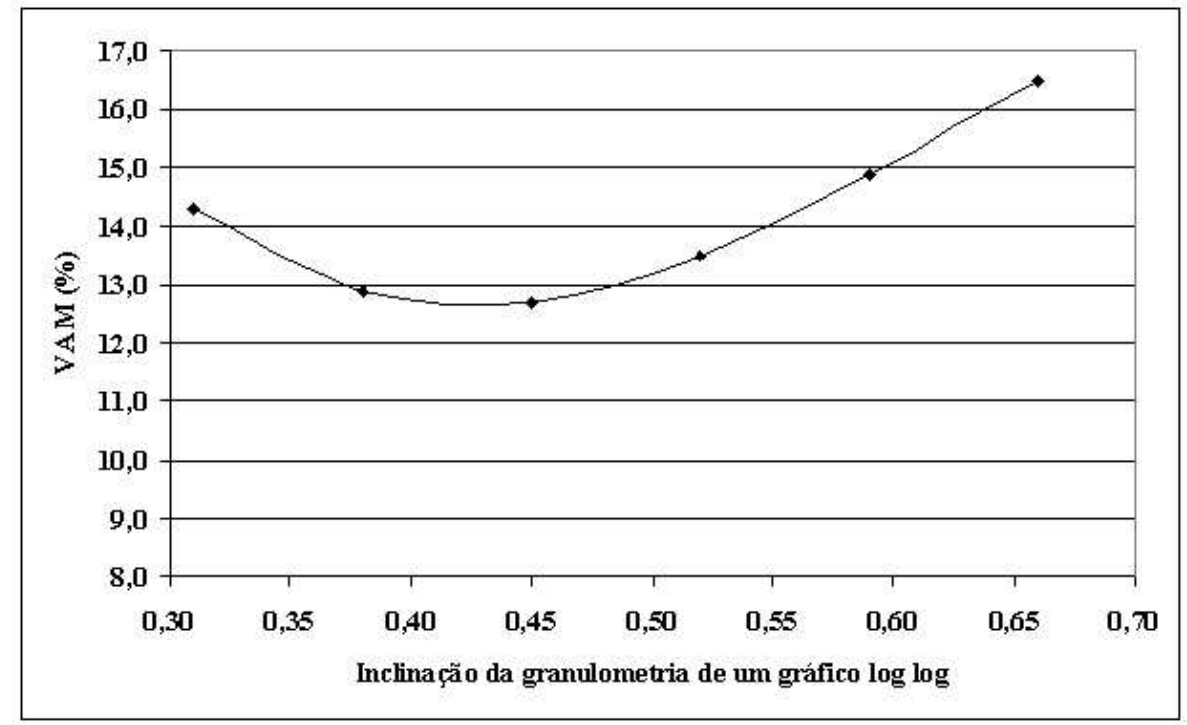

Figura 5.2: VAM da mistura versus inclinação das curvas granulométricas (Nijboer (1948) apud Huber \& Shuler (1992))

a porcentagem passante, em escala aritmética, e no eixo horizontal a abertura de cada peneira, expressa em mícrons e elevada à potência 0,45 .

Goode \& Lufsey (1962) também utilizaram o gráfico de potência 0, 45 para avaliar as granulometrias que não apresentavam linhas retas, quando plotadas no gráfico 0,45 . Eles desenvolveram uma série de experimentos usando granulometrias idealizadas, as quais tinham diferentes níveis de "corcunda" na peneira 0,60 mm, ilustradas na Figura 5.3. Três grupos de granulometrias curvas foram avaliadas. O primeiro grupo tinha quantidade alta de agregado fino, o outro média e o terceiro baixa. Eles estudaram também as granulometrias abertas, as quais tinham quantidades deficientes de material entre as peneiras 4, $75 \mathrm{~mm}$ e 2, $36 \mathrm{~mm}$. Goode \& Lufsey (1962) observaram que as granulometrias abertas não reagiam da mesma forma que as de granulometrias curvas. Então, eles sugeriram que as granulometrias abertas poderiam produzir misturas mais densas que as de granulometrias de linhas curvas plotadas acima da linha de densidade máxima. A Figura 5.4 mostra algumas das granulometrias estudadas por Goode \& Lufsey (1962) de números 12, 22, 23 e 24, com os correspondentes vazios do agregado mineral. A linha de densidade máxima, sugerida por eles, está desenhada passando pela origem do gráfico e pela peneira de maior diâmetro. A granulometria 12 está mais próxima da linha de densidade máxima e apresenta valor de VAM mais alto do que os das granulometrias 23 e 24, apesar da granulometria 24 estar mais distante da linha de densidade máxima. Goode \& Lufsey (1962) concluem que, para granulometrias abertas, vazios do agregado mineral baixos estão associados com as curvas que ficam abaixo da linha de densidade máxima. Segundo eles, esse fato deve ser levado em conta quando a linha de densidade máxima for utilizada como referência para o ajuste de curvas granulométricas abertas. 


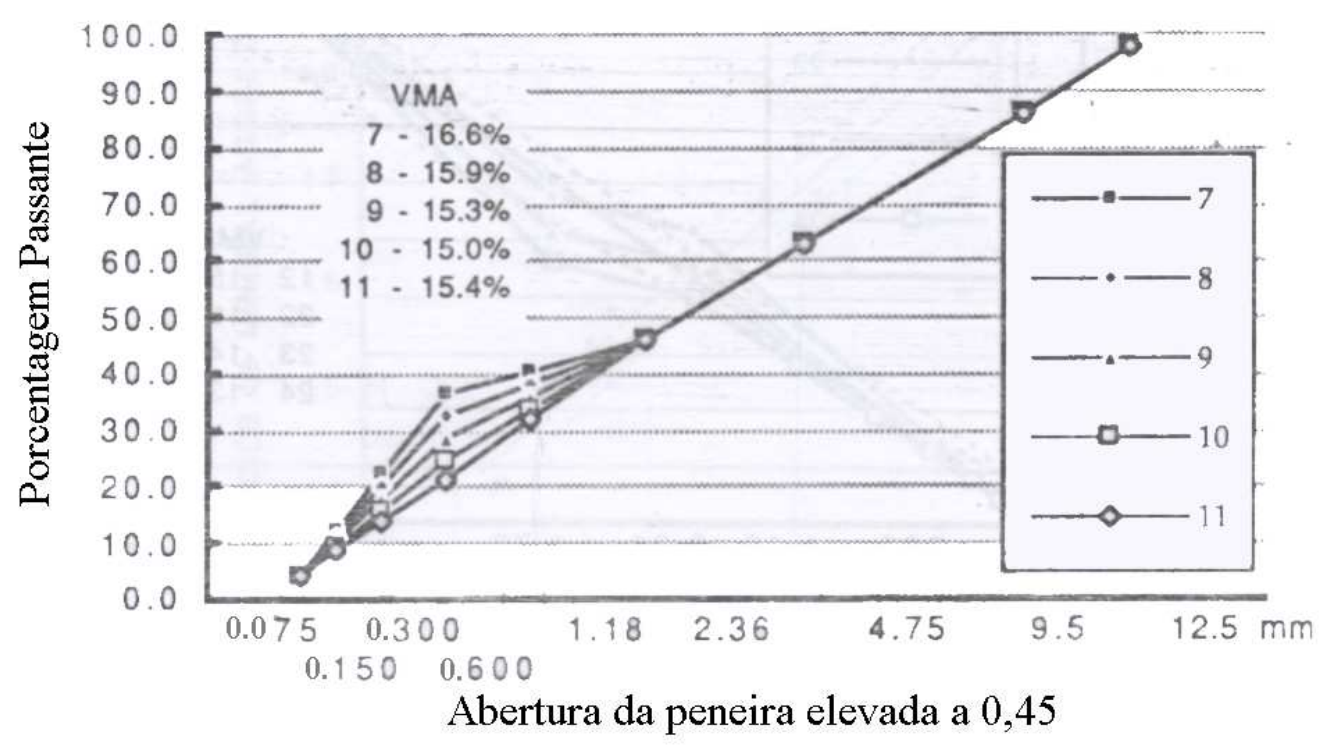

Figura 5.3: Granulometrias estudadas por Goode \& Lufsey (1962)

O gráfico de potência 0,45 teve grande aceitação, porém as recomendações de Goode \& Lufsey (1962) a respeito da obtenção da linha de densidade máxima, não. Vários métodos de obtenção da linha de densidade máxima estão em uso, mas não há um consenso a respeito do melhor método a ser utilizado. Na tentativa de resolver esse impasse, Huber \& Shuler (1992) realizaram um experimento, no Asphalt Institute, para avaliar a relação entre o VAM das misturas e as distâncias da curva granulométrica dessas misturas à linha de densidade máxima. A linha de densidade máxima usada como referência foi a utilizada no Asphalt Institute, que define diâmetro máximo nominal (DMN) como a primeira peneira a reter algum material e como diâmetro máximo (DM) a menor peneira através da qual todo o agregado passa, sendo o traçado da linha passando pela origem e pelo diâmetro máximo. Considerando a hipótese de que o afastamento da linha de densidade máxima para a obtenção de um VAM maior é válida, então o VAM deveria aumentar progressivamente com o afastamento progressivo da curva granulométrica. Porém, os resultados encontrados foram o inverso disso, ou seja, os VAM decresceram e então aumentaram novamente, conforme a curva se afastava da linha de densidade máxima.

Por definição, a linha de densidade máxima é a granulometria que proporciona um arranjo mais denso entre as partículas de agregados. Então, quanto mais próxima a granulometria está em relação à linha de densidade máxima, mais denso deve ser o arranjo entre as partículas. Como as curvas granulométricas ensaiadas não satisfizeram a definição da linha de densidade máxima, poder-se-ia imaginar que o VAM não estivesse relacionado com a distância da linha de densidade máxima. No entanto, julgando pelos VAM de cada granulometria e considerando 


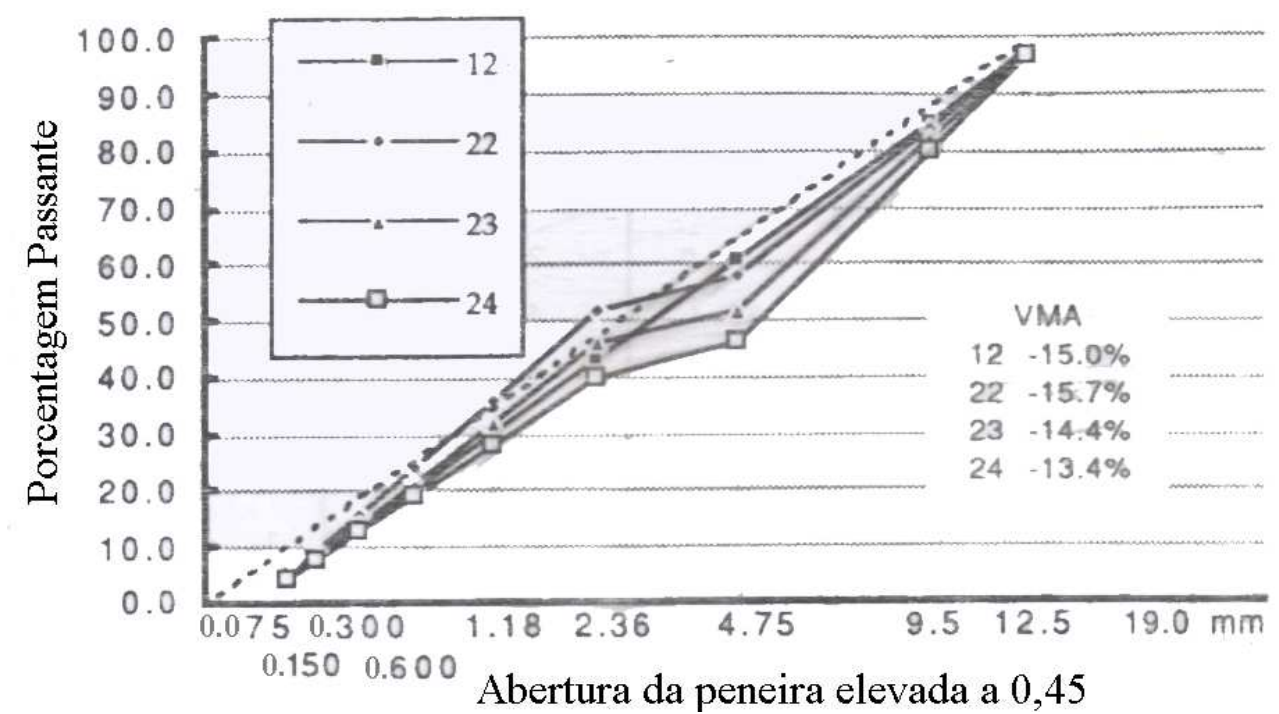

Figura 5.4: Granulometrias do tipo "S" estudadas por Goode \& Lufsey (1962)

o aumento com posterior decréscimo do VAM, a linha de densidade máxima parecia estar em algum lugar mais ou menos central a essas granulometrias.

Então, surgiu a hipótese de que essa suposta localização incorreta da linha de densidade máxima pudesse estar relacionada às definições diversas em relação à peneira de diâmetro máximo nominal. O diâmetro máximo nominal e o traçado da linha de densidade máxima são dois pontos técnicos que sempre causaram confusão. Pelo menos duas diferentes definições de peneira de diâmetro máximo nominal são habitualmente usadas pelas agências dos Estados Unidos, ASTM e Asphalt Institute.

O Asphalt Institute define:

- Diâmetro máximo nominal: a primeira peneira a reter algum material;

- Diâmetro máximo: a menor peneira através da qual todo o agregado passa.

A ASTM define:

- Diâmetro máximo nominal: a maior peneira que retém algumas partículas de agregado, mas geralmente não mais que $10 \%$;

- Diâmetro máximo: a menor peneira através da qual 100\% das partículas da amostra passam. 
Portanto, Huber \& Shuler (1992) reavaliaram os dados de Goode \& Lufsey, de LeFebvre ${ }^{3}$ e do Projeto 74 da Federal Highway Administration ${ }^{4}$, quanto à relação entre a distância da curva granulométrica das misturas à linha de densidade máxima de referência, em função do VAM, na tentativa de responder a questão de qual método deve ser usado para traçar a linha de densidade máxima.

As avaliações foram realizadas utilizando as três bases de dados acima citadas e utilizando dois métodos de traçado da linha de densidade máxima:

- da origem à peneira de diâmetro máximo nominal;

- da origem à peneira de diâmetro máximo.

As definições de diâmetro máximo nominal e de diâmetro máximo utilizadas na análise de Huber \& Shuler (1992) foram as sugeridas por McLeod (1987):

- Diâmetro máximo nominal: é uma peneira maior que a primeira peneira que retém mais que $10 \%$ do agregado;

- Diâmetro máximo: é uma peneira superior à do diâmetro máximo nominal.

As distâncias da linha de densidade máxima foram quantificadas por Huber \& Shuler (1992) como a soma das diferenças absolutas entre a linha de densidade máxima e a granulometria da mistura em cada peneira utilizada, como mostra a Equação 5.2.

$$
\operatorname{def}=\sum\left|P_{x}-P_{x}^{m}\right|
$$

onde:

def = soma da diferença entre os valores absolutos;

$P_{x}=$ porcentagem passante na peneira $x$;

$P_{x}^{m}=$ porcentagem passante na peneira $x$ da linha de densidade máxima considerada.

Ao reanalisar os dados de Goode \& Lufsey, de LeFebvre e do Projeto 74, com base nas novas considerações estabelecidas, Huber \& Shuler (1992) concluem que existe correlação entre o

\footnotetext{
${ }^{3}$ LeFebvre, J. (1957) Recent investigations of design of asphalt paving mixtures. Proceedings of the Association of Asphalt Paving Technologists vol.26, p.321-294.

${ }^{4}$ D’ Angelo, J. A.; Ferragut, T. (1991) Summary of simulation studies from demonstration project n.74: Field management of asphalt mixes. Proceedings of the Association of Asphalt Paving Technologists vol.60.
} 
VAM e a distância da linha de densidade máxima, quando a linha de densidade máxima é traçada, em um gráfico 0,45 , passando pela origem e pela peneira de diâmetro máximo com $100 \%$ de material passante. Os autores concluem que o diâmetro máximo nominal deve ser um tamanho maior que a primeira peneira que retém mais que $10 \%$ do agregado e que o diâmetro máximo deve ser definido como a menor abertura da peneira através da qual passa todo o material, ou seja, uma peneira maior que o diâmetro máximo nominal, como já sugerido por McLeod (1987).

A reavaliação dos dados permitiu aos autores concluírem também que, para uma dada granulometria, a angularidade e a textura dos agregados influenciam o arranjo estrutural entre as partículas, verificando que agregados arredondados produzem misturas com aproximadamente 1\% menos de VAM que agregados britados. Portanto, comparações granulométricas válidas, utilizando a linha de densidade máxima, só podem ser realizadas entre agregados de mesmo tipo, assim como, o efeito das características superficiais dos agregados, como forma, angularidade e textura superficial, só pode ser determinado através da comparação de misturas numa mesma granulometria. Os pesquisadores concluíram também que comparações entre misturas com diferenças grandes nas porcentagens de material passante na peneira $0,075 \mathrm{~mm}$ não devem ser realizadas utilizando as distâncias da linha de densidade máxima.

\subsubsection{Método Bailey}

Atualmente, tem-se pesquisado no Brasil e em alguns outros países como Emirados Árabes Unidos, França, Canadá e Estados Unidos a utilização do método Bailey para a determinação de granulometrias mais adequadas. O método Bailey foi desenvolvido pelo engenheiro Robert Bailey do Departamento de Transportes de Illinois, Estados Unidos, com base em sua experiência prática no desenvolvimento de projetos de misturas asfálticas. O objetivo principal do engenheiro Bailey era desenvolver um método que proporcionasse misturas com características estruturais melhores, como forma de combater a deformação permanente e, ao mesmo tempo, manter as propriedades de durabilidade das misturas (Vavrik et al., 2002).

Conceitualmente, esse método considera as características superficiais das partículas para a obtenção de curvas granulométricas que possibilitem um arranjo melhor entre partículas e, portanto, com esqueleto estrutural mais resistente. Os parâmetros do método estão relacionados diretamente com os vazios do agregado mineral, volume de vazios e propriedades de compactação. Por ser um método sistemático de determinação granulométrica, a variação de seus parâmetros de controle permite modificar o intertravamento das partículas e, portanto, o 
esqueleto estrutural das misturas asfálticas. Fundamentalmente, o método Bailey apresenta ferramentas que permitem a avaliação da combinação de agregados considerando suas características superficiais de forma, angularidade e textura para obtenção de granulometrias que satisfaçam às necessidades do pavimento ao qual a mistura é designada.

O método Bailey promove uma seleção granulométrica de agregados, por volume, com objetivo de otimizar os vazios e o intertravamento entre as partículas, de maneira a promover misturas com maiores estabilidades, utilizando dois princípios básicos:

- Arranjo entre partículas de agregados;

- Definições de agregados grossos e finos.

Com base nesses princípios, os passos principais do método são:

- avaliar o arranjo entre agregados grossos e finos, individualmente;

- definir a peneira de divisão entre agregados grossos e finos;

- avaliar a proporção de diferentes diâmetros de partículas;

- avaliar os agregados individualmente e suas combinações, por volume.

\section{Arranjo entre partículas de agregados}

O arranjo entre partículas deve ser o mais próximo possível, mas ao mesmo tempo deve destinar espaço suficiente para a incorporação de quantidades adequadas de asfalto, visando a durabilidade da mistura. O grau de arranjamento entre partículas depende dos aspectos seguintes:

- Tipo e grau de compactação. Vários tipos de esforço de compactação podem ser usados, incluindo pressão estática e impacto. Densidades mais altas podem ser alcançadas pelo acréscimo de energia de compactação.

- Forma das partículas. Partículas planas e alongadas tendem a ter maiores dificuldades de arranjarem-se que partículas cúbicas, em uma configuração densa.

- Angularidade das partículas. Partículas arredondadas tendem a se arranjar com maior proximidade e facilidade quando comparadas às partículas angulares. 
- Textura superficial das partículas. Partículas com textura superficial lisa tendem a deslizar umas sobre as outras, sem contudo promover intertravamento.

- Graduação das partículas. Partículas de um só diâmetro têm arranjamento menos denso que partículas de diâmetros variados.

- Resistência das partículas. A resistência das partículas afeta diretamente o grau de degradação que ocorre durante a compactação da mistura. Agregados menos resistentes geralmente degradam-se mais que agregados mais resistentes e, sendo assim, pode-se obter misturas com maiores quantidades de finos que a projetada inicialmente.

\section{Definição de Agregados Grossos e Finos}

O método define agregados grossos e finos como:

- Agregado grosso: maior partícula de agregado que, quando colocada em uma unidade de volume, cria vazios;

- Agregado fino: partículas de agregados que podem preencher os vazios criados pelo agregado grosso na mistura.

A definição de agregado grosso e fino depende do diâmetro máximo nominal da partícula. A peneira de divisão entre agregado grosso e fino é denominada de Primeira Peneira de Controle (PPC). Essa peneira é determinada de acordo com o Diâmetro Máximo Nominal (DMN), que, segundo Bailey, é um tamanho maior que a primeira peneira que retém mais que $10 \%$ do agregado, como sugerido por McLeod (1987), confirmado por Huber \& Shuler (1992) e também definido pelo Superpave. A PPC é definida como a peneira mais próxima do valor do diâmetro obtido através da Equação 5.3. A Figura 5.5 ilustra a divisão entre o agregado grosso e fino, determinada através da PPC.

$$
P P C=D M N \times 0,22
$$

O valor 0, 22 utilizado foi determinado através de análises bidimensionais (2D) e tridimensionais (3D) do arranjamento entre partículas de agregados grossos de formas distintas. A análise 2D da combinação de partículas mostra taxas de diâmetros de partículas da ordem de 0,155 (todas arredondadas) a 0,289 (todas planas), com valor médio de 0,22, como apresentado na Figura 5.6. 


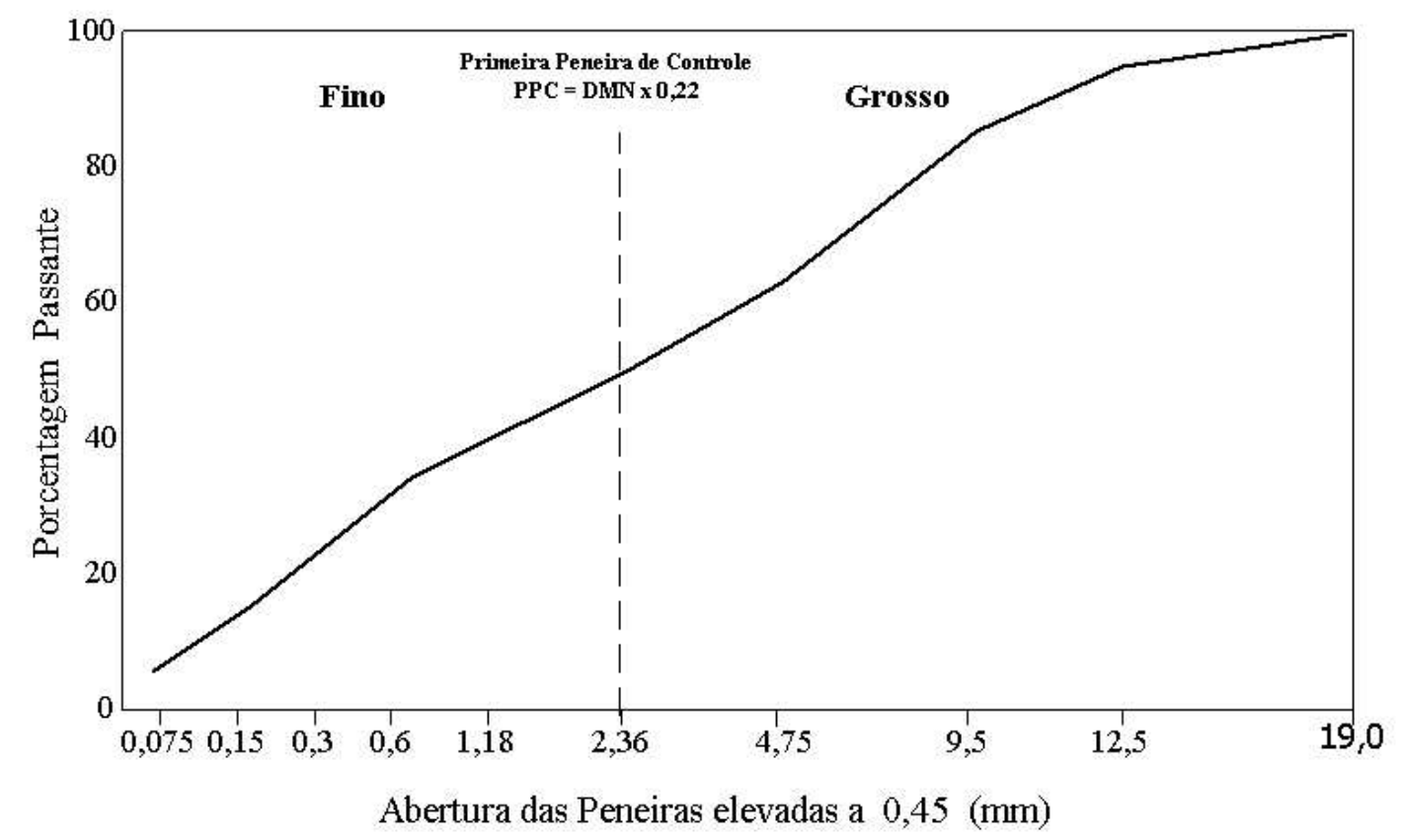

Figura 5.5: Peneiras de controle - Primeira Peneira de Controle (PPC)

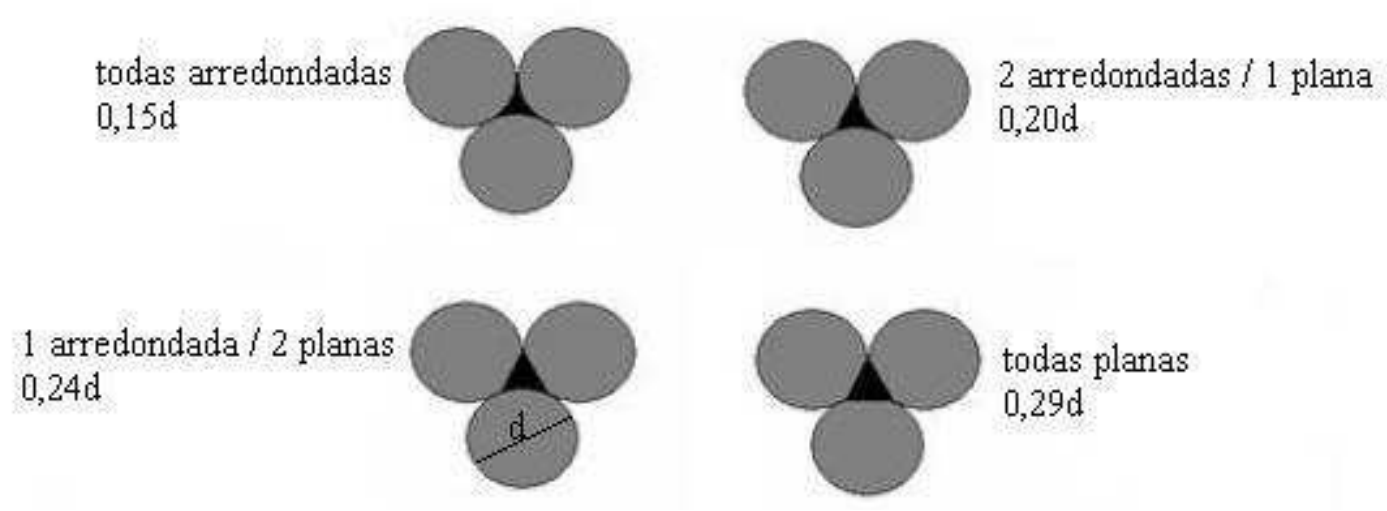

Figura 5.6: Combinação entre formas de partículas e vazios resultantes (Vavrik et al., 2001)

Ao analisar a Figura 5.6 pode-se compreender que quando todas as faces das partículas são arredondadas, o espaço vazio entre elas é 0,15 vezes o diâmetro da partícula $(0,15 \mathrm{~d})$ e quando todas são planas o espaço vazio entre elas é 0,29 vezes o diâmetro da partícula. As análises 3D da combinação de partículas, realizadas por Mavko et al. ${ }^{5}$, Reed ${ }^{6}$ e Bourbie ${ }^{7}$, forneceram resultados similares, com taxas de diâmetros de partículas da ordem de 0,15 a 0,42 . Ainda que 0,22 não seja exatamente correto para todas as misturas asfálticas, a análise da granulometria não é afetada se os valores estiverem entre 0,18 a 0,28 , além de que o fator 0,22 é a condição média de muitos arranjos entre partículas diferentes (Vavrik et al., 2002).

\footnotetext{
${ }^{5}$ Mavko, G. T.; Mukerji, T.; Dvorkin J. The rock physics handbook-Tools for seismic analysis in porous media Cambridge University Press, Mass.

${ }^{6}$ Reed, J. S. (1988) Introduction to the principles of ceramic processing John Wiley \& Sons, New York.

${ }^{7}$ Bourbie, T.; Coussy, O.; Zinszner, B (1987) Acoustics of porous media. Gulf Publishing Co., Houston, Tex.
} 
A fração grossa do agregado de qualquer mistura pode ser definida como a porção de material retida na PPC. No entanto, o agregado grosso pode ser subdividido em uma fração grossa do agregado grosso e em uma fração fina do agregado grosso, utilizando uma Peneira Média (PM), a qual determina esse ponto de separação (Figura 5.7). A peneira média é definida como sendo a peneira de abertura mais próxima da metade do diâmetro máximo nominal da mistura, como mostra a Equação 5.4.

$$
P M=D M N \times 0,50
$$

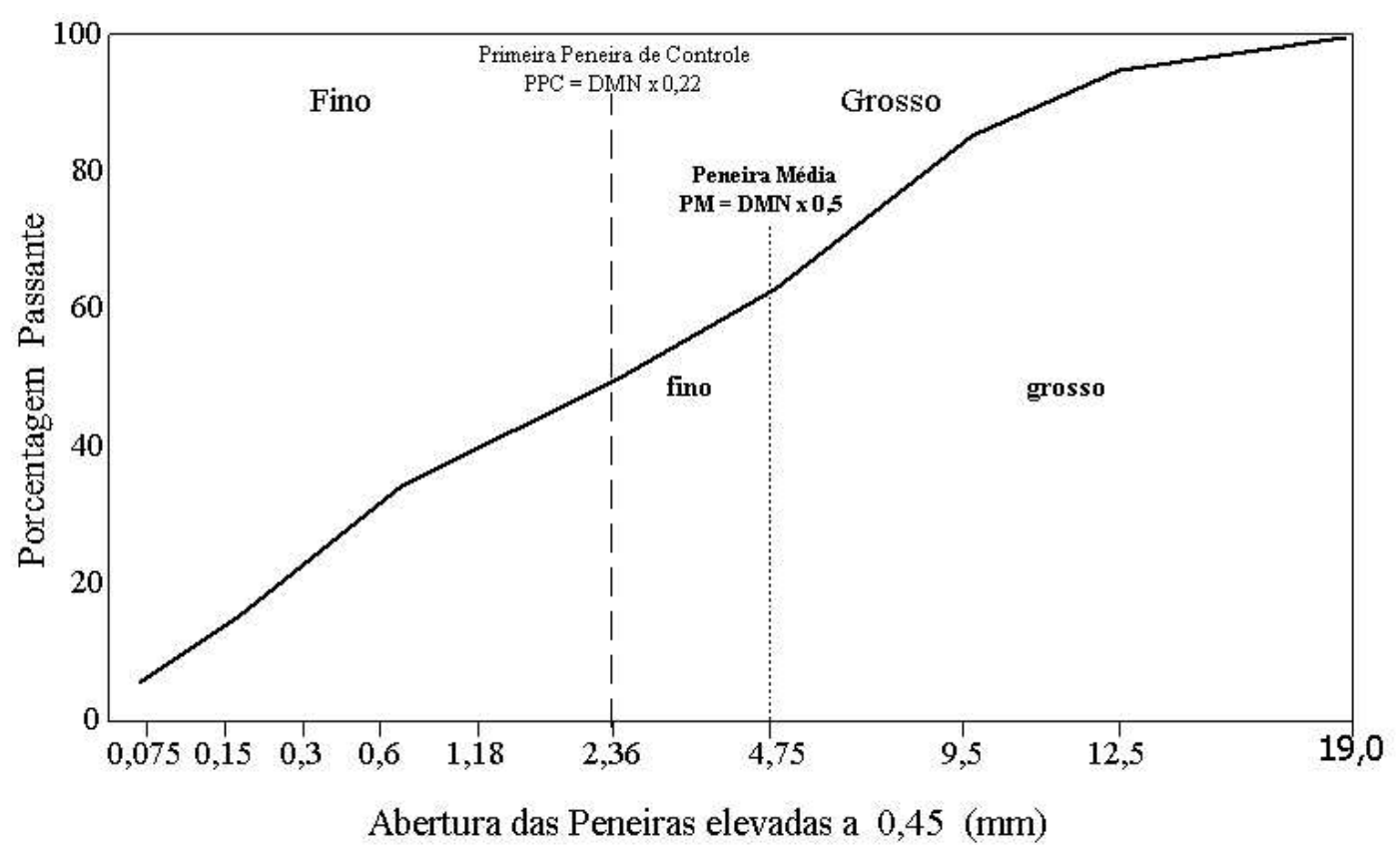

Figura 5.7: Peneiras de controle - Peneira Média (PM)

A PM representa uma divisão na estrutura formada pelo agregado grosso. As características da estrutura formada pelas partículas da fração grossa do agregado grosso podem ser alteradas através da proporção de Agregado Grosso (AG). É importante lembrar que não existe partícula pertencente à fração grossa do agregado (formadoras de espaços) que possa preencher os vazios criados por elas.

A proporção do AG na mistura pode ser alterada em função da porcentagem do material passante na PPC e na PM, como mostra a Equação 5.5.

$$
A G=\frac{\% P M-\% P P C}{100 \%-\% P M}
$$

onde:

$\% P M=$ porcentagem passante na peneira média; 
$\% P P C=$ porcentagem passante na primeira peneira de controle.

As partículas passantes na PM, correspondentes às partículas finas do agregado grosso, são chamadas de interceptoras. São chamadas assim por serem muito grandes para preencher os vazios criados pelas partículas da fração grossa, tendo então a função de espalhá-las ou dispersá-las. O balanceamento dessas partículas pode ser usado para o ajuste das propriedades volumétricas da mistura, ou seja, através de alterações nas quantidades das partículas interceptoras é possível alterar o VAM, com o intuito de promover um arranjo estrutural mais balanceado entre as partículas grossas (formadoras de espaços). Ter uma mistura com arranjo estrutural balanceado significa dizer que essa mistura permitirá uma compactação adequada no campo e apresentará estabilidade satisfatória sob a ação das cargas no pavimento.

Variações na proporção AG podem alterar o arranjo estrutural formado pelas partículas da fração grossa do agregado. Segundo Vavrik et al. (2002), a proporção AG de misturas densas deve permanecer entre 0,30 e 0,80 para que um arranjo estrutural balanceado seja formado. Misturas com valores baixos da proporção AG são controladas estruturalmente pelos agregados finos. Valores muito altos da proporção AG $(>1)$ devem ser evitados, pois as misturas se tornariam muito ricas em partículas interceptoras, fato que poderia causar dificuldades de compactação da mistura, devido à tendência de movimentação das partículas durante a passagem do rolo compactador.

Outras divisões entre frações grossas e finas são utilizadas pelo método. Utilizando uma Segunda Peneira de Controle (SPC), é realizada uma divisão na fração fina do agregado, considerando uma fração grossa do agregado fino e uma fração fina do agregado fino. As partículas de agregado que passam pela Primeira Peneira de Controle (PPC) e ficam retidas na Segunda Peneira de Controle (SPC) são denominadas de fração grossa do agregado fino e as partículas que passam pela SPC são denominadas de fração fina do agregado fino (Figura 5.8). A SPC é determinada através da Equação 5.6.

$$
S P C=P P C \times 0,22
$$

O agregado fino pode ser visto como uma mistura composta por partículas grossas e partículas finas, onde as partículas grossas criam vazios que devem ser preenchidos por partículas finas, porém sem excesso, para que seja preservado algum espaço vazio dentro dessa estrutura criada. As características do arranjo estrutural formado entre as partículas da fração grossa do 


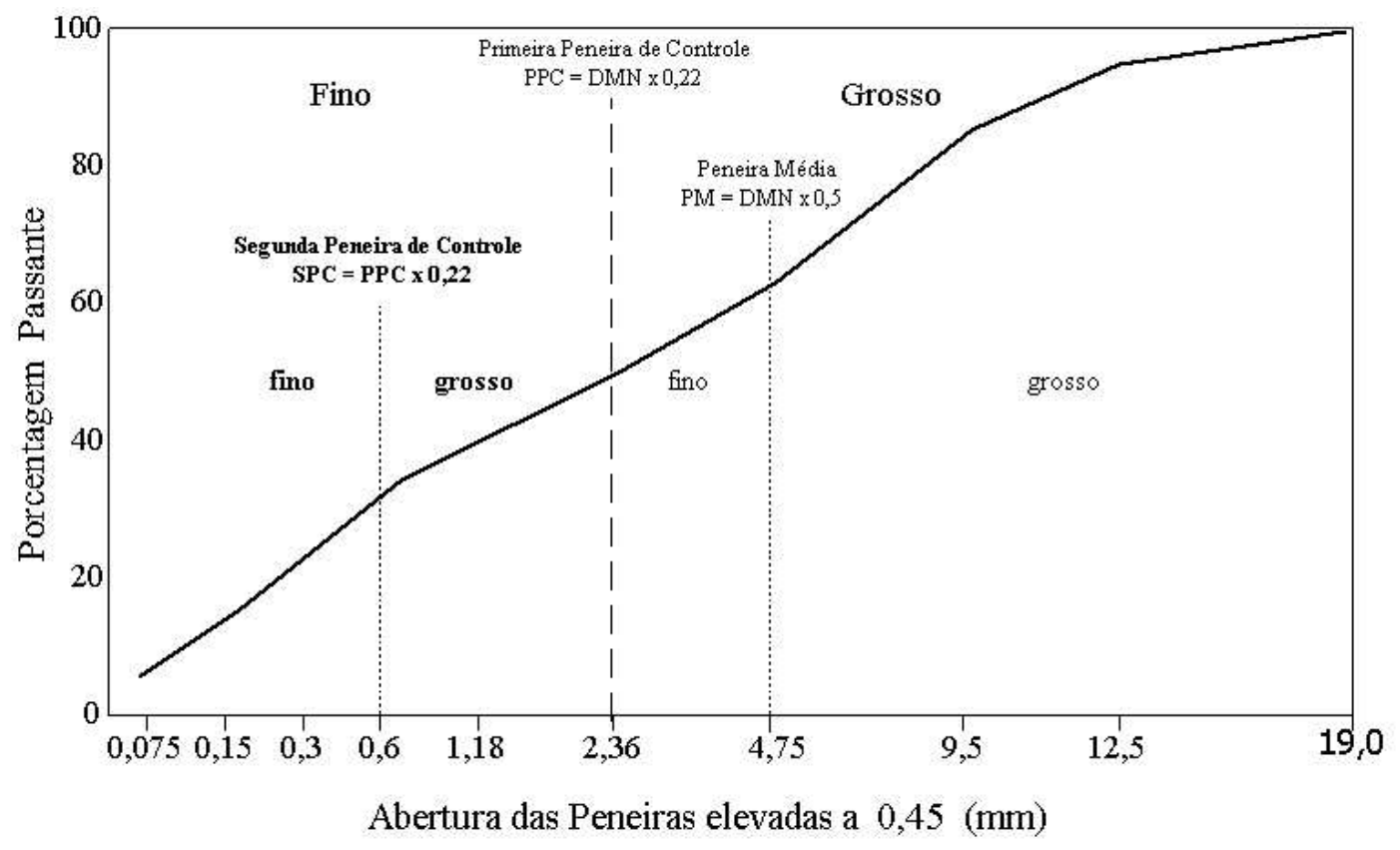

Figura 5.8: Peneiras de controle - Segunda Peneira de Controle (SPC)

agregado fino podem ser alteradas através da proporção Grossa do Agregado Fino (GAF).

$$
G A F=\frac{\% S P C}{\% P P C}
$$

onde:

$G A F=$ proporção grossa do agregado fino;

$\% S P C=$ porcentagem passante na segunda peneira de controle;

$\% P P C=$ porcentagem passante na primeira peneira de controle.

A proporção GAF de misturas densas deve permanecer entre 0,35 e 0,50 . Valores superiores a 0,50 comprometem o preenchimento dos vazios formados pela fração grossa do agregado fino com quantidades excessivas da fração fina do agregado fino, causando problemas estruturais na mistura, particularmente se areias naturais forem utilizadas. A proporção GAF pode ser utilizada para o controle da quantidade de vazios na mistura, ou seja, se o objetivo for diminuir o Vv e o VAM, deve-se elevar a proporção GAF ou se for aumentar o Vv e o VAM, então a proporção GAF deve ser diminuída.

Uma Terceira Peneira de Controle (TPC) também é utilizada para controlar a fração fina do agregado fino. Para tanto, procede-se uma subdivisão entre uma fração grossa e uma fração fina, da fração fina do agregado fino. A TPC é determinada através da Equação 5.8 e está representada na Figura 5.9.

$$
T P C=S P C \times 0,22
$$




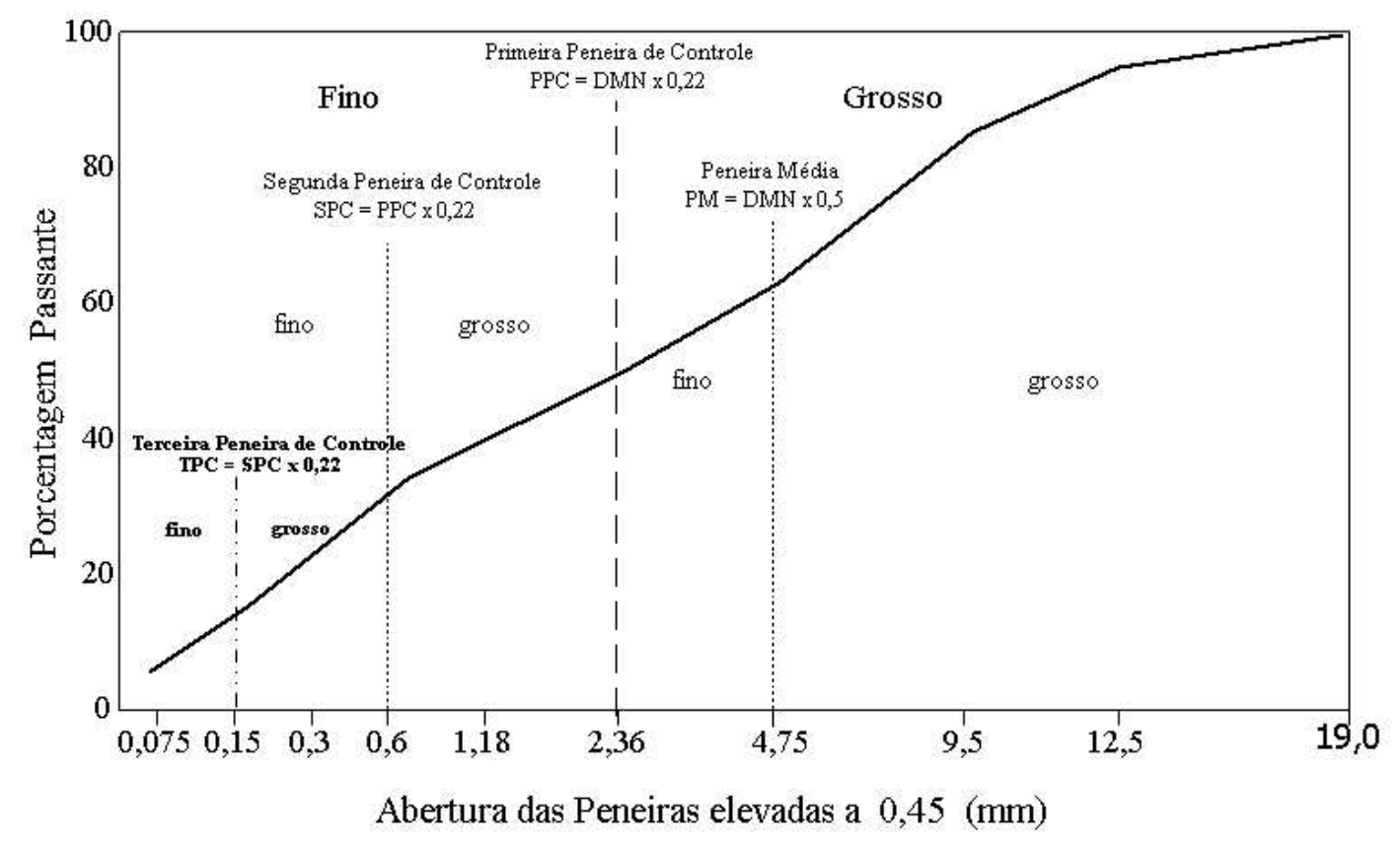

Figura 5.9: Peneiras de controle - Terceira Peneira de Controle (TPC)

O mesmo conceito de criação de vazios pela fração grossa da fração fina do agregado fino pode ser considerado. A fração fina do agregado fino pode ser vista como uma mistura que contém partículas grossas e partículas finas. As partículas grossas criam vazios que devem ser preenchidos com partículas finas, sem, no entanto, preencher esses vazios excessivamente. As características da estrutura formada entre as partículas grossas da fração fina do agregado fino podem ser estimadas através da proporção Fina do Agregado Fino (FAF).

$$
F A F=\frac{\% T P C}{\% S P C}
$$

onde:

$F A F=$ proporção fina do agregado fino;

$\% T P C=$ porcentagem passante na terceira peneira de controle;

$\% S P C=$ porcentagem passante na segunda peneira de controle.

Assim como a proporção GAF, a proporção FAF deve permanecer entre 0,35 e 0,50 para prevenir o preenchimento excessivo dos vazios criados pelas partículas mais grossas. Mudanças nessa proporção também afetam os vazios da mistura de maneira similar, ou seja, com o aumento da proporção FAF ocorre um decréscimo dos vazios da mistura.

Na Tabela 5.5, estão apresentados os valores recomendados por Vavrik et al. (2002) para as proporções de AG, GAF e FAF, considerando misturas densas, em função do diâmetro máximo nominal do agregado. 
Tabela 5.5: Valores recomendados para as proporções de AG, GAF e FAF em misturas densas

\begin{tabular}{lcccccc}
\hline \multicolumn{7}{c}{ Diâmetro Máximo Nominal (mm) } \\
& $\mathbf{3 7 , 5}$ & $\mathbf{2 5 , \mathbf { 0 }}$ & $\mathbf{1 9 , 0}$ & $\mathbf{1 2 , 5}$ & $\mathbf{9 , 5}$ & $\mathbf{4 , 7 5}$ \\
\hline$A G$ & $0,80-0,95$ & $0,70-0,85$ & $0,60-0,75$ & $0,50-0,65$ & $0,40-0,55$ & $0,30-0,45$ \\
$G A F$ & $0,35-0,50$ & $0,35-0,50$ & $0,35-0,50$ & $0,35-0,50$ & $0,35-0,50$ & $0,35-0,50$ \\
$F A F$ & $0,35-0,50$ & $0,35-0,50$ & $0,35-0,50$ & $0,35-0,50$ & $0,35-0,50$ & $0,35-0,50$ \\
\hline
\end{tabular}

\section{Combinação dos Agregados por Volume}

Após a definição das frações grossa e fina, a próxima etapa é a combinação dos agregados por volume, como estabelece o método Bailey. É prática comum a combinação de agregados pela massa, porém, essa forma de combinação não permite uma avaliação realística das proporções volumétricas dos agregados na mistura, pois, agregados com densidades diferentes têm volumes diferentes se considerada uma mesma massa. Portanto, essa maneira simplificada de combinar agregados pela massa só pode ser feita se as densidades dos vários agregados utilizados na mistura forem muito próximas.

Porém, antes que a combinação de agregados seja feita por volume, informações sobre o grau de entretecimento, ou seja, a quantidade de vazios formados entre as partículas após arranjarem-se entre si, são necessárias. Em vista disso, para cada agregado grosso utilizado na mistura é necessária a determinação de sua massa específica solta e compactada e, para cada agregado fino utilizado é necessária apenas a determinação de sua massa específica compactada. O objetivo dessas informações volumétricas é representar o arranjamento e o grau de entretecimento das partículas dos agregados. O procedimento para a determinação das massas específicas solta e compactadas dos agregados estão descritos no item 5.3.2 deste capítulo.

O próximo passo, após a determinação das massas específicas solta e compactada, é a escolha do grau de entretecimento desejado para o agregado grosso (formador de espaços) na mistura. A escolha do grau de entretecimento desejado do agregado grosso, ou simplesmente a massa específica escolhida do agregado grosso, subentende a escolha do tipo de mistura que pretende-se projetar, ou seja, se pretende-se projetar uma mistura fina, uma mistura grossa ou uma mistura SMA (Stone Matrix Asphalt). Com o auxílio da Figura 5.10, pode-se obter maiores esclarecimentos sobre a seleção da massa específica escolhida.

A massa específica solta, apresentada na Figura 5.10, corresponde ao limite inferior de intertravamento entre partículas de agregados grossos, ou seja, teoricamente, seria a linha divisória entre uma mistura fina e uma mistura grossa. Por exemplo, se fosse escolhida uma massa específica do agregado grosso menor que a massa específica solta, significaria dizer que 


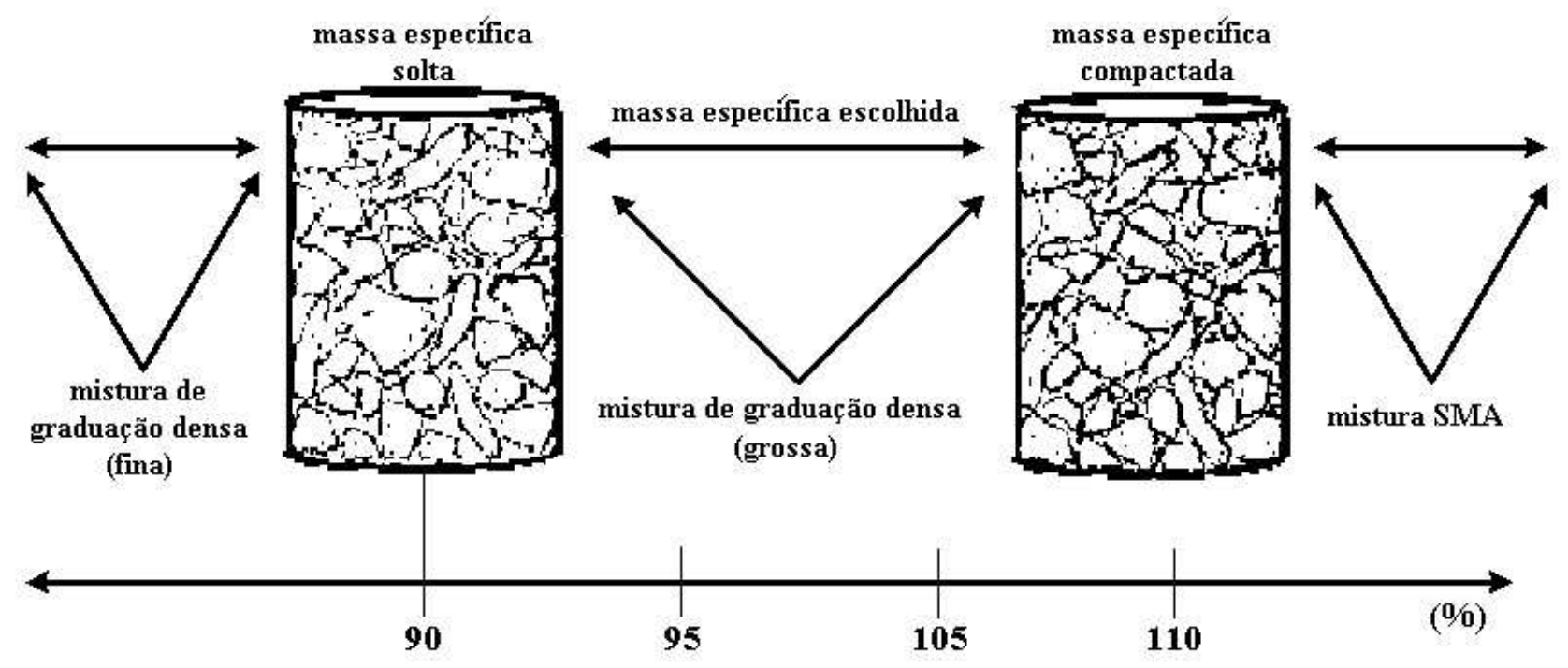

Figura 5.10: Seleção da massa específica solta dos agregados grossos para misturas densas (adaptada de Vavrik et al. (2002))

as partículas de agregados grossos estariam espalhadas umas em relação às outras, ou melhor, longe da condição de contato e intertravamento. Então, escolher um valor de massa específica do agregado grosso abaixo do valor da massa específica solta é o mesmo que optar por utilizar uma mistura fina, com esqueleto estrutural formado apenas por agregados finos. Por outro lado, a massa específica compactada (Figura 5.10) é considerada como o limite máximo de intertravamento do agregado grosso para misturas densas, cujo valor de densidade é geralmente próximo de $110 \%$ da massa específica solta. Portanto, se escolhida uma massa específica do agregado grosso próxima desse valor, significa dizer que as misturas projetadas serão grossas e bastante densas. Misturas assim, muitas vezes, apresentam dificuldades construtivas devido à sua densidade elevada, necessitando de um aumento significativo no esforço de compactação para alcançar a densidade de campo.

Segundo Vavrik et al. (2001), se a opção for por projetar misturas grossas densas, então a porcentagem da massa específica escolhida deve ficar entre 95 e $105 \%$ da massa específica solta, pois valores acima de $105 \%$ podem resultar em misturas difíceis de serem compactadas no campo e valores abaixo de $95 \%$ podem resultar em misturas sem intertravamento adequado do agregado grosso.

Depois de selecionada a massa específica escolhida do agregado grosso, determina-se o volume de agregados finos necessário para preencher os vazios criados pelo agregado grosso, utilizando a massa específica compactada do agregado fino. O procedimento para a determinação dessa massa específica compactada do agregado fino está descrito no item 5.3.2, 
deste capítulo. O objetivo de fazer uso da massa específica compactada do agregado fino para a determinação do volume necessário desse agregado no preenchimento dos vazios é que o esqueleto estrutural formado esteja o mais próximo possível de sua estabilidade máxima. Um exemplo detalhado sobre a utilização do Método Bailey, como instrumento de seleção granulométrica em misturas asfálticas densas, pode ser encontrado nos anexos da dissertação de mestrado de Cunha (2004).

\subsubsection{Método Superpave}

Como comentado anteriormente, as pesquisas do SHRP desenvolveram métodos de análise de ligantes asfálticos e de misturas, inicialmente, sem se preocupar com os agregados. $\mathrm{Na}$ tentativa de consertar o equívoco cometido, o grupo de especialistas realizou uma abordagem consensual, mediante utilização do método de Delfos modificado, com o objetivo de conseguir informações relevantes, em um curto espaço de tempo e com um mínimo de pesquisa bibliográfica e experimental. Ainda que a granulometria tenha sido considerada a propriedade mais importante da mistura, houve considerável desacordo quanto ao método ou métodos de controle da granulometria que deveriam ser adotados (Anderson \& Bahia, 1997).

A Tabela 5.6 traz o resumo classificatório das notas dadas pelos especialistas do SHRP quanto aos métodos que acreditavam ser os mais adequados para o controle da granulometria. Como se pode observar, o método de controle da granulometria, que considera pontos de controle e zona restrita, teve a pontuação mais baixa e a mais aceita foi a que considera somente os pontos de controle. Essa pontuação baixa indica a ocorrência de controvérsias sobre a zona restrita durante o desenvolvimento do SHRP.

O Superpave estabelece que seja usado o método das tentativas para a escolha da granulometria associado ao gráfico de potência 0,45 contendo pontos de controle, zona de restrição e linha de densidade máxima (Figura 5.11). A Figura 5.11 apresenta uma representação do gráfico de potência 0,45 contendo a linha de densidade máxima, corresponde a uma reta que parte da origem e vai até o ponto do diâmetro máximo, zona de restrição, que repousa sobre a linha de densidade máxima, entre as peneiras intermediárias 4,75 ou 2,36 $\mathrm{mm}$ e $0,30 \mathrm{~mm}$ e os pontos de controle, que funcionam como limites dentro dos quais a curva granulométrica deve passar, fixados nas peneiras de diâmetro máximo, diâmetro máximo nominal, uma peneira abaixo do diâmetro máximo nominal e nas peneiras de aberturas $2,36 \mathrm{~mm}$ e $0,075 \mathrm{~mm}$. Os pontos de controle e zona de restrição foram definidos pelo Superpave de acordo com o diâmetro máximo 
nominal dos agregados, de $37,5 \mathrm{~mm}, 25 \mathrm{~mm}, 19 \mathrm{~mm}, 12,5 \mathrm{~mm}$ e $9,5 \mathrm{~mm}$, como mostram as Tabelas 5.7, 5.8 ,5.9, 5.10 e 5.11 (Cominsky et al., 1994).

Tabela 5.6: Resumo classificatório das notas dadas pelos especialistas do SHRP para os métodos de controle da granulometria

\begin{tabular}{lcc}
\hline Limites Granulométricos & Média $^{a}$ & desvio padrão \\
\hline mínimo/máximo & 4,50 & 1,95 \\
pontos de controle/zona restrita & 4,14 & 1,79 \\
pontos de controle somente & 5,29 & 1,68 \\
\hline
\end{tabular}

(Cominsky et al., 1994)

${ }^{a}$ escala de notas:

1 - desacordo total

2 - desacordo forte

3 - desacordo

4 - neutro

5 - concordância

6 - concordância forte

7 - concordância total

A escolha dos métodos de controle da granulometria foi bastante controversa e não parece claro o motivo ou motivos que levaram a zona restrita a tornar-se parte das especificações Superpave, com vistas em sua pontuação baixa que reflete o desacordo de opiniões a seu respeito. Posteriormente, muitas controvérsias foram e vêm sendo levantadas em relação às especificações granulométricas Superpave, principalmente no que tange a zona restrita. O motivo principal dessas dúvidas e controvérsias é que muitas misturas densas, as quais transpõem a zona restrita, vinham e vêm apresentando desempenho bom em campo (Kandhal \& Cooley Jr., 2002; Hand \& Epps, 2001). 


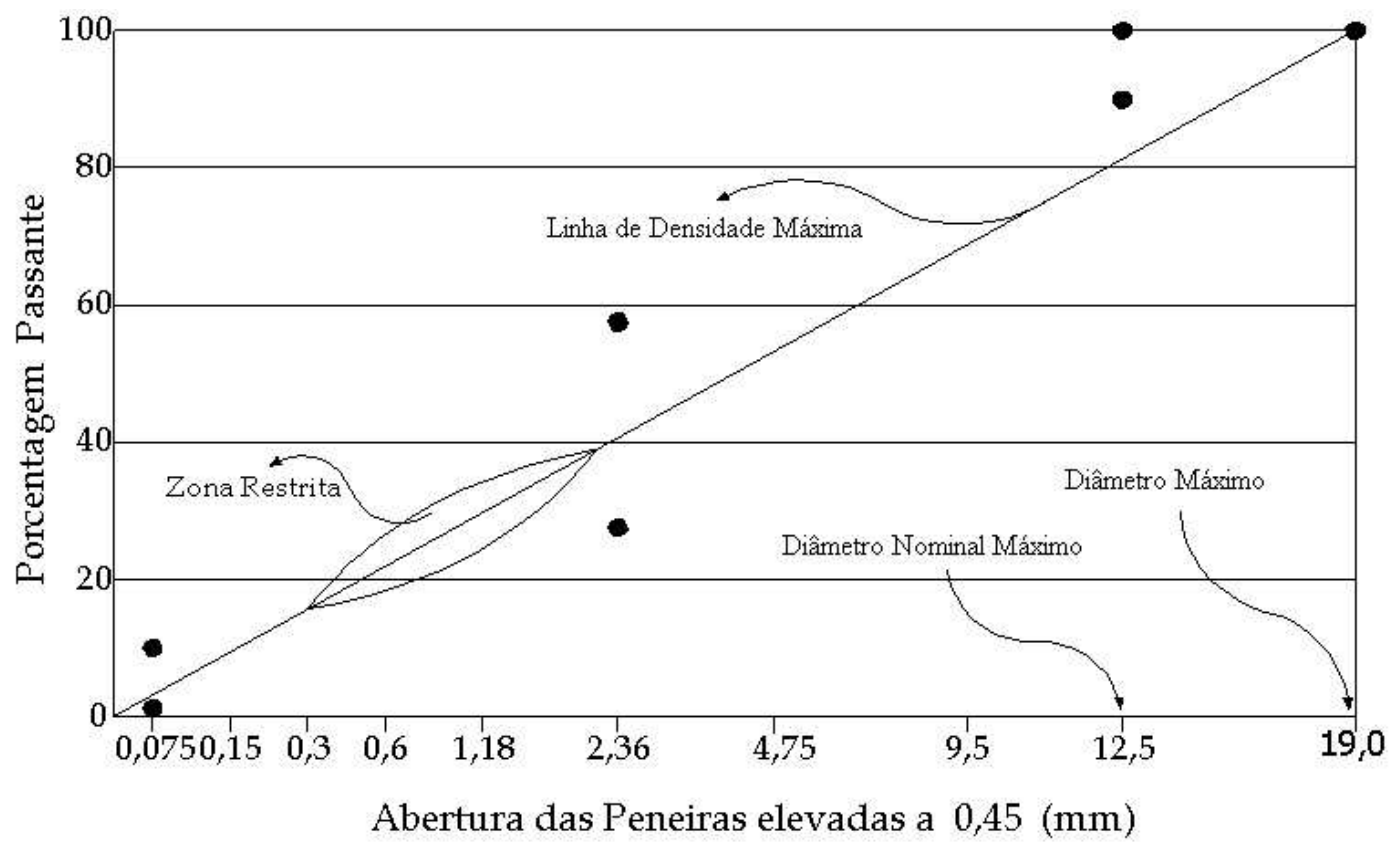

Figura 5.11: Representação gráfica da especificação granulométrica Superpave, para o diâmetro máximo nominal de $12,5 \mathrm{~mm}$

Tabela 5.7: Especificação granulométrica para o diâmetro máximo nominal de $37,5 \mathrm{~mm}$

\begin{tabular}{ccccc}
\hline $\begin{array}{c}\text { Peneiras } \\
(\mathbf{m m})\end{array}$ & \multicolumn{2}{c}{ Pontos de Controle } & \multicolumn{2}{c}{ Limites da Zona de Restrição } \\
Mínimo & Máximo & Mínimo & Máximo \\
\hline 50 & 100 & 100 & - & - \\
37,5 & 90 & 100 & - & - \\
25 & - & - & - & - \\
19 & - & - & - & - \\
12,5 & - & - & - & - \\
9,5 & - & - & - & - \\
4,75 & - & - & 34,7 & 34,7 \\
2,36 & 15 & 41 & 23,3 & 27,3 \\
1,18 & - & - & 15,5 & 21,5 \\
0,6 & - & - & 11,7 & 15,7 \\
0,3 & - & - & 10 & 10 \\
0,15 & - & - & - & - \\
0,075 & 0 & 6 & - & - \\
\hline
\end{tabular}


Tabela 5.8: Especificação granulométrica para o diâmetro máximo nominal de $25 \mathrm{~mm}$

\begin{tabular}{ccccc}
\hline $\begin{array}{c}\text { Peneiras } \\
(\mathbf{m m})\end{array}$ & \multicolumn{2}{c}{ Pontos de Controle } & \multicolumn{2}{c}{ Limites da Zona de Restrição } \\
Mínimo & Máximo & Mínimo & Máximo \\
\hline 37,5 & 100 & 100 & - & - \\
25 & 90 & 100 & - & - \\
19 & - & 90 & - & - \\
12,5 & - & - & - & - \\
9,5 & - & - & - & 39,5 \\
4,75 & - & - & 39,5 & 30,8 \\
2,36 & 19 & 45 & 26,8 & 24,1 \\
1,18 & - & - & 18,1 & 17,6 \\
0,6 & - & - & 13,6 & - \\
0,3 & - & - & 11,4 & - \\
0,15 & - & - & - & - \\
0,075 & 1 & 7 & - & \\
\hline
\end{tabular}

Tabela 5.9: Especificação granulométrica para o diâmetro máximo nominal de $19 \mathrm{~mm}$

\begin{tabular}{ccccc}
\hline $\begin{array}{c}\text { Peneiras } \\
(\mathbf{m m})\end{array}$ & \multicolumn{2}{c}{ Pontos de Controle } & \multicolumn{2}{c}{ Limites da Zona de Restrição } \\
Mínimo & Máximo & Mínimo & Máximo \\
\hline 25 & 100 & 100 & - & - \\
19 & 90 & 100 & - & - \\
12,5 & - & 90 & - & - \\
9,5 & - & - & - & - \\
4,75 & - & - & - & - \\
2,36 & 23 & 49 & 34,6 & 28,3 \\
1,18 & - & - & 22,3 & 20,7 \\
0,6 & - & - & 16,7 & 13,7 \\
0,3 & - & - & 13,7 & - \\
0,15 & - & - & - & - \\
0,075 & 2 & 8 & - & \\
\hline
\end{tabular}


Tabela 5.10: Especificação granulométrica para o diâmetro máximo nominal de 12,5 mm

\begin{tabular}{ccccc}
\hline $\begin{array}{c}\text { Peneiras } \\
(\mathbf{m m})\end{array}$ & \multicolumn{2}{c}{ Pontos de Controle } & \multicolumn{2}{c}{ Limites da Zona de Restrição } \\
Mínimo & Máximo & Mínimo & Máximo \\
\hline 19 & 100 & 100 & - & - \\
12,5 & 90 & 100 & - & - \\
9,5 & - & 90 & - & - \\
4,75 & - & - & - & 39,1 \\
2,36 & 28 & 58 & 39,1 & 31,6 \\
1,18 & - & - & 25,6 & 23,1 \\
0,6 & - & - & 19,1 & 15,5 \\
0,3 & - & - & 15,5 & - \\
0,15 & - & - & - & - \\
0,075 & 2 & 10 & - & \\
\hline
\end{tabular}

Tabela 5.11: Especificação granulométrica para o diâmetro máximo nominal de $9,5 \mathrm{~mm}$

\begin{tabular}{ccccc}
\hline $\begin{array}{c}\text { Peneiras } \\
(\mathbf{m m})\end{array}$ & \multicolumn{2}{c}{ Pontos de Controle } & \multicolumn{2}{c}{ Limites da Zona de Restrição } \\
Mínimo & Máximo & Mínimo & Máximo \\
\hline 12,5 & 100 & 100 & - & - \\
9,5 & 90 & 100 & - & - \\
4,75 & - & 90 & - & 47,2 \\
2,36 & 32 & 67 & 47,2 & 37,6 \\
1,18 & - & - & 31,6 & 27,5 \\
0,6 & - & - & 23,5 & 18,7 \\
0,3 & - & - & 18,7 & - \\
0,15 & - & - & - & - \\
0,075 & 2 & 10 & - & \\
\hline
\end{tabular}

As especificações granulométricas Superpave, parte integrante do procedimento de projeto de misturas Superpave, recomenda, em seu relatório SHRP-A-408 de Cominsky et al. (1994), que se evite granulometrias que passem através da zona de restrição e também que seja dada preferência à utilização de misturas mais grossas (passando abaixo da zona de restrição - BZR) em relação às misturas mais finas (passando Acima da Zona de Restrição - AZR) em pavimentos com alto volume de tráfego.

As razões para a inclusão da zona restrita foi informada no texto original do relatório SHRP-A-410 de Kennedy et al. (1994):

- limitar a inclusão de quantidades elevadas de agregado de areia natural;

- desencorajar o uso de granulometrias que se situem sobre a linha de densidade máxima, que freqüentemente apresentam valores inadequados de VAM.

Pode-se ler em outro trecho desse mesmo relatório: "Deve-se dar preferência ao desenvolvimento de granulometrias que passem abaixo da zona restrita àquelas que passem acima. 
Isso produzirá granulometrias mais grossas e maximizará o desenvolvimento de esqueletos estruturais mais robustos". Porém, não foram encontradas as razões que encorajaram os autores dos relatórios SHRP-A-408 e SHRP-A-410 a estimular o uso de granulometrias que passem abaixo da zona de restrição (BZR).

Apesar dos relatórios do SHRP apresentarem apenas recomendações quanto a evitar que as curvas granulométricas passem através da zona de restrição e que seja dada preferência à utilização de misturas mais grossas (BZR), muitas agências de pavimentação estadunidenses têm rejeitado categoricamente o uso de granulometrias que passem pela zona restrita e têm utilizado quase que exclusivamente misturas BZR. Isso tem causado muitas controvérsias pois, em muitos estados, historicamente têm sido observados pavimentos com bom desempenho que utilizam granulometrias que passam através da zona restrita (Watson et al., 1997).

Essas controvérsias ganharam força após a constatação do desempenho fraco das misturas grossas (BZR) quando comparadas com as finas (AZR) em campo (Hand \& Epps, 2001). Provavelmente, o motivo das agências de pavimentação entenderem essa recomendação como forma de proibição deve-se ao texto produzido pelo Asphalt Institute-Superpave Mix Design ${ }^{8} \mathrm{e}$ Federal Highway Administration-Background of Superpave Asphalt Mixture Design and Analysis ${ }^{9}$ apud Hand \& Epps (2001), os quais foram publicados da seguinte forma: "A zona restrita representa uma área através da qual a granulometria não pode passar".

Recentes pesquisas vêm sendo desenvolvidas especificamente a respeito do impacto da zona restrita sobre o desempenho das misturas asfálticas. Pesquisadores variaram o tipo, a forma e a angularidade dos agregados, o tipo de asfalto e a granulometria das misturas, não observando relação alguma entre curvas que passam acima (AZR), através (TRZ) ou abaixo (BZR) da zona restrita com a deformação permanente, quando utilizados agregados com angularidade do agregado fino (AAF) adequada aos requisitos Superpave. Porém, quando utilizados agregados com AAF abaixo do especificado, mesmo que em pequenas porcentagens, as misturas apresentaram desempenhos piores quanto à deformação permanente comparadas às demais, independentemente da localização da curva em relação à zona restrita (Kandhal \& Cooley Jr., 2001; Chowdhury et al., 2001; Mallick et al., 1998; Anderson \& Bahia, 1997; McGennis, 1997; Sebaaly et al., 1997; Roberts et al., 1991). Esses resultados são bastante esclarecedores, pois mostram que passar ou não pela zona restrita não interfere no desempenho das misturas e ressaltam a importância da angularidade dos agregados finos como critério a ser respeitado para projetar misturas com bom desempenho.

\footnotetext{
${ }^{8}$ Superpave Mix Design Manual Series SP-2 (1996). Asphalt Institute, Lexington, Kentucky.

${ }^{9}$ Background of Superpave Asphalt Mixture Design and Analysis FHWA-SA-95-003 (1995). Federal Highway Administration, U. S. Department of Transportation, Washington, D.C.
} 
A recomendação Superpave de dar preferência a curvas granulométricas mais grossas com o objetivo de desenvolver esqueletos estruturais mais resistentes, também têm levantado controvérsias e estimulado muitas pesquisas sobre o assunto. Essa recomendação reavivou o velho ideal de encontrar a granulometria perfeita. Então, pesquisas se sucederam procurando descobrir qual seria o melhor arranjo granulométrico, aquele com misturas mais finas (AZR) e (TZR), ou então aquele com misturas grossas (BZR). Um vasto levantamento bibliográfico foi realizado sobre o assunto, através de trabalhos investigativos que levaram em conta uma variedade grande de tipos de agregados com diferentes características de superfície e físicas, diâmetros máximos nominais e granulometrias, além de uma variedade grande de ferramentas de análise de desempenho das misturas. Todos os artigos pesquisados indicaram claramente que granulometrias mais finas (AZR e TZR) podem produzir misturas com desempenho bom $\mathrm{e}$, a maioria desses artigos mostraram que as granulometrias AZR e TZR produzem misturas com desempenho melhor que granulometrias BZR (Prowell et al., 2005; Kandhal \& Cooley Jr., 2001; Chowdhury et al., 2001; Hand et al., 2001; Mallick et al., 1998; Anderson \& Bahia, 1997; McGennis, 1997; Sebaaly et al., 1997). Em resumo, as pesquisas consultadas mostram claramente que não existe relação entre a zona restrita e o desempenho das misturas quanto à deformação permanente e à fadiga, tampouco foi verificada a superioridade de desempenho de misturas com granulometria BZR.

Como resposta a todas essas pesquisas e ao forte apelo da comunidade científica, a zona de restrição foi retirada da publicação mais atual das especificações Superpave (AASHTO M 323). Contudo, apesar da forte indicação de que granulometrias grossas ou finas podem igualmente produzir misturas com desempenho adequado, resultados estes corroborados com os publicados no relatório de 2000 do National Center for Asphalt Technology (Prowell et al., 2005), ainda nada foi divulgado a esse respeito.

\subsection{Experimentos Laboratoriais}

\subsubsection{Seleções Granulométricas}

Três tipos de granulometrias foram estudadas nesta pesquisa, uma AZR determinada através dos procedimentos Superpave e duas Bailey, determinadas utilizando o sistema de seleção granulométrica Bailey.

Os agregados foram previamente secos em estufa, por um período mínimo de 12 horas, e deixados esfriar, em temperatura ambiente, por mais 12 horas. Não foi promovida a lavagem de 
nenhum dos agregados estudados pois isso anularia o efeito dos finos plásticos, quantificados através do ensaio de equivalente de areia, cuja propriedade é avaliada nesta pesquisa. Além disso, provavelmente em campo, esses agregados não seriam submetidos à lavagem por terem apresentado valores de equivalente de areia dentro dos limites aceitáveis para utilização em misturas de concreto asfáltico.

Os materiais foram peneirados manualmente e fracionados utilizando peneiras de abertura de 19,$00 ; 12,50 ; 9,50 ; 4,75 ; 2,36 ; 1,18 ; 0,60 ; 0,30 ; 0,15 ; 0,075 \mathrm{~mm}$, remisturados de acordo com as três curvas granulométricas adotadas e colocados em pequenos sacos plásticos, compondo a quantidade de material necessária para a confecção de um corpo-de-prova.

A curva granulométrica AZR, utilizada nesta pesquisa para a confecção de misturas asfálticas compostas por agregados de gabro (AZRg), basalto (AZRb) e areia natural (AZRa), passa acima da zona de restrição e, quase totalmente, acima da linha de densidade máxima, respeitando os pontos de controle. A granulometria AZR estudada está apresentada na Tabela 5.12 e pode ser visualizada na Figura 5.12.

Tabela 5.12: Curva granulométrica AZR

\begin{tabular}{cc}
\hline Peneiras $(\mathbf{m m})$ & Porcentagem Passante \\
\hline 19,00 & 100 \\
12,50 & 95 \\
9,50 & 86 \\
4,75 & 61 \\
2,36 & 45 \\
1,18 & 35 \\
0,60 & 26 \\
0,30 & 19 \\
0,15 & 11 \\
0,075 & 3,5 \\
\hline
\end{tabular}

Utilizando o método Bailey de seleção granulométrica, foram determinadas mais duas curvas distintas, uma para cada tipo de material (basalto e gabro), apresentadas na Tabela 5.13. A curva Bailey determinada para o agregado de basalto $(\mathrm{Bb})$ passa, em sua fração grossa, acima da linha de densidade máxima e, em sua fração fina, abaixo da linha de densidade máxima, respeitando os pontos de controle e a zona de restrição (Figura 5.13). Já a curva Bailey determinada para o agregado de gabro (Bg) inicia-se acima da linha de densidade máxima, cruza a zona de restrição e termina abaixo da linha de densidade máxima, sempre respeitando os pontos de controle (Figura 5.14). Na Figura 5.15, estão apresentadas as três curvas granulométricas estudadas nesta pesquisa. 


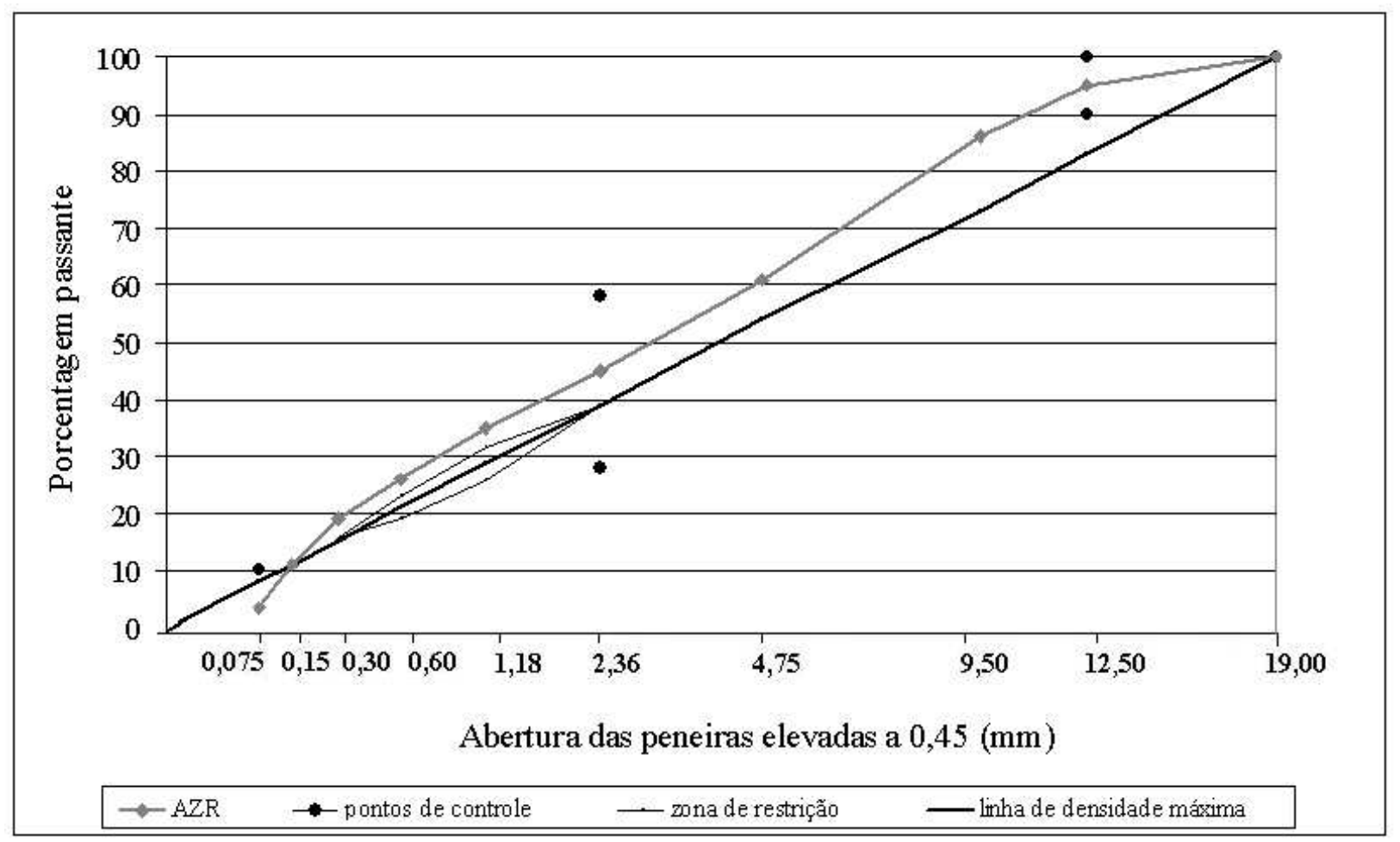

Figura 5.12: Curva granulométrica AZR utilizada na composição de misturas asfálticas com agregados de gabro (AZRg), basalto (AZRb) e areia natural (AZRa)

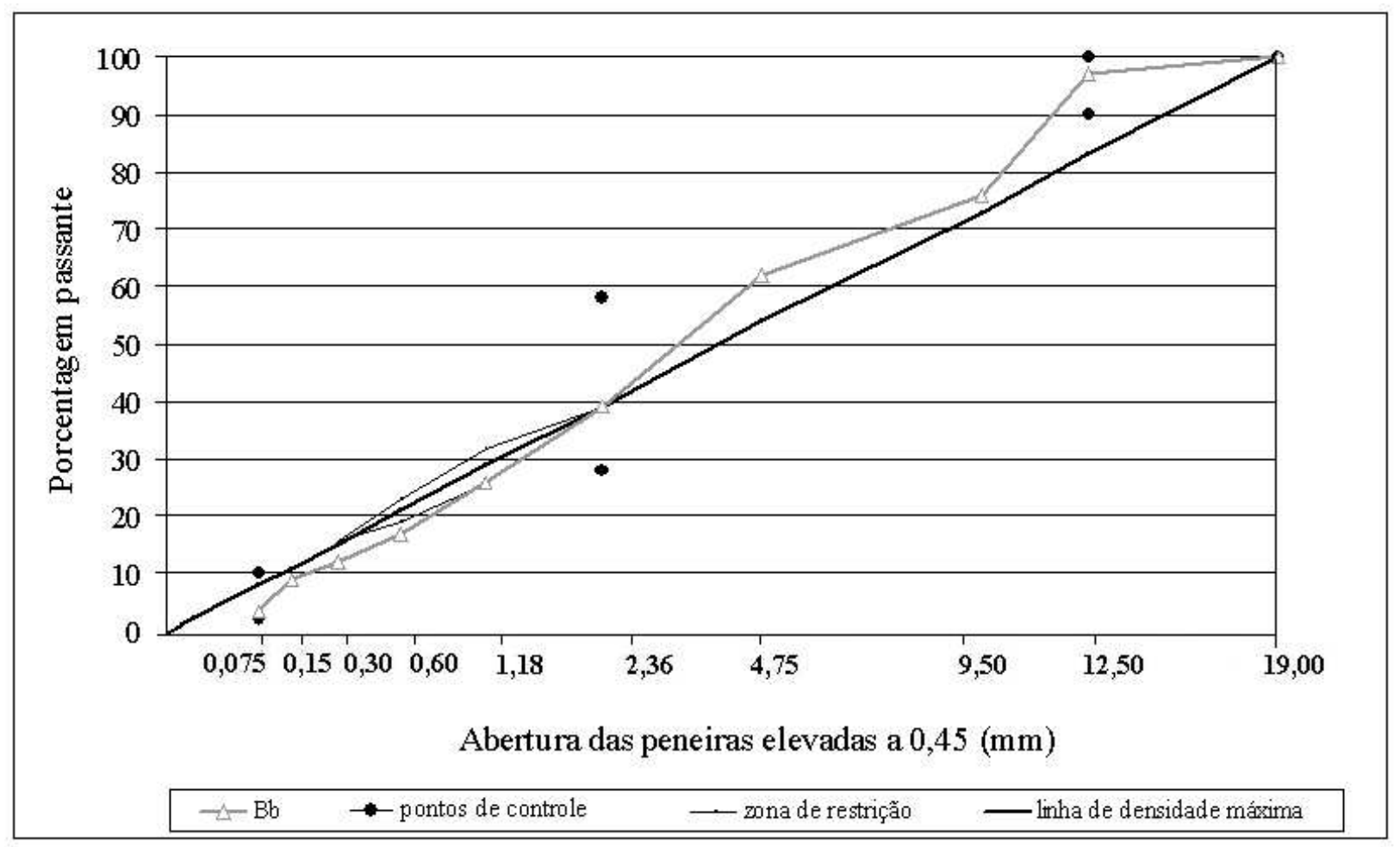

Figura 5.13: Curva granulométrica Bailey para agregado de basalto (Bb) 


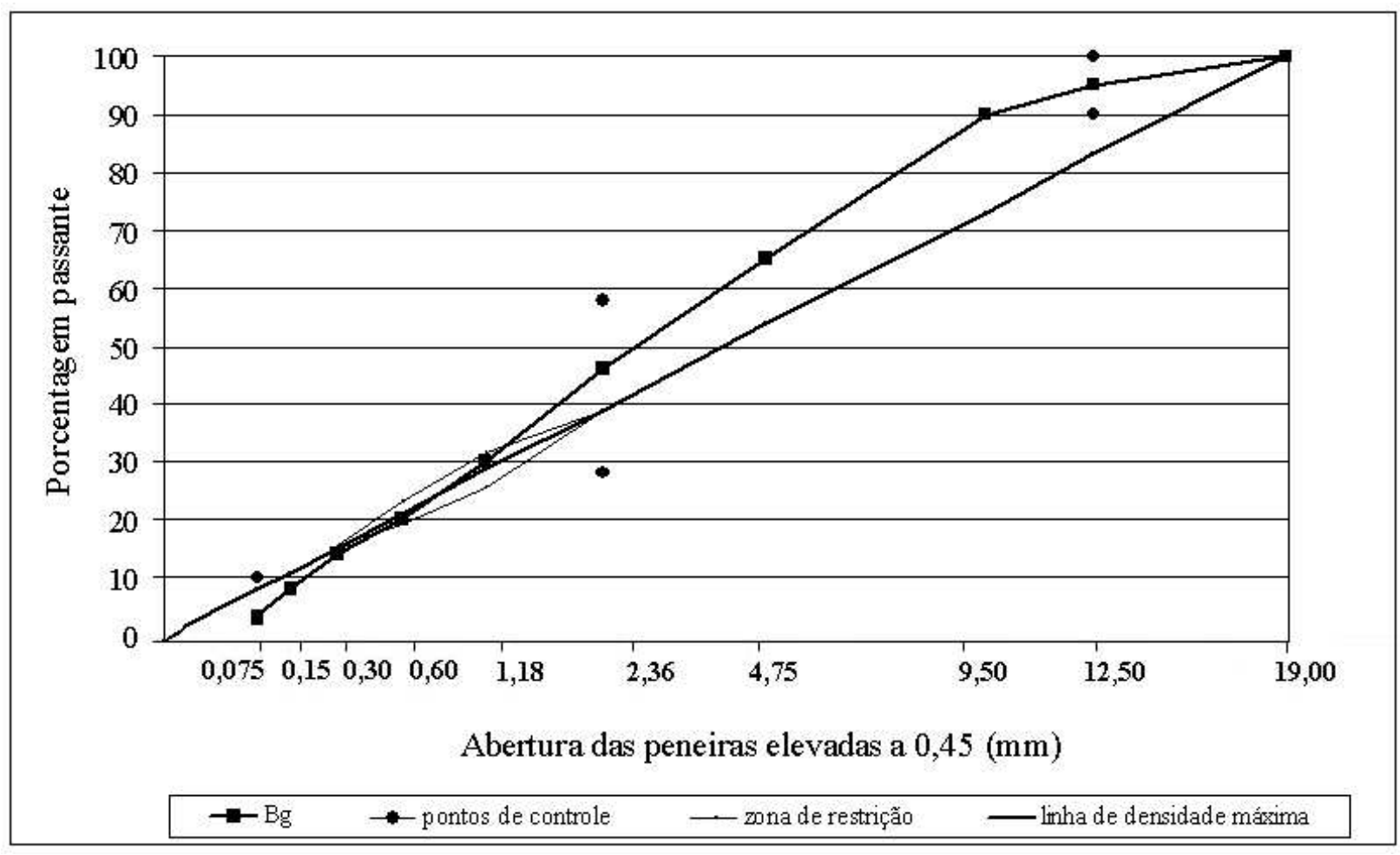

Figura 5.14: Curva granulométrica Bailey para agregado de gabro $(\mathrm{Bg})$

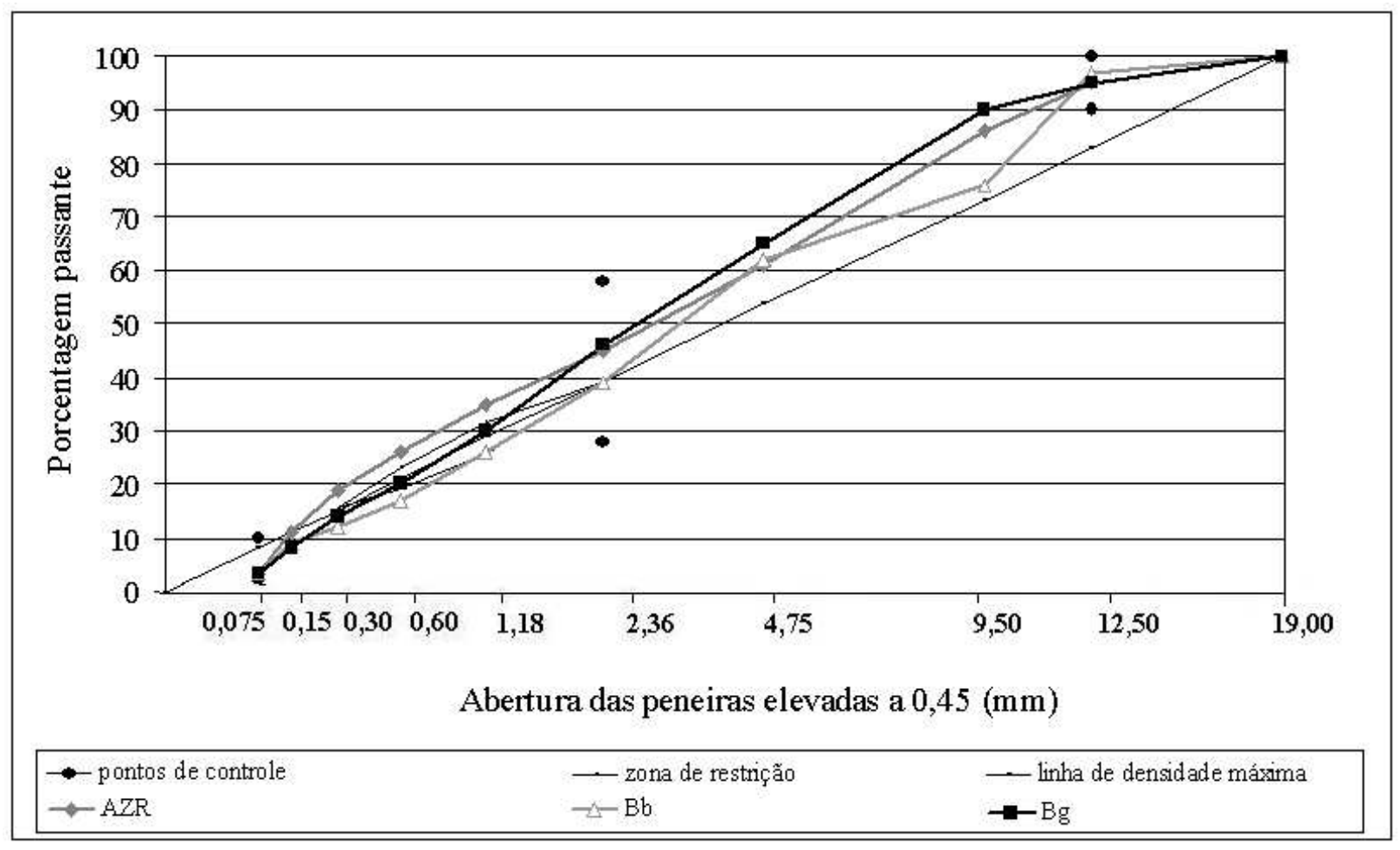

Figura 5.15: Curvas granulométricas utilizadas nesta pesquisa 
Tabela 5.13: Curvas granulométricas Bailey

\begin{tabular}{|c|c|c|}
\hline \multirow{2}{*}{$\begin{array}{c}\text { Peneiras } \\
(\mathbf{m m})\end{array}$} & \multicolumn{2}{|c|}{ Porcentagem Passante } \\
\hline & Basalto & Gabro \\
\hline 19,00 & 100 & 100 \\
\hline 12,50 & 97 & 95 \\
\hline 9,50 & 76 & 90 \\
\hline 4,75 & 62 & 65 \\
\hline 2,36 & 39 & 46 \\
\hline 1,18 & 26 & 30 \\
\hline 0,60 & 17 & 20 \\
\hline 0,30 & 12 & 14 \\
\hline 0,15 & 9 & 8 \\
\hline 0,075 & 3,5 & 3,5 \\
\hline
\end{tabular}

Tanto as misturas AZR quanto as Bailey, além de terem controladas as porcentagens passantes na peneira de abertura de $0,075 \mathrm{~mm}$ em 3,5\%, apenas um tipo de fíler, pó de areia natural, foi utilizado. O propósito do uso do pó de areia natural como fíler é eliminar a variação de propriedades decorrentes da utilização de fíleres distintos e em quantidades diferentes. Tayebali et al. (1998) concluíram em suas pesquisas sobre o efeito do tipo e da quantidade de fíler mineral em misturas asfálticas dosadas utilizando o método Marshall, que o desempenho de duas misturas de agregados distintos é bastante próximo quando são utilizadas quantidades de fíler baixas (em torno de $4 \%$ ).

Não foram produzidas misturas Bailey com areia natural, pois, além do material não atender aos requisitos de caracterização de agregados Superpave e apresentar propriedades volumétricas das misturas em desacordo com os requisitos volumétricos especificados pelo Superpave, houve a impossibilidade de composição da fração fina do agregado com base no método Bailey, pois o material proveniente da mineradora Jundu foi fornecido previamente peneirado e ensacado, o que inviabilizou o levantamento da curva granulométrica das frações do agregado que chegam da pedreira, que é um requisito de entrada do método.

\subsubsection{Massas Específicas dos Agregados}

Pode-se definir como massa específica solta do agregado a massa de agregados necessária para preencher um cilindro de volume conhecido, sem que haja qualquer forma de compactação da amostra. Essa forma de determinação representa um contato mínimo entre as partículas de agregado. 
A massa específica solta é obtida ao verter uma amostra dentro de um cilindro de volume conhecido, até preenchê-lo completamente. A altura de queda da amostra não deve ser superior a $5 \mathrm{~cm}$ do topo do cilindro. Cuidados devem ser tomados para prevenir, tanto quanto possível, a segregação das partículas que compõem a amostra. O diâmetro do cilindro deve ter no mínimo 10 vezes o diâmetro máximo nominal, para minimizar o efeito da parede do cilindro no arranjo entre as partículas (Vavrik et al., 2001). Então, a massa específica solta do agregado pode ser determinada através da razão entre a massa de agregados soltos contidos no cilindro pelo volume do cilindro, considerando a média de três determinações.

Pode-se definir como massa específica compactada do agregado a massa de agregados necessária para preencher um cilindro de volume conhecido, quando sofre a ação de compactação, de maneira a aumentar o contato entre as partículas. A determinação da massa específica compactada consiste em preencher, com o auxílio de uma pá, $1 / 3$ do cilindro com a amostra, despejando-a de uma altura máxima de $5 \mathrm{~cm}$ em relação ao topo do cilindro e, em seguida, compactar essa primeira camada com 25 golpes de um soquete de ferro com $16 \mathrm{~mm}$ de diâmetro e $600 \mathrm{~mm}$ de comprimento. Após, procede-se a colocação da segunda camada, preenchendo $2 / 3$ do volume do cilindro e desferindo mais 25 golpes do soquete. Na terceira camada, após a compactação com mais 25 golpes, retira-se o material em excesso, através do arrasamento da amostra. A massa específica compactada do agregado pode então ser determinada através da razão entre a massa de agregado compactada contida no cilindro pelo volume do cilindro, correspondente à média de três determinações.

A determinação da massa específica deve ser realizada para cada fração do agregado recebido da pedreira, por exemplo, pedra 1, pedrisco e pó. De acordo com o método Bailey, deve-se determinar a massa específica compactada para as frações grossas e finas dos agregados e a massa específica solta apenas para as frações grossas do agregado. O procedimento de determinação das massas específicas dos agregados, aqui descrito, está baseado nas normas AASHTO T 19 e ASTM C 29.

\subsubsection{Execução dos Corpos-de-Prova Marshall}

Através das dosagens Marshall foram produzidas misturas AZR com agregados de gabro, de basalto e de areia natural e misturas Bailey com agregados de gabro e de basalto, dentro dos critérios volumétricos Superpave. As misturas de agregados foram compostas, em suas frações grossa e fina, por apenas um tipo de agregado (gabro, basalto ou areia natural) e, como fíler, pó de areia natural. 
A temperatura de aquecimento do asfalto CAP 20 utilizado foi de $160^{\circ} \mathrm{C}$, correspondente a uma viscosidade Saybolt-Furol de 85 segundos, determinada a partir da curva de viscosidade versus temperatura do material, ilustrada na Figura 5.16. Já o agregado foi aquecido a $175^{\circ} \mathrm{C}$, ou seja, $15^{\circ} \mathrm{C}$ acima da temperatura do asfalto, como estabelece a norma NBR 12891.

A temperatura de compactação da mistura foi mantida a $146^{\circ} \mathrm{C}$, correspondente a uma viscosidade Saybolt-Furol de 130 segundos. Essa temperatura encontra-se dentro da faixa limite especificada para a temperatura de compactação, na qual o ligante deve apresentar uma viscosidade Saybolt-Furol de $140 \pm 15$ segundos (Figura 5.16).

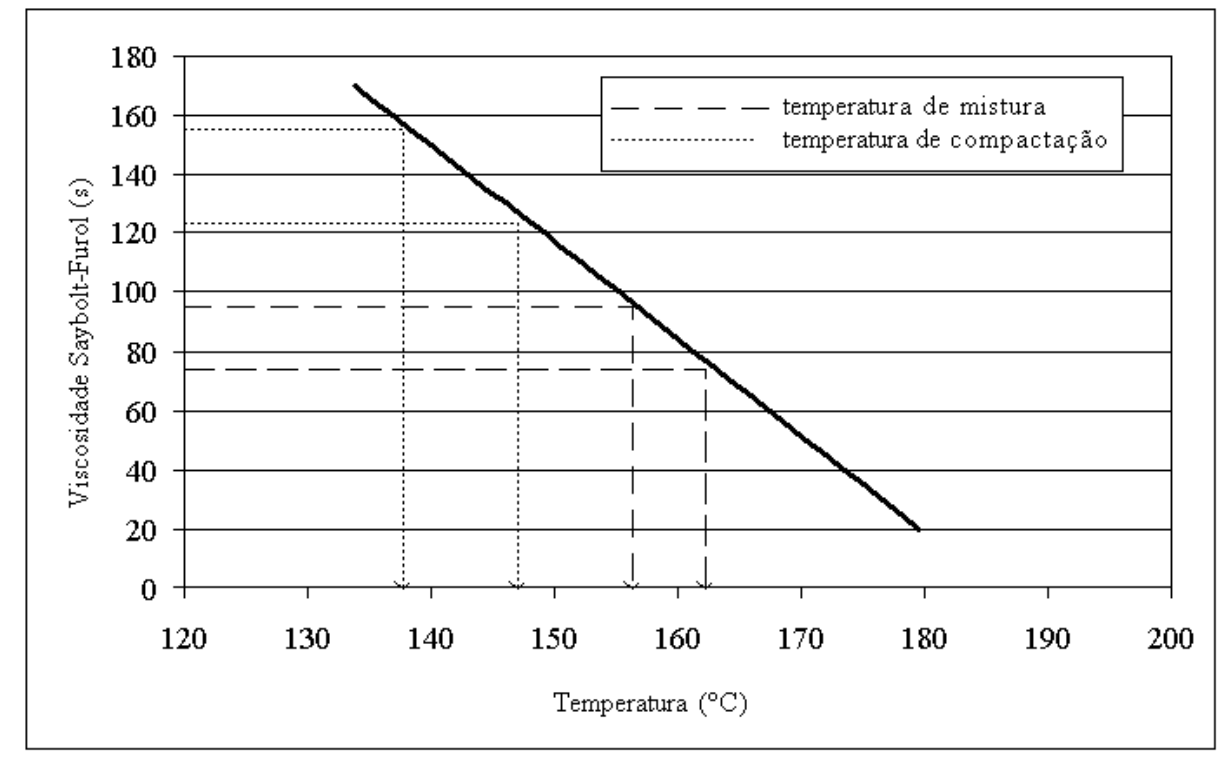

Figura 5.16: Curva de viscosidade Saybolt-Furol versus temperatura do asfalto

Para maior controle das temperaturas de aquecimento, tanto do asfalto como do agregado, foi utilizado um termômetro digital com haste, ilustrado na Figura 5.17(a). A temperatura de compactação das misturas foi controlada através de um termômetro a laser, que possibilita leituras rápidas (Figura 5.17(b)).

Após o processo de mistura do agregado com o asfalto, realizado individualmente na confecção de cada corpo-de-prova, a massa asfáltica resultante de cada mistura foi colocada em uma vasilha de alumínio e levada à estufa, onde permaneceu por 2 horas na temperatura de compactação, conforme estabelece a norma AASHTO PP2. Horan (2001), pesquisador do Asphalt Institute, denomina esse período de permanência da mistura em estufa, na temperatura de compactação, antes da compactação, de tempo de cura em laboratório. Maiores detalhes sobre o tempo de cura em laboratório pode ser encontrado no item 5.6 deste capítulo. 


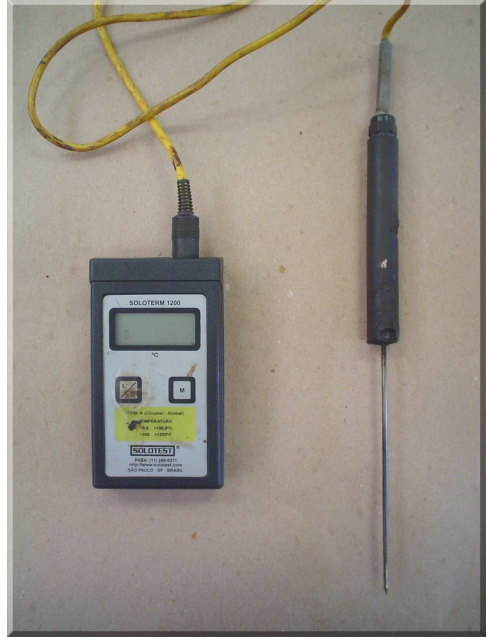

(a) Termômetro digital com haste

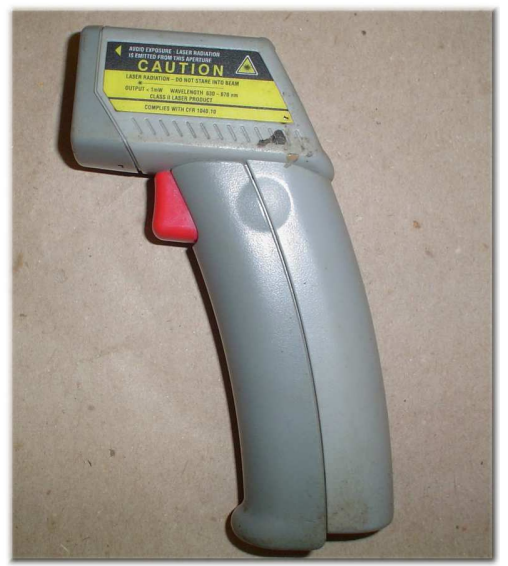

(b) Termômetro digital a laser

Figura 5.17: Termômetros usados, nesta pesquisa, para controle da temperatura

Passadas as 2 horas de cura, iniciou-se a compactação dos corpos-de-prova com energia de 75 golpes por face, a qual é recomendada para pressões de enchimento de pneu entre 0,7 e 1,4 MPa. A Figura 5.18 ilustra o equipamento empregado para a compactação dos corpos-de-prova Marshall.

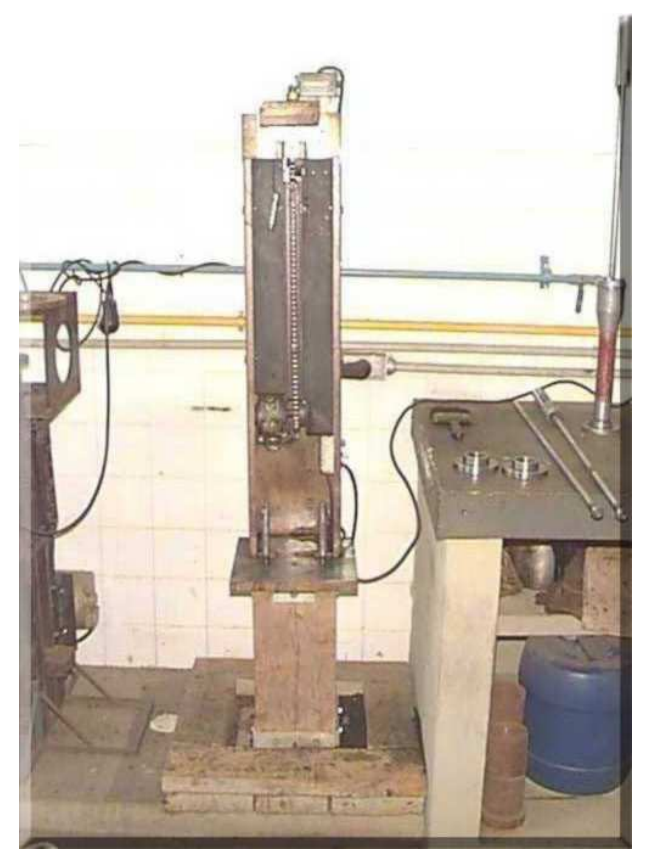

Figura 5.18: Compactador Marshall usado nesta pesquisa

Após a compactação, os corpos-de-prova permaneceram em seus moldes metálicos cilíndricos em temperatura ambiente, durante cerca de 3 horas. Nesse período, ocorre o resfriamento da mistura e esta passa a ter consistência suficiente para evitar a deformação dos corpos-de-prova, no momento de sua extração dos moldes metálicos. 
Terminada a extração, os corpos-de-prova foram deixados em temperatura ambiente, por no mínimo 12 horas, para, após esse período, ser determinada a densidade aparente da mistura utilizando o método de secagem superficial dos corpos-de-prova (AASHTO T 166).

\subsection{Resultados e Análises dos Resultados}

\subsubsection{Dosagens das Misturas Asfálticas AZR}

Os resultados das dosagens das misturas AZR com agregado de gabro, basalto e areia natural estão apresentados nas Tabelas 5.14, 5.15 e 5.16, respectivamente. Nessas tabelas, constam a porcentagem de asfalto adicionada à mistura $(\mathrm{Pb})$, absorção de água pelo corpo-de-prova após permanência de 2 minutos submerso $\left(\% A b_{c p}\right)$, a densidade aparente $(d)$, a densidade máxima medida (DMM), o volume de vazios (Vv), os vazios do agregado mineral (VAM), a relação betume-vazios (RBV) e a estabilidade $(E)$ e fluência $(F)$ Marshall.

Na Tabela 5.17, encontra-se o resumo dos cálculos necessários para a elaboração do diagrama de componentes das misturas AZR produzidas com agregados de gabro, basalto e areia natural, obtendo-se as propriedades volumétricas, a porcentagem de asfalto absorvido pelo agregado, a porcentagem de asfalto efetivo na mistura e a espessura do filme de asfalto que cobre o agregado. A Figura 5.19 apresenta a representação gráfica das propriedades volumétricas das misturas AZR obtidas nas dosagens.

Tabela 5.14: Dosagem Marshall - mistura AZR - gabro

\begin{tabular}{lcccccccc}
\hline $\boldsymbol{P b}$ & $\mathbf{\%} \boldsymbol{A b} \boldsymbol{c p}$ & $\boldsymbol{d}$ & $\boldsymbol{D M M}$ & $\begin{array}{c}\boldsymbol{V} \boldsymbol{v} \\
(\%)\end{array}$ & $\begin{array}{c}\boldsymbol{V A M} \boldsymbol{M} \\
(\%)\end{array}$ & $\begin{array}{c}\boldsymbol{R B} \boldsymbol{V} \\
(\%)\end{array}$ & $\begin{array}{c}\boldsymbol{E} \\
(N)\end{array}$ & $\begin{array}{c}\boldsymbol{F} \\
(0,1 \mathrm{~mm})\end{array}$ \\
\hline 5,2 & 0,45 & 2,387 & 2,573 & 7,2 & 17,3 & 58,3 & 16.299 & 36 \\
\hline 5,7 & 0,31 & 2,396 & 2,553 & 6,2 & 17,5 & 64,8 & 16.838 & 39 \\
\hline 6,2 & 0,10 & 2,423 & 2,533 & 4,3 & 17,0 & 74,5 & 17.583 & 42 \\
\hline 6,7 & 0,07 & 2,444 & 2,513 & 2,8 & 16,7 & 83,5 & 16.848 & 47 \\
\hline 7,2 & 0,04 & 2,440 & 2,493 & 2,2 & 17,3 & 87,5 & 15.249 & 49 \\
\hline
\end{tabular}

Tabela 5.15: Dosagem Marshall - mistura AZR - basalto

\begin{tabular}{llccccccc}
\hline $\boldsymbol{P b}$ & $\boldsymbol{\%}_{\boldsymbol{A b}} \boldsymbol{c p}$ & $\boldsymbol{d}$ & $\boldsymbol{D M M}$ & $\begin{array}{c}\boldsymbol{V} \boldsymbol{v} \\
(\%)\end{array}$ & $\begin{array}{c}\boldsymbol{V A M} \\
(\%)\end{array}$ & $\begin{array}{c}\boldsymbol{R B V} \\
(\%)\end{array}$ & $\begin{array}{c}\boldsymbol{E} \\
(N)\end{array}$ & $\begin{array}{c}\boldsymbol{F} \\
(0,1 \mathrm{~mm})\end{array}$ \\
\hline 5,2 & 0,49 & 2,400 & 2,631 & 8,8 & 20,5 & 57,3 & 11.010 & 36 \\
\hline 5,7 & 0,14 & 2,424 & 2,609 & 7,1 & 20,2 & 64,9 & 11.219 & 39 \\
\hline 6,2 & 0,10 & 2,445 & 2,588 & 5,5 & 19,9 & 72,3 & 11.915 & 42 \\
\hline 6,7 & 0,06 & 2,467 & 2,567 & 3,9 & 19,6 & 80,3 & 12.837 & 44 \\
\hline 7,2 & 0,03 & 2,470 & 2,546 & 3,0 & 19,9 & 85,0 & 12.209 & 49 \\
\hline
\end{tabular}


Tabela 5.16: Dosagem Marshall - mistura AZR - areia natural

\begin{tabular}{lcccccccc}
\hline $\boldsymbol{P b}$ & $\boldsymbol{\% A B}_{\boldsymbol{c p}}$ & $\boldsymbol{d}$ & $\boldsymbol{D M M}$ & $\begin{array}{c}\boldsymbol{V} \boldsymbol{v} \\
(\%)\end{array}$ & $\begin{array}{c}\boldsymbol{V} \boldsymbol{A M} \\
(\%)\end{array}$ & $\begin{array}{c}\boldsymbol{R B V} \\
(\%)\end{array}$ & $\begin{array}{c}\boldsymbol{E} \\
(N)\end{array}$ & $\begin{array}{c}\boldsymbol{F} \\
(0,1 \mathrm{~mm})\end{array}$ \\
\hline 3,4 & 0,16 & 2,371 & 2,483 & 4,5 & 12,3 & 63,4 & 9.463 & 24 \\
\hline 3,9 & 0,09 & 2,393 & 2,464 & 2,9 & 12,0 & 75,7 & 9.581 & 27 \\
\hline 4,4 & 0,06 & 2,410 & 2,446 & 1,5 & 11,8 & 87,4 & 9.071 & 28 \\
\hline 4,9 & 0,04 & 2,419 & 2,429 & 0,4 & 11,9 & 96,8 & 8.140 & 29 \\
\hline 5,4 & 0,02 & 2,410 & 2,411 & 0,03 & 12,7 & 99,8 & 6.443 & 30 \\
\hline
\end{tabular}

Tabela 5.17: Propriedades das misturas AZR

\begin{tabular}{|c|c|c|c|c|c|}
\hline Propriedades & & Gabro & Basalto & Areia Natural & \\
\hline Volume Total & $(V t)$ & 1 & 1 & 1 & $\mathrm{~cm}^{3}$ \\
\hline Densidade Aparente da Mistura & $(d)$ & 2,423 & 2,467 & 2,371 & \\
\hline Densidade do Asfalto & $\left(\rho_{b}\right)$ & 1,02 & 1,02 & 1,02 & \\
\hline Porcentagem de Asfalto & $(\mathrm{Pb})$ & 6,2 & 6,7 & 3,4 & $\%$ \\
\hline Densidade Aparente do Agregado & $\left(\rho_{a p}\right)$ & 2,742 & 2,860 & 2,612 & \\
\hline Densidade Efetiva do Agregado & $\left(\rho_{e f}\right)$ & 2,808 & 2,880 & 2,615 & \\
\hline Porcentagem do Fíler & $(\% F)$ & 3,5 & 3,5 & 3,5 & $\%$ \\
\hline Área Superficial do Agregado & $(A S)$ & 7,66 & 7,66 & 7,66 & $m^{2} / k g$ \\
\hline Massa Total da Mistura & $(M t)$ & 2,423 & 2,467 & 2,371 & $g$ \\
\hline Massa do Asfalto & $(M b)$ & 0,150 & 0,165 & 0,081 & $g$ \\
\hline Massa do Agregado & $(M a)$ & 2,273 & 2,302 & 2,290 & $g$ \\
\hline Volume Efetivo do Agregado & $\left(V_{e f}\right)$ & 0,809 & 0,799 & 0,876 & $\mathrm{~cm}^{3}$ \\
\hline Volume Aparente do Agregado & $\left(V_{a p}\right)$ & 0,830 & 0,805 & 0,877 & $\mathrm{~cm}^{3}$ \\
\hline Volume do Asfalto & $(V b)$ & 0,147 & 0,162 & 0,079 & $\mathrm{~cm}^{3}$ \\
\hline Volume do Asfalto Absorvido & $\left(V b_{a b s}\right)$ & 0,021 & 0,006 & 0,001 & $\mathrm{~cm}^{3}$ \\
\hline Volume do Asfalto Efetivo & $\left(V b_{e f}\right)$ & 0,127 & 0,156 & 0,078 & $\mathrm{~cm}^{3}$ \\
\hline Volume de Ar & $\left(V_{a r}\right)$ & 0,043 & 0,039 & 0,045 & $\mathrm{~cm}^{3}$ \\
\hline Massa do Asfalto Efetivo & $\left(M b_{e f}\right)$ & 0,129 & 0,159 & 0,080 & $g$ \\
\hline Massa do Asfalto Absorvido & $\left(M b_{a b s}\right)$ & 0,021 & 0,006 & 0,001 & $g$ \\
\hline Porcentagem de Volume de Vazios & $(V v)$ & 4,3 & 3,9 & 4,5 & $\%$ \\
\hline Vazios do Agregado Mineral & $(V A M)$ & 17,0 & 19,5 & 12,3 & $\%$ \\
\hline Relação Betume Vazios & $(R B V)$ & 74,5 & 80,2 & 63,4 & $\%$ \\
\hline Asfalto Efetivo & $\left(P b_{e f}\right)$ & 5,3 & 6,5 & 3,4 & $\%$ \\
\hline Asfalto Absorvido & $\left(A_{a b s}\right)$ & 0,9 & 0,3 & 0,04 & $\%$ \\
\hline Densidade Máxima Medida & $(D M M)$ & 2,533 & 2,567 & 2,483 & \\
\hline Espessura do Filme de Asfalto & $\left(E f_{b}\right)$ & 7,3 & 8,9 & 4,5 & $\mu m$ \\
\hline
\end{tabular}




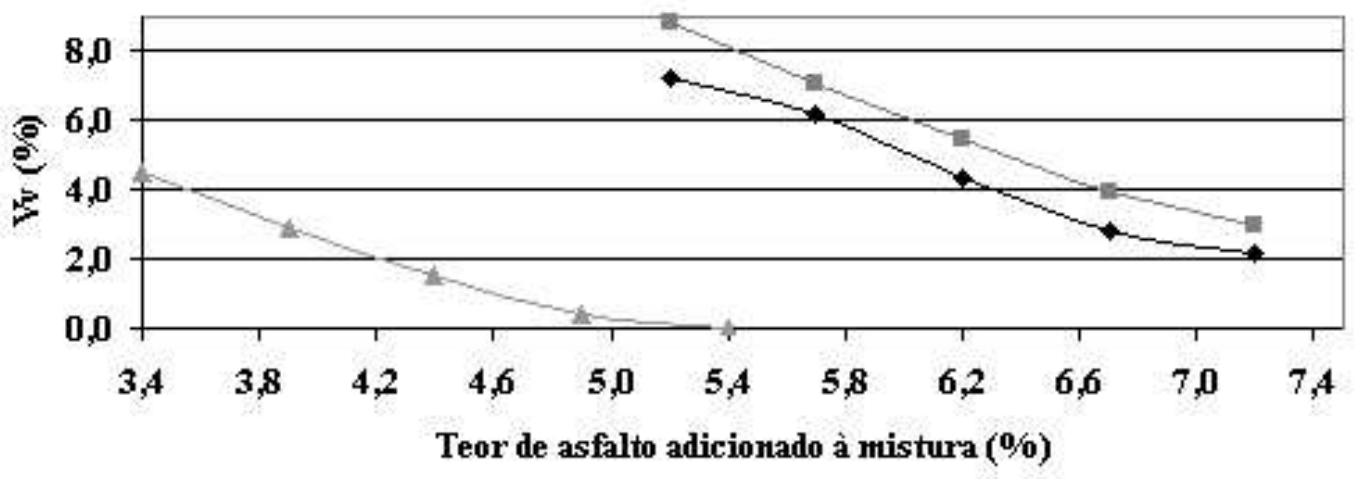

$$
\rightarrow \text { AZRg } \rightarrow-A Z R b \rightarrow A Z R a
$$
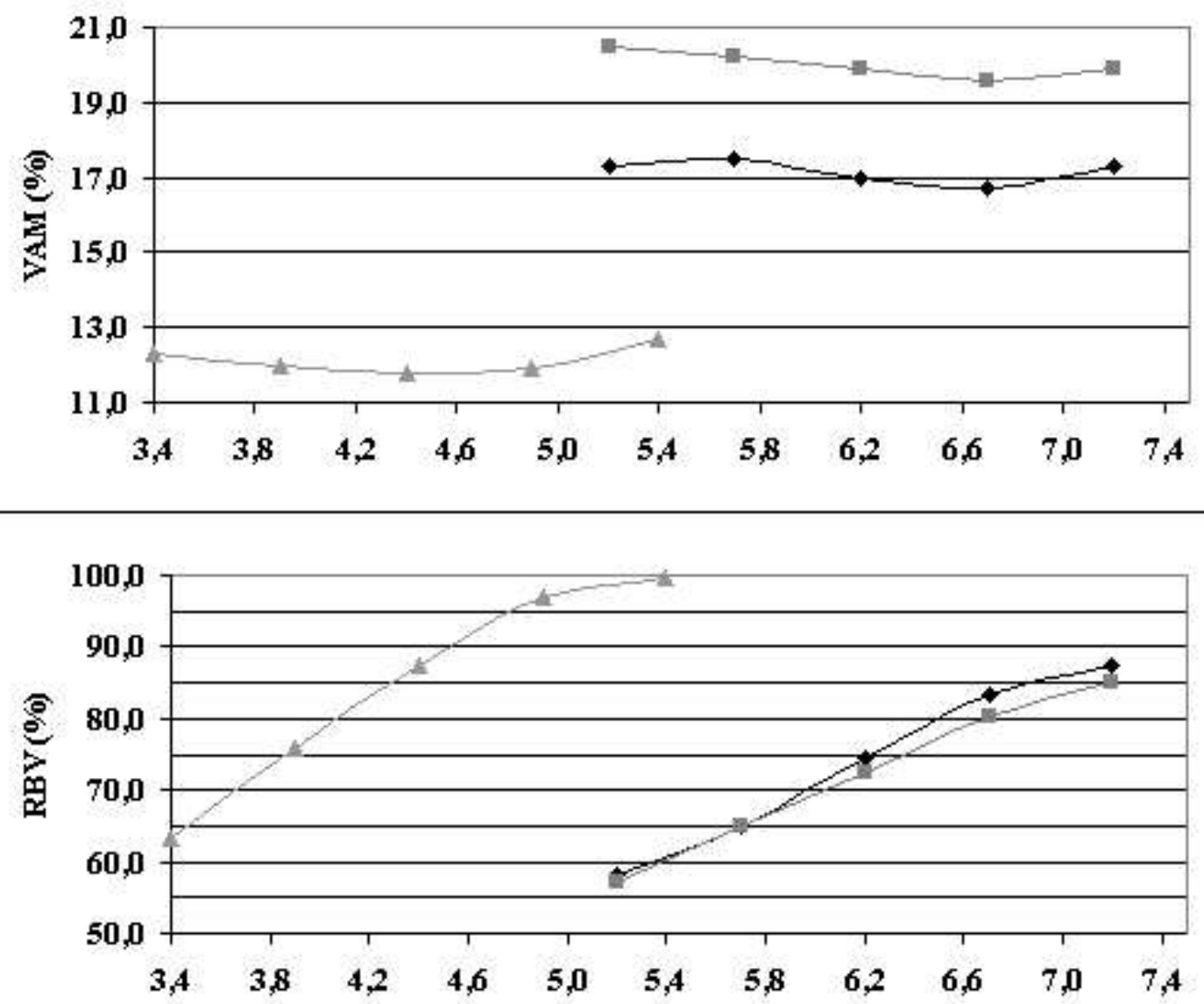

Figura 5.19: Propriedades volumétricas obtidas na dosagem das misturas AZRg, AZRb e AZRa compactadas com 75 golpes por face 
Com base nos resultados das dosagens das misturas AZR, pode-se perceber que o maior teor de asfalto de projeto é o da mistura AZR basalto (AZRb) com 6,7\%, seguido da mistura AZR gabro (AZRg) com 6, 2\% e da mistura AZR areia natural (AZRa) com 3, 4\%. Lembrando que o agregado de gabro absorve cerca de $0,9 \%$ de asfalto, portanto, a análise correta deve ser feita considerando o teor de asfalto efetivo das misturas, que é de 6,5\% para a mistura AZRb, 5, 3\% para a mistura AZRg e 3,4\% para a AZRa, sempre para um volume de vazios de aproximadamente $4 \%$ (Tabela 5.17). Considerando que essas misturas têm a mesma granulometria, poder-se-ia imaginar que os valores do teor de asfalto de projeto das três misturas fossem próximos. Porém, foram observados teores bem diferentes entre as misturas, por exemplo, a mistura AZRb apresentou teor de asfalto de projeto cerca de 1,2\% mais elevado que o teor de projeto obtido para a mistura AZRg e aproximadamente $3 \%$ maior que o teor de projeto da mistura AZRa. Esse fato evidencia a influência direta das características de superfície do agregado de basalto no VAM e, conseqüentemente, no teor de asfalto de projeto, pois, quando o valor do VAM é alto, o teor de asfalto adicionado à mistura também é alto, para satisfazer a condição de Vv em torno de $4 \%$. Analisando esse aspecto, fica clara a influência das propriedades de forma, de angularidade e de textura superficial das partículas de cada agregado no arranjo entre partículas e, conseqüentemente, nas propriedades volumétricas das misturas, particularmente no VAM.

A areia natural, que apresenta forma arredondada, porcentagem baixa de partículas fraturadas, AAF baixo $(40,7)$ e textura superficial lisa, apresenta um arranjo entre partículas bastante próximo, levando a VAM baixos $(12,3 \%)$ e, conseqüentemente, impedindo que uma quantidade suficiente de asfalto seja adicionada à mistura, como pode ser observado ao analisar a espessura do filme de asfalto de 4,5 $\mu \mathrm{m}$ (Figura 5.20) e RBV de 63, 4\% (Tabela 5.17).

Nesta pesquisa, a espessura do filme de asfalto foi calculada em função do volume de asfalto efetivo na mistura, da área superficial de cobertura do agregado, da densidade da mistura e da porcentagem de agregado na mistura, como mostra a Equação 5.10. A espessura média do filme de asfalto considerada adequada para muitas misturas é de $8 \mu \mathrm{m}$, sendo conhecidas misturas com desempenho satisfatório com espessuras do filme de asfalto entre $6 \mu \mathrm{m}$ e $10 \mu m$ (Kandhal et al., 1998).

$$
E f_{b}=\frac{V b_{e f}}{A S \times(d \times P a)}
$$

onde:

$E f_{b}=$ espessura do filme de asfalto, $\mu m$;

$V b_{e f}=$ volume de asfalto efetivo na mistura, $\mathrm{cm}^{3}$;

$A S=$ área superficial do agregado, $\mathrm{cm}^{2} ;$

$d=$ densidade aparente da mistura; 
$P a=$ agregado na mistura, $\%$.

O gabro, apesar de apresentar forma arredondada, tem 100\% de suas partículas grossas com mais de duas faces fraturadas, AAF de 48,3\%, acima do valor de referência mínimo de $45 \%$, e textura superficial rugosa. As partículas de gabro proporcionaram um arranjo bom entre partículas, porém não muito próximo, permitindo um VAM de $17 \%$, superior ao limite mínimo de $14 \%$ especificado. Esse valor de VAM permitiu que fosse adicionada à mistura $5,3 \%$ de asfalto efetivo, possibilitando a cobertura das partículas com película de asfalto de aproximadamente 7,3 $\mu \mathrm{m}$ (Figura 5.20) e RBV de 74,5\%, próximo do limite superior de $75 \%$ especificado pelo Superpave (Tabela 5.17).

O basalto tem, segundo a avaliação Superpave, parte de suas partículas com forma lamelar ou, segundo a avaliação da ASTM D 4791, parte de suas partículas planas, apresentando angularidade alta tanto do agregado grosso quanto do agregado fino $(51,1)$ e textura superficial rugosa, que proporciona um arranjo entre partículas menos próximo, levando a valores de VAM bastante altos (19,6\%). Conseqüentemente, a quantidade de asfalto efetivo na mistura também é alta (6,5\%), que permite uma espessura de filme de asfalto em torno de 8, $9 \mu \mathrm{m}$ (Figura 5.20) e RBV de 80,3\%, valor este acima do limite máximo especificado pelo Superpave, porém abaixo do limite máximo especificado pelo DNER (82\%) (Tabela 5.17). O excesso de asfalto na mistura pôde ser percebido visualmente, no momento da mistura asfalto/agregado, e também após a compactação do corpo-de-prova. A aparência final do corpo-de-prova era brilhante e grudenta ao toque, diferente dos corpos-de-prova feitos com o agregado de gabro e areia natural e também dos de experiências anteriores com o mesmo agregado de basalto e o mesmo ligante.

O Superpave, ao especificar valores mínimos de VAM, tenta assegurar que as misturas tenham asfalto em quantidade suficiente para garantir durabilidade à mistura e, ao mesmo tempo, ao especificar valores máximos de RBV, tenta limitar a introdução excessiva de asfalto nessa mistura. Porém, esse é outro assunto que causa controvérsias. Alguns pesquisadores, como Kandhal et al. (1998), acham que especificar valores de VAM é uma forma errada de controlar o teor de asfalto na mistura, visto que o VAM pode ser influenciado por vários fatores além da granulometria. Os resultados desta pesquisa concordam com essa afirmação e permitem dizer que a maneira simplista proposta pelo Superpave de controlar o teor de asfalto na mistura, através do VAM, pode ser enganosa, pois, como se pode observar, misturas produzidas com agregados com características diferentes de forma e de angularidade, porém, com uma mesma granulometria, apresentam valores muito diferentes de VAM e, portanto, teores de asfalto e espessuras do filme de asfalto também bastante diferentes (Figura 5.20). 


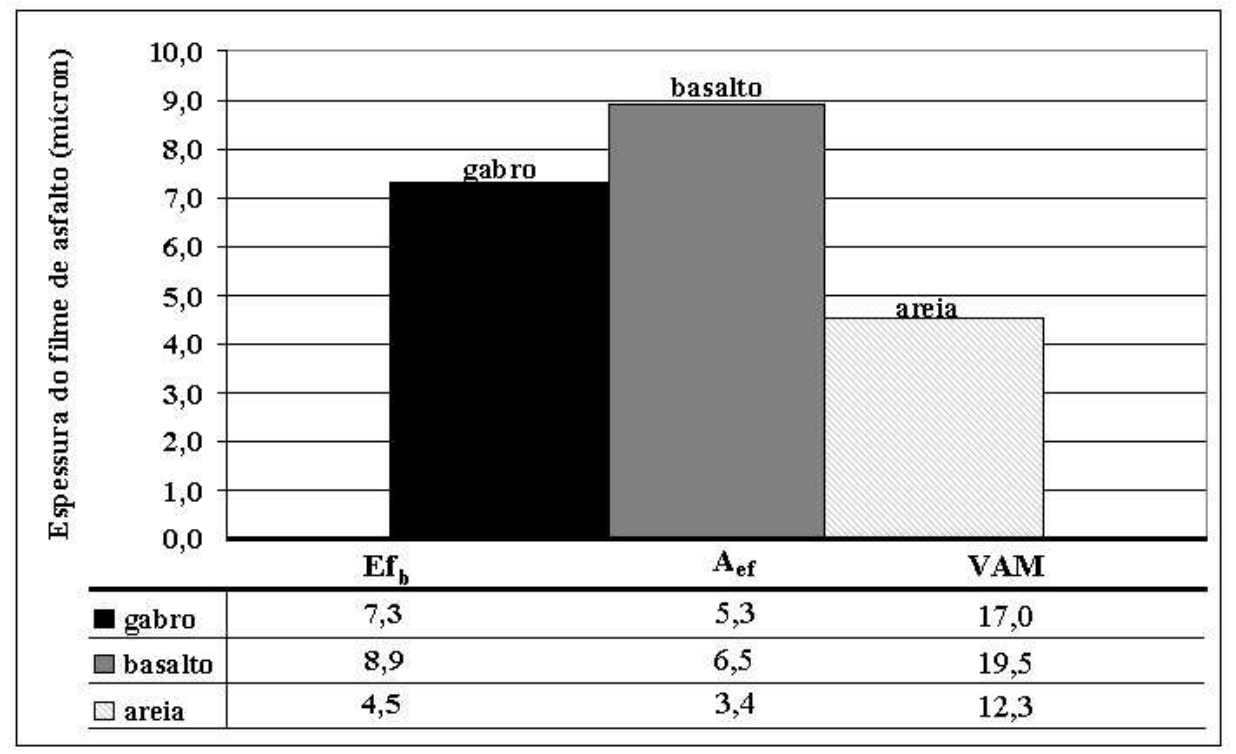

Figura 5.20: Espessura do filme de asfalto obtidas na dosagem das misturas AZRg, AZRb e AZRa

O agregado de basalto, devido às suas características de superfície, apresentou VAM muito alto e, conseqüentemente, para um Vv de 4\%, valor de RBV também alto (80,3\%), acima do limite superior de $75 \%$ especificado pelo Superpave. Portanto, para que o valor do RBV ficasse dentro da faixa de especificação Superpave, o valor do VAM da mistura deveria ser mais baixo. Um cálculo rápido permite estabelecer limites para o VAM com vistas no RBV, ou seja, para que o RBV da mistura permanecesse dentro do limite de $65 \%$ a $75 \%$ os valores do VAM deveriam conservar-se entre $11,5 \%$ e $16 \%$, considerando um Vv de $4 \%$. Valores de VAM superiores a esses produziriam misturas com excesso de asfalto. Alguns autores sugerem, quando o VAM da mistura é alto, que se altere a granulometria. Porém, analisando os resultados apresentados, pode-se perceber que não se trata apenas de um problema de granulometria e sim de características de forma e de angularidade do agregado, pois ocorreram misturas com VAM muito alto (AZRb), VAM adequado (AZRg) e VAM abaixo do limite especificado (AZRa), para uma mesma curva granulométrica. Além disso, é de conhecimento da comunidade científica que misturas com agregados mais angulares e com textura superficial rugosa apresentam resistência à compactação elevada. Esses dois fatos despertam a idéia de que, talvez, a mistura AZRb, que apresenta VAM muito alto e resistência à compactação elevada, devesse ser compactada com mais energia na tentativa de diminuir o VAM, melhorando dessa maneira o arranjo entre partículas, diminuindo o RBV, além de melhorar a estabilidade da mistura. Essa idéia será melhor explorada no Capítulo 6.

A concepção de que com arranjos mais próximos melhora-se a estabilidade das misturas pôde ser verificada através dos resultados de estabilidade Marshall obtidos. O melhor arranjo entre as partículas do agregado de gabro (VAM de 17\%), em decorrência de suas características 
de forma, de angularidade e de textura superficial, pode ser verificado quando comparados os valores de sua estabilidade Marshall aos das outras misturas AZR. A mistura AZRg apresentou estabilidade Marshall, obtida através do ensaio de compressão diametral, de $17.583 \mathrm{~N}$, enquanto a mistura AZRb teve um valor de $12.837 \mathrm{~N}$ e a mistura AZRa apresentou um valor de $9.463 \mathrm{~N}$, no teor de projeto (Figura 5.21).

A fluência Marshall, que corresponde à deformação sofrida pelo corpo-de-prova até o momento da ruptura, foi de 4,2 $\mathrm{mm}$ para a mistura AZRg, 4, $4 \mathrm{~mm}$ para a mistura AZRb, considerados estatisticamente iguais com um nível de confiança de $95 \%$ e 2, $4 \mathrm{~mm}$ para a mistura AZRa (Figura 5.21).

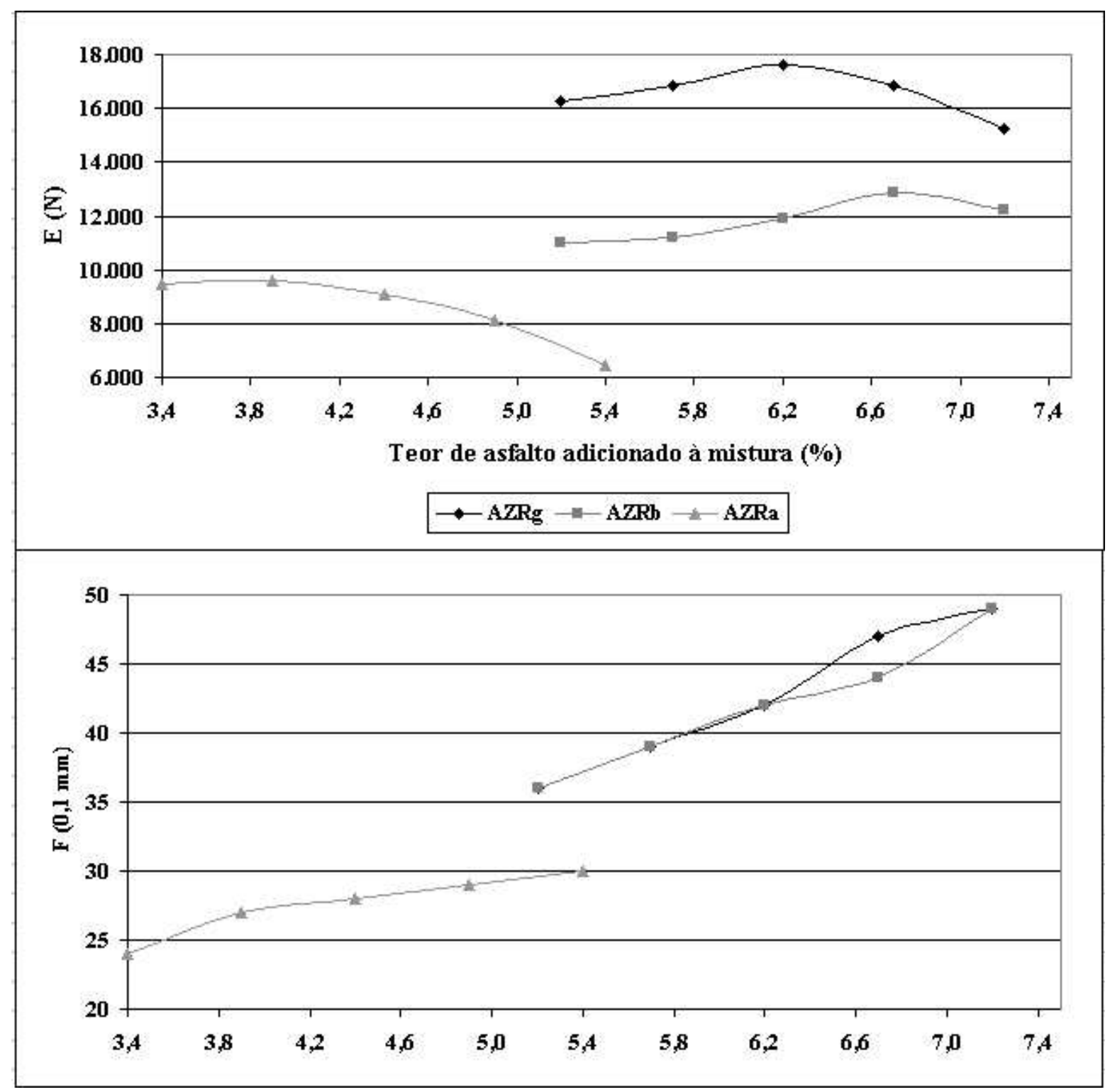

Figura 5.21: Estabilidade e Fluência Marshall obtidas na dosagem das misturas AZRg, AZRb e AZRa 


\subsubsection{Dosagens das Misturas Asfálticas Bailey}

Os resultados da dosagem das misturas Bailey, com agregado de gabro e basalto, estão apresentados nas Tabelas 5.18 e 5.19, respectivamente. Nessas Tabelas, constam a porcentagem de asfalto adicionada à mistura $(\mathrm{Pb})$, a absorção de água pelo corpo-de-prova, após 2 minutos de imersão $\left(\% A b_{c p}\right)$, a densidade aparente da mistura $(d)$, a densidade máxima medida da mistura (DMM), o volume de vazios (Vv), os vazios do agregado mineral (VAM), a relação betume-vazios (RBV) e a estabilidade $(E)$ e fluência $(F)$ Marshall.

Tabela 5.18: Dosagem Marshall - mistura Bailey - gabro

\begin{tabular}{lcccccccc}
\hline $\boldsymbol{P b}$ & $\% \boldsymbol{A b} \boldsymbol{c p}$ & $\boldsymbol{d}$ & $\boldsymbol{D M M}$ & $\begin{array}{c}\boldsymbol{V} \boldsymbol{v} \\
(\%)\end{array}$ & $\begin{array}{c}\boldsymbol{A} \boldsymbol{M} \boldsymbol{( \% )} \\
\end{array}$ & $\begin{array}{c}\boldsymbol{R} \boldsymbol{B} \boldsymbol{V} \\
(\%)\end{array}$ & $\begin{array}{c}\boldsymbol{E} \\
(N)\end{array}$ & $\begin{array}{c}\boldsymbol{F} \\
(0,1 \mathrm{~mm})\end{array}$ \\
\hline 6,0 & 0,32 & 2,338 & 2,541 & 8,0 & 19,8 & 59,8 & 13.327 & 36 \\
\hline 6,5 & 0,09 & 2,348 & 2,521 & 6,8 & 19,9 & 65,6 & 12.827 & 38 \\
\hline 7,0 & 0,04 & 2,372 & 2,501 & 5,2 & 19,5 & 73,6 & 13.317 & 41 \\
\hline 7,5 & 0,03 & 2,388 & 2,482 & 3,8 & 19,4 & 80,6 & 12.798 & 40 \\
\hline 8,0 & 0,02 & 2,392 & 2,463 & 2,9 & 19,7 & 85,4 & 12.719 & 45 \\
\hline
\end{tabular}

Tabela 5.19: Dosagem Marshall - mistura Bailey - basalto

\begin{tabular}{ccccccccc}
\hline $\boldsymbol{P b}$ & $\boldsymbol{\%} \boldsymbol{A b} \boldsymbol{c p}$ & $\boldsymbol{d}$ & $\boldsymbol{D M M}$ & $\boldsymbol{V} \boldsymbol{v}$ & $\boldsymbol{V} \boldsymbol{A} \boldsymbol{M}$ & $\boldsymbol{R} \boldsymbol{B} \boldsymbol{V}$ & $\boldsymbol{E}$ & $\boldsymbol{F}$ \\
& & & & $(\%)$ & $(\%)$ & $(\%)$ & $(N)$ & $(0,1 \mathrm{~mm})$ \\
\hline 5,5 & 0,15 & 2,421 & 2,618 & 7,5 & 20,1 & 62,5 & 9.503 & 35 \\
\hline 6,0 & 0,08 & 2,440 & 2,596 & 6,0 & 19,8 & 69,7 & 10.199 & 40 \\
\hline 6,5 & 0,06 & 2,462 & 2,575 & 4,4 & 19,6 & 77,6 & 9.875 & 42 \\
\hline 6,8 & 0,03 & 2,464 & 2,562 & 3,8 & 19,7 & 80,6 & 9.985 & 42 \\
\hline 7,0 & 0,03 & 2,465 & 2,554 & 3,5 & 19,9 & 82,6 & 9.208 & 42 \\
\hline 7,5 & 0,03 & 2,468 & 2,534 & 2,6 & 20,2 & 87,2 & 10.101 & 48 \\
\hline
\end{tabular}

Na Tabela 5.20, encontra-se o resumo dos cálculos necessários para a elaboração do diagrama de componentes das misturas Bailey com agregados de gabro e de basalto, obtendo-se as propriedades volumétricas, a porcentagem de asfalto absorvido pelo agregado, a porcentagem de asfalto efetivo na mistura e a espessura do filme de asfalto. A Figura 5.22 apresenta uma representação gráfica das propriedades volumétricas das misturas Bailey obtidas nas dosagens. 
Tabela 5.20: Propriedades das misturas Bailey

\begin{tabular}{lcccc}
\hline Propriedades & \multicolumn{5}{c}{ Gabro } & Basalto \\
\hline Volume Total & $(V t)$ & 1 & 1 & $\mathrm{~cm}^{3}$ \\
Densidade Aparente da Mistura & $(d)$ & 2,388 & 2,464 & \\
Densidade de Asfalto & $\left(\rho_{b}\right)$ & 1,02 & 1,02 & \\
Porcentagem do Asfalto & $(P b)$ & 7,5 & 6,8 & $\%$ \\
Densidade Aparente do Agregado & $\left(\rho_{a p}\right)$ & 2,742 & 2,860 & \\
Densidade Efetiva do Agregado & $\left(\rho_{e f}\right)$ & 2,808 & 2,880 & \\
Porcentagem do Fíler & $(\% F)$ & 3,5 & 3,5 & $\%$ \\
Área Superficial do Agregado & $(A S)$ & 7,66 & 7,66 & $\mathrm{~m}^{2} / \mathrm{kg}$ \\
\hline & & & & \\
Massa Total da Mistura & $(M t)$ & 2,388 & 2,464 & $g$ \\
Massa do Asfalto & $(M b)$ & 0,179 & 0,168 & $\mathrm{~g}$ \\
Massa do Agregado & $(M a)$ & 2,209 & 2,297 & $\mathrm{~g}$ \\
\hline & & & & \\
Volume Efetivo do Agregado & $\left(V_{e f}\right)$ & 0,787 & 0,798 & $\mathrm{~cm}^{3}$ \\
Volume Aparente do Agregado & $\left(V_{a p}\right)$ & 0,806 & 0,803 & $\mathrm{~cm}^{3}$ \\
Volume do Asfalto & $(V b)$ & 0,176 & 0,164 & $\mathrm{~cm}^{3}$ \\
Volume do Asfalto Absorvido & $\left(V b_{a b s}\right)$ & 0,019 & 0,005 & $\mathrm{~cm}^{3}$ \\
Volume do Asfalto Efetivo & $\left(V b_{e f}\right)$ & 0,157 & 0,159 & $\mathrm{~cm}^{3}$ \\
Volume de Ar & $\left(V_{a r}\right)$ & 0,038 & 0,038 & $\mathrm{~cm}^{3}$ \\
\hline & & & & \\
Massa do Asfalto Efetivo & $\left(M b_{e f}\right)$ & 0,160 & 0,162 & $\mathrm{~g}$ \\
Massa do Asfalto Absorvido & $\left(M b_{a b s}\right)$ & 0,019 & 0,005 & $\mathrm{~g}$ \\
\hline & & & & \\
Porcentagem de Volume de Vazios & $(V v)$ & 3,8 & 3,8 & $\%$ \\
Vazios do Agregado Mineral & $(V A M)$ & 19,4 & 19,7 & $\%$ \\
Relação Betume Vazios & $(R B V)$ & 80,5 & 80,6 & $\%$ \\
Asfalto Efetivo & $\left(P b_{e f}\right)$ & 6,7 & 6,6 & $\%$ \\
Asfalto Absorvido & $\left(A_{a b s}\right)$ & 0,9 & 0,2 & $\%$ \\
Densidade Máxima Medida & $(D M M)$ & 2,482 & 2,562 & \\
Espessura do Filme de Asfalto & $\left(E f_{b}\right)$ & 9,3 & 9,0 & $\mu m$ \\
\hline & & & & \\
& & &
\end{tabular}




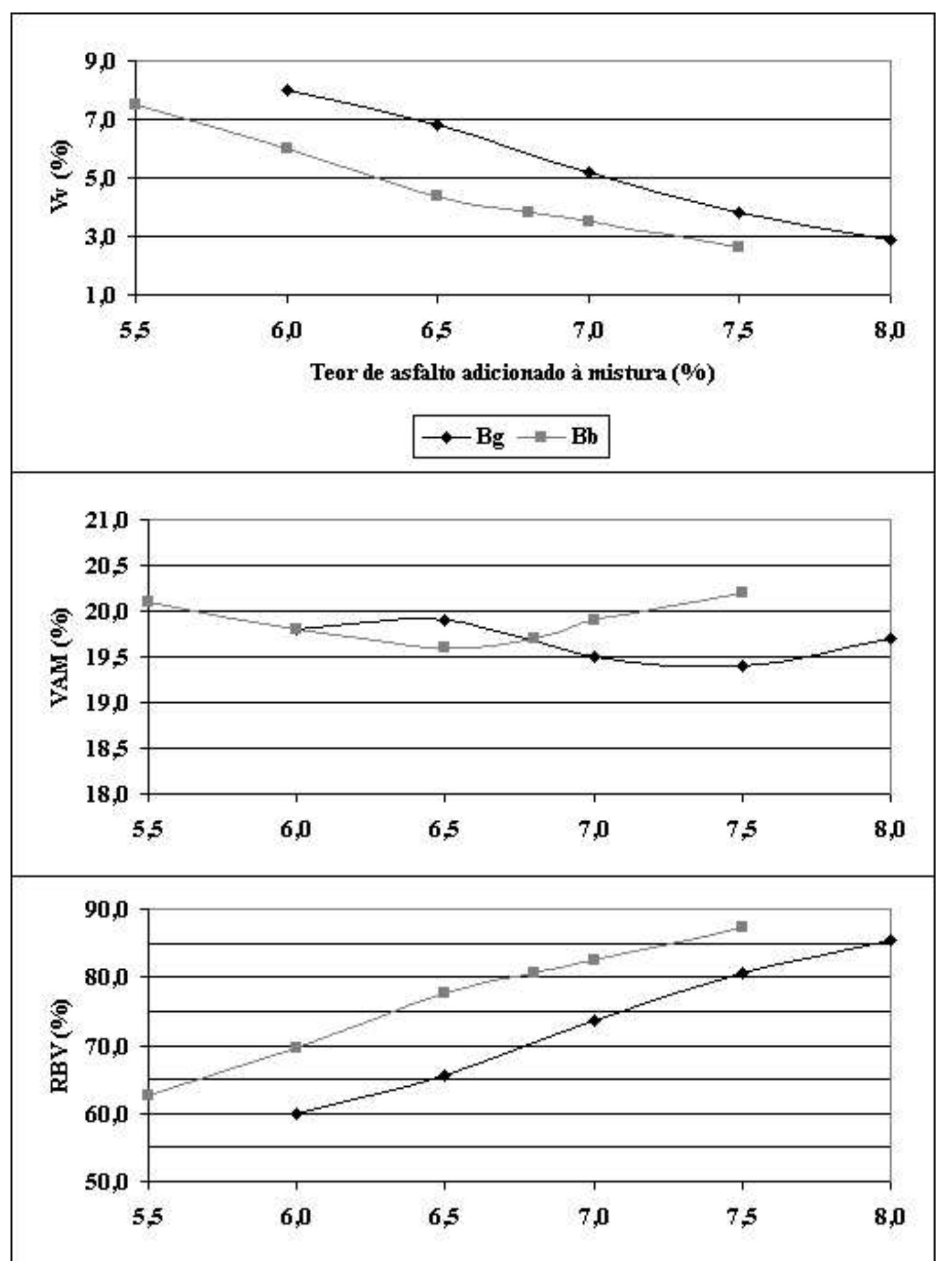

Figura 5.22: Propriedades volumétricas obtidas nas dosagens das misturas $\mathrm{Bg}$ e $\mathrm{Bb}$, compactadas com 75 golpes por face 
As misturas Bailey gabro (Bg) e Bailey basalto (Bb), diferentemente das misturas AZR, não têm mesma granulometria. Portanto, a análise comparativa entre essas misturas deve ser feita em função do arranjo entre partículas e das propriedades volumétricas.

Com base nos resultados das dosagens das misturas Bailey apresentados, pode-se perceber que o teor de asfalto efetivo de projeto das misturas $\mathrm{Bg}$ e Bb são muito próximos, 6,7\% para a mistura $\mathrm{Bg}$ e $6,6 \%$ para a mistura Bb (Tabela 5.20). As propriedades volumétricas das duas misturas são também aproximadamente iguais, sendo os valores de VAM de 19,4\% e 19,7\%, RBV de 80, $5 \%$ e 80,6\%, para as misturas $\mathrm{Bg}$ e Bb, respectivamente, considerando um Vv de $3,8 \%$ para ambas as misturas (Tabela 5.20). As espessuras do filme de asfalto para as duas misturas também são muito similares, a mistura Bg apresenta aproximadamente $9,3 \mu \mathrm{m}$ e a mistura $\mathrm{Bb}$ apresenta 9,0 $\mathrm{\mu m}$. Isso pode indicar que, apesar das diferentes características de forma e angularidade dos agregados, a utilização do método Bailey permitiu que se configurasse um arranjo similar entre as partículas dos dois tipos de granulometrias, compondo misturas com características volumétricas similares. Destaca-se, portanto, a capacidade do método de considerar as propriedades de superfície das partículas na obtenção de curvas granulométricas.

Mas apesar da similaridade das propriedades volumétricas, as misturas Bailey apresentaram VAM altos e, conseqüentemente, RBV acima do valor limite de $75 \%$. Os corpos-de-prova compactados apresentaram também excesso aparente de asfalto, mais explícito nos corpos-de-prova da mistura $\mathrm{Bb}$, com aparência bastante brilhante e grudentos ao toque.

Isso demonstra que misturas com agregados de diferentes características de forma e angularidade, mesmo utilizando o método Bailey, que considera essas diferenças, podem apresentar valores altos de VAM e, portanto, também teores de asfalto efetivo altos. Esse fato reforça a idéia da possível utilização de energias de compactação mais elevadas para a diminuição do VAM das misturas, pois teores de asfalto superiores ao necessário podem ocasionar problemas de deformação permanente e aumentar o custo da obra de pavimentação.

A mistura Bg apresentou estabilidade Marshall de $12.798 \mathrm{~N}$ enquanto a mistura $\mathrm{Bb}$ de 9.985 N. Porém, ao analisar as Tabelas 5.18 e 5.19 e a Figura 5.23, pode-se verificar que a estabilidade, tanto da mistura $\mathrm{Bg}$ como da $\mathrm{Bb}$, oscilam com a variação do teor de asfalto sem aparentemente apresentar alguma tendência, ao contrário da maioria das misturas que tendem a aumentar a estabilidade Marshall ao se aproximar do teor efetivo de projeto. Uma possível explicação poderia ser que a estabilidade da mistura está tão condicionada ao esqueleto estrutural formado pelas partículas dos agregados que, ao variar o teor de asfalto, este pouco contribui para o aumento ou diminuição da estabilidade da mistura. Mas, considerando apenas 
esse ensaio, essa idéia deve ser encarada apenas como uma possível suposição. A fluência Marshall foi de $40 \mathrm{~mm}$ para a mistura $\mathrm{Bg}$ e de $42 \mathrm{~mm}$ para a mistura Bb (teor de projeto), podendo ser consideradas iguais ao analisar a dispersão dos resultados (Figura 5.23).

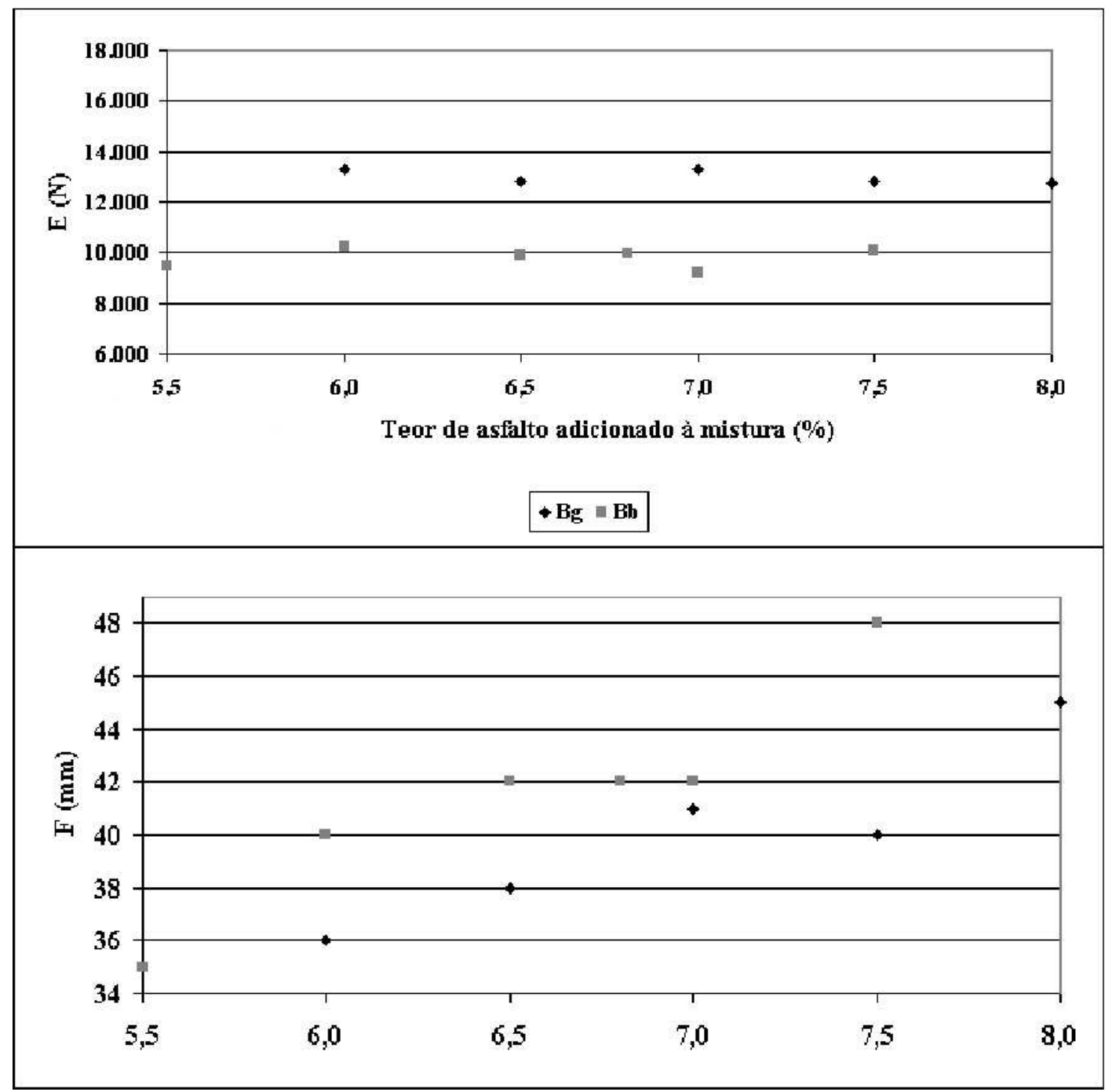

Figura 5.23: Estabilidade e Fluência Marshall obtidas na dosagem das misturas $\mathrm{Bg}$ e Bb, compactadas com 75 golpes por face 


\subsubsection{Comparando Misturas AZR e Bailey}

Na Figura 5.24, pode-se visualizar a variação do VAM das misturas AZR e Bailey. A mistura AZRg apresenta VAM inferior ao da mistura Bg, indicando um arranjo entre as partículas mais próximo. Esse arranjo mais próximo, somado às boas características de forma, angularidade e textura superficial das partículas, produzem um melhor intertravamento entre as partículas, que pode ser constatado através da maior estabilidade Marshall da mistura AZRg comparada à das outras misturas, como representado nos gráficos da Figura 5.25.

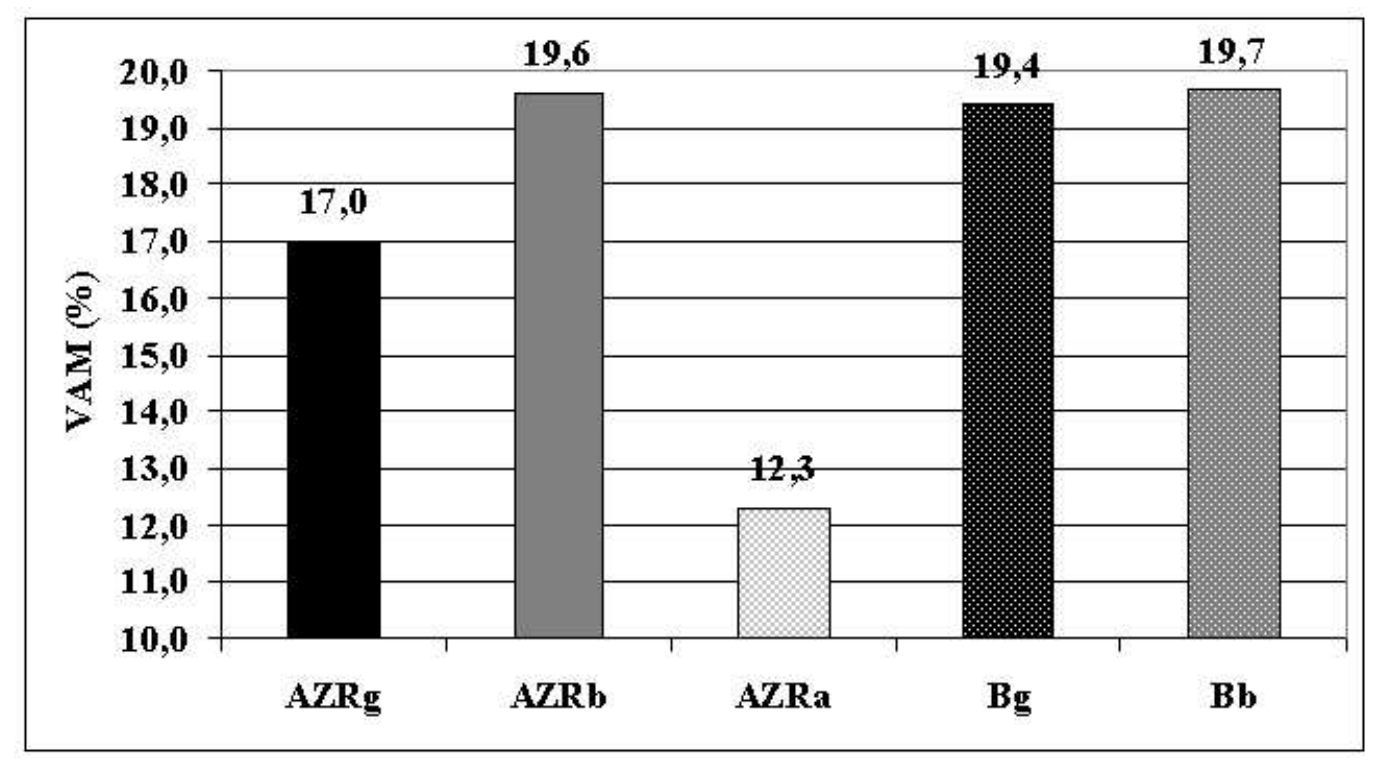

Figura 5.24: VAM das misturas AZRg, AZRb, AZRa, Bg e Bb

Vale notar que VAMs muito baixos também são indesejáveis, como é o caso da mistura AZRa. Devido às características de forma, angularidade e textura superficial das partículas do agregado de areia, elas assumem posições muito próximas umas das outras, permitindo que uma quantidade de asfalto pequena seja adicionada à mistura, ocasionando uma espessura do filme de asfalto muito delgada. As partículas de areia natural, com cantos arredondados e textura superficial lisa, não proporcionam intertravamento adequado, que pode ser percebido em razão da menor estabilidade Marshall da mistura em comparação às outras (Figura 5.25). Essas partículas, devido aos seus cantos arredondados e à sua textura superficial lisa, tendem a escorregar umas sobre as outras ao invés de intertravarem-se e, assim, a capacidade de carga resistida pelo esqueleto estrutural formado é prejudicada.

Já as misturas AZRb e Bb, que apresentaram VAM similares, mostram valores de estabilidade Marshall distintos. A estabilidade Marshall da mistura AZRb é superior à da mistura $\mathrm{Bb}, 12.837$ e 9.985 , respectivamente. Isso pode demonstrar que, apesar dos valores do VAM serem similares, um melhor arranjo entre as partículas da mistura AZRb foi formado, mas essa 


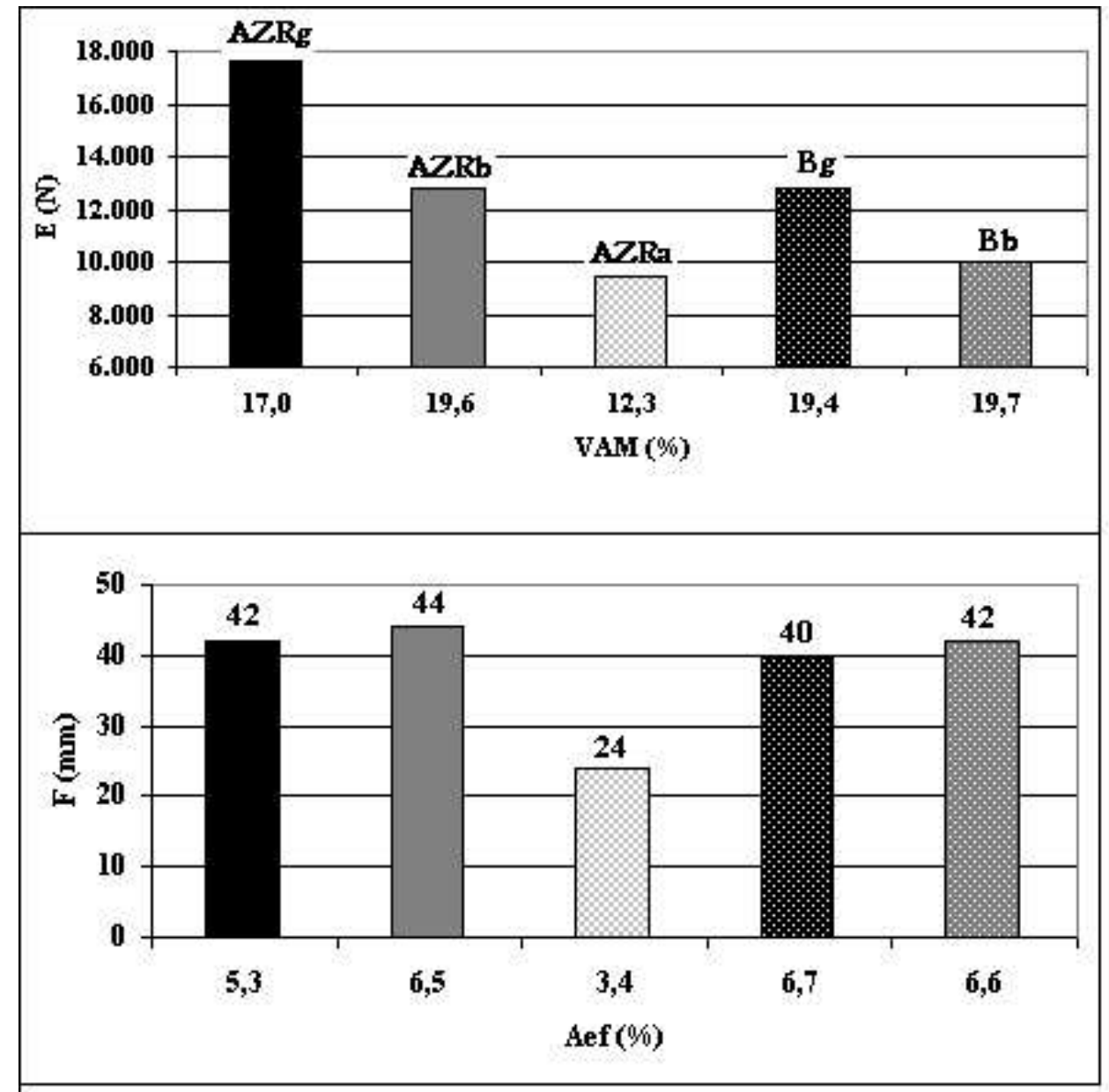

Figura 5.25: Comparação entre a estabilidade e fluência Marshall das misturas AZR e Bailey

hipótese poderá ou não ser validada através de outros ensaios realizados com essas mesmas misturas, que serão apresentados nos próximos capítulos.

Pode-se notar que tanto as misturas AZR quanto as Bailey, para os agregados de gabro e basalto, demonstram forte similaridade quanto à fluência Marshall (Figura 5.25), apesar de apresentarem valores distintos de asfalto efetivo (Figura 5.26).

De forma geral, os resultados indicam que quanto maior o VAM, maior a quantidade de asfalto efetivo na mistura e, VAMs similares ( $\mathrm{AZRb}, \mathrm{Bg}$ e $\mathrm{Bb}$ ) produzem valores muito próximos de asfalto efetivo $(6,5 ; 6,7$ e $6,6 \%)$, de $\operatorname{RBV}(80,2 ; 80,5$ e 80,6\%) e de espessura do filme de asfalto $(8,9 ; 9,3$ e $9,3 \mu \mathrm{m})$, respectivamente. 


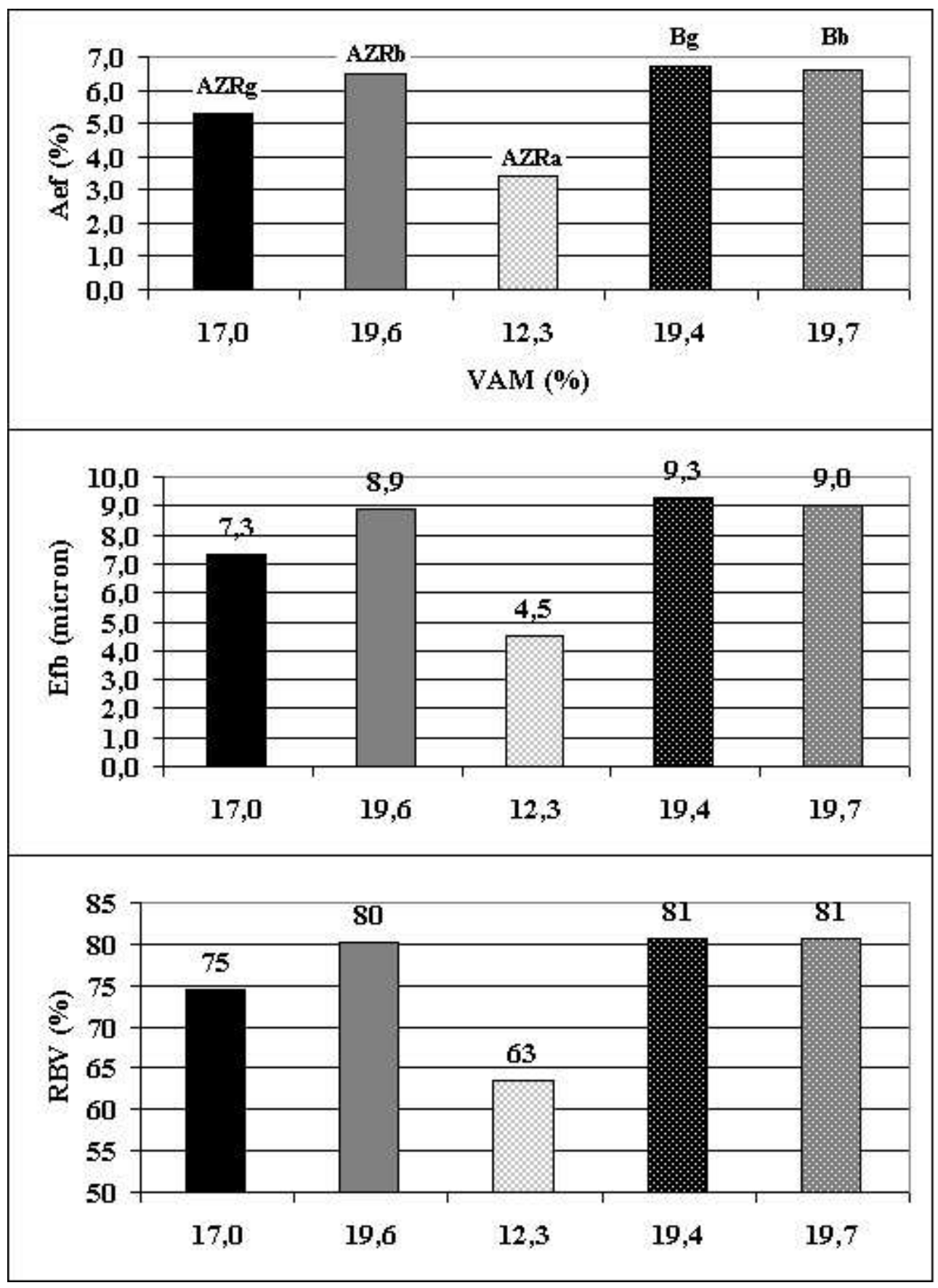

Figura 5.26: Comparação entre o asfalto efetivo, espessura do filme de asfalto e relação betume-vazios das misturas AZR e Bailey 
A Tabela 5.21 traz as distâncias da linha de densidade máxima (LDM), em relação à curva granulométrica utilizada, e os valores de VAM encontrados para essas misturas produzidas com agregados de mesma origem.

Tabela 5.21: Comparação entre as distâncias da linha de densidade máxima e VAM

\begin{tabular}{ccc}
\hline Mistura & Distância da LDM & VAM \\
\hline$A Z R g$ & 57,5 & 17,0 \\
$B g$ & 57,5 & 19,4 \\
\hline$A Z R b$ & 57,5 & 19,5 \\
$B b$ & 41,5 & 19,7 \\
\hline
\end{tabular}

A mistura AZRg e Bg têm mesma distância da LDM, calculada através da Equação 5.2, porém os valores do VAM são diferentes (Tabela 5.21). Já a mistura AZRb tem distância da LDM maior que a mistura $\mathrm{Bb}$, portanto deveria apresentar VAM maior, o que também não ocorreu, pelo contrário, o VAM da mistura $\mathrm{Bb}$ mostra-se ligeiramente mais elevado. Como visto anteriormente, a LDM estaria associada à granulometria que resultaria do arranjo mais denso formado entre as partículas dos agregados. Portanto, teoricamente, quanto mais próxima a granulometria estivesse da LDM, mais denso seria o arranjo formado entre as partículas. Contudo, as curvas granulométricas ensaiadas não satisfizeram a definição da LDM, mesmo utilizando o traçado da LDM proposto por McLeod (1987), defendido por Huber \& Shuler (1992) e também utilizado pelo Superpave.

Através do gráfico da Figura 5.15, pode-se ver que a granulometria AZR é mais fina que a granulometria Bg. A mistura AZR possui menor quantidade de partículas grossas, em sua fração grossa, e possui maior quantidade de partículas finas, em sua fração fina, quando comparada à mistura Bg. A quantidade menor de partículas grossas e a quantidade maior de partículas finas, preenchedoras dos vazios formados pelas partículas grossas, podem explicar o VAM menor encontrado para a mistura AZR, em comparação à mistura $\mathrm{Bg}$, que possui quantidade maior de partículas grossas, em sua fração grossa, e quantidade menor de partículas finas, em sua fração fina. Isso demonstra que apenas a avaliação da distância da LDM não permite dizer se as misturas terão VAMs maiores ou menores, se não for levado em conta as características granulométricas das misturas. A porcentagem de agregados grossos (formadores de espaços) e a porcentagem de agregados finos (preenchedores desses espaços) também influenciam o valor do VAM, ou seja, além da distância da LDM, as características das curvas granulométricas devem ser consideradas. Portanto, a hipótese de que ao afastar a curva granulométrica da LDM seriam encontrados VAMs mais altos, para agregados de mesma origem, pode ser refutada, pois há mais a que se considerar que apenas a distância da LDM. 
Uma explicação possível para o desacordo entre os resultados encontrados por Huber \& Shuler (1992) e os relatados nesta pesquisa é que Huber \& Shuler (1992) compararam o VAM entre curvas granulométricas com características granulométricas semelhantes, ou seja, havia um balanceamento constante entre as frações grossas e finas das curvas granulométricas analisadas. Já as curvas granulométricas estudadas nesta pesquisa não têm balanceamento constante, como visto no parágrafo anterior. Portanto, os resultados apontam que a distância da LDM parece não estar relacionada com o VAM de maneira tão direta e simplista como relatado por Huber \& Shuler (1992).

A não correlação observada entre o VAM e a LDM pode não ser um problema de localização incorreta da linha, como suposto por Huber \& Shuler (1992), mas talvez seja a desconsideração do balanceamento entre as proporções de frações grossas, formadoras de vazios, e finas, preenchedoras de vazios. Parece razoável afirmar que comparações entre curvas granulométricas, com o objetivo de avaliar o VAM através da distância da LDM, só podem ser válidas se as curvas granulométricas tiverem formas parecidas, ou seja, comparações entre curvas do tipo "S" e curvas que passam acima ou abaixo da LDM proporcionariam resultados inconsistentes quanto ao VAM.

\subsection{Conclusões}

Os ensaios realizados serviram para avaliar os efeitos das características de superfície dos agregados e da granulometria. Um dos objetivos do experimento foi avaliar a granulometria sem confundí-la com os efeitos das diferentes formas, angularidades e texturas superficiais dos agregados. Para tanto, foram comparados os VAMs das misturas, as quais possuíam granulometrias idênticas, mas com agregados de características de superfície diferentes (forma, angularidade e textura superficial). Também foram comparados os VAMs das misturas que possuíam o mesmo tipo de agregado, mas com granulometrias diferentes.

Foram pesquisados três tipos de agregados, gabro com taxa de absorção de asfalto média, basalto com taxa de absorção de asfalto baixa e uma areia natural com taxa de absorção baixa, e três curvas granulométricas, AZR, determinada conforme as especificações Superpave, Bg e $\mathrm{Bb}$, determinadas através do método Bailey. Todas as granulometrias selecionadas para este estudo continham $3,5 \%$ de material passante na peneira $0,075 \mathrm{~mm}$.

Ao serem realizadas as dosagens Marshall para cada uma das três granulometrias e para cada um dos três tipos de agregados estudados, pôde-se estabelecer comparações entre tipo de 
agregado e VAM e, entre granulometria e características de superfície do agregado. O VAM foi utilizado como modo de comparar as densidades relativas das misturas produzidas com agregados com características de superfície diferentes, pois, a densidade relativa da mistura pode ser expressa através da quantidade de vazios formados entre as partículas do agregado mineral, após a compactação da mistura.

Os experimentos realizados permitem concluir que:

- Para uma dada granulometria, as características de forma, angularidade e textura superficial do agregado influenciam o arranjo entre partículas;

- Partículas arredondadas, de angularidade baixa e textura superficial lisa, produzem misturas com arranjo entre partículas muito próximos e, conseqüentemente, VAMs mais baixos do que os VAMs encontrados para misturas produzidas com agregados angulares e de textura superficial rugosa;

- Valores muito baixos de VAM impossibilitam que uma quantidade suficiente de asfalto seja adicionada à mistura e, conseqüentemente, as partículas do agregado são envolvidas por uma película de asfalto muito fina, podendo comprometer a durabilidade da mistura;

- Para uma mesma granulometria, agregados com diferentes características de forma e angularidade podem apresentar valores muito diferentes de VAM e, portanto, teores de asfalto bastante distintos;

- Apesar das diferentes características de forma e angularidade dos agregados de gabro e basalto estudados, a utilização do método Bailey permitiu que se configurasse um arranjo similar entre as partículas das misturas $\mathrm{Bg}$ e $\mathrm{Bb}$, compondo misturas com características volumétricas similares, o que vem destacar a capacidade do método de considerar as propriedades de superfície das partículas para a obtenção de curvas granulométricas;

- As misturas AZRb, Bg e Bb apresentaram um excesso aparente de asfalto após compactadas, provavelmente devido aos valores altos do VAM dessas misturas;

- As estabilidades Marshall das misturas Bailey oscilaram com a variação do teor de asfalto, sem aparentemente apresentar uma tendência, ao contrário da maioria das misturas, que tendem a aumentar a estabilidade Marshall ao se aproximar do teor de asfalto efetivo de projeto;

- Quanto maior o VAM, mais elevado é o teor de asfalto de projeto da mistura para satisfazer a condição de Vv em torno de $4 \%$. As misturas estudadas que apresentaram VAM 
altos, conseqüentemente, apresentaram RBV acima do valor limite de $75 \%$ especificado pelo Superpave;

- VAMs similares (AZRb, Bg e $\mathrm{Bb}$ ) produzem valores muito próximos de asfalto efetivo, de RBV e de espessura do filme de asfalto;

- Apenas a avaliação da distância da LDM não permite concluir se as misturas terão VAMs maiores ou menores, se não for levado em conta as características granulométricas das misturas. A distância da LDM não está relacionada com o VAM de maneira tão direta e simplista como relatado por Huber \& Shuler (1992). A não correlação observada, nesta pesquisa, entre o VAM e a LDM pode não ser um problema de localização incorreta da LDM, como suposto por Huber \& Shuler (1992), mas, talvez, seja a desconsideração do balanceamento entre as proporções de frações grossas, formadoras de vazios, e finas, preenchedoras desses vazios. Comparações entre curvas granulométricas, com o objetivo de avaliar o VAM através da distância da LDM, só podem ser válidas se as curvas tiverem formas parecidas, ou seja, se houver balanceamento entre as proporções de frações grossas e finas. Comparações entre curvas do tipo "S"e curvas que passam acima ou abaixo da LDM podem proporcionar resultados inconsistentes quanto ao VAM.

\subsection{Considerações Finais}

O objetivo do processo de cura em laboratório é possibilitar que ocorra a absorção de asfalto dentro dos poros dos agregados, durante o processo de mistura. Pois, considerando que o asfalto absorvido não faz mais parte do volume da mistura, a DMM real não pode ser obtida até que a absorção ocorra.

O tempo de cura em laboratório estabelecido pelo Superpave é de 4 horas, mas como normalmente o tempo de cura em laboratórios estadunidenses é de 2 horas, o AASHTO Subcommittee on Materials alterou o tempo de cura de 4 para 2 horas (Horan, 2001). Segundo Horan (2001), essa especificação da AASHTO sugere a utilização de um tempo de cura de 2 horas quando utilizados agregados não absorsores na mistura, porém, esta não define agregado absorsor nem esclarece qual deveria ser o tempo de cura a ser considerado se utilizados agregados absorsores.

Horan (2001) propõe que a distinção entre agregados que absorvem e que não absorvem asfalto seja feita considerando os valores de absorção de água desses agregados. Segundo ele, quando um agregado apresenta absorção menor que $2,5 \%$, este deve ser considerado como não 
absorsor ou de absorção baixa. Porém, essa hipótese de classificação entre agregados que absorvem e que não absorvem asfalto, tendo como base a absorção de água, deve ser vista com muita cautela, pois, os dados sobre absorção levantados nesta pesquisa (apresentados no Capítulo 4) permitem que essa hipótese seja refutada. $\mathrm{O}$ agregado de gabro estudado, mesmo apresentando absorção de água de 1,67\%, apresentou absorção de asfalto em torno de 0,9\% para 2 horas de cura, valor este que pode acarretar sensíveis diferenças nas propriedades volumétricas das misturas caso essa absorção não seja considerada, como demonstrado no Capítulo 4. Portanto, o valor de 2,5\% proposto por Horan (2001) parece estar muito acima do valor limite de absorção de água que pode influenciar os cálculos das propriedades volumétricas das misturas. Uma das idéias defendidas neste trabalho de pesquisa é que a capacidade de absorção de água de um agregado não deve ser utilizada como forma de classificação de agregados e muito menos para predizer o grau de absorção de asfalto desse agregado, pois, como visto no Capítulo 3, muitos fatores podem afetar a porcentagem de asfalto absorvido em comparação à porcentagem de água absorvida pelo agregado, dentre eles o tipo do agregado, o tamanho dos poros e sua distribuição, a temperatura do asfalto e a espessura da película de asfalto.

Deve-se sempre ter em mente que o propósito base do processo de cura é permitir que a quantidade de asfalto absorvido durante o projeto da mistura seja equivalente à absorção de asfalto que ocorrerá durante a prática de produção de misturas no campo. Portanto, o método de predição da absorção que parece mais realístico para o campo é o proposto nesta pesquisa e apresentado no Capítulo 3, que sugere o traçado da reta absorção versus DMM como forma de predição das propriedades volumétricas das misturas, após a compactação em campo, transcorrido um determinado tempo de armazenamento e transporte.

Com base nos resultados apresentados neste capítulo, pode-se concluir que o VAM é influenciado diretamente pelas características de forma, angularidade e textura superficial das partículas, além da granulometria. No entanto, no momento da escolha do agregado ou dos agregados que serão utilizados no desenvolvimento de um projeto de mistura, essas características de superfície do agregado geralmente não são levadas em conta para a obtenção do VAM e, conseqüentemente, o VAM é obtido aleatoriamente. Também é comum, quando se faz necessário aumentar ou diminuir o VAM, simplesmente prescrever alterações na granulometria da mistura, mas, como visto neste capítulo, muitas vezes a granulometria não é a responsável principal pela obtenção de VAM altos ou baixos, mas sim as características de forma, angularidade e textura superficial das partículas dos agregados. Além de que o ajuste granulométrico pode, muitas vezes, apresentar resultados confusos, pois, em alguns casos, o afastamento da curva granulométrica da LDM, com o objetivo de aumentar o VAM, pode provocar a sua diminuição. 
Portanto, granulometria e propriedades de superfície das partículas não podem ser dissociadas quando se trata do VAM da mistura.

A proporção final entre agregados grossos e finos e suas propriedades individuais determinam o conjunto geral de características da mistura para um dado tipo e esforço de compactação. É de conhecimento consolidado que quanto maior a angularidade e quanto mais rugosas forem as partículas, maior será a resistência à compactação e, portanto, maior deverá ser o esforço de compactação necessário para a obtenção da densificação desejada da mistura. Esse fato levanta a hipótese de que talvez as misturas produzidas com agregados bastante angulares apresentem VAM muito altos devido à resistência à compactação elevada imposta por suas partículas. Como o VAM é dependente do tipo e grau de compactação das misturas, um maior esforço de compactação poderia proporcionar uma diminuição do VAM, proporcionando um arranjo mais próximo entre as partículas, formando um esqueleto estrutural mais resistente. Essa hipótese será estudada no capítulo próximo, onde se pretende avaliar a variação das propriedades volumétricas das misturas em função da energia de compactação, com variação do número de golpes do soquete Marshall. 



\section{CAPÍTULO}

\section{Vazios do Agregado Mineral e Energia de Compactação}

\subsection{Considerações Iniciais}

A função do VAM tem mudado desde sua introdução como critério de projeto de misturas. Inicialmente, alguns projetistas tentaram minimizar o VAM para aumentar a estabilidade das misturas, outros, alteraram seu valor na tentativa de garantir durabilidade à mistura. Na década de 1950, o VAM era um parâmetro periférico e não muito enfatizado. Nessa época, o Corps of Engineers especificava valores para RBV em projetos de misturas Marshall, mas não para o VAM. No período entre 1955 e 1962, Norman McLeod demonstrou a necessidade de utilização de um VAM mínimo como critério de projeto, em vários artigos publicados. Então, em 1962, o Asphalt Institute passou a adotar a sugestão de McLeod quanto a utilização do VAM como critério de projeto.

Atualmente, com a implementação do Superpave, novas pesquisas sobre o VAM vêm sendo desenvolvidas, com abordagem principal às dificuldades de alcançar o VAM mínimo especificado. Alguns pesquisadores, como Anderson \& Bahia (1997), ressaltam que o processo de avaliação e seleção da granulometria, com o objetivo de alterar o VAM para enquadrá-lo nas especificações Superpave, é bastante difícil, além do grande tempo consumido no processo. Outros, como Hinrichsen \& Heggen (1996), salientam que as especificações para o VAM mínimo são muito restritivas e muitas vezes impedem projetos econômicos de misturas com desempenho aceitável. 
Mas o problema abordado pelos pesquisadores estadunidenses é sempre a dificuldade de encontrar o VAM mínimo especificado. Esse problema aparentemente está associado à elevação do esforço de compactação devido ao uso do compactador giratório, durante a implementação do Superpave (Kandhal et al., 1998). No entanto, os resultados desta pesquisa evidenciam o problema inverso, misturas que apresentam VAMs bastante altos e, conseqüentemente, RBVs acima dos especificados pelo Superpave.

Partindo do princípio que o problema de não atingir o VAM mínimo nos Estados Unidos esteja realmente associado à energia de compactação mais elevada atualmente utilizada, faz-se, então, a seguinte indagação: "estariam as misturas produzidas com agregados brasileiros sendo subestimadas quanto às suas potencialidades mecânicas, devido ao uso de energias de compactação inadequadas, ou melhor, inferiores ao que realmente seria necessário para promover um arranjo mais próximo entre partículas e produzir misturas com esqueleto estrutural mais resistente?"

O número de giros do compactador giratório Superpave é função do clima no qual a mistura vai ser colocada e do nível de tráfego. Quanto mais quente a região de pavimentação e quanto maior o nível de tráfego, maior o número de giros do compactador giratório. Porém, na compactação Marshall, são especificados apenas três níveis de esforços de compactação possíveis: 35 golpes por face para níveis de tráfego baixo; 50 golpes por face para níveis de tráfego médio e 75 golpes por face para níveis de tráfego alto. Essa limitação relativa, que impossibilita a diminuição do VAM através de um maior esforço de compactação, pode fazer com que as misturas produzidas com agregados mais angulares e rugosos, que sabidamente impõem uma maior resistência à compactação, tenham sua capacidade de carga subestimada, pois a diminuição do VAM, supostamente, resultaria em misturas com arranjos estruturais mais densos e, portanto, mais resistentes à deformação permanente.

O ideal seria que o esforço de compactação pudesse ser fixado em função tanto do tipo quanto das características de superfície dos agregados, além do clima da região e do nível de tráfego. Porém, já que um processo como esse ainda não foi divulgado no meio científico, neste capítulo, pretende-se avaliar os efeitos do aumento da energia de compactação sobre as propriedades volumétricas das misturas asfálticas, utilizando o compactador Marshall, que é o equipamento disponível na grande maioria dos laboratórios de pesquisa brasileiros. 


\subsection{Vazios do Agregado Mineral}

Vários estudos foram desenvolvidos enfocando de maneira direta ou indireta o VAM das misturas. Uma revisão bibliográfica vasta, realizada durante o desenvolvimento desta pesquisa, permite, através de pinceladas conclusivas dos pesquisadores, vislumbrar conceitualmente o VAM:

- minimizar o VAM é uma forma de conseguir granulometrias adequadas e de aumentar a estabilidade das misturas (Hudson \& Davis, 1965);

- não é aconselhável estabelecer limites para o VAM, considerando aplicações universais, devido à versatilidade das aplicações dos materiais betuminosos e dos vários tipos e granulometrias de agregados (Marshall (1949) ${ }^{1}$ apud Coree \& Hislop (1998));

- os agregados finos são os componentes mais críticos para o controle do VAM e os que mais contribuem para a estabilidade das misturas. Deve-se sempre utilizar agregados finos angulares, com textura superficial rugosa e com distribuição granulométrica adequada (Lefebvre, 1957);

- quantidades maiores de agregados grossos podem ser usadas para controle do VAM, em misturas densas (Vavrik et al., 2002);

- em misturas densas, os valores do VAM controlam a quantidade de asfalto que pode ser incorporada à mistura (Field, 1978).

Vários fatores foram citados como influentes no VAM e, dentre os mais citados, encontram-se:

- características de superfície do agregado, como forma, angularidade e textura superficial;

- arranjo entre partículas e grau de compactação da mistura;

- granulometria;

- proporção entre agregados grossos e finos na mistura;

- proporção e características de superfície dos agregados finos;

- teor de fíler.

\footnotetext{
${ }^{1}$ The Marshall Method for the Design and Control of Bituminous Paving Mixtures, $3{ }^{r d}$ rev., Marshall Consulting and Testing Laboratory, Jackson, MS 1949.
} 


\subsection{Vazios do Agregado Mineral e Energia de Compactação}

Considerando uma mesma granulometria, o VAM depende do grau de compactação e das características de superfície dos agregados, que por sua vez, influenciam o arranjo entre partículas. VAMs mais elevados são encontrados quando misturas com agregados bastante angulares e com textura superficial rugosa são utilizados para a produção de misturas. Agregados assim apresentam resistência à compactação mais elevada que agregados de angularidade baixa e/ou textura superficial lisa (Kandhal \& Cooley Jr., 2001). Isso foi demonstrado por Anderson \& Bahia (1997) quando correlacionaram o VAM com a inclinação da curva de densificação da mistura, utilizando o compactador giratório Superpave. A inclinação, K, foi calculada como a variação da porcentagem da densidade máxima medida como uma função do logaritmo do número de giros. Essa propriedade indica a resistência da mistura à compactação. Os resultados também mostraram que quanto mais angulares e com textura superficial mais rugosa forem os agregados usados na mistura, maior será a resistência à compactação e, portanto, maior o valor de K.

Uma maneira apropriada de vencer essa resistência à compactação elevada, derivada do arranjo formado entre partículas angulares e rugosas, seria a elevação da energia de compactação aplicada à mistura. De acordo com Anderson \& Bahia (1997), uma energia de compactação mais elevada pode ser encarada de duas maneiras:

- um esforço de compactação maior resulta em misturas com teores de asfalto menores;

- um esforço de compactação maior resulta em misturas com uma estrutura granular mais resistente.

A primeira maneira influencia diretamente a espessura do filme de asfalto, que é um elemento chave à durabilidade da mistura. A durabilidade da mistura refere-se à sua habilidade de reter propriedades originais, com o passar do tempo (Chadbourn et al., 2000). Se a espessura do filme de asfalto for muito fina, pode-se criar um problema de falta de coesão entre as partículas do agregado, ou então, a mistura pode sofrer mais rapidamente os efeitos da oxidação do asfalto. Se a espessura do filme for muito grossa, ou seja, a mistura estiver com excesso de asfalto, isso pode acarretar vários problemas, dentre eles exsudação e instabilidade da mistura.

Nesta pesquisa, pode-se encarar a diminuição da película de asfalto, devido à elevação da energia de compactação, de uma maneira salutar para as misturas, pois, com os VAMs altos encontrados e, conseqüentemente, RBVs acima dos valores especificados, há a preocupação 
quanto a ocorrência de excesso de asfalto. Portanto, neste estudo, a maneira apropriada de ver uma energia de compactação mais elevada é considerar que esse esforço de compactação adicional resultará em misturas com estruturas granulares mais resistentes.

Como os resultados desta pesquisa apontam valores de VAMs altos, será testada a hipótese de que, para uma mesma granulometria (AZR), misturas produzidas com agregados com resistência à compactação elevada (gabro e basalto) devem ser mais compactadas, na tentativa de diminuir o VAM e melhorar o arranjo entre partículas, aumentando a estabilidade das misturas.

\subsection{Experimentos Laboratoriais}

Utilizando a granulometria AZR para produzir misturas com agregados de gabro (AZRg) e de basalto (AZRb), foram moldados corpos-de-prova Marshall com energias de compactação de 75, 110 e 155 golpes por face, sendo determinados os teores de projeto para cada nível de compactação. As misturas AZRg e AZRb compactadas com energias de 110 e 155 golpes, foram dosadas e moldadas da mesma maneira que as executadas com 75 golpes, como descrito no Capítulo 5, item 5.3.3. A Figura 6.1 ilustra como se desenvolveu o procedimento de escolha das energias de compactação de 110 e 155 golpes por face do corpo-de-prova. Pode-se observar que se procurou manter o aumento padrão dos níveis de energias de compactação correntes no método Marshall.

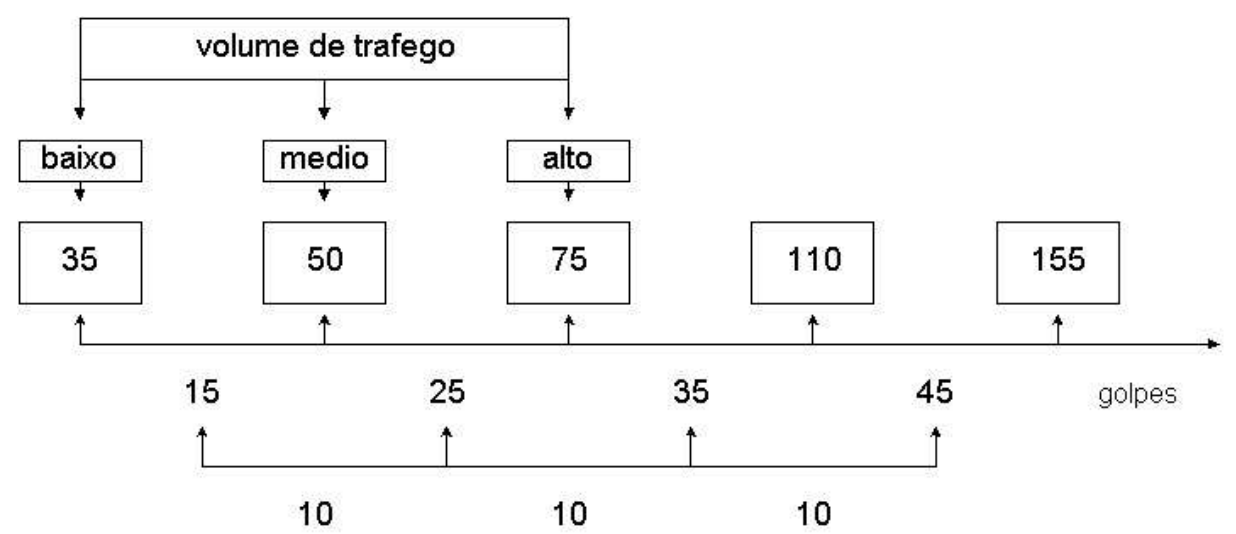

Figura 6.1: Procedimento para escolha das energias de compactação correspondentes a 110 e 155 golpes por face do corpo-de-prova Marshall

Com o propósito de verificar a ocorrência de quebra de partículas durante a compactação, avaliou-se a granulometria das misturas após a compactação, através da extração de asfalto com posterior peneiramento do agregado no mesmo conjunto de peneiras utilizado neste estudo. A porcentagem de quebras de partículas foi determinada através das diferenças, entre a 
granulometria encontrada após a compactação Marshall e a granulometria original, em todas as peneiras.

As amostras utilizadas na extração de asfalto foram colocadas dentro de um cesto revestido com papel filtro, para que não houvesse perda de finos. A Figura 6.2 ilustra o equipamento utilizado para a extração de asfalto.

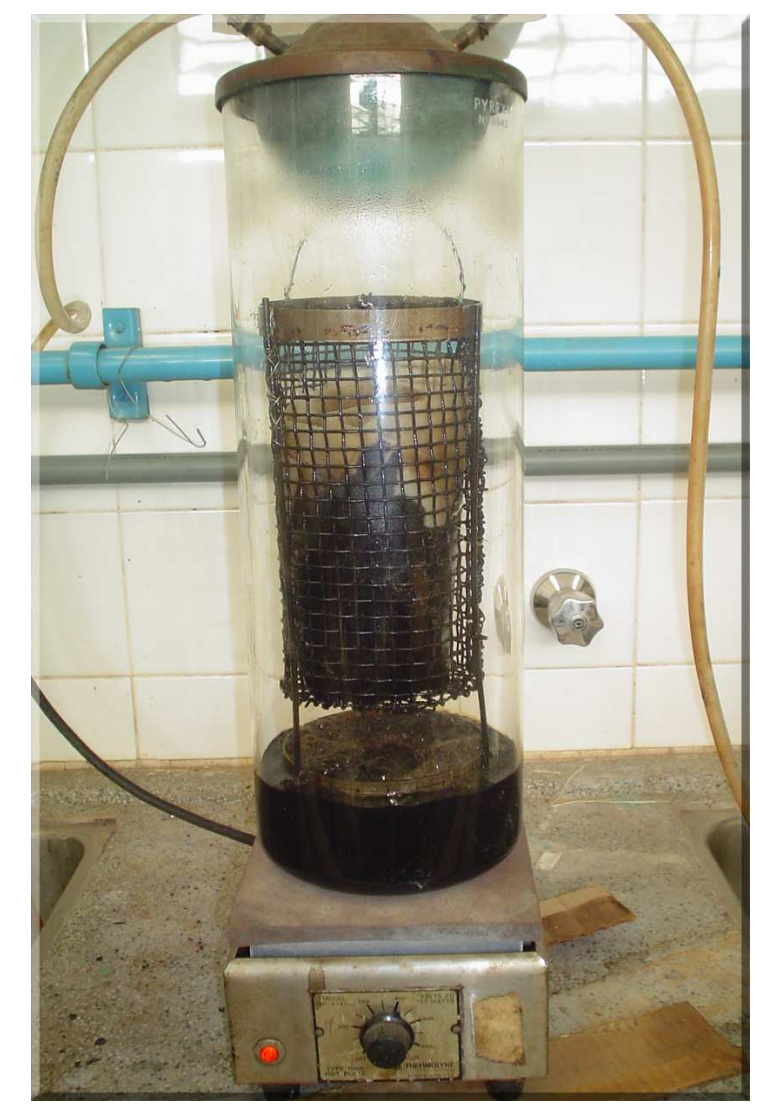

Figura 6.2: Equipamento utilizado para extração de asfalto

O processo de extração de asfalto, ilustrado na Figura 6.3, consiste em retirar o asfalto aderido às partículas de agregado, através do uso de um solvente que irá gotejar sobre a mistura, escorrendo ao fundo do recipiente misturado ao asfalto (Figura 6.3(a)). O fundo do equipamento é aquecido para que, através da fervura, promova a evaporação apenas do solvente (Figura 6.3(b)), que, ao encontrar uma superfície fria, condensa-se, tornando a gotejar sobre a amostra (Figura 6.3(c)). Esse processo se repete até que o gotejamento ao fundo do recipiente torne-se límpido e a amostra encontre-se livre de asfalto (Figura 6.3(d)). 


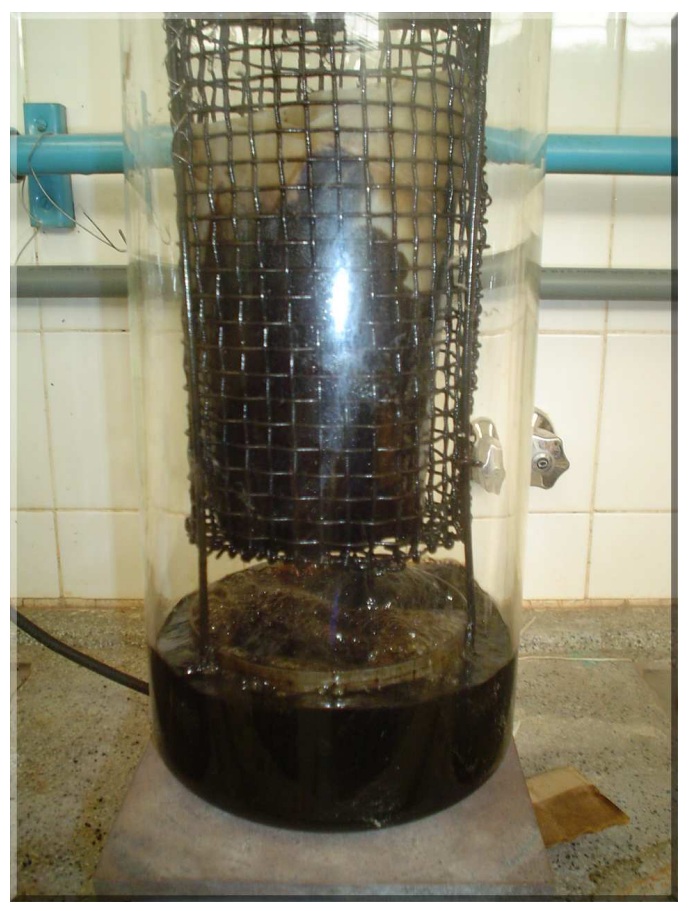

(a) Asfalto diluído

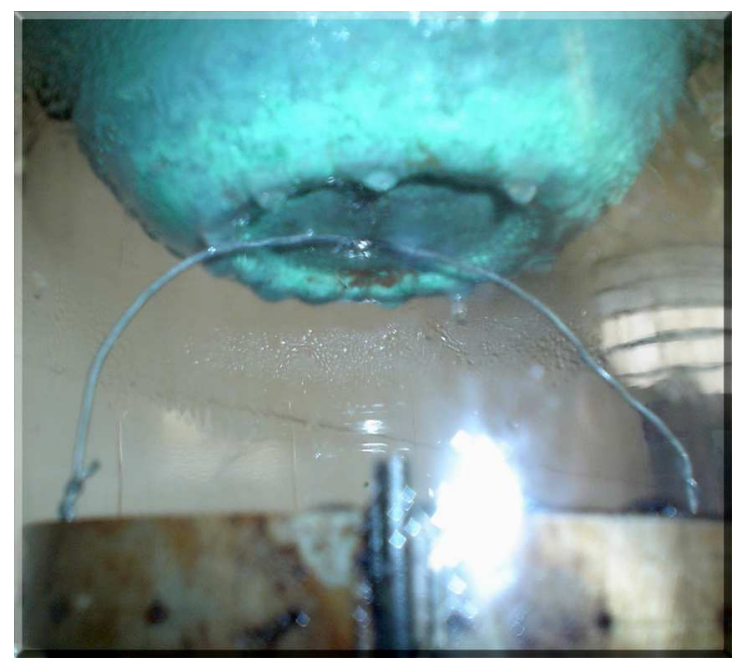

(c) Condensação

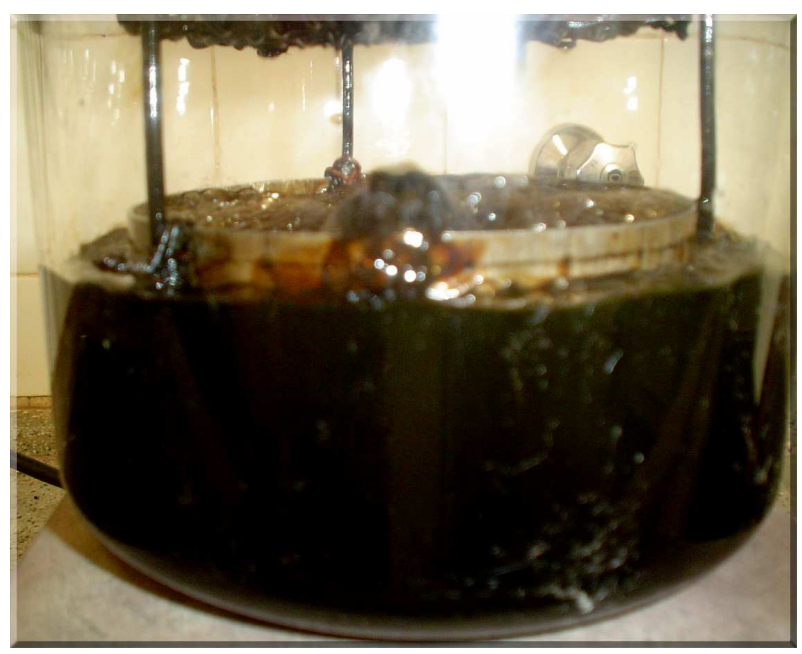

(b) Fervura

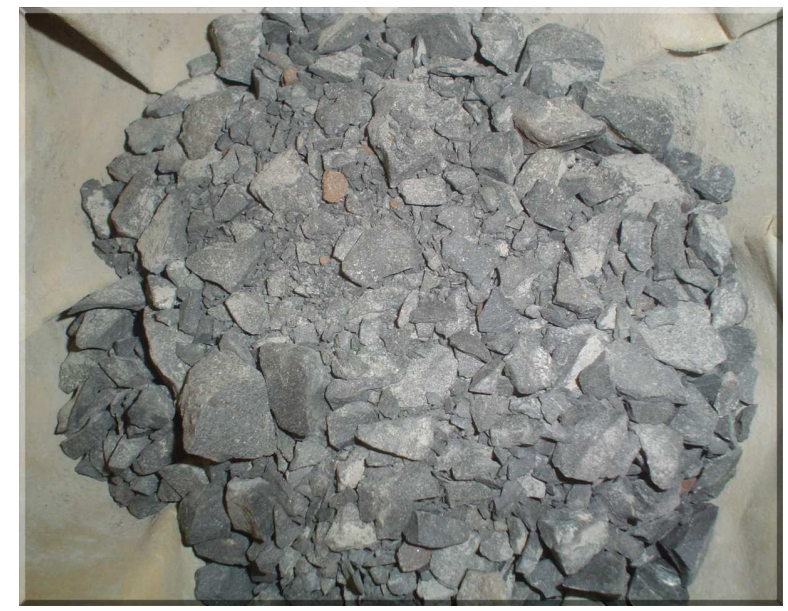

(d) Amostra sem asfalto

Figura 6.3: Processo de extração de asfalto 


\subsection{Resultados e Análises dos Resultados}

\subsubsection{Análise de Quebra de Partículas}

Na Tabela 6.1, encontram-se as porcentagens de quebra sofridas pelos agregados após a compactação com 110 e 155 golpes do soquete Marshall. Na Figura 6.4, encontram-se as curvas granulométricas obtidas após a compactação e plotadas junto com a curva granulométrica original da mistura AZR. Pode-se observar, tanto na Tabela 6.1 como na Figura 6.4, que as porcentagens de quebra das partículas foram baixas, tanto para o agregado de gabro quanto para o agregado de basalto, o que vem corroborar com os resultados bons de abrasão los angeles encontrados de 18,3\% e 16,2\%, respectivamente. Pode-se observar também que o aumento da energia de compactação de 110 para 155 golpes não alterou significativamente as porcentagens de quebras. Portanto, a preocupação inicial quanto a possíveis quebras de partículas que poderiam afetar as propriedades mecânicas das misturas e, portanto, os resultados dos ensaios mecânicos realizados (apresentados no próximo capítulo), fica descartada.

Tabela 6.1: Resultados, em porcentagem, referentes à quebra de partículas

\begin{tabular}{l|cc|cc|c}
\hline & \multicolumn{5}{c}{ Porcentagem Passante } \\
\hline & \multicolumn{3}{|c|}{ AZRg } & \multicolumn{3}{c}{ AZRb } & AZR de Projeto \\
\hline Peneiras & \multicolumn{2}{|c|}{ número de golpes } & \multicolumn{3}{c}{ número de golpes } \\
(mm) & $\mathbf{1 1 0}$ & $\mathbf{1 5 5}$ & $\mathbf{1 1 0}$ & $\mathbf{1 5 5}$ & \\
\hline 19,0 & 100 & 100 & 100 & 100 & 100 \\
12,5 & 95 & 95 & 95 & 95 & 95 \\
9,5 & 87 & 89 & 88 & 89 & 86 \\
4,75 & 63 & 64 & 62 & 62 & 61 \\
2,36 & 47 & 45 & 46 & 46 & 45 \\
1,19 & 37 & 37 & 38 & 40 & 35 \\
0,6 & 27 & 29 & 29 & 30 & 26 \\
0,3 & 20 & 21 & 21 & 19 & 19 \\
0,15 & 11 & 12 & 12 & 12 & 11 \\
0,075 & 3,6 & 4 & 4,1 & 4 & 3,5 \\
\hline \%quebra & 0,9 & 1,5 & 1,4 & 1,6 & \\
\hline
\end{tabular}

Obs.: A porcentagem de quebra corresponde à soma das diferenças, dividida pelo número de peneiras 


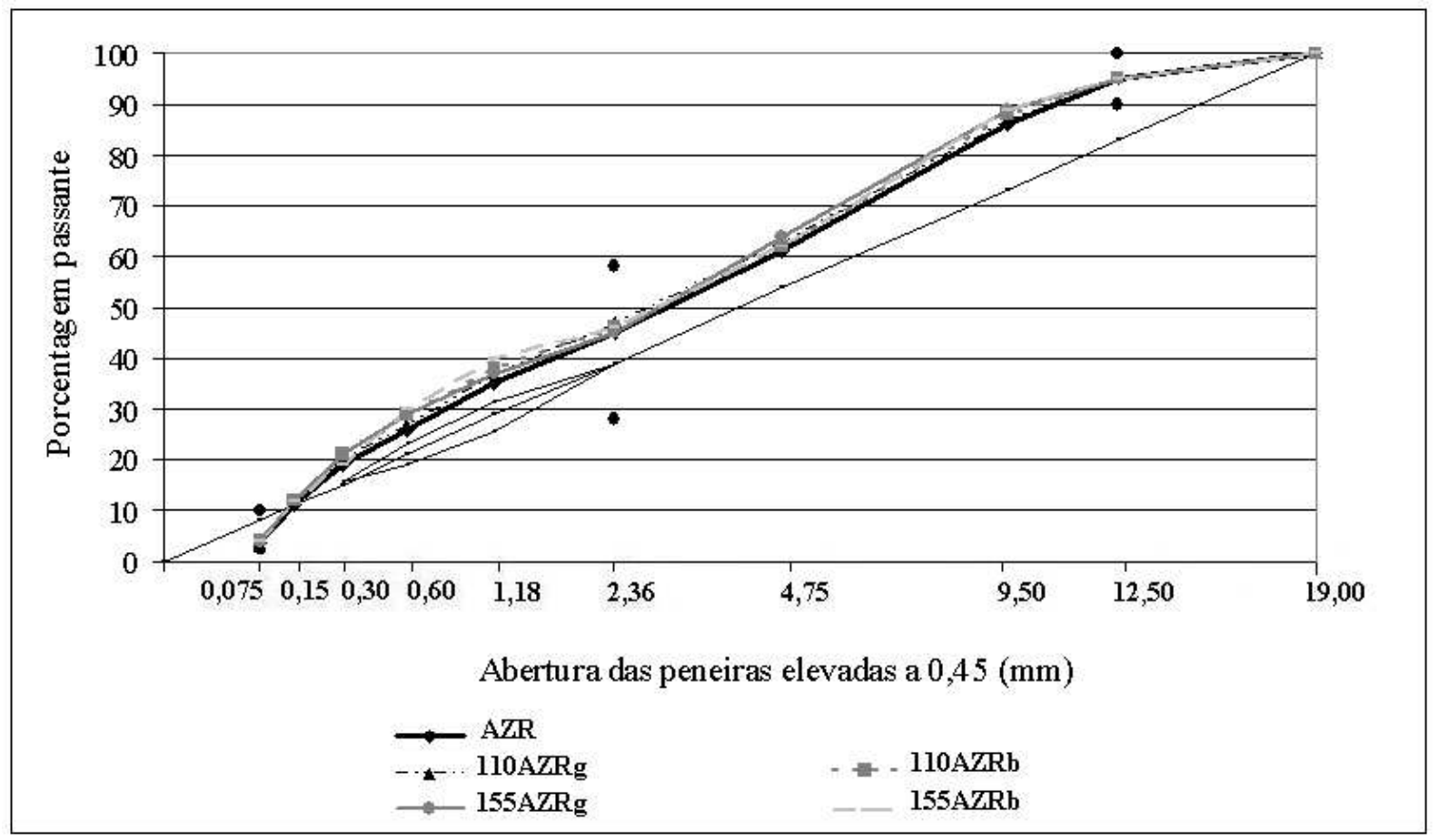

Figura 6.4: Curvas granulométricas AZRg e AZRb obtidas após compactação e curva granulométrica AZR de projeto

\subsubsection{Propriedades Volumétricas das Misturas AZR versus Energia de Compactação}

VAM

Os resultados das propriedades volumétricas, correspondentes à média entre aproximadamente 25 corpos-de-prova, compactados com 75, 110 e 155 golpes do soquete Marshall, estão apresentados na Tabela 6.2. Os resultados mostram que o aumento da energia de compactação realmente faz diminuir o VAM das misturas, ou seja, melhora o arranjo formado entre as partículas dos agregados. A mistura AZRb apresentou decréscimo em torno de 2,1\% no valor do VAM e a mistura AZRg apresentou decréscimo de aproximadamente $1 \%$ no valor do VAM (Figura 6.5).

A mistura AZRb, que apresentava o maior valor de VAM quando compactada com energia de 75 golpes por face, foi a que apresentou melhor entretecimento entre suas partículas com o aumento da energia de compactação, tornando a mistura relativamente mais densa. Já a mistura AZRg, que não apresentava VAM tão elevado quanto o da mistura AZRb, teve uma aproximação entre partículas, porém, não tão acentuada como a da mistura AZRb. Isso pode indicar que a mistura AZRb estava realmente sendo subestimada quanto à sua capacidade de arranjamento entre partículas. 
Tabela 6.2: Resultados das propriedades volumétricas das misturas AZR para energias de compactação de 75,110 e 155 golpes

\begin{tabular}{l|ccc|ccc|ccc|}
\hline & \multicolumn{7}{|c|}{ Propriedades Volumétricas } \\
\hline & \multicolumn{3}{|c|}{ VAM $(\%)$} & \multicolumn{3}{c|}{ RBV $(\%)$} & \multicolumn{3}{c|}{ Vv $(\%)$} \\
\hline Misturas & $\mathbf{7 5}$ & $\mathbf{1 1 0}$ & $\mathbf{1 5 5}$ & $\mathbf{7 5}$ & $\mathbf{1 1 0}$ & $\mathbf{1 5 5}$ & $\mathbf{7 5}$ & $\mathbf{1 1 0}$ & $\mathbf{1 5 5}$ \\
\hline AZRg & 17,0 & 16,5 & 16,0 & 74,5 & 74,9 & 74,5 & 4,3 & 4,1 & 4,1 \\
AZRb & 19,5 & 18,3 & 17,4 & 80,2 & 79,3 & 78,4 & 3,9 & 3,8 & 3,8 \\
\hline
\end{tabular}

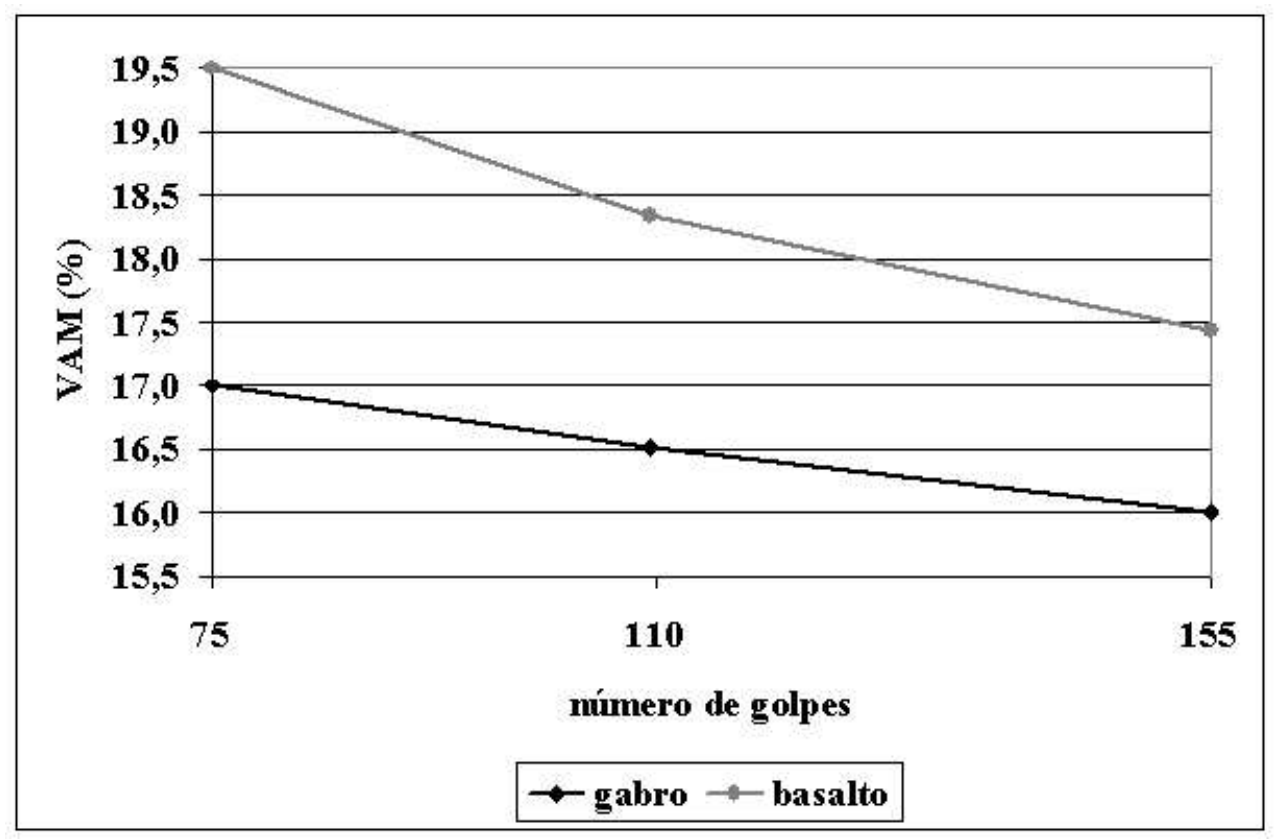

Figura 6.5: Variação dos vazios do agregado mineral das misturas AZRg e AZRb, conforme a energia de compactação aplicada

O método Marshall especifica que se utilize energia de compactação de 75 golpes em projetos de misturas destinadas a revestir rodovias com volume de tráfego alto. Considerando que essa energia de 75 golpes é suficiente e adequada para promover um arranjo forte e estável entre partículas, poder-se-ia imaginar que, ao compactar a mistura com energia de 110 golpes por face, não haveria ganhos significativos quanto à sua densificação, indicativo de que a mistura já estaria com arranjo bastante próximo entre suas partículas. Em vista dessa suposição inicial, empregar energias de compactação ainda mais elevadas (por exemplo 155 golpes) seria apenas para constatar que fora alcançado o limite de densificação das misturas. Porém, nesta pesquisa, ao aumentar a energia de compactação de 75 para 110 golpes, observou-se a elevação da densidade relativa das misturas, indicando que quando compactadas com 75 golpes estas ainda não estavam próximas de seu limite de densificação. Ao elevar ainda mais a energia de compactação, de 110 para 155 golpes, observou-se que ainda não havia sido atingido o limite de densificação das misturas. No entanto, energias de compactação ainda mais elevadas que 155 golpes não foram testadas, na tentativa de alcançar o limite de densificação, porque, mesmo 
que a mistura permitisse ser ainda mais compactada, provavelmente sua rigidez seria tão elevada que poderia prejudicar a sua vida de fadiga.

\section{RBV}

Os resultados, encontrados na Tabela 6.2, indicam que houve uma tendência de diminuição do RBV conforme o aumento do esforço de compactação. A mistura AZRb apresentou um decréscimo mais elevado de RBV comparado à mistura AZRg (Figura 6.6), porém, mesmo com 155 golpes por face, a mistura AZRb não se enquadrou na faixa de especificação Superpave. No entanto, os corpos-de-prova compactados tanto com 110 como com 155 golpes deixaram de aparentar excesso de asfalto. Essa aparência mais seca dos corpos-de-prova deve-se à diminuição do teor de asfalto efetivo da mistura e, conseqüentemente, da espessura do filme de asfalto, em decorrência da utilização de energias de compactação mais elevadas.

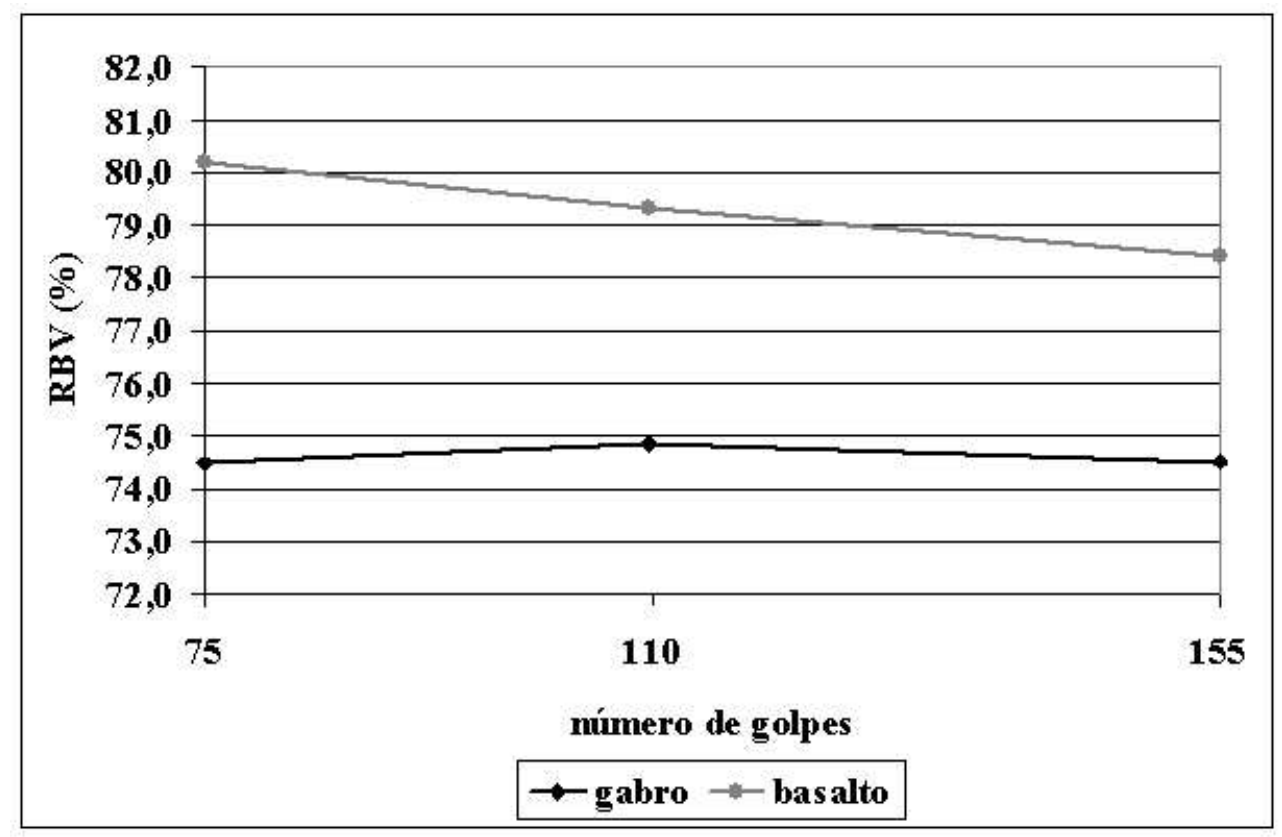

Figura 6.6: Variação da relação betume-vazios das misturas AZRg e AZRb conforme a energia de compactação aplicada

\subsubsection{Asfalto Efetivo e Espessura do Filme de Asfalto versus Energia de Compactação}

Na Tabela 6.3, estão apresentadas as variações dos valores do asfalto efetivo e da espessura do filme de asfalto, conforme a energia de compactação aplicada. O aumento da energia de compactação, tanto de 75 para 110 golpes como de 110 para 155 golpes, representou uma 
diminuição do asfalto efetivo da mistura AZRg em aproximadamente $0,1 \%$ e de $0,2 \%$, respectivamente, e uma diminuição da espessura do filme de asfalto em aproximadamente $0,3 \%$ e $0,2 \%$, respectivamente (Tabela 6.3). Já a mistura AZRb, com o aumento da energia de compactação de 75 para 110 golpes, apresentou uma diminuição do asfalto efetivo em torno de $0,5 \%$ e entre 110 para 155 golpes uma diminuição de $0,4 \%$. A espessura do filme de asfalto da mistura AZRb variou em aproximadamente $0,8 \%$ ao aumentar a energia de compactação de 75 para 110 golpes e em $0,5 \%$ ao aumentar a energia de 110 para 155 golpes. A Figura 6.7 traz as ilustrações gráficas da variação do teor de asfalto efetivo (Figura 6.7(a)) e da variação da espessura do filme de asfalto (Figura 6.7(b)), conforme a energia de compactação aplicada.

Tabela 6.3: Resultados do asfalto efetivo e da espessura do filme de asfalto, para energias de compactação de 75, 110 e 155 golpes por face

\begin{tabular}{l|ccc|ccc}
\hline & \multicolumn{3}{|c|}{ Asfalto efetivo $(\%)$} & \multicolumn{3}{c}{ Espessura do filme de asfalto $(\mu m)$} \\
\hline Misturas & $\mathbf{7 5}$ & $\mathbf{1 1 0}$ & $\mathbf{1 5 5}$ & $\mathbf{7 5}$ & $\mathbf{1 1 0}$ & $\mathbf{1 5 5}$ \\
\hline AZRg & 5,3 & 5,2 & 5,0 & 7,3 & 7,0 & 6,8 \\
AZRb & 6,5 & 6,0 & 5,6 & 8,9 & 8,1 & 7,6 \\
\hline
\end{tabular}

\subsubsection{RBV sob Nova Óptica}

Os limites mínimos e máximos de RBV estabelecidos pelo Superpave podem ser analisados de maneira inversa. Através do controle do VAM dentro de determinados limites, poder-se-ia assegurar que os valores mínimos e máximos do RBV especificados pelo Superpave fossem respeitados. Por exemplo, para manter os valores de RBV entre 65 e $75 \%$, considerando-se um volume de vazios de $4 \%$, as misturas deveriam ter valores de VAM entre $11,5 \%$ e $16 \%$.

Em vista disso, poder-se-ia conceber que misturas com granulometrias adequadas, produzidas com agregados altamente angulares e rugosos, que apresentem valores de RBV acima do limite máximo estabelecido pelo Superpave, devessem ser submetidas a esforços maiores de compactação para vencer a resistência à compactação imposta por suas partículas, diminuindo o VAM para valores entre 11, 5 e 16\%. Esta pesquisa mostra que a mistura AZRb, mesmo quando submetida a 155 golpes por face do corpo-de-prova, continuou apresentando RBV acima do especificado $(78,4 \%)$. Em outras palavras, mesmo com uma energia de compactação tão elevada não foi possível diminuir o VAM da mistura AZRb para valores dentro desse intervalo. Isso parece indicar que os limites de RBV estabelecidos pelo Superpave são inadequados para misturas produzidas com agregados altamente angulares e rugosos, representativos de muitos dos agregados brasileiros. 


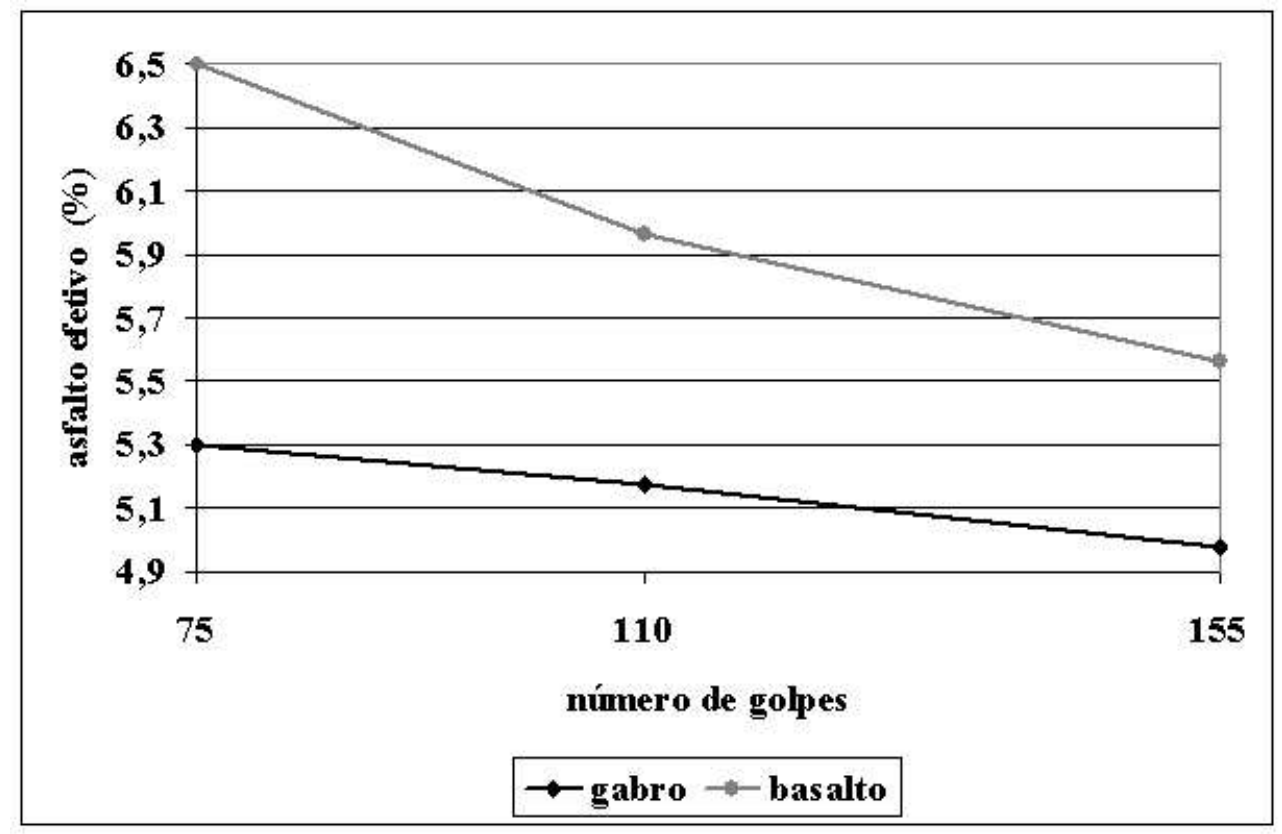

(a) Variação do asfalto efetivo com a energia de compactação

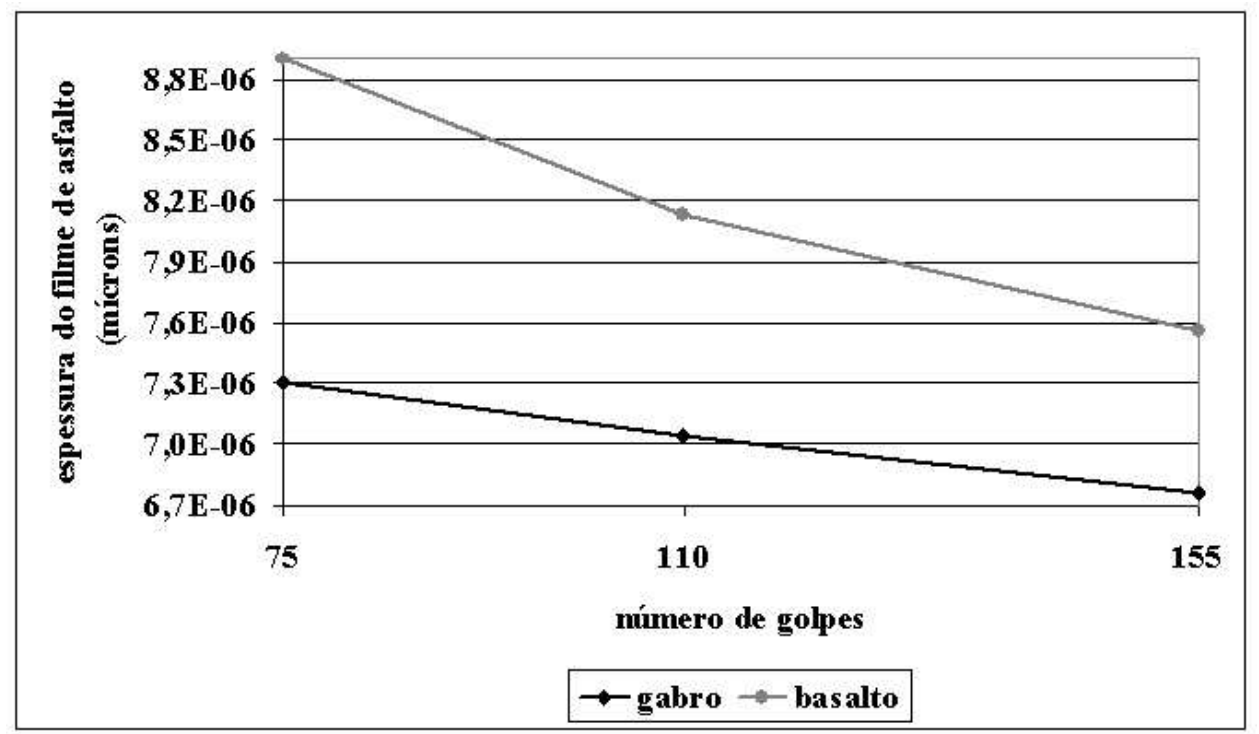

(b) Variação da espessura do filme de asfalto com a energia de compactação

Figura 6.7: Variação do asfalto efetivo e espessura do filme de asfalto das misturas AZRg e AZRb, conforme a energia de compactação aplicada 
Assim como as especificações Superpave para agregados, os valores limites das propriedades volumétricas das misturas foram escolhidos às pressas, apenas com base no conhecimento de especialistas locais estadunidenses, ou melhor, com base na experiência que absorveram utilizando agregados locais. É de conhecimento comum que os tipos de agregados normalmente utilizados nos EUA em pesquisas e também em pavimentação são diferentes dos agregados mais comumente pesquisados e utilizados na pavimentação de rodovias brasileiras. A exemplo, a norma NBR 12891, desenvolvida com base na experiência adquirida através da produção de misturas asfálticas com agregados nacionais, especifica valores de RBV entre 75 a $82 \%$, valores estes bem mais elevados que os praticados nos EUA, de 65 a $75 \%$, para misturas Marshall projetadas para tráfego alto. Portanto, considerando as características dos agregados nacionais estudados, que possuem angularidades elevadas e texturas superficiais bastante rugosas, os valores de RBV especificados pelo Superpave estão inadequados.

Apesar da importância do VAM para o controle da densidade relativa das misturas (arranjo entre partículas) e do teor de asfalto efetivo, essa propriedade só passou a fazer parte da norma brasileira de dosagem de misturas pelo Método Marshall em 2004 (DNIT 0312004 - ES). No entanto, para estipular valores limites adequados para o VAM e RBV, faz-se necessário ampliar os estudos, com amostragens amplas de agregados nacionais, considerando o VAM em função das características dos agregados e também em função do grau de compactação da mistura.

\subsection{Conclusões}

- As porcentagens de quebra de partículas foram baixas, tanto para o agregado de gabro quanto para o agregado de basalto, com a elevação da energia de compactação;

- A elevação da energia de compactação de 75 para 110 ou de 75 para 155 golpes não alterou significativamente as porcentagens de quebra das partículas;

- A elevação da energia de compactação promoveu a diminuição do VAM das misturas;

- A mistura AZRb, a qual apresentou o valor mais elevado de VAM quando compactada com 75 golpes por face, teve o decréscimo mais significativo de VAM com o aumento da energia de compactação, indicando que suas partículas, angulosas e rugosas, arranjaram-se de maneira mais próxima, aumentando a densidade relativa da mistura;

- A mistura AZRg, que não apresentava VAM tão elevado quanto a mistura AZRb, também teve uma aproximação entre partículas com o aumento da energia de compactação, porém, não tão acentuada; 
- A elevação da energia de compactação promove a diminuição do asfalto efetivo e da espessura do filme de asfalto das misturas;

- A mistura AZRb apresentou um decréscimo elevado de RBV, se comparada à mistura AZRg, porém, mesmo recebendo 155 golpes em cada face do corpo-de-prova Marshall, a mistura AZRb continuou não se enquadrando nos limites de RBV estabelecidos pelo Superpave;

- Para as misturas Marshall produzidas com os agregados brasileiros estudados, que apresentam angularidades elevadas e texturas superficiais rugosas, os valores de RBV especificados pelo Superpave mostraram-se inadequados.

\subsection{Considerações Finais}

Os especialistas do Strategic Highway Research Program (SHRP) estabeleceram, através de uma escala de notas, quais das propriedades volumétricas das misturas que deveriam ser consideradas e incorporadas pelo Superpave. A média das notas, dadas pelos especialistas e publicadas por Cominsky et al. (1994) (SHRP A-408), podem ser vistas na Tabela 6.4. Ao analisar a pontuação, parece claro que o VAM foi considerado como uma propriedade importante, no entanto, o RBV não. O Vv e o VAM tiveram aceitação forte, porém, o RBV e a porcentagem de fíler (dust asphalt ratio) tiveram aceitação neutra e a espessura do filme de asfalto teve aceitação baixa.

Provavelmente, sob a influência da publicação do relatório SHRP A-408, no mesmo ano de 1994, o Asphalt Institute reintroduziu o RBV como critério de projeto de misturas Marshall, mesmo este não sendo um critério muito popular entre os especialistas do SHRP, e alterou o Vv para $4 \%$, assim como introduziu o VAM como função do Vv e do diâmetro máximo nominal (Coree \& Hislop, 1998).

A experiência adquirida nesta pesquisa mostra que se fosse utilizado o critério do RBV, a mistura AZRb não seria adequada aos propósitos de pavimentação por apresentar excesso de asfalto. Mesmo aumentando a energia de compactação, ainda assim a mistura AZRb continuaria apresentando excesso de asfalto, sob a óptica do RBV. Se fosse utilizado o critério de espessura do filme de asfalto, essa mistura seria considerada adequada, pois apresentou, mesmo para 75 golpes, espessura de $8,9 \mu m$, apropriada para uma mistura densa. 
Tabela 6.4: Resumo classificatório das notas dadas pelos especialistas do SHRP para as características das misturas asfálticas

\begin{tabular}{lccc}
\hline Características & Média $^{b}$ & desvio padrão & "melhor" maneira de determinação \\
\hline VV & 6,77 & 0,44 & método Rice \\
VAM & 6,15 & 0,90 & densidade aparente do agregado \\
RBV & 4,00 & 1,68 & não definida \\
Dust asphalt ratio & 4,46 & 1,85 & não definida \\
Esp. do filme de asfalto & 3,31 & 1,89 & MS-2 Procedure $^{a}$ \\
\hline
\end{tabular}

${ }^{a}$ Método que considera o teor efetivo de asfalto e área superficial do agregado

${ }^{b}$ escala de notas:

1 - desacordo total

2 - desacordo forte

3 - desacordo

4 - neutro

5 - concordância

6 - concordância forte

7 - concordância total

Existe muita polêmica quanto ao melhor critério a ser usado para garantir durabilidade à mistura, VAM e RBV ou espessura do filme de asfalto. McLeod (1957), defensor principal do uso do VAM para garantir durabilidade à mistura, afirma que para uma mistura compactada com 3 a $5 \%$ de Vv, deveria ser requerido apenas um VAM mínimo de 15\%, pois especificar RBVs entre "75 e 85\%" seria muito restritivo. Vale notar que o limite de RBV que McLeod (1957) achava restritivo demais, por não permitir que uma quantidade suficiente de asfalto fosse adicionada à misturas Marshall para garantir-lhes durabilidade, é bem superior ao especificado pelo Superpave.

Outros pesquisadores, como Kandhal et al. (1998), afirmam que misturas asfálticas duráveis estão diretamente relacionadas com a espessura da película de asfalto que envolve o agregado. De acordo com esses pesquisadores, o VAM mínimo deveria ser baseado na espessura mínima da película de asfalto ao invés de uma quantidade mínima de asfalto necessária dentro da mistura, pois a quantidade mínima de asfalto difere entre misturas que contêm agregados com características de superfície e granulometrias diferentes.

Já que o propósito da utilização do VAM é propiciar que pelo menos uma quantidade mínima de asfalto seja adicionada à mistura, garantindo-lhe assim durabilidade, parece mais racional que seja realmente utilizada uma espessura mínima de película de asfalto, pois, dessa maneira, estaria sendo considerado o que realmente interessa, o quanto de asfalto está envolvendo cada partícula do agregado. No entanto, quão válida pode ser a espessura do filme de asfalto cal- 
culada simplesmente pela divisão da área superficial do agregado pelo teor de asfalto efetivo da mistura? É improvável que todas as partículas na mistura tenham a mesma espessura de película envolvendo-as. Partículas de agregados mais grossas podem ou não ter espessura de filme de asfalto mais finas que partículas mais finas e, algumas partículas muito finas, podem ser simplesmente incorporadas ao asfalto. Além de que, apesar de existirem muitas formas de estimar a área superficial dos agregados, as mais comumente utilizadas partem do pressuposto de que as partículas têm textura superficial lisa e que são completamente esféricas, o que obviamente é origem de erros apreciáveis. No entanto, outras formas de estimar a área superficial dos agregados podem ser utilizadas, mas geralmente são muito complexas e/ou exigem equipamentos sofisticados. Portanto, utilizando a forma atual e mais comum de cálculo, o termo espessura do filme de asfalto é enganoso e de difícil definição.

Dúvidas permanecem quanto ao melhor critério a ser usado para permitir que uma quantidade suficiente de asfalto seja adicionada à mistura, porém, o VAM pode ser um critério adequado se, ao utilizá-lo, for levado em conta as propriedades de superfície das partículas de agregado e o grau de compactação adequado a cada mistura. 



\section{CAPÍTULO}

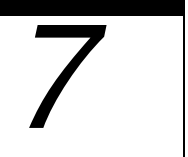

\section{Propriedades Mecânicas e de Adesividade das Misturas Asfálticas}

\subsection{Considerações Iniciais}

O pavimento pode ser entendido como um sistema de camadas sujeitos às cargas dos veículos que causam tensões, deformações e deslocamentos a essas camadas. Como parte integrante desse sistema de camadas tem-se a camada de revestimento, objeto de estudo desta pesquisa, responsável por receber a ação do rolamento dos veículos, além de propiciar comodidade e segurança àqueles que trafegam pelo pavimento. Essa explanação exprime aquilo que foi historicamente o propósito da pavimentação no mundo, desde a construção das primeiras estradas.

O desempenho de uma camada de revestimento asfáltico está relacionado diretamente à resposta da mistura à ação das cargas. O agregado é responsável por formar a estrutura de sustentação ou o esqueleto estrutural da mistura, cuja função é resistir majoritariamente à compressão e ao movimento das cargas dos veículos. Portanto, as propriedades dos agregados estão intimamente ligadas à capacidade de sustentação do esqueleto estrutural formado e, conseqüentemente, intimamente relacionadas aos parâmetros de desempenho dos pavimentos, tais como: deformação permanente, trincas por fadiga e desgaste. 


\subsection{Deformação Permanente}

A Pesquisa sobre o Inter-relacionamento dos Custos Rodoviários (PICR), desenvolvida pelo GEIPOT em 1982, mostra que na década de 1970 a deformação permanente não era um problema grave para os pavimentos brasileiros. Atualmente, em função do aumento do volume de tráfego e, principalmente, da evolução tecnológica da modalidade rodoviária, que permitiu maiores cargas por eixo, maiores pressões de enchimento dos pneus e novos tipos de pneus e de rodagem (pneus extralargos), a deformação permanente tem merecido toda a atenção no dimensionamento e dosagem de misturas asfálticas e tem condicionado muitos projetos de reabilitação de pavimentos. Nos dias atuais, o acúmulo de deformação permanente nas trilhas de roda tornou-se uma das principais formas de deterioração dos pavimentos flexíveis brasileiros, a exemplo do que ocorre há várias décadas nos Estados Unidos e na Europa (Figura 7.1).

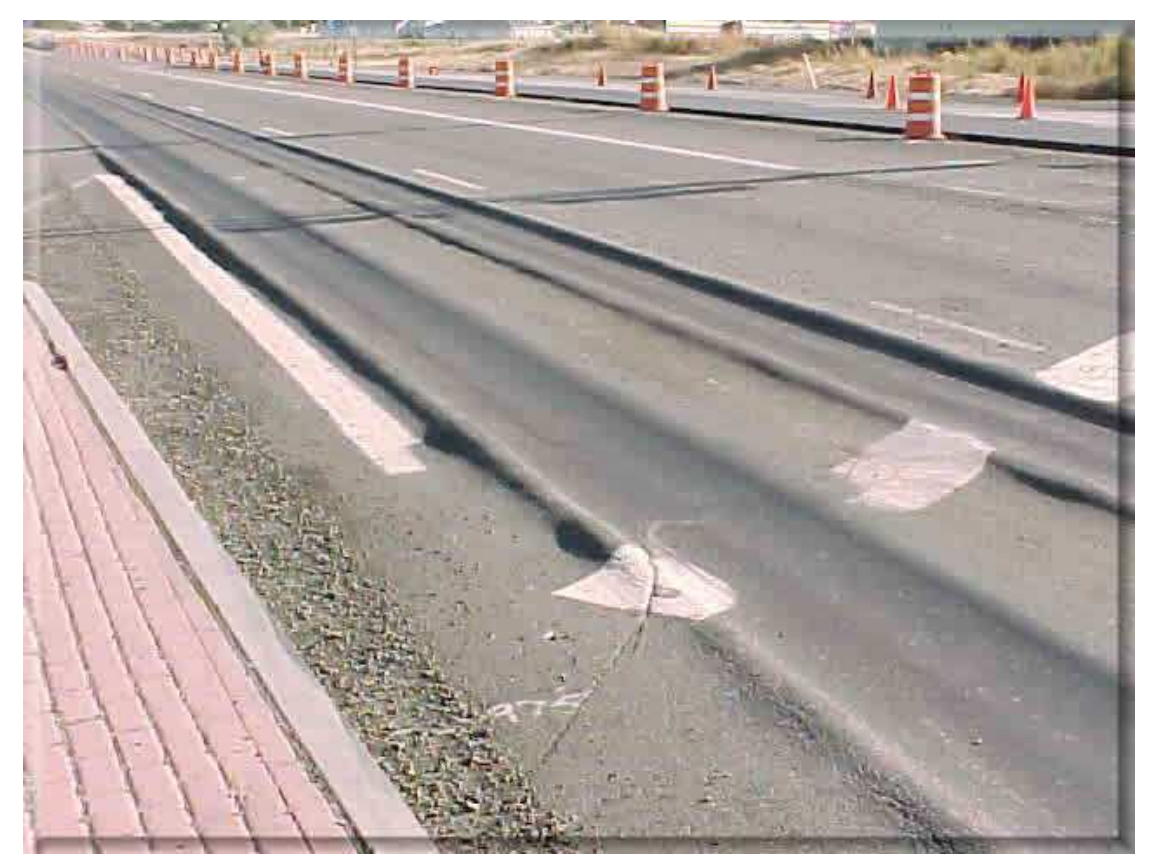

Figura 7.1: Exemplo de deformação permanente associada a problemas na mistura asfáltica

Estudos realizados por Parker Jr. \& Brown (1992) mostram que a pressão de enchimento dos pneus dos caminhões e, conseqüentemente, a pressão de contato dos pneus com o pavimento, têm aumentado, estando muito acima dos $550 \mathrm{kPa}$ (75 psi), valor de referência do AASHTO Road Test. A média de pressão dos pneus utilizada atualmente é de $700 \mathrm{kPa}$ (100 psi), com uma parcela grande de caminhões usando pressões de pneus ainda maiores, entre 900 e $960 \mathrm{kPa}$ (120 e 130 psi).

A deformação permanente desenvolve-se gradualmente com o aumento das solicitações das cargas por eixo e geralmente aparece sob a forma de depressões longitudinais nas faixas de 
rodagem (trilhas de roda), acompanhadas ou não de elevações laterais ao longo dessas faixas. A variação longitudinal da magnitude da deformação permanente causa irregularidades ao pavimento, tornando a via menos segura e causando desconforto ao usuário, além de aumentar os custos de operação dos veículos. A falta de segurança é mais explícita em dias chuvosos, quando a água passa a acumular-se nas depressões longitudinais das faixas de rodagem, diminuindo o atrito pneu/pavimento. Como consequiência, há redução da resistência à derrapagem e aumento do potencial de hidroplanagem, além do indesejável spray, que reduz a visibilidade dos motoristas.

Geralmente, incutem-se como causas da deformação permanente a ação combinada de densificação (compactação pelo tráfego) e de deformação por cisalhamento, ambas podendo ocorrer em uma ou mais camadas do pavimento, inclusive no próprio subleito. A parcela de deformação permanente causada pela densificação refere-se à compactação adicional da camada asfáltica devida à ação do tráfego, caracterizada pela diminuição do volume da camada, sem movimento relativo entre as partículas senão a aproximação entre elas. Isso ressalta a importância da compactação da camada para obtenção de rigidez inicial suficiente.

A parcela de deformação causada por cisalhamento resulta em um fluxo plástico lateral à trilha de roda. Segundo Roberts et al. (1991), esse tipo de deformação é causado por misturas que apresentam rigidez insuficiente para resistir à passagem das cargas atuantes no pavimento.

A rigidez das misturas asfálticas pode ser afetada por vários fatores, dentre eles, a temperatura. Variações diárias e sazonais da temperatura causam variações na rigidez das misturas, ou seja, a deformabilidade maior ou menor do pavimento está condicionada às variações da temperatura do ar ou das condições meteorológicas de um modo geral (Medina, 1997). Misturas menos suscetíveis às variações de temperatura apresentam esqueleto estrutural resistente, pois, principalmente nos meses quentes de verão, quando a viscosidade do asfalto está mais baixa, as cargas do tráfego são suportadas principalmente pela estrutura e capacidade de intertravamento dos agregados. Dessa forma, independentemente da origem, método de processamento ou mineralogia, espera-se que o agregado seja resistente (duro e durável) e que tenha características de forma, angularidade e textura superficial adequadas para a formação de um esqueleto estrutural resistente às aplicações de cargas repetidas.

Em uma mistura apenas de agregados, os fatores principais que interferem em sua resistência ao cisalhamento são: compacidade, tamanho, angularidade, textura superficial das partículas e granulometria. A influência da compacidade pode ser percebida quando os materiais granulares mais compactos apresentam maior rigidez que os materiais granulares fofos. Quanto ao 
tamanho das partículas, tem-se observado que materiais granulares grossos apresentam maiores ângulos de atrito do que os materiais finos. Nota-se, também, que materiais granulares compostos de partículas angulares apresentam ângulos de atrito mais elevados do que materiais granulares formados por partículas menos angulares, assim como partículas mais rugosas apresentam ângulos de atrito maiores do que partículas mais lisas. Quanto à granulometria, sabe-se que agregados bem graduados oferecem melhores oportunidades de entrosamento entre suas partículas, que resultam em uma estrutura granular mais compacta (melhor arranjada) e, conseqüentemente, mais rígida que uma estrutura formada por agregados mal graduados (Bueno \& Vilar, 1985).

Ao adicionar asfalto às misturas de agregados passa-se a considerar um número maior de fatores que interferem na rigidez da mistura asfáltica formada. Por exemplo, do ponto de vista apenas do asfalto, um decréscimo da quantidade de asfalto pode elevar a rigidez da mistura, mas, por sua vez, causar a diminuição de sua durabilidade e de resistência à fadiga. Analogamente, o aumento da viscosidade do asfalto pode enrijecer a mistura, porém, pode aumentar sua suscetibilidade às trincas for fadiga. Portanto, vários pesquisadores, dentre eles Parker Jr. \& Brown (1992), são defensores de que mudanças nas propriedades dos agregados geralmente são alternativas mais indicadas para alterar a rigidez das misturas e garantir desempenho adequado ao pavimento.

Misturas mais rígidas são produzidas ao utilizar agregados compostos por partículas, em sua maioria, angulares e com textura superficial rugosa (Cross \& Brown, 1992; Button et al., 1990). Os resultados obtidos por Button et al. (1990) mostram que misturas asfálticas compostas por agregados de areia natural com formas arredondadas e angularidade baixa deformam-se plasticamente, sob a ação de cargas estáticas ou dinâmicas, muito mais rapidamente que misturas de graduação similar contendo somente partículas angulares.

Também no estudo realizado por Kim et al. (1992) a mesma conclusão foi obtida, ou seja, ao investigar a influência do tipo do agregado e da granulometria na resistência à deformação permanente das misturas, em função dos fatores tipo do agregado, granulometria, tipo de asfalto (maior e menor suscetibilidade térmica), teor de asfalto, volume de vazios, temperatura e nível de tensão aplicada, os pesquisadores concluíram que o tipo do agregado afeta diretamente a estabilidade da mistura e que o melhor intertravamento entre partículas mais angulares resulta em deformações permanentes menores. Os resultados mostraram também que mudanças nas proporções das frações fina e grossa dos agregados com um mesmo diâmetro máximo nominal não afetam a deformação permanente. Um fato curioso observado pelos pesquisadores foi que o efeito das outras variáveis (como o tipo de asfalto, volume de vazios e temperatura) 
na estabilidade da mistura foi mais pronunciado em misturas produzidas com agregados com angularidade baixa e com textura superficial lisa. Os pesquisadores justificaram a ocorrência desse fato devido, provavelmente, à capacidade de suporte das misturas, prejudicada pelo intertravamento fraco entre as partículas de agregados com angularidade baixa e textura superficial lisa, depender muito mais da viscosidade do asfalto do que misturas com agregados mais angulares que proporcionam intertravamento melhor entre suas partículas formando um esqueleto estrutural resistente.

\subsection{Trincas por Fadiga}

A fadiga é um fenômeno pelo qual a estrutura da camada asfáltica é gradualmente enfraquecida pela ação repetida da aplicação de tensões menores que a tensão de ruptura. As trincas por fadiga e rupturas são causadas pelo movimento da carga das rodas, que produzem alternadamente tensões de compressão e de flexão (Maupin, 1970). As trincas iniciam-se geralmente na parte inferior do revestimento asfáltico, propagando-se para cima até atingir a superfície (Figura 7.2).

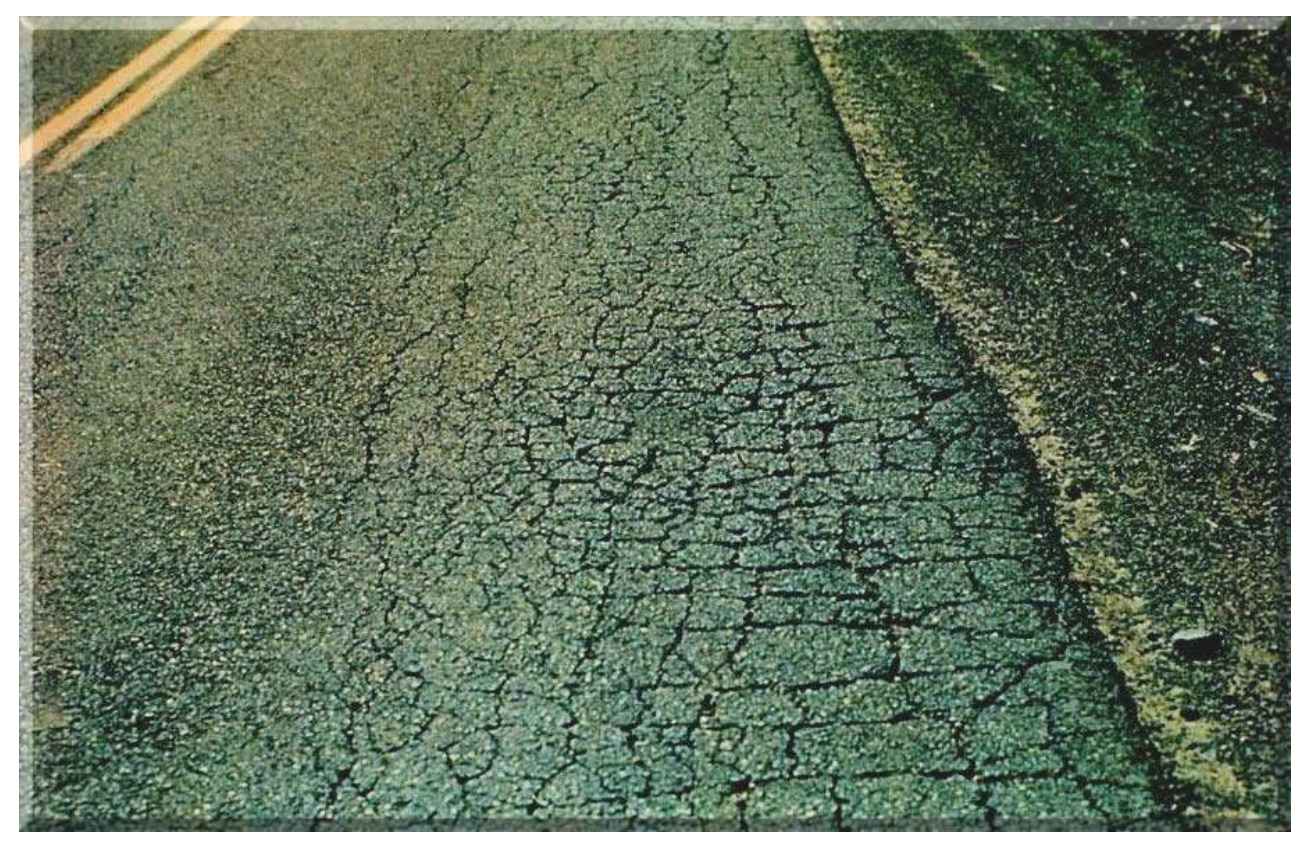

Figura 7.2: Exemplo de trincas por fadiga

Inicialmente, a trinca por fadiga não foi reconhecida como um fenômeno devido à ação de cargas repetidas, mas sim como um mero envelhecimento do pavimento. No entanto, por volta da década de 1950, pesquisadores como Hveem passaram a incutir como causa dessas trincas a ação repetida de flexão das camadas asfálticas sobre bases resilientes (Maupin, 1970). 
Hveem entendia que o trincamento progressivo da camada asfáltica se devia à deformação resiliente (elástica) das camadas subjacentes. Hveem passou a utilizar o termo deformação resiliente ao invés de deformação elástica, em virtude das deformações elásticas relativas a pavimentos serem muito maiores do que as deformações que ocorrem em sólidos elásticos como concreto e aço, por exemplo. O termo resiliência significa energia armazenada num corpo deformado elasticamente, a qual é devolvida quando cessam as tensões causadoras das deformações (Medina, 1997).

As investigações de Hveem relacionaram trincas por fadiga, magnitude de deflexão e rigidez do pavimento, indicando que, se bem projetado, o pavimento deve ser capaz de resistir às deflexões, ou melhor, ter rigidez suficiente para reduzir as deflexões a níveis aceitáveis (Maupin, 1970). Como visto anteriormente, a rigidez da mistura pode ser afetada tanto pelo asfalto quanto pelo agregado utilizado na mistura. Geralmente, atribui-se um peso maior à influência que o asfalto exerce sobre o desempenho à fadiga das misturas, mas, como o agregado é o objeto de estudo desta pesquisa, seus efeitos sobre a fadiga é que serão investigados.

Maupin (1970) ao realizar pesquisas sobre os efeitos da forma e da textura dos agregados no comportamento à fadiga obteve evidências de que misturas produzidas com agregados com formas mais arredondadas apresentam vida de fadiga maior que misturas produzidas com agregados com formas cúbicas e lamelares, ou seja, a vida de fadiga tende a decrescer com o aumento da rigidez da mistura. A explicação desse fato foi vislumbrada ao seccionar as misturas produzidas com agregados de forma arredondada, cúbica e lamelar, revelando que agregados com partículas lamelares e cúbicas apresentavam uma melhor estrutura de intertravamento entre suas partículas, enquanto as partículas arredondadas e com angularidade baixa pareciam "flutuar" entre o material asfáltico. Maupin explica que quando uma mesma tensão é aplicada, misturas produzidas com partículas que proporcionam maior intertravamento podem transmitir tensões maiores ao filme de asfalto que envolve essas partículas, resultando em uma vida de fadiga menor da mistura.

Maupin (1970) cita o trabalho de Monismith ${ }^{1}$, que apresenta resultados que mostram que as misturas produzidas com partículas britadas (angulares) têm vida de fadiga maior que misturas produzidas com partículas não britadas. Maupin relata como possível explicação para esse desacordo o fato de que Monismith obteve volumes de vazios mais elevados para as misturas produzidas com agregados britados comparados aos obtidos com as misturas produzidas com agregados não britados e, conseqüentemente, as misturas com Vv mais elevados seriam mais flexíveis e, portanto, mais resistentes à fadiga.

\footnotetext{
${ }^{1}$ Monismith, C. L. (1965) Asphalt Mixture Behavior in Repeated Flexure. California Div. Of. Highways, Rept. TE-65-9
} 
Kim et al. (1992), ao desenvolver pesquisas sobre os efeitos do tipo do agregado na vida de fadiga das misturas, investigaram cinco fatores: tipo do agregado, onde são testados agregados com textura superficial rugosa e agregados com textura superficial lisa; tipo de asfalto; teor de asfalto; volume de vazios e variação da temperatura. Os resultados obtidos mostram que as misturas contendo agregados com textura superficial rugosa são mais resistentes à fadiga, indicando que a textura rugosa confere à partícula uma superfície mais adequada para proporcionar a aderência do asfalto às partículas e o resultado dessa interface melhor na união asfalto agregado é uma resistência à fadiga mais elevada. Exames cuidadosos nas superfícies de ruptura, após os ensaios de fadiga, revelaram que a ruptura (fratura) ocorrida nas misturas contendo agregados de textura superficial lisa se dava através da interface entre o agregado e o asfalto, provavelmente devido à união fraca entre o asfalto e a superfície lisa do agregado. Por outro lado, a fratura em misturas contendo agregados com superfície rugosa progrediu através das partículas dos agregados grossos, indicando uma união muito forte entre o asfalto e o agregado.

\subsection{Desgaste}

O desgaste é um dos responsáveis pelo surgimento de defeitos como panelas e buracos, que são atribuídos à desagregação da camada de rolamento. A desagregação é caracterizada pela desintegração da camada de revestimento que ocorre a partir da superfície do pavimento, iniciando-se com a perda de finos e progredindo, com a ação do tráfego, para o deslocamento de partículas maiores do agregado. A desagregação é precedida pela perda de adesividade entre as partículas de agregado e o asfalto. Dentre as causas que levam à desagregação podem ser citadas a presença excessiva de finos, a segregação e a densificação baixa da camada de revestimento.

A desagregação pode ocorrer quando há excesso de finos na mistura de agregados, evidenciado por uma cobertura de pó sobre as partículas. Essa cobertura de pó torna-se danosa à mistura quando se apresenta grossa o suficiente para que o filme de asfalto una-se à ela em vez de unir-se ao agregado. A segregação também é causa de desagregação da camada por proporcionar a diminuição dos pontos de contato entre partículas, ou melhor explicando, em áreas segregadas da camada asfáltica, a parcela maior de contato entre as partículas se dá entre agregados grossos unidos pontualmente pelo asfalto e, com o passar do tempo, o endurecimento (envelhecimento) do asfalto, além da presença de umidade, podem comprometer essa ligação pontual asfalto/agregado e vir a ocasionar sua quebra, com posterior remoção das partículas pela passagem dos veículos. A desagregação pode ocorrer, também, devido à baixa densidade da capa asfáltica, resultado de uma compactação inadequada. Quando a compactação da camada 
asfáltica é insuficiente, a coesão entre as partículas do agregado envoltas pela película adesiva de asfalto também é insuficiente, tornando a mistura propensa a desagregar durante a passagem de veículos.

Outro defeito, mais difícil de ser detectado, é o descolamento da película de asfalto do agregado na presença de umidade, denominado stripping em língua inglesa. O stripping geralmente inicia-se na parte inferior da camada de rolamento, devido aos esforços de tração resultantes da passagem dos veículos, progredindo até a superfície (Figura 7.3).

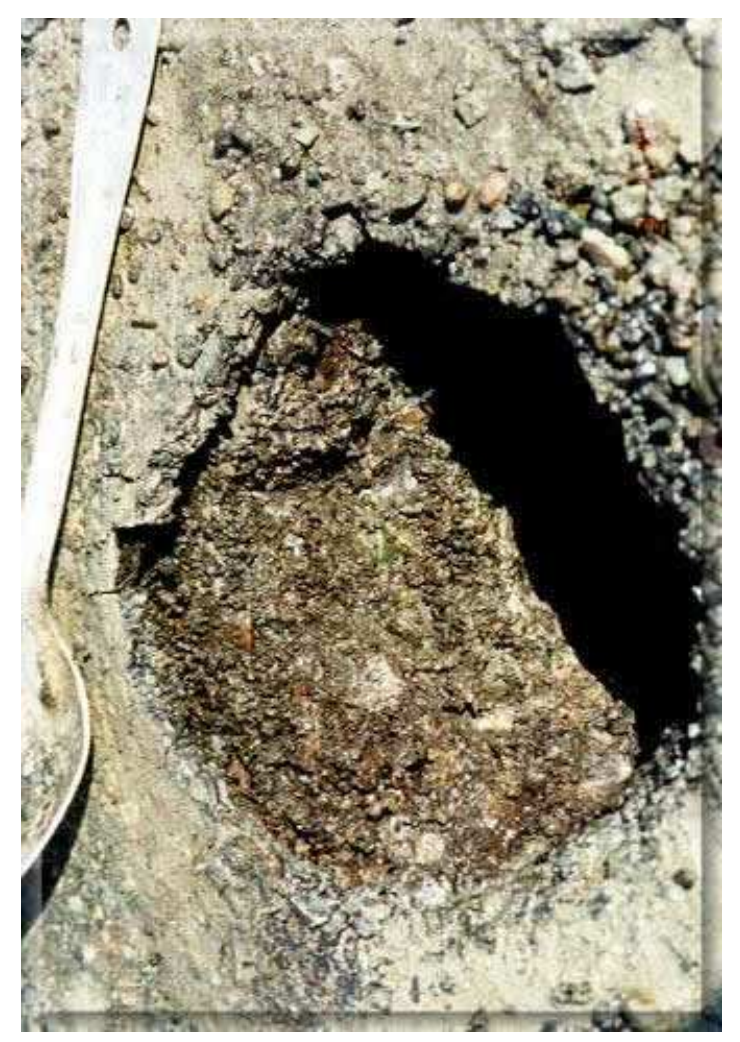

Figura 7.3: Exemplo de perda de adesividade entre o asfalto e o agregado na presença de água

Tanto na desagregação como no stripping, o problema é a perda de adesividade, devido a uma ligação adesiva deficiente, que pode estar aliada a uma solicitação capaz de descolar o asfalto do agregado, ou ainda à ação da água na interface asfalto/agregado. O problema da perda de adesividade entre o asfalto e o agregado é complexo e dependente de muitas variáveis, incluindo o tipo e o uso da mistura, as características do asfalto, as características do agregado, os fatores climáticos, o tráfego, as práticas de construção e o uso de aditivos para melhorar a adesividade. Entretanto, a presença de umidade é um fator comum. Na literatura, verifica-se que a perda de adesividade entre o agregado e a película de asfalto tem como causas principais a influência da umidade, a mineralogia e a composição química do agregado. Mas, os estudos realizados nesta pesquisa mostram evidências de que outro fator também pode influenciar a adesividade entre o asfalto e o agregado, a absorção de asfalto. 


\subsection{Experimentos Laboratoriais}

As propriedades mecânicas das misturas AZRg, AZRb, Bg e Bb foram avaliadas através dos ensaios de estabilidade e fluência Marshall, fluência por compressão uniaxial estática e dinâmica, resistência à tração por compressão diametral estática, módulo de resiliência por compressão diametral dinâmica e fadiga por compressão diametral dinâmica. As misturas foram avaliadas também quanto à sua suscetibilidade aos danos causados pela umidade (stripping), de acordo com as normas AASHTO T 283 e ASTM D 4867, utilizando os ensaios de resistência à tração por compressão diametral estática e módulo de resiliência por compressão diametral dinâmica para a verificação da variação dessas propriedades mecânicas.

\subsubsection{Estabilidade e Fluência Marshall}

Para a determinação da estabilidade (E) e fluência (F) Marshall, os corpos-de-prova são imersos em um banho de água a $60^{\circ} \mathrm{C}$, por 20 minutos. Após, cada qual é imediatamente submetido ao ensaio de compressão diametral, na forma idealizada por Marshall, para a determinação da estabilidade, que corresponde à carga de ruptura, e da fluência, que corresponde à deformação sofrida pelo corpo-de-prova até o momento da ruptura. A prensa empregada para a compressão diametral dos corpos-de-prova tem velocidade de compressão de $50 \mathrm{~mm} / \mathrm{min}$. e está ilustrada na Figura 7.4.

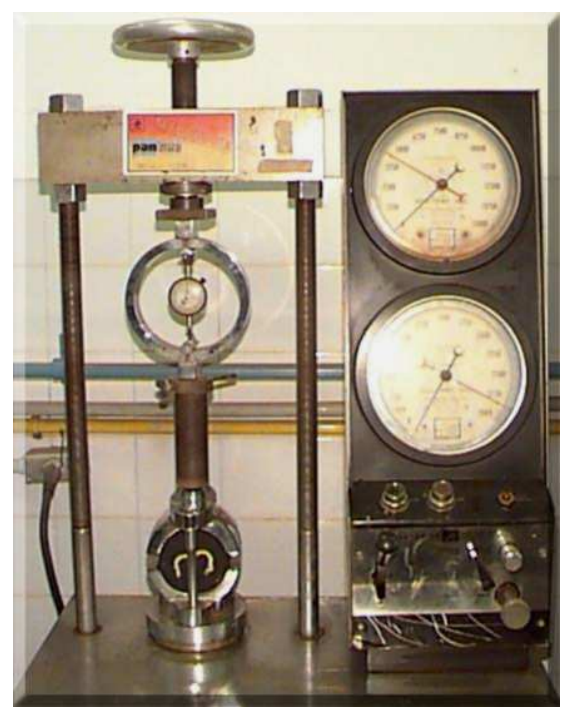

Figura 7.4: Prensa empregada na realização dos ensaios Marshall 


\subsubsection{Ensaio de Fluência por Compressão Uniaxial Estática}

O ensaio de fluência por compressão uniaxial estática, também conhecido por creep estático, consiste na aplicação contínua de uma carga de compressão de $0,1 \mathrm{MPa}$, durante 60 minutos, seguido de um período de recuperação de 15 minutos, com temperatura controlada em $40^{\circ} \mathrm{C}$. Essas condições de ensaio foram adotadas para atender às recomendações de De Hilster \& Van De Loo (1977), tendo em vista a permanência da mistura em seu trecho de viscoelasticidade linear.

O equipamento de compressão uniaxial estática é composto por componentes que permanecem dentro de uma câmara de isolamento térmico, com regulagem térmica, e por componentes externos a essa câmara de isolamento térmico. A parte do equipamento que permanece dentro da câmara consiste basicamente de prensa pneumática, LVDTs, suporte para a fixação dos LVDTs e placa metálica para a distribuição de carga sobre o corpo-de-prova. Já a parte do equipamento externa à câmara de isolamento térmico consiste basicamente de indicadores digitais de deslocamento e de tensão e de um microcomputador, necessário para o registro dos dados obtidos no transcorrer do ensaio (Figura 7.5).

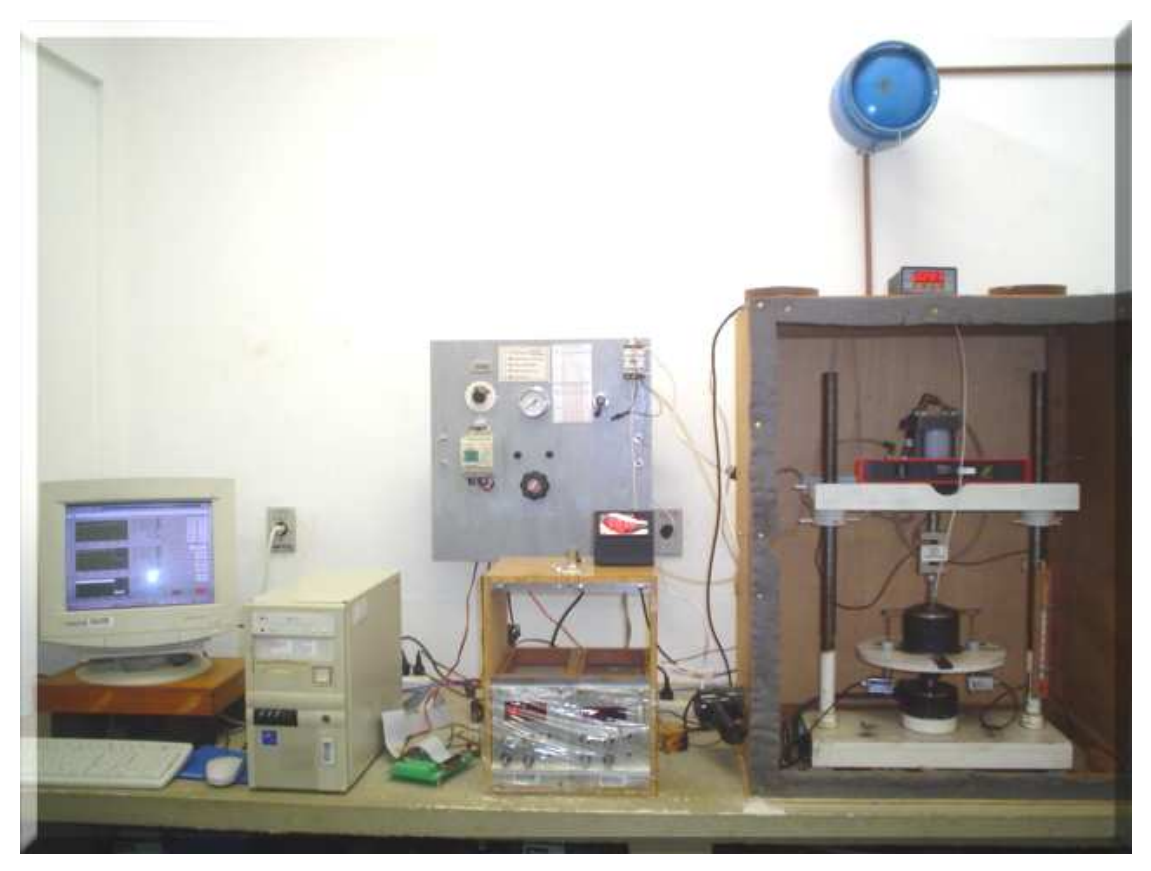

Figura 7.5: Equipamento usado nos ensaios de fluência por compressão uniaxial estática

\section{Procedimentos Prévios}

Antes da realização dos ensaios, os corpos-de-prova têm suas bases circulares polidas com lixa ferro n. 80, sendo o acabamento dado com uma lixa mais fina (n. 120). Após o polimento, 
determinam-se as alturas dos corpos-de-prova com o auxílio de um paquímetro, com resolução em centésimos de milímetro.

Após, encaminham-se os corpos-de-prova à estufa, mantida em $40^{\circ} \mathrm{C}$, onde permanecem por 12 horas precedentes ao ensaio, com o objetivo de estabilizar e homogeneizar a temperatura por todo o corpo-de-prova. No momento que antecede a realização do ensaio, as bases circulares do corpo-de-prova são lubrificadas com uma fina camada de vaselina comum. Esse procedimento é utilizado por recomendação de Souza et al. (1991), que afirmam que os resultados do ensaio de fluência por compressão uniaxial estática, quando expressos sob a forma de deformação (variação da altura do corpo-de-prova dividida por sua altura original), não dependem do formato nem das dimensões do corpo-de-prova empregado, desde que as bases do cilindro, delineado pelo corpo-de-prova, sejam paralelas entre si e estejam adequadamente polidas e lubrificadas. Tanto o polimento quanto a lubrificação das bases do corpo-de-prova são necessários para evitar o aparecimento de tensões cisalhantes, garantindo assim a uniformidade da distribuição da tensão normal.

\section{Pré-condicionamento}

Em cada corpo-de-prova é efetuado um pré-condicionamento imediatamente anterior ao período de realização do ensaio. No pré-condicionamento, o corpo-de-prova é mantido sob a aplicação da carga do ensaio durante 5 minutos e, em seguida, é submetido a um período de descanso ou de recuperação também de 5 minutos.

\section{Realização do Ensaio}

Após o pré-condicionamento, inicia-se o ensaio com aplicação da carga no corpo-de-prova por 60 minutos, correspondente a uma tensão de compressão de $0,1 \mathrm{MPa}$, seguido pela desaplicação da carga por 15 minutos, correspondente ao período de recuperação. Durante os 75 minutos de ensaio, a carga aplicada e os deslocamentos axiais sofridos pelo corpo-de-prova são obtidos eletronicamente através de dois sensores do tipo LVDT (Linear Variable Differential Transducers).

Os ensaios são gerenciados por um programa computacional que realiza a aquisição de dados, desenvolvido no ambiente LabView pelo professor Dr. Glauco Tulio Pessa Fabbri. Esse programa permite o controle da prensa pneumática, registra as leituras dos deslocamentos axiais obtidos pelo LVDT e da carga aplicada. As leituras são armazenadas na memória secundária 
do microcomputador, em formato texto (arquivos .txt). O programa de cálculo, também desenvolvido em LabView, lê o arquivo texto gerado durante todo o ensaio, transforma as leituras de volt para milímetro, calcula a deformação total, a deformação elástica, a deformação plástica, a recuperação, a declividade média ou inclinação do trecho entre 1000 e 3600 segundos (trecho de fluência uniforme) e os módulos de fluência para 3600 e 4500 segundos e grava esses resultados em outro arquivo texto.

A Figura 7.6 é ilustrativa de uma tela do programa obtida após a realização de um ensaio de fluência por compressão uniaxial estática, onde podem ser vistas as curvas de fluência obtidas através registros dos deslocamentos axiais e a variação da carga aplicada ao longo do ensaio. Na Figura 7.7, pode-se visualizar uma tela do programa de cálculo, com cálculos de deformação total, deformação elástica, deformação plástica, recuperação, inclinação do trecho entre $1000 \mathrm{~s}$ e 3600 s e os módulos de fluência para 3600 s e 4500 s, referentes à média das leituras obtidas nos dois LVDTs.

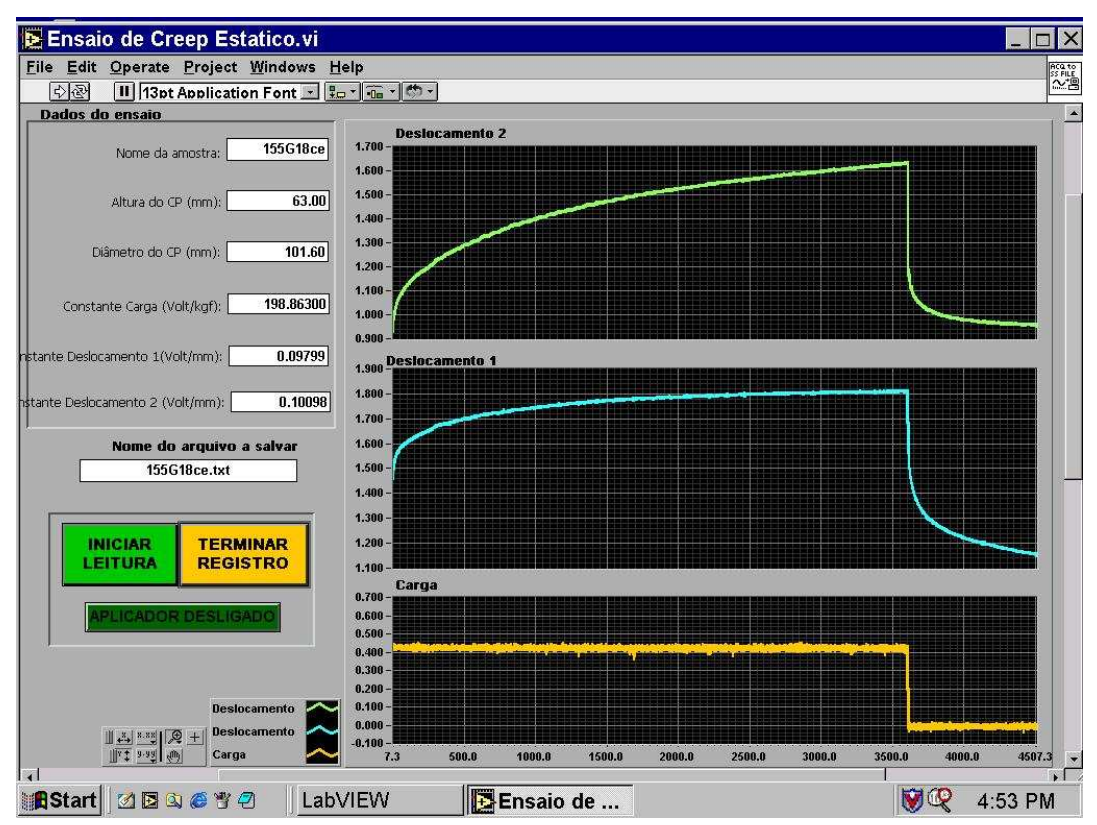

Figura 7.6: Exemplo da tela de registro do ensaio de fluência por compressão uniaxial estática

\subsubsection{Ensaio de Fluência por Compressão Uniaxial Dinâmica}

O ensaio de fluência por compressão uniaxial dinâmica, também conhecido por creep dinâmico, é realizado com a aplicação de 5.000 ciclos de carregamento, cada ciclo com duração de $1 \mathrm{~s}$, sendo $0,1 s$ de aplicação de carga e $0,9 s$ de descanso, com tensão de compressão de 0, $1 \mathrm{MPa}\left(1 \mathrm{kgf} / \mathrm{cm}^{2}\right)$ e temperatura controlada de $40^{\circ} \mathrm{C}$. No momento imediatamente anterior 


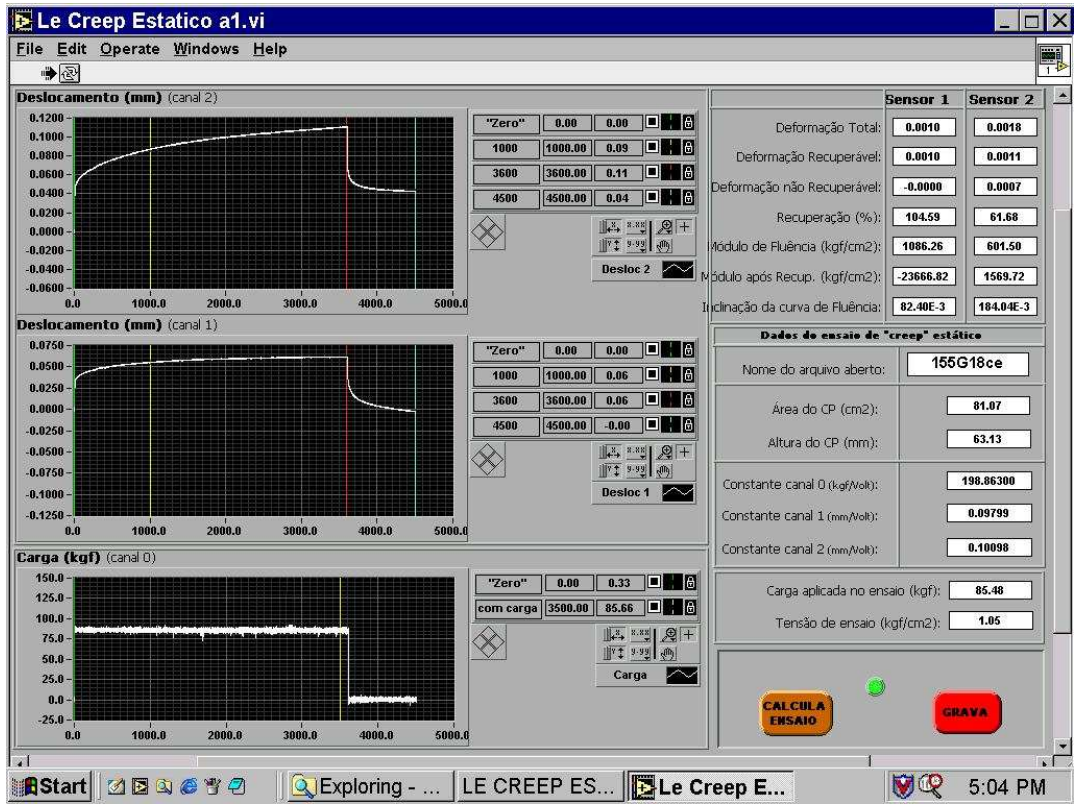

Figura 7.7: Exemplo da tela de cálculo do ensaio de fluência por compressão uniaxial estática ao início do ensaio, o corpo-de-prova é submetido a um pré-condicionamento, com aplicação de 200 ciclos de carregamento nas mesmas condições de tensão e de temperatura do ensaio.

O equipamento, a forma de aquisição de dados, a preparação dos corpos-de-prova e o condicionamento térmico a que os corpo-se-prova são submetidos antes do ensaio são os mesmos descritos para o ensaio de fluência por compressão uniaxial estática.

Para o processamento dos dados obtidos durante o ensaio utiliza-se um programa computacional também desenvolvido pelo professor Dr. Glauco Tulio Pessa Fabbri em LabView, que calcula a deformação total, a inclinação da curva de deformação axial versus tempo no trecho entre $100 \mathrm{~s}$ e $5.000 \mathrm{~s}$ e o módulo de fluência para $5.000 \mathrm{~s}$. A Figura 7.8 ilustra telas do programa, onde podem ser vistas, em geral e em detalhe, as curvas de fluência obtidas através do registro dos deslocamentos axiais e da variação da carga aplicada ao longo do ensaio.

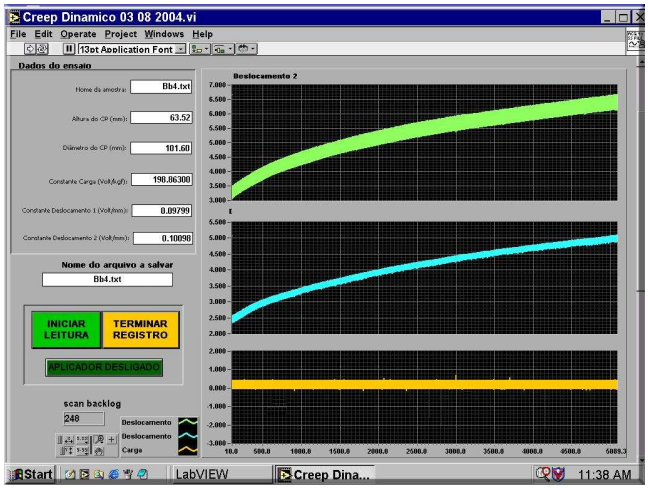

(a) geral

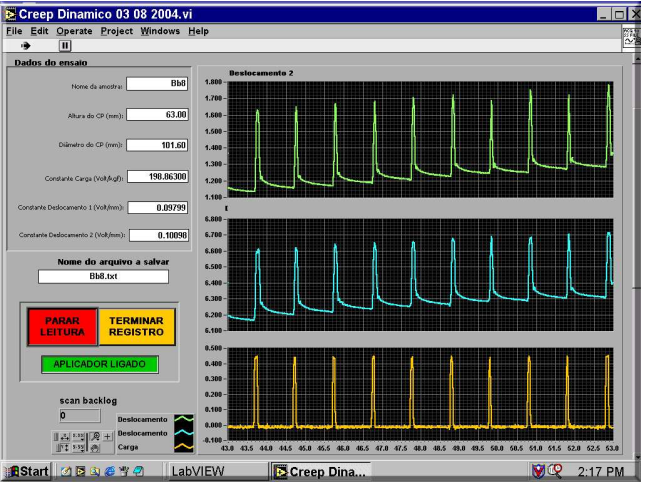

(b) detalhe

Figura 7.8: Exemplos das telas de um ensaio de fluência por compressão uniaxial dinâmica 


\subsubsection{Ensaios de Compressão Diametral}

Os ensaios de avaliação das propriedades mecânicas das misturas procuram simular as condições reais de solicitações no campo. O ensaio de compressão diametral, idealizado pelo professor Fernando Luiz Lobo B. Carneiro ${ }^{2}$, foi desenvolvido com base na investigação da resistência que cilindros de concreto, dentro de tubos metálicos, teriam quando solicitados diametralmente. Tratava-se de um projeto de deslocamento de uma velha igreja para a abertura da Avenida Presidente Vargas no Rio de Janeiro, no início dos anos de 1940 (Medina, 1997).

O ensaio de compressão diametral, conhecido mundialmente como Ensaio Brasileiro, inspirou o professor Icarahy da Silveira ${ }^{3}$ apud Medina (1997) a desenvolver estudos sobre compressão diametral em amostras compactadas de solos coesivos, prevendo as potencialidades desse ensaio simples na determinação da tração de maneira indireta. Medina (1997) atribui a Schmidt (1972) a primeira aplicação desse ensaio, sob carregamento dinâmico, em misturas betuminosas.

\section{Ensaio de Resistência à Tração por Compressão Diametral Estática}

O ensaio consiste na aplicação progressiva de carga de compressão diametral até a ruptura do corpo-de-prova (Figura 7.9). A resistência à tração é definida como a tensão de tração sob a qual ocorre a ruptura diametral do corpo-de-prova quando submetido a uma carga de compressão paralela ao eixo de ruptura.

Como procedimentos prévios à realização do ensaio, determina-se as alturas médias dos corpos-de-prova, para em seguida, acomodá-los dentro de uma sala climatizada na mesma temperatura de realização do ensaio $\left(25^{\circ} \mathrm{C}\right)$, durante pelo menos 24 horas. O ensaio resume-se em submeter o corpo-de-prova, acondicionado ao suporte com frisos (Figura 7.12(a)), à aplicação progressiva de carga pela prensa, com velocidade de compressão de $0,8 \mathrm{~mm} / \mathrm{s}$, até a ruptura do corpo-de-prova (Figura 7.10).

Com o valor da carga de ruptura, pode-se calcular a resistência à tração do corpo-de-prova, através da Equação 7.1.

$$
\sigma_{T} \text { ou } R T=\frac{2 F}{\Pi \times D \times H \times 10,2}
$$

\footnotetext{
${ }^{2}$ Carneiro, F. L. L. B. (1943) Um novo método para a determinação da resistência à tração dos concretos. Comunicação, 5. Reunião da Associação Brasileira de Normas Técnicas, publ. Instituto Nacional de Tecnologia, Rio de Janeiro.

${ }^{3}$ Silveira, I. (1944) Ensaio de compressão diametral em solos. R. Municipal de Engenharia, v.11, n.3 e 4, Rio de Janeiro.
} 


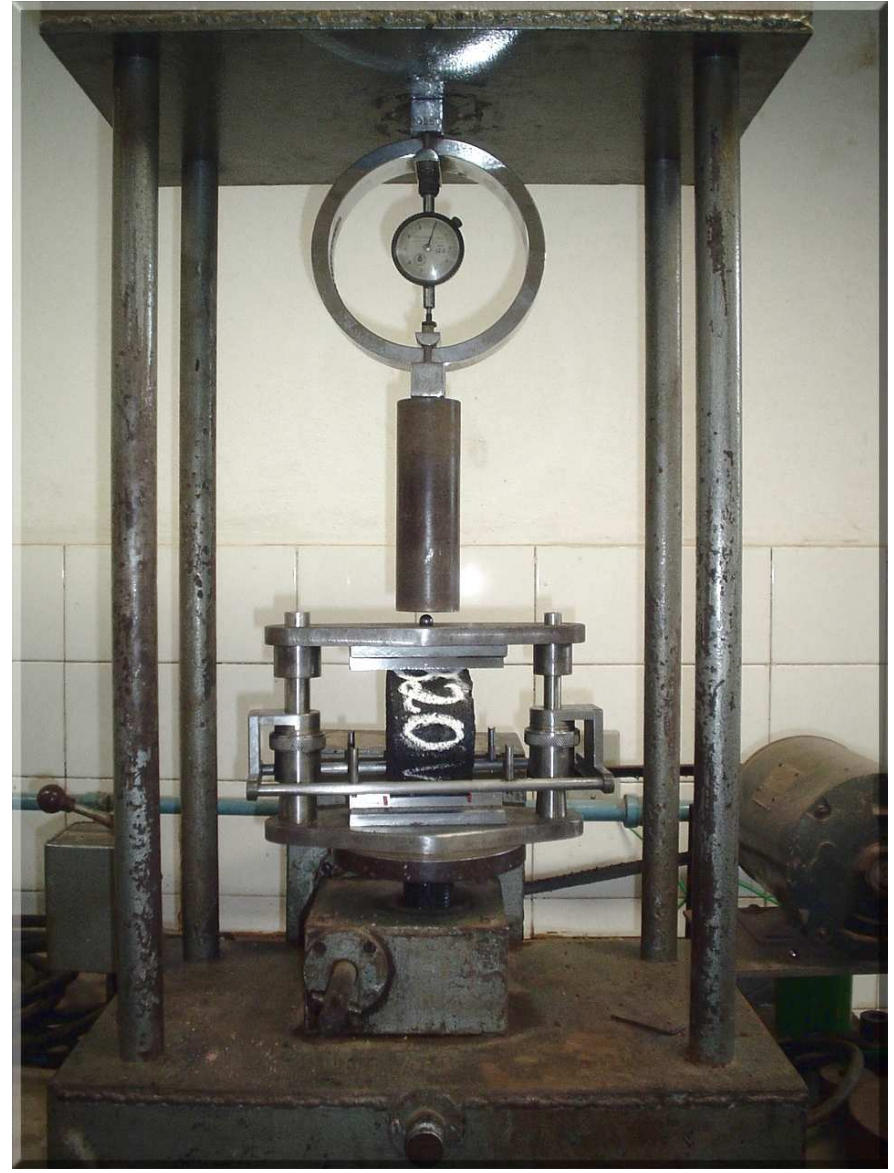

Figura 7.9: Ensaio de resistência à tração por compressão diametral estática

onde:

$\sigma_{T}$ ou $R T=$ resistência à tração indireta, $M P a$;

$F=$ carga de ruptura, $k g f$;

$D$ = diâmetro do corpo-de-prova, $\mathrm{cm}$;

$H=$ altura do corpo-de-prova, $\mathrm{cm}$.

A resistência à tração (DNER ME 138) também foi utilizada nesta pesquisa para a definição da carga aplicada aos corpos-de-prova submetidos aos ensaios de módulo de resiliência e de fadiga.

\section{Ensaio de Compressão Diametral de Cargas Repetidas}

A simulação da solicitação dinâmica dos pavimentos é bastante difícil e complexa, pois os pavimentos estão sujeitos a cargas de intensidades diferentes e freqüências variáveis ao longo do dia e do ano. Os ensaios de cargas repetidas procuram reproduzir as condições de campo, onde a força aplicada atua no sentido de compressão, de zero a um máximo e depois diminui até 


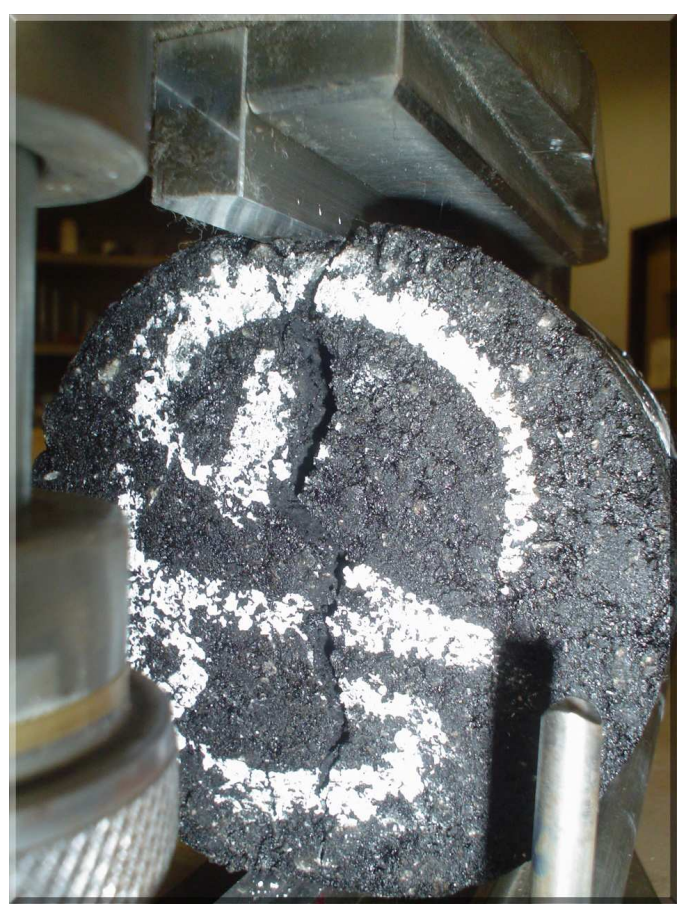

(a) Aplicação de carga até a ruptura

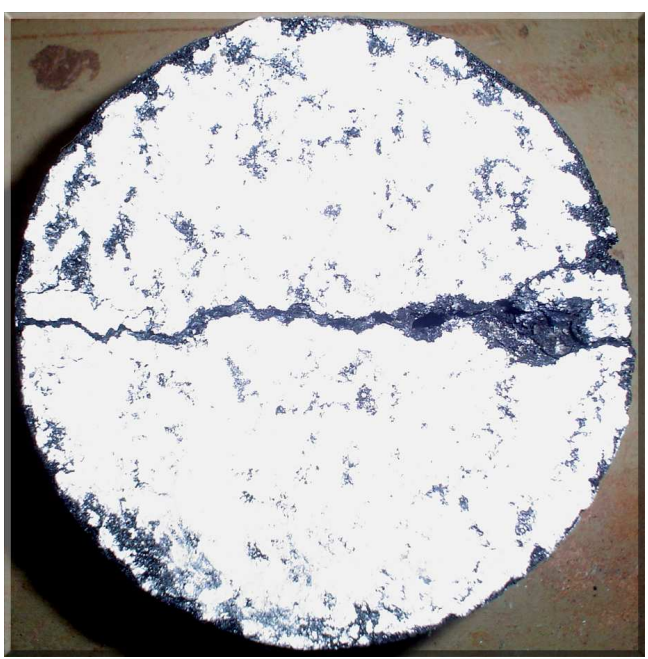

(b) Exemplo de trinca produzida no corpo-de-prova

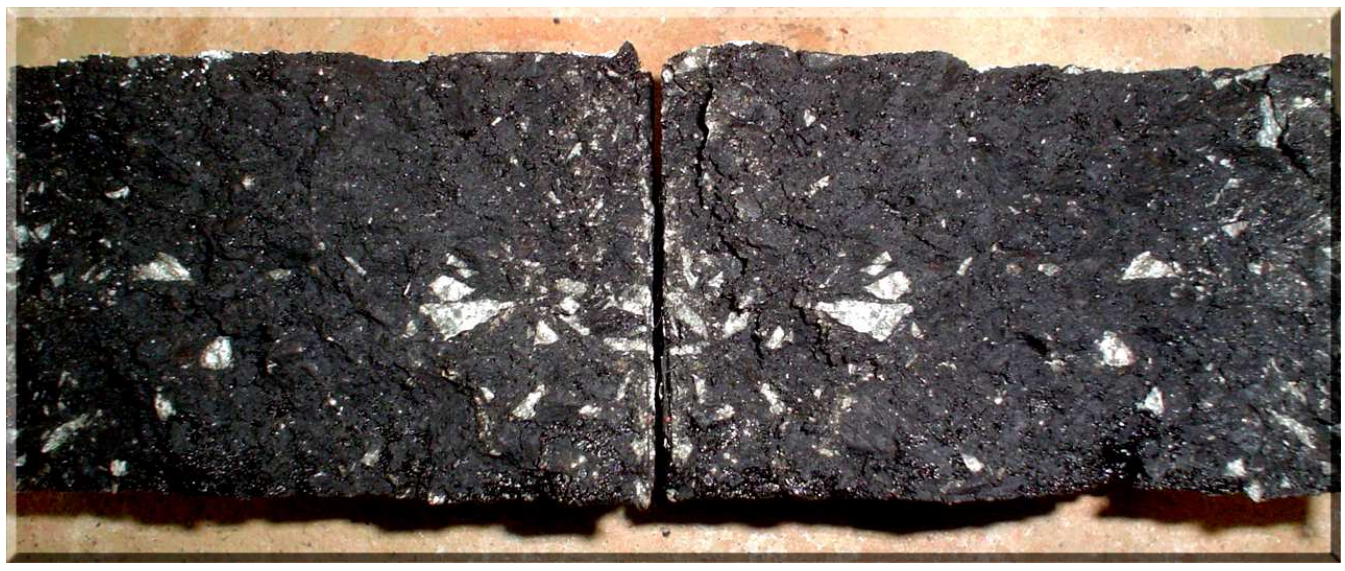

(c) Exemplo da ruptura interna produzida no corpo-de-prova

Figura 7.10: Exemplos de ruptura do corpo-de-prova por compressão diametral estática

anular-se ou atingir um patamar inferior, para atuar novamente após um intervalo pequeno de repouso. A amplitude da carga e seu tempo de pulso são função da velocidade do veículo e da profundidade em que se calculam as tensões e deformações produzidas no pavimento, enquanto a freqüência retrata o fluxo dos veículos.

O ensaio de compressão diametral de cargas repetidas é um ensaio de tração indireta conduzido em um corpo-de-prova cilíndrico. As cargas repetidas são de compressão, atuantes ao longo de um plano diametral, aplicadas através de dois frisos de carga opostos (Figura 7.12(a)), produzindo uma tensão de tração relativamente uniforme ao longo do plano diametral vertical. Para o estado biaxial de tensões, considerando as misturas homogêneas, isotrópicas e elásticas, as tensões de tração e de compressão, que ocorrem no centro do corpo-de-prova, podem ser 
modeladas da seguinte maneira:

$$
\begin{gathered}
\sigma_{T}=\frac{2 F}{\Pi \times D \times H \times 10,2} \\
\sigma_{C}=-\frac{6 F}{\Pi \times D \times H \times 10,2}
\end{gathered}
$$

onde:

$\sigma_{T}=$ tensão de tração, em MPa;

$\sigma_{C}=$ tensão de compressão, em MPa;

$F=$ carga de ruptura, em kgf;

$D=$ diâmetro do corpo de prova, em cm;

$H=$ altura do corpo-de-prova, em $\mathrm{cm}$.

\section{Módulo de Resiliência}

A resiliência das misturas asfálticas refere-se à deformação recuperável ou elástica da mistura sob a ação de cargas repetidas, onde a energia armazenada no corpo-de-prova deformado elasticamente é devolvida quando cessam as tensões causadoras da deformação. Outro termo bastante usado também é rigidez, para indicar a capacidade das misturas asfálticas de resistir à deformação (Medina, 1997). A repetição das deformações resilientes, na camada asfáltica do pavimento, provoca deterioração gradual por fadiga.

Nesta pesquisa, o módulo de resiliência das misturas foi obtido através do ensaio de compressão diametral dinâmica, ou ensaio de tração indireta, utilizando o equipamento ilustrado na Figura 7.11. Esse equipamento é composto por: prensa pneumática, LVDT, frisos com suporte para a acomodação do corpo-de-prova, suporte para a fixação dos LVDT, indicadores digitais de deslocamento e de tensão e microcomputador, necessário para o registro dos dados obtidos no transcorrer do ensaio. O detalhe dos frisos pode ser visto na Figura 7.12(a), do suporte para a fixação dos LVDT na Figura 7.12(b) e do conjunto montado na Figura 7.12(c).

Os procedimentos que antecedem a realização do ensaio consistem em determinar as alturas dos corpos-de-prova e mantê-los, por pelo menos 24 horas, em uma sala climatizada a $25^{\circ} \mathrm{C}$.

Nos minutos que antecedem ao ensaio, faz-se um pré-condicionamento do corpo-de-prova, para a redução da influência das deformações permanentes. Para tanto, são aplicados 200 ciclos de carregamento no corpo-de-prova, com mesma carga e temperatura do ensaio e, só então, as medições das deformações resilientes começaram a ser computadas. 


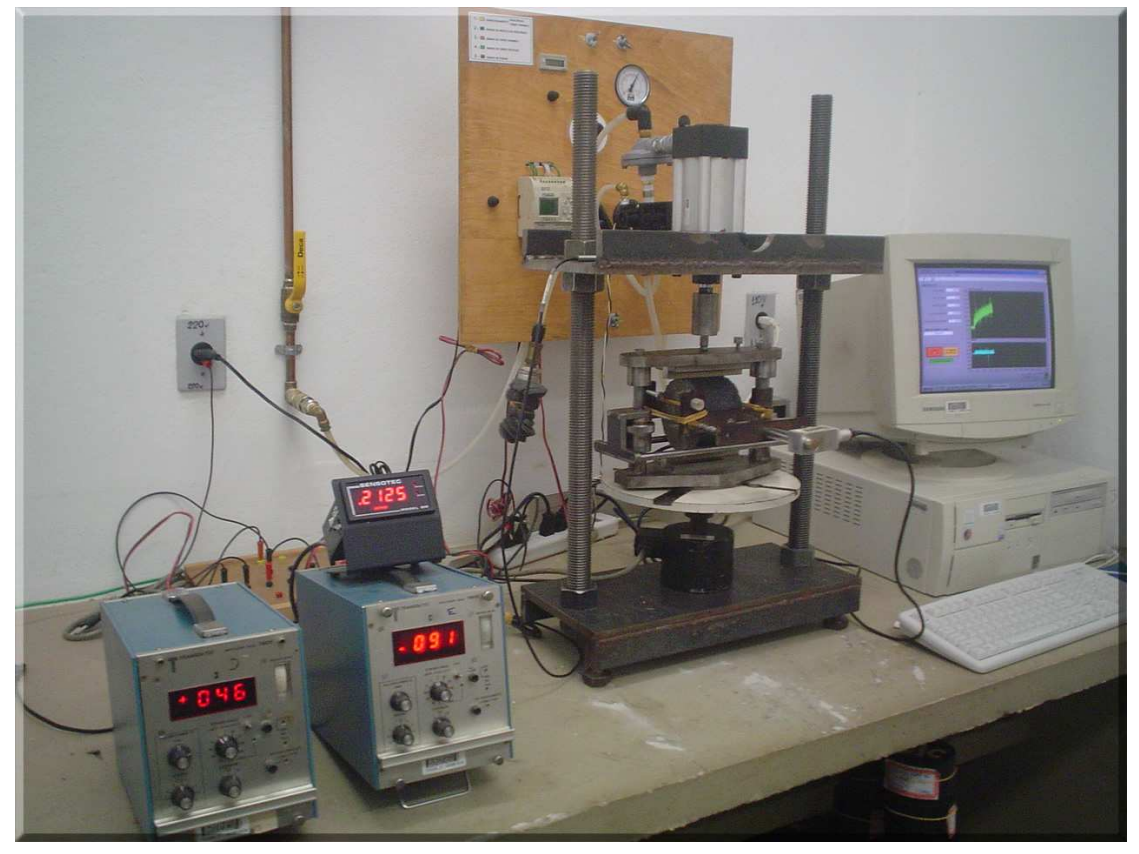

Figura 7.11: Equipamento do ensaio de compressão diametral

O ensaio é realizado a $25^{\circ} \mathrm{C}$, com a aplicação de 500 ciclos de carregamento, tendo cada ciclo duração de $1 s$, com $0,1 s$ de aplicação da carga e $0,9 s$ de recuperação. A magnitude da carga aplicada varia de 20 a $25 \%$ da resistência à tração do corpo-de-prova, com freqüência de 60 ciclos por minuto. Segundo Medina (1997), só é admissível que se aplique a teoria da elasticidade em misturas asfálticas se os níveis de tensão de tração forem considerados baixos (menores que 50\%) em relação à tensão de ruptura e se forem utilizadas temperaturas inferiores a $40^{\circ} \mathrm{C}$. A Figura 7.13 ilustra a realização do ensaio, com uma visão geral do equipamento 7.13(a) e um detalhe 7.13(b). 


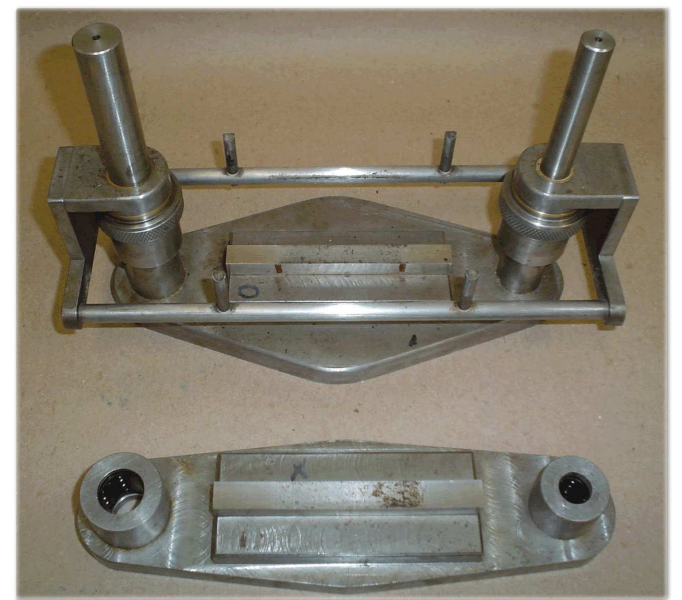

(a) frisos

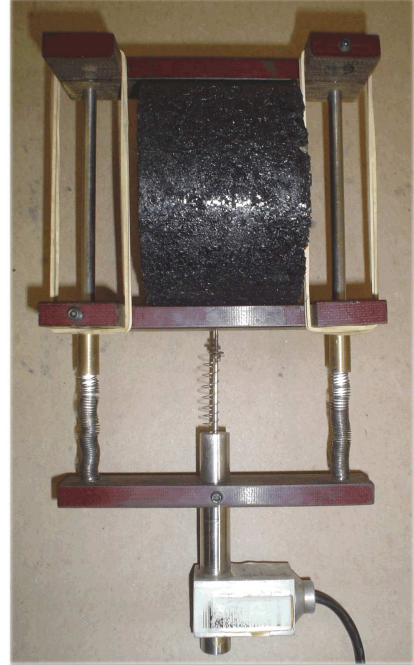

(b) suporte

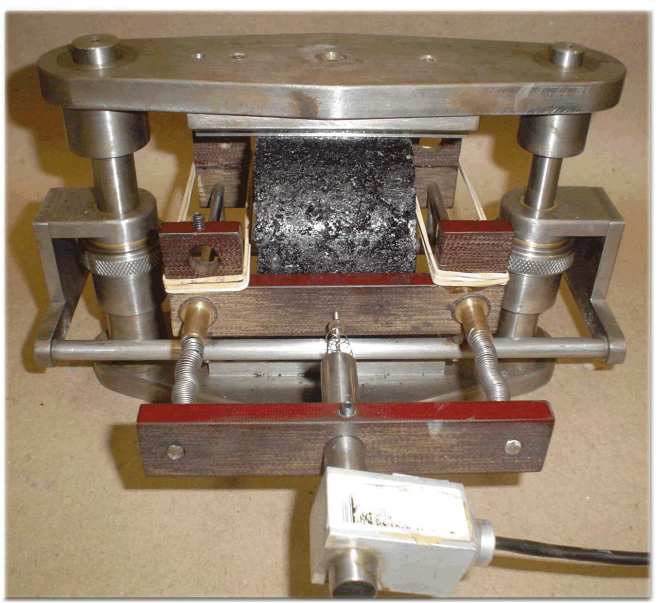

(c) Conjunto montado

Figura 7.12: Frisos e suporte do LVDT

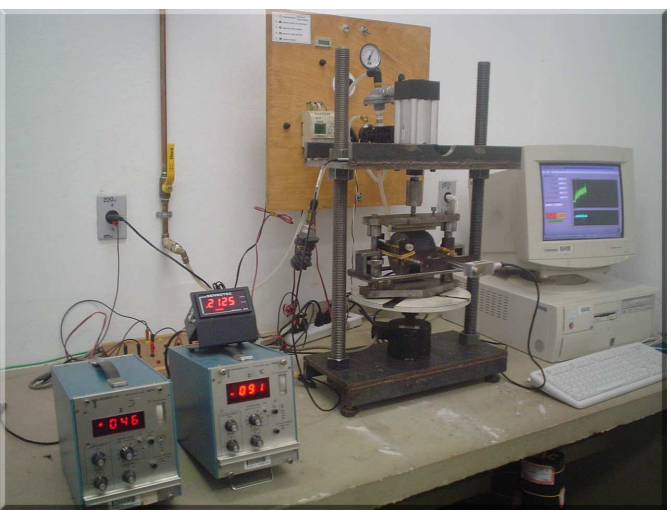

(a) geral

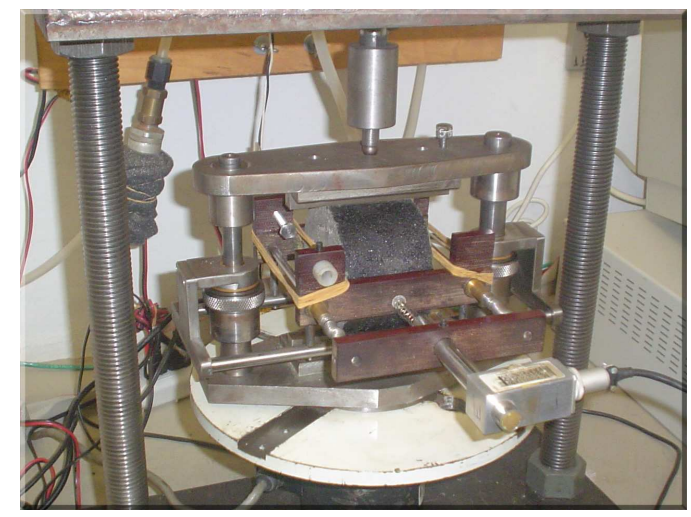

(b) detalhe

Figura 7.13: Vistas do equipamento de ensaio de módulo de resiliência 
O módulo de resiliência pode então ser calculado através da Equação 7.4.

$$
M R=\frac{F}{\Delta \times H \times 10,2} \times(0,9976 \mu+0,2692)
$$

onde:

$M R=$ módulo de resiliência, $M P a$;

$F=$ carga vertical repetida e aplicada diametralmente no corpo-de-prova $n$ vezes, $k g f$;

$\Delta=$ deslocamento resiliente sofrido pelo corpo-de-prova, na direção perpendicular às aplicações da carga, $\mathrm{cm}$;

$H=$ altura do corpo-de-prova, $\mathrm{cm}$;

$\mu=$ coeficiente de Poisson.

O controle do carregamento e a aquisição dos dados são gerenciados por um programa computacional desenvolvido em LabView, pelo professor Dr. Glauco Tulio Pessa Fabbri, que registra as informações, adquiridas durante o ensaio, na memória do computador, em formato texto (arquivos .txt). A Figura 7.14 apresenta telas do programa. Outro programa, também desenvolvido em LabView, lê o arquivo texto gerado durante o ensaio, transforma as leituras de volt para milímetro, calcula o módulo de resiliência médio, módulo de resiliência instantâneo e a carga média aplicada, considerando todos os ciclos, e grava os resultados em outro arquivo texto.

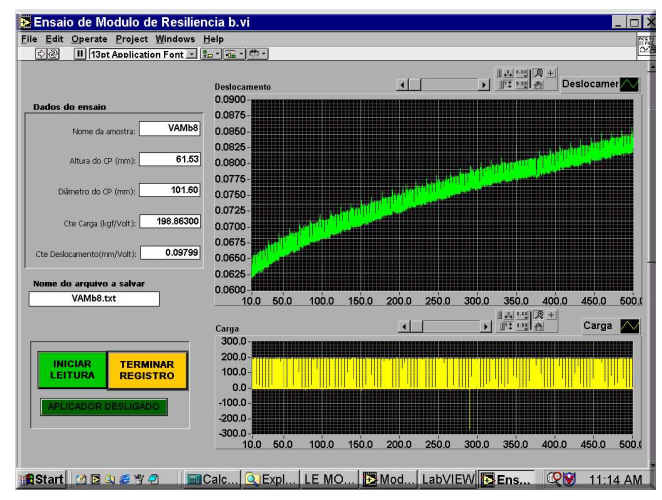

(a) geral

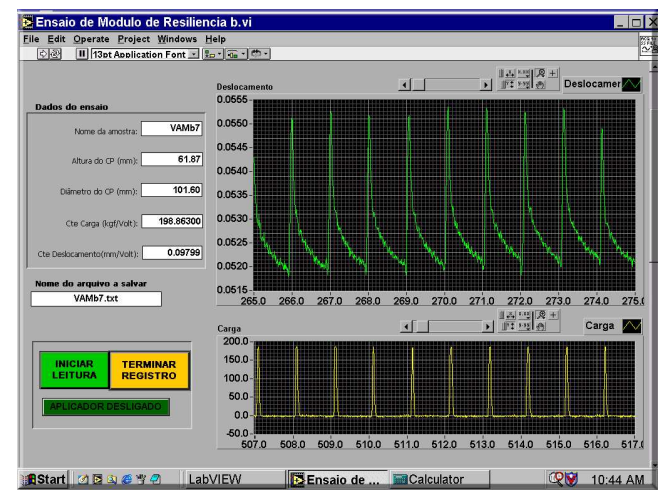

(b) detalhe

Figura 7.14: Telas obtidas após um ensaio de módulo de resiliência

A norma da AASHTO TP31 menciona dois tipos de módulo de resiliência, o módulo de resiliência total $(\mathrm{MR})$ e o módulo de resiliência instantâneo $\left(M R_{i}\right)$, determinados com base na curva deformação versus tempo de cada ciclo de carregamento (Figura 7.15).

O módulo de resiliência instantâneo é calculado com a deformação recuperada instantaneamente na fase de descarregamento do ciclo (deformação instantânea, $\Delta_{i n s t}$ ), não incluindo a 
deformação recuperada durante o período de descanso ou recuperação, ou seja, período em que a deformação é recuperada ao longo do tempo. A deformação instantânea é determinada pela diferença entre a deformação máxima atingida pelo corpo-de-prova, no referido ciclo, e a deformação na base do trecho de descarregamento da curva de deformação. O ponto da curva no qual a deformação da base do trecho de descarregamento é considerada é determinado gerando-se uma linha vertical a partir da intersecção de duas retas de regressão e estendendo-a até que intercepte a curva de deformação. A reta de regressão denominada reta 1 (Figura 7.15) é uma extensão da parte linear do trecho de descarregamento da curva de deformação e baseia-se em todos os pontos localizados após o pico da curva e antes da recuperação de $75 \%$ da deformação máxima sofrida. A reta de regressão, denominada reta 2 , baseia-se nos pontos correspondentes aos últimos 0,75 segundos do ciclo. Essas duas retas são estendidas e interceptam-se em um ponto, a partir do qual é traçada a linha vertical que por sua vez interceptará a curva de deformação (AASHTO TP31 apud Greco (2004)).

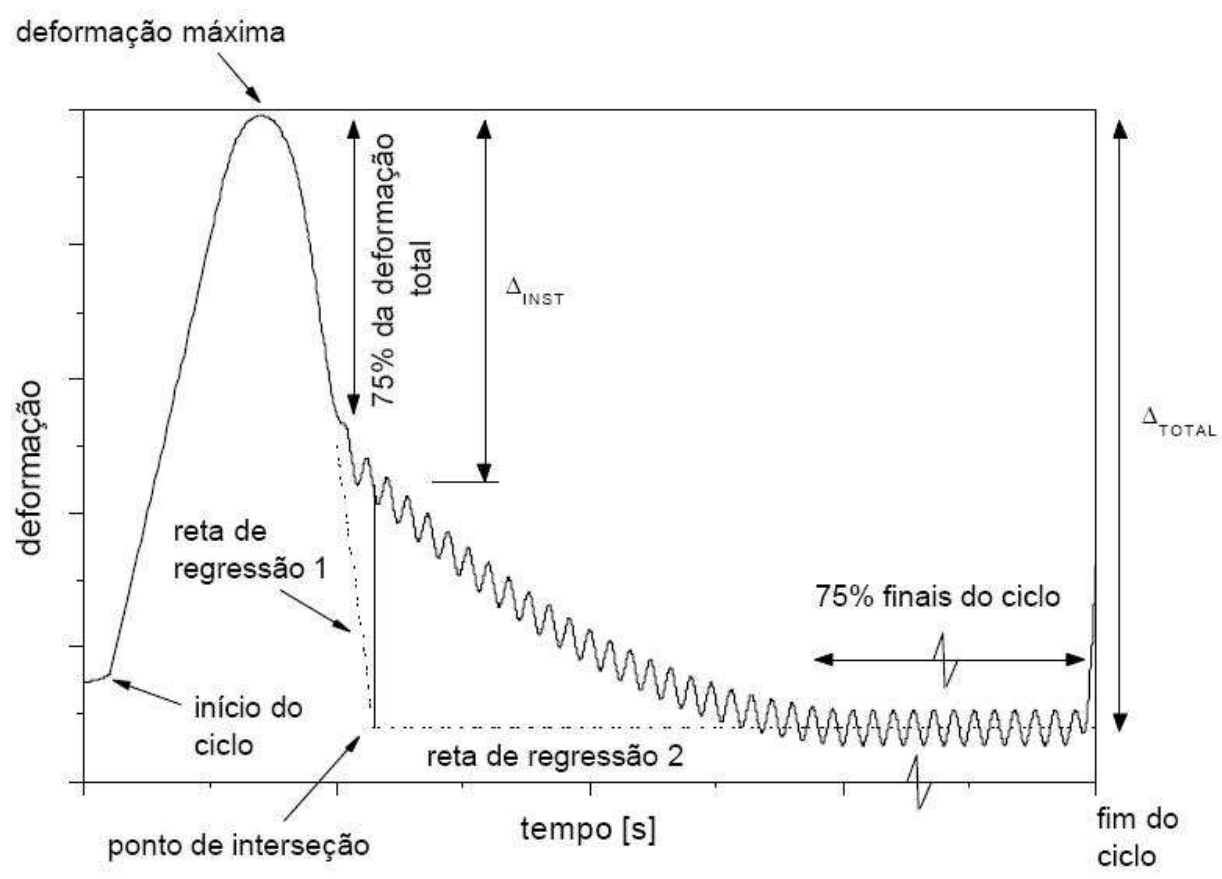

(AASHTO TP31 apud Greco (2004))

Figura 7.15: Curva de deformação versus tempo, para um ciclo de carregamento

O módulo de resiliência total (MR) é calculado a partir da deformação resiliente total $\left(\Delta_{\text {Total }}\right)$, que inclui tanto a deformação que é recuperada instantaneamente como a deformação recuperada durante a fase do ciclo em que o corpo-de-prova permanece sem carregamento, ou seja, em descanso. A deformação total é definida como a diferença entre a deformação máxima do ciclo de carregamento e a deformação final, determinada pela média dos valores de deformação dos últimos $75 \%$ do ciclo (Greco, 2004). 


\section{Estimativa da Vida de Fadiga}

O ensaio de compressão diametral serve também para o estudo de fadiga das misturas asfálticas. Para esse fim, aplicam-se vários níveis de tensão calculadas como uma porcentagem em relação à ruptura estática. Então, determina-se o número de aplicações de carga até o trincamento e ruptura num plano vertical.

O ensaio de fadiga é realizado a $25^{\circ} \mathrm{C}$, sob o regime de tensão controlada (TC), isto é, com a tensão de tração repetidamente aplicada e induzida pela força vertical distribuída no friso da geratriz, sem sofrer alterações até a ruptura do corpo-de-prova. A aplicação de carga, com frequiência de 60 ciclos por minuto, tem duração de $0,1 \mathrm{~s}$ e recuperação de $0,9 \mathrm{~s}$. Pode-se ter uma visão geral do equipamento utilizado na realização do ensaio na Figura 7.16(a) e um detalhe da aplicação de carga no corpo-de-prova na Figura 7.16(b). Nesta pesquisa, utilizou-se como critério de parada do ensaio a ruptura do corpo-de-prova, caracterizada pelo seccionamento ao longo do plano vertical, ou a deformação vertical máxima de $4 \mathrm{~mm}$.

A estimativa da vida de fadiga das misturas foi realizada através da aplicação de cargas verticais repetidas de tal forma que as tensões geradas correspondessem a 20, 30 e $40 \%$ da resistência à tração, para misturas produzidas com diferentes tipos de agregados (gabro e basalto) e de granulometrias (AZR e Bailey). De uma maneira geral foram ensaiados dois corpos-de-prova, para cada nível de tensão de tração atuante.

As cargas verticais aplicadas podem ser determinadas em função da resistência à tração e do nível de tensão desejado, como mostra a Equação 7.5.

$$
F=\frac{\Pi \times D \times H \times \% R T}{2}
$$

onde:

$F=$ carga de ruptura, em $k g f$

$\% R T$ = nível de tensão de tração, em $\mathrm{kgf} / \mathrm{cm}^{2}$;

$D=$ diâmetro do corpo de prova, em $\mathrm{cm}$;

$H=$ altura do corpo-de-prova, em $\mathrm{cm}$.

A vida de fadiga é expressa pelo número $N$ de solicitações necessárias para a conclusão do ensaio e modelada através da diferença de tensões, no estado biaxial de tensões, como mostra a Equação 7.6.

$$
N=K\left(\frac{1}{\Delta \sigma}\right)^{n}
$$


sendo,

$$
\Delta \sigma=\sigma_{T}-\sigma_{C}
$$

onde:

$N$ = vida de fadiga, expressa em número de solicitações de carga;

$\Delta \sigma=$ diferença entre as tensões horizontal (de tração) e vertical (de compressão) no centro da amostra, em MPa;

$$
\Delta \sigma=\sigma_{T}-\left(-\sigma_{C}\right)=8 \sigma_{T}
$$

$K$ e $n$ = parâmetros de fadiga, determinados experimentalmente;

$\sigma_{T}=$ tensão de tração, em $M P a$;

$\sigma_{C}=$ tensão de compressão, em $M P a$. 


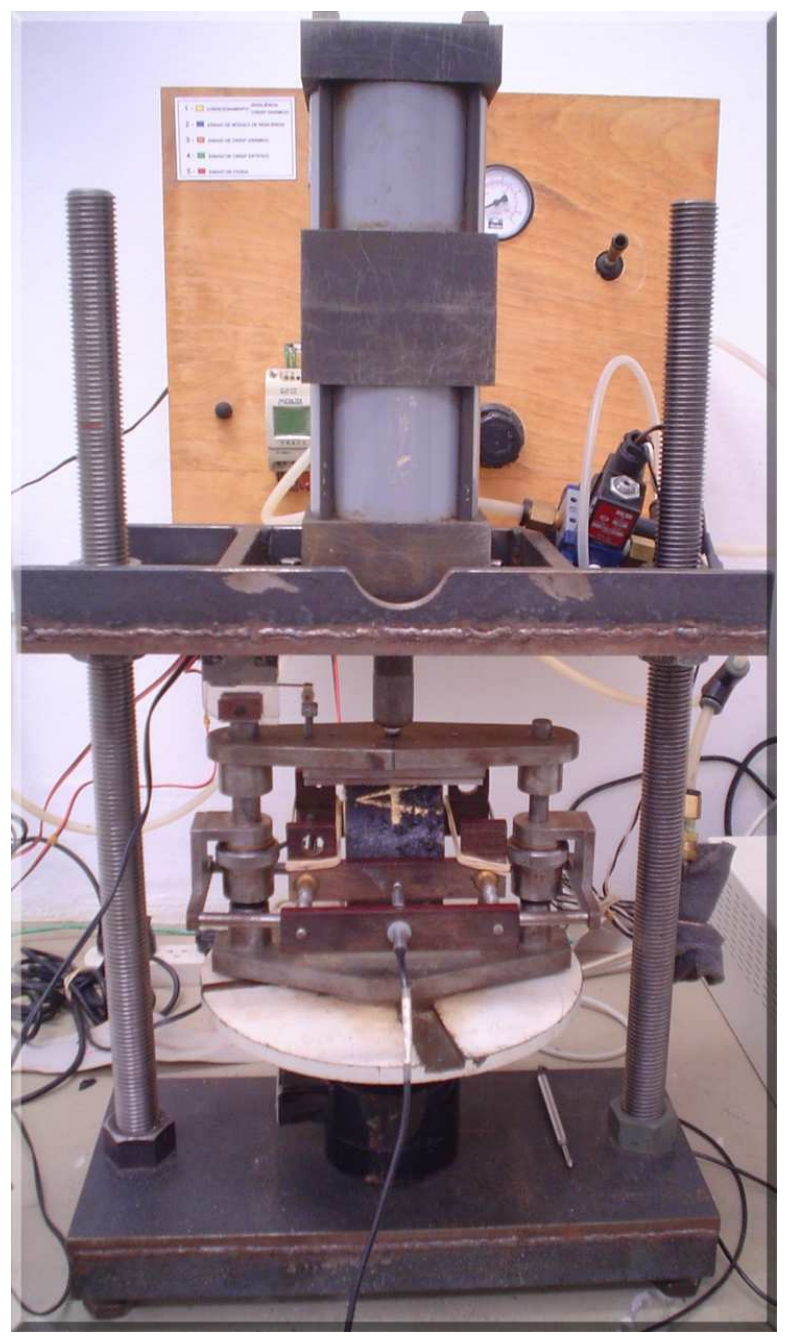

(a) Visão geral do equipamento

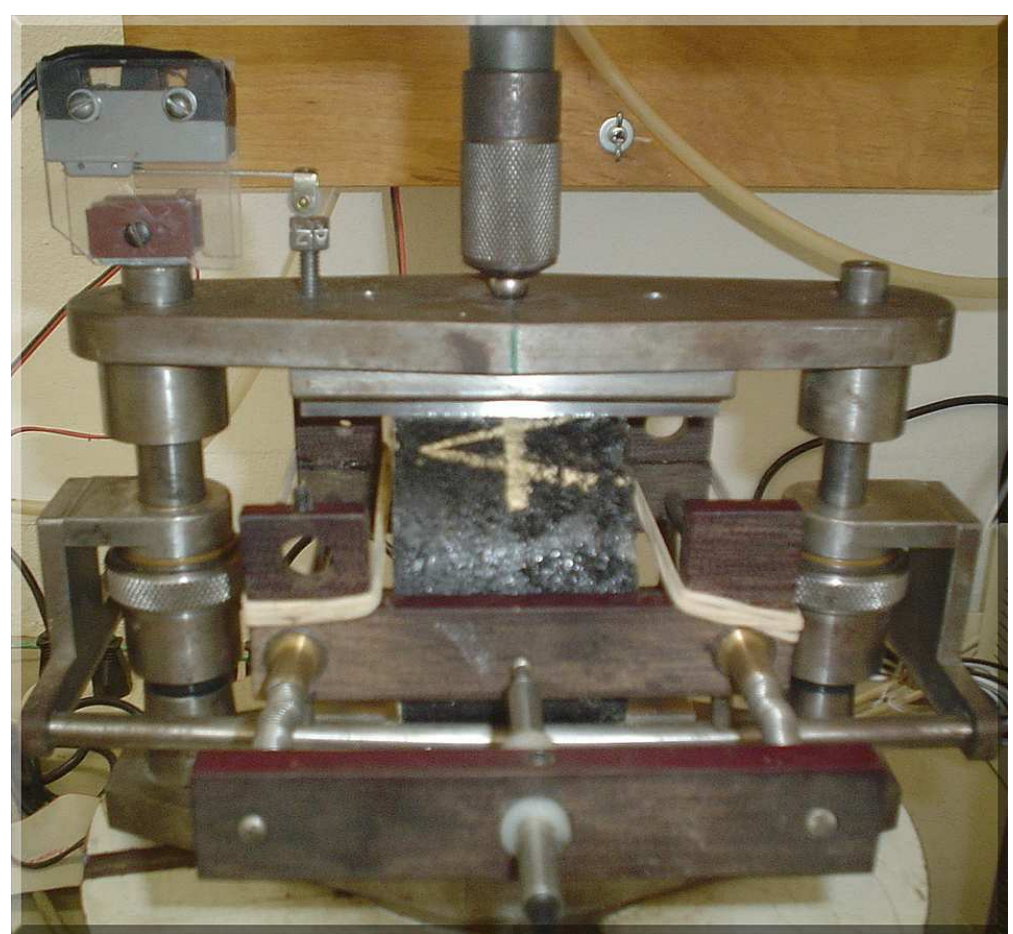

(b) Detalhe da aplicação de carga no corpo-de-prova

Figura 7.16: Ensaio realizado para a estimativa da vida de fadiga das misturas 


\subsubsection{Adesividade entre o Asfalto e o Agregado}

A adesividade entre o asfalto e o agregado pode ser avaliada através de métodos de análise visual ou de análise do comportamento mecânico das misturas asfálticas. Nesta pesquisa, foram empregadas tanto a forma de avaliação da adesividade através de análises visuais, utilizando os ensaios de adesividade do agregado grosso (DNER ME 078) e de adesividade do agregado fino (DNER ME 079), como através de análises do comportamento mecânico das misturas, utilizando os métodos de avaliação da sensibilidade à umidade das misturas, normalizados pela ASTM D 4867 e AASHTO T 283.

\section{Adesividade do Agregado Grosso}

A propriedade de aderência entre o agregado grosso e o asfalto é avaliada visualmente quanto ao descolamento da película de asfalto que envolve a partícula do agregado, quando a mistura é submetida à ação da água destilada, numa temperatura de $40^{\circ} \mathrm{C}$ por 72 horas, como estabelece a norma DNER ME 078.

Uma amostra com cerca de $500 \mathrm{~g}$ de agregado grosso, fracionado por peneiramento entre as peneiras de abertura 19,0 $\mathrm{mm}$ e 12,5 mm, é lavada e deixada submersa em água destilada durante 1 minuto. Após, drena-se a amostra levando-a à estufa onde permanece por 2 horas numa temperatura de $120^{\circ} \mathrm{C}$.

A próxima etapa do ensaio é realizar a mistura asfalto/agregado. Para tanto, aquece-se o asfalto a $120^{\circ} \mathrm{C}$ e o agregado a $100^{\circ} \mathrm{C}$, vertendo cerca de $17,5 \mathrm{~g}$ de asfalto sobre o agregado e efetuando um completo envolvimento entre os materiais, com o auxílio de uma espátula. Logo depois, a mistura é colocada sobre uma superfície lisa e limpa, onde permanece até que atinja a temperatura ambiente, para então ser submersa em água destilada a $40^{\circ} C$, por 72 horas.

Após as 72 horas, analisa-se visualmente a amostra, classificando-a como de adesividade satisfatória, quando não houver descolamento da película de asfalto, ou como não satisfatória, quando ocorrer descolamento total ou parcial da película. A Figura 7.17 ilustra um exemplo da aparência de uma partícula de agregado com rompimento da película de asfalto. 


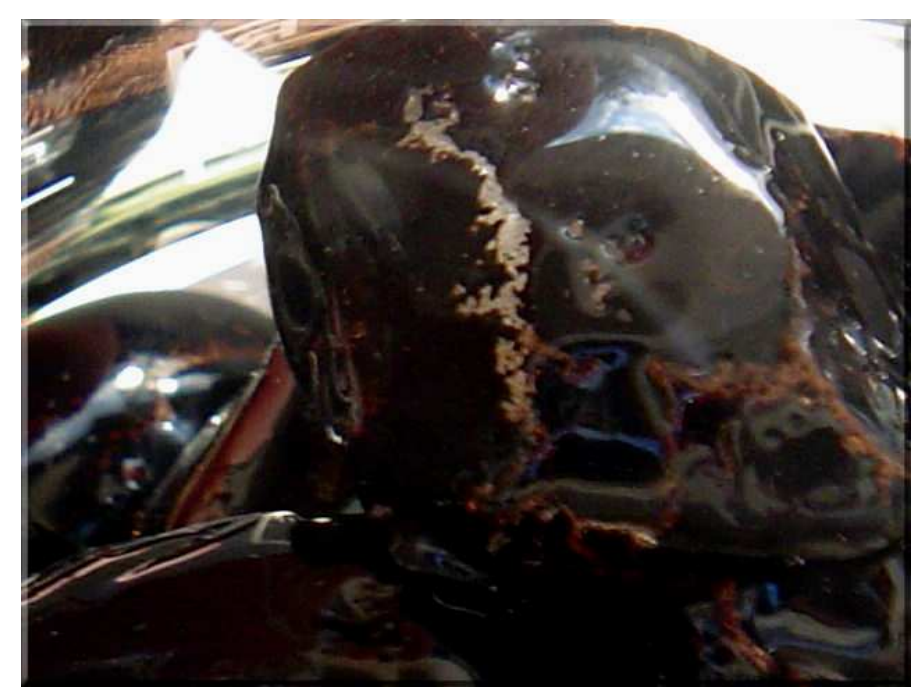

Figura 7.17: Exemplo de descolamento da película de asfalto, observado nesta pesquisa

\section{Adesividade do Agregado Fino}

A propriedade de aderência entre o agregado fino e o asfalto é avaliada visualmente quanto ao descolamento da película de asfalto que envolve a partícula do agregado, quando a mistura é submetida à ação da água destilada fervente e a soluções molares de carbonato de sódio fervente, como estabelece a norma DNER ME 079.

A amostra de agregado utilizada no ensaio é fracionada por peneiramento entre as peneiras de abertura 0,59 $\mathrm{mm}$ e 0,21 $\mathrm{mm}$, lavada e seca em estufa. Em seguida, procede-se a produção da mistura asfalto/agregado, aquecendo cerca de $29 \%$ de asfalto a $160^{\circ} \mathrm{C}$ e $71 \%$ de agregado a $175^{\circ} \mathrm{C}$, e efetuando um completo envolvimento entre os materiais. Após, coloca-se a mistura sobre uma superfície lisa e limpa, onde permanece até que atinja a temperatura ambiente. Completado o período de resfriamento, cerca de $5 \mathrm{~g}$ da mistura é colocada dentro de um tubo de ensaio com água destilada. Em seguida, aquece-se uma solução de glicerina em um bécher a aproximadamente $110^{\circ} \mathrm{C}$ (banho-maria), submetendo o conjunto (tubo, amostra e água destilada) a submersão parcial nesse banho-maria, até que seja completado 1 minuto de fervura da água. Em seguida, a mistura é retirada do tubo para a avaliação visual quanto ao descolamento ou não da película de asfalto. Se houver descolamento da película, o agregado é classificado como material de adesividade má, a exemplo do material ilustrado na Figura 7.18.

Se o descolamento não ocorrer, o ensaio é repetido, sendo agora substituída a água por soluções de carbonato de sódio em concentrações diferentes, partindo da solução menos concentrada para a mais concentrada, objetivando a determinação da concentração na qual ocorrerá o descolamento da película de asfalto. Dependendo da concentração em que ocorrer o descolamento, a adesividade do agregado poderá ser classificada como satisfatória, boa ou ótima. 


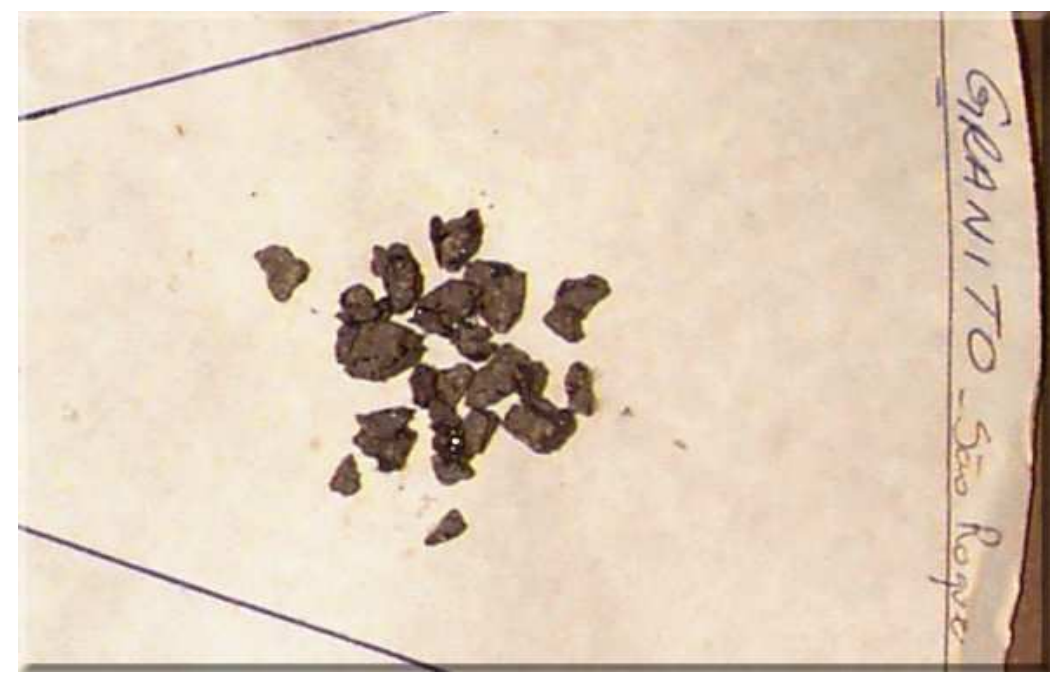

Figura 7.18: Exemplo de descolamento da película de asfalto do agregado fino, observado nesta pesquisa

\section{Sensibilidade das Misturas à Umidade}

Os danos causados pela umidade às misturas asfálticas podem ser avaliados através dos métodos padronizados pela ASTM D 4867 e pela AASHTO T 283. Basicamente, as diferenças entre esses dois métodos, destinados ao mesmo propósito, estão na etapa de cura e de condicionamento das misturas à umidade. Durante o estudo desses dois métodos, suspeitou-se que, em virtude dessas diferenças, poderiam ocorrer absorções de asfalto em maior ou menor grau pelos agregados e que, talvez isso, pudesse influenciar a suscetibilidade à umidade das misturas. Portanto, optou-se por utilizar tanto o método da ASTM D 4867 como o da AASHTO T 283 nesta pesquisa, com o objetivo de estabelecer comparações entre os métodos e avaliar o efeito da absorção de asfalto sobre os resultados encontrados.

De uma maneira geral, ambos os métodos consistem em avaliar a variação de uma propriedade mecânica da mistura, antes e depois desta ser submetida à ação da água. Para tanto, são produzidos 6 corpos-de-prova Marshall, divididos em 2 grupos de 3 corpos-de-prova, onde o primeiro grupo é submetido a algum tipo de condicionamento à água, chamado de grupo condicionado, e outro não é submetido a nenhum tipo de condicionamento, denominado grupo de controle. Ambos os métodos estabelecem como propriedade mecânica a ser avaliada a resistência à tração das misturas, no entanto, em vista dos resultados apresentados por Furlan et al. (2004) e Gouveia et al. (2004), que indicam o módulo de resiliência como uma propriedade mecânica bastante sensível à detecção de variações sofridas pela mistura quando submetida à ação da água, optou-se por também avaliar o módulo de resiliência das misturas antes e depois de submetidas ao condicionamento por umidade. 
As diferenças entre os dois procedimentos de ensaios utilizados estão na fase de cura e de condicionamento das misturas. Quanto à cura, as misturas destinadas à realização do ensaio da ASTM D 4867 são produzidas conforme o procedimento de moldagem utilizado nesta pesquisa, como descrito no Capítulo 5, item 5.3.3, ou seja, são submetidas a um período de cura de 2 horas, antes da compactação. Já as misturas destinadas à realização do ensaio da AASHTO T 283, após a mistura do asfalto com o agregado, são espalhadas em bandejas e colocadas em estufas ventiladas onde permanecem por 16 horas a uma temperatura de $60^{\circ} \mathrm{C}$, ou seja, são submetidas a uma fase de envelhecimento. Após as 16 horas, as misturas são colocadas numa estufa não ventilada mantida na temperatura de compactação, onde permanecem por 2 horas, para só então serem compactadas. Nesta pesquisa, para a avaliação de ambos os métodos, os grupos de controle foram submetidos ao ensaio de módulo de resiliência e de resistência à tração, após 24 horas da moldagem.

O processo de condicionamento, do grupo condicionado da ASTM D 4867, consiste em colocar os corpos-de-prova submersos em água em temperatura ambiente e submetê-los a vácuo parcial até que atinjam um grau de saturação entre 55 e $80 \%$. Após a saturação, os corpos-de-prova são colocados submersos em água destilada a $60^{\circ} \mathrm{C}$, por 24 horas, e, em seguida, são submersos em água destilada a $25^{\circ} \mathrm{C}$, por 1 hora. Já o condicionamento do grupo condicionado da AASHTO T 283 consiste em, após o mesmo procedimento de saturação por vácuo parcial (entre 55 a 80\%) descrito, submeter os corpos-de-prova a uma fase de congelamento, onde permanecem por 16 horas a $-18^{\circ} \mathrm{C}$ e, posteriormente, a uma fase de descongelamento, onde permanecem por 24 horas a $60^{\circ} \mathrm{C}$. Terminada a fase de descongelamento, os corpos-de-prova são submersos em água destilada a $25^{\circ} C$, por 2 horas. Nesta pesquisa, terminada a fase de condicionamento, os corpos-de-prova são submetidos ao ensaio de módulo de resiliência e ao ensaio de resistência à tração. A Tabela 7.1 apresenta resumidamente os procedimentos que compõem os ensaios da ASTM D 4867 e da AASHTO T 283.

De posse dos valores de módulo de resiliência e de resistência à tração do grupo de controle e do grupo condicionado de ambos os métodos, pode-se calcular a relação entre os módulos de resiliência, denominada de módulo de resiliência retido $(M R R)$, através da razão entre o módulo de resiliência do grupo condicionado $\left(M R_{2}\right)$ e do grupo de controle $\left(M R_{1}\right)$, e a relação entre as resistências à tração, denominada resistência à tração retida $(R T R)$, através da razão entre a resistência à tração do grupo condicionado $\left(R T_{2}\right)$ e do grupo de controle $\left(R T_{1}\right)$. É bastante aceito na literatura que misturas que apresentem propriedade retida superior a $70 \%$, ou seja, perda de propriedade causada pelo ação da água inferior a 30\%, sejam consideradas aceitáveis. 
Tabela 7.1: Resumo dos procedimentos de ensaio da ASTM D 4867 e da AASHTO T 283

\begin{tabular}{|c|c|c|c|c|}
\hline Ensaio & Corpo-de-prova & Cura e Envelhecimento & Condicionamento & Critério de aceitação \\
\hline ASTM & $\begin{array}{l}n=6 \\
V v=7 \pm 1 \% \\
\text { ou de campo } \\
\end{array}$ & $\begin{array}{l}\text { cura: temp. de } \\
\text { compac. por } 2 \mathrm{~h} \\
\text { envelhec.: não há }\end{array}$ & $\begin{array}{l}\text { congel.: não há } \\
\text { aquec.: } 60^{\circ} \mathrm{C} \text { por } 24 \mathrm{~h} \\
\text { imersão: } 25^{\circ} \mathrm{C} \text { por } 1 \mathrm{~h} \\
\end{array}$ & $\begin{array}{c}\text { Propr. retida } \\
>70 \%\end{array}$ \\
\hline AASHTO & $\begin{array}{l}n=6 \\
V v=7 \pm 1 \% \\
\text { ou de campo }\end{array}$ & $\begin{array}{l}\text { cura: não há } \\
\text { envelhec.: mistura } \\
\text { solta a } 60^{\circ} C \text { por } 16 \mathrm{~h}\end{array}$ & $\begin{array}{l}\text { congel.: }-18^{\circ} \mathrm{C} \text { por } 16 \mathrm{~h} \\
\text { descong.: } 60^{\circ} \mathrm{C} \text { por } 24 \mathrm{~h} \\
\text { imersão: } 25^{\circ} \mathrm{C} \text { por } 2 \mathrm{~h}\end{array}$ & $\begin{array}{c}\text { Propr. retida } \\
>70 \%\end{array}$ \\
\hline
\end{tabular}

\subsection{Resultados das Propriedades Mecânicas das Misturas}

\subsubsection{Estabilidade e Fluência Marshall}

Na Tabela 7.2, estão apresentados os valores médios e o desvio padrão da estabilidade e fluência Marshall das misturas AZR executadas com energia de compactação de 75, 110 e 155 golpes por face dos corpos-de-prova Marshall, produzidas com agregados de gabro e de basalto.

Tabela 7.2: Resultados da estabilidade (E) e fluência (F) Marshall das misturas AZR compactadas com energias de 75,110 e 155 golpes por face

\begin{tabular}{l|ccc|ccc}
\hline Agregados & \multicolumn{3}{|c|}{$\boldsymbol{E}(\boldsymbol{N})$} & \multicolumn{3}{c}{$\boldsymbol{F}(\mathbf{0 , 1} \boldsymbol{m m})$} \\
& 75 & 110 & 155 & 75 & 110 & 155 \\
\hline Gabro & 17.583 & 22.080 & 28.924 & 42 & 38 & 37 \\
Dpadrão & 531 & 873 & 1.026 & 1 & 3 & 1 \\
\hline Basalto & 12.837 & 16.981 & 19.299 & 44 & 44 & 43 \\
Dpadrão & 873 & 325 & 219 & 2 & 2 & 1 \\
\hline
\end{tabular}

Os resultados mostram que com a elevação da energia de compactação aplicada ocorre ganho de estabilidade (Figura 7.19). O aumento da energia de compactação de 75 golpes para 110 golpes representou um ganho de estabilidade em torno de $20 \%$ para a mistura AZRg e de $24 \%$ para a mistura AZRb. Aumentando a energia de compactação de 110 para 155 golpes, o ganho de estabilidade foi de $24 \%$ para a mistura AZRg e de $12 \%$ para a mistura AZRb. O ganho de estabilidade, comparando as estabilidades alcançadas com energias de 75 e 155 golpes, foi de $39 \%$ para a mistura AZRg e de $33 \%$ para a mistura AZRb. Os ganhos de estabilidade observados, devem-se, provavelmente, à energia de compactação adicional benéfica aplicada, que possibilitou que fosse vencida a resistência à compactação promovida pelas partículas angulosas e de textura rugosa, tornando possível a formação de arranjos mais próximos entre partículas, constatado através da diminuição do VAM (ver Tabela 7.3), culminado em misturas com esqueletos estruturais mais resistentes. 


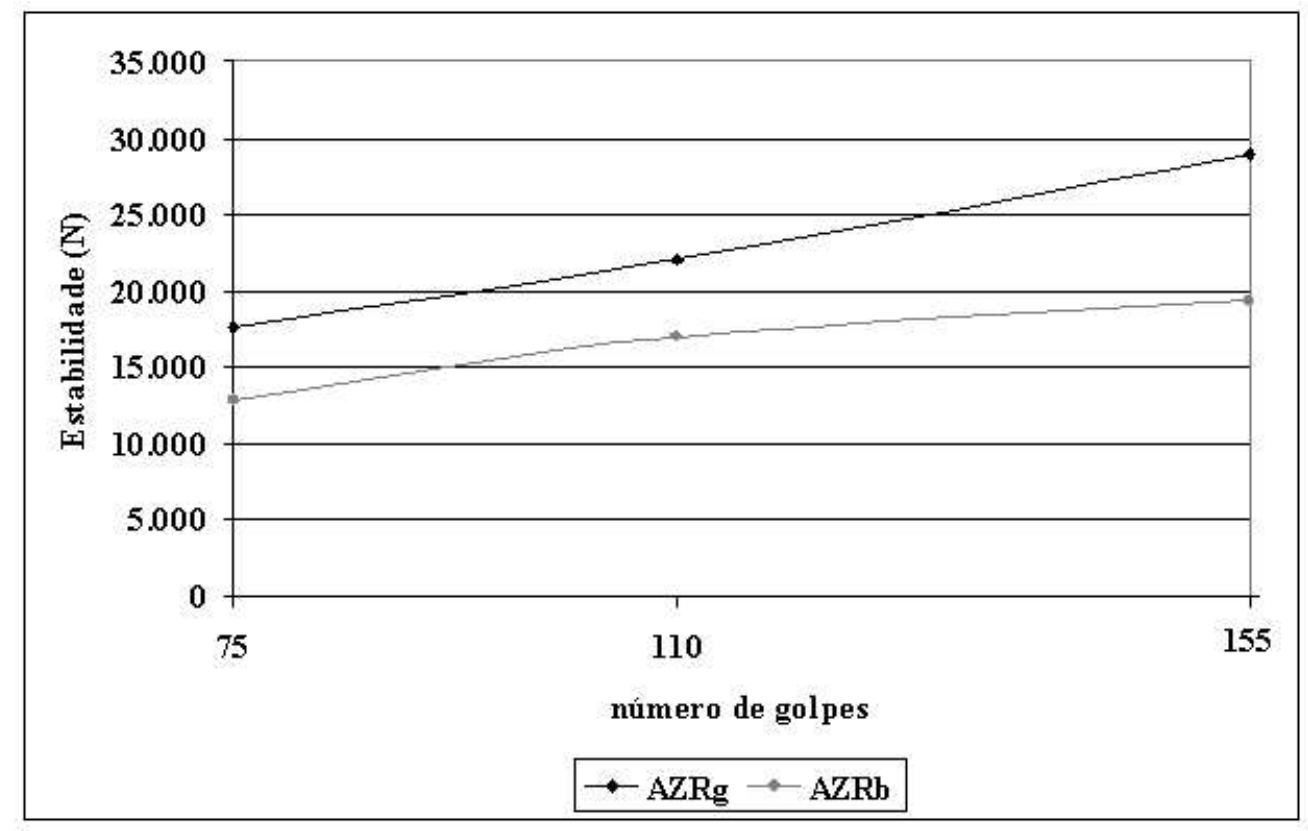

Figura 7.19: Variação da estabilidade em função da energia de compactação aplicada

Tabela 7.3: Resultados do VAM e do asfalto efetivo, para energias de compactação de 75, 110 e 155 golpes

\begin{tabular}{l|ccc|ccc}
\hline & \multicolumn{3}{|c|}{ VAM $(\%)$} & \multicolumn{3}{c}{ Asfalto efetivo $(\%)$} \\
\hline Agregados & $\mathbf{7 5}$ & $\mathbf{1 1 0}$ & $\mathbf{1 5 5}$ & $\mathbf{7 5}$ & $\mathbf{1 1 0}$ & $\mathbf{1 5 5}$ \\
\hline AZRg & 17,0 & 16,5 & 16,0 & 5,3 & 5,2 & 5,0 \\
AZRb & 19,5 & 18,3 & 17,4 & 6,5 & 6,0 & 5,6 \\
\hline
\end{tabular}

O aumento da energia de compactação, tanto de 75 para 110 golpes como de 110 para 155 golpes, representou uma diminuição do VAM em torno de $0,5 \%$ e de asfalto efetivo em aproximadamente $0,1 \%$, para a mistura AZRg (Tabela 7.3). Já a mistura AZRb, com o aumento da energia de compactação tanto de 75 para 110 golpes como de 110 para 155 golpes, apresentou uma diminuição mais acentuada do VAM, em torno de $1 \%$ e de asfalto efetivo de $0,5 \%$. No entanto, apesar da mistura AZRg ter apresentado uma diminuição menor do VAM e, portanto, do teor de asfalto efetivo de projeto, esta teve ganho de estabilidade mais pronunciado se comparado ao ganho de estabilidade da mistura AZRb (Figura 7.20). Uma possível explicação é que uma maior energia de compactação não somente aproxima as partículas entre si, mas possibilita também que elas arranjem-se de maneira mais eficaz para promover um melhor intertravamento entre partículas. E devido às características de forma da partícula de gabro serem mais adequadas para promover o intertravamento entre partículas, o ganho de estabilidade da mistura AZRg foi maior.

Vale notar também que as misturas produzidas com o agregado de gabro são mais estáveis que as produzidas com o agregado de basalto, para todas as energias de compactação aplicadas 


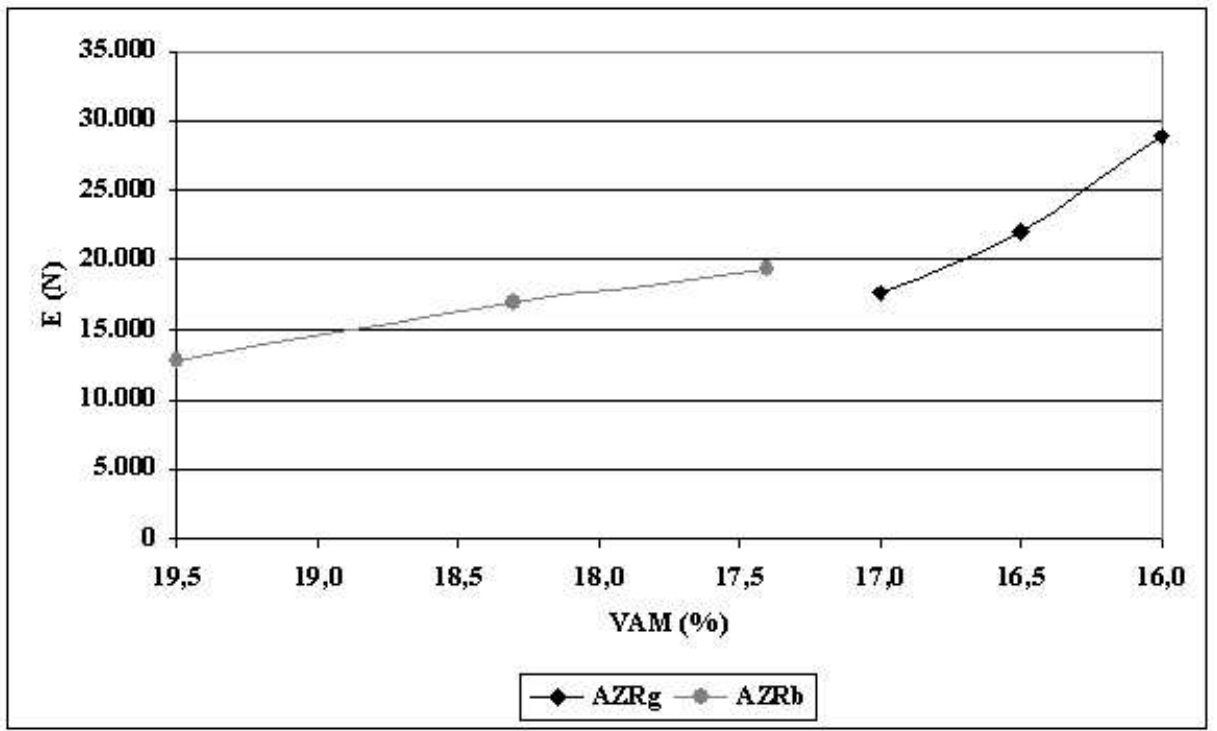

Figura 7.20: Variação da estabilidade Marshall em função do VAM das misturas

(Figura 7.19). Esse fato mostra a superioridade das características de forma do agregado de gabro comparadas às do agregado de basalto e destaca a importância dessa propriedade na formação do esqueleto estrutural da mistura.

A fluência Marshall das misturas sofreu pouca variação com o aumento da energia de compactação (Tabela 7.2). Estatisticamente, não houve variação da fluência da mistura AZRg com o aumento da energia de compactação de 75 para 110 golpes ou de 110 para 155 golpes. Somente foi verificada uma diminuição da fluência da mistura AZRg quando comparados os valores médios obtidos com energias de compactação de 75 e 155 golpes. Já para a mistura $\mathrm{AZRb}$ não houve variação da fluência com o aumento da energia de compactação.

\subsubsection{Fluência por Compressão Uniaxial Estática}

O ensaio de fluência por compressão uniaxial estática resulta numa curva de fluência, a qual consiste na deformação sofrida pelo corpo-de-prova em função do tempo de realização do ensaio. Através dessa curva de fluência pode-se calcular os parâmetros de análise do ensaio. Esses parâmetros são a deformação total do corpo-de-prova ao final do ensaio, a deformação plástica, aquela que permanece após o período de recuperação, a deformação elástica, determinada pela diferença entre a deformação total e a deformação plástica, a recuperação elástica, a qual representa uma relação percentual entre a deformação elástica e a deformação total, o módulo de fluência após 3600 s de ensaio e a inclinação da curva de fluência. O módulo de fluência pode ser obtido pela relação entre a tensão aplicada e a deformação sofrida pelo corpo-de-prova após 3600 s de aplicação de carga, enquanto a inclinação da curva deformação 
versus tempo pode ser determinada no trecho entre 1000 e 3600 s após o início da aplicação de carga.

Nas Tabelas 7.4 e 7.5, estão apresentados os valores médios referentes a três determinações e o desvio padrão das deformações totais (Dt), deformações elásticas (De), deformações plásticas (Dp), recuperações (Recup.), módulos de fluência (MF) e inclinações (Inclin.), obtidos através do ensaio de fluência por compressão uniaxial estática.

Tabela 7.4: Valores médios do ensaio de fluência por compressão uniaxial estática para misturas produzidas com 75 golpes por face

\begin{tabular}{lcccccc}
\hline $\begin{array}{l}\text { Misturas e } \\
\text { Agregados }\end{array}$ & $\begin{array}{c}\mathbf{D t} \\
(\mathrm{mm} / \mathrm{mm})\end{array}$ & $\begin{array}{c}\text { De } \\
(\mathrm{mm} / \mathrm{mm})\end{array}$ & $\begin{array}{c}\text { Dp } \\
(\mathrm{mm} / \mathrm{mm})\end{array}$ & $\begin{array}{c}\text { Recup. } \\
(\%)\end{array}$ & $\begin{array}{c}\text { MF } \\
(\mathrm{MP} a)\end{array}$ & Inclin. \\
\hline AZRg & 0,00270 & 0,00159 & 0,00111 & 60 & 36,39 & 0,04030 \\
Dpadrão & 0,00001 & 0,00001 & 0,00001 & 1 & 1,08 & 0,00098 \\
\hline AZRb & 0,00358 & 0,00166 & 0,00192 & 51 & 35,01 & 0,05993 \\
Dpadrão & 0,00060 & 0,00004 & 0,00066 & 6 & 5,59 & 0,00623 \\
\hline Bg & 0,00292 & 0,00162 & 0,00131 & 59 & 34,89 & 0,05537 \\
Dpadrão & 0,00039 & 0,00008 & 0,00055 & 10 & 5,10 & 0,02613 \\
\hline Bb & 0,00190 & 0,00123 & 0,00067 & 71 & 59,18 & 0,03733 \\
Dpadrão & 0,00055 & 0,00027 & 0,00028 & 4 & 13,5 & 0,00391 \\
\hline
\end{tabular}

\section{Curva Granulométrica}

Ao analisar comparativamente a granulometria das misturas AZR e Bg, produzidas com agregado de gabro e compactadas com 75 golpes por face (Tabela 7.4), pode-se verificar que as misturas AZRg e Bg tiveram valores considerados estatisticamente iguais de deformações (total, elástica e plástica), assim como de recuperação, de módulo de fluência e de inclinação (Figura 7.22). Os parâmetros analisados pelo ensaio de fluência uniaxial estática indicam que as misturas produzidas com as granulometrias AZR e Bg apresentam comportamento mecânico semelhante, não indicando superioridade de uma granulometria em relação à outra.

Já as misturas $\mathrm{AZRb}$ e $\mathrm{Bb}$ apresentaram apenas deformações elásticas estatisticamente iguais. A mistura AZRb deformou-se plasticamente cerca de $65 \%$ a mais que a mistura $\mathrm{Bb}$, com deformação total $47 \%$ maior à da mistura $\mathrm{Bb}$ (Figura 7.21). A capacidade de recuperação elástica da mistura Bb foi aproximadamente $28 \%$ maior que a da mistura AZRb (Figura 7.22(a)). O módulo de fluência da mistura $\mathrm{Bb}$ foi $41 \%$ mais elevado que o módulo da mistura AZRb (Figura 7.22(b)) e a inclinação da curva de fluência da mistura Bb foi cerca de $38 \%$ mais baixa que a inclinação da mistura AZRb (Figura 7.22(c)). Os parâmetros analisados pelo ensaio de 
fluência uniaxial estática, de uma maneira geral, indicam a superioridade da granulometria $\mathrm{Bb}$ em relação à granulometria AZR para resistir às deformações permanentes.

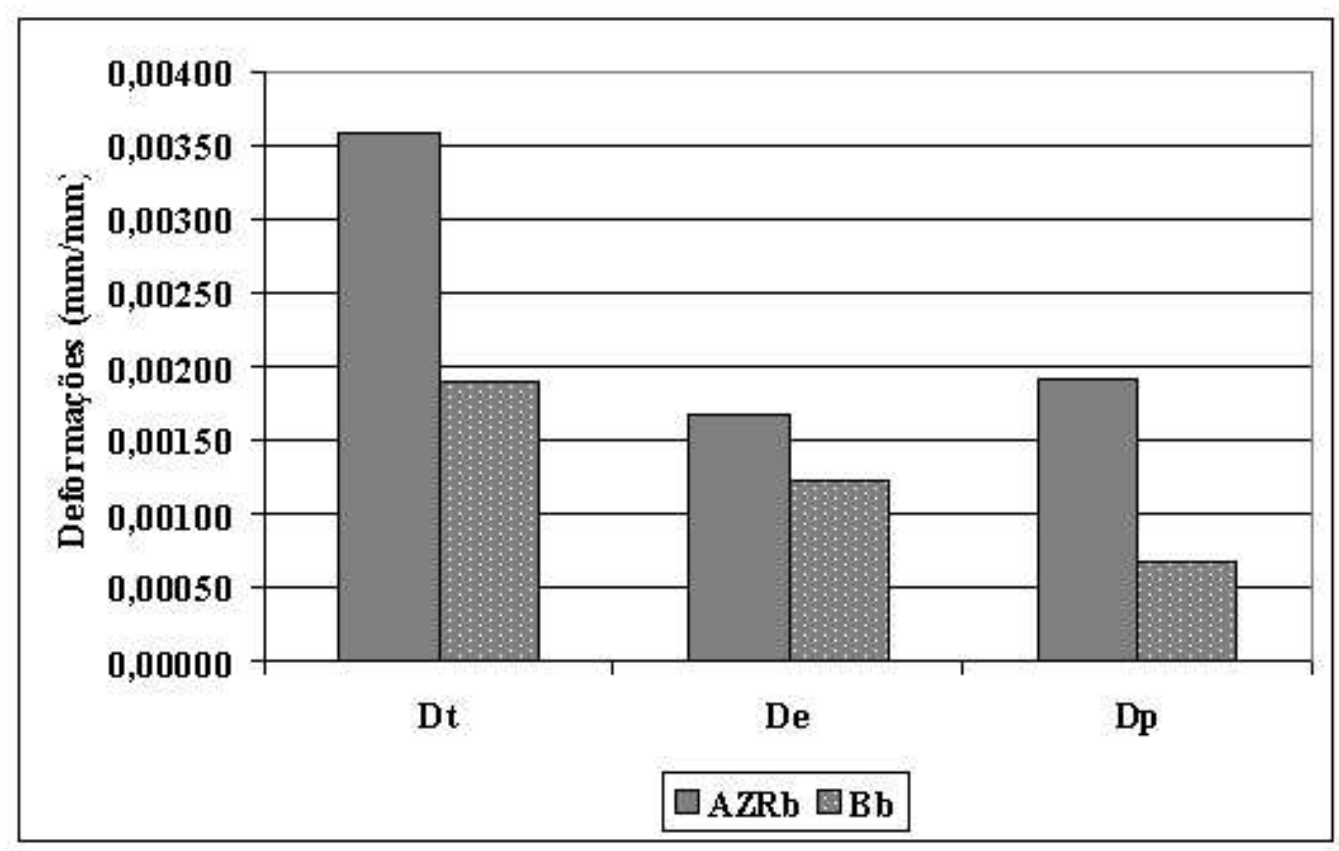

Figura 7.21: Variações das deformações total, elástica e plástica das misturas AZRb e Bb, compactadas com 75 golpes por face 


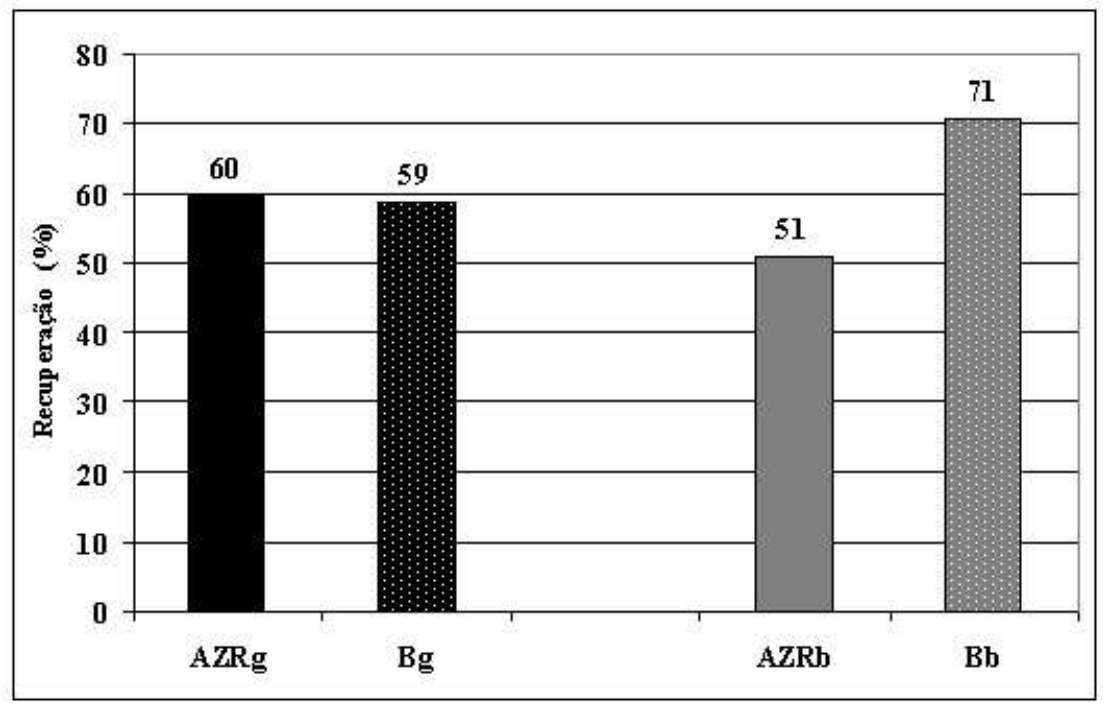

(a) Recuperação elástica

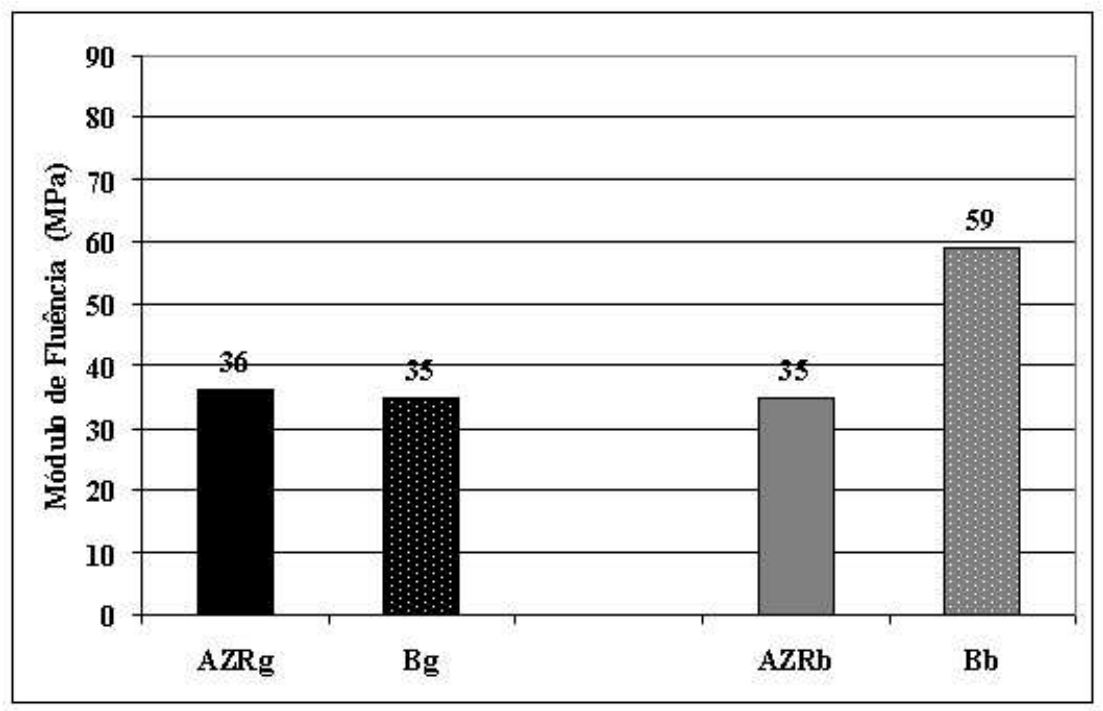

(b) Módulo de fluência

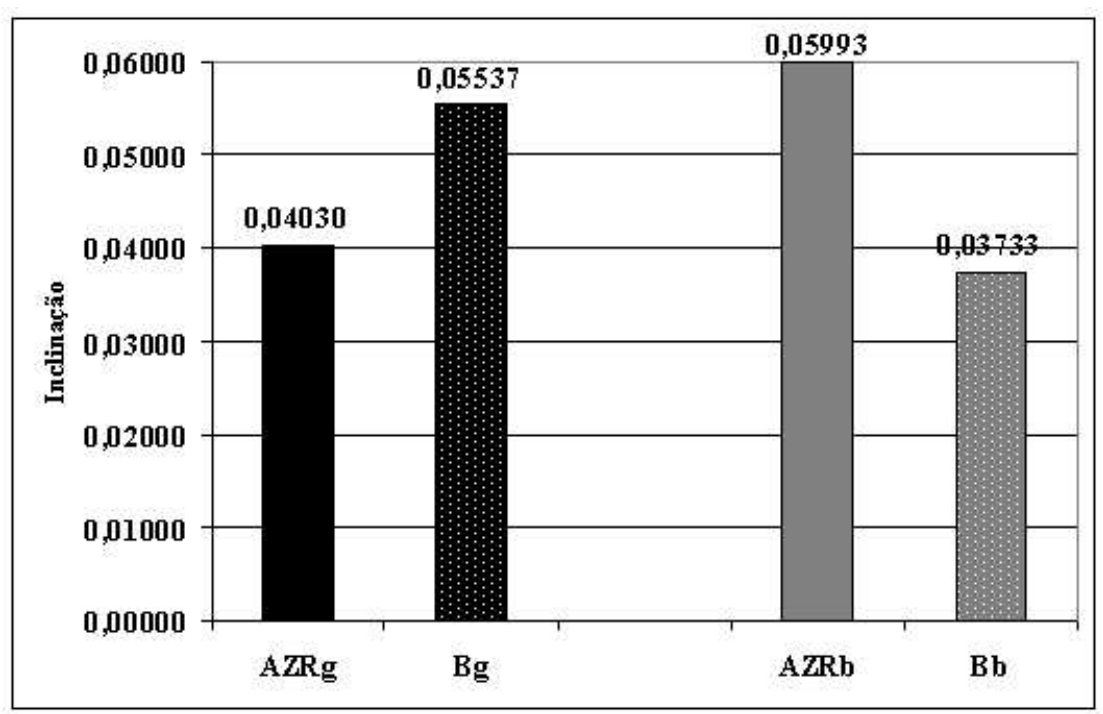

(c) Inclinação

Figura 7.22: Variações da recuperação elástica, módulo de fluência e inclinação, obtidas através do ensaio de fluência uniaxial estática, das misturas AZRg, Bg, AZRb e Bb, compactadas com 75 golpes por face 


\section{Tipo de Agregado}

Os parâmetros do ensaio encontrados para as misturas AZRg e AZRb, compactadas com 75 golpes por face (Tabela 7.4), indicam que não há diferença entre as médias, ou seja, os valores de deformação total, elástica e plástica, assim como a recuperação e módulo de fluência podem ser considerados estatisticamente iguais. Apenas a inclinação da curvas de fluência da mistura AZRb foi mais elevada comparada à da mistura AZRg, mas, de uma maneira geral, os desvios padrões referentes às médias das inclinações foram relativamente altos.

Na Tabela 7.5, estão apresentados os parâmetros do ensaio encontrados para as misturas AZRg e AZRb compactadas com 110 e 155 golpes por face do corpo-de-prova. Os resultados também indicam que não há diferença entre os valores de deformação total, elástica e plástica, assim como, de recuperação, módulo de fluência e inclinação ao comparar as misturas 110AZRg e 110AZRb ou 155AZRg e 155AZRb. Portanto, pode-se concluir que, para uma mesma granulometria AZR, o comportamento das misturas produzidas com agregado de gabro e de basalto são semelhantes quanto à deformação permanente, considerando os parâmetros analisados através do ensaios de fluência por compressão uniaxial estática.

Tabela 7.5: Valores médios do ensaio de fluência por compressão uniaxial estática para misturas produzidas com 110 e 155 golpes por face

\begin{tabular}{lcccccc}
\hline $\begin{array}{l}\text { Misturas e } \\
\text { Agregados }\end{array}$ & $\begin{array}{c}\text { Dt } \\
(\mathrm{mm} / \mathrm{mm})\end{array}$ & $\begin{array}{c}\text { De } \\
(\mathrm{mm} / \mathrm{mm})\end{array}$ & $\begin{array}{c}\text { Dp } \\
(\mathrm{mm} / \mathrm{mm})\end{array}$ & $\begin{array}{c}\text { Recup. } \\
(\%)\end{array}$ & $\begin{array}{c}\text { MF } \\
(\mathrm{MPa})\end{array}$ & Inclin. \\
\hline 110AZRg & 0,00147 & 0,00128 & 0,00019 & 87 & 72,69 & 0,04678 \\
Dpadrão & 0,00012 & 0,00001 & 0,00012 & 6 & 9,12 & 0,03221 \\
\hline 110AZRb & 0,00172 & 0,00124 & 0,00049 & 73 & 62,29 & 0,08773 \\
Dpadrão & 0,00027 & 0,00013 & 0,00019 & 7 & 8,34 & 0,03045 \\
\hline 155AZRg & 0,00118 & 0,00087 & 0,00031 & 75 & 77,99 & 0,13120 \\
Dpadrão & 0,00017 & 0,00015 & 0,00006 & 7 & 15,40 & 0,02286 \\
\hline 155AZRb & 0,00133 & 0,00086 & 0,00047 & 67 & 89,37 & 0,14318 \\
Dpadrão & 0,00010 & 0,00020 & 0,00030 & 14 & 13,64 & 0,04147 \\
\hline
\end{tabular}

\section{Energia de Compactação}

Já se for considerada a variação da energia de compactação aplicada para um mesmo tipo de agregado, outras observações podem ser conjeturadas. Para misturas produzidas com agregado de gabro, com o aumento da energia de compactação de 75 golpes para 110 golpes, ocorreu uma redução da deformação total em torno de $46 \%$, uma redução da deformação plástica em 83\% (Figura 7.23), a capacidade de recuperação elástica da mistura foi melhorada em cerca de $31 \%$ (Figura 7.24(a)) e o módulo de fluência foi $50 \%$ maior (Figura 7.24(b)). Com base nesses resultados, pode-se depreender que ao aumentar a energia de compactação de 75 para 
110 golpes, na produção das misturas com gabro, há uma melhora média superior a $50 \%$ quanto à sua capacidade de resistir à deformação permanente.

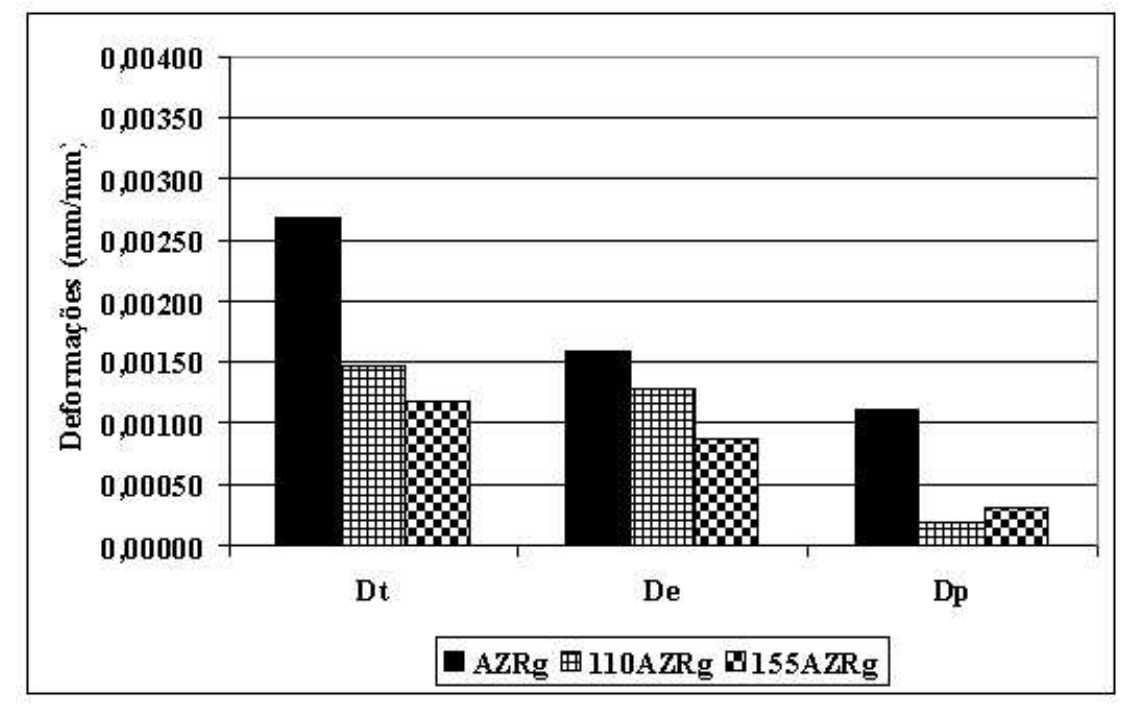

Figura 7.23: Variação das deformações das misturas produzidas com gabro, obtidas através do ensaio de fluência uniaxial estática, conforme o aumento da energia de compactação

No entanto, o aumento da energia de compactação de 110 para 155 golpes por face não acrescentou ganhos significativos quanto à capacidade de resistir à deformação permanente. Tanto a mistura 110AZRg como a mistura 155AZRg tiveram valores estatisticamente equivalentes quanto à deformação total e deformação plástica, recuperação e módulo de fluência (Figura 7.24).

Também para as misturas produzidas com agregado de basalto, com o aumento da energia de compactação de 75 golpes para 110 golpes, as misturas 110AZRb tiveram uma redução da deformação total em torno de 51\%, uma redução da deformação plástica em 75\% (Figura 7.25), a capacidade de recuperação elástica da mistura foi melhorada cerca de $31 \%$ e o módulo de fluência foi $44 \%$ maior (Figura 7.24). Com base nesses resultados, pode-se concluir que ao aumentar a energia de compactação de 75 para 110 golpes há uma melhoria média superior a $50 \%$ quando à capacidade da mistura produzida com basalto de resistir à deformação permanente. Com a elevação da energia de compactação de 110 para 155 golpes por face, as misturas produzidas com basalto apresentaram resultados estatisticamente equivalentes quanto às deformações (total, elástica e plástica) e recuperação, porém, o módulo de fluência da mistura $155 \mathrm{AZRb}$ foi cerca de $30 \%$ maior que o módulo da mistura 110AZRb (Figura 7.24). 


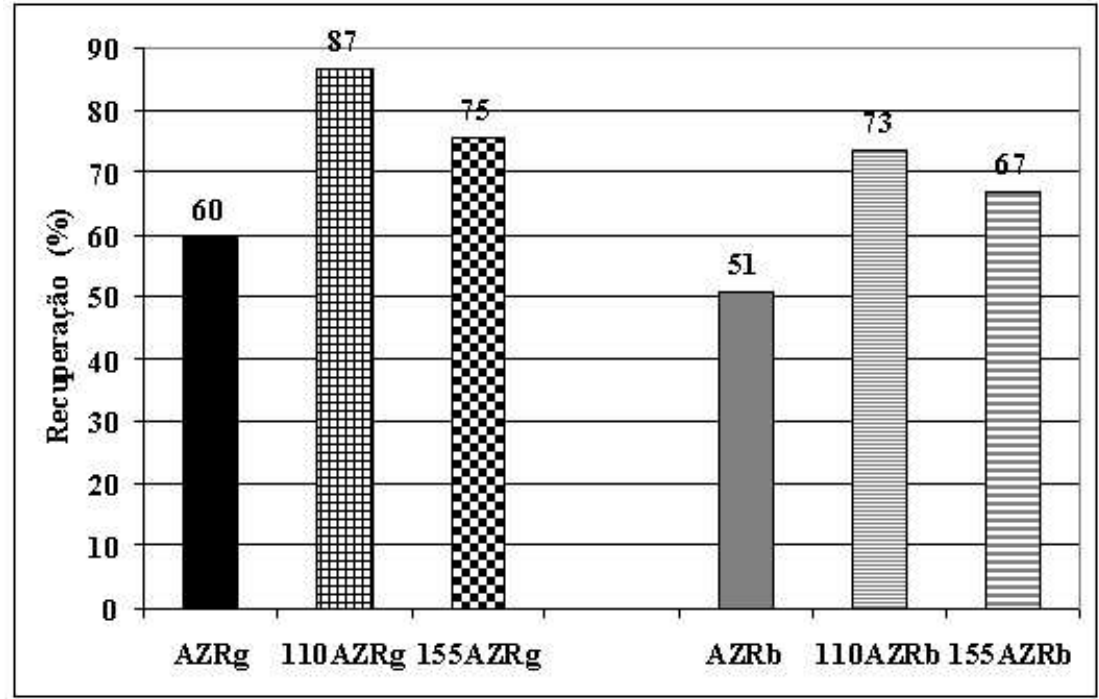

(a) Recuperação

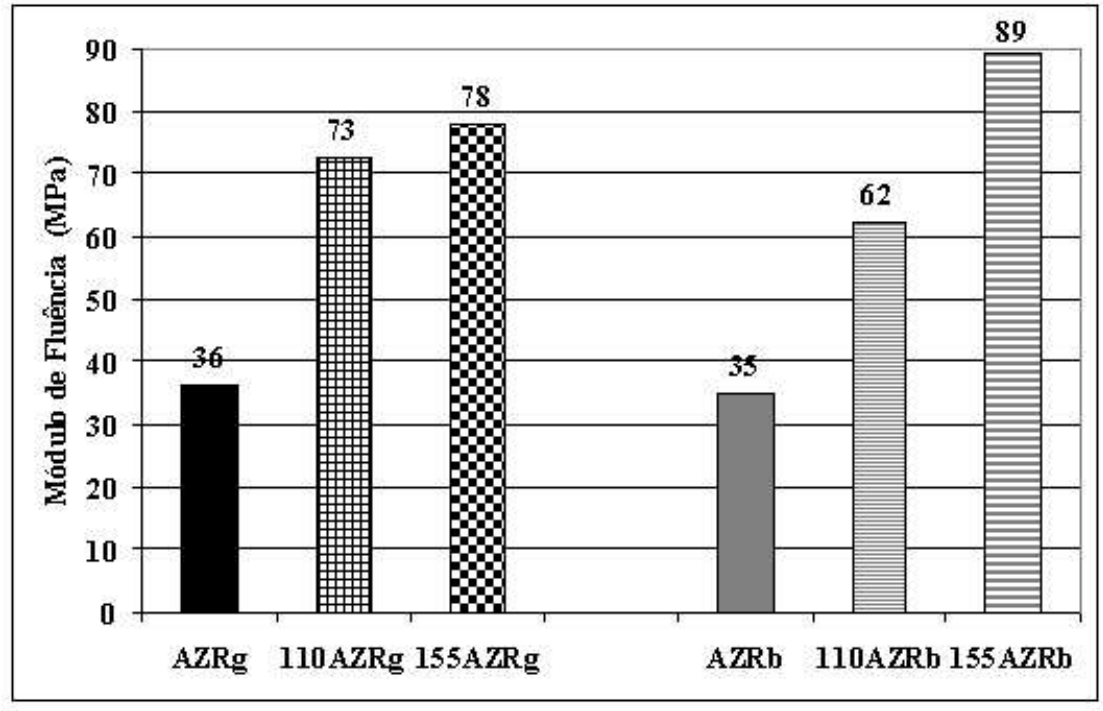

(b) Módulo de fluência

Figura 7.24: Variações da recuperação e do módulo de fluência, obtidos através do ensaio de fluência uniaxial estática, das misturas produzidas com agregado de gabro e de basalto, em função da energia de compactação aplicada 


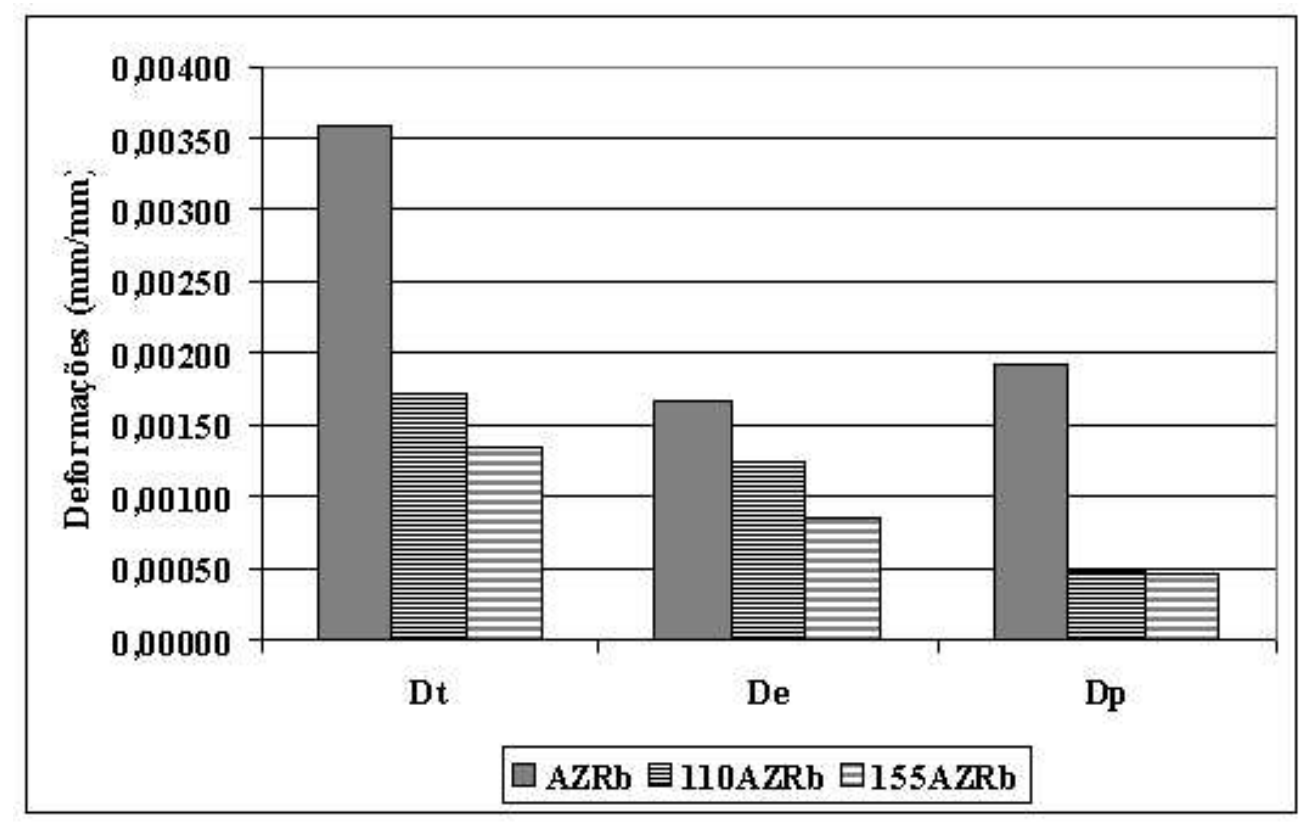

Figura 7.25: Variação das deformações das misturas produzidas com basalto, obtidas através do ensaio de fluência uniaxial estática, conforme o aumento da energia de compactação

\subsubsection{Fluência por Compressão Uniaxial Dinâmica}

Nas Tabelas 7.6 e 7.7, estão apresentados os valores médios referentes a três determinações e desvio padrão das deformações totais, módulos de fluência e inclinações nos trechos entre 100 e $5000 s$ da curva de fluência, obtidos através do ensaio de fluência por compressão uniaxial dinâmica.

Tabela 7.6: Valores médios do ensaio de fluência por compressão uniaxial dinâmica para misturas produzidas com 75 golpes por face

\begin{tabular}{lccc}
\hline $\begin{array}{l}\text { Mistura e Tipo } \\
\text { de Agregado }\end{array}$ & $\begin{array}{c}\text { Dt } \\
(\mathrm{mm} / \mathrm{mm})\end{array}$ & $\begin{array}{c}\text { MF } \\
(\mathrm{MPa})\end{array}$ & Inclinação \\
\hline AZRg & 0,00267 & 38,37 & 0,34798 \\
Dpadrão & 0,00036 & 3,36 & 0,02520 \\
\hline AZRb & 0,00351 & 32,09 & 0,34633 \\
Dpadrão & 0,00024 & 2,83 & 0,02450 \\
\hline Bg & 0,00396 & 27,13 & 0,34096 \\
Dpadrão & 0,00021 & 0,34 & 0,05005 \\
\hline Bb & 0,00485 & 22,95 & 0,36388 \\
Dpadrão & 0,00034 & 1,23 & 0,03078 \\
\hline
\end{tabular}




\section{Curva Granulométrica}

Ao analisar comparativamente as curvas granulométricas AZR e Bg, produzidas com agregado de gabro, pode-se observar que as misturas AZRg e Bg apresentam deformação total e módulo de fluência estatisticamente diferentes. A mistura AZRg deformou-se cerca de 33\% menos que a mistura $\mathrm{Bg}$ e apresentou módulo de fluência $29 \%$ maior que o módulo da mistura Bg (Figura 7.26). Já as inclinações das duas misturas podem ser consideradas estatisticamente iguais. De uma maneira geral, esses resultados indicam comportamento melhor quanto à deformação permanente das misturas com a granulometria AZR, contrariando os resultados encontrados através do ensaio de fluência por compressão estática, que indicam comportamento equivalente entre as duas misturas.

A mistura AZRb também apresentou deformação total cerca de $28 \%$ menor que a deformação total da mistura Bb e módulo de fluência aproximadamente $28 \%$ mais elevado que o módulo da mistura Bb. Já a inclinação das duas misturas podem ser consideradas estatisticamente iguais (Figura 7.26). Esses resultados também indicam um comportamento melhor quanto à deformação permanente das misturas produzidas com a granulometria AZR quando comparado ao comportamento da mistura produzida com granulometria $\mathrm{Bb}$, contrariando os resultados obtidos com o ensaio de fluência por compressão estática, que apontam a superioridade da granulometria $\mathrm{Bb}$ para resistir à deformação permanente. 


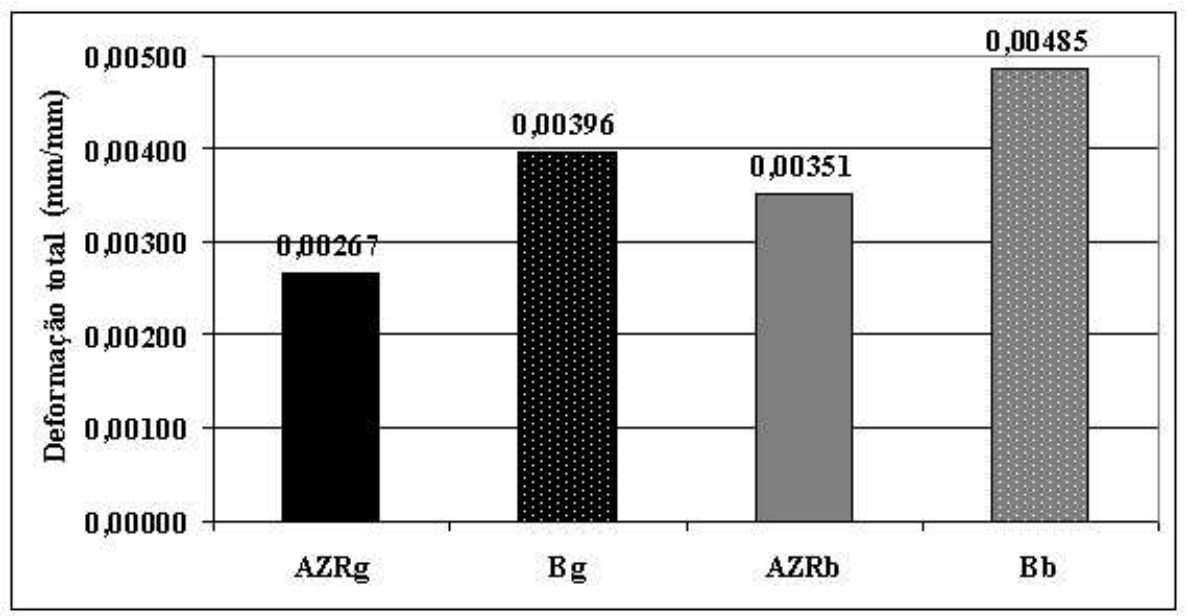

(a) Deformação total

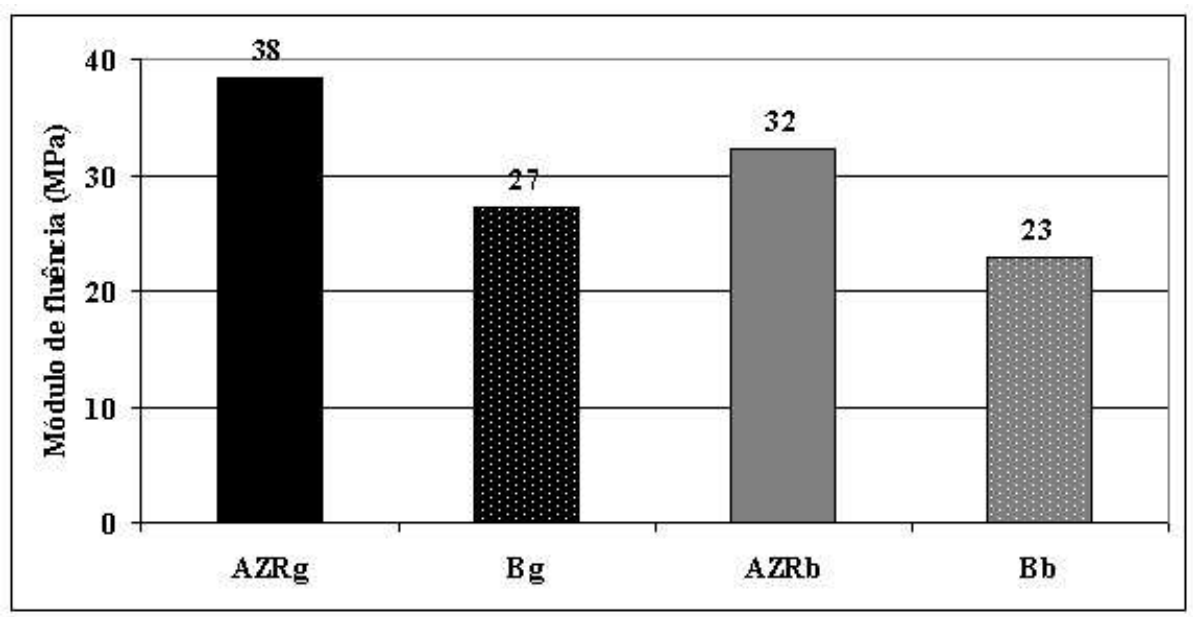

(b) Módulo de fluência

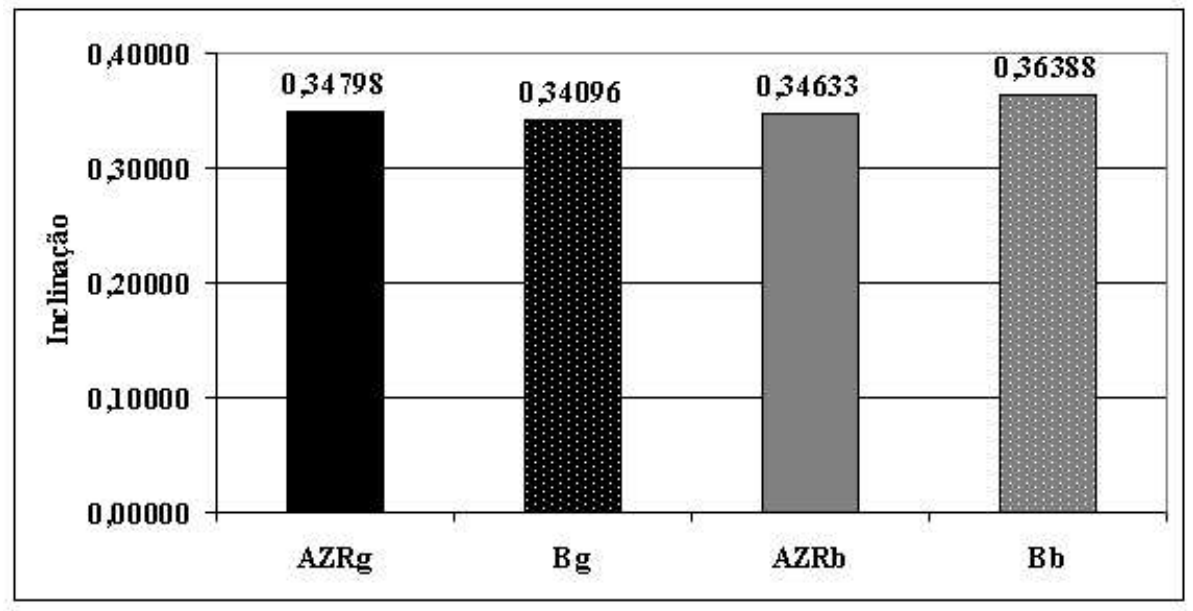

(c) Inclinação

Figura 7.26: Parâmetros do ensaio de fluência uniaxial dinâmica para misturas com granulometrias AZR e Bailey, produzidas com agregados de gabro e de basalto, compactadas com 75 golpes por face 


\section{Tipo de Agregado}

$\mathrm{Na}$ Tabela 7.6, estão apresentados os parâmetros do ensaio encontrados para as misturas AZRg e AZRb, compactadas com 75 golpes por face. Os resultados mostram que a mistura AZRg deformou-se cerca de $24 \%$ menos que a mistura AZRb, porém com módulos de fluência e inclinações estatisticamente equivalentes, concordando com os resultados obtidos no ensaio de fluência por compressão uniaxial estática.

Na Tabela 7.7, estão apresentados os parâmetros do ensaio de fluência uniaxial dinâmica encontrados para as misturas AZRg e AZRb, compactadas com 110 e 155 golpes por face do corpo-de-prova. A comparação entre os resultados das misturas 110AZRg e 110AZRb e, 155AZRg e 155AZRb também indica não haver diferenças estatísticas entre os valores de deformação total, módulo de fluência e inclinação da curva de fluência das misturas (Figura 7.27). Portanto, pode-se concluir que para uma mesma granulometria AZR, mesmo empregando energias de compactação diferentes, os parâmetros analisados através do ensaios de fluência por compressão uniaxial dinâmica indicam comportamento semelhante entre as misturas produzidas com agregado de gabro e de basalto quanto à deformação permanente, concordando inteiramente com os resultados encontrados através do ensaio de fluência por compressão uniaxial estática.

Tabela 7.7: Valores médios do ensaio de fluência por compressão uniaxial dinâmica para misturas produzidas com 110 e 155 golpes por face

\begin{tabular}{lccc}
\hline $\begin{array}{l}\text { Mistura e Tipo } \\
\text { de Agregado }\end{array}$ & $\begin{array}{c}\text { Dt } \\
(\mathrm{mm} / \mathrm{mm})\end{array}$ & $\begin{array}{c}\text { MF } \\
(\mathrm{MPa})\end{array}$ & Inclinação \\
\hline AZRg & 0,00267 & 38,37 & 0,34798 \\
Dpadrão & 0,00036 & 3,36 & 0,02520 \\
\hline 110AZRg & 0,00163 & 74,93 & 0,27692 \\
Dpadrão & 0,00015 & 5,47 & 0,01462 \\
\hline 155AZRg & 0,00066 & 174,38 & 0,18435 \\
Dpadrão & 0,00007 & 20,79 & 0,02317 \\
\hline \hline AZRb & 0,00351 & 32,09 & 0,34633 \\
Dpadrão & 0,00024 & 2,83 & 0,02450 \\
\hline 110AZRb & 0,00161 & 67,59 & 0,29953 \\
Dpadrão & 0,00027 & 14,32 & 0,03184 \\
\hline 155AZRb & 0,00068 & 166,74 & 0,16015 \\
Dpadrão & 0,00004 & 7,21 & 0,00859 \\
\hline
\end{tabular}




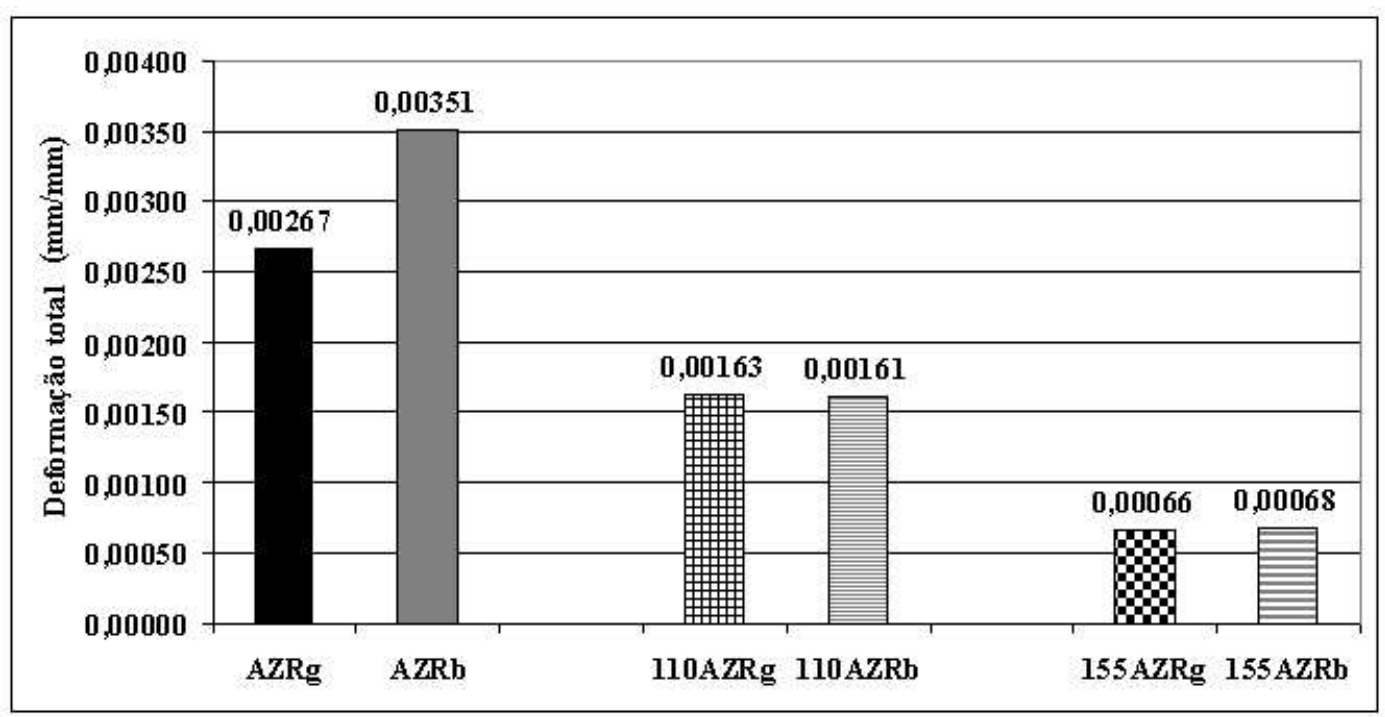

(a) Deformação total

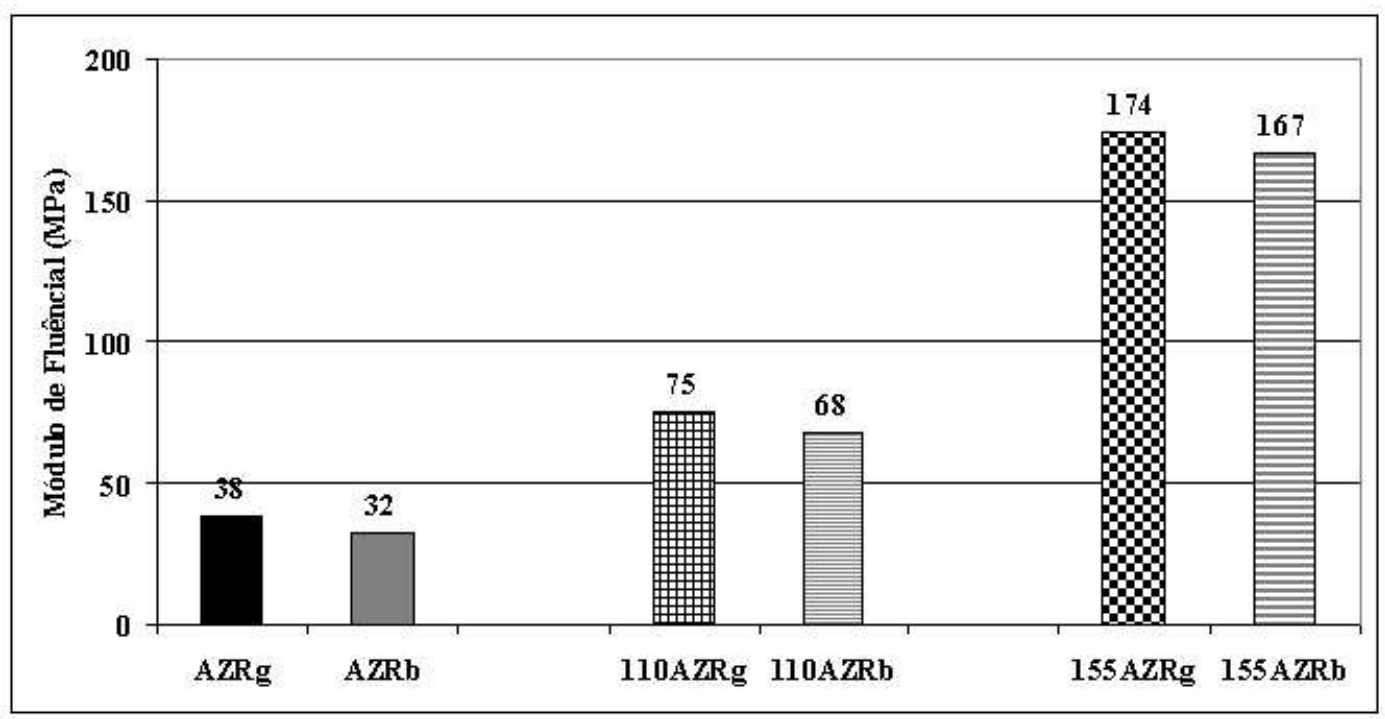

(b) Módulo de fluência

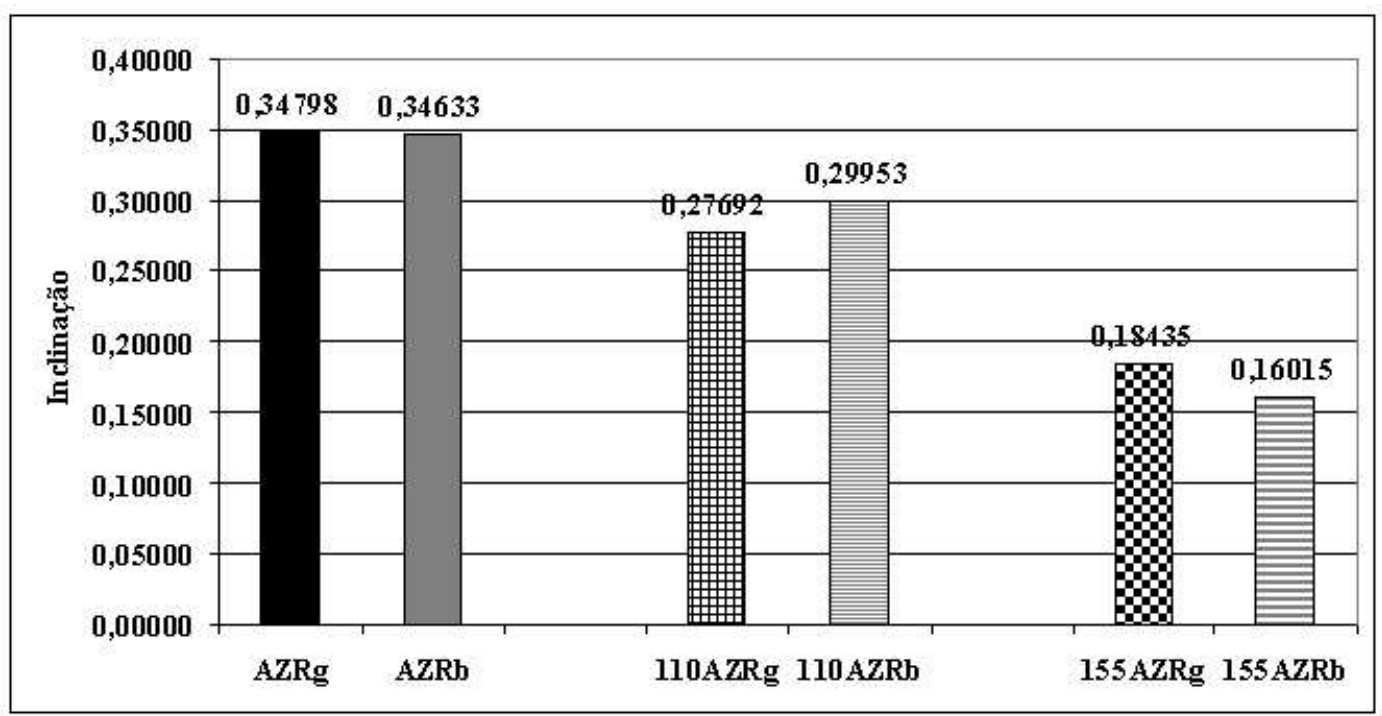

(c) Inclinação

Figura 7.27: Parâmetros do ensaio de fluência uniaxial dinâmica das misturas produzidas com agregados de gabro e de basalto com energias de compactação de 75, 110 e 155 golpes 


\section{Energia de Compactação}

Já se for considerada a variação da energia de compactação aplicada (75, 110 e 155), para um mesmo tipo de agregado (gabro ou basalto), outras considerações podem ser feitas. Considerando as misturas produzidas com agregado de gabro, com o aumento da energia de compactação de 75 golpes para 110 golpes houve redução da deformação total em torno de $39 \%$, aumento do módulo de fluência em aproximadamente $49 \%$ e redução da inclinação da curva de fluência em aproximadamente $20 \%$ (Figura 7.28). Com base nesses resultados, pode-se concluir que ao aumentar a energia de compactação de 75 para 110 golpes, em misturas produzidas com gabro, há uma melhoria média superior a $35 \%$ quando à resistência à deformação permanente, fato que vem corroborar os resultados do ensaio de fluência por compressão estática.

Também foi constatada uma melhora média superior a $50 \%$ quanto à capacidade da mistura AZRg de resistir à deformação permanente, quando a energia de compactação passou de 110 para 155 golpes por face do corpo-de-prova. A mistura 155AZRg apresentou deformação total diminuída em aproximadamente $60 \%$, módulo de fluência majorado cerca de $57 \%$ e inclinação da curva de fluência diminuída em $33 \%$ (Figura 7.28). Esses resultados encontrados através do ensaio de fluência por compressão uniaxial dinâmica diferem dos resultados do ensaio de fluência por compressão estática, o qual, com aumento da energia de compactação de 110 para 155 golpes, não detectou melhoria da resistência à deformação permanente das misturas.

Também para as misturas produzidas com agregado de basalto, o aumento da energia de compactação de 75 para 110 golpes resultou numa diminuição da deformação total da mistura 110AZRb em torno de $54 \%$ e numa elevação da estabilidade, evidenciada através do aumento do módulo de fluência, em aproximadamente $53 \%$ (Figura 7.28). Portanto, pode-se concluir que ao aumentar a energia de compactação de 75 para 110 golpes há uma melhoria média superior a 50\% quando à capacidade da mistura produzida com basalto de resistir à deformação permanente, resultados estes concordantes com os resultados obtidos no ensaio de fluência por compressão estática.

Ao aumentar a energia de compactação de 110 para 155 golpes, a mistura 155AZRb teve sua deformação total diminuída em $58 \%$, seu módulo de fluência elevado em cerca de $60 \%$ e a inclinação da curva de fluência diminuída em 47\%, ou seja, a elevação da energia de compactação de 110 para 155 golpes resultou numa elevação da resistência à deformação permanente da mistura superior a $50 \%$ (Figura 7.28). 


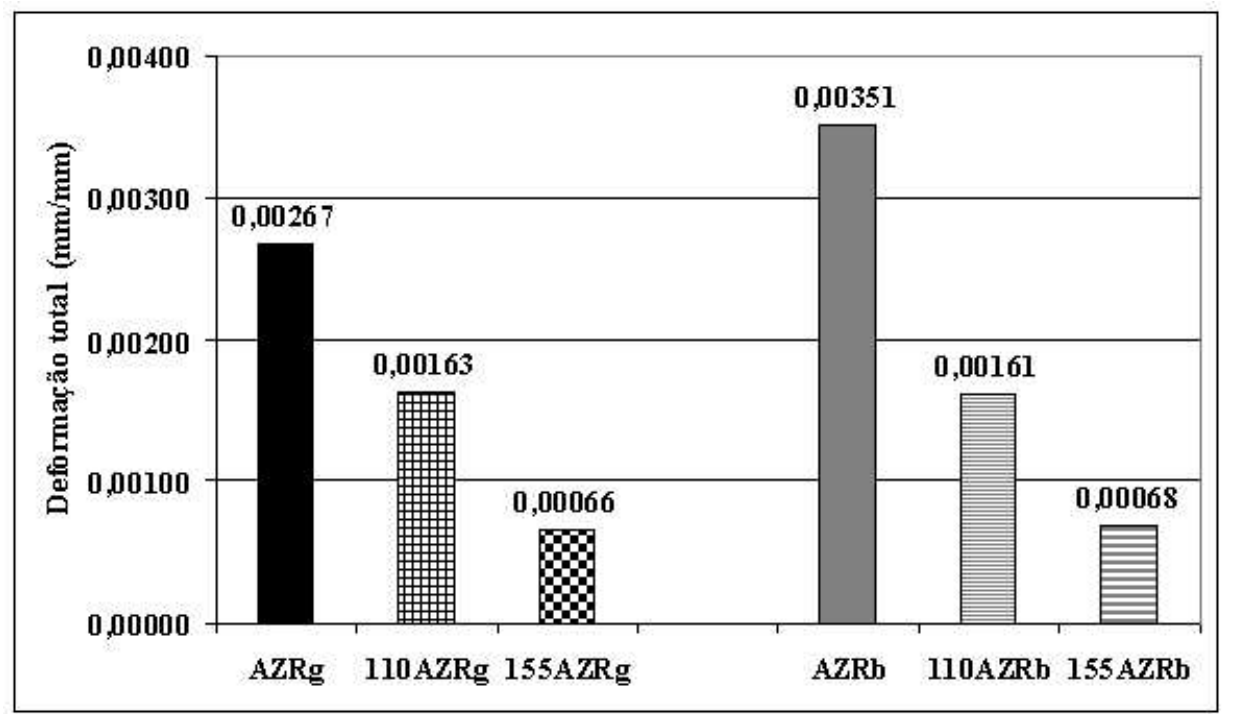

(a) Deformação total

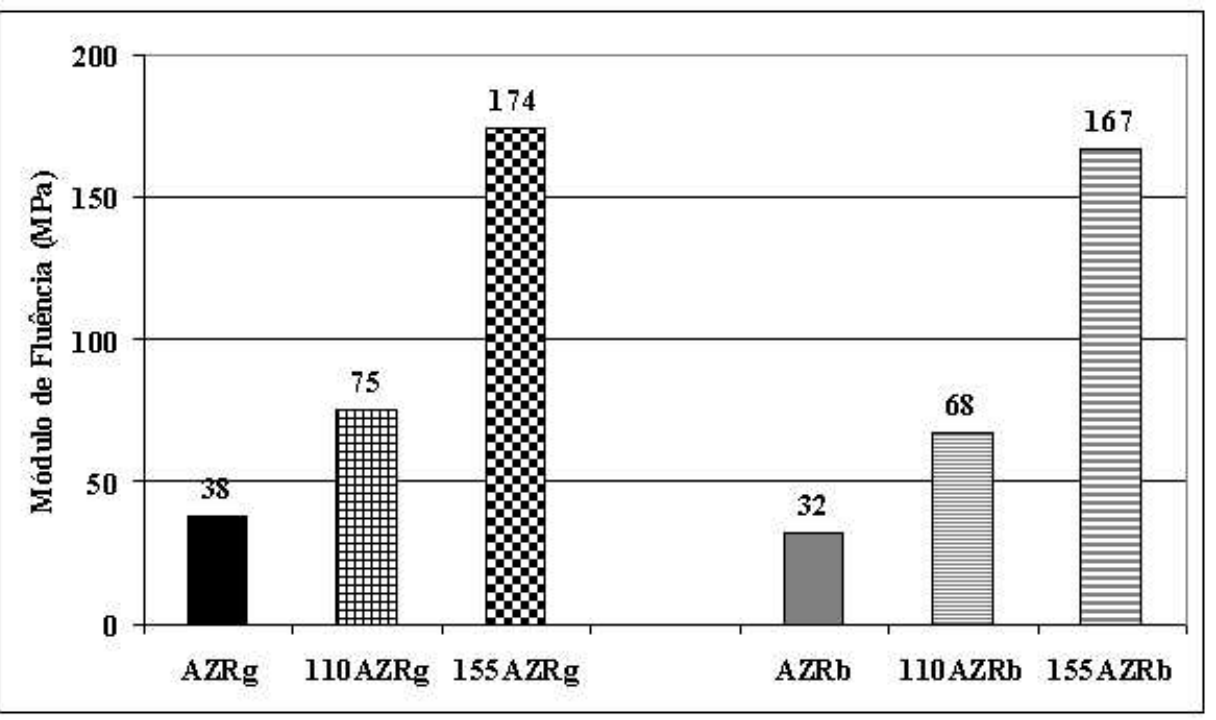

(b) Módulo de fluência

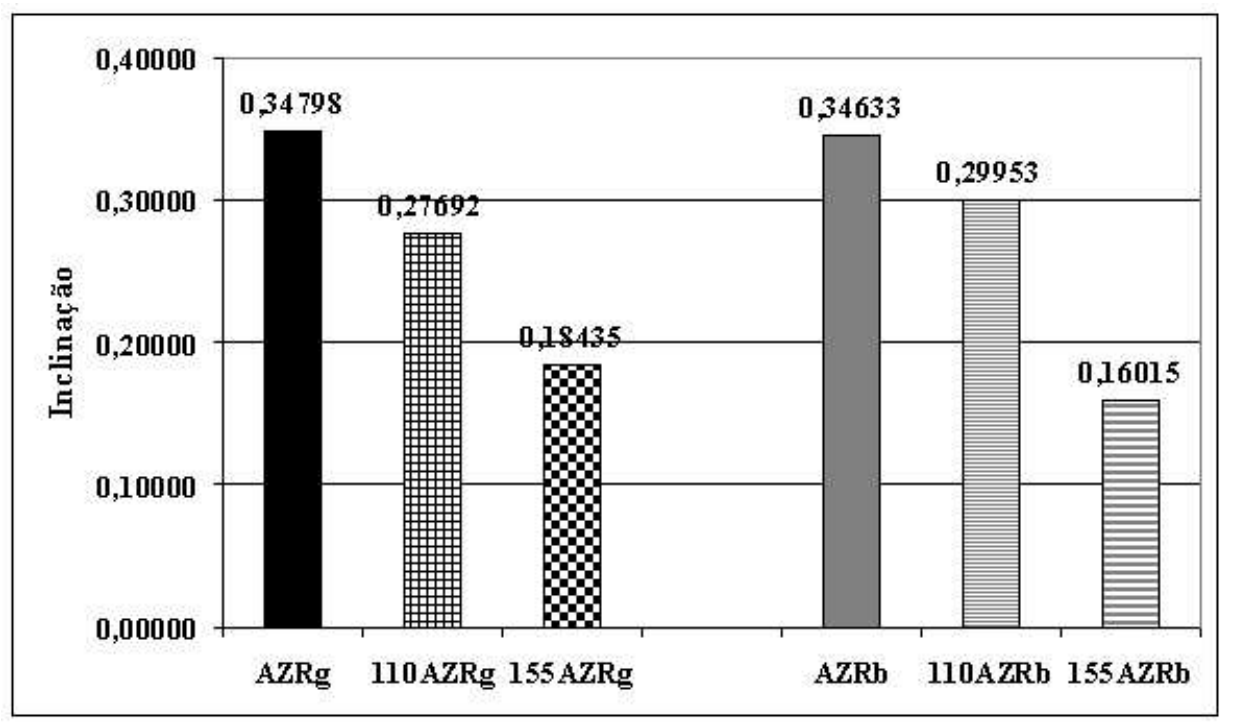

(c) Inclinação

Figura 7.28: Parâmetros do ensaio de fluência uniaxial dinâmica das misturas AZRg e AZRb ao variar a energia de compactação aplicada 


\section{Comparação entre os Resultados dos Ensaios de Fluência por Compressão Uniaxial Estática e por Compressão Uniaxial Dinâmica}

Os resultados encontrados através do ensaio de fluência por compressão uniaxial dinâmica diferem dos resultados do ensaio de fluência por compressão estática, o qual, com aumento da energia de compactação de 110 para 155 golpes, não detectou melhoria da resistência à deformação permanente das misturas, já os resultados obtidos através do ensaio dinâmico mostram melhora significativa. Contudo, os resultados alcançados através do ensaio dinâmico parecem mais realísticos, considerando que o aumento da energia de compactação de 110 para 155 produziram diminuição do VAM, indicando um aumento da densidade relativa das misturas devido à formação de arranjos mais próximos entre partículas, também sinalizado pelo aumento da estabilidade Marshall dessas misturas. Portanto, é razoável supor que o ensaio dinâmico tenha sido mais sensível que o ensaio estático para diagnosticar ganhos de estabilidades com a elevação da energia de compactação. Ou ainda, que o ensaio estático talvez não seja sensível o suficiente para detectar variações na estabilidades de misturas muito compactadas, ou seja, produzidas com energias de compactação muito elevadas.

\section{Conclusões Parciais}

- A estabilidade Marshall varia conforme a energia de compactação aplicada, maiores energias de compactação foram responsáveis por maiores valores de estabilidades;

- As misturas com granulometria AZR, produzidas tanto com o agregado de gabro (AZRg) como com o agregado de basalto (AZRb), apresentaram estabilidades Marshall superiores às encontradas nas misturas Bailey gabro $(\mathrm{Bg})$ e Bailey basalto $(\mathrm{Bb})$;

- As misturas AZRg apresentaram estabilidades Marshall mais elevadas que as misturas AZRb, para todas as energias de compactação aplicadas (75, 110 e 155 golpes);

- A fluência Marshall das misturas sofreu pouca variação com o aumento da energia de compactação;

- O ensaio de fluência uniaxial dinâmica indicou potencialidades melhores quanto a resistência à deformação permanente das misturas com granulometria AZR (AZRg e AZRb) quando comparadas às misturas com granulometrias Bailey $(\mathrm{Bg}$ e $\mathrm{Bb})$;

- O ensaio de fluência uniaxial estática indicou potencialidades semelhantes quanto à deformação permanente entre as misturas com granulometria AZR e Bg, produzidas com agregado de gabro. Os parâmetros do ensaio de fluência uniaxial estática, de uma maneira 
geral, indicaram superioridade quanto à deformação permanente das misturas com granulometria $\mathrm{Bb}$ em relação às misturas com granulometria AZR, produzidas com agregado de basalto;

- Considerando uma mesma granulometria AZR, o comportamento das misturas produzidas com agregado de gabro e de basalto foram semelhantes quanto à deformação permanente, para as três energias de compactação estudadas, com base nos parâmetros analisados através do ensaios de fluência por compressão uniaxial estática e dinâmica;

- A resistência à deformação permanente das misturas variou conforme a energia de compactação aplicada, energias de compactação mais elevadas foram responsáveis por melhores comportamentos quanto à deformação permanente;

- De uma maneira geral, o ensaio de fluência uniaxial dinâmica demonstrou ser mais sensível para detectar variações nas estabilidades das misturas estudadas. 


\subsubsection{Ensaios de Resistência à Tração e de Módulo de Resiliência}

Através do ensaio de resistência à tração por compressão diametral estática pode-se estimar a tensão máxima a ser utilizada na realização do ensaio de módulo de resiliência por compressão diametral dinâmica e também a relação $M R / R T$. Nas Tabelas 7.8 e 7.9, estão apresentados os valores médios, referentes a três determinações, da resistência à tração por compressão diametral $(R T)$, módulo de resiliência $(M R)$, módulo de resiliência instantâneo $\left(M R_{i}\right)$ e a relação módulo de resiliência/resistência à tração $(M R / R T)$.

Tabela 7.8: Valores médios de resistência à tração, módulo de resiliência, módulo de resiliência instantâneo e da relação $M R / R T$, para misturas compactadas com 75 golpes por face

\begin{tabular}{lcccc}
\hline Mistura e Agregado & $\begin{array}{c}\boldsymbol{R} \boldsymbol{T} \\
(M P a)\end{array}$ & $\begin{array}{c}\boldsymbol{M R} \\
(M P a)\end{array}$ & $\begin{array}{c}\boldsymbol{M R}_{\boldsymbol{i}} \\
(M P a)\end{array}$ & $\boldsymbol{M R} \boldsymbol{R} \boldsymbol{R}$ \\
\hline AZRg & 1,36 & 5.410 & 5.938 & 3.972 \\
Dpadrão & 0,05 & 182 & 162 & \\
\hline AZRb & 1,35 & 5.146 & 5.576 & 3.809 \\
Dpadrão & 0,04 & 150 & 475 & \\
\hline Bg & 1,16 & 3.528 & 3.922 & 3.041 \\
Dpadrão & 0,04 & 353 & 409 & \\
\hline Bb & 1,10 & 2.817 & 3.233 & 2.561 \\
Dpadrão & 0,05 & 445 & 502 & \\
\hline
\end{tabular}

Tabela 7.9: Valores médios de resistência à tração, módulo de resiliência, módulo de resiliência instantâneo e da relação $M R / R T$, para misturas compactadas com 110 e 155 golpes por face

\begin{tabular}{lcccc}
\hline Mistura e Agregado & $\begin{array}{c}\boldsymbol{R} \boldsymbol{T} \\
(M P a)\end{array}$ & $\begin{array}{c}\boldsymbol{M R} \\
(M P a)\end{array}$ & $\begin{array}{c}\boldsymbol{M R}_{\boldsymbol{i}} \\
(M P a)\end{array}$ & $\boldsymbol{M R} \boldsymbol{R} \boldsymbol{R}$ \\
\hline 110AZRg & 2,12 & 12.130 & 14.550 & 5.735 \\
Dpadrão & 0,02 & 917 & 1.014 & \\
\hline 110AZRb & 1,69 & 7.282 & 8.623 & 4.306 \\
Dpadrão & 0,02 & 787 & 1.053 & \\
\hline 155AZRg & 2,35 & 19.016 & 22.392 & 8.098 \\
Dpadrão & 0,01 & 1.893 & 2.054 & \\
\hline 155AZRb & 1,90 & 11.011 & 12.815 & 5.809 \\
Dpadrão & 0,03 & 1.494 & 1.716 & \\
\hline
\end{tabular}




\section{Curva Granulométrica}

Ao analisar comparativamente a granulometria das misturas AZR e Bg, produzidas com agregado de gabro e compactadas com 75 golpes por face (Tabela 7.8), pode-se verificar que a mistura AZRg apresenta valores de resistência à tração, de módulo de resiliência e de módulo de resiliência instantâneo mais elevados que os valores obtidos para a mistura Bg. A resistência à tração da mistura AZRg mostra-se cerca de $15 \%$ superior a resistência à tração da mistura $\mathrm{Bg}$, seu módulo de resiliência e módulo de resiliência instantâneo são aproximadamente $35 \%$ mais elevados que os módulos da mistura Bg (Figura 7.29). Também o valor da relação $M R / R T$ obtido para a mistura AZRg é $23 \%$ superior ao valor obtido para a mistura Bg (Figura 7.30), no entanto, esses valores são semelhantes à gama de valores de relações $M R / R T$ encontrados em vários trabalhos de pesquisa, dentre eles, os apresentados na Tabela 7.10.

A mistura AZRb também apresentou resistência à tração, módulo de resiliência e módulo de resiliência instantâneo mais elevados que os valores encontrados para a mistura $\mathrm{Bb}$. $\mathrm{O}$ valor da resistência à tração da mistura AZRb mostra-se cerca de $19 \%$ superior a resistência à tração da mistura $\mathrm{Bb}$, seu módulo de resiliência e módulo de resiliência instantâneo são aproximadamente $45 \%$ mais elevados que os módulos da mistura $\mathrm{Bb}$ (Figura 7.29). Também o valor da relação $M R / R T$ obtido para a mistura AZRb é aproximadamente $33 \%$ maior que o valor encontrado para a mistura $\mathrm{Bb}$ (Figura 7.30) e, ainda assim, esses valores podem ser considerados adequados, pois encontram-se dentro da faixa de valores de relações $M R / R T$ freqüentemente encontrados (Tabela 7.10).

Como visto, a utilização da granulometria AZR gerou misturas com resistência à tração, módulos de resiliência e relação $M R / R T$ mais elevados que os valores dessas propriedades obtidos para as misturas produzidas com granulometrias Bailey. 


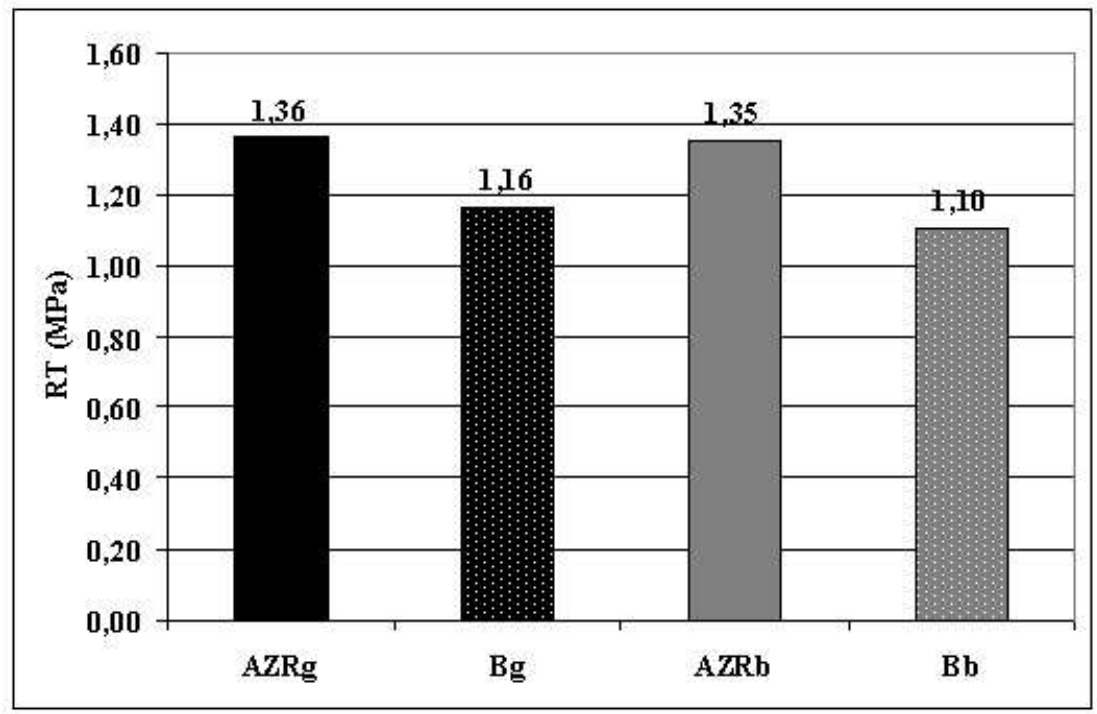

(a) Resistência à tração

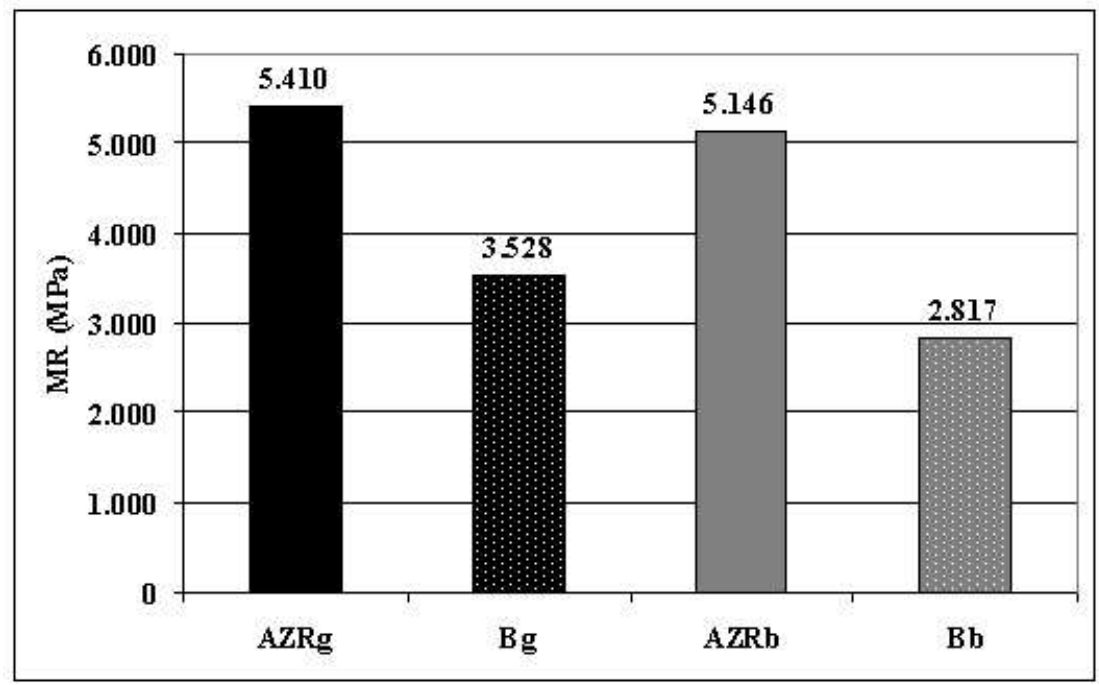

(b) Módulo de resiliência

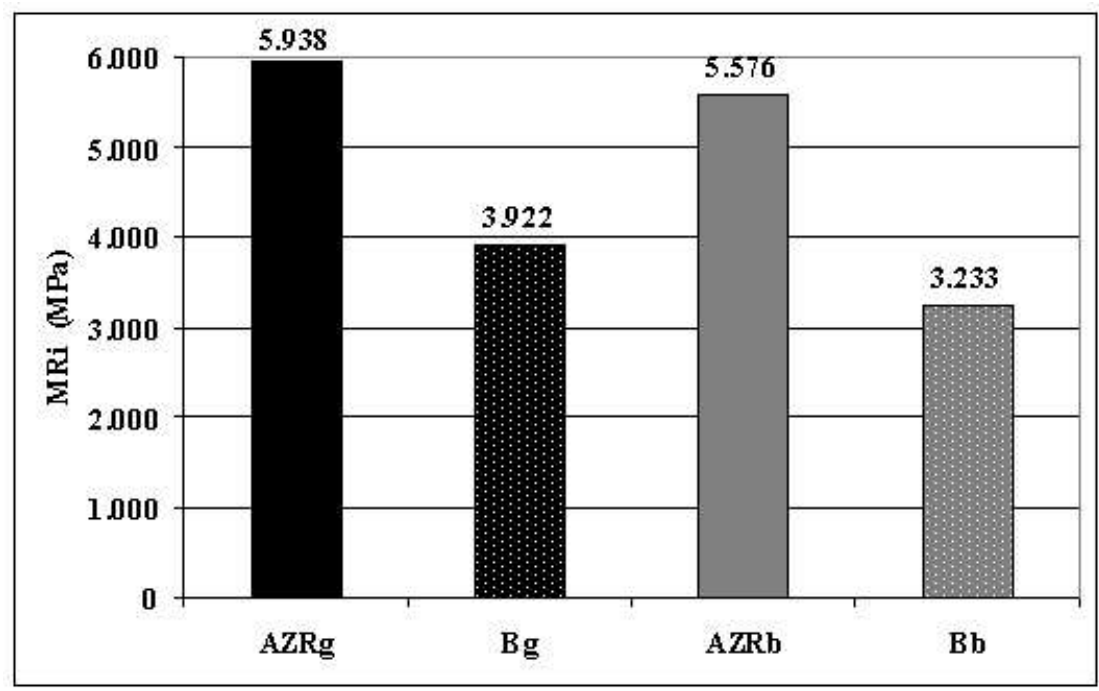

(c) Módulo de resiliência instantâneo

Figura 7.29: Resistência à tração, módulos de resiliência e módulos de resiliência instantâneo das misturas produzidas com agregados de gabro e de basalto compactadas com 75 golpes por face 
Tabela 7.10: Relações $M R / R T$ encontradas em estudos realizados a $25^{\circ} \mathrm{C}$

\begin{tabular}{lcc}
\hline Pesquisas & tipo de asfalto & $\boldsymbol{M R / R T}$ \\
\hline Pinto (1991) & CAP 20 & 4.347 \\
\hline Motta \& Pinto (1994) & asfalto convencional & $M R=343+4028 R T$ \\
\hline Magalhães (2004) & CAP 20 & 4.183 \\
\hline Santos (2004) & CAP 20 & 2.671 \\
\hline Motta \& Leite (2002) & CAP 40 & $4.125 *$ \\
\hline
\end{tabular}

* valor médio obtido dentre as observações realizadas no trecho experimental denominado Rio Orla, que é parte integrante de uma extensa pesquisa de campo realizada pelo CENPES e UFRJ

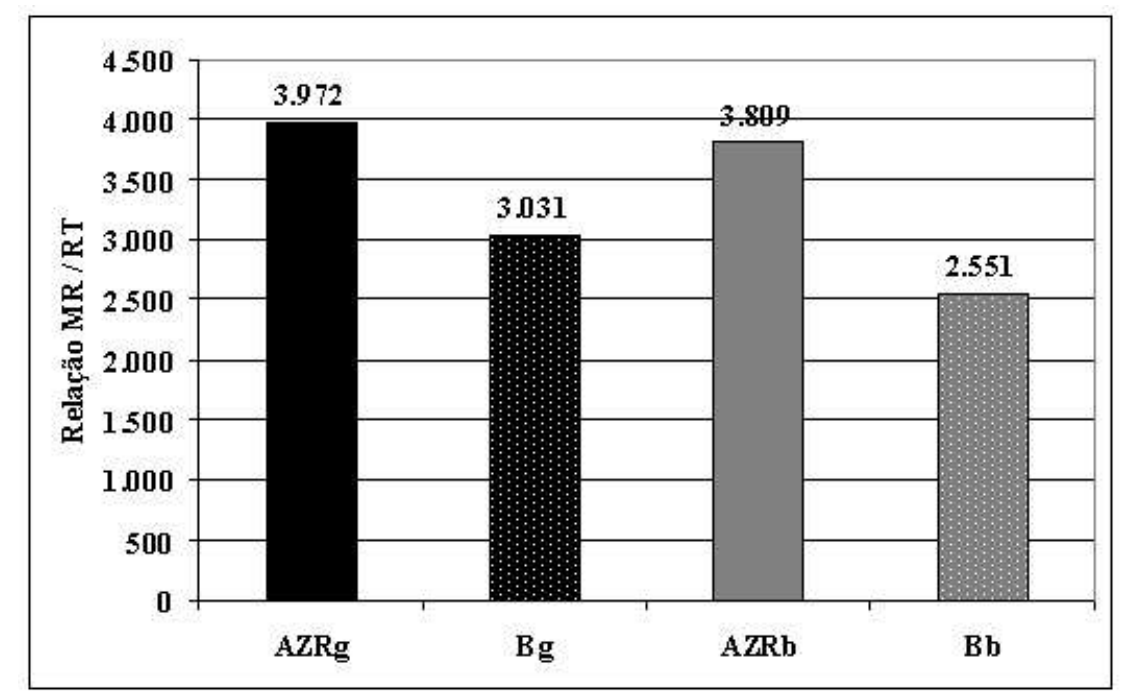

Figura 7.30: Relação $M R / R T$ das misturas AZRg, AZRb, Bg e Bb

\section{Tipo de Agregado}

Os valores da resistência à tração, do módulo de resiliência e do módulo de resiliência instantâneo encontrados para as misturas AZRg e AZRb podem ser considerados estatisticamente iguais, tendo em vista as misturas produzidas com energia de compactação de 75 golpes por face do corpo-de-prova (Tabela 7.8).

No entanto, as misturas produzidas com agregado de gabro e de basalto passaram a apresentar comportamentos distintos ao serem compactadas com energias mais elevadas (Tabela 7.9). A mistura 110AZRg apresentou valor de resistência à tração cerca de $20 \%$ maior que o valor encontrado para a mistura 110AZRb (Figura 7.32(a)), seus valores de módulo de resiliência e de módulo de resiliência instantâneo também foram cerca de $40 \%$ mais elevados que os obtidos para a mistura 110AZRb (Figura 7.32(b)).

O mesmo comportamento foi observado ao empregar energia de compactação de 155 golpes por face, ou seja, a mistura 155AZRg apresentou ganhos de resistência à tração superior a $20 \%$ 
e de módulos de resiliência acima de 40\%, em relação aos valores encontrados para a mistura 155AZRb (Figura 7.32).

Com base nesses resultados, pode-se concluir que as misturas produzidas com agregados de gabro e de basalto, quando compactadas com 75 golpes por face do corpo-de-prova, apresentam comportamento elástico semelhante. No entanto, a elevação da energia de compactação, proporcionando aproximação e melhor arranjo entre partículas, tornou evidente a maior rigidez alcançada pelas misturas produzidas com o agregado de gabro em relação às misturas com basalto, destacando a influência das características de forma desse agregado no comportamento elástico das misturas.

A Figura 7.31 ilustra os valores da relação $M R / R T$ das misturas AZRg, AZRb, 110AZRg, $110 \mathrm{AZRb}$ e 155AZRb, considerados adequados com base nos exemplos de valores freqüentemente observados, apresentados na Tabela 7.10. A mistura 155AZRg apresentou valor da relação $M R / R T$ mais alto do que o padrão observado, no entanto, vale lembrar que os valores da relação $M R / R T$ usados como referência (Tabela 7.10) foram obtidos para misturas produzidas com energias compactação padronizadas pelo método Marshall.

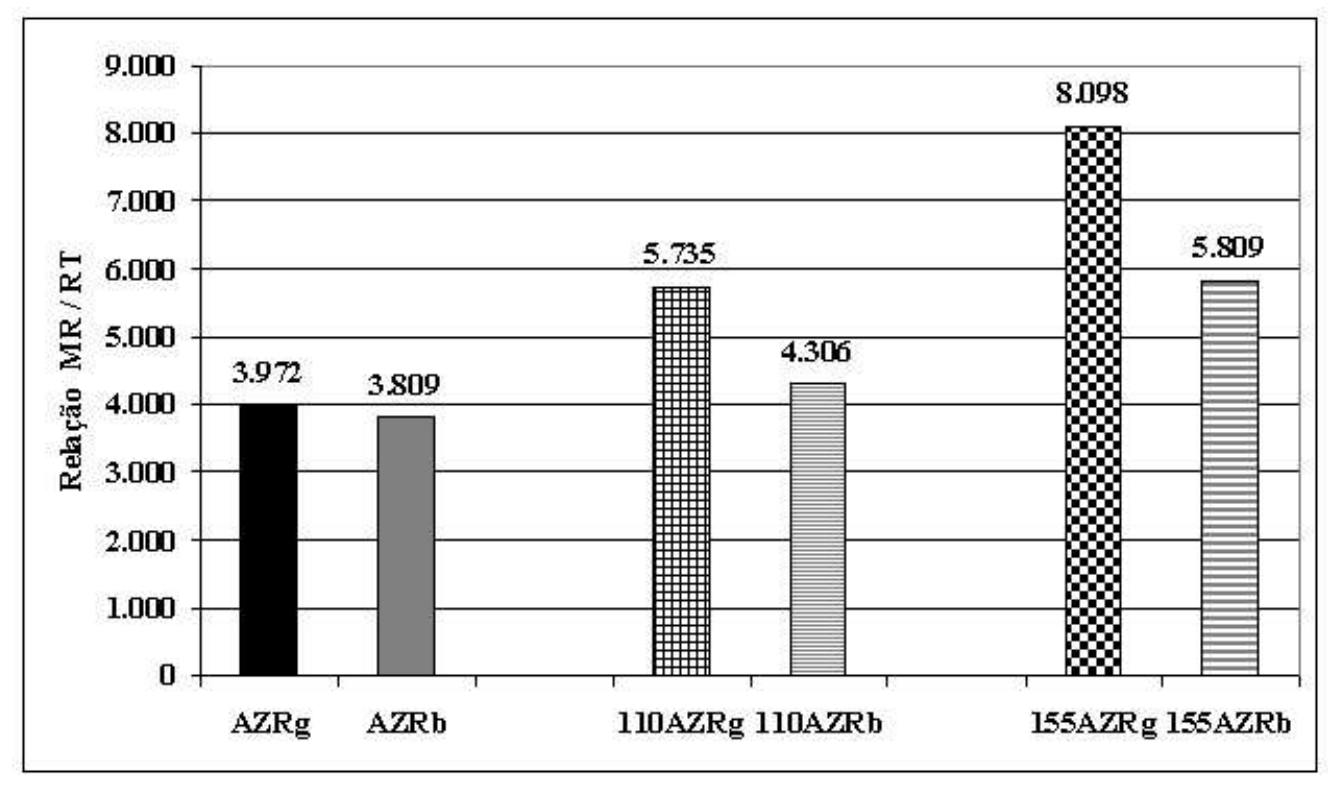

Figura 7.31: Relação $M R / R T$ das misturas AZR produzidas com agregados de gabro (AZRg) e com agregado de basalto (AZRb), compactadas com 110 e 155 golpes por face 


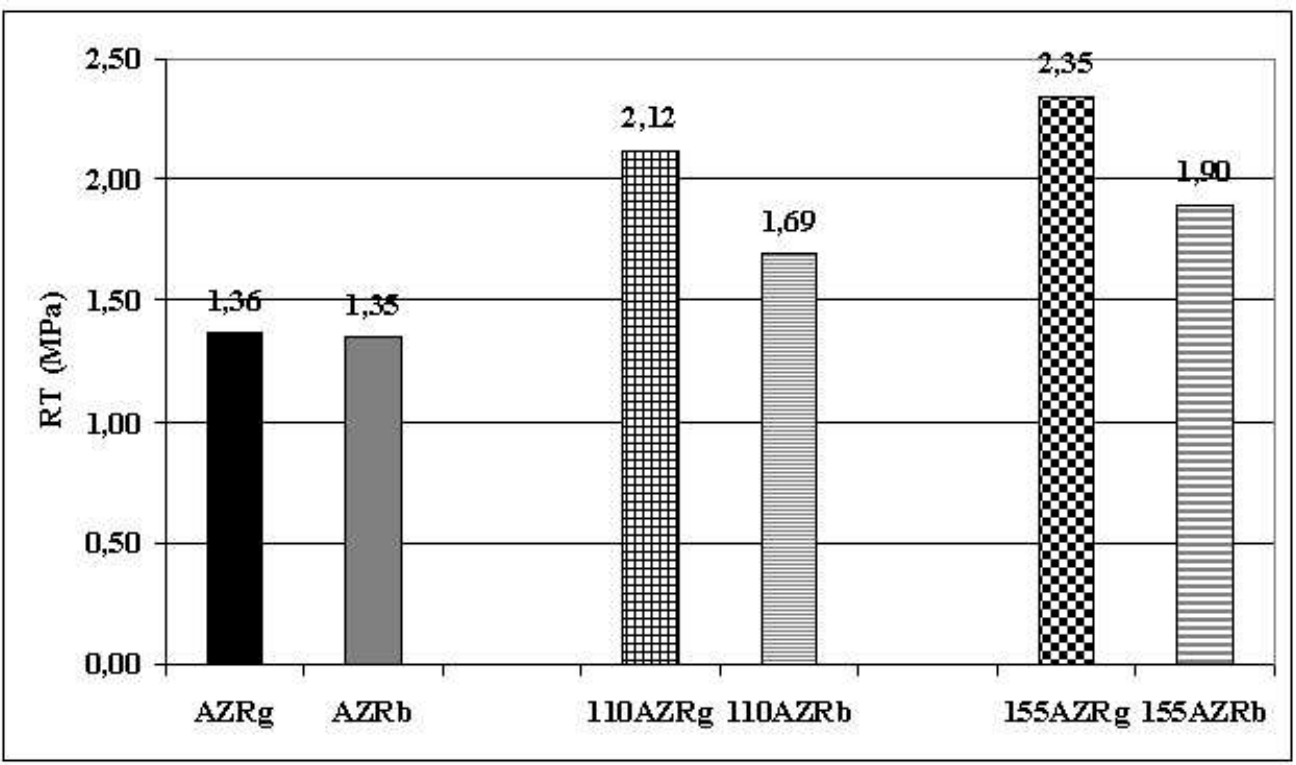

(a) Resistência à tração

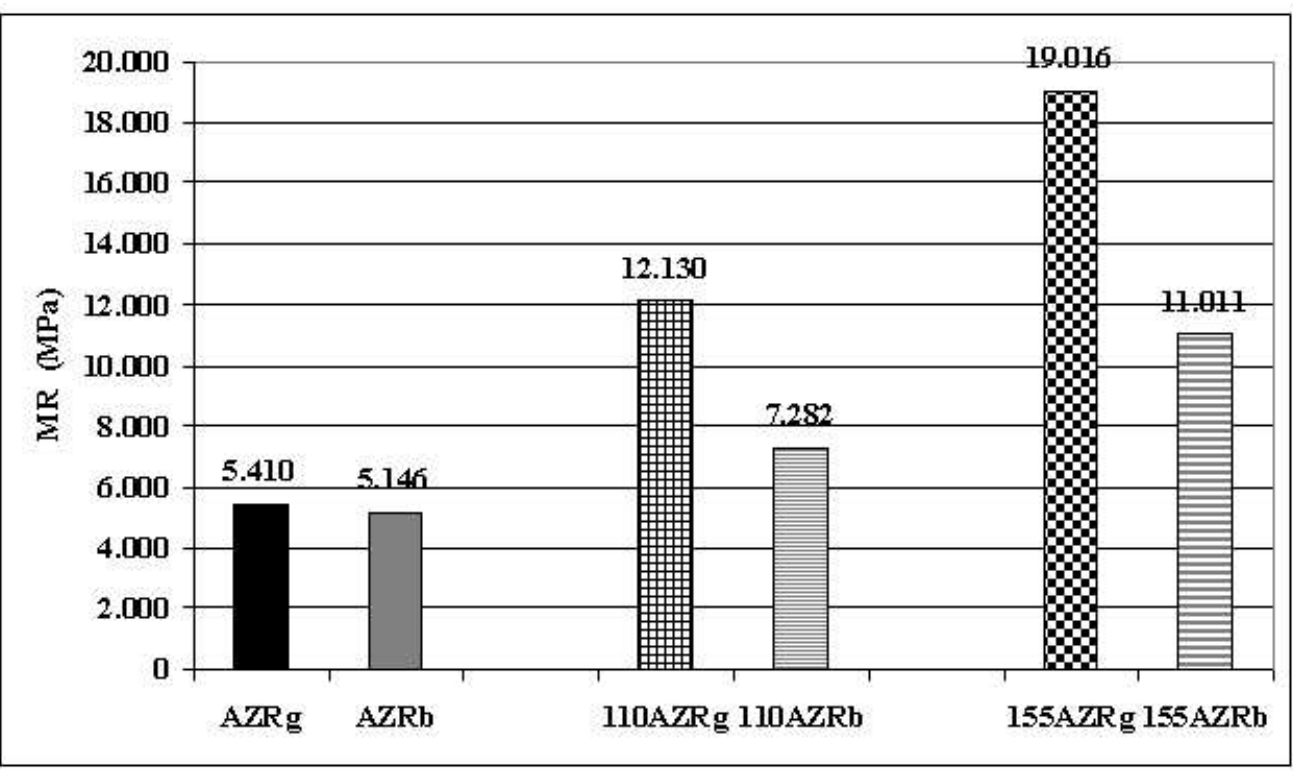

(b) Módulo de resiliência

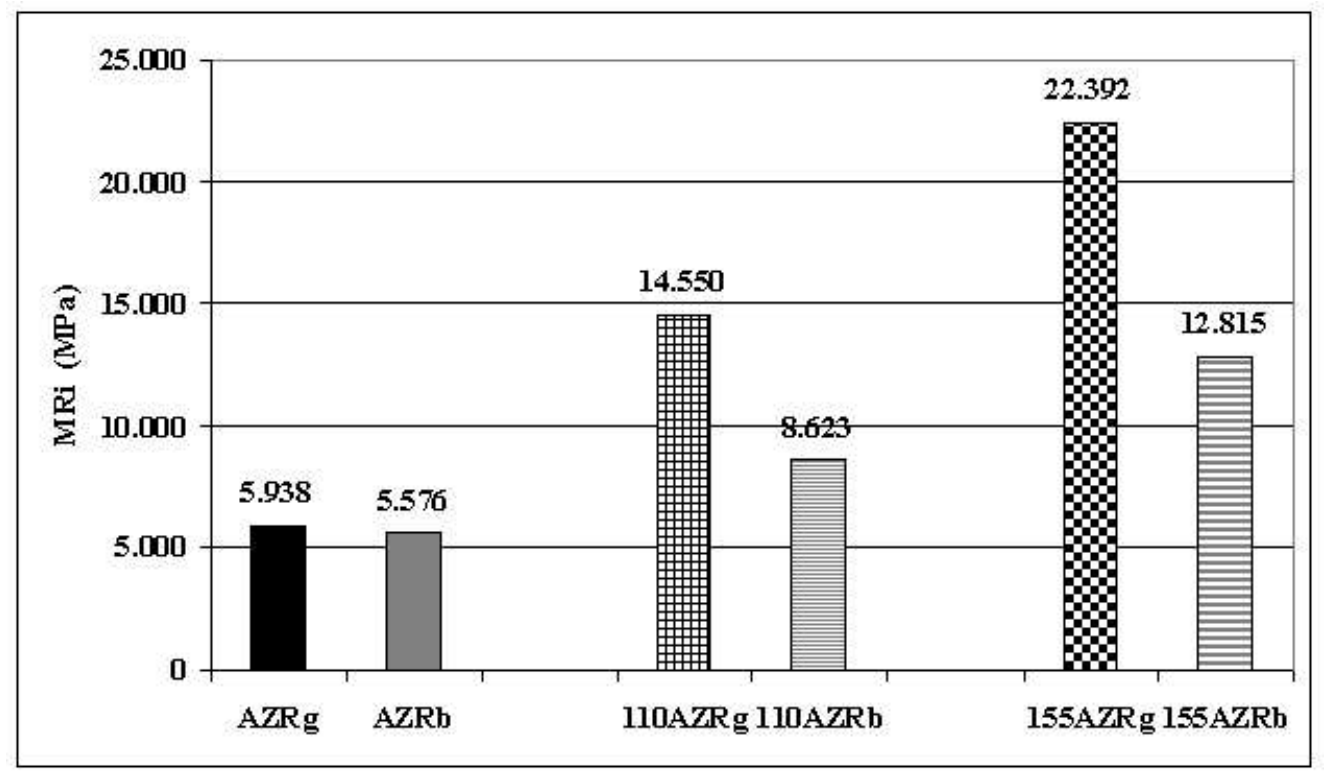

(c) Módulo de resiliência instantâneo

Figura 7.32: Resistência à tração, módulos de resiliência e módulos de resiliência instantâneo das misturas AZR produzidas com gabro e com basalto, compactadas com 110 e 155 golpes por face 


\section{Energia de Compactação}

A resistência à tração das misturas variou conforme a energia de compactação aplicada. A elevação da energia de compactação de 75 para 110 golpes por face do corpo-de-prova gerou um ganho de resistência à tração na mistura 110AZRg em torno de 35\%, enquanto que de 110 para 155 golpes, o ganho de resistência à tração foi de aproximadamente 10\% (Figura 7.33). Já nas misturas produzidas com basalto, a elevação da energia de compactação de 75 para 110 golpes proporcionou ganho de resistência à tração em torno de $20 \%$ e de 110 para 155 golpes, a resistência à tração da mistura 155AZRb foi aproximadamente $11 \%$ mais elevada. (Figura 7.33).

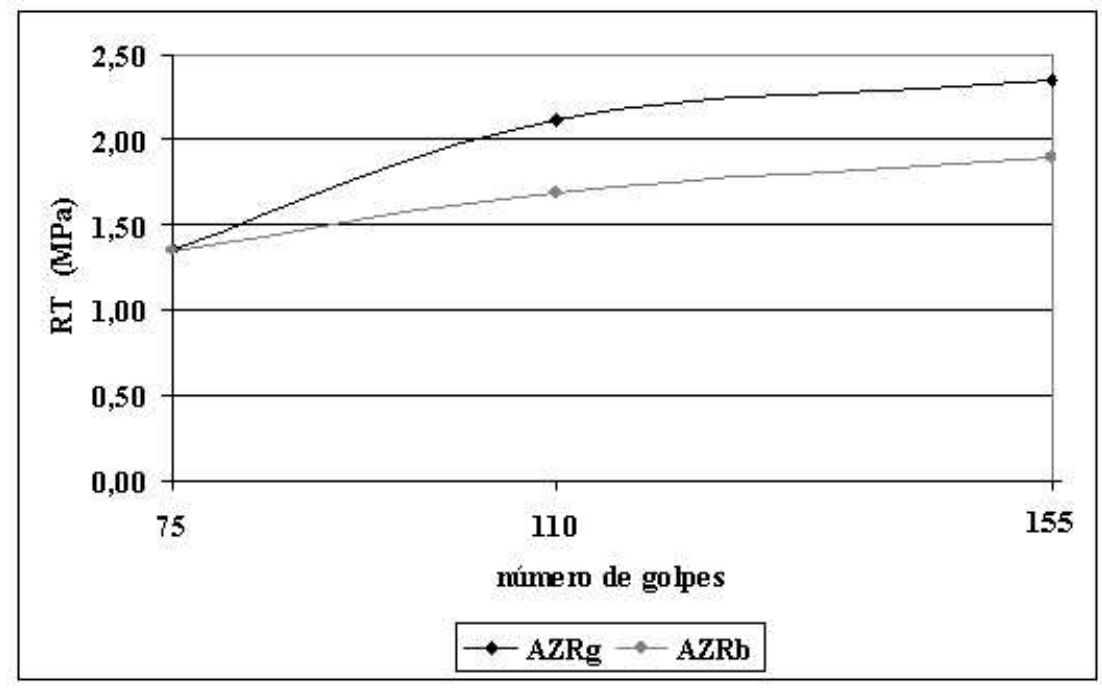

Figura 7.33: Variação de resistência à tração das misturas AZR, produzidas com agregados de gabro e de basalto, com a elevação da energia de compactação aplicada

O módulo de resiliência das misturas também variou com a energia de compactação aplicada. Tanto as misturas AZR produzidas com agregado de gabro quanto as produzidas com agregado de basalto tiveram elevação do módulo de resiliência com o aumento da energia de compactação aplicada. De 75 para 110 golpes, o aumento do módulo de resiliência da mistura 110AZRg foi de aproximadamente $55 \%$ e de 110 para 155 golpes, a mistura 155AZRg passou a apresentar módulo de resiliência 35\% superior (Figura 7.34). A mistura 110AZRb apresentou módulo de resiliência cerca de $30 \%$ maior que a mistura AZRb e, ao aumentar ainda mais a energia de compactação, de 110 para 155 golpes, o módulo de resiliência obtido para a mistura 155AZRb foi $34 \%$ mais elevado que o módulo da mistura 110AZRb.

A mesma análise feita para o módulo de resiliência pode ser considerada para o módulo de resiliência instantâneo, pois os resultados do módulo de resiliência instantâneo são muito 


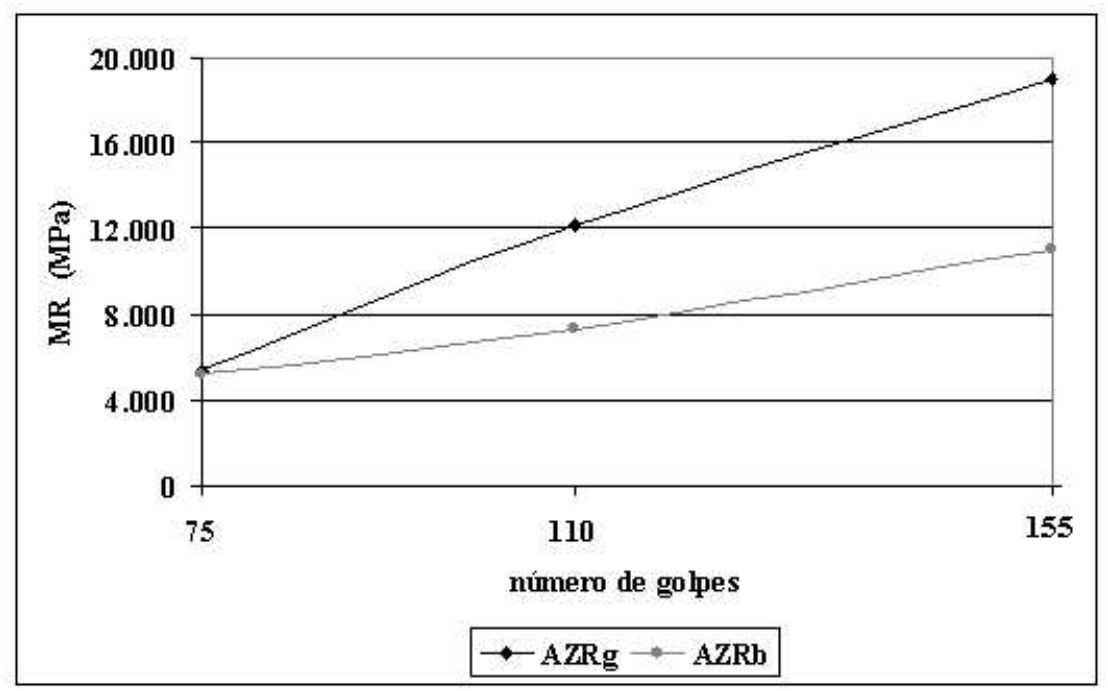

Figura 7.34: Variação do módulo de resiliência das misturas AZR, produzidas com agregados de gabro e de basalto, com a elevação da energia de compactação aplicada

semelhantes aos resultados do módulo de resiliência, tendo como diferença apenas a magnitude de seus valores.

Com base nos resultados, pode-se concluir que a elevação da energia de compactação promove acréscimos de resistência à tração e de módulo de resiliência nas misturas. Pode-se concluir também (Figuras 7.33 e 7.34), que as misturas AZRg e AZRb apresentaram resistências à tração e módulos de resiliência semelhantes quando compactadas com 75 golpes por face do corpo-de-prova. Porém, ao aplicar energias de compactação mais elevadas, as misturas com gabro passaram a apresentar valores de resistência à tração e de módulos de resiliência mais elevados, trazendo à luz a influência das características de forma dos agregados no comportamento resiliente e de resistência à tração das misturas.

A relação $M R / R T$ também variou com a energia de compactação. Tanto as misturas com gabro como as com basalto apresentaram valores mais elevados para a relação $M R / R T$ quanto maior a energia de compactação aplicada (Figura 7.35). Os valores da relação $M R / R T$ das misturas AZR produzidas com gabro saltaram de 3.972 para 5.735 e então para 8.098, ao aplicar 75,110 e 155 golpes, respectivamente. O mesmo ocorreu com as misturas AZR produzidas com basalto, que aumentaram seus valores de relação $M R / R T$ de 3.809 para 4.306 e para 5.809 com a elevação da energia de compactação de 75 para 110 e então para 155 golpes. Pode-se concluir que o aumento da energia de compactação proporciona às misturas uma elevação gradual da relação $M R / R T$. Entretanto, embora as misturas tenham se tornado mais rígidas em função de sua maior compactação, ainda assim, as relações $M R / R T$ encontradas são indicativas do bom comportamento mecânico dessas misturas, combinando boa flexibilidade e resistência à tração 
adequada, antecipando o que será apresentado na análise mecanística das misturas (item 7.6.5, página 257).

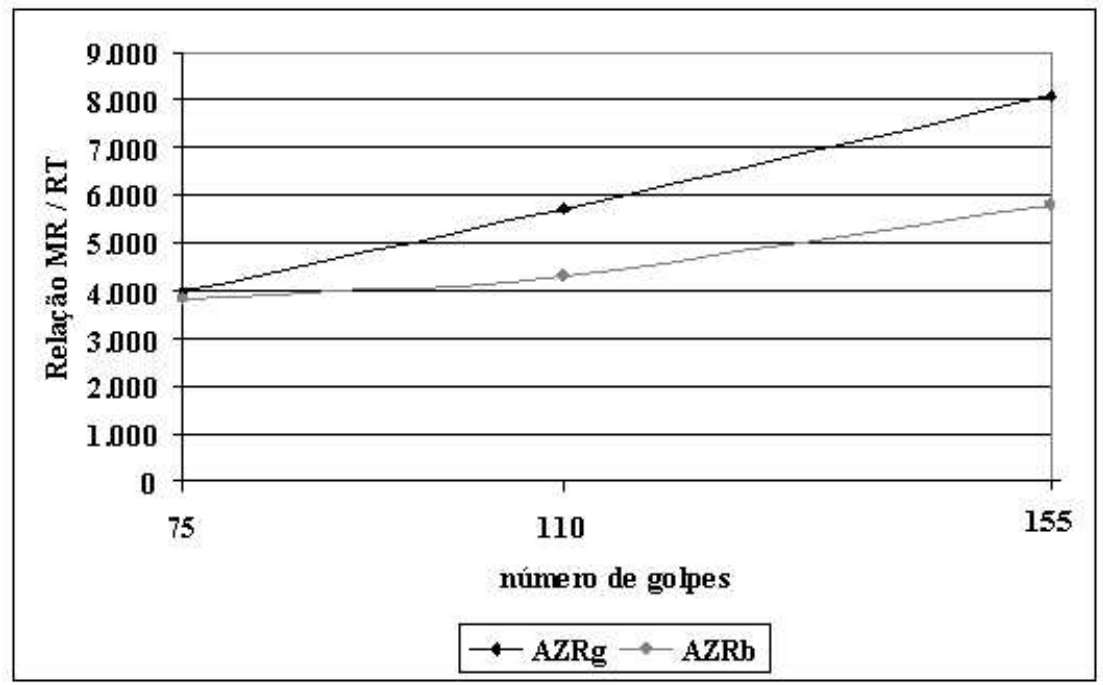

Figura 7.35: Variação da relação $M R / R T$ das misturas AZR, produzidas com agregados de gabro e de basalto, com a elevação da energia de compactação aplicada

\subsubsection{Estimativa da Vida de Fadiga}

A vida de fadiga pode ser definida como sendo o número total de aplicações de carga necessário para proporcionar fratura completa da amostra (Monismith, 1958). Nesta pesquisa, a vida de fadiga das misturas foi estimada através da Equação 7.6. Os ensaios de fadiga a tensão controlada foram realizados com níveis de tensão variando de 20 a $40 \%$ da resistência à tração, com freqüência de aplicação de carga de $1 \mathrm{~Hz}$ (carregamento de $0,1 \mathrm{~s}$ e descarregamento de $0,9 \mathrm{~s}$ ) e temperatura de $25^{\circ} \mathrm{C}$. Segundo Medina (1997), as solicitações a tensão controlada são representativas das tensões que ocorrem em pavimentos com revestimentos asfálticos muito mais rígidos do que a camada de base, que ao resistirem às cargas determinam a magnitude das deformações impostas ao pavimento. Medina (1997) também sugere que os ensaios de fadiga sejam realizados a $25^{\circ} \mathrm{C}$, com base nos vários estudos desenvolvidos no Brasil, que demonstram que as temperaturas da superfície do revestimento betuminoso permanecem entre 10 e $40^{\circ} \mathrm{C}$ durante cerca de $70 \%$ do ano.

Nas Tabelas 7.11, 7.12, 7.13, 7.14, 7.15, 7.16, 7.17 e 7.18, estão apresentados os resultados dos ensaios de fadiga, com seus respectivos modelos de fadiga e coeficientes de determinação $R^{2}$. O $R^{2}$ corresponde à qualidade do ajuste do modelo em relação aos pontos plotados, ou seja, quanto mais próximo de 1 estiver o $R^{2}$, menor será a dispersão dos pontos ensaiados em relação ao modelo (Schefler, 1988). 
Tabela 7.11: Resultados do ensaio de fadiga das misturas produzidas com granulometria AZR utilizando agregado de gabro e energia de compactação de 75 golpes por face

\begin{tabular}{|c|c|c|c|c|}
\hline Mistura AZRg & \multicolumn{2}{|c|}{$\mathrm{RT}=1,36 \mathrm{MPa}$} & \multicolumn{2}{|c|}{$\mathrm{MR}=5.410 \mathrm{MPa}$} \\
\hline $\mathbf{C P}$ & Carga $(\mathbf{N})$ & $\% R T$ & $\Delta \sigma$ & $N$ \\
\hline 1 & 5.719 & 40,6 & 2,20 & 1.237 \\
\hline 2 & 5.719 & 40,6 & 2,20 & 1.035 \\
\hline 3 & 4.267 & 30,3 & 1,64 & 2.307 \\
\hline 4 & 4.267 & 30,3 & 1,64 & 2.045 \\
\hline 5 & 2.815 & 20,0 & 1,07 & 22.725 \\
\hline 6 & 2.815 & 20,0 & 1,08 & 33.417 \\
\hline & \multicolumn{2}{|c|}{ Modelo de fadiga } & \multicolumn{2}{|c|}{$\begin{array}{l}\boldsymbol{N}=\mathbf{3 2 . 5 5 2}\left(\frac{1}{\Delta \boldsymbol{\sigma}}\right)^{4,5 \varepsilon} \\
R^{2}=0,94\end{array}$} \\
\hline
\end{tabular}

Tabela 7.12: Resultados do ensaio de fadiga das misturas produzidas com granulometria Bailey gabro utilizando agregado de gabro e energia de compactação de 75 golpes por face

\begin{tabular}{|c|c|c|c|c|}
\hline Mistura Bg & \multicolumn{2}{|c|}{$\mathrm{RT}=1,16 \mathrm{MPa}$} & \multicolumn{2}{|c|}{$\mathrm{MR}=3.528 \mathrm{MPa}$} \\
\hline $\mathbf{C P}$ & Carga (N) & $\% R T$ & $\Delta \sigma$ & $N$ \\
\hline 1 & 5.033 & 41,0 & 1,90 & 680 \\
\hline 2 & 5.033 & 41,0 & 1,89 & 588 \\
\hline 3 & 3.571 & 29,1 & 1,35 & 4.276 \\
\hline 4 & 3.571 & 29,1 & 1,36 & 3.256 \\
\hline 5 & 2.492 & 20,3 & 0,94 & 29.027 \\
\hline 6 & 2.492 & 20,3 & 0,94 & 40.290 \\
\hline & \multicolumn{2}{|c|}{ Modelo de fadiga } & \multicolumn{2}{|c|}{ 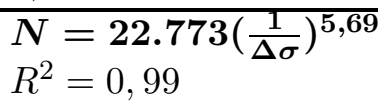 } \\
\hline
\end{tabular}

Tabela 7.13: Resultados do ensaio fadiga das misturas produzidas com granulometria AZR utilizando agregado de basalto e energia de compactação de 75 golpes por face

\begin{tabular}{|c|c|c|c|c|}
\hline Mistura AZRb & \multicolumn{2}{|c|}{$\mathrm{RT}=1,35 \mathrm{MPa}$} & \multicolumn{2}{|c|}{$\mathrm{MR}=5.146 \mathrm{MPa}$} \\
\hline $\mathbf{C P}$ & Carga $(\mathrm{N})$ & $\% R T$ & $\Delta \sigma$ & $N$ \\
\hline 1 & $\overline{5.562}$ & 40,9 & 2,21 & 791 \\
\hline 2 & 5.562 & 40,9 & 2,21 & 887 \\
\hline 3 & 4.081 & 30,0 & 1,64 & 7.953 \\
\hline 4 & 4.081 & 30,0 & 1,63 & 2.551 \\
\hline 5 & 2.659 & 19,5 & 1,06 & 16.448 \\
\hline 6 & 2.659 & 19,5 & 1,06 & 12.892 \\
\hline & \multicolumn{2}{|c|}{ Modelo de fadiga } & \multicolumn{2}{|c|}{$\begin{array}{l}\mathbf{N}=\mathbf{2 0 . 6 9 4}\left(\frac{1}{\Delta \boldsymbol{\sigma}}\right)^{3,7} \\
R^{2}=0,88\end{array}$} \\
\hline
\end{tabular}


Tabela 7.14: Resultados do ensaio de fadiga das misturas produzidas com granulometria Bailey basalto utilizando agregado de basalto e energia de compactação de 75 golpes por face

\begin{tabular}{|c|c|c|c|c|}
\hline Mistura Bb & \multicolumn{2}{|c|}{$\mathrm{RT}=1,10 \mathrm{MPa}$} & \multicolumn{2}{|c|}{$\mathrm{MR}=2.817 \mathrm{MPa}$} \\
\hline $\mathbf{C P}$ & Carga (N) & $\% R T$ & $\Delta \sigma$ & $N$ \\
\hline 1 & 4.571 & 40,7 & 1,82 & 828 \\
\hline 2 & 4.571 & 40,7 & 1,82 & 717 \\
\hline 3 & 3.522 & $\overline{31,4}$ & 1,38 & 1.523 \\
\hline 4 & 3.522 & 31,4 & 1,40 & 1.852 \\
\hline 5 & 2.227 & 19,8 & 0,89 & 41.809 \\
\hline 6 & 2.227 & 19,8 & 0,88 & 6.026 \\
\hline & \multicolumn{2}{|c|}{ Modelo de fadiga } & \multicolumn{2}{|c|}{$\begin{array}{l}\boldsymbol{N}=\mathbf{8 . 5 2 1}\left(\frac{1}{\Delta \boldsymbol{\sigma}}\right)^{\mathbf{4 , 2}} \\
R^{2}=0,82\end{array}$} \\
\hline
\end{tabular}

Tabela 7.15: Resultados do ensaio de fadiga das misturas produzidas com granulometria AZR utilizando agregado de gabro e energia de compactação de 110 golpes por face

\begin{tabular}{lcclc}
\hline Mistura 110AZRg & \multicolumn{2}{c}{$\mathrm{RT}=2,12 \mathrm{MPa}$} & \multicolumn{2}{c}{$\mathrm{MR}=12.130 \mathrm{MPa}$} \\
\hline $\mathbf{C P}$ & Carga $(\mathbf{N})$ & $\mathbf{\%} \boldsymbol{R} \boldsymbol{T}$ & $\boldsymbol{\Delta} \boldsymbol{\sigma}$ & $\boldsymbol{N}$ \\
\hline 1 & 8.535 & 39,9 & 3,37 & 255 \\
2 & 8.535 & 39,9 & 3,38 & 315 \\
\hline 3 & 6.455 & 30,2 & 2,57 & 1.396 \\
4 & 6.455 & 30,2 & 2,57 & 1.195 \\
\hline 5 & 4.277 & 20,0 & 1,70 & 9.194 \\
6 & 4.277 & 20,0 & 1,70 & 9.654 \\
\hline \multicolumn{5}{c}{$\mathbf{N}=\mathbf{1 4 5 . 4 1 2}\left(\frac{1}{\boldsymbol{\Delta} \boldsymbol{\sigma}}\right)^{\mathbf{5 , 1 0}}$} \\
\hline
\end{tabular}

Tabela 7.16: Resultados do ensaio de fadiga das misturas produzidas com granulometria AZR utilizando agregado de basalto e energia de compactação de 110 golpes por face

\begin{tabular}{lcclc}
\hline Mistura 110AZRb & \multicolumn{2}{c}{$\mathrm{RT}=1,69 \mathrm{MPa}$} & \multicolumn{2}{c}{$\mathrm{MR}=7.282 \mathrm{MPa}$} \\
\hline $\mathbf{C P}$ & Carga $(\mathbf{N})$ & $\mathbf{\%} \boldsymbol{R} \boldsymbol{T}$ & $\boldsymbol{\Delta} \boldsymbol{\sigma}$ & $\boldsymbol{N}$ \\
\hline 1 & 6.710 & 40,2 & 2,71 & 518 \\
2 & 6.710 & 40,2 & 2,71 & 1.461 \\
\hline 3 & 5.013 & 30,0 & 2,02 & 1.989 \\
4 & 5.013 & 30,0 & 2,03 & 1.350 \\
\hline 5 & 3.335 & 20,0 & 1,36 & 5.148 \\
6 & 3.335 & 20,0 & 1,35 & 13.519 \\
\hline \multicolumn{5}{c}{$\mathbf{N}=\mathbf{2 1 . 2 2 6}\left(\frac{1}{\mathbf{\Delta} \boldsymbol{\sigma}}\right)^{\mathbf{3}, 33}$} \\
\hline
\end{tabular}


Tabela 7.17: Resultados do ensaio de fadiga das misturas produzidas com granulometria AZR utilizando agregado de gabro e energia de compactação de 155 golpes por face

\begin{tabular}{|c|c|c|c|c|}
\hline Mistura 155AZRg & \multicolumn{2}{|c|}{$\mathrm{RT}=2,35 \mathrm{MPa}$} & \multicolumn{2}{|c|}{$\mathrm{MR}=19.016 \mathrm{MPa}$} \\
\hline $\mathbf{C P}$ & Carga $(\mathbf{N})$ & $\% R T$ & $\Delta \sigma$ & $N$ \\
\hline 1 & 9.329 & 39,4 & 3,71 & 363 \\
\hline 2 & 9.329 & 39,4 & 3,71 & 768 \\
\hline 3 & 7.044 & 29,8 & 2,80 & 2.793 \\
\hline 4 & 7.044 & 29,8 & 2,80 & 2.473 \\
\hline 5 & 4.728 & 20,0 & 1,88 & 7.750 \\
\hline 6 & 4.728 & 20,0 & 1,88 & 7.188 \\
\hline & \multicolumn{2}{|c|}{ Modelo de fadiga } & \multicolumn{2}{|c|}{$\begin{array}{l}\boldsymbol{N}=\mathbf{9 5 . 0 5 8}\left(\frac{1}{\Delta \boldsymbol{\sigma}}\right)^{3,8} \\
R^{2}=0,91\end{array}$} \\
\hline
\end{tabular}

Tabela 7.18: Resultados do ensaio de fadiga das misturas produzidas com granulometria AZR utilizando agregado de basalto e energia de compactação de 155 golpes por face

\begin{tabular}{|c|c|c|c|c|}
\hline \multirow{2}{*}{$\begin{array}{l}\text { Mistura 155AZRb } \\
\text { CP }\end{array}$} & \multicolumn{2}{|c|}{$\mathrm{RT}=1,90 \mathrm{MPa}$} & \multicolumn{2}{|c|}{$\mathrm{MR}=11.011 \mathrm{MPa}$} \\
\hline & Carga $(\mathrm{N})$ & $\% R T$ & $\Delta \sigma$ & $N$ \\
\hline 1 & 7.456 & 40,3 & 3,05 & 970 \\
\hline 2 & 7.456 & 40,3 & 3,05 & 1.264 \\
\hline 3 & 5.503 & 29,7 & 2,29 & 2.633 \\
\hline 4 & 5.503 & 29,7 & 2,26 & 3.101 \\
\hline 5 & 3.708 & 20,0 & 1,52 & 11.827 \\
\hline \multirow[t]{2}{*}{6} & 3.708 & 20,0 & 1,52 & 11.231 \\
\hline & \multicolumn{2}{|c|}{ Modelo de fadiga } & \multicolumn{2}{|c|}{$\begin{array}{l}\boldsymbol{N}=\mathbf{4 7 . 2 1 5}\left(\frac{1}{\Delta \sigma}\right)^{3,3 \varepsilon} \\
R^{2}=0,99\end{array}$} \\
\hline
\end{tabular}


Na Figura 7.36, estão ilustradas as curvas de fadiga das misturas AZRg e Bg. Pode-se observar uma maior inclinação (n) da curva da mistura Bg em relação à curva da mistura AZRg, indicativa de uma maior suscetibilidade da mistura $\mathrm{Bg}$ às variações da diferença de tensões, ou seja, com pequenas alterações da diferença de tensões, a mistura $\mathrm{Bg}$ ganha ou perde capacidade de aplicações de carga mais rapidamente do que a mistura AZRg. A Figura 7.37 mostra as curvas de fadiga das misturas AZRb e Bb, onde se pode observar que a inclinação das curvas são próximas, mostrando quase um paralelismo entre elas.

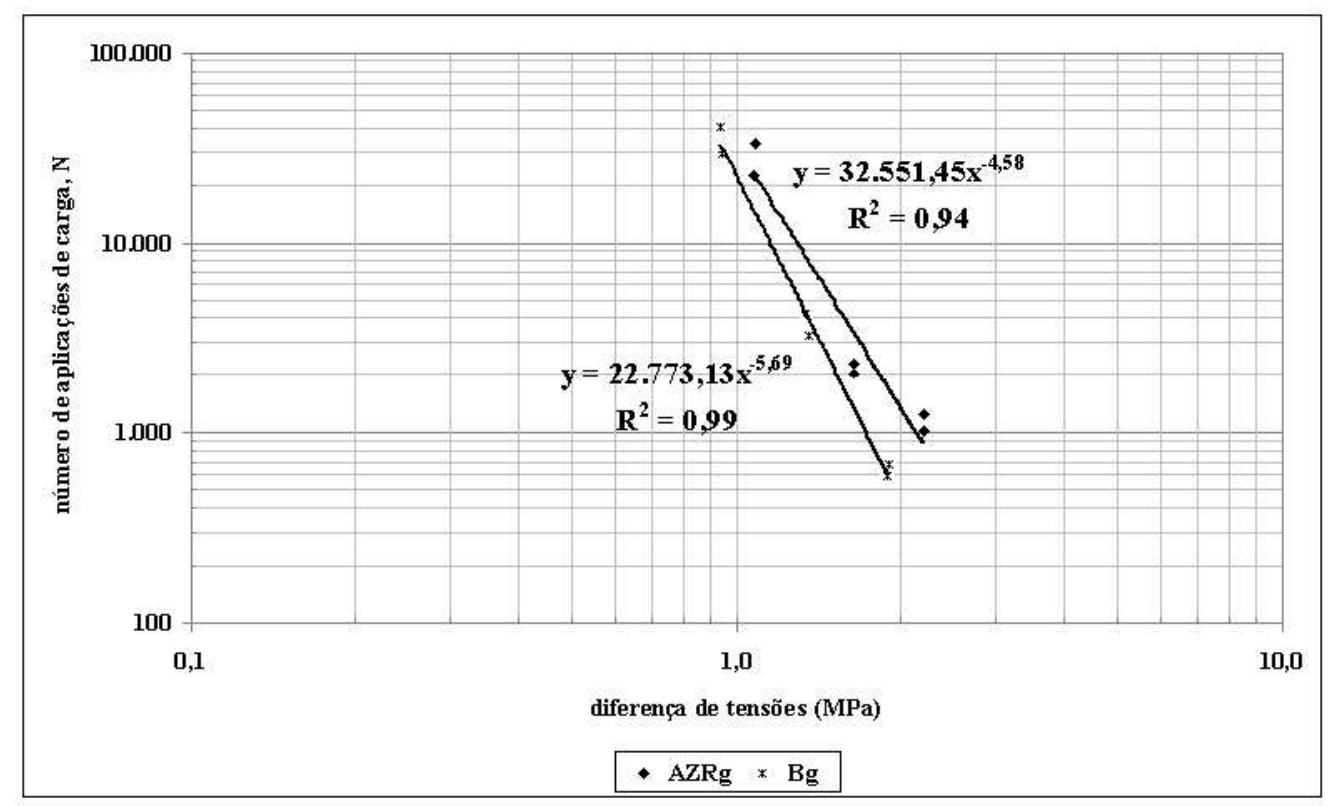

Figura 7.36: Curvas de fadiga das misturas AZR e Bailey produzidas com agregado de gabro e energia de compactação de 75 golpes por face

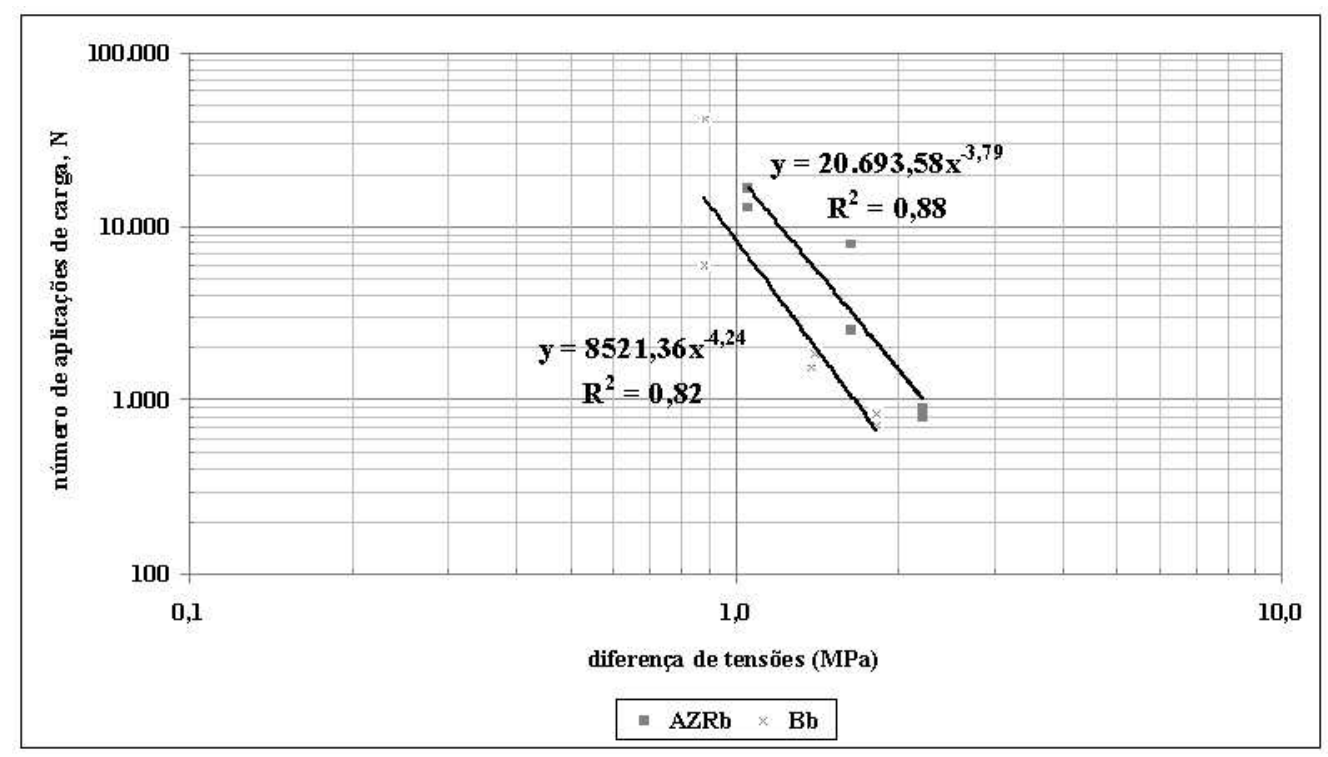

Figura 7.37: Curvas de fadiga das misturas AZR e Bailey produzidas com agregado de basalto e energia de compactação de 75 golpes por face 
Na Figura 7.38, estão ilustradas as curvas de fadiga das misturas AZRg e AZRb compactadas com 75 golpes por face do corpo-de-prova. Pode-se observar uma maior inclinação da curva da mistura AZRg em relação à inclinação da curva da mistura AZRb, indicativa da maior suscetibilidade da mistura produzida com gabro às variações da diferença de tensões.

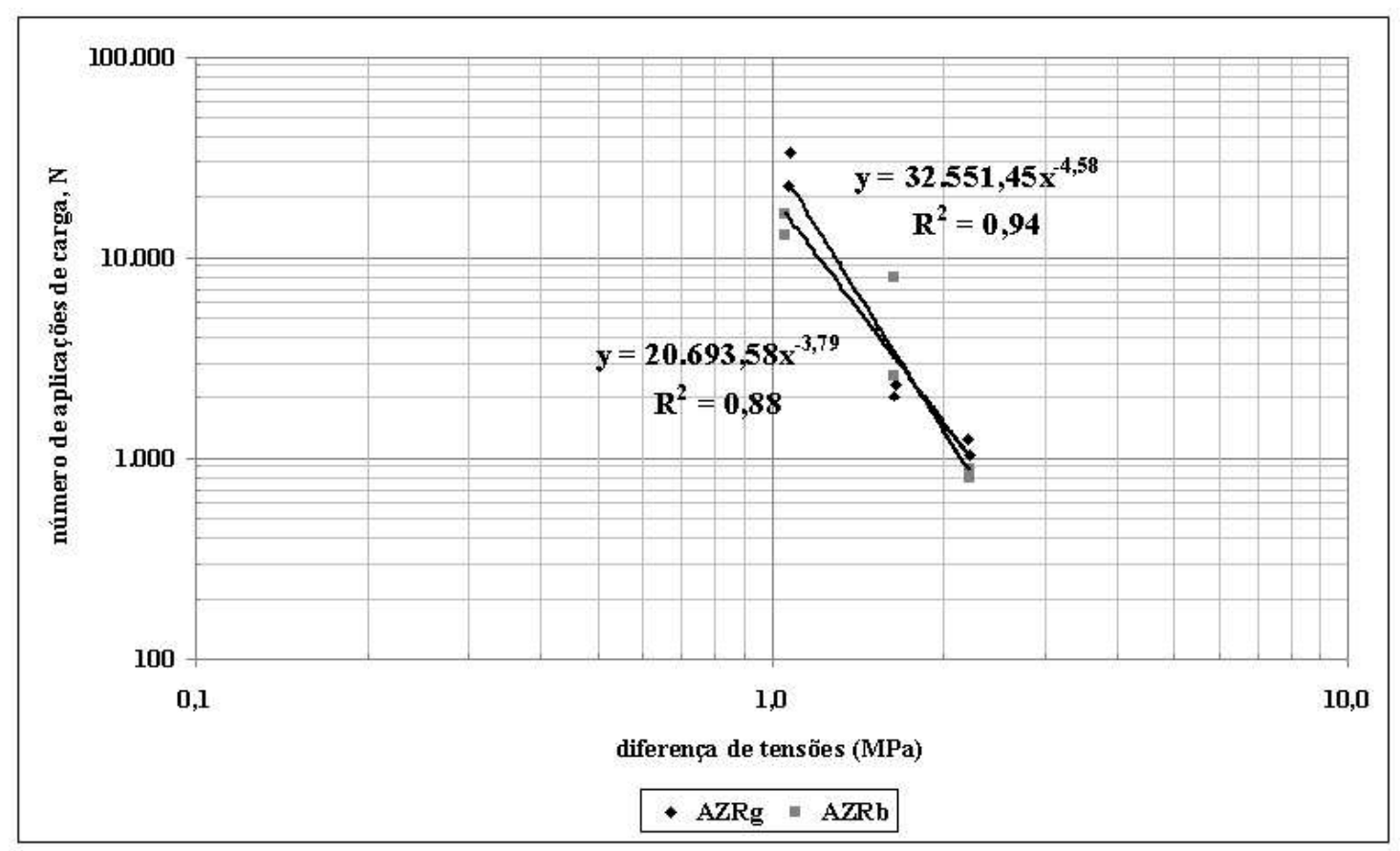

Figura 7.38: Curvas de fadiga das misturas AZR produzidas com agregados de gabro e de basalto com energia de compactação de 75 golpes por face

Também a comparação entre as curvas de fadiga das misturas 110AZRg e 110AZRb, compactadas com 110 golpes por face do corpo-de-prova (Figura 7.39), indicam uma maior suscetibilidade da mistura com agregado de gabro às variações da diferença de tensões. No entanto, ao empregar a energia de compactação de 155 golpes por face, a inclinação das curvas 155AZRg e 155AZRb apresentaram valores próximos (Figura 7.40). 


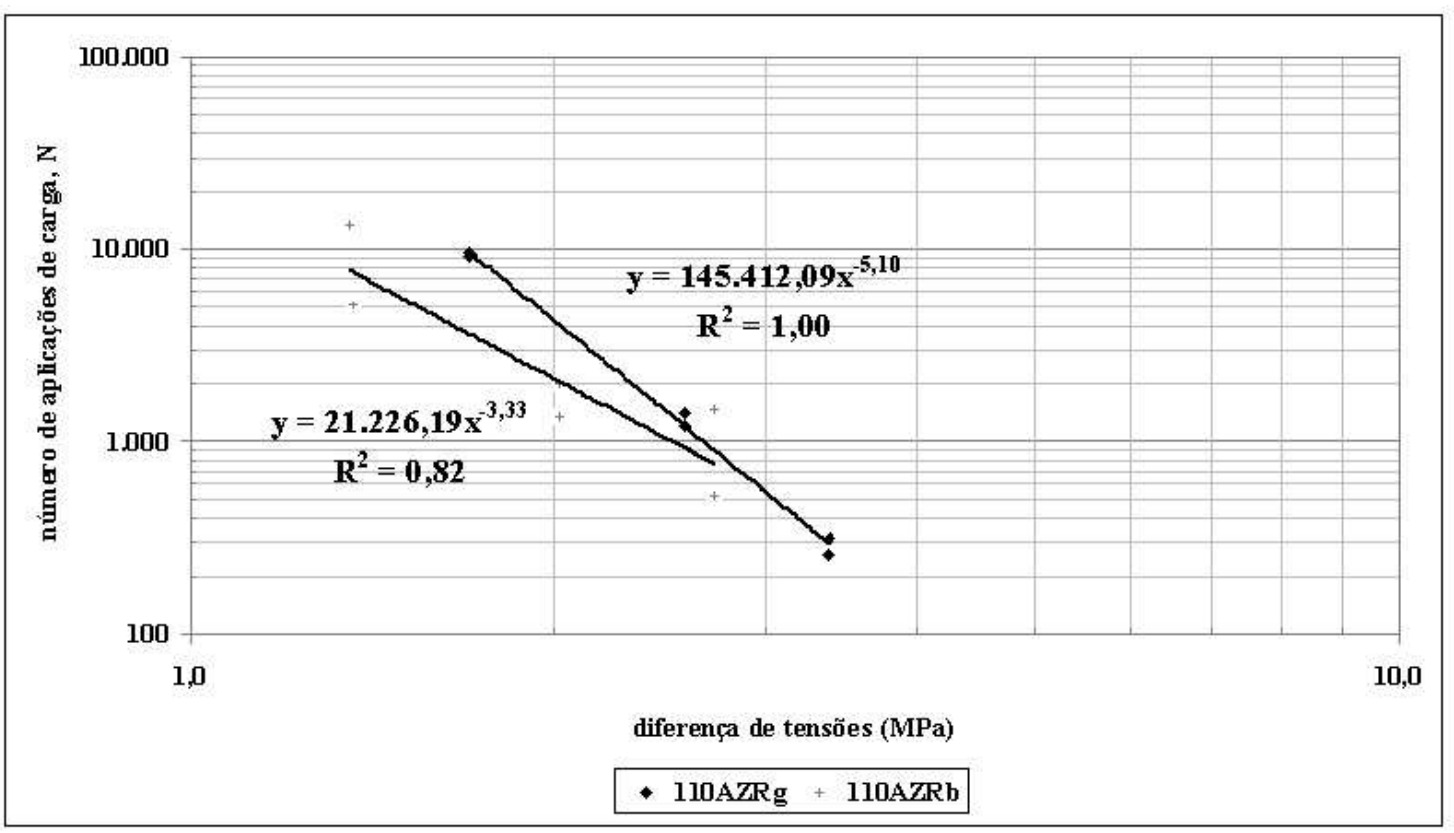

Figura 7.39: Curvas de fadiga das misturas AZR produzidas com agregados de gabro e de basalto com energia de compactação de 110 golpes por face

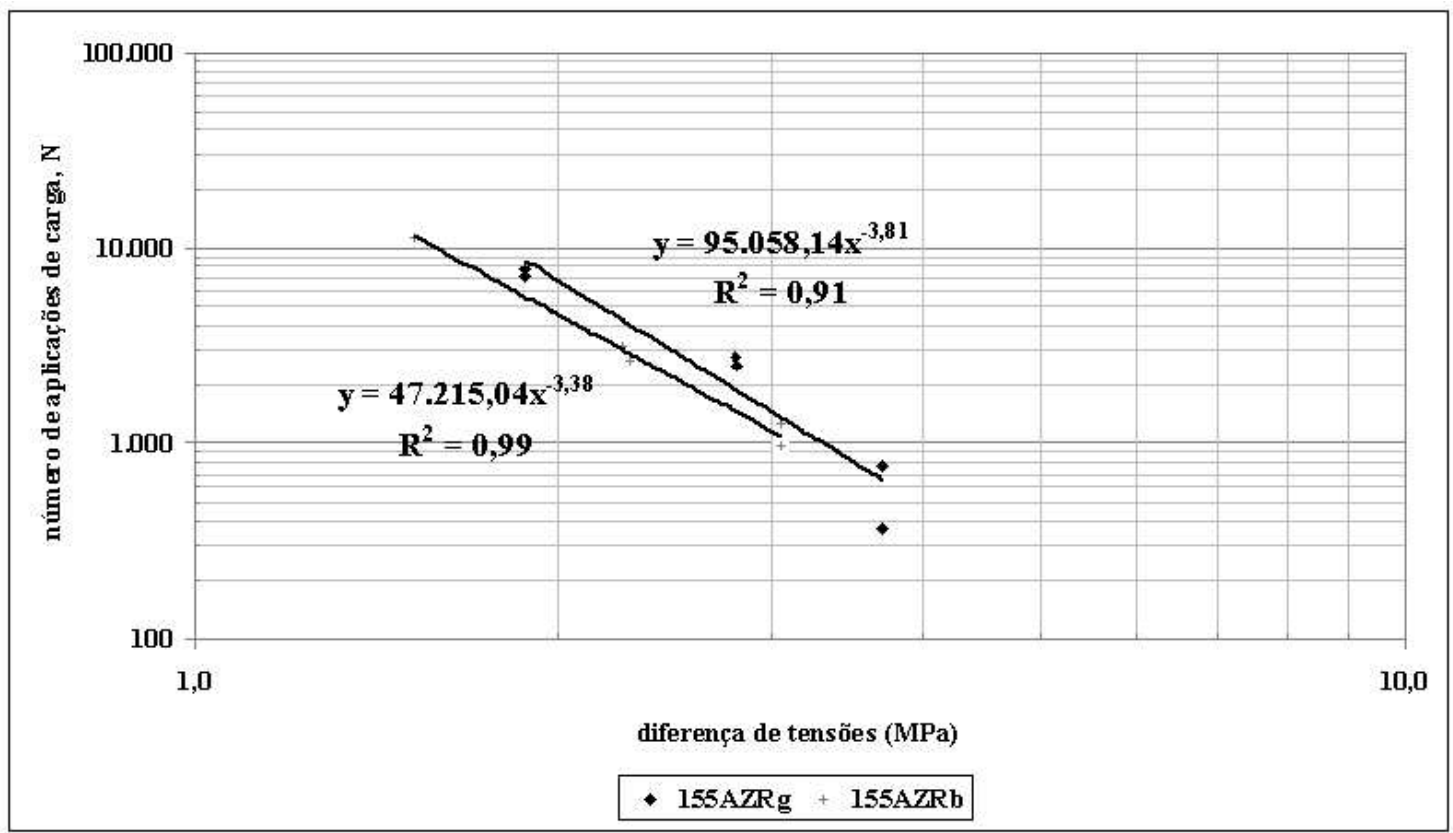

Figura 7.40: Curvas de fadiga das misturas AZR produzidas com agregados de gabro e de basalto com energia de compactação de 155 golpes por face 
Analisando as inclinações das curvas de fadiga em função da variação da energia de compactação aplicada, pode-se observar que as misturas produzidas com gabro apresentaram inclinações entre 3,81 e 5,10, cuja menor inclinação ocorreu para a mistura 155AZRg $(3,81)$ (Figura 7.41). Já as misturas com basalto apresentaram inclinações bastante próximas para os três níveis de energias de compactação aplicadas, com $n$ variando entre 3, 33 e 3,79 (Figura 7.42).

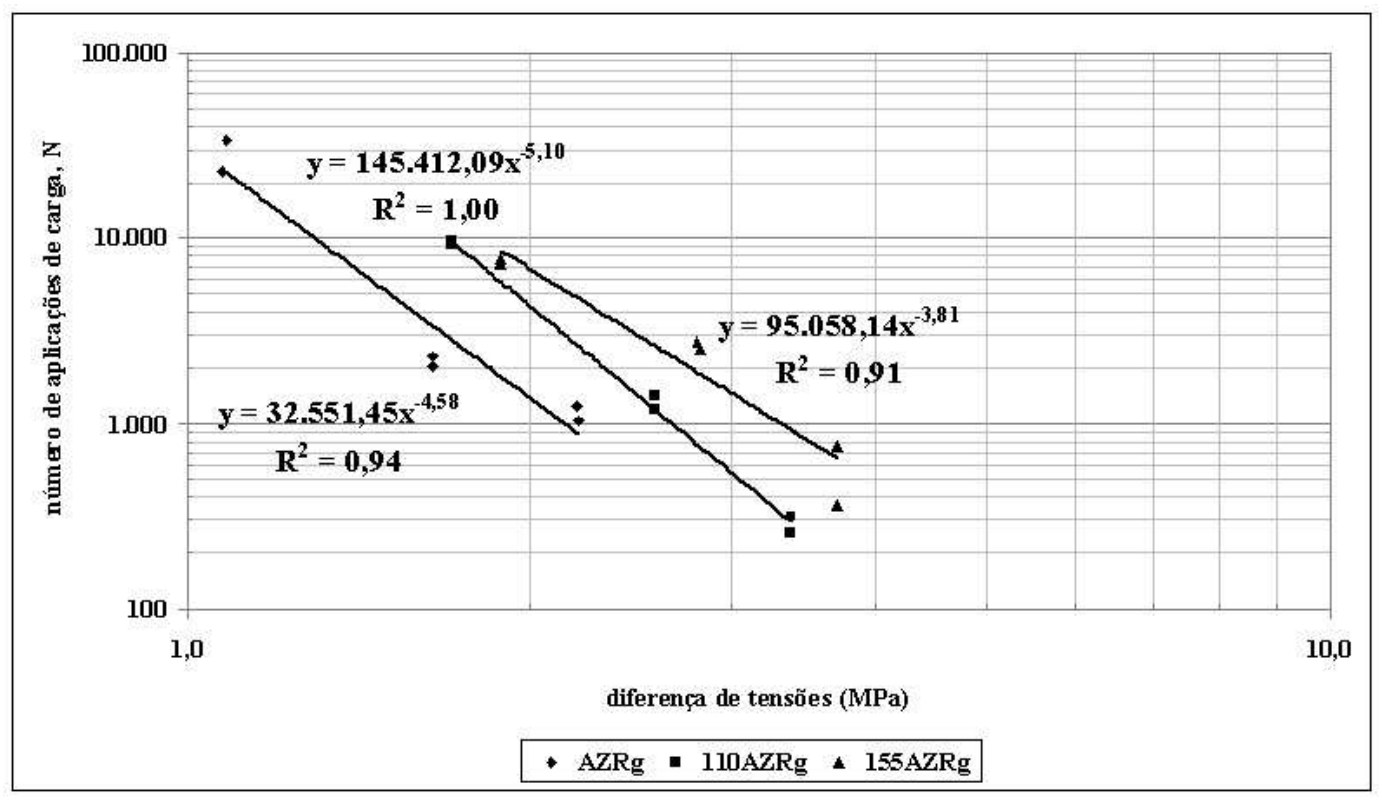

Figura 7.41: Curvas de fadiga das misturas AZR produzidas com agregados de gabro com energias de compactação de 75, 110 e 155 golpes por face

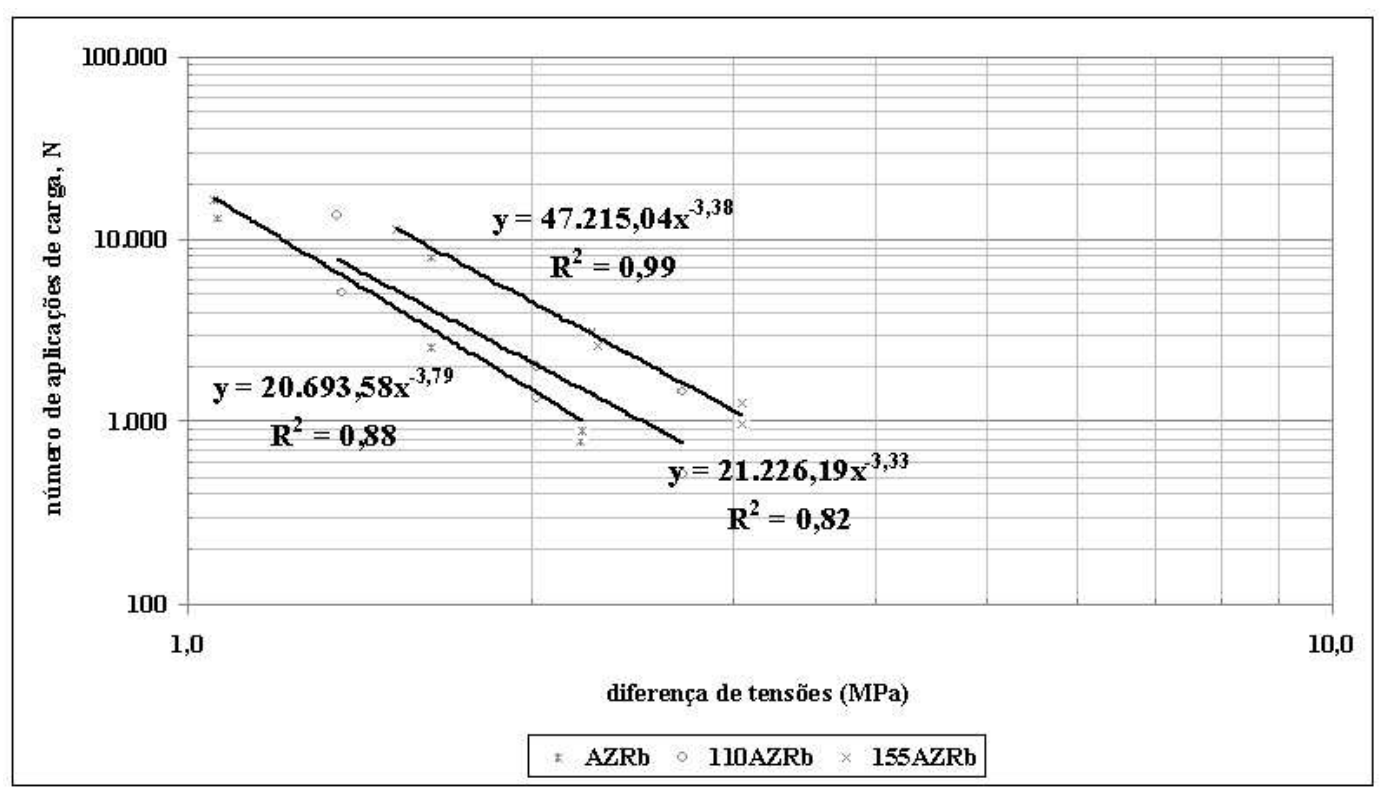

Figura 7.42: Curvas de fadiga das misturas AZR produzidas com agregados de basalto com energias de compactação de 75, 110 e 155 golpes por face 


\section{Análise Mecanística}

Análises comparativas quanto às estimativas da vida de fadiga utilizando as curvas de fadiga de diversas misturas só devem ser realizadas nos casos em que as misturas tenham rigidez, ou especificamente, módulos de resiliência, semelhantes. Isso se deve ao fato de que misturas mais rígidas absorvem muito mais tensões, gerando tensões de tração também maiores, não sendo possível, nesse caso, simplesmente comparar a vida de fadiga de cada mistura para um mesmo valor de $\Delta \sigma$ (Laura Maria Goretti da Motta, comunicação pessoal apud Magalhães (2004)). Portanto, a partir de uma mesma estrutura de camadas do pavimento, deve-se calcular as tensões geradas na base da camada asfáltica, para cada mistura estudada e, então, comparar o número de solicitações admissíveis ou vida de fadiga.

As misturas estudadas apresentam módulos de resiliência distintos, com exceção das misturas AZRg e AZRb, então, o comportamento à fadiga das misturas serão comparados a partir de um mesmo referencial, utilizando perfis de pavimentos pertinentes ao estudo, utilizando-se valores de tensões obtidos computacionalmente através do programa Elsym5. O procedimento de cálculo adotado pelo programa computacional Elsym5, com base na Teoria Elástica de Sistema de Camadas, idealiza o pavimento como um sistema elástico tridimensional de camadas sobrepostas, semi-finito no plano horizontal. Os materiais são assumidos como sendo isotrópicos e homogêneos, com comportamento elástico-linear, obedecendo à lei de Hooke generalizada.

Dois perfis estruturais serviram como referência para a estimativa da vida de fadiga das misturas estudadas. Ambos os perfis são compostos por 4 camadas, porém, cada perfil foi idealizado com níveis de rigidez diferentes, como se pode observar através das Figuras 7.43(a) e 7.43(b).

Através do programa computacional Elsym5, foram determinadas as respostas estruturais dos pavimentos em questão para solicitações de uma carga equivalente do eixo padrão do DNER. A Figura 7.43 ilustra as características e a localização do carregamento e as localizações dos pontos de aferição das tensões e deformações, que nesta pesquisa localizaram-se nas fibras inferiores da capa asfáltica.

Nas Tabelas 7.19 e 7.20 encontram-se as características mecânicas e de fadiga das misturas estudadas, organizadas comparativamente. Estão apresentados os parâmetros do ensaio de fadiga, assim como a diferença de tensões de tração e compressão calculadas para as estruturas hipotéticas (1 e 2) e a vida de fadiga (N) das misturas. 
Tabela 7.19: Características mecânicas e de fadiga das misturas - Análise 1 - Perfil 1

\begin{tabular}{|c|c|c|c|c|c|c|c|}
\hline \multirow[b]{2}{*}{ Mistura } & \multirow[b]{2}{*}{ MR (MPa) } & \multirow[b]{2}{*}{ RT (MPa) } & \multirow[b]{2}{*}{ MR/RT } & \multicolumn{4}{|c|}{$N=k\left(\frac{1}{\Delta \sigma}\right)^{n}$} \\
\hline & & & & $\mathbf{k}$ & $\mathbf{n}$ & $\boldsymbol{\Delta} \boldsymbol{\sigma}(\mathrm{MPa})$ & $\mathrm{N}$ \\
\hline AZRg & 5.410 & 1,36 & 3.972 & 32.552 & 4,58 & 0,14 & $3,0 \times 10^{8}$ \\
\hline $\mathrm{Bg}$ & 3.528 & 1,16 & 3.041 & 22.773 & 5,69 & 0,21 & $1,6 \times 10^{8}$ \\
\hline AZRb & 5.146 & 1,35 & 3.809 & 20.694 & 3,79 & 0,17 & $1,8 \times 10^{7}$ \\
\hline $\mathrm{Bb}$ & 2.817 & 1,10 & 2.561 & 8.521 & 4,24 & 0,24 & $3,4 \times 10^{6}$ \\
\hline AZRg & 5.410 & 1,36 & 3.972 & 32.552 & 4,58 & 0,14 & $3,0 \times 10^{8}$ \\
\hline $\mathrm{AZRb}$ & 5.146 & 1,35 & 3.809 & 20.694 & 3,79 & 0,17 & $1,8 \times 10^{7}$ \\
\hline 110AZRg & 12.130 & 2,12 & 5.735 & 145.412 & 5,10 & 1,08 & $9,9 \times 10^{4}$ \\
\hline 110AZRb & 7.282 & 1,69 & 4.306 & 21.226 & 3,33 & 0,36 & $6,4 \times 10^{5}$ \\
\hline 155AZRg & 19.016 & 2,35 & 8.098 & 95.058 & 3,81 & 1,49 & $5,3 \times 10^{3}$ \\
\hline $155 \mathrm{AZRb}$ & 11.011 & 1,90 & 5.809 & 47.215 & 3,38 & 1,00 & $2,2 \times 10^{4}$ \\
\hline AZRg & 5.410 & 1,36 & 3.972 & 32.552 & 4,58 & 0,14 & $3,0 \times 10^{8}$ \\
\hline 110AZRg & 12.130 & 2,12 & 5.735 & 145.412 & 5,10 & 1,08 & $9,9 \times 10^{4}$ \\
\hline $155 \mathrm{AZRg}$ & 19.016 & 2,35 & 8.098 & 95.058 & 3,81 & 1,49 & $5,3 \times 10^{3}$ \\
\hline AZRb & 5.146 & 1,35 & 3.809 & 20.694 & 3,79 & 0,17 & $1,8 \times 10^{7}$ \\
\hline 110AZRb & 7.282 & 1,69 & 4.306 & 21.226 & 3,33 & 0,36 & $6,4 \times 10^{5}$ \\
\hline 155AZRb & 11.011 & 1,90 & 5.809 & 47.215 & 3,38 & 1,00 & $2,2 \times 10^{4}$ \\
\hline
\end{tabular}

Tabela 7.20: Características mecânicas e de fadiga das misturas - Análise 2 - Perfil 2

\begin{tabular}{|c|c|c|c|c|c|c|c|}
\hline \multirow[b]{2}{*}{ Mistura } & \multirow[b]{2}{*}{ MR (MPa) } & \multirow[b]{2}{*}{ RT (MPa) } & \multirow[b]{2}{*}{ MR/RT } & \multicolumn{4}{|c|}{$N=k\left(\frac{1}{\Delta \sigma}\right)^{n}$} \\
\hline & & & & $\mathbf{k}$ & $\mathbf{n}$ & $\Delta \boldsymbol{\sigma}(\mathrm{MPa})$ & $\mathrm{N}$ \\
\hline$\overline{\mathrm{AZRg}}$ & 5.410 & 1,36 & 3.972 & 32.552 & 4,58 & 0,23 & $2,6 \times 10^{7}$ \\
\hline $\mathrm{Bg}$ & 3.528 & 1,16 & 3.041 & 22.773 & 5,69 & 0,26 & $4,8 \times 10^{7}$ \\
\hline AZRb & 5.146 & 1,35 & 3.809 & 20.694 & 3,79 & 0,23 & $5,0 \times 10^{6}$ \\
\hline $\mathrm{Bb}$ & 2.817 & 1,10 & 2.561 & 8.521 & 4,24 & 0,28 & $2,0 \times 10^{6}$ \\
\hline$\overline{\text { AZRg }}$ & 5.410 & 1,36 & 3.972 & 32.552 & 4,58 & 0,23 & $2,6 \times 10^{7}$ \\
\hline $\mathrm{AZRb}$ & 5.146 & 1,35 & 3.809 & 20.694 & 3,79 & 0,23 & $5,0 \times 10^{6}$ \\
\hline 110AZRg & 12.130 & 2,12 & 5.735 & 145.412 & 5,10 & 0,19 & $7,6 \times 10^{8}$ \\
\hline 110AZRb & 7.282 & 1,69 & 4.306 & 21.226 & 3,33 & 0,22 & $3,4 \times 10^{7}$ \\
\hline 155AZRg & 19.016 & 2,35 & 8.098 & 95.058 & 3,81 & 0,15 & $1,2 \times 10^{8}$ \\
\hline $155 \mathrm{AZRb}$ & 11.011 & 1,90 & 5.809 & 47.215 & 3,38 & 0,20 & $1,2 \times 10^{7}$ \\
\hline AZRg & 5.410 & 1,36 & 3.972 & 32.552 & 4,58 & 0,23 & $2,6 \times 10^{7}$ \\
\hline 110AZRg & 12.130 & 2,12 & 5.735 & 145.412 & 5,10 & 0,19 & $7,6 \times 10^{8}$ \\
\hline 155AZRg & 19.016 & 2,35 & 8.098 & 95.058 & 3,81 & 0,15 & $1,2 \times 10^{8}$ \\
\hline $\mathrm{AZRb}$ & 5.146 & 1,35 & 3.809 & 20.694 & 3,79 & 0,23 & $5,0 \times 10^{6}$ \\
\hline 110AZRb & 7.282 & 1,69 & 4.306 & 21.226 & 3,33 & 0,22 & $3,4 \times 10^{7}$ \\
\hline 155AZRb & 11.011 & 1,90 & 5.809 & 47.215 & 3,38 & 0,20 & $1,2 \times 10^{7}$ \\
\hline
\end{tabular}




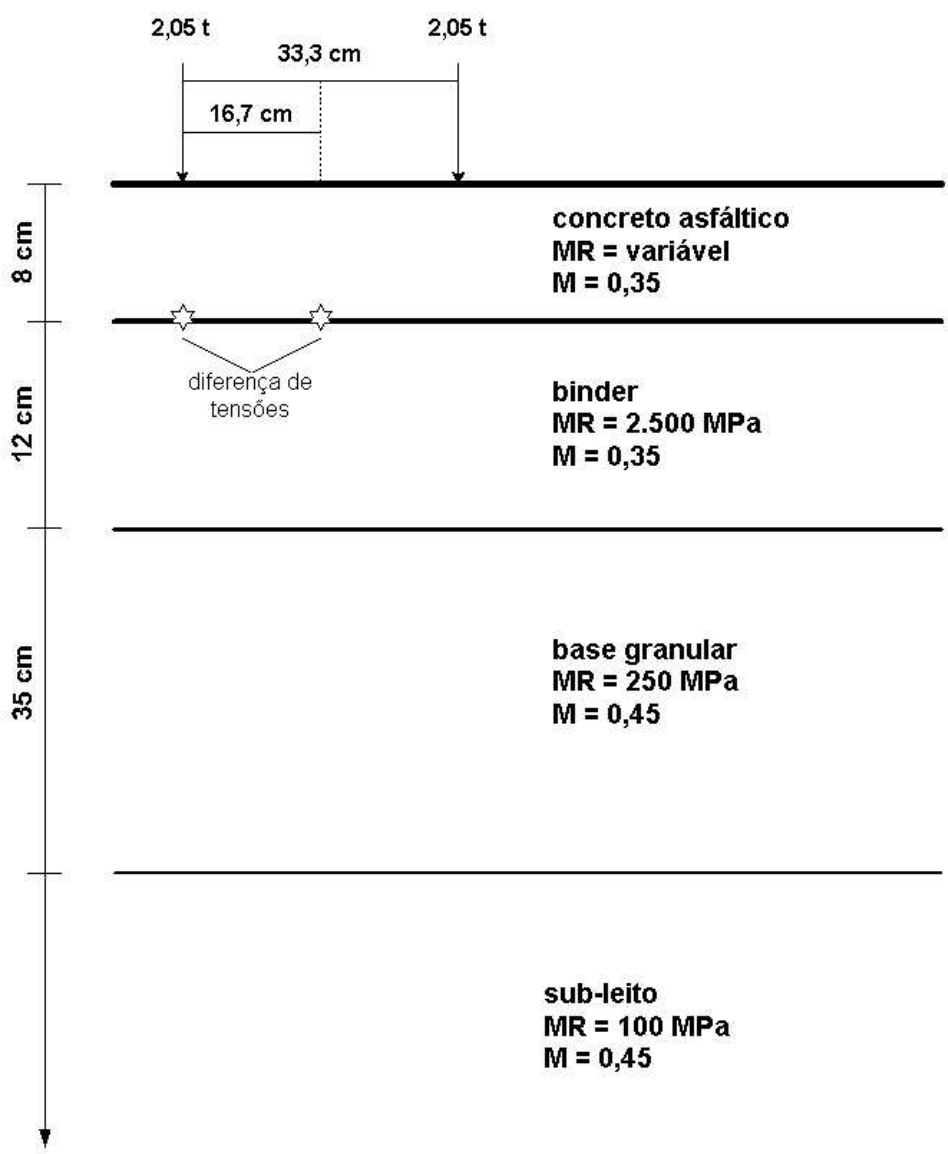

(a) Perfil 1

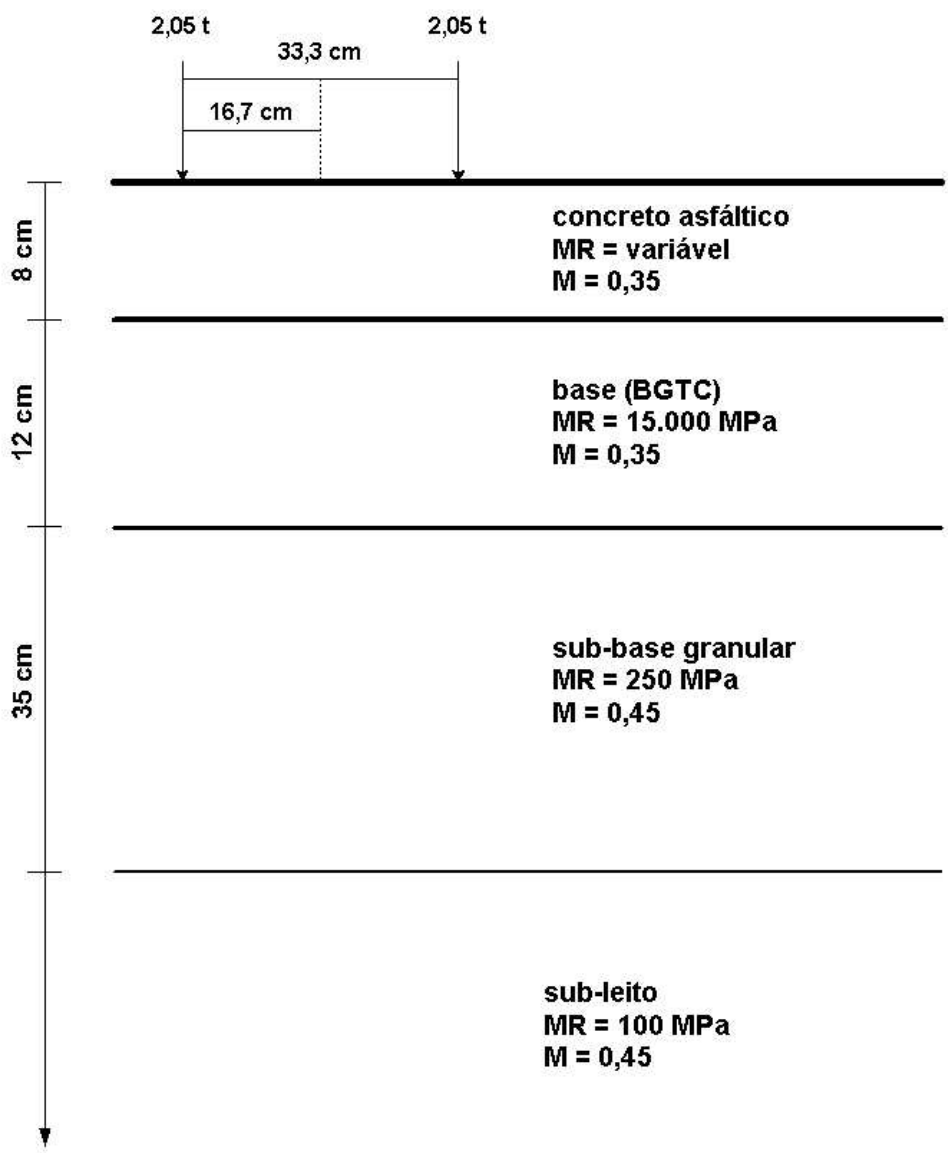

(b) Perfil 2

Figura 7.43: Perfis utilizados, características e localização do carregamento e pontos de aferição das tensões 


\section{Granulometria}

Considerando o perfil estrutural 1, pode-se analisar comparativamente a influência das granulometrias AZR e Bg e das granulometrias AZR e Bb quanto à vida de fadiga estimada das misturas compactadas com 75 golpes por face. Os resultados mostram que as misturas AZRg apresentam vida de fadiga cerca de 2 vezes maior que a vida de fadiga obtida para as misturas Bg. Também a vida de fadiga das misturas AZRb mostraram-se pelo menos 5 vezes mais elevadas que a vida de fadiga obtida para as misturas $\mathrm{Bb}$. Portanto, os resultados indicam uma superioridade da granulometria AZR comparada às granulometrias $\mathrm{Bg}$ e Bb quanto à resistência à fadiga, considerando os resultados obtidos com base no perfil 1.

No entanto, ao considerar uma estrutura muito mais rígida (perfil estrutural 2), a mistura Bg passou a apresentar vida de fadiga 2 vezes maior à encontrada para a mistura AZRg. Já a vida de fadiga da mistura AZRb permaneceu mais elevada que a vida de fadiga da mistura $\mathrm{Bb}$. Vale lembrar que o perfil 1 corresponde a uma estrutura de menor rigidez, ou seja, mais compatível com a rigidez das misturas compactadas com 75 golpes por face do corpo-de-prova.

\section{Tipo de Agregado}

Analisando a influência do tipo do agregado na vida de fadiga das misturas compactadas com 75 golpes, pode-se constatar que as misturas AZR produzidas com agregado de gabro mostram-se pelo menos 17 vezes mais resistentes à fadiga que as misturas AZR produzidas com basalto (Tabela 7.19).

Ainda considerando os resultados obtidos com base no perfil 1, observa-se que para misturas mais rígidas (compactadas com 110 e 155 golpes) os resultados se invertem, ou seja, as misturas produzidas com basalto mostram-se mais resistentes à fadiga que as misturas produzidas com gabro. Porém, essas misturas com módulos de resiliência elevados devem ser analisadas com base numa estrutura com maior compatibilidade quanto à rigidez (perfil 2). Ao analisá-las com base no perfil estrutural 2, os resultados tornam a indicar a superioridade das misturas produzidas com agregado de gabro quanto à resistência à fadiga (Tabela 7.20).

\section{Energia de Compactação}

O gráfico da vida de fadiga versus número de golpes empregados na compactação das misturas (Figura 7.44), mostra que a elevação da energia de compactação de 75 para 110 golpes 
proporcionou um aumento da vida de fadiga da mistura 110AZRg em cerca de 2,5 vezes e que a elevação da energia de compactação de 110 para 155 golpes ocasionou um decréscimo da vida de fadiga da mistura 155AZRg de aproximadamente 6 vezes.

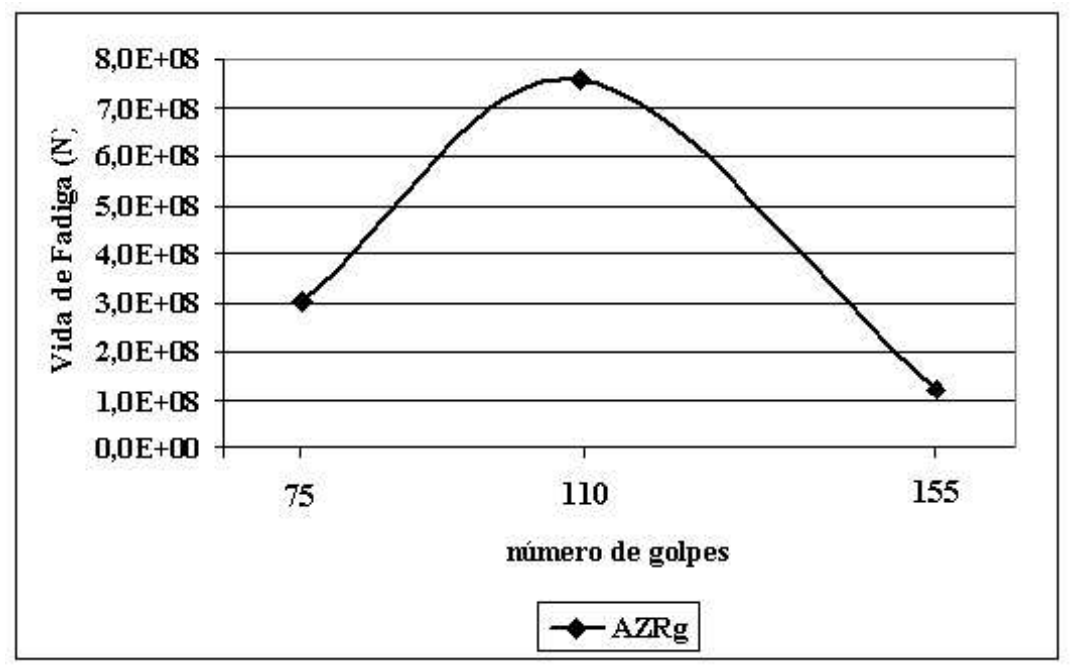

Figura 7.44: Variação da vida de fadiga das misturas AZR produzidas com agregado de gabro, em função da energia de compactação aplicada

O mesmo comportamento, quanto à variação da vida de fadiga em função da energia de compactação aplicada, foi observado para as misturas AZR produzidas com basalto (Figura 7.45). A elevação da energia de compactação de 75 para 110 golpes fez com que a vida de fadiga da mistura 110AZRb praticamente dobrasse; no entanto, a mistura compactada com 155 golpes teve sua vida de fadiga diminuída em aproximadamente 3 vezes. Os resultados indicam que tanto as misturas com gabro quanto as misturas com basalto tiveram comportamento melhor quanto à fadiga quando compactadas com 110 golpes por face do corpo-de-prova.

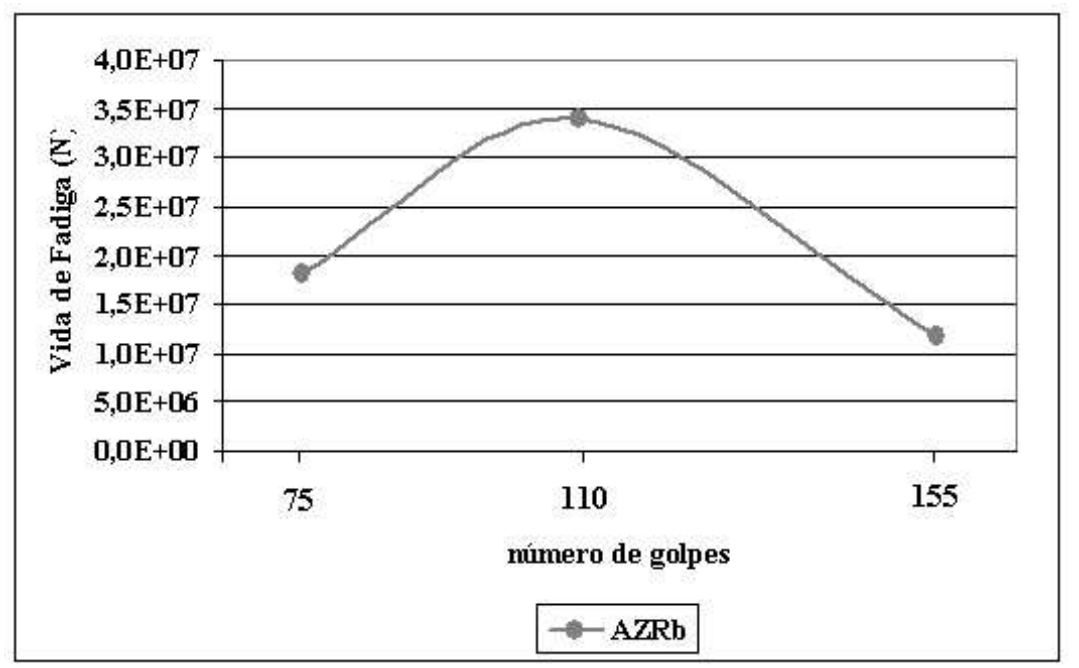

Figura 7.45: Variação da vida de fadiga das misturas AZR produzidas com agregado de basalto, em função da energia de compactação aplicada 
É interessante notar que as misturas com agregado de gabro tiveram comportamento melhor quanto à fadiga que as misturas com basalto, para todas as energias de compactação aplicadas (Figura 7.46).

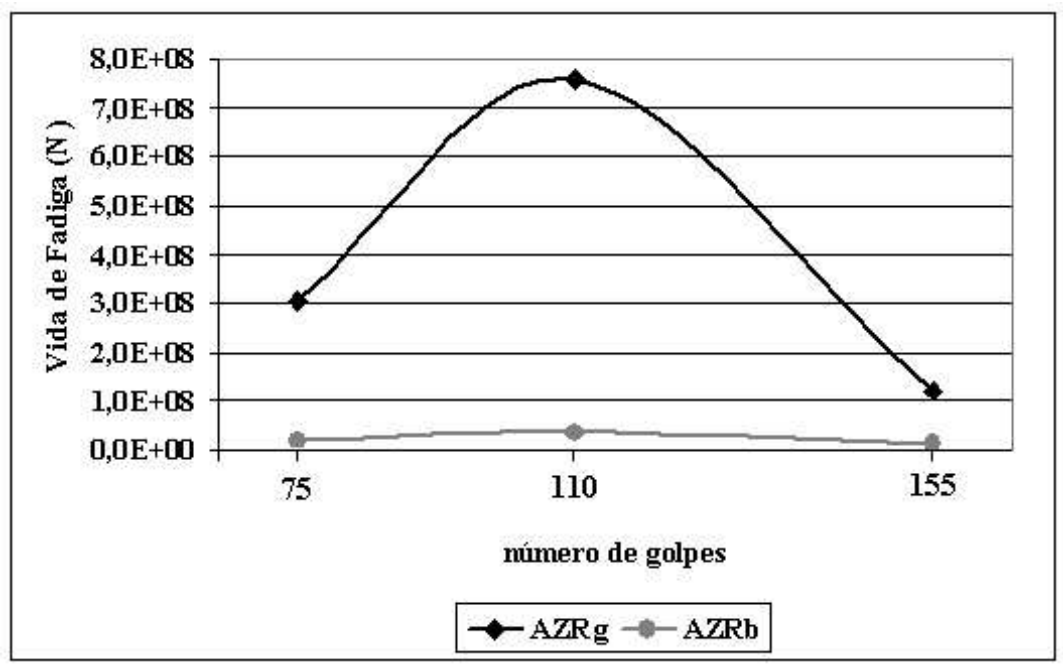

Figura 7.46: Comparação entre as vidas de fadiga das misturas produzidas com agregado de gabro e agregado de basalto, em função da energia de compactação aplicada

\section{Conclusões Parciais}

- As misturas produzidas com a granulometria AZR apresentaram valores de resistência à tração, módulos de resiliência e relação $M R / R T$ mais elevados que os valores dessas propriedades obtidos para as misturas produzidas com granulometrias Bailey;

- Ao serem compactadas com energia de 75 golpes por face do corpo-de-prova, as misturas AZRg e AZRb apresentaram valores semelhantes de resistência à tração, de módulo de resiliência e de módulo de resiliência instantâneo;

- Tanto a elevação da energia de compactação de 75 para 110 golpes como de 110 para 155 golpes ocasionou ganho de resistência à tração em torno de $20 \%$ nas misturas produzidas com gabro em relação ao valor obtido para as misturas produzidas com basalto, assim como valores de módulo de resiliência e de módulo de resiliência instantâneo, cerca de $40 \%$ maiores que os obtidos para as misturas com basalto;

- Quando compactadas com 75 golpes por face do corpo-de-prova, as misturas produzidas com gabro e com basalto apresentaram módulos de resiliência e resistência à tração semelhantes. Porém, energias de compactação mais elevadas tornaram evidentes a influência das características de forma dos agregados no comportamento das misturas. O agregado de gabro, possuidor de formas mais arredondadas, porém com angularidade e textura 
superficial adequadas, gerou misturas mais rígidas e mais resistentes à tração que aquelas produzidas com basalto, possuidor de formas mais planas;

- A relação $M R / R T$ varia com a energia de compactação aplicada, quanto maior a energia de compactação, mais elevados os valores da relação $M R / R T$;

- As misturas produzidas com granulometria AZR apresentaram vida de fadiga maior que aquelas produzidas com granulometrias $\mathrm{Bg}$ e $\mathrm{Bb}$;

- Analisando a influência do tipo do agregado na vida de fadiga das misturas compactadas com 75, 110 e 155 golpes, foram obtidas evidências de que as misturas produzidas com agregados com formas mais arredondadas, porém com angularidade e textura superficial adequadas (gabro), apresentam vida de fadiga maior que as misturas produzidas com agregados com formas mais planas (basalto), ou seja, a vida de fadiga tende a aumentar com o aumento da rigidez das misturas;

- Ao analisar a influência da energia de compactação aplicada em relação à vida de fadiga das misturas, pode-se verificar que o melhor comportamento à fadiga foi obtido ao compactar as misturas com 110 golpes por face do corpo-de-prova. No entanto, resultados satisfatórios quanto à vida de fadiga, na ordem de $10^{7}$ e de $10^{8}$, também foram observados ao empregar energias de compactação tanto de 75 como de 155 golpes por face do corpo-de-prova. 


\subsection{Resultados de Adesividade das Misturas}

\subsubsection{Adesividade entre o Asfalto e o Agregado - Análise Visual}

\section{Agregado Grosso}

A Figura 7.47 ilustra o modo de avaliação visual da adesividade entre o asfalto e o agregado grosso. Como se pode perceber, houve descolamento da película de asfalto que envolve as partículas do agregado de gabro (Figuras 7.48(a) e 7.48(b)), indicando que a ligação adesiva do asfalto e a superfície do agregado é insatisfatória. Insatisfatórias também foram as ligações adesivas observadas entre o asfalto e o agregado de basalto e entre o asfalto e o agregado de areia natural. Portanto, com base nos resultados observados através do procedimento de análise visual quanto à adesividade do agregado grosso, pode-se concluir que os três agregados estudados apresentaram ligações adesivas asfalto/agregado insatisfatórias.

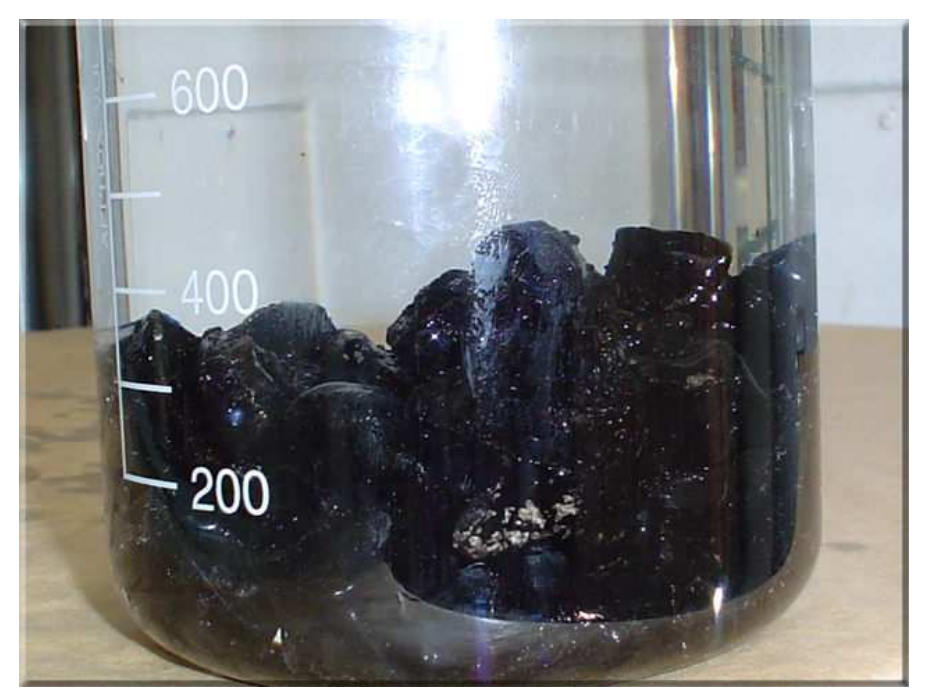

Figura 7.47: Modo de análise visual da adesividade entre o asfalto e o agregado grosso

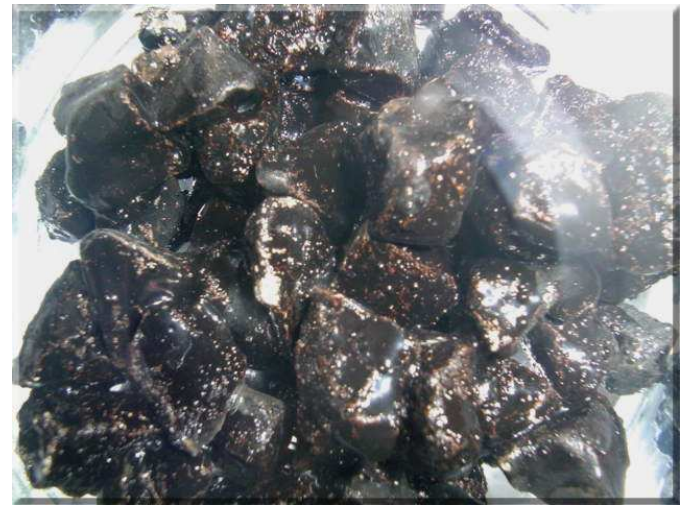

(a) Descolamento da película

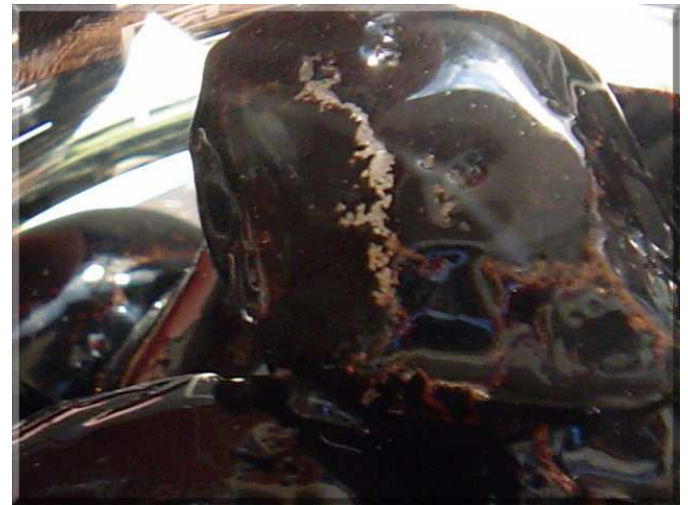

(b) Detalhe

Figura 7.48: Detalhamento da análise visual da adesividade entre o asfalto e o agregado grosso 


\section{Agregado Fino}

A Figura 7.49 ilustra a aparência dos agregados finos de gabro (Figura 7.49(a)), de basalto (Figura 7.49(b)) e de areia natural (Figura 7.49(c)) obtida após submeter as amostras a 1 minuto de fervura em água destilada. Como se pode observar, as amostras de agregados finos apresentaram descolamento severo da película de asfalto, logo na primeira etapa do ensaio, quando as misturas são submetidas à ação da água fervente. Portanto, com base nos resultados observados através do procedimento de análise visual quanto à adesividade do agregado fino, pode-se concluir que os três agregados estudados apresentam ligações adesivas asfalto/agregado insatisfatórias.

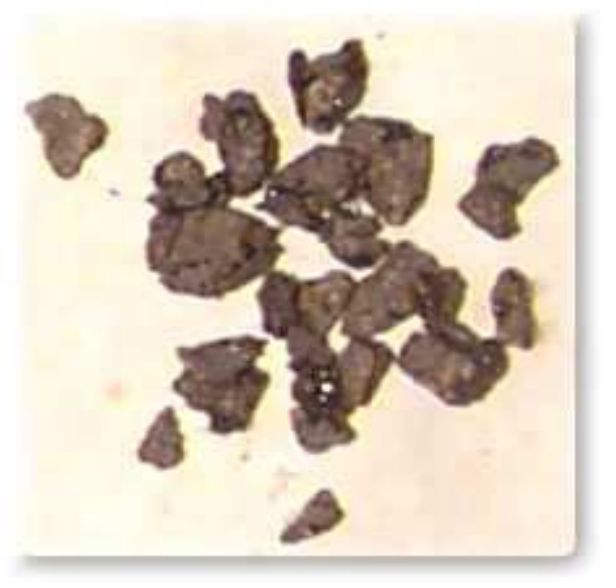

(a) Gabro

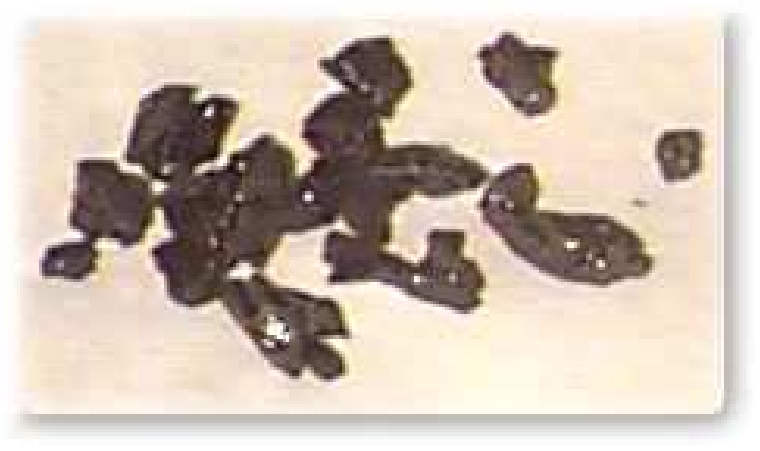

(b) Basalto

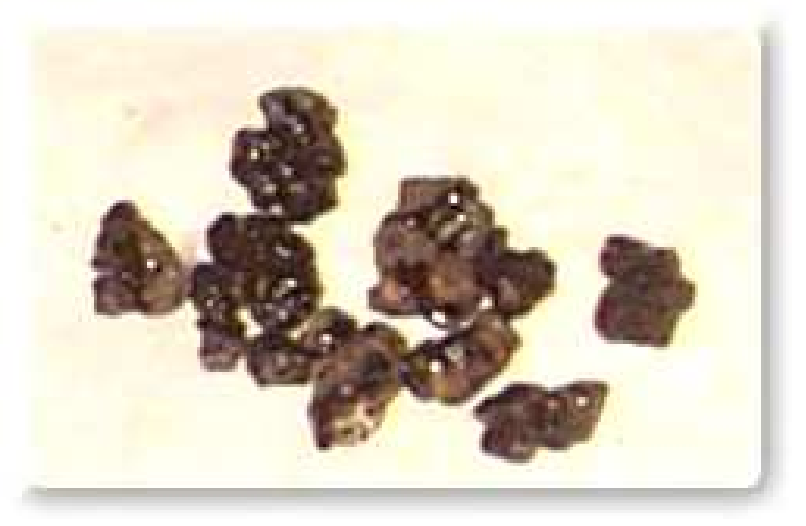

(c) Areia natural

Figura 7.49: Análise visual da adesividade entre o asfalto e os agregados finos 


\subsubsection{Sensibilidade à Umidade das Misturas Asfálticas}

\section{Variação da Absorção de Asfalto pelos Agregados}

Durante o processo de avaliação da sensibilidade à umidade das misturas, através dos métodos padronizados pela ASTM D 4867 e pela AASHTO T 283, pode-se verificar a ocorrência de variações da taxa de absorção de asfalto das misturas conforme o método de ensaio utilizado, como mostra a Tabela7.21.

Tabela 7.21: Variação da absorção de asfalto

\begin{tabular}{lcc}
\hline Agregado & $\begin{array}{c}\text { AASHTO } \\
\text { Abs (\%) }\end{array}$ & $\begin{array}{c}\text { ASTM } \\
\text { Abs (\%) }\end{array}$ \\
\hline Gabro & 0,22 & 0,88 \\
\hline Basalto & 0,04 & 0,21 \\
\hline
\end{tabular}

As causas principais das variações da taxa de absorção de asfalto observadas são a temperatura e o tempo utilizados. Como visto anteriormente, as misturas destinadas à avaliação da sensibilidade à umidade através do método da ASTM D 4867 são submetidas a um período de permanência em estufa na temperatura de compactação $\left(148^{0} \mathrm{C}\right)$ por 2 horas (sem envelhecimento). Já as misturas destinadas à avaliação da sensibilidade à umidade através do método da AASHTO T 283 são submetidas a um período de envelhecimento, permanecendo numa estufa ventilada a $60^{\circ} \mathrm{C}$ por 16 horas. Ao observar os resultados de absorção de asfalto obtidos para um mesmo agregado em função do método utilizado (Tabela7.21), pode-se observar que absorções de asfalto mais elevadas foram apresentadas pelas misturas destinadas à avaliação pelo método da ASTM D 4867.

Provavelmente as misturas ASTM D 4867 apresentaram taxas de absorção de asfalto 4 a 5 vezes mais elevadas que as obtidas nas misturas AASHTO T 283 em função da temperatura a que foram expostas $\left(146^{\circ} \mathrm{C}\right)$, que permitiu que o asfalto se tornasse menos viscoso, facilitando sua penetração no interior dos poros dos agregados. Como visto através dos resultados apresentados no Capítulo 3, o tempo de 2 horas na temperatura de compactação é suficiente para que ocorra a saturação dos poros dos agregados estudados. Já as misturas AASHTO T 283, embora tenham permanecido por um tempo maior na estufa, tiveram taxa de absorção de asfalto menor, devido à menor temperatura da mistura $\left(60^{\circ} C\right)$ e, conseqüentemente, à viscosidade mais elevada do asfalto. 


\section{Avaliação dos Danos Causados pela Umidade}

Na Tabela 7.22 estão apresentados os resultados da resistência à tração por compressão diametral dos grupos de controle $\left(R T_{1}\right)$ e condicionado $\left(R T_{2}\right)$ e da resistência a tração retida $(R T R)$. Os resultados mostram que tanto as misturas ASTM D 4867 como as misturas AASHTO T 283 produzidas com o agregado de gabro apresentaram perdas de apenas $6 \%$. Também foram pequenas as perdas de resistência à tração apresentadas pelas misturas ASTM D 4867 e AASHTO T 283 produzidas com o agregado de basalto. Considerando a RTR, pode-se verificar que as misturas ASTM D 4867 e as misturas AASHTO T 283, produzidas tanto com o agregado de gabro como com o agregado de basalto, atenderam aos critérios de aceitação estabelecidos (ver Tabela 7.1).

Tabela 7.22: Resultados de suscetibilidade aos danos por umidade ao avaliar a propriedade de resistência à tração

\begin{tabular}{l|c|c|c|c}
\hline Propriedade & \multicolumn{2}{|c|}{ Gabro } & \multicolumn{2}{c}{ Basalto } \\
& AASHTO T 283 & ASTM D 4867 & AASHTO T 283 & ASTM D 4867 \\
\hline$V v_{1}(\%)$ & 4,5 & 5,0 & 6,1 & 6,9 \\
$R T_{1}(M P a)$ & 1,58 & 1,78 & 1,34 & 1,54 \\
$V v_{2}(\%)$ & 4,3 & 4,8 & 5,3 & 6,1 \\
$R T_{2}(M P a)$ & 1,48 & 1,68 & 1,46 & 1,50 \\
$R T R(\%)$ & 94 & 94 & 109 & 97 \\
\hline
\end{tabular}

Na Tabela 7.23 estão apresentados os resultados do módulo de resiliência dos grupos de controle $\left(M R_{1}\right)$, condicionado $\left(M R_{2}\right)$ e do módulo de resiliência retido $(M R R)$, além do volume de vazios $(V v)$ e do grau de saturação $(G s)$ dos corpos-de-prova ensaiados.

Os resultados mostram que as misturas ASTM D 4867 produzidas com gabro apresentam perdas de propriedade devido a ação danosa da água em torno de $40 \%$, ou seja, superior ao limite máximo de 30\% estabelecido. Já as misturas ASTM D 4867, produzidas com basalto, apresentam perdas de propriedade aceitáveis, em torno de $15 \%$. Considerando os resultados obtidos com as misturas AASHTO T 283, pode-se observar o mesmo comportamento já verificado para as misturas ASTM D 4867, ou seja, as misturas produzidas com gabro apresentaram perdas de propriedade, devido à ação danosa da água, também em torno de $40 \%$ e as misturas com basalto mostram perdas de $26 \%$, ou seja, inferior ao limite máximo de $30 \%$ estabelecido. Com base nos resultados obtidos por ambos os métodos, pode-se concluir que as misturas com gabro são mais sensíveis à ação da água que as misturas com basalto, pois apresentaram perdas da propriedade mecânica, referente ao módulo de resiliência, superiores a $30 \%$.

É importante lembrar que o agregado de gabro apresentou valor de equivalente de areia (EA) de 75\%, como visto no Capítulo 2, item 2.5.4. Aparentemente esse valor de EA deve-se 
à camada de pó presente sobre suas partículas e/ou à presença excessiva de frações muito finas do próprio agregado. Tanto a camada de pó quanto a presença excessiva de frações argilosas podem influenciar negativamente a aderência asfalto/agregado, podendo levar a danos ainda mais significativos na presença de umidade.

Tabela 7.23: Resultados de suscetibilidade aos danos por umidade ao avaliar a propriedade módulo de resiliência

\begin{tabular}{|c|c|c|c|c|c|}
\hline \multirow[t]{2}{*}{ сp } & \multicolumn{5}{|c|}{ Gabro-ASTM4867 } \\
\hline & $V v(\%)$ & $G s(\%)$ & $M R_{1}(M P a)$ & $M R_{2}(M P a)$ & $M R R(M P a)$ \\
\hline 1 & 5,0 & 58 & 14.622 & 6.054 & 0,41 \\
\hline 3 & 4,7 & 55 & 10.669 & 5.444 & 0,51 \\
\hline 5 & 4,9 & 57 & 10.176 & 7.606 & 0,75 \\
\hline média & 4,9 & 57 & 11.822 & 6.368 & 0,56 \\
\hline desvio padrão & 0,15 & 2 & 2.437 & 1.115 & 0,17 \\
\hline \multirow[t]{2}{*}{$\mathbf{c p}$} & \multicolumn{5}{|c|}{ Gabro-AASHTO T 283} \\
\hline & $V v(\%)$ & $G s(\%)$ & $M R_{1}(M P a)$ & $M R_{2}(M P a)$ & $M R R(M P a)$ \\
\hline 3 & 4,2 & 77 & 10.267 & 5.731 & 0,56 \\
\hline 4 & 4,2 & 71 & 11.274 & 6.441 & 0,57 \\
\hline 5 & 4,1 & 75 & 9.639 & 5.592 & 0,58 \\
\hline média & 4,2 & 77 & 10.393 & 5.921 & 0,57 \\
\hline desvio padrão & 0,06 & 3 & 825 & 455 & 0,01 \\
\hline \multirow[t]{2}{*}{ cp } & \multicolumn{5}{|c|}{ Basalto-ASTM4867 } \\
\hline & $V v(\%)$ & $G s(\%)$ & $M R_{1}(M P a)$ & $M R_{2}(M P a)$ & $M R R(M P a)$ \\
\hline 2 & 6,8 & 62 & 8.205 & 6.839 & 0,83 \\
\hline 3 & 6,2 & 59 & 6.482 & 5.304 & 0,82 \\
\hline 5 & 6,1 & 88 & 7.446 & 6.725 & 0,90 \\
\hline média & 6,4 & 70 & 7.378 & 6.289 & 0,85 \\
\hline desvio padrão & 0,38 & 16 & 864 & 855 & 0,04 \\
\hline \multirow[t]{2}{*}{ cp } & \multicolumn{5}{|c|}{ Basalto-AASHTO T 283} \\
\hline & $V v(\%)$ & $G s(\%)$ & $M R_{1}(M P a)$ & $M R_{2}(M P a)$ & $M R R(M P a)$ \\
\hline 3 & 6,0 & 71 & 6.358 & 3.995 & 0,63 \\
\hline 4 & 5,4 & 59 & 6.696 & 4.842 & 0,72 \\
\hline 6 & 5,8 & 59 & 6.068 & 5.299 & 0,87 \\
\hline média & 5,7 & 63 & 6.374 & 4.712 & 0,74 \\
\hline desvio padrão & 0,31 & 7 & 314 & 662 & 0,12 \\
\hline
\end{tabular}

Os resultados da sensibilidade à umidade obtidos com base na variação da resistência à tração (RTR) não foram concordantes com os resultados obtidos com base na variação do módulo de resiliência (MRR) das misturas, embora tal feito mereça destaque, não constitui surpresa, pois as propriedades de resistência à tração e de módulo de resiliência podem não ser igualmente sensíveis às mudanças de comportamento das misturas quando submetidas à ação da água.

Os valores dos módulos de resiliência, tanto das misturas ASTM D 4867 quanto das misturas AASHTO T 283, produzidas com agregado de gabro, foram estatisticamente iguais (Tabela 7.23). O mesmo pode-se afirmar quanto aos valores do módulo de resiliência obtidos para 
as misturas ASTM D 4867 e AASHTO T 283, produzidas com agregado de basalto. Esses resultados indicam que a aplicação de ambos os métodos levam a resultados semelhantes e, portanto, induzem às mesmas conclusões sobre a sensibilidade à umidade das misturas.

Vale notar também que as misturas não envelhecidas (ASTM) apresentaram-se tão rígidas quanto as misturas envelhecidas (AASHTO), ou seja, não foi detectada qualquer contribuição do período de envelhecimento ao qual as misturas AASHTO T 283 foram submetidas.

As Figuras 7.50 e 7.51 mostram, graficamente, os resultados dos módulos de resiliência obtidos para cada corpo-de-prova ensaiado, utilizando o método da ASTM D 4867 e o método da AASHTO T 283, respectivamente. Ao observar esses gráficos pode-se notar claramente que o ensaio de módulo de resiliência foi capaz de detectar as alterações mecânicas sofridas pelas misturas em razão do condicionamento ao qual foram expostas.

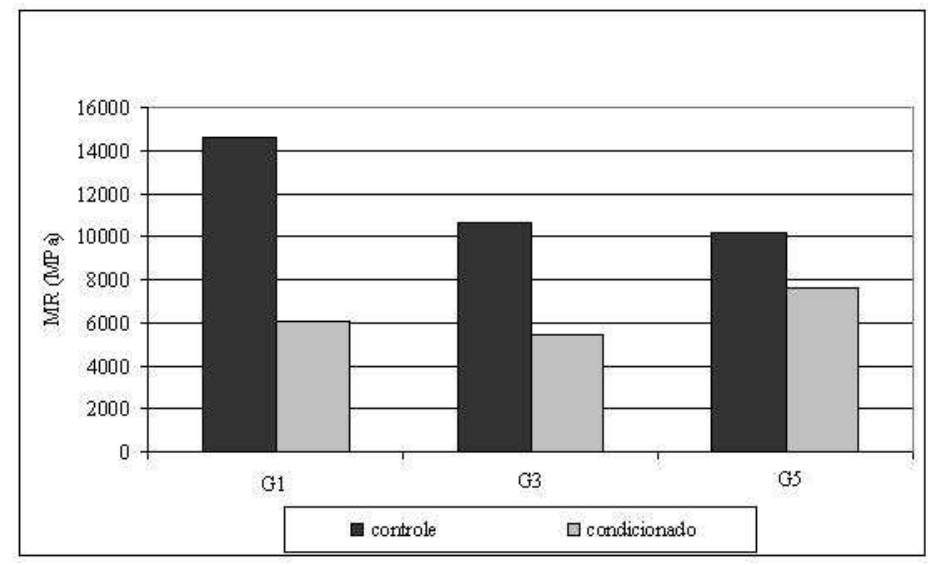

(a) Misturas realizadas com agregado de gabro

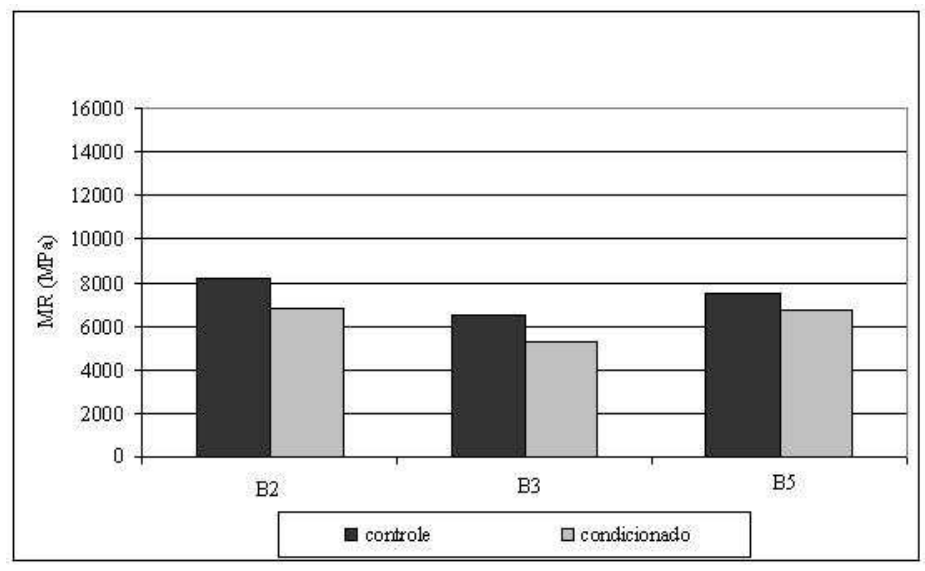

(b) Misturas realizadas com agregado de basalto

Figura 7.50: Misturas avaliadas pelo método da ASTM D 4867 


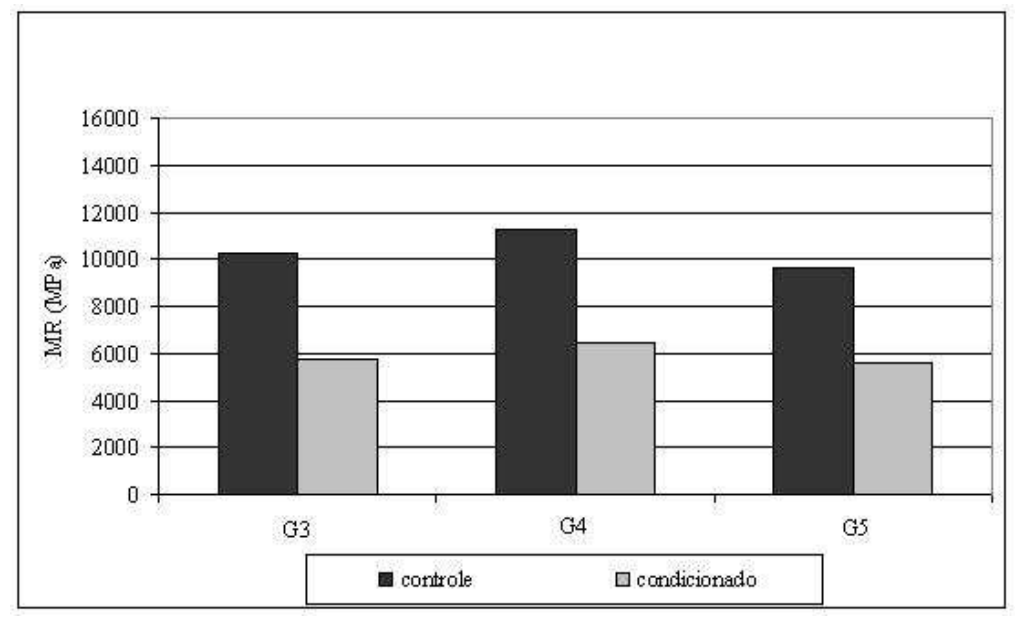

(a) Misturas realizadas com agregado de gabro

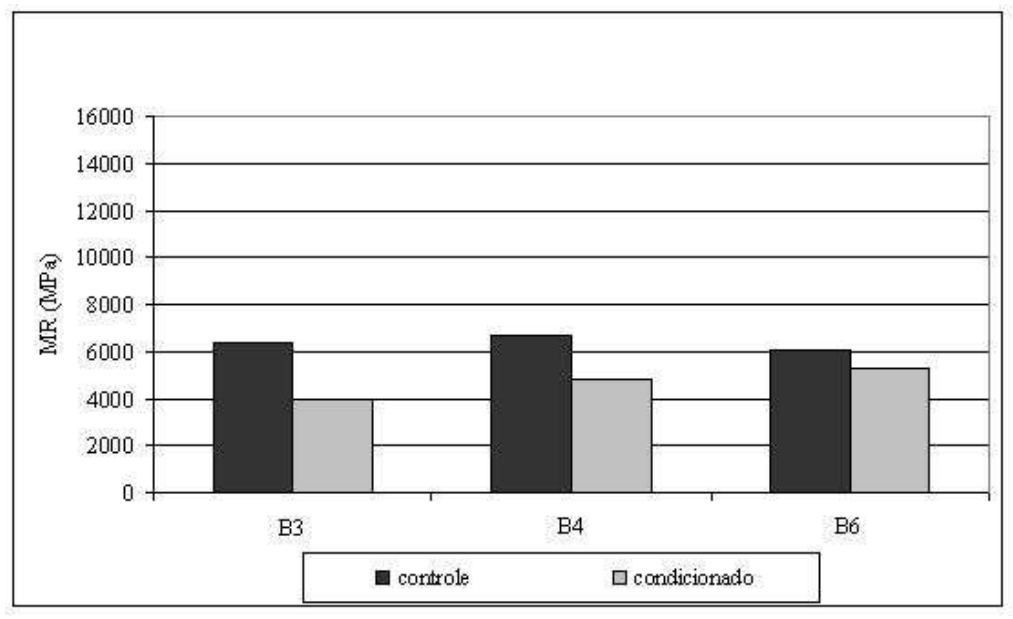

(b) Misturas realizadas com agregado de basalto

Figura 7.51: Misturas avaliadas pelo método da AASHTO T 283

Ainda que o método da AASHTO T 283 pareça mais severo que o método da ASTM D 4867 em termos de condicionamento, os resultados obtidos por ambos os métodos foram concordantes quanto ao grau de sensibilidade à umidade das misturas avaliadas. Em vista disso, o método da ASTM D 4867 pode ser uma opção boa para a avaliação dos efeitos da umidade em misturas asfálticas, por ser um método mais simples e rápido quando comparado ao método da AASHTO T 283.

Também a determinação do módulo de resiliência para avaliação das perdas de propriedade sofrida pela mistura após o condicionamento parece promissora, pois, além do ensaio de módulo de resiliência ser não destrutível, possibilitando que determinações sejam repetidas, ele mostra-se mais sensível às mudanças ocorridas nas misturas após serem submetidas à ação da água (Furlan, 2006). No entanto, deve-se ampliar as pesquisas nessa direção, com o intuito de averiguar se o limite de $30 \%$ é adequado para representar perdas de propriedade aceitáveis após o condicionamento da mistura à umidade. 


\subsubsection{Conclusões}

Com base nos experimentos laboratoriais apresentados, pode-se concluir que:

- Os resultados observados através da análise visual da adesividade do agregado grosso e do agregado fino ao asfalto indicam que os três agregados estudados (gabro, basalto e areia natural) possuem ligações adesivas asfalto/agregado insatisfatórias;

- Taxas de absorção de asfalto mais elevadas foram obtidas para as misturas destinadas à avaliação da sensibilidade à umidade pelo método da ASTM D 4867. As causas principais das variações da taxa de absorção de asfalto observadas são a temperatura e o tempo;

- Os resultados dos ensaios da ASTM D 4867 e da AASHTO T 283 indicam que as misturas produzidas com gabro são mais sensíveis à umidade, pois, após submetidas à ação da água passaram a apresentar valores de módulo de resiliência cerca de $40 \%$ mais baixos, quando comparadas às misturas produzidas com basalto, que apresentaram perdas aceitáveis, inferiores a $30 \%$;

- As misturas não envelhecidas (ASTM D 4867) apresentaram módulos de resiliência semelhantes aos módulos de resiliência das misturas envelhecidas (AASHTO T 283), indicando que aparentemente essas misturas não sofreram alterações devido ao período de envelhecimento ao qual foram submetidas;

- A maior severidade aparente do método da AASHTO T 283 em relação ao método da ASTM D 4867, em termos de condicionamento, não foi verificada;

- O método da ASTM D 4867 é uma opção boa para a avaliação dos efeitos da umidade em misturas asfálticas, pois, apesar de ser um método mais simples e mais rápido que método da AASHTO T 283, classifica semelhantemente as misturas quanto à sensibilidade à umidade;

- A determinação do módulo de resiliência para avaliação das perdas de propriedade sofrida pela mistura após o condicionamento parece promissora, pois, além do ensaio de módulo de resiliência não ser destrutível, possibilitando que determinações sejam repetidas, ele mostra-se mais sensível às mudanças ocorridas nas misturas após serem submetidas à ação da água. 

CAPÍTULO

\section{Conclusões e Sugestões para Estudos Futuros}

O comportamento e o desempenho das misturas asfálticas são afetados diretamente pelas características dos agregados utilizados em sua composição, levando-se em conta que 80 a $90 \%$ do volume total da mistura constitui-se de agregados. Então, poder-se-ia conceber que para ter um prognóstico aproximado do comportamento de novas misturas em campo bastaria conhecer as propriedades dos agregados. No entanto, essa aparente facilidade não se confirma na prática. Muitos laboratórios de pesquisa do mundo todo vêm tentando relacionar as propriedades dos agregados com o desempenho das misturas, mas, essa não é uma tarefa fácil, tendo em vista que uma única propriedade desse material pode influenciar propriedades fundamentais das misturas, culminando em alterações complexas do todo.

Desde o início desta pesquisa, a importância e a influência dos agregados nas características volumétricas e mecânicas das misturas asfálticas ficaram bastante claras. Já nos primeiros passos, durante as avaliações de uma mistura teste Superpave, que passava abaixo da linha de densidade máxima, evitando a zona de restrição, verificou-se que as misturas produzidas com os agregados de gabro e de basalto apresentavam Vv mais elevados que o esperado. Então, deu-se início a um processo de investigação de prováveis fatores que poderiam estar ocasionando esse problema.

Primeiramente, verificou-se a ocorrência de problemas com a temperatura de compactação da mistura, executando outros corpos-de-prova, com o mesmo teor de asfalto das misturas anteriormente executadas, porém, com temperatura de compactação mais elevada. Os 
corpos-de-prova foram compactados com temperatura de $160^{\circ} \mathrm{C}$, cerca de $14^{\circ} \mathrm{C}$ acima da temperatura utilizada na dosagem. No entanto, os valores do Vv continuaram elevados, indicando que as misturas não eram sensíveis a grandes variações da temperatura de compactação. Como possível explicação pode-se conceber que em razão da viscosidade baixa do asfalto, decorrente da temperatura de compactação alta, a capacidade de carga da mistura foi desempenhada principalmente pelo esqueleto estrutural formado pelo agregado. Então, possivelmente, devido à granulometria das misturas e às características de forma, angularidade e textura superficial dos agregados, formou-se um arranjo entre partículas tal que, independentemente da viscosidade do asfalto estar ou não mais baixa, ao receberem os golpes do soquete durante a compactação, as partículas se aproximaram uma das outras até um certo ponto e, depois, passaram a resistir aos golpes.

Também foram apontadas como possíveis causas do insucesso da mistura teste Superpave, a escolha incorreta da densidade do agregado, assim como a negligenciação da absorção de asfalto pelos agregados. Inicialmente, foram utilizadas a densidade real do agregado e a densidade máxima teórica (DMT) das misturas para o cálculo das propriedades volumétricas, assumindo, dessa maneira, que os agregados utilizados na pesquisa não absorviam asfalto. Tomada a decisão de realizar o ensaio de determinação da densidade máxima medida (DMM), detectou-se que os agregados absorviam asfalto e, portanto, apresentavam porosidade em suas partículas, o que na prática representa que há diferenças entre os valores das densidades aparente, efetiva e real dos agregados. Então, os parâmetros volumétricos das misturas foram recalculados, utilizando-se as densidades aparente e efetiva dos agregados e a DMM das misturas, sendo observada uma sensível diminuição nos valores do volume de vazios.

Esse pontapé inicial da pesquisa revelou que não seria possível desenvolver um estudo consistente sobre as misturas asfálticas à luz da influência dos agregados, sem o entendimento sobre o real significado de se utilizar uma ou outra densidade do agregado, sobre a absorção de asfalto e também sobre a granulometria das misturas. Além de ter ficado a lição de que todo agregado deve ser considerado como absorsor de asfalto até que se prove o contrário.

Então, uma investigação sobre a absorção foi direcionada em função do tempo e do teor de asfalto, com o objetivo de prever seu comportamento durante os processos de mistura e ao longo da vida em serviço do pavimento. Como função do tempo, observou-se que a absorção de curto prazo aumentava ao longo das horas de exposição das misturas à temperatura de compactação, de maneira mais acentuada nas primeiras duas a três horas, tendendo à estabilização. Como função do teor de asfalto, observou-se que, tanto as absorções de curto prazo como as de longo prazo, as misturas absorviam menos asfalto quando produzidas com teores de asfalto mais 
elevados, em outras palavras, observou-se que os agregados absorviam mais asfalto quando a espessura da película que os envolvia estava mais fina. Nesse ínterim, a hipótese levantada é a de que quando o teor de asfalto na mistura é menor, também é menor a espessura da película de asfalto que envolve a partícula, permitindo que o asfalto migre com mais facilidade ao interior dos poros devido à diminuição de sua tensão superficial.

Outro fato observado foi a proximidade entre os valores da absorção de curto e de longo prazos, indicativa de que, as misturas mesmo estando com temperaturas muito diferentes, ou melhor, mesmo o asfalto estando com viscosidades muito diferentes, as misturas com um mesmo teor de asfalto absorveram quantidades semelhantes de asfalto, porém, o tempo necessário para que a absorção se complete é diretamente proporcional à viscosidade. Como base nesse fato, uma outra hipótese seria a de que o limite da absorção de asfalto é função da saturação dos poros do agregado, independentemente de quanto tempo leve para isso.

Os testes realizados sobre o comportamento da absorção de longo prazo após 2 horas de cura vêm corroborar as duas hipóteses levantadas, pois, foram indicativos de que o agregado absorve asfalto durante as duas horas de permanência da mistura na temperatura de compactação, não absorvendo mais asfalto ao longo dos próximos seis meses (hipótese da saturação), além de terem apresentado valores muito próximos dos valores das absorções de longo prazo, para os três teores de asfalto estudados. Também na absorção de longo prazo após 2 horas de cura foi observado o mesmo padrão de comportamento da absorção de curto e de longo prazos em relação à espessura da película de asfalto, ou seja, quanto mais fina a película, maior a taxa de absorção (hipótese da espessura da película de asfalto). Essas observações podem substanciar ainda uma outra hipótese, a de que se as misturas forem submetidas a períodos de 2 horas de cura, estas deixarão de apresentar absorções de longo prazo, que são absorções muito difíceis de serem previamente diagnosticadas e que podem causar danos importantes ao pavimento.

O comportamento da absorção verificado através desta pesquisa tanto em função do tempo como do teor de asfalto são reveladores, porém, as hipóteses aqui levantadas foram concebidas com base em observações feitas por esta pesquisa, portanto, sugere-se que estudos de maior abrangência quanto a amostragem de agregados, além de estudos sobre a absorção à luz do comportamento do asfalto, sejam desenvolvidos, pois, através de olhares distintos sobre o mesmo foco, pode-se ampliar conceitualmente o entendimento do fenômeno da absorção.

A absorção de asfalto também foi estudada com vistas nas propriedades dos agregados de gabro e de basalto estudados, ou seja, em função do comportamento da absorção em tipos diferentes de agregados de mesma origem. Os resultados mostraram que quanto menor a 
densidade aparente entre agregados de mesma origem, maior é a absorção tanto de água como de asfalto, devido à maior porosidade total do agregado. Essa observação leva à conclusão de que a absorção, como função da densidade, está diretamente relacionada com a porcentagem de interstícios (poros) da massa cristalina das partículas. Com base nisso, fica fácil perceber que o cálculo correto das propriedades volumétricas depende da escolha correta das densidades dos agregados a serem utilizadas e também da quantidade de asfalto absorvido pelo agregado.

Tradicionalmente no Brasil, utiliza-se a densidade real do agregado e a DMT, que levam a erros apreciáveis no cálculo das propriedades volumétricas ao se deparar com agregados que absorvem asfalto. Nesta pesquisa, através de exemplos ilustrativos da magnitude dos erros cometidos no cálculo das propriedades volumétricas quando são utilizados métodos que usam equivocadamente densidades inadequadas do agregado, ficou claro que a utilização de uma determinada densidade pode vir a estabelecer a adequação ou não da mistura projetada às especificações requeridas em um método de dosagem. Em outras palavras, significa dizer que uma mistura pode ser aceita ou não dependendo da densidade do agregado empregada e da existência ou não de asfalto absorvido pelos agregados. Por conseguinte, fica a sugestão de que as propriedades volumétricas das misturas sejam sempre calculadas através de métodos que considerem a absorção de asfalto, como o Método Seguro e o Método do Diagrama de Componentes, pois não se pode considerar a priori que um agregado não absorve asfalto.

As propriedades volumétricas das misturas, além de serem sensíveis às densidades dos agregados e à taxa de absorção destes, são influenciadas diretamente pela granulometria, pelas características de superfície dos agregados, assim como pela energia de compactação aplicada. Nesta pesquisa procurou-se avaliar a granulometria sem confundí-la com os efeitos das diferentes características de superfície dos agregados. Para tanto, foram comparados VAMs de misturas com granulometrias idênticas, mas com agregados com características de superfície diferentes (forma, angularidade e textura superficial). Os resultados mostraram que agregados com diferentes características de forma e angularidade podem produzir misturas com valores muito diferentes de VAM, apesar de apresentarem mesma granulometria. Isso mostra que as características de forma, angularidade e textura superficial do agregado influenciam diretamente o arranjo entre partículas e, consequientemente, influenciam os valores do teor de asfalto e da espessura do filme de asfalto.

Os resultados desta pesquisa evidenciaram a importância de se conhecer o VAM como forma de analisar e prever a estruturação das partículas dos agregados. No entanto, atualmente, no momento da escolha do agregado ou dos agregados que serão utilizados no desenvolvimento de um projeto de mistura, suas características de superfície geralmente não são levadas em 
conta e, conseqüentemente, o VAM é obtido aleatoriamente. Também é comum, quando se faz necessário aumentar ou diminuir o VAM, simplesmente prescrever alterações na granulometria da mistura, mas, como visto neste trabalho, muitas vezes a granulometria não é a responsável principal pela obtenção de VAMs altos ou baixos, mas sim as características de forma, angularidade e textura superficial das partículas dos agregados. Além de que o ajuste granulométrico pode apresentar resultados confusos, pois, em alguns casos, o afastamento da curva granulométrica da linha de densidade máxima, com o objetivo de aumentar o VAM, pode provocar a sua diminuição. Em resumo, granulometria e propriedades de superfície das partículas não podem ser dissociadas quando se trata do VAM da mistura.

Atualmente nos Estados Unidos, uma das dificuldades encontradas com a implementação do Método Superpave de dosagem de misturas asfálticas tem sido alcançar os valores de VAM mínimos especificados, destacando-se a hipótese de que o problema está associado ao aumento do esforço de compactação provocado pelo compactador giratório Superpave. No entanto, as misturas estudadas nesta pesquisa apresentaram o problema inverso, ou seja, apresentaram VAMs altos e, conseqüentemente, RBV acima do valor limite de $75 \%$ especificado pelo Superpave. A primeira hipótese levantada foi que esse fato poderia estar relacionado à energia de compactação aplicada, de 75 golpes por face do corpo-de-prova, pois o $V v$, assim como o $V A M$ e o $R B V$, são dependentes do tipo e grau de compactação das misturas.

A limitação relativa à compactação Marshall, que impossibilita a diminuição do VAM de misturas que contenham agregados muito angulares e rugosos, difíceis de serem compactados, através de um maior esforço de compactação, poderia estar dissimulando as reais potencialidades mecânicas das misturas. Portanto, tomou-se a decisão de investigar mais detalhadamente a influência do grau de compactação nas propriedades volumétricas e mecânicas das misturas, variando-se gradativamente a energia de compactação de 75 golpes para 110 golpes e, então, para 155 golpes, aplicados pelo soquete Marshall.

Neste ínterim, os estudos foram desenvolvidos com base na hipótese de que as misturas produzidas com agregados angulares e rugosos (mais difíceis de serem compactados), poderiam ser mais compactadas para diminuir o VAM, de maneira a melhorar o arranjo estrutural formado entre suas partículas e, portanto, melhorar a estabilidade das misturas, sem no entanto, trazer qualquer tipo de prejuízo. Os resultados mostraram que realmente as características volumétricas das misturas são alteradas conforme a energia de compactação aplicada e, também, que as partículas angulosas e rugosas dos agregados de gabro e de basalto estudados arranjaram-se de maneira mais próxima com o aumento da energia de compactação aplicada. Por consequiência, houve a diminuição do VAM, elevação da estabilidade e rigidez das misturas, sem causar 
prejuízos à vida de fadiga, pelo contrário, houve ganho de vida de fadiga ao aumentar a energia de compactação de 75 para 110 golpes por face do corpo-de-prova. Portanto, a hipótese de aumentar a energia de compactação aplicada à misturas produzidas com agregados angulosos e rugosos e que tenham resistência adequada parece promissora, porém, estudos de maior abrangência em relação à amostragem de agregados, além de análises de desempenho das misturas em campo devem ser realizados.

Os resultados deste estudo também permitiram constatar que, de uma maneira geral, o agregado de gabro estudado apresentou superioridade em relação ao agregado de basalto e de areia natural, quando analisado sozinho e também quando analisado como parte integrante das misturas asfálticas. Suas características de forma, angularidade e textura superficial permitiram arranjos entre partículas adequados, formando esqueletos estruturais resistentes à deformação permanente e também à fadiga. Também as análises das misturas à luz da granulometria mostram que, de uma maneira geral, a granulometria AZR produziu misturas mais estáveis, mais resistentes à deformação permanente e à fadiga. Os resultados evidenciaram também que alterações granulométricas modificam o arranjo entre partículas e alteram o espaço existente no esqueleto estrutural formado.

Outra etapa deste trabalho foi a de caracterizar os agregados através das propriedades de consenso e de origem especificadas pelo Superpave, com o objetivo de não somente realizar ensaios para obtenção de resultados, mas também realizar uma análise crítica sobre os critérios estabelecidos pelo SHRP para selecionar, avaliar e estabelecer limites para essas propriedades. Através da experiência adquirida durante a utilização desses ensaios com agregados brasileiros, muitas observações e conclusões puderam ser feitas, dentre elas, observou-se que alguns dos ensaios selecionados para avaliar determinadas propriedades não foram adequados, como é o caso do ensaio de porcentagens de faces fraturadas (ASTM D 5821), adotado pelo Superpave para avaliação da angularidade do agregado grosso, por determinar apenas o número de faces fraturadas da partícula, não fazendo menção à angularidade. Outros ensaios também se mostraram inadequados, ora por não avaliarem satisfatoriamente determinada propriedade, ora por apresentarem metodologia imprópria para o objetivo ao qual se propõem, como é o caso do ensaio de análise de materiais deletérios (ASTM C 142).

Resumidamente, as deficiências dos ensaios que mais chamaram à atenção foram:

- A incapacidade do ensaio de angularidade do agregado fino (ASTM C 1252) de diferenciar agregados com formas mais apropriadas daqueles com formas menos apropriadas ao 
propósito da pavimentação, podendo induzir a escolha de agregados com formas menos favoráveis por apresentarem valores de AAF mais elevados.

- O ensaio de determinação da forma das partículas de agregados grossos (ASTM D 4791), se realizado utilizando razão dimensional de $5: 1$, como especifica o Superpave, torna-se insensível para indicar mudanças de forma do agregado, dificultando a percepção das reais características de forma das partículas, ao passo que a razão dimensional de $3: 1$ ressalta essas diferenças. Também é questionável a classificação das formas das partículas através da avaliação de sua máxima dimensão (comprimento) e mínima dimensão (espessura), como especificado pelo Superpave, pois não representa o quanto as partículas são planas nem o quanto são alongadas. Classificar as partículas através de formas definidas (planas, alongadas) torna possível uma compreensão melhor de suas características de forma, permitindo julgar mais realisticamente a possibilidade de quebras dessas partículas durante a compactação da mistura ou durante a vida em serviço do pavimento. Portanto, com vistas ao desenvolvimento de novas pesquisas sobre esse assunto, visando estabelecer um limite máximo realístico de partículas planas e alongadas que podem ser utilizadas sem causar riscos ao pavimento, fica a sugestão de classificação das formas das partículas através de formas definidas, assim como a sugestão de utilização da razão dimensional de $3: 1$.

- Apesar do ensaio de equivalente de areia (DNER ME 054) ser rápido e prático, portanto, ideal para ser utilizado no campo, ele não permite a determinação exata da composição dos finos plásticos ou da fração argilosa, levando a dúvidas quanto à presença ou não de argilominerais no agregado.

- O procedimento adotado pelo Superpave para análise de materiais deletérios (ASTM C 142) mostrou-se inadequado ao objetivo ao qual se propõe, pois, da maneira como foi concebido, apenas partículas deletérias frágeis, que podem ser quebradas com a pressão dos dedos, são consideradas friáveis, não sendo computadas como deletérias aquelas partículas duras e/ou resistentes não constituídas por material rochoso. Outros problemas quanto a esse ensaio puderam ser detectados, dentre eles, a apresentação dos resultados como porcentagem de massa e sua subjetividade.

Os especialistas do SHRP identificaram propriedades dos agregados importantes para a pavimentação, no entanto, várias dessas propriedades não puderam ser adequadamente avaliadas através dos métodos de análise selecionados. Provavelmente, parte do fracasso na seleção dos ensaios se deve ao critério de escolha, que limitou as opções possíveis apenas entre os ensaios comumente usados pelas agências rodoviárias estadunidenses, desconsiderando ensaios 
utilizados em outros países e já consagrados por produzirem bons resultados. Vale lembrar também que propriedades de extrema importância para o bom desempenho dos pavimentos não foram consideradas pelo Superpave, dentre elas, forma e textura superficial do agregado grosso, densidades, porosidade e absorção. No entanto, visto que toda a especificação Superpave para agregados foi baseada apenas na opinião de 14 especialistas, esse malogro já deveria ser esperado.

Contudo, apesar das propriedades selecionadas pelos especialistas do SHRP serem de extrema importância, os métodos utilizados para avaliá-las assim como os valores limites estipulados devem ser considerados com ressalvas, visto que ainda há muito a ser estudado e compreendido a respeito dos agregados e também a respeito de sua interação com as propriedadas das misturas.

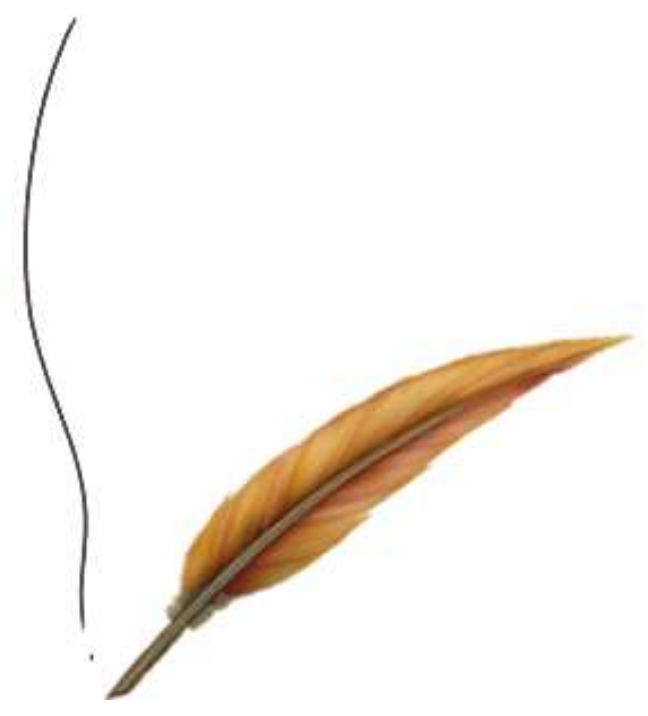




\section{Referências Bibliográficas}

AASHTO M 323 (2005). Standard Practice for Superpave Volumetric Mix Design. American Association of State Highway and Transportation Officials.

AASHTO PP2 (1990). Standard Practice for Mixture Conditioning of Hot Mix Asphalt. American Association of State Highway and Transportation Officials.

AASHTO T 166 (1990). Bulk Specific Gravity of Compacted Bituminous Mixtures using Saturated Surface-Dry Specimens. American Association of State Highway and Transportation Officials.

AASHTO T 19 (1997). Standard Practice for Unit Weight and Voids in Aggregate. American Association of State Highway and Transportation Officials.

AASHTO T 283 (1989). Standard Practice for Resistence of Compacted Bituminous Mixture to Moisture Induced Damage. American Association of State Highway and Transportation Officials.

AASHTO TP31 (1994). Standard test method for determining the resilient modulus of betuminous mixtures by indirect tension. American Association of State Highway and Transportation Officials.

Anderson, R. M.; Bahia, H. U. (1997). Evaluation and selection of aggregate gradations for asphalt mixtures using Superpave. Transportation Research Record, n. 1583, p. 91 - 97.

ASTM C 1252 (1993). Standard Test Methods for Uncompacted Void Content of Fine Aggregate (as Influenced by Particle Shape, Surface Texture, and Grading). American Society for Testing and Materials, Philadelphia.

ASTM C 127 (1993). Standard Test Methods for specific gravity and absorption of coarse aggregate. American Society for Testing and Materials, Philadelphia. 
ASTM C 128 (1993). Standard Test Methods for specific gravity and absorption of fine aggregate. American Society for Testing and Materials, Philadelphia.

ASTM C 131 (1996). Standard Test Methods for Resistance to Degradation of Small-Size Coarse Aggregate by Abrasion and Impact in the Los Angeles Machine. American Society for Testing and Materials, Philadelphia.

ASTM C 142 (1978). Standard Test Methods for Clay Lumps and Friable Particles in Aggregates. American Society for Testing and Materials, Philadelphia.

ASTM C 29 (1997). Standard Test Methods for Unit Weight and Voids in Aggregate. American Society for Testing and Materials, Philadelphia.

ASTM C 88 (1990). Standard Test Methods for Soundness of Aggregates by Use of Sodium Sulfate or Magnesium Sulfate. American Society for Testing and Materials, Philadelphia.

ASTM D 2041 (1995). Standard Test Methods for Theoretical Maximum Specific Gravity and Density of Betuminous Paving Mixtures. American Society for Testing and Materials, Philadelphia.

ASTM D 2419 (1995). Standard Test Methods for Sand Equivalent Value of Soils and Fine Aggregate. American Society for Testing and Materials, Philadelphia.

ASTM D 4791 (1995). Standard Test Methods for Flat Particles, Elongated Particles, or Flat and Elongated Particles in Coarse Aggregate. American Society for Testing and Materials, Philadelphia.

ASTM D 4867 (1988). Standard Test Methods for Effect of Moisture on Asphalt Concrete Paving Mixtures. American Society for Testing and Materials, Philadelphia.

ASTM D 5821 (1995). Standard Test Methods for Determining the Percentage of Fractured Particles in Coarse Aggregate. American Society for Testing and Materials, Philadelphia.

Bellis, M. (2004a). Asphalt Origins. http://inventors.about.com/library/inventors/blcar3.htm.

Bellis, M. (2004b). The History of Roads and Asphalt. http://inventors.about.comlibraryinventorsblasphalt.htm.

Bowman, E. T.; Soga, K.; Drummond, T. W. (2000). Particle shape characterisation using Fourier analysis. Cambridge University, Engineering Department. http://www-civ.eng.cam.ac.uk/geotech_new/.

Bueno, B. S.; Vilar, M. (1985). Mecânica dos Solos, v. II. Escola de Engenharia de São Carlos - Universidade de São Paulo, São Carlos. 
Button, J. W.; Perdomo, D.; Lytton, R. L. (1990). Influence of aggregate on rutting of asphalt concrete pavements. Transportation Research Record, n. 1259, p. 141 - 152.

Campen, W. H. (1940). The development of a maximum density curve and its apllication to the grading of aggregates for bituminous mixtures. Proceedings of The Association of Asphalt Paving Technologists, v.11, p.302-314.

Castro Neto, A. M. (1996). Determinação da densidade máxima teórica de misturas betuminosas. $30^{a}$ Reunião Anual de Pavimentação, v. 1, p. 35 - 60, Salvador - Bahia.

CEPA (2006). Rodovia. Centro de Ensino e Pesquisa Aplicada da USP. http://cepa.if.usp.br.

Chadbourn, B. A.; Skok Jr., E. L.; Crow, B. L.; Spindler, S. (2000). The effect of voids in mineral aggregate (vma) on hot-mix asphalt pavements. Relatório técnico, National Asphalt Pavement Association.

Chowdhury, A.; Graw, J. C.; Button, J. W.; Little, D. N. (2001). Effect of aggregate gradation on permanent deformation of Superpave hma. Transportation Research Board.

Cominsky, R. J.; Killingsworth, B. M.; Anderson, R. M.; Anderson, D. A.; Crockford, W. W. (1998). Quality control and acceptance of Superpave-designed hot mix asphalt. National Cooperative Highway Research Program, n. 409, p. 1 - 26.

Cominsky, R. R.; Leahy, R. B.; Harrigan, E. G. (1994). Level one mix design: Materials selection, compaction, and conditioning. Relatório Técnico SHRP-A-408, Strategic Highway Research Program (SHRP).

Coree, B. J. (1999). Hot-mix asphalt volumetrics revisited. Transportation Research Record, n. 1681 , p. $50-58$.

Coree, B. J.; Hislop, W. P. (1998). The difficult nature of minimum vma: A historical perspective. Transportation Research Record.

Costa, P.; Figueiredo, W. C. (2001). Estradas - Estudos e Projetos. Edufba, Bahia.

Cross, S. A.; Brown, E. R. (1992). Selection of aggregate properties to minimize rutting of heavy duty pavements. Meininger, R. C., editor, Effects of Aggregates and Mineral Fillers on Asphalt Mixture Performance. American Society for Testing and Materials, Philadelphia.

Cunha, M. B. (2004). Avaliação do método bailey de seleção granulométrica de agregados para misturas asfálticas. Dissertação (Mestrado), Escola de Engenharia de São Carlos Universidade de São Paulo. 
De Hilster, E.; Van De Loo, P. J. (1977). The creep test: Influence of test parameters. Relatório técnico, Koninklijke e Shell-Laboratorium, Amsterdam.

DNER ME 035 (1998). Agregados - determinação da abrasão Los Angeles. Departamento Nacional de Estradas de Rodagem, Rio de Janeiro.

DNER ME 054 (1997). Equivalente de Areia. Departamento Nacional de Estradas de Rodagem, Rio de Janeiro.

DNER ME 078 (1994). Agregado graúdo - adesividade a ligante betuminoso. Departamento Nacional de Estradas de Rodagem, Rio de Janeiro.

DNER ME 079 (1994). Agregado - adesividade a ligante betuminoso. Departamento Nacional de Estradas de Rodagem, Rio de Janeiro.

DNER ME 089 (1994). Agregados - Avaliação da durabilidade pelo emprego de soluções de sulfato de sódio ou de magnésio. Departamento Nacional de Estradas de Rodagem, Rio de Janeiro.

DNER ME 138 (1994). Misturas Betuminosas - Determinação da Resistência à Tração por compressão Diametral. Departamento Nacional de Estradas de Rodagem, Rio de Janeiro.

DNIT 0312004 - ES (2004). Pavimentos flexíveis - Concreto asfáltico - Especificação de serviço. Departamento Nacional de Infra-estrutura de Transportes, Rio de Janeiro.

Fernandes, J. L.; Roque, R.; Tia, M.; Casanova, L. (2000). Evaluation of uncompacted void content of fine aggregate as a quality indicator of materials used in Superpave mixtures. Transportation Research Board.

Ferreira, A. B. H. (1999). Século XXI - O Dicionário da Língua Portuguesa. Rio de Janeiro, 3 edição.

Field, F. (1978). Voids in the mineral aggregate: Test methods and specification criteria. Canadian Technical Asphalt Association, v. 23.

Furlan, A. P. (2006). Considerações acerca da adesão e da suscetibilidade à umidade de misturas asfálticas densas à luz de algumas propriedades mecânicas. Tese (Doutorado), Escola de Engenharia de São Carlos - Universidade de São Paulo.

Furlan, A. P.; Gouveia, L. T.; Fabbri, G. T. P.; Jr., J. L. F. (2004). Influência de características dos agregados na susceptibilidade a dano por umidade de misturas asfálticas. $17^{\circ}$ Encontro de Asfalto - Instituto Brasileiro de Petróleo e Gás, Rio de Janeiro - Rio de Janeiro. 
Galvão, O. J. A. (2006). Desenvolvimento dos Transportes e Integração Regional no Brasil Uma Perspectiva Histórica. Disponível em: http://ipea.gov.br/pub/ppp/ppp13/galvao.pdf.

Goode, J. F.; Lufsey, L. A. (1962). A new graphical chart for evaluating aggregate gradations. Proceedings of The Association of Asphalt Paving Technologists, v.31, p.176 - 207.

Gouveia, L. T. (2002). Avaliação do ensaio de angularidade do agregado fino (faa) da especificação Superpave. Dissertação (Mestrado), Universidade de São Paulo - Escola de Engenharia de São Carlos, São Carlos.

Gouveia, L. T.; Furlan, A. P.; Parreira, A. B.; Fernandes Jr., J. L.; Fabbri, G. T. P. (2004). Considerações acerca da absorção de asfalto pelos agregados e sua influência na suscetibilidade à umidade. XVIII ANPET - Congresso de Pesquisa e Ensino em Transportes, Florianópolis - Santa Catarina.

Greco, J. A. S. (2004). Avaliação da influência de alguns fatores nas propriedades mecânicas de misturas asfálticas densas, à luz da técnica de planejamento e análise de experimentos fatoriais fracionários assimétricos. Tese (Doutorado), Escola de Engenharia de São Carlos Universidade de São Paulo.

Hand, A. J.; Epps, A. L. (2000). Effects of test variability on mixture volumetrics and mix design verification. Association of Asphalt Pavement Technologists, v.69, p.635 - 674 .

Hand, A. J.; Epps, A. L. (2001). Impact of gradation relative to the Superpave restricted zone on hma performance. Transportation Research Board.

Hand, A. J.; Stiady, J. L.; White, T. D.; Noureldin, A. S.; Galal, K. (2001). Gradation effects on hot-mix asphalt performance. Transportation Research Board, n. 1767, p. 152 - 157.

Herodoto (424a). História - O Relato Clássico da Guerra Entre Gregos e Persas.

Hinrichsen, J. A.; Heggen, J. (1996). Minimum voids in mineral aggregate in hot-mix asphalt based on gradation and volumetric properties. Transportation Research Record, n. 1545, p. $75-79$.

Hoffman, P. (2004). Asas da Loucura. Objetiva.

Horan, R. D. (2001). Asphalt Mix Curing at the Design Lab and at the Field Lab. Disponível em: http://asphaltinstitute.orguploadAsphalt_Mix_Curing.pdf.

Hubbard, P.; Field, F. C. (1932). Adaptation of the stability test to include coarse aggregate asphalt paving mixtures. Proceedings, Association of Asphalt Paving Technologists, p. 109 114. 
Huber, G. A.; Shuler, T. S. (1992). Providing sufficient void space for asphalt cement: Relationship of mineral aggregate voids and aggregate gradation. Meininger, R. C., editor, Effects of Aggregates and Mineral Fillers on Asphalt Mixture Performance, n. 1147, p. 225 251. American Society for Testing and Materials, Philadelphia.

Hudson, S. B.; Davis, R. L. (1965). Relationship of aggregate voidage to gradation. Association of Asphalt Paving Technologists, v.34.

Hveem, F. N. (1942). Use of centrifuge kerosene equivalent as applied to determine the requerid oil content for dense graded bituminous mixtures. Association of Asphalt Paving Technologists, v.13, p.9-40.

Hveem, F. N. (1953). Sand equivalent test for control of materials during construction. Highway Research Board, v.32, p.238 - 250.

Kandhal, P. S.; Cooley Jr., L. A. (2001). The restricted zone in the Superpave aggregate gradation specification. National Cooperative Highway Research Program, n. 464.

Kandhal, P. S.; Cooley Jr., L. A. (2002). Coarse versus fine-graded Superpave mixtures: Comparative evaluation of resistance to rutting. Transportation Research Board.

Kandhal, P. S.; Foo, K. Y.; Mallick, R. B. (1998). Critical review of voids in mineral aggregate requirements in Superpave. Transportation Research Record, n. 1609, p. 21 - 27.

Kandhal, P. S.; Khatri, M. A. (1991). Evaluation of asphalt absorption by mineral aggregates. Relatório Técnico 91 - 4, National Center for Asphalt Technology.

Kandhal, P. S.; Khatri, M. A. (1992). Relating asphalt absorption to properties of asphalt cement and aggregates. Relatório Técnico 92 - 2, National Center of Asphalt Technology.

Kandhal, P. S.; Lee, D. (1972). Asphalt absorption as related to pore characteristics of aggregates. Highway Research Record, n. 404.

Kandhal, P. S.; Parker Jr., F. (1998). Aggregate tests related to asphalt concrete performance in pavements. National Cooperative Highway Research Program, n. 405.

Kaszynski, W. (2000). The American Highway: The History and Culture of Roads in the United States. McFarland \& Company.

Keller, W. (2002). E a Bíblia tinha Razão. Editora Melhoramentos Ltda., 25 edição.

Kennedy, T. W.; Huber, G. A.; Harrigan, E. T.; Cominsky, R. J.; Von Quintas, H.; Moulthrop, J. S. (1994). Summary report on permanent deformation in asphalt concrete. Relatório Técnico SHRP-A-410, Strategic Highway Research Program (SHRP). 
Kim, Y. R.; Kim, N.; Khosla, N. P. (1992). Effects of aggregate type and gradation on fatigue and permanent deformation of asphalt concrete. Meininger, R. C., editor, Effects of Aggregates and Mineral Fillers on Asphalt Mixture Performance. American Society for Testing and Materials, Philadelphia.

Lee, D. Y. (1969). The relationship between physical and chemical properties of aggregates and their asphalt absorption. Association of Asphalt Paving Technologists, v.38, p.242 - 275.

Lee, D. Y.; Guinn, J. A.; Kandhal, P. S.; Dunning, R. L. (1990). Absorption of asphalt into porous aggregates. Relatório Técnico UIR-90-009, Strategic Highway Research Program (SHRP).

Lefebvre, J. (1957). Recent investigations of the design of asphalt paving mixtures. Association of Asphalt Paving Technologists, v.26.

Lettier, J. A.; Fink, D. F.; Wilson, N. B.; Farley, F. F. (1949). Mechanism of absorption of bituminous materials by aggregate. Association of Asphalt Pavement Technologists, v.18, p. $278-300$.

Magalhães, S. T. (2004). Misturas asfálticas de módulo elevado para pavimentos de alto desempenho. Dissertação (Mestrado), COPPE - Universidade Federal do Rio de Janeiro.

Mallick, R. B.; Buchanan, S.; Brown, E. R.; Huner, M. (1998). An evaluation of Superpave gyratory compaction of hot mix asphalt (hma). Transportation Research Board, n. 1638, p. $111-119$.

Maupin, G. W. (1970). Effect of particle shape and surface texture on the fatigue behavior of asfhaltic concrete. Highway Research Record, n. 313, p. 55 - 62.

McGennis, R. B. (1997). Evaluation of materials from northeast texas using Superpave mix design technology. Transportation Research Board, n. 1583, p. 98 - 105.

McLeod, N. W. (1956). Relationships between density, betumen content, and voids properties of compacted bituminous paving mixtures. Highway Research Board, v.35, p.327 - 404.

McLeod, N. W. (1957). Selecting the aggregate specific gravity for bituminous paving mixtures. Highway Research Board, v.36, p.281 - 317.

McLeod, N. W. (1987). Design of dense graded asphalt concrete pavements. Proceedings of The Association of Asphalt Paving Technologists, v.32, p.352 - 404.

Medina, J. (1962). O ensaio do equivalente de areia. Relatório Técnico 07, Instituto de Pesquisas Rodoviárias. 
Medina, J. (1997). Mecânica dos Pavimentos. UFRJ.

Monismith, C. L. (1958). Flexibility caracteristics of asphalt paving mixtures. Proceedings of The Association of Asphalt Paving Technologists, v.27, p.302 - 314.

Motta, L. M. G.; Leite, L. M. F. (2002). Desempenho de trechos de pavimentos acompanhados nos últimos 10 anos. $16^{\circ}$ Encontro de Asfalto - Instituto Brasileiro de Petróleo e Gás, Rio de Janeiro.

Motta, L. M. G.; Pinto, S. (1994). O uso de ensaios estáticos na definição de parâmetros de comportamento de misturas asfálticas. $12^{\circ}$ Encontro de Asfalto - Instituto Brasileiro de Petróleo e Gás, p. 152 - 178, Rio de Janeiro.

Motta, L. M. G.; Tonial, I.; Leite, L. M.; Constantino, R. S.; Bukowski, J. R.; McGennis, R. B.; Anderson, M.; Kennedy, T. W.; Solaimanian, M. (1994). Princípios do Projeto e Análise Superpave de Misturas Asfálticas. Instituto Brasileiro de Petróleo, Rio de Janeiro.

NBR 12891 (1993). Dosagem de Misturas Betuminosas pelo Método Marshall. Associação Brasileira de Normas Técnicas, Rio de Janeiro.

Parker Jr., F.; Brown, E. R. (1992). Effects of aggregate properties on flexible pavement rutting in alabama. Meininger, R. C., editor, Effects of Aggregates and Mineral Fillers on Asphalt Mixture Performance, n. 1147, p. 68 - 89. American Society for Testing and Materials, Philadelphia.

Pinto, S. (1991). Estudo do comportamento à fadiga de misturas betuminosas e aplicação na avaliação estrutural de pavimentos. Tese (Doutorado), COPPE - Universidade Federal do Rio de Janeiro.

Prowell, B. D.; Zhang, J.; Brown, E. R. (2005). Aggregate properties and performance of Superpave-designed hot mix asphalt. National Cooperative Highway Research Program, n. 539.

Rice, J. M. (1953). New test method for direct measurement of maximum density of bituminous mixtures. Crushed Stone Journal.

Richardson, C. (1905). The Modern Asphalt Pavement. John Wiley \& Sons, 1 edição.

Roberts, F. L.; Kandhal, P. S.; Brown, E. R.; Lee, D. Y.; Kennedy, T. W. (1991). Hot mix asphalt materials, mixture design, and construction. NAPA Education Foundation, Maryland, primeira edição. 
Santos, C. R. G. (2004). Avaliação das influências do tipo de ligante e do volume de vazios na vida de fadiga de algumas misturas asfálticas. Dissertação (Mestrado), Escola de Engenharia de São Carlos - Universidade de São Paulo.

Schefler, W. C. (1988). Statistics: Concepts and Applications. The Benjamin/Cummings Publishing Company.

Schmidt, R. J. (1972). A pratical method for measuring resilient modulus of asphalt-treated mixes. Highway Research Record, n. 404.

Scientific American (2004). Petróleo. N. Edição Especial 3.

Sebaaly, E. P.; Ridolfi, D.; Gangavaram, R. S.; Epps, J. A. (1997). Selection of the most desirable hma mixture. Transportation Research Record, n. 1590, p. 99 - 107.

Smith, D. E. (1992). Use of a modified delphi method to develop specifications for aggregates and asphalt-aggregate mixtures for the strategic highway research program. Strategic Highway Research Program.

Souza, J. B.; Crausss, J.; Monismith, C. L. (1991). Summary report on permanent deformation in asphalt concrete. Relatório Técnico SHRP-A/IR-91-104, Strategic Highway Research Program (SHRP).

Suguio, K. (1973). Introdução à Sedimentologia. Edgard Blucher Ltda. / Universidade de São Paulo, São Paulo.

Tayebali, A. A.; Malpass, G. A.; Khosla, N. P. (1998). Effect of mineral filler type and amount on design and performance of asphalt concrete mixtures. Transportation Research Record, n. 1609 , p. $36-43$.

Vasconcelos, K. L.; Soares, J. B.; Leite, L. M. (2003). Influência da densidade máxima teórica na dosagem de misturas asfálticas. Congresso de Pesquisa e Ensino em Transportes - XVII ANPET, v. 1, p. 5 - 17, Rio de Janeiro - Brasil.

Vavrik, W. R.; Huber, G.; Pine, W. J.; Carpenter, S. H.; Bailey, R. (2002). Bailey method for gradation selection in hot-mix asphalt mixture design. Transportation Research Circular, n. E-C044.

Vavrik, W. R.; Pine, J.; Huber, G.; Carpenter, S. H.; Bailey, R. (2001). The bailey method of gradation evaluation: The influence of aggregates gradation and packing characteristics on voids in the mineral aggregate. Association of Asphalt Pavement Technologists, v.70, p.132 175. 
Watson, D. E.; Johnson, A.; Jared, D. (1997). The Superpave gradation restricted zone and performance testing with the georgia loaded wheel tester. Transportation Research Record, n. 1583 , p. $106-111$.

Wu, Y.; Parker Jr., F.; Kandhal, P. S. (1998). Aggregate toughness/abrasion resistance and durability/soundness tests related to asphalt concrete performance in pavements. Transportation Research Record, n. 1638, p. 85 - 93. 


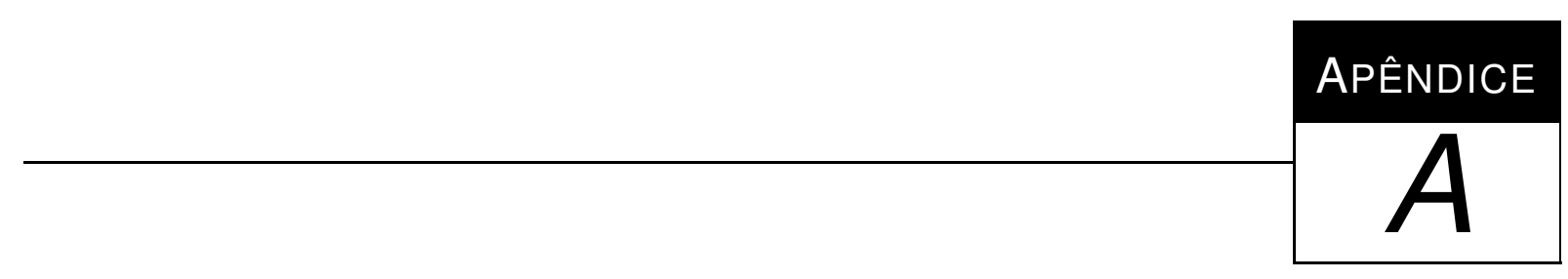

Análise Petrográfica 


\section{Unesp 唼 UNIVERSIDADE ESTADUAL PAULISTA}

Câmpus de Rio Claro

Instituto de Geociências e Ciências Exatas

Departamento de Petrologia e Metalogenia

\section{ANÁLISE PETROGRÁFICA}

Interessado: José Eduardo Rodrigues

Material: Amostra de Leucodiabásio ou Leucogabro

Data de entrada: 18/09/03

Data saída: 10/10/03

\section{Descrição Macroscópica}

- Classificação Petrográfica: Leucodiabásio (ou leucogabro) Médio

Obs.: consideraria como leucodiabásio por representar porções internas de sill ou soleira.

Rocha de coloração cinza esbranquiçada com estrutura isotrópica, maciça e compacta. Apresenta textura fanerítica intergranular de granulação média, pouco inequigranular, com granulação predominante entre 2,0 e 4,0 mm e caracterizada pela presença de cristais de piroxênios prismáticos longos (praticamente aciculares) que podem atingir dimensões de até $1,5 \mathrm{x}$ $1,5 \times 25,0 \mathrm{~mm}$.

\section{Descrição Microscópica}

\section{Lâmina 1 - Leucodiabásio}

\section{Composição Mincralógica}

(\% modal)

Plagioclásio (andesina básica a labradorita ácida) ................. 65,0

Clinopiroxênios (augita e alguma pigeonita) ........................ 26,0

Opacos (magnetita/titano-magnetita) ………....................... 3,0

Feldispatos AicalinosiQuartzo ............................................ 1,0

Apatita ….............................................................. $\mathrm{Tr}$

Minerais Secundários: . ....................................................... 5,0

- Clorofeíta

- Sericita

- Óxidos/hidróxidos de Ferro (responsáveis pela pigmentação do material pulverulento)

- Argilo-minerais (celadonita ?/nontronita)

- Epidoto

- Anfibólios fibrosos

- Carbonatos

Estrutura: Compacta, isotrópica. 


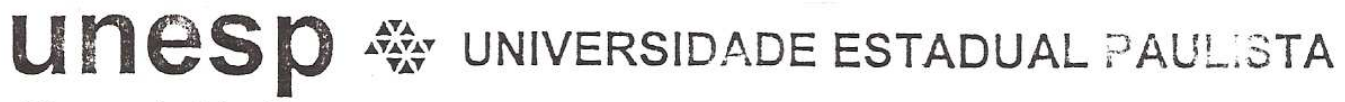 \\ Câmpus de Rio Claro \\ Instituto de Geociências e Ciências Exatas \\ Departamento de Petrologia e Metalogenia}

Textura: Microscopicamente cxibe textura fanerítica fina a fina/média, hipidiomórfica, com a presença de esparsos núcleos intergranulares a localmente sub-ofíticos. A granulação oscila entre 0,5 a $1,5 \mathrm{~mm}$, sendo que a augita corresponde, localmente, aos cristais com as maiores dimensões. Intersticialmente pode conter minúsculas manchas irregulares, submilimétricas, compostas por intercrescimentos entre feldspato potássico e quartzo com discreta textura granofírica. A lâmina caracteriza-se por generalizado aspecto de sujeira dado por material pulverulento (argilo-minerais e óxidos/hidróxidos de ferro) disseminado sobre plagioclásios e piroxênios).

Transformações minerais: de origem hidrotermal, provavelmente ocorrido em estado subsólidus, e responsável pela formação de agregados submilimétricos a milimétricos de clorofeíta, localmente de nontronita, e do material de aspecto pulverulento (filossilicatos, epidotos, anfibólios fibrosos, argilo-minerais, óxidos e hidróxidos de ferro) principalmente disseminados sobre cristais de augita e ao longo de microfissuras, planos de clivagens e interfácies minerais.

\section{Descrição dos Minerais:}

Plagioclásio: Labradorita ácida a andesina básica, e constituem cristais ripiformes a prismáticos subedrais com dimensões oscilando basicamente entre $0,25 \mathrm{~mm}$ e cerca de 1,0 $\mathrm{mm}$ ao longo do seu maior eixo, com ampla predominância de cristais submilimétricos. Apresenta zoneamento composicional, característica geminação Carlsbad e polissintética e mostram-se afetados por discreta alteração de aspecto pulverulento dada principalmente por massa sericítica, alguma argilomineralização, raros carbonatos, pigmentada por óxidos c hidróxidos de ferro. São freqüentes inclusões de minúsculas agulhas de apatita.

Clinopiroxênios: Augita, e mais raramente pıgeonita. A augita ocorre tanto em posições intersticiais (caracterizando a textura intergranular), com dimensões submilimétricas, quanto constituindo cristais anedrais isolados com dimensões de até $1,5 \mathrm{~mm}$ e/ou constituindo pequenos agregados irregulares, ocasião em desenvolvem texturas sub-ofiticas. Os cristais de pigeonita encontram-se intensamente transformados para finos agregados de clorofeítas e/ou de argilo-minerais, pigmentados por óxidos/hidróxidos de ferro.

Opacos: Correspondem a cristais de magnetita, titano-magnetita e alguma ilmenita e formam cristais irregulares a esqueléticos com dimensões desde submilimétricas até cerca de $1,5 \mathrm{~mm}$, predominantemente associados aos clinopiroxênios. Apresentam-se praticamente inalterados.

Feldspatos Alcalinos/Quartzo: Constituem minúsculos agregados intersticiais, por vezes bordejando cristais de plagioclásio, intercrescidos entre si, com discretas texturas micropegmatíticas ou granofiricas.

Apatita: Apresenta-se principalmente sob forma de minúsculas acículas inclusas no plagioclásio e como pequenos cristais prismáticos ou sub-hexagonais dispersos pela lâmina.

Av. 24-A, 1515 - 13506-900 - Rio Claro (SP) - Caixa Postal 178 - Fone: (019) 526.2809

FAX: (019) 524-9644 / e-mail: secretar@dpm.igce.unesp.br 


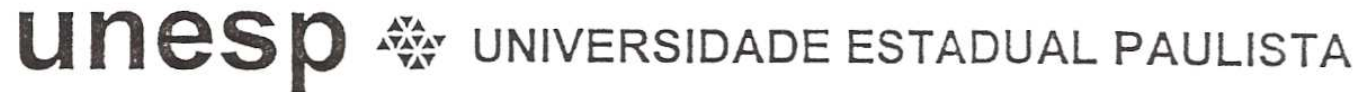

Câmpus de Rio Claro

Instituto de Geociências e Ciências Exatas

Departamento de Petrologia e Metalogenia

Minerais Secundários: Correspondem aos produtos de alteração hidrotermal (efeito de voláteis residuais do final da cristalização magmática) da pigeonita e menos freqüentemente do plagioclásio e da augita. Estão representados por agregados esverdeados de clorofeítas (perfazem cerca de 1,0\% da lâmina) e por fina massa pulverulenta constituída por filossilicatos (clorita, sericita), epidotos, anfibólios fibrosos, argilo-minerais (nontronita e alguma celadonita?), óxidos/hidróxidos de ferro e carbonatos disseminados sobre cristais de pigeonita e ao longo de microfissuras, clivagens e interfácies minerais (estimados em cerca de $4 \%$ do total da lâmina).

\section{Lâmina 2 - Leucodiabásio ou leucogabro (consideraria como leucodiabásio por corresponder a material proveniente de sill)}

Obs.: Composicionalmente é muito similar ao material da lâmina 1, diferindo da mesma quanto: - granulação pouco mais grosseira; - pelo maior efeito da alteração pulverulenta sobre os minerais; - pouco mais enriquecida em augita; e, pela presença de augita aciculares (mas com cristais de dimensões menores que as presentes na amostra de mão).

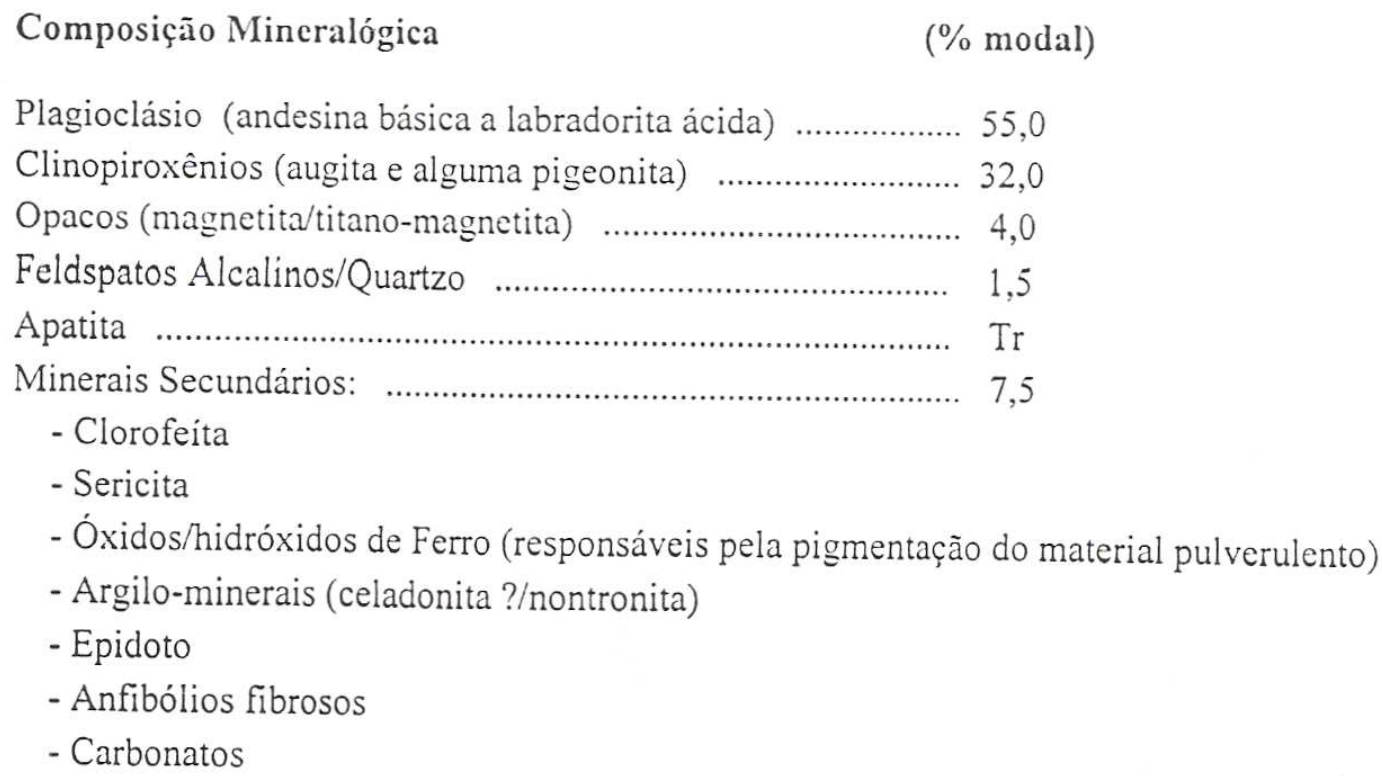

Estrutura: Compacta, isotrópica.

Textura: Microscopicamente exibe textura faneritica média a fina, hipidiomórfica, com a presença de esparsos núcleos intergranulares a localmente sub-ofíticos. A granulação oscila de submilimétrica a cerca de 3,0 $\mathrm{mm}$, com predominância entre 1 e $2 \mathrm{~mm}$. A augita desenvolve cristais prismáticos longos que pode atingir cerca de $3,0 \mathrm{~mm}$ ao longo do maior cixo. Intersticialmente pode conter minúsculas manchas irregulares, submilimétricas, compostas por 


\section{UneSO 崒 UNIVERSIDADE ESTADUAL PAULISTA}

Câmpus de Rio Claro

Instituto de Geociências e Ciências Exatas

Departamento de Petrologia e Metalogenia

intercrescimentos entre feldspato potássico e quartzo com discreta textura granofírica. A lâmina caracteriza-se por generalizado aspecto de sujeira (bastante superior ao da lâmina 1) dado por material pulverulento (argilo-minerais, fino agregado sericítico? e óxidos/hidróxidos de ferro, os quais imprimem uma coloração castanha a marronzada responsável pelo aspecto de sujeira visível em nível microscópico) disseminado sobre plagioclásios, piroxênios, interfácies minerais e ao longo de clivagens minerais.

Transformações minerais: praticamente a mesma que a presente na lâmina 1, mas de maior intensidade.

\section{Descrição dos Minerais:}

Plagioclásio: Labradorita ácida a andesina básica, sob forma de cristais ripiformes a prismáticos subedrais com dimensões oscilando basicamente entre $0,3 \mathrm{~mm}$ e cerca de $2,5 \mathrm{~mm}$ ao longo do seu maior eixo, na média entre 1,0 e 2,0 mm. Apresenta zoneamento composicional, característica geminação Carlsbad e polissintética e mostram-se afetados por alteração de aspecto pulverulento disseminada por todo o cristal (massa sericítica, argilomineralização, raros carbonatos, pigmentados por óxidos e hidróxidos de ferro). São freqüentes inclusões de minúsculas agulhas de apatita

Clinopiroxênios: Augita, e mais raramente pigeonita. Difere da lâmina 1 pelas dimensões médias superiores dos cristais de augita (os quais atingem até cerca de 3,0 mm) e pela maior intensidade da alteração da pigeonita produzindo finos agregados de clorofeitas e/ou de argilo-minerais, pigmentados por óxidos/hidróxidos de ferro.

Opacos: Correspondem a cristais de magnetita, titano-magnetita e alguma ilmenita $c$ formam cristais irregulares a esqueléticos associadas ou não aos clinopiroxênios. Apresentamse praticamente inalterados.

Feldspatos Alcalinos/Quartzo: Constituem minúsculos agregados intersticiais, por vezes bordejando cristais de plagioclásio, intercrescidos entre si, com discretas texturas granofiricas.

Apatita: Apresenta-se sob forma de minúsculas acículas inclusas nos cristais de plagioclásio e como pequenos cristais prismáticos ou sub-hexagonais dispersos pela lâmina.

Obs.: petrograficamente consideraria como leucodiabásios (plagioclásio e piroxênios); entretanto, quimicamente correspondem a leucodioritos. Análises químicas efetuados pelo Nardy em materiais similares da Pedreira Cavinatto (próximo a Limeira) apresentam teores de $\mathrm{SiO} 2$ entre $47 \%$ e $55 \%$.

Prof. Dr. ANTONIO CARLOS ARTUR

DPM/IGCE/UNESP - Campus de Rio Claro

$$
\begin{gathered}
\text { Av. 24-A, } 1515 \text { - 13506-900 - Rio Claro (SP) - Caixa Postal } 178 \text { - Fone: (019) 526.2809 } \\
\text { FAX: (019) 524-9644 / e-mail: secretar@dpm.igce.unesp.br }
\end{gathered}
$$



APÊNDICE

\section{Análises Estatísticas}

Neste Apêndice estão apresentadas as análises estatísticas dos resultados obtidos através dos experimentos realizados nesta pesquisa. Para a comparação dos resultados foram realizadas análises estatísticas baseadas no teste de hipóteses para diferenças entre médias de amostras pequenas e independentes utilizando a variável t-Student. O teste t verifica se a hipótese H0 (hipótese nula) é verdadeira, ou seja, se há igualdede entre as médias. Os resultados acompanham suas estatísticas descritivas, como os valores de média, variância e desvio padrão, assim como os resultados das inferências estatísticas empregadas. Todas as descrições e premissas do teste de hipóteses podem ser encontradas em Schefler (1988).

\section{B.1 Ensaios de Estabilidade e Fluência Marshall}

Tabela B.1: Análise estatística dos resultados de Estabilidade e Fluência Marshall das misturas AZRg e Bg

\begin{tabular}{lcc}
\hline \multicolumn{3}{c}{ Valor crítico de T igual a 2,776 com 4 graus de liberdade } \\
\hline Material & $\mathbf{E}(\mathbf{N})$ & $\mathbf{F}(\mathbf{0 , 1} \mathbf{~ m m})$ \\
\hline AZRg & 17583,41130 & 41,66667 \\
Bg & 12797,89056 & 39,79333 \\
Estimativa da Variância & 282758,07666 & 1,24193 \\
Estimativa do Erro & 434,17207 & 0,90992 \\
Valor de T & 11,02218 & 2,05879 \\
Teste de Hipóteses & Rejeita H0 & Aceita H0 \\
\hline
\end{tabular}


Tabela B.2: Análise estatística dos resultados de Estabilidade e Fluência Marshall das misturas $\mathrm{AZRb}$ e Bb

\begin{tabular}{lcc}
\hline \multicolumn{3}{c}{ Valor crítico de T igual a 2,776 com 4 graus de liberdade } \\
\hline Material & $\mathbf{E}(\mathbf{N})$ & $\mathbf{F}(\mathbf{0 , 1} \mathbf{~ m m})$ \\
\hline AZRb & 12836,93174 & 43,72667 \\
Bb & 9985,13989 & 42,33333 \\
Estimativa da Variância & 389265,05512 & 3,27873 \\
Estimativa do Erro & 509,42128 & 1,47845 \\
Valor de T & 5,59810 & 0,94243 \\
Teste de Hipóteses & Rejeita H0 & Aceita H0 \\
\hline
\end{tabular}

Tabela B.3: Análise estatística dos resultados de Estabilidade e Fluência Marshall das misturas AZRg e AZRb

\begin{tabular}{lcc}
\hline \multicolumn{3}{c}{ Valor crítico de T igual a 2,776 com 4 graus de liberdade } \\
\hline Material & $\mathbf{E}(\mathbf{N})$ & $\mathbf{F}(\mathbf{0 , 1} \mathbf{~ m m})$ \\
\hline AZRg & 17583,41130 & 41,66667 \\
AZRb & 12836,93174 & 43,72667 \\
Estimativa da Variância & 522114,19939 & 2,27873 \\
Estimativa do Erro & 589,97977 & 1,23254 \\
Valor de T & 8,04516 & $-1,67134$ \\
Teste de Hipóteses & Rejeita H0 & Aceita H0 \\
\hline
\end{tabular}

Tabela B.4: Análise estatística dos resultados de Estabilidade e Fluência Marshall das misturas 110AZRg e 110AZRb

\begin{tabular}{lcc}
\hline \multicolumn{3}{c}{ Valor crítico de T igual a 2,776 com 4 graus de liberdade } \\
\hline Material & $\mathbf{E}(\mathbf{N})$ & $\mathbf{F}(\mathbf{0 , 1} \mathbf{~ m m})$ \\
\hline 110AZRg & 22079,69400 & 38,06667 \\
110AZRb & 16980,53448 & 43,96667 \\
Estimativa da Variância & 433797,77997 & 4,38433 \\
Estimativa do Erro & 537,77181 & 1,70965 \\
Valor de T & 9,48201 & $-3,45101$ \\
Teste de Hipóteses & Rejeita H0 & Rejeita H0 \\
\hline
\end{tabular}

Tabela B.5: Análise estatística dos resultados de Estabilidade e Fluência Marshall das misturas 155AZRg e $155 \mathrm{AZRb}$

\begin{tabular}{lcc}
\hline \multicolumn{2}{c}{ Valor crítico de T igual a 2,776 com 4 graus de liberdade } \\
\hline Material & $\mathbf{E}(\mathbf{N})$ & $\mathbf{F}(\mathbf{0 , 1} \mathbf{~ m m})$ \\
\hline 155AZRg & 28924,39914 & 36,88667 \\
155AZRb & 19298,90235 & 44,72333 \\
Estimativa da Variância & 550120,14094 & 1,20908 \\
Estimativa do Erro & 605,59620 & 0,89781 \\
Valor de T & 15,89425 & $-8,72869$ \\
Teste de Hipóteses & Rejeita H0 & Rejeita H0 \\
\hline
\end{tabular}


Tabela B.6: Análise estatística dos resultados de Estabilidade e Fluência Marshall das misturas AZRg e 110AZRg

\begin{tabular}{lcc}
\hline \multicolumn{3}{c}{ Valor crítico de T igual a 2,776 com 4 graus de liberdade } \\
\hline Material & $\mathbf{E}(\mathbf{N})$ & $\mathbf{F}(\mathbf{0 , 1} \mathbf{~ m m})$ \\
\hline AZRg & 17583,41130 & 41,66667 \\
110AZRg & 22079,69400 & 38,06667 \\
Estimativa da Variância & 521936,77064 & 3,39413 \\
Estimativa do Erro & 589,87952 & 1,50425 \\
Valor de T & $-7,62237$ & 2,39323 \\
Teste de Hipóteses & Rejeita H0 & Aceita H0 \\
\hline
\end{tabular}

Tabela B.7: Análise estatística dos resultados de Estabilidade e Fluência Marshall das misturas AZRg e 155AZRg

\begin{tabular}{lcc}
\hline \multicolumn{3}{c}{ Valor crítico de T igual a 2,776 com 4 graus de liberdade } \\
\hline Material & $\mathbf{E}(\mathbf{N})$ & $\mathbf{F}(\mathbf{0 , 1} \mathbf{~ m m})$ \\
\hline AZRg & 17583,41130 & 41,66667 \\
155AZRg & 28924,39914 & 36,88667 \\
Estimativa da Variância & 667124,87420 & 0,97793 \\
Estimativa do Erro & 666,89573 & 0,80744 \\
Valor de T & $-17,00564$ & 5,91996 \\
Teste de Hipóteses & Rejeita H0 & Rejeita H0 \\
\hline
\end{tabular}

Tabela B.8: Análise estatística dos resultados de Estabilidade e Fluência Marshall das misturas 110AZRg e 155AZRg

\begin{tabular}{lcc}
\hline \multicolumn{2}{c}{ Valor crítico de T igual a 2,776 com 4 graus de liberdade } \\
\hline Material & $\mathbf{E}(\mathbf{N})$ & $\mathbf{F}(\mathbf{0 , 1} \mathbf{~ m m})$ \\
\hline 110AZRg & 22079,69400 & 38,06667 \\
155AZRg & 28924,39914 & 36,88667 \\
Estimativa da Variância & 906921,45546 & 4,03873 \\
Estimativa do Erro & 777,56948 & 1,64088 \\
Valor de T & $-8,80269$ & 0,71913 \\
Teste de Hipóteses & Rejeita H0 & Aceita H0 \\
\hline
\end{tabular}

Tabela B.9: Análise estatística dos resultados de Estabilidade e Fluência Marshall das misturas $\mathrm{AZRb}$ e 110AZRb

\begin{tabular}{lcc}
\hline \multicolumn{3}{c}{ Valor crítico de T igual a 2,776 com 4 graus de liberdade } \\
\hline Material & $\mathbf{E}(\mathbf{N})$ & $\mathbf{F}(\mathbf{0 , 1} \mathbf{~ m m})$ \\
\hline AZRb & 12836,93174 & 43,72667 \\
110AZRb & 16980,53448 & 43,96667 \\
Estimativa da Variância & 433975,20872 & 3,26893 \\
Estimativa do Erro & 537,88178 & 1,47624 \\
Valor de T & $-7,70356$ & $-0,16258$ \\
Teste de Hipóteses & Rejeita H0 & Aceita H0 \\
\hline
\end{tabular}


Tabela B.10: Análise estatística dos resultados de Estabilidade e Fluência Marshall das misturas $\mathrm{AZRb}$ e $155 \mathrm{AZRb}$

\begin{tabular}{lcc}
\hline \multicolumn{3}{c}{ Valor crítico de T igual a 2,776 com 4 graus de liberdade } \\
\hline Material & $\mathbf{E}(\mathbf{N})$ & $\mathbf{F}(\mathbf{0 , 1} \mathbf{~ m m})$ \\
\hline AZRb & 12836,93174 & 43,72667 \\
155AZRb & 19298,90235 & 44,72333 \\
Estimativa da Variância & 405109,46613 & 2,50988 \\
Estimativa do Erro & 519,68546 & 1,29354 \\
Valor de T & $-12,43439$ & $-0,77049$ \\
Teste de Hipóteses & Rejeita H0 & Aceita H0 \\
\hline
\end{tabular}

Tabela B.11: Análise estatística dos resultados de Estabilidade e Fluência Marshall das misturas $110 \mathrm{AZRb}$ e $155 \mathrm{AZRb}$ Valor crítico de T igual a 2,776 com 4 graus de liberdade

\begin{tabular}{lcc}
\hline Material & $\mathbf{E}(\mathbf{N})$ & $\mathbf{F}(\mathbf{0 , 1} \mathbf{~ m m})$ \\
\hline 110AZRb & 16980,53448 & 43,96667 \\
155AZRb & 19298,90235 & 44,72333 \\
Estimativa da Variância & 76996,46545 & 1,55468 \\
Estimativa do Erro & 226,56341 & 1,01806 \\
Valor de T & $-10,23276$ & $-0,74324$ \\
Teste de Hipóteses & Rejeita H0 & Aceita H0 \\
\hline
\end{tabular}




\section{B.2 Ensaios de Fluência por Compressão Uniaxial Uniforme}

Tabela B.12: Análise estatística dos resultados de fluência por compressão uniaxial estática das misturas AZRg e Bg

\begin{tabular}{lcccccc}
\hline \multicolumn{7}{c}{ Valor crítico de T igual a 2,776 com 4 graus de liberdade } \\
\hline Material & $\mathbf{D t}(\mathbf{m m} / \mathbf{m m})$ & $\mathbf{D e}(\mathbf{m m} / \mathbf{m m})$ & $\mathbf{D p}(\mathbf{m m} / \mathbf{m m})$ & $\mathbf{R e c}(\boldsymbol{\%})$ & $\mathbf{M F}\left(\mathrm{kgf} / \mathrm{cm}^{2}\right)$ & Inclin. \\
\hline AZRg & 0,00270 & 0,00159 & 0,00111 & 59,62 & 370,92 & 0,04030 \\
Bg & 0,00292 & 0,00162 & 0,00131 & 58,68 & 355,66 & 0,05537 \\
Estimativa da Variância & 0,00000 & 0,00000 & 0,00000 & 47,58087 & 1426,61444 & 0,00034 \\
Estimativa do Erro & 0,00022 & 0,00005 & 0,00021 & 5,63210 & 30,83952 & 0,01510 \\
Valor de T & $-1,00049$ & $-0,67344$ & $-0,94156$ & 0,16734 & 0,49477 & $-0,99842$ \\
Teste de Hipóteses & Aceita H0 & Aceita H0 & Aceita H0 & Aceita H0 & Aceita H0 & Aceita H0 \\
\hline
\end{tabular}

Tabela B.13: Análise estatística dos resultados de fluência por compressão uniaxial estática das misturas $\mathrm{AZRb}$ e $\mathrm{Bb}$

\begin{tabular}{lcccccc}
\hline \multicolumn{7}{c}{ Valor crítico de T igual a 2,776 com 4 graus de liberdade } \\
\hline Material & $\mathbf{D t}(\mathbf{m m} / \mathbf{m m})$ & $\mathbf{D e}(\mathbf{m m} / \mathbf{m m})$ & $\mathbf{D p}(\mathbf{m m} / \mathbf{m m})$ & Rec $(\boldsymbol{\%})$ & $\mathbf{M F}\left(\mathrm{kgf} / \mathrm{cm}^{2}\right)$ & Inclin. \\
\hline $\mathrm{AZRb}$ & 0,00358 & 0,00166 & 0,00192 & 50,80 & 356,89 & 0,05993 \\
$\mathrm{Bb}$ & 0,00190 & 0,00123 & 0,00067 & 70,56 & 603,28 & 0,03733 \\
Estimativa da Variância & 0,00000 & 0,00000 & 0,00000 & 26,27233 & 11170,54434 & 0,00003 \\
Estimativa do Erro & 0,00047 & 0,00016 & 0,00038 & 4,18508 & 86,29617 & 0,00425 \\
Valor de T & 3,59615 & 2,67650 & 3,30814 & $-4,72193$ & $-2,85515$ & 5,31965 \\
Teste de Hipóteses & Rejeita H0 & Aceita H0 & Rejeita H0 & Rejeita H0 & Rejeita H0 & Rejeita H0 \\
\hline
\end{tabular}

Tabela B.14: Análise estatística dos resultados de fluência por compressão uniaxial estática das misturas AZRg e AZRb

\begin{tabular}{lcccccc}
\hline \multicolumn{7}{c}{ Valor crítico de T igual a 2,776 com 4 graus de liberdade } \\
\hline Material & $\mathbf{D t}(\mathbf{m m} / \mathbf{m m})$ & $\mathbf{D e}(\mathbf{m m} / \mathbf{m m})$ & $\mathbf{D p}(\mathbf{m m} / \mathbf{m m})$ & $\mathbf{R e c}(\mathbf{\%})$ & $\mathbf{M F}\left(\mathrm{kgf} / \mathrm{cm}^{2}\right)$ & Inclin. \\
\hline AZRg & 0,00270 & 0,00159 & 0,00111 & 59,62 & 370,92 & 0,04030 \\
AZRb & 0,00358 & 0,00166 & 0,00192 & 50,80 & 356,89 & 0,05993 \\
Estimativa da Variância & 0,00000 & 0,00000 & 0,00000 & 17,97476 & 1687,26032 & 0,00002 \\
Estimativa do Erro & 0,00034 & 0,00002 & 0,00032 & 3,46167 & 33,53864 & 0,00364 \\
Valor de T & $-2,57091$ & $-3,15063$ & $-2,51154$ & 2,54814 & 0,41842 & $-5,39039$ \\
Teste de Hipóteses & Aceita H0 & Rejeita H0 & Aceita H0 & Aceita H0 & Aceita H0 & Rejeita H0 \\
\hline
\end{tabular}


Tabela B.15: Análise estatística dos resultados de fluência por compressão uniaxial estática das misturas 110AZRg e 110AZRb

\begin{tabular}{lcccccc}
\hline \multicolumn{7}{c}{ Valor crítico de T igual a 2,776 com 4 graus de liberdade } \\
\hline Material & $\mathbf{D t}(\mathbf{m m} / \mathbf{m m})$ & $\mathbf{D e}(\mathbf{m m} / \mathbf{m m})$ & $\mathbf{D p}(\mathbf{m m} / \mathbf{m m})$ & $\mathbf{R e c}(\boldsymbol{\%})$ & $\mathbf{M F}\left(\mathrm{kgf/ \textrm {cm } ^ { 2 }}\right)$ & Inclin. \\
\hline 110AZRg & 0,00147 & 0,00128 & 0,00019 & 86,51 & 740,86 & 0,06303 \\
110AZRb & 0,00172 & 0,00124 & 0,00049 & 73,47 & 635,06 & 0,08773 \\
Estimativa da Variância & 0,00000 & 0,00000 & 0,00000 & 41,42605 & 7946,23055 & 0,00098 \\
Estimativa do Erro & 0,00017 & 0,00008 & 0,00013 & 5,25522 & 72,78384 & 0,02559 \\
Valor de T & $-1,52535$ & 0,52223 & $-2,32152$ & 2,48071 & 1,45360 & $-0,96512$ \\
Teste de Hipóteses & Aceita H0 & Aceita H0 & Aceita H0 & Aceita H0 & Aceita H0 & Aceita H0 \\
\hline
\end{tabular}

Tabela B.16: Análise estatística dos resultados de fluência por compressão uniaxial estática das misturas 155AZRg e 155AZRb

\begin{tabular}{lcccccc}
\hline \multicolumn{7}{c}{ Valor crítico de T igual a 2,776 com 4 graus de liberdade } \\
\hline Material & Dt(mm/mm) & De(mm/mm) & Dp(mm/mm) & Rec (\%) & MF $\left(\mathrm{kgf} / \mathrm{cm}^{2}\right)$ & Inclin. \\
\hline 155AZRg & 0,00118 & 0,00087 & 0,00031 & 75,49 & 795,22 & 0,13120 \\
155AZRb & 0,00133 & 0,00086 & 0,00047 & 66,88 & 910,68 & 0,14318 \\
Estimativa da Variância & 0,00000 & 0,00000 & 0,00000 & 122,35528 & 21894,57328 & 0,00112 \\
Estimativa do Erro & 0,00012 & 0,00015 & 0,00018 & 9,03162 & 120,81549 & 0,02734 \\
Valor de T & $-1,35269$ & 0,06864 & $-0,92012$ & 0,95332 & $-0,95569$ & $-0,43799$ \\
Teste de Hipóteses & Aceita H0 & Aceita H0 & Aceita H0 & Aceita H0 & Aceita H0 & Aceita H0 \\
\hline
\end{tabular}

Tabela B.17: Análise estatística dos resultados de fluência por compressão uniaxial estática das misturas AZRg e 110AZRg

\begin{tabular}{lcccccc}
\hline \multicolumn{7}{c}{ Valor crítico de T igual a 2,776 com 4 graus de liberdade } \\
\hline Material & $\mathbf{D t}(\mathbf{m m} / \mathbf{m m})$ & $\mathbf{D e}(\mathbf{m m} / \mathbf{m m})$ & $\mathbf{D p}(\mathbf{m m} / \mathbf{m m})$ & Rec $(\%)$ & MF $\left(\mathrm{kgf} / \mathrm{cm}^{2}\right)$ & Inclin. \\
\hline AZRg & 0,00270 & 0,00159 & 0,00111 & 59,62250 & 370,92000 & 0,04030 \\
110AZRg & 0,00147 & 0,00128 & 0,00019 & 86,50500 & 740,85667 & 0,06303 \\
Estimativa da Variância & 0,00000 & 0,00000 & 0,00000 & 17,50463 & 4425,35523 & 0,00052 \\
Estimativa do Erro & 0,00007 & 0,00001 & 0,00007 & 3,41610 & 54,31608 & 0,01861 \\
Valor de T & 18,49448 & 48,02499 & 13,48725 & $-7,86935$ & $-6,81081$ & $-1,22152$ \\
Teste de Hipóteses & Rejeita H0 & Rejeita H0 & Rejeita H0 & Rejeita H0 & Rejeita H0 & Aceita H0 \\
\hline
\end{tabular}

Tabela B.18: Análise estatística dos resultados de fluência por compressão uniaxial estática das misturas AZRg e 155AZRg

\begin{tabular}{lcccccc}
\hline \multicolumn{7}{c}{ Valor crítico de T igual a 2,776 com 4 graus de liberdade } \\
\hline Material & $\mathbf{D t}(\mathbf{m m} / \mathbf{m m})$ & $\mathbf{D e}(\mathbf{m m} / \mathbf{m m})$ & $\mathbf{D p}(\mathbf{m m} / \mathbf{m m})$ & Rec $(\boldsymbol{\%})$ & MF $\left(\mathrm{kgf} / \mathrm{cm}^{2}\right)$ & Inclin. \\
\hline AZRg & 0,00270 & 0,00159 & 0,00111 & 59,62250 & 370,92000 & 0,04030 \\
155AZRg & 0,00118 & 0,00087 & 0,00031 & 75,48833 & 795,22000 & 0,13120 \\
Estimativa da Variância & 0,00000 & 0,00000 & 0,00000 & 25,56901 & 12312,74597 & 0,00026 \\
Estimativa do Erro & 0,00010 & 0,00009 & 0,00003 & 4,12868 & 90,60076 & 0,01321 \\
Valor de T & 15,32880 & 7,97392 & 24,64799 & $-3,84283$ & $-4,68318$ & $-6,88254$ \\
Teste de Hipóteses & Rejeita H0 & Rejeita H0 & Rejeita H0 & Rejeita H0 & Rejeita H0 & Rejeita H0 \\
\hline
\end{tabular}


Tabela B.19: Análise estatística dos resultados de fluência por compressão uniaxial estática das misturas 110AZRg e 155AZRg

\begin{tabular}{lcccccc}
\hline \multicolumn{7}{c}{ Valor crítico de T igual a 2,776 com 4 graus de liberdade } \\
\hline Material & $\mathbf{D t}(\mathbf{m m} / \mathbf{m m})$ & $\mathbf{D e}(\mathbf{m m} / \mathbf{m m})$ & $\mathbf{D p}(\mathbf{m m} / \mathbf{m m})$ & Rec $(\boldsymbol{\%})$ & $\mathbf{M F}\left(\mathrm{kgf} / \mathrm{cm}^{2}\right)$ & Inclin. \\
\hline 110AZRg & 0,00147 & 0,00128 & 0,00019 & 86,50500 & 740,85667 & 0,06303 \\
155AZRg & 0,00118 & 0,00087 & 0,00031 & 75,48833 & 795,22000 & 0,13120 \\
Estimativa da Variância & 0,00000 & 0,00000 & 0,00000 & 41,14848 & 16624,57218 & 0,00078 \\
Estimativa do Erro & 0,00012 & 0,00009 & 0,00008 & 5,23759 & 105,27606 & 0,02280 \\
Valor de T & 2,43172 & 4,51568 & $-1,50962$ & 2,10339 & $-0,51639$ & $-2,98956$ \\
Teste de Hipóteses & Aceita H0 & Rejeita H0 & Aceita H0 & Aceita H0 & Aceita H0 & Rejeita H0 \\
\hline
\end{tabular}

Tabela B.20: Análise estatística dos resultados de fluência por compressão uniaxial estática das misturas AZRb e 110AZRb

\begin{tabular}{lcccccc}
\hline \multicolumn{7}{c}{ Valor crítico de T igual a 2,776 com 4 graus de liberdade } \\
\hline Material & $\mathbf{D t}(\mathbf{m m} / \mathbf{m m})$ & $\mathbf{D e}(\mathbf{m m} / \mathbf{m m})$ & $\mathbf{D}(\mathbf{m m} / \mathbf{m m})$ & Rec $\mathbf{\%})$ & MF $\left(\mathrm{kgf} / \mathrm{cm}^{2}\right)$ & Inclin. \\
\hline AZRb & 0,00358 & 0,00166 & 0,00192 & 50,80167 & 356,88667 & 0,05993 \\
110AZRb & 0,00172 & 0,00124 & 0,00049 & 73,46833 & 635,05833 & 0,08773 \\
Estimativa da Variância & 0,00000 & 0,00000 & 0,00000 & 41,89618 & 5208,13563 & 0,00048 \\
Estimativa do Erro & 0,00038 & 0,00008 & 0,00034 & 5,28496 & 58,92445 & 0,01795 \\
Valor de T & 4,93423 & 5,31596 & 4,22583 & $-4,28890$ & $-4,72082$ & $-1,54929$ \\
Teste de Hipóteses & Rejeita H0 & Rejeita H0 & Rejeita H0 & Rejeita H0 & Rejeita H0 & Aceita H0 \\
\hline
\end{tabular}

Tabela B.21: Análise estatística dos resultados de fluência por compressão uniaxial estática das misturas AZRb e 155AZRb

\begin{tabular}{lcccccc}
\hline \multicolumn{7}{c}{ Valor crítico de T igual a 2,776 com 4 graus de liberdade } \\
\hline Material & $\mathbf{D t}(\mathbf{m m} / \mathbf{m m})$ & $\mathbf{D e}(\mathbf{m m} / \mathbf{m m})$ & $\mathbf{D p}(\mathbf{m m} / \mathbf{m m})$ & Rec (\%) & MF $\left(\mathrm{kgf} / \mathrm{cm}^{2}\right)$ & Inclin. \\
\hline AZRb & 0,00358 & 0,00166 & 0,00192 & 50,80167 & 356,88667 & 0,05993 \\
155AZRb & 0,00133 & 0,00086 & 0,00047 & 66,87833 & 910,68167 & 0,14318 \\
Estimativa da Variância & 0,00000 & 0,00000 & 0,00000 & 114,76103 & 11269,08762 & 0,00088 \\
Estimativa do Erro & 0,00035 & 0,00012 & 0,00036 & 8,74685 & 86,67598 & 0,02421 \\
Valor de T & 6,43651 & 6,79929 & 3,96417 & $-1,83800$ & $-6,38926$ & $-3,43849$ \\
Teste de Hipóteses & Rejeita H0 & Rejeita H0 & Rejeita H0 & Aceita H0 & Rejeita H0 & Rejeita H0 \\
\hline
\end{tabular}

Tabela B.22: Análise estatística dos resultados de fluência por compressão uniaxial estática das misturas 110AZRb e 155AZRb

\begin{tabular}{lcccccc}
\hline \multicolumn{7}{c}{ Valor crítico de T igual a 2,776 com 4 graus de liberdade } \\
\hline Material & $\mathbf{D t}(\mathbf{m m} / \mathbf{m m})$ & $\mathbf{D e}(\mathbf{m m} / \mathbf{m m})$ & $\mathbf{D p}(\mathbf{m m} / \mathbf{m m})$ & Rec (\%) & MF $\left(\mathrm{kgf} / \mathrm{cm}^{2}\right)$ & Inclin. \\
\hline 110AZRb & 0,00172 & 0,00124 & 0,00049 & 73,46833 & 635,05833 & 0,08773 \\
155AZRb & 0,00133 & 0,00086 & 0,00047 & 66,87833 & 910,68167 & 0,14318 \\
Estimativa da Variância & 0,00000 & 0,00000 & 0,00000 & 122,63286 & 13216,23165 & 0,00132 \\
Estimativa do Erro & 0,00016 & 0,00014 & 0,00020 & 9,04186 & 93,86597 & 0,02970 \\
Valor de T & 2,35727 & 2,70056 & 0,08943 & 0,72883 & $-2,93635$ & $-1,86667$ \\
Teste de Hipóteses & Aceita H0 & Aceita H0 & Aceita H0 & Aceita H0 & Rejeita H0 & Aceita H0 \\
\hline
\end{tabular}




\section{B.3 Ensaios de Fluência por Compressão Uniaxial Dinâmica}

Tabela B.23: Análise estatística dos resultados de fluência por compressão uniaxial dinâmica das misturas AZRg e Bg

\begin{tabular}{lccc}
\hline \multicolumn{4}{c}{ Valor crítico de T igual a 2,776 com 4 graus de liberdade } \\
\hline Material & $\mathbf{D t}(\mathbf{m m} / \mathbf{m m})$ & MF $(\mathbf{M P a})$ & Inclin. \\
\hline AZRg & 0,00267 & 38,36591 & 0,34798 \\
Bg & 0,00396 & 27,13321 & 0,34096 \\
Estimativa da Variância & 0,00000 & 5,71867 & 0,00157 \\
Estimativa do Erro & 0,00024 & 1,95255 & 0,03235 \\
Valor de T & $-5,30527$ & 5,75284 & 0,21706 \\
Teste de Hipóteses & Rejeita H0 & Rejeita H0 & Aceita H0 \\
\hline
\end{tabular}

Tabela B.24: Análise estatística dos resultados de fluência por compressão uniaxial dinâmica das misturas AZRb e Bb

Valor crítico de T igual a 2,776 com 4 graus de liberdade

\begin{tabular}{lccc}
\hline Material & $\mathbf{D t}(\mathbf{m m} / \mathbf{m m})$ & $\mathbf{M F} \mathbf{( M P a})$ & Inclin. \\
\hline AZRb & 0,00351 & 32,09149 & 0,34633 \\
$\mathrm{Bb}$ & 0,00485 & 22,95269 & 0,36388 \\
Estimativa da Variância & 0,00000 & 4,77132 & 0,00077 \\
Estimativa do Erro & 0,00024 & 1,78350 & 0,02271 \\
Valor de T & $-5,53189$ & 5,12408 & $-0,77254$ \\
Teste de Hipóteses & Rejeita H0 & Rejeita H0 & Aceita H0 \\
\hline
\end{tabular}

Tabela B.25: Análise estatística dos resultados de fluência por compressão uniaxial dinâmica das misturas AZRg e AZRb

\begin{tabular}{lccc}
\hline \multicolumn{4}{c}{ Valor crítico de T igual a 2,776 com 4 graus de liberdade } \\
\hline Material & $\mathbf{D t}(\mathbf{m m} / \mathbf{m m})$ & MF $(\mathbf{M P a})$ & Inclin. \\
\hline AZRg & 0,00267 & 38,36591 & 0,34798 \\
AZRb & 0,00351 & 32,09149 & 0,34633 \\
Estimativa da Variância & 0,00000 & 9,67466 & 0,00062 \\
Estimativa do Erro & 0,00025 & 2,53964 & 0,02029 \\
Valor de T & $-3,32079$ & 2,47060 & 0,08123 \\
Teste de Hipóteses & Rejeita H0 & Aceita H0 & Aceita H0 \\
\hline
\end{tabular}


Tabela B.26: Análise estatística dos resultados de fluência por compressão uniaxial dinâmica das misturas 110AZRg e 110AZRb

\begin{tabular}{lccc}
\hline \multicolumn{3}{c}{ Valor crítico de T igual a 2,776 com 4 graus de liberdade } \\
\hline Material & $\mathbf{D t}(\mathbf{m m} / \mathbf{m m})$ & MF $(\mathbf{M P a})$ & Inclin. \\
\hline 110AZRg & 0,00163 & 74,92788 & 0,27692 \\
110AZRb & 0,00161 & 67,58646 & 0,29953 \\
Estimativa da Variância & 0,00000 & 117,57549 & 0,00061 \\
Estimativa do Erro & 0,00018 & 8,85345 & 0,02023 \\
Valor de T & 0,08310 & 0,82922 & $-1,11766$ \\
Teste de Hipóteses & Aceita H0 & Aceita H0 & Aceita H0 \\
\hline
\end{tabular}

Tabela B.27: Análise estatística dos resultados de fluência por compressão uniaxial dinâmica das misturas 155AZRg e 155AZRb

\begin{tabular}{lccc}
\hline \multicolumn{3}{c}{ Valor crítico de T igual a 2,776 com 4 graus de liberdade } \\
\hline Material & $\mathbf{D t}(\mathbf{m m} / \mathbf{m m})$ & MF $(\mathbf{M P a})$ & Inclin. \\
\hline 155AZRg & 0,00066 & 174,37929 & 0,18435 \\
155AZRb & 0,00068 & 166,74384 & 0,16015 \\
Estimativa da Variância & 0,00000 & 242,21355 & 0,00031 \\
Estimativa do Erro & 0,00005 & 12,70731 & 0,01427 \\
Valor de T & $-0,47343$ & 0,60087 & 1,69583 \\
Teste de Hipóteses & Aceita H0 & Aceita H0 & Aceita H0 \\
\hline
\end{tabular}

Tabela B.28: Análise estatística dos resultados de fluência por compressão uniaxial dinâmica das misturas AZRg e 110AZRg

\begin{tabular}{lccc}
\hline \multicolumn{4}{c}{ Valor crítico de T igual a 2,776 com 4 graus de liberdade } \\
\hline Material & $\mathbf{D t}(\mathbf{m m} / \mathbf{m m})$ & MF $(\mathbf{M P a})$ & Inclin. \\
\hline AZRg & 0,00267 & 38,36591 & 0,34798 \\
110AZRg & 0,00163 & 74,92788 & 0,27692 \\
Estimativa da Variância & 0,00000 & 20,63618 & 0,00042 \\
Estimativa do Erro & 0,00023 & 3,70910 & 0,01682 \\
Valor de T & 4,59221 & $-9,85736$ & 4,22484 \\
Teste de Hipóteses & Rejeita H0 & Rejeita H0 & Rejeita H0 \\
\hline
\end{tabular}

Tabela B.29: Análise estatística dos resultados de fluência por compressão uniaxial dinâmica das misturas AZRg e 155AZRg

\begin{tabular}{lccc}
\hline \multicolumn{4}{c}{ Valor crítico de T igual a 2,776 com 4 graus de liberdade } \\
\hline Material & $\mathbf{D t}(\mathbf{m m} / \mathbf{m m})$ & MF $(\mathbf{M P a})$ & Inclin. \\
\hline AZRg & 0,00267 & 38,36591 & 0,34798 \\
155AZRg & 0,00066 & 174,37929 & 0,18435 \\
Estimativa da Variância & 0,00000 & 221,85498 & 0,00059 \\
Estimativa do Erro & 0,00021 & 12,16155 & 0,01976 \\
Valor de T & 9,41890 & $-11,18388$ & 8,27963 \\
Teste de Hipóteses & Rejeita H0 & Rejeita H0 & Rejeita H0 \\
\hline
\end{tabular}


Tabela B.30: Análise estatística dos resultados de fluência por compressão uniaxial dinâmica das misturas 110AZRg e 155AZRg

\begin{tabular}{lccc}
\hline \multicolumn{4}{c}{ Valor crítico de T igual a 2,776 com 4 graus de liberdade } \\
\hline Material & Dt(mm/mm) & MF (MPa) & Inclin. \\
\hline 110AZRg & 0,00163 & 74,92788 & 0,27692 \\
155AZRg & 0,00066 & 1777,56667 & 0,18435 \\
Estimativa da Variância & 0,00000 & 22480,00337 & 0,00038 \\
Estimativa do Erro & 0,00010 & 122,42005 & 0,01582 \\
Valor de T & 10,04045 & $-13,90817$ & 5,85313 \\
Teste de Hipóteses & Rejeita H0 & Rejeita H0 & Rejeita H0 \\
\hline
\end{tabular}

Tabela B.31: Análise estatística dos resultados de fluência por compressão uniaxial dinâmica das misturas AZRb e 110AZRb

Valor crítico de T igual a 2,776 com 4 graus de liberdade

\begin{tabular}{lccc}
\hline Material & Dt $(\mathbf{m m} / \mathbf{m m})$ & MF $\mathbf{M P a})$ & Inclin. \\
\hline AZRb & 0,00351 & 32,09149 & 0,34633 \\
110AZRb & 0,00161 & 67,58646 & 0,29953 \\
Estimativa da Variância & 0,00000 & 106,61397 & 0,00081 \\
Estimativa do Erro & 0,00021 & 8,43066 & 0,02320 \\
Valor de T & 9,01360 & $-4,21023$ & 2,01769 \\
Teste de Hipóteses & Rejeita H0 & Rejeita H0 & Aceita H0 \\
\hline
\end{tabular}

Tabela B.32: Análise estatística dos resultados de fluência por compressão uniaxial dinâmica das misturas AZRg e 155AZRg

\begin{tabular}{lccc}
\hline \multicolumn{4}{c}{ Valor crítico de T igual a 2,776 com 4 graus de liberdade } \\
\hline Material & $\mathbf{D t}(\mathbf{m m} / \mathbf{m m})$ & MF $(\mathbf{M P a})$ & Inclin. \\
\hline $\mathrm{AZRb}$ & 0,00351 & 32,09149 & 0,34633 \\
155AZRb & 0,00068 & 166,74384 & 0,16015 \\
Estimativa da Variância & 0,00000 & 30,03322 & 0,00034 \\
Estimativa do Erro & 0,00014 & 4,47461 & 0,01499 \\
Valor de T & 20,10911 & $-30,09253$ & 12,42000 \\
Teste de Hipóteses & Rejeita H0 & Rejeita H0 & Rejeita H0 \\
\hline
\end{tabular}

Tabela B.33: Análise estatística dos resultados de fluência por compressão uniaxial dinâmica das misturas 110AZRb e 155AZRb

\begin{tabular}{lccc}
\hline \multicolumn{3}{c}{ Valor crítico de T igual a 2,776 com 4 graus de liberdade } \\
\hline Material & $\mathbf{D t}(\mathbf{m m} / \mathbf{m m})$ & MF $(\mathbf{M P a})$ & Inclin. \\
\hline 155AZRb & 0,00161 & 67,58646 & 0,29953 \\
110AZRb & 0,00068 & 166,74384 & 0,16015 \\
Estimativa da Variância & 0,00000 & 128,61851 & 0,00054 \\
Estimativa do Erro & 0,00016 & 9,25990 & 0,01904 \\
Valor de T & 5,86267 & $-10,70826$ & 7,31999 \\
Teste de Hipóteses & Rejeita H0 & Rejeita H0 & Rejeita H0 \\
\hline
\end{tabular}




\section{B.4 Ensaios de Resistência à Tração e de Módulo de Resiliência}

Tabela B.34: Análise estatística dos resultados de resistência à tração e de módulo de resiliência das misturas AZRg e Bg

\begin{tabular}{lccc}
\hline \multicolumn{4}{c}{ Valor crítico de T igual a 2,776 com 4 graus de liberdade } \\
\hline Material & RT(MPa) & MR $\left(\mathrm{kgf} / \mathrm{cm}^{2}\right)$ & MRi $\left(\mathrm{kgf} / \mathrm{cm}^{2}\right)$ \\
\hline AZRg & 1,36 & 55144,19667 & 60527,88000 \\
Bg & 1,16 & 35968,38333 & 39983,10667 \\
Estimativa da Variância & 0,00210 & 8194489,35193 & 10036720,93582 \\
Estimativa do Erro & 0,03740 & 2337,30462 & 2586,72521 \\
Valor de T & 5,29041 & 8,20424 & 7,94239 \\
Teste de Hipóteses & Rejeita H0 & Rejeita H0 & Rejeita H0 \\
\hline
\end{tabular}

Tabela B.35: Análise estatística dos resultados de resistência à tração e de módulo de resiliência das misturas AZRb e Bg

\begin{tabular}{lccc}
\hline \multicolumn{4}{c}{ Valor crítico de T igual a 2,776 com 4 graus de liberdade } \\
\hline Material & RT(MPa) & MR $\left(\mathrm{kgf} / \mathrm{cm}^{2}\right)$ & MRi $\left(\mathrm{kgf} / \mathrm{cm}^{2}\right)$ \\
\hline AZRb & 1,35097 & 52461,22333 & 56842,28000 \\
$\mathrm{Bb}$ & 1,10419 & 28712,32000 & 32959,53000 \\
Estimativa da Variância & 0,00204 & 11461449,44907 & 24777118,14830 \\
Estimativa do Erro & 0,03684 & 2764,22978 & 4064,24394 \\
Valor de T & 6,69882 & 8,59151 & 5,87631 \\
Teste de Hipóteses & Rejeita H0 & Rejeita H0 & Rejeita H0 \\
\hline
\end{tabular}

Tabela B.36: Análise estatística dos resultados de resistência à tração e de módulo de resiliência das misturas AZRg e AZRb

\begin{tabular}{lccc}
\hline \multicolumn{4}{c}{ Valor crítico de T igual a 2,776 com 4 graus de liberdade } \\
\hline Material & RT(MPa) & MR $\left(\mathrm{kgf} / \mathrm{cm}^{2}\right)$ & MRi $\left(\mathrm{kgf} / \mathrm{cm}^{2}\right)$ \\
\hline AZRg & 1,36191 & 55144,19667 & 60527,88000 \\
AZRb & 1,35097 & 52461,22333 & 56842,28000 \\
Estimativa da Variância & 0,00227 & 2890407,77473 & 13062734,66855 \\
Estimativa do Erro & 0,03889 & 1388,14211 & 2951,01504 \\
Valor de T & 0,28111 & 1,93278 & 1,24893 \\
Teste de Hipóteses & Aceita H0 & Aceita H0 & Aceita H0 \\
\hline
\end{tabular}


Tabela B.37: Análise estatística dos resultados de resistência à tração e de módulo de resiliência das misturas 110AZRg e 110AZRb

\begin{tabular}{lccc}
\hline \multicolumn{4}{c}{ Valor crítico de T igual a 2,776 com 4 graus de liberdade } \\
\hline Material & RT(MPa) & MR $\left(\mathrm{kgf} / \mathrm{cm}^{2}\right)$ & MRi $\left(\mathrm{kgf} / \mathrm{cm}^{2}\right)$ \\
\hline 110AZRg & 2,11503 & 123654,17667 & 148315,56667 \\
110AZRb & 1,69085 & 74226,37000 & 87899,66667 \\
Estimativa da Variância & 0,00047 & 75861027,29132 & 111045501,77113 \\
Estimativa do Erro & 0,01765 & 7111,54120 & 8604,08824 \\
Valor de T & 24,02880 & 6,95036 & 7,02177 \\
Teste de Hipóteses & Rejeita H0 & Rejeita H0 & Rejeita H0 \\
\hline
\end{tabular}

Tabela B.38: Análise estatística dos resultados de resistência à tração e de módulo de resiliência das misturas 155AZRg e 155AZRb

\begin{tabular}{lccc}
\hline \multicolumn{4}{c}{ Valor crítico de T igual a 2,776 com 4 graus de liberdade } \\
\hline Material & RT(MPa) & MR $\left(\mathrm{kgf} / \mathrm{cm}^{2}\right)$ & MRi $\left(\mathrm{kgf} / \mathrm{cm}^{2}\right)$ \\
\hline 155AZRg & 2,34837 & 193847,79667 & 228259,83333 \\
155AZRb & 1,89542 & 112239,13333 & 130631,80000 \\
Estimativa da Variância & 0,00051 & 302197426,58928 & 372078550,70067 \\
Estimativa do Erro & 0,01846 & 14193,83497 & 15749,67832 \\
Valor de T & 24,53578 & 5,74959 & 6,19873 \\
Teste de Hipóteses & Rejeita H0 & Rejeita H0 & Rejeita H0 \\
\hline
\end{tabular}

Tabela B.39: Análise estatística dos resultados de resistência à tração e de módulo de resiliência das misturas AZRg e 110AZRg

\begin{tabular}{lccc}
\hline \multicolumn{4}{c}{ Valor crítico de T igual a 2,776 com 4 graus de liberdade } \\
\hline Material & RT(MPa) & MR $\left(\mathrm{kgf} / \mathrm{cm}^{2}\right)$ & MRi $\left(\mathrm{kgf} / \mathrm{cm}^{2}\right)$ \\
\hline AZRg & 1,36191 & 55144,19667 & 60527,88000 \\
110AZRg & 2,11503 & 123654,17667 & 148315,56667 \\
Estimativa da Variância & 0,00151 & 45378763,51843 & 54793360,22652 \\
Estimativa do Erro & 0,03175 & 5500,22809 & 6043,91486 \\
Valor de T & $-23,72315$ & $-12,45584$ & $-14,52497$ \\
Teste de Hipóteses & Rejeita H0 & Rejeita H0 & Rejeita H0 \\
\hline
\end{tabular}

Tabela B.40: Análise estatística dos resultados de resistência à tração e de módulo de resiliência das misturas AZRg e 155AZRg

\begin{tabular}{lccc}
\hline \multicolumn{4}{c}{ Valor crítico de T igual a 2,776 com 4 graus de liberdade } \\
\hline Material & RT(MPa) & MR $\left(\mathrm{kgf} / \mathrm{cm}^{2}\right)$ & MRi $\left(\mathrm{kgf} / \mathrm{cm}^{2}\right)$ \\
\hline AZRg & 1,36191 & 55144,19667 & 60527,88000 \\
155AZRg & 2,34837 & 193847,79667 & 228259,83333 \\
Estimativa da Variância & 0,00143 & 187918726,30893 & 220515748,87952 \\
Estimativa do Erro & 0,03091 & 11192,81693 & 12124,78863 \\
Valor de T & $-31,91079$ & $-12,39220$ & $-13,83380$ \\
Teste de Hipóteses & Rejeita H0 & Rejeita H0 & Rejeita H0 \\
\hline
\end{tabular}


Tabela B.41: Análise estatística dos resultados de resistência à tração e de módulo de resiliência das misturas 110AZRg e 155AZRg

\begin{tabular}{lccc}
\hline \multicolumn{4}{c}{ Valor crítico de T igual a 2,776 com 4 graus de liberdade } \\
\hline Material & RT(MPa) & MR $\left(\mathrm{kgf} / \mathrm{cm}^{2}\right)$ & MRi $\left(\mathrm{kgf} / \mathrm{cm}^{2}\right)$ \\
\hline 110AZRg & 2,11503 & 123654,17667 & 148315,56667 \\
155AZRg & 2,34837 & 193847,79667 & 228259,83333 \\
Estimativa da Variância & 0,00025 & 229844533,14793 & 272582675,61363 \\
Estimativa do Erro & 0,01288 & 12378,59801 & 13480,42224 \\
Valor de T & $-18,11809$ & $-5,67056$ & $-5,93040$ \\
Teste de Hipóteses & Rejeita H0 & Rejeita H0 & Rejeita H0 \\
\hline
\end{tabular}

Tabela B.42: Análise estatística dos resultados de resistência à tração e de módulo de resiliência das misturas AZRb e 110AZRb

\begin{tabular}{lccc}
\hline \multicolumn{4}{c}{ Valor crítico de T igual a 2,776 com 4 graus de liberdade } \\
\hline Material & RT(MPa) & MR $\left(\mathrm{kgf} / \mathrm{cm}^{2}\right)$ & MRi $\left(\mathrm{kgf} / \mathrm{cm}^{2}\right)$ \\
\hline AZRb & 1,35097 & 52461,22333 & 56842,28000 \\
110AZRb & 1,69085 & 74226,37000 & 87899,66667 \\
Estimativa da Variância & 0,00122 & 33372671,54762 & 69314876,21317 \\
Estimativa do Erro & 0,02857 & 4716,82602 & 6797,78769 \\
Valor de T & $-11,89811$ & $-4,61436$ & $-4,56875$ \\
Teste de Hipóteses & Rejeita H0 & Rejeita H0 & Rejeita H0 \\
\hline
\end{tabular}

Tabela B.43: Análise estatística dos resultados de resistência à tração e de módulo de resiliência das misturas AZRb e 155AZRb

\begin{tabular}{lccc}
\hline \multicolumn{3}{c}{ Valor crítico de T igual a 2,776 com 4 graus de liberdade } \\
\hline Material & RT(MPa) & MR $\left(\mathrm{kgf} / \mathrm{cm}^{2}\right)$ & MRi $\left(\mathrm{kgf} / \mathrm{cm}^{2}\right)$ \\
\hline AZRb & 1,35097 & 52461,22333 & 56842,28000 \\
155AZRb & 1,89542 & 112239,13333 & 130631,80000 \\
Estimativa da Variância & 0,00135 & 117169108,05508 & 164625536,48970 \\
Estimativa do Erro & 0,02996 & 8838,14113 & 10476,18049 \\
Valor de T & $-18,17495$ & $-6,76363$ & $-7,04355$ \\
Teste de Hipóteses & Rejeita H0 & Rejeita H0 & Rejeita H0 \\
\hline
\end{tabular}

Tabela B.44: Análise estatística dos resultados de resistência à tração e de módulo de resiliência das misturas 110AZRb e 155AZRb

\begin{tabular}{lccc}
\hline \multicolumn{4}{c}{ Valor crítico de T igual a 2,776 com 4 graus de liberdade } \\
\hline Material & RT(MPa) & MR $\left(\mathrm{kgf} / \mathrm{cm}^{2}\right)$ & MRi $\left(\mathrm{kgf} / \mathrm{cm}^{2}\right)$ \\
\hline 110AZRb & 1,69085 & 74226,37000 & 87899,66667 \\
155AZRb & 1,89542 & 112239,13333 & 130631,80000 \\
Estimativa da Variância & 0,00073 & 148213920,73267 & 210541376,85817 \\
Estimativa do Erro & 0,02206 & 9940,28573 & 11847,40131 \\
Valor de T & $-9,27433$ & $-3,82411$ & $-3,60688$ \\
Teste de Hipóteses & Rejeita H0 & Rejeita H0 & Rejeita H0 \\
\hline
\end{tabular}


